\author{
UNIVERSIDADE DE SÃO PAULO \\ FACULDADE DE FILOSOFIA, LETRAS E CIÊNCIAS HUMANAS \\ DEPARTAMENTO DE LETRAS CLÁSSICAS E VERNÁCULAS \\ PROGRAMA DE PÓS-GRADUAÇÃO EM FILOLOGIA E LÍNGUA PORTUGUESA
}

\title{
ESTUDO COMPARATIVO DE ASPECTOS SEMÂNTICOS DO SUFIXO -ISTA NO PORTUGUÊS E NO GALEGO
}

\author{
Nilsa Areán García
}

Dissertação apresentada ao Programa de Pós-Graduação em Filologia e Língua Portuguesa, do Departamento de Letras Clássicas e Vernáculas da Faculdade de Filosofia, Letras e Ciências Humanas da Universidade de São Paulo, para obtenção do título de Mestre em Letras.

Orientador: Prof. Dr. Mário Eduardo Viaro

VOL. I

São Paulo

2007 


\title{
UNIVERSIDADE DE SÃO PAULO
}

FACULDADE DE FILOSOFIA, LETRAS E CIÊNCIAS HUMANAS DEPARTAMENTO DE LETRAS CLÁSSICAS E VERNÁCULAS PROGRAMA DE FILOLOGIA E LÍNGUA PORTUGUESA

\section{ESTUDO COMPARATIVO DE ASPECTOS SEMÂNTICOS DO SUFIXO -ISTA NO PORTUGUÊS E NO GALEGO}

\author{
Nilsa Areán García
}

VOL. I

São Paulo 
Estudo comparativo de aspectos semânticos do sufixo -ista no português e no galego.

A

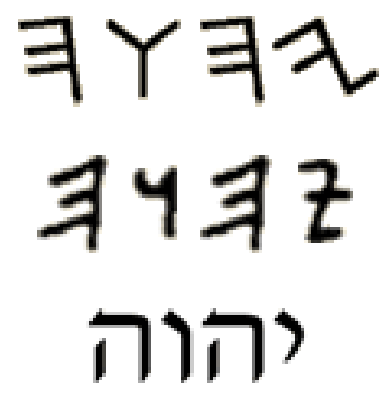




\section{AGRADECIMENTOS}

\section{Der Himmel über Berlin}

(Wim Wenders)

Apesar do crédito de uma dissertação de mestrado ser dado apenas ao seu único autor, há, no entanto, "anjos" que orientam, ensinam, inspiram, ajudam e contribuem de forma especial na elaboração de um trabalho acadêmico. Assim, ainda que estas poucas palavras não consigam abranger o quanto por mim fizeram, deixo aqui expresso o mais sincero e eterno agradecimento aos "anjos" que se me atravessaram no caminho em meio ao desenvolvimento deste trabalho, ainda que não todos estejam aqui explicitamente nomeados:

Ao brilhante orientador Prof. Dr. Mário Eduardo Viaro: pelos cursos "Fonética e Fonologia do Português", "Morfologia do Português" e "Semântica" que me despertaram o interesse pela área; por me integrar às pesquisas do Grupo de Morfologia Histórica do Português (GMHP), das quais este trabalho é fruto; pela atenção e detalhamento das críticas e sugestões pertinentes à dissertação; pela disponibilidade e acessibilidade; pelo profissionalismo; pelo grande apoio e confiança nas minhas atividades e pela infinita paciência que sempre demonstrou.

À, tão brilhante quanto, Profa. Dra. Valéria Gil Condé, do Departamento de Letras Clássicas e Vernáculas da Faculdade de Filosofia, Letras e Ciências Humanas da Universidade de São Paulo (FFLCH-USP), que foi como uma verdadeira co-orientadora, cujas sugestões, observações, críticas e indicações bibliográficas, principalmente em relação à língua galega, ajudaram-me a direcionar a pesquisa e levaram-me a escrever o capítulo quatro e o glossário deste trabalho.

Aos pesquisadores Dr. Zwinglio de Oliveira Guimarães Filho e Leandro Mariano, do Instituto de Física da Universidade de São Paulo (IF-USP), pelo ótimo trabalho de processamento computacional de informações no Grupo de Morfologia Histórica do Português, e especialmente pelos gráficos: 4.1. e 5.2 desta dissertação.

À Profa. Dra. Isabel Gretel María Eres Fernández, do Departamento de Metodologia do Ensino e Educação Comparada da Faculdade de Educação da Universidade de São Paulo 
Estudo comparativo de aspectos semânticos do sufixo -ista no português e no galego.

(FE-USP), pelo curso "Metodologia do Ensino de Espanhol I" e por compartilhar as suas experiências principalmente na elaboração de material didático, apostilas, livros e dicionários.

Ao Prof. Dr. Osvaldo Humberto Leonardi Ceschin, do Departamento de Letras Clássicas e Vernáculas desta Faculdade (FFLCH-USP), pelas longas conversas, verdadeiras aulas, sobre a história sócio-política e religiosa da Idade Média e seu impacto na formação das línguas portuguesa e galega.

À Profa. Dra. Elis de Almeida Caretta, do Departamento de Letras Clássicas e Vernáculas desta Faculdade (FFLCH-USP) e integrante da banca de Qualificação de Mestrado, pelas sugestões e indicações pontuais.

Ao Prof. Dr. Xoán Lagares, do Departamento de Lingüística desta Faculdade (FFLCH-USP), pelas excelentes e indispensáveis indicações bibliográficas sobre o galego.

À Profa. Dra. Safa Alfred Abou Chahla Jubran, do Departamento de Letras Orientais desta Faculdade (FFLCH-USP), pelas informações e esclarecimentos sobre o processo de sufixação em língua árabe.

À Profa. Dra. Ruth Leftel, do Departamento de Letras Orientais desta Faculdade (FFLCH-USP), pelos inesquecíveis cursos: "Língua Hebraica I" e "Língua Hebraica II".

Às Profa. Dra. Mirta María Groppi A. de Varalla e Profa. Dra. María Teresa Celada, do Departamento de Letras Modernas desta Faculdade (FFLCH-USP), pelos cursos de língua espanhola que me forneceram uma sólida base lingüística.

Aos meus amigos e falantes nativos de russo: Profa. Dra. Elena Vitalievna Goussevskaia do Departamento de Química e Prof. Dr. Nicolai Alexandrovitch Goussevskii do Departamento de Matemática do Instituto de Ciências Exatas da Universidade Federal de Minas Gerais (UFMG), pela ajuda e pelas interessantes conversas e esclarecimentos sobre a língua e cultura russa.

Ao amigo e falante nativo de japonês: Prof. Dr. Kunio Okuda do Instituto de Matemática e Estatística da Universidade de São Paulo (IME-USP), pelas explicações sobre sua língua, bem como pelos exemplos que me forneceu. 
Estudo comparativo de aspectos semânticos do sufixo -ista no português e no galego.

Ao amigo e falante nativo de polonês: Prof. Dr. Piotr Koszmider do Instituto de Matemática e Estatística da Universidade de São Paulo (IME-USP), pelos esclarecimentos sobre sufixos e formação de palavras em sua língua materna.

À Profa. Dra. Laura Geatti do Departamento de Matemática da Universitá de Roma "Tor Vergata", pela indicação bibliográfica sobre a língua italiana e por toda a sua grande ajuda propiciada com extrema boa vontade.

Ao sempre prestativo Estebe Ormazabal, professor de Basco e Presidente da Euskal Etxea de São Paulo, por toda a informação, pesquisa e indicações bibliográficas sobre a sufixação em euskera, sua língua materna.

À Isabel Martínez López, professora e especialista em catalão, por todas as informações e indicações bibliográficas sobre o sufixo -ista em sua língua.

Aos amigos, colegas e professores do curso de graduação, pós-graduação e do Grupo de Morfologia Histórica do Português (GMHP) e aos funcionários desta Faculdade pela sincera ajuda e cooperação.

Ao poeta anônimo, cuja obra levou-me aos caminhos da análise semântica.

À minha grande e querida amiga Solange da Conceição Torres, que, apesar de ser uma pessoa extremamente ocupada, está sempre disposta a me ajudar, reservando-me seu precioso tempo e fazendo tudo quanto ao seu alcance estiver da maneira mais singela que conheço.

Aos meus queridos genitores, pela grande quantidade de livros sobre galego, indispensáveis à pesquisa, que me trouxeram das suas viagens à Galiza, mas também pelo carinho e apoio que sempre me prestaram.

Ao meu querido tio, que juntamente com meus pais, sempre esteve ao meu lado dando-me forças e incondicional apoio.

Ao meu querido esposo pelo amor. 


\section{RESUMO}

O presente trabalho, resultado das pesquisas do Grupo de Morfologia Histórica do Português, procura estudar os aspectos semânticos do sufixo -ista no português e no galego, baseando-se na afirmação de VIARO (2005), segundo a qual a semântica da base é diferente da semântica do sufixo e da semântica da palavra formada pela derivação com este, e ressaltando, que não necessariamente a semântica da palavra formada é a soma das semânticas do sufixo e base. Desde esta ótica, traça-se, inicialmente, um panorama histórico e um mapeamento geral da semântica das palavras derivadas com o sufixo proveniente da

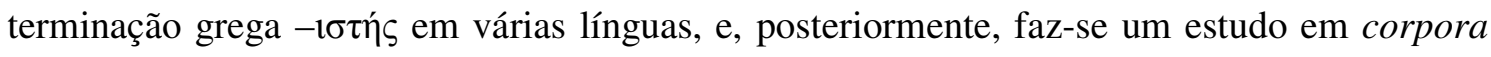
das línguas portuguesa e galega, propondo-se uma classificação semântica das palavras formadas com o sufixo -ista, a qual, detalhada por perspectivas históricas e etimológicas, conduz a uma classificação semântica do sufixo -ista, no português e no galego.

\section{PALAVRAS-CHAVE}

Língua Galega; Língua Portuguesa; Morfologia; Semântica; Sufixo -ista. 
Estudo comparativo de aspectos semânticos do sufixo -ista no português e no galego.

\section{ABSTRACT}

The present work, which is the result of the researches carried out by the Grupo de Morfologia Histórica do Português ["Group of Historical Morphology of the Portuguese Language"], studies the semantic aspects of the suffix -ista, in Portuguese and Galician, based on VIARO's (2005) assertion, according to which the base semantics is different from the suffix semantics and also different from the semantics of the word formed by the derivation with this suffix, and the semantics of the word formed isn't necessarily the sum of the base semantics with the suffix semantics. From this standpoint, we initially draw a historical overview and a general map of the semantics of the words derived with the suffix

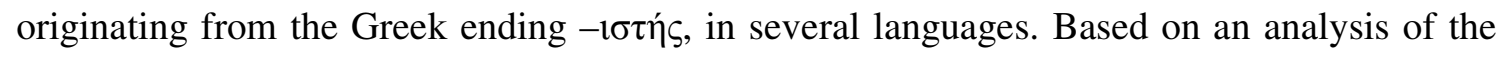
Portuguese corpora and the Galician corpora, we subsequently propose a semantic classification of the words formed by the suffix -ista, which, after providing a detailed historical and etymological perspective, leads to a semantic classification of the suffix -ista, in the Portuguese and Galician languages.

\section{KEY WORDS}

Galician Language; Morfology; Portuguese Language; Semantics; Suffix -ista. 
Estudo comparativo de aspectos semânticos do sufixo -ista no português e no galego.

\section{RESUMO}

O presente traballo, resultado das investigaciós do Grupo de Morfologia Histórica do Português, procura estudalos aspectos semánticos do sufixo -ista no portugués e mais no galego, centrándose no que afirma VIARO (2005) que a semántica da base é distinta da semántica do sufixo e mais da semántica da palabra formada pola derivación con el, e resaltando que a semántica da palavra formada nin sempre é a soma da semántica do sufixo maila semántica da base. Desde esta óptica, se fai, inicialmente, un panorama histórico e un mapeamento xeral da semántica das palavras derivadas co sufixo que provén da terminación

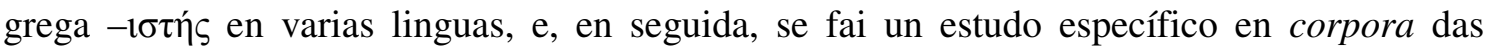
linguas portuguesa e galega e a proposta dunha classificación semántica das palabras formadas co sufixo -ista, que, ó ser detallada por perspectivas históricas e etimolóxicas, encamiña a unha classificación semántica do sufixo -ista no portugués e mais no galego.

\section{PALABRAS-CHAVE}

Lingua Galega; Lingua Portuguesa; Morfoloxía; Semántica; Sufixo -ista. 


\section{SUMÁRIO}

\section{VOLUME I}

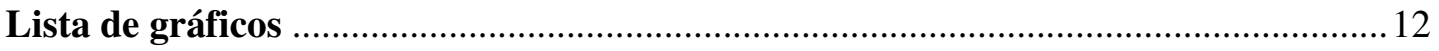

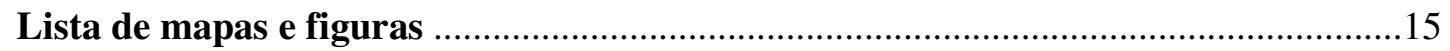

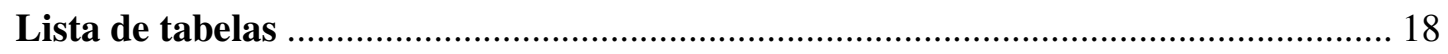

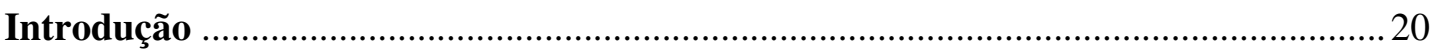

\section{Capítulo 1}

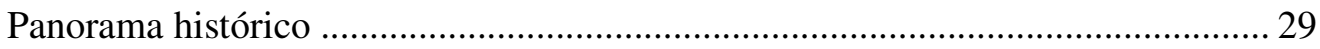

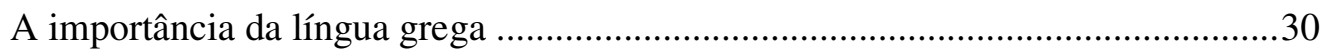

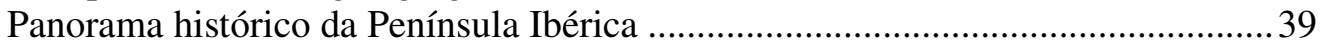

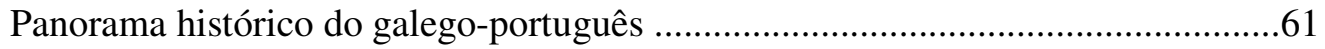

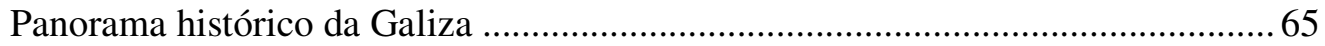

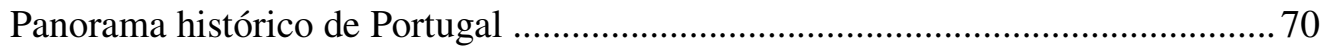

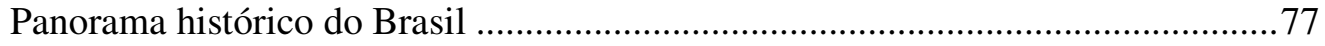

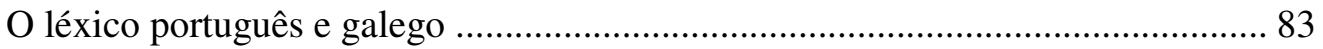

\section{Capítulo 2}

A formação de palavras ................................................................................... 89

Os procedimentos de formação de palavras ....................................................... 91

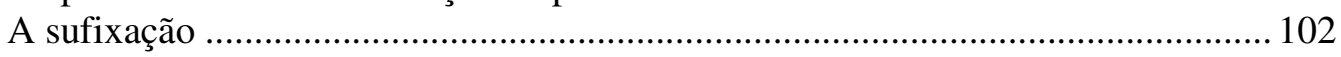

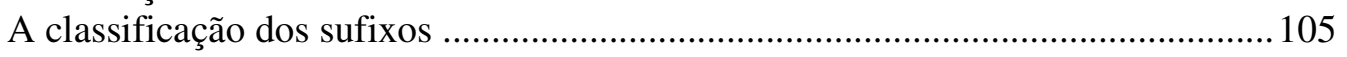

As paráfrases semânticas e as regras de formação de palavras .............................. 133

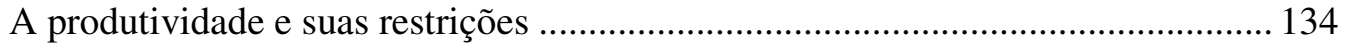

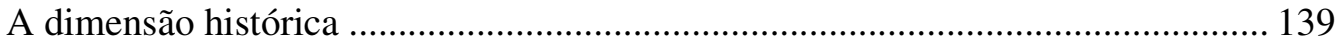

\section{Capítulo 3}

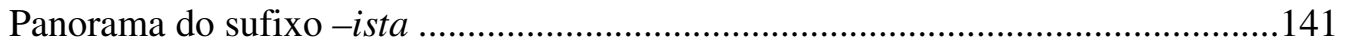

\section{Capítulo 4}

Ocorrências do sufixo -ista em corpora ............................................................ 182

Ocorrências dos sufixos -ista e -ismo em corpora medieval ............................... 185

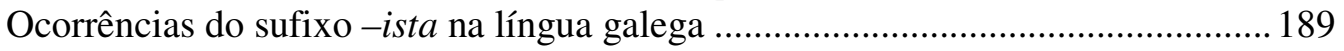

Ocorrências do sufixo -ista no português ............................................................. 198

Ocorrências do sufixo -ista no português europeu ..................................................199

Ocorrências do sufixo -ista no português brasileiro .............................................. 209

Comparações de uso entre o galego e o português ..................................................2218

\section{Capítulo 5}

Uma classificação semântica ................................................................................ 243

Proposta de classificação para derivações com -ista ........................................... 244

Classificação das palavras derivadas com o sufixo -ista ..................................... 251

Considerações sobre a classificação das palavras derivadas ..................................2257

Classificação semântica para o sufixo -ista ........................................................ 274

Considerações sobre a concorrência na formação de agentivos .............................2277 


\section{Capítulo 6}

Estudo dos valores gentílicos

\section{Conclusão}

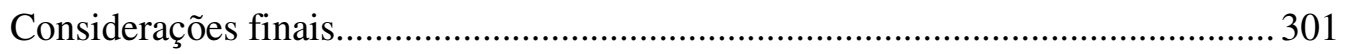

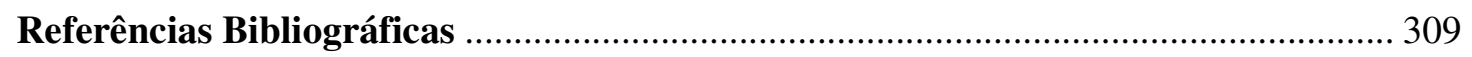

\section{VOLUME II - ANEXOS}

I. Introdução

\section{Anexo I}

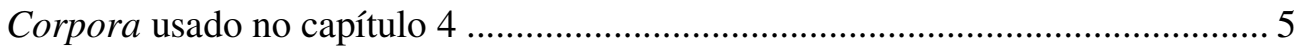

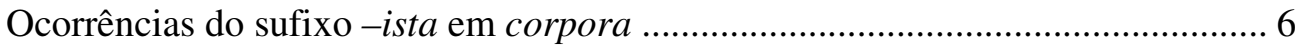

Ocorrências do sufixo -ista em corpora galego ................................................ 7

Ocorrências do sufixo -ista no português europeu ...............................................20

Ocorrências do sufixo -ista no português brasileiro ............................................ 35

\section{Anexo II}

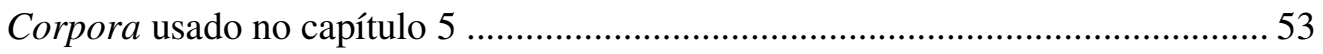

Inventário de palavras com -ista na língua galega ............................................54

Inventário de palavras com -ista na língua portuguesa ........................................59

\section{Anexo III}

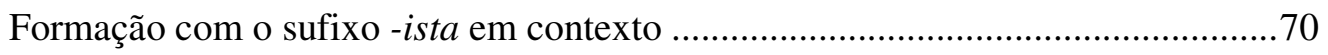

\section{Anexo IV}

Glossário galego-português 
Estudo comparativo de aspectos semânticos do sufixo -ista no português e no galego.

\section{Lista de gráficos}

\section{Capítulo 4}

Gráfico 4.1. Produtividade dos sufixos -ista e -ismo por século......................................... 188

Gráfico 4.2. Ocorrências do sufixo -ista em corpora galego............................................. 189

Gráfico 4.3. Distribuição nos gêneros da escrita em corpora galego do século XIX.......... 190

Gráfico 4.4. Distribuição nos gêneros da escrita em corpora galego do século XX........... 191

Gráfico 4.5. Ocorrências do sufixo -ista nos gêneros da escrita em corpora galego...........192

Gráfico 4.6. Valores percentuais nos gêneros da escrita em corpora galego (I)..................193

Gráfico 4.7. Valores percentuais nos gêneros da escrita em corpora galego (II).................193

Gráfico 4.8. Classificação semântica das ocorrências do sufixo -ista em galego................195

Gráfico 4.9. Valores percentuais da classificação semântica obtida em galego (I)..............196

Gráfico 4.10. Valores percentuais da classificação semântica obtida em galego (II).......... 196

Gráfico 4.11. Ocorrências do sufixo -ista em corpora lusitano.......................................... 199

Gráfico 4.12. Distribuição nos gêneros da escrita em corpora lusitano do século XIX..... 199

Gráfico 4.13. Distribuição nos gêneros da escrita em corpora lusitano do século XX...... 200

Gráfico 4.14. Ocorrências do sufixo -ista nos gêneros da escrita em corpora lusitano......201

Gráfico 4.15. Valores percentuais nos gêneros da escrita em corpora português (I)........ 202

Gráfico 4.16. Valores percentuais nos gêneros da escrita em corpora português (II)....... 202

Gráfico 4.17. Classificação semântica das ocorrências de -ista em português lusitano.....206

Gráfico 4.18. Valores percentuais da classificação semântica no português lusitano (I)...207

Gráfico 4.19. Valores percentuais da classificação semântica no português lusitano (II). 207

Gráfico 4.20. Ocorrências do sufixo -ista em corpora brasileiro.......................................209

Gráfico 4.21. Distribuição nos gêneros da escrita em corpora brasileiro do século XIX...209

Gráfico 4.22. Distribuição nos gêneros da escrita em corpora brasileiro do século XX....210

Gráfico 4.23. Ocorrências do sufixo -ista nos gêneros da escrita em corpora brasileiro... 211

Gráfico 4.24. Valores percentuais nos gêneros da escrita em corpora brasileiro(I).......... 211

Gráfico 4.25. Valores percentuais nos gêneros da escrita em corpora brasileiro (II)........212

Gráfico 4.26. Classificação semântica das ocorrências de -ista em português brasileiro.. 215

Gráfico 4.27. Valores percentuais da classificação semântica no português do Brasil (I).216 
Estudo comparativo de aspectos semânticos do sufixo -ista no português e no galego.

Gráfico 4.28. Valores percentuais da classificação no português do Brasil (II).................216

Gráfico 4.29. Formações usadas com o sufixo -ista, em números absolutos.......................218

Gráfico 4.30. Crescimento do uso de formações com o sufixo -ista..................................219

Gráfico 4.31. Uso de formações com o sufixo -ista nas três variedades idiomáticas.........219

Gráfico 4.32. Uso de formações com o sufixo -ista na prosa, valores percentuais............. 221

Gráfico 4.33. Crescimento do uso de formações com o sufixo -ista na prosa......................222

Gráfico 4.34. Uso de formações com o sufixo -ista na poesia, valores percentuais............223

Gráfico 4.35. Crescimento do uso de formações com o sufixo -ista na poesia....................224

Gráfico 4.36. Uso de formações com o sufixo -ista no teatro, valores percentuais.............225

Gráfico 4.37. Crescimento do uso de formações com o sufixo -ista no teatro....................225

Gráfico 4.38. Índice de crescimento do uso do sufixo -ista nos gêneros da escrita.............227

Gráfico 4.39. Valores percentuais nos gêneros da escrita em corpora galego....................228

Gráfico 4.40. Valores percentuais nos gêneros da escrita em corpora brasileiro................228

Gráfico 4.41. Valores percentuais nos gêneros da escrita em corpora português...............228

Gráfico 4.42. Uso de formações como sufixo -ista em uma única edição de jornal......... 230

Gráfico 4.43. Uso de -ista em uma única edição de jornal, valores percentuais..................230

Gráfico 4.44. Classificação semântica das palavras com -ista nos três jornais....................231

Gráfico 4.45. Classificação semântica das palavras com -ista na prosa galega..................234

Gráfico 4.46. Classificação semântica das palavras com -ista na prosa brasileira.............234

Gráfico 4.47. Classificação semântica das palavras com -ista na prosa portuguesa.......... 234

Gráfico 4.48. Classificação semântica das palavras com -ista na poesia galega.................236

Gráfico 4.49. Classificação semântica das palavras com -ista na poesia brasileira........... 236

Gráfico 4.50. Classificação semântica das palavras com -ista na poesia portuguesa.........236

Gráfico 4.51. Classificação semântica das palavras com -ista no teatro galego..................238

Gráfico 4.52. Classificação semântica das palavras com -ista no teatro brasileiro............ 238

Gráfico 4.53. Classificação semântica das palavras com -ista no teatro português.......... 238

Gráfico 4.54. Índice de crescimento das classes semânticas de palavras com -ista........... 239

Gráfico 4.55. Valores percentuais da classificação semântica obtida em galego..................240

Gráfico 4.56. Valores percentuais da classificação no português do Brasil...................... 240 
Estudo comparativo de aspectos semânticos do sufixo -ista no português e no galego.

Gráfico 4.57. Valores percentuais da classificação semântica no português lusitano........240

\section{Capítulo 5}

Gráfico 5.1. Número de palavras formadas com o sufixo -ista no português e no galego.245

Gráfico 5.2. Produtividade dos sufixos - eiro e -ista, de acordo com o século

\section{Capítulo 6}

Gráfico 6.1. Localidade dos topônimos-base de gentílicos sufixados com -ista................289

Gráfico 6.2. Topônimos-base (confirmados) de gentílicos sufixados com -ista ................ 290

Gráfico 6.3. Tipos dos topônimos-base dos gentílicos sufixados com -ista.......................291

Gráfico 6.4. Datação dos gentílicos sufixados com -ista ...............................................296 
Estudo comparativo de aspectos semânticos do sufixo -ista no português e no galego.

\section{Lista de mapas e figuras}

\section{Capítulo 1}

Mapa 1.1: Primeiras civilizações gregas

Extraido de: ORÍGENES DEL HOMBRE. TIME LIFE. Ediciones Folio S.A. 1993. http://www.pais-global.com.ar/oh/oh14.htm

Mapa 1.2: Divisão política da Grécia Antiga.

Adaptado e traduzido de: http://www.pais-global.com.ar/mapas/mapa00.htm

http://www.pais-global.com.ar/mapas/mapa09.htm

Mapa 1.3: O Império Alexandrino e suas principais rotas de expansão.

Adaptado e traduzido de: http://www.pais-global.com.ar/mapas/mapa00.htm http://www.pais-global.com.ar/mapas/mapa11.htm

Mapa 1.4: O Império Romano.

Adaptado e traduzido de: http://www.pais-global.com.ar/mapas/mapa00.htm

http://www.pais-global.com.ar/mapas/mapa15.htm

Mapa 1.5: A divisão do Império Romano e as rotas dos povos não-romanos.

Adaptado e traduzido de: http://www.pais-global.com.ar/mapas/mapa00.htm http://www.pais-global.com.ar/mapas/mapa16y17.htm

Mapa 1.6: A queda do Império Romano (do Ocidente)

Adaptado e traduzido de: http://www.pais-global.com.ar/mapas/mapa00.htm

http://www.pais-global.com.ar/mapas/mapa19.htm

Mapa 1.7: A expansão do Império Árabe.

Adaptado e traduzido de: http://www.pais-global.com.ar/mapas/mapa00.htm http://www.pais-global.com.ar/mapas/mapa20.htm

Mapa 1.8: A expansão do Império Turco..

Adaptado e traduzido de: http://www.pais-global.com.ar/mapas/mapa00.htm

http://www.pais-global.com.ar/mapas/mapa42.htm

Mapa 1.9: Povos pré-romanos.

Adaptado e traduzido de: http://www.sabuco.com/historia/atlas_hespaña.htm

http://www.sabuco.com/historia/images/Pueblos_prerromanos.jpg

Mapa 1.10: A expansão Romana na Península Ibérica.

Adaptado e traduzido de: http://www.sabuco.com/historia/atlas_hespaña.htm http://www.sabuco.com/historia/images/Fases_colonización.jpg

Mapa 1.11: Divisão Provincial da Península Ibérica, durante o Império Romano.

Adaptado e traduzido de: http://clio.rediris.es/n32/atlas/atlasubieto.htm

http://clio.rediris.es/n32/atlas/018.jpg

Mapa 1.12: Rede viária na Península Ibérica durante o Império de Dioclesiano.

Adaptado e traduzido de: http://www.sabuco.com/historia/atlas_hespaña.htm

http://www.sabuco.com/historia/images/Calzadas_y_ciudades.jpg 
Estudo comparativo de aspectos semânticos do sufixo -ista no português e no galego.

Mapa 1.13: Principais zonas de imigrações na Península Ibérica.

Adaptado e traduzido de: http://www.sabuco.com/historia/atlas_hespaña.htm

http://www.sabuco.com/historia/images/Hispania_Bajo_Imperio.jpg

Mapa 1.14: Os reinos dos povos não-romanos na Península Ibérica.

Adaptado e traduzido de: http://www.sabuco.com/historia/atlas_hespaña.htm

http://www.sabuco.com/historia/images/España_visigoda.jpg

Mapa 1.15: Expansão do Império Árabe.

Adaptado e traduzido de: http://www.sabuco.com/historia/atlas_hespaña.htm http://www.sabuco.com/historia/images/La_expansion_del_Islam.jpg

Mapa 1.16: Expansão do domínio árabe na Península Ibérica

Adaptado e traduzido de: http://www.sabuco.com/historia/atlas_hespaña.htm

http://www.sabuco.com/historia/images/Conquista_musulmana.jpg

Mapa 1.17: Crise do Emirado de Córdoba.

Adaptado e traduzido de: http://clio.rediris.es/n32/atlas/atlasubieto.htm

http://clio.rediris.es/n32/atlas/038.jpg

Mapa 1.18: Reinos Taifas em 1012

Adaptado e traduzido de: http://www.sabuco.com/historia/atlas_hespaña.htm

http://www.sabuco.com/historia/images/Reinos_de_taifas.jpg

Mapa 1.19: Os territórios cristãos, no século VIII, com Afonso I...

Adaptado e traduzido de: http://www.sabuco.com/historia/atlas_hespaña.htm

http://www.sabuco.com/historia/images/Asturias_con_Alfonso_I.jpg

Mapa 1.20: Colonizações iniciais.

Adaptado e traduzido de: http://www.sabuco.com/historia/atlas_hespaña.htm http://www.sabuco.com/historia/images/Repoblacion_valle_del_Duero.jpg

Mapa 1.21: Divisão política dos territórios cristãos no período de 1000 a 1035 Adaptado e traduzido de: http://www.sabuco.com/historia/atlas_hespaña.htm http://www.sabuco.com/historia/images/Estados_de_Sancho_III.jpg

Mapa 1.22: Caminho original à Santiago de Compostela, no século IX.

Adaptado e traduzido de: http://www.caminhodesantiago.com/mapas.htm

http://www.caminhodesantiago.com/mapas/mapa_credencial_fr_nor_vlp.htm

Mapa 1.23: Caminho francês de peregrinação a Santiago de Compostela.

Adaptado e traduzido de: http://www.sabuco.com/historia/atlas_hespaña.htm

http://www.sabuco.com/historia/images/Camino_de_Santiago.jpg

Mapa 1.24: Caminho Português de Peregrinação a Santiago de Compostela

Adaptado e traduzido de: http://www.caminhodesantiago.com/mapas.htm

http://www.caminhodesantiago.com/mapas/mapa_credencial_portugues.htm

Mapa 1.25: O processo de reconquista cristã na Península Ibérica.

Extraído de: http://br.geocities.com/fernandomcvbr/reconquista.html

Mapa 1.26: Divisão política dos reinos cristãos no século XII

Adaptado e traduzido de: http://clio.rediris.es/n32/atlas/atlasubieto.htm

http://clio.rediris.es/n32/atlas/052.jpg 
Estudo comparativo de aspectos semânticos do sufixo -ista no português e no galego.

Mapa 1.27: Evolução da reconquista cristã no século XIII.

Adaptado e traduzido de: http://www.sabuco.com/historia/atlas_hespaña.htm

Mapa 1.27a: Início do século XIII.

http://www.sabuco.com/historia/images/Reconquista_principios_del_XIII.jpg

Mapa 1.27b: Meados do século XIII.

http://www.sabuco.com/historia/images/Reconquista_mediados_del_XIII.jpg

Mapa 1.28: Atual divisão dialetal da Península Ibérica.

Adaptado de: http://es.wikipedia.org/wiki/Imagen:Mapadialectos.jpg

Mapa 1.29: As fronteiras entre Portugal e Galiza.....

Adaptado e traduzido de: http://www.sabuco.com/historia/atlas1.htm

Mapa 1.30: A reconquista cristã portuguesa.

Adaptado e traduzido de: http://www.sabuco.com/historia/atlas_hespaña.htm

http://www.sabuco.com/historia/images/Reconquista_y_repoblacion_portuguesas.jpg

Mapa 1.31: Divisão dialetal em Portugal. .75

Extraído de: http://www.instituto-camoes.pt/cvc/hlp/geografia/mapa02.html

Mapa 1.32: A língua portuguesa no mundo.

Extraído de: http://www.instituto-camoes.pt/cvc/hlp/geografia/index.html

Mapa 1.33: As atividades portuguesas no litoral brasileiro, no século XVI

Extraído de: http://www.multirio.rj.gov.br/historia/modulo01/top01.html

Mapa 1.34: As expedições bandeirantes do século XVIII. .78

Extraído de: http://www.multirio.rj.gov.br/historia/modulo01/top01.html

Mapa 1.35: A expansão da colonização e a expansão territorial do Brasil...... 79 Extraído de: http://www.multirio.rj.gov.br/historia/modulo01/top01.html

\section{Capítulo 3}

Figura 3.1: Mafalda e o sufixo -ista.

Extraído de: http:// www.mafalda.net. 


\section{Lista de tabelas}

\section{Capítulo 2}

Tabela 2.1. Alguns prefixos gregos e latinos.....................................................................

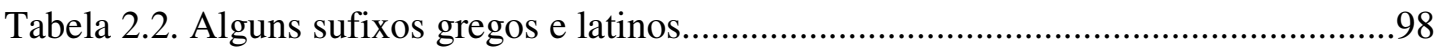

\section{Capítulo 4}

Tabela 4.1. Ocorrências do sufixo -ista nos gêneros da escrita em corpora galego. 192

Tabela 4.2. O sufixo -ista nos gêneros da escrita em corpora galego em valores absolutos e em valores percentuais.

Tabela 4.3. Classificação semântica das ocorrências do sufixo -ista em corpora galego..195

Tabela 4.4. Classificação semântica das ocorrências do sufixo -ista em corpora galego com os valores absolutos e com os valores percentuais obtidos.........................................196

Tabela 4.5. Ocorrências do sufixo -ista em corpora do português medieval.......................198

Tabela 4.6. Ocorrências do sufixo -ista nos gêneros da escrita em corpora lusitano...........200

Tabela 4.7. O sufixo -ista nos gêneros da escrita em corpora português em valores

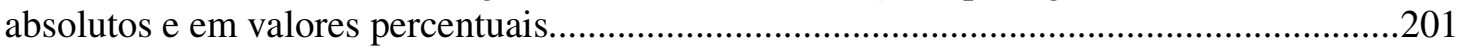

Tabela 4.8. Classificação semântica das ocorrências de -ista em corpora lusitano............206

Tabela 4.9. Classificação semântica das ocorrências do sufixo -ista em corpora português com os valores absolutos e com os valores percentuais obtidos.........................207

Tabela 4.10. Ocorrências do sufixo -ista nos gêneros da escrita em corpora brasileiro.....210

Tabela 4.11. O sufixo -ista nos gêneros da escrita em corpora brasileiro em valores

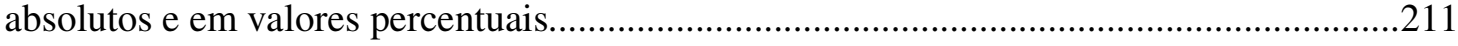

Tabela 4.12. Classificação semântica das ocorrências de -ista em corpora brasileiro........215

Tabela 4.13. Classificação semântica das ocorrências do sufixo -ista em corpora brasileiro com os valores absolutos e com os valores percentuais obtidos..........................216

Tabela 4.14. Uso de formações com o sufixo -ista ...........................................................218

Tabela 4.15. Ocorrência de formações com o sufixo -ista nos gêneros da escrita...............220

Tabela 4.16. Uso de formações com o sufixo -ista no gênero prosaico................................220

Tabela 4.17. Uso de formações com o sufixo -ista no gênero poético.................................222 
Estudo comparativo de aspectos semânticos do sufixo -ista no português e no galego.

Tabela 4.18. Uso de formações com o sufixo -ista no gênero teatral..................................224

Tabela 4.19. Crescimento do uso do sufixo -ista nos gêneros da escrita.............................226

Tabela 4.20. Uso de formações como sufixo -ista em uma única edição de jornal...........229

Tabela 4.21. Classificação semântica das palavras com -ista na edição de jornal..............231

Tabela 4.22. Classificação semântica das palavras com -ista na prosa..............................233

Tabela 4.23. Classificação semântica das palavras com -ista na poesia.............................235

Tabela 4.24. Classificação semântica das palavras com -ista no teatro..............................237

Tabela 4.25. Classificação semântica geral das formações usadas com o sufixo -ista......239

\section{Capítulo 6}

Tabela 6.1. Localidade dos topônimos-base de gentílicos sufixados com -ista.................289

Tabela 6.2. Topônimos-base (confirmados) de gentílicos sufixados com -ista .................290

Tabela 6.3. Tipos dos topônimos-base dos gentílicos sufixados com -ista.......................291

Tabela 6.4. Datação dos gentílicos sufixados com -ista...............................................296 
Estudo comparativo de aspectos semânticos do sufixo -ista no português e no galego.

INTRODUÇÃO

Muchas veces tomé la pluma para escribille, y muchas la dejé, por no saber lo que escribiría.

(Miguel de Cervantes) 
Estudo comparativo de aspectos semânticos do sufixo -ista no português e no galego.

\section{Introdução}

A presente dissertação nasceu das discussões e estudos desenvolvidos pelo Grupo de Morfologia Histórica do Português (GMHP), cadastrado no CNPq e liderado pelo Prof. Dr. Mário Eduardo Viaro, cujo objeto de trabalho é, entre outros, desenvolver uma metodologia para melhor refletir e procurar entender a formação de palavras no português, aliando o método sincrônico por meio da análise das regras de formação de palavras (RPF) ao estudo diacrônico e etimológico da formação lexical. Dessa maneira, o grupo, inicialmente, decidiu concentrar seus esforços no viés da análise semântica do processo de derivação sufixal.

De acordo com SAID ALI (1930: 15), frente à derivação prefixal, a derivação por sufixação geralmente tem se mostrado como um processo mais produtivo na formação de palavras; em parte, pela grande quantidade de sufixos existentes na língua portuguesa e pela flexibilidade que apresentam na sua distribuição e combinação com os demais sufixos, em parte, pela variedade semântica que adquirem no processo ao longo do tempo. Por outro lado, também o processo de sufixação envolvido na formação lexical é reflexo não só da semântica do sufixo desenvolvida em cada período e/ou em cada região, mas também do desgaste de uso sofrido pela partícula sufixal quando de alta frequiência e/ou produtividade.

Daí, o estudo da produtividade dos sufixos, aliado à freqüência de uso e à observação de mudanças semânticas são partes fundamentais de um processo diacrônico. Assim, propõese um estudo semântico das palavras formadas com o elemento -ista e uma classificação semântica do sufixo -ista, comparativo no português e no galego.

É bastante comum ouvir que o português brasileiro é mais parecido com o galego que com o português lusitano, sobretudo em muitos traços fonéticos, como alguns vocalismos e em certas estruturas sintáticas, como o uso de verbos em gerúndios. Entretanto, apesar das várias pesquisas já concentradas nessa área, é preciso uma gama maior de estudos científicos acerca dos fatos observados por viajantes e visitantes no Brasil, Portugal e Galiza, que englobem os vários fatores, não somente fonéticos e sintáticos, pertinentes à proximidade dos falares dessas regiões.

Segundo PAZ (1999: 461), na primeira década do século XX, o presidente da Real Academia Galega, cujo nome não é citado pelo autor, teria definido a língua galega como "a que falam e entendem cerca de três milhões de galegos, dezoito milhões de habitantes em 
Portugal e seus domínios, e doze milhões no Brasil”. Já, o filólogo português José Leite de Vasconcelos, apud PAZ (1999: 461), em seu artigo "Língua e literatura gallega", afirma que o galego e o português compartilharam um passado comum, mas que no final do século XIX, seus elementos diferenciais eram suficientes para serem consideradas duas línguas distintas, entretanto, como o galego, segundo o autor, carecia de uma literatura suficientemente desenvolvida e não era um idioma representativo de um país independente, optava por considerá-lo como um co-dialeto do português. No mesmo período, José Leite de Vasconcelos, também considerara como dialeto à modalidade que o português havia assumido na América, orientando-se pelo parentesco historicamente condicionado entre o português originário, e suas formas ultramarinas. Sabe-se que as variedades dialetais, tanto no Brasil como em Portugal, sempre sofreram com a pressão da língua culta, pelo menos dentro de cada um dos dois países que têm o português como língua oficial. Na Galiza, no entanto, a pressão sobre as falas locais não foi exercida pelo galego culto, mas pela língua oficial do país que é o castelhano, e isto, entre outros fatores, trouxe consigo o afastamento entre o galego e o português, ainda que a marca destas duas línguas seja a proximidade, dado seu passado comum. Segundo BASSETTO (2001: 242), ainda que tenha sofrido forte influência do castelhano como língua imposta, "o galego não se descaracterizou, mantendo sua feição própria, bem mais próxima do português".

Assim, as circunstâncias históricas fizeram com que o galego divergisse do português na sua forma ortográfica, devido principalmente à atual ortografia oficial galega estar apoiada na perspectiva do castelhano. De forma menos gritante, também divergem as ortografias do português brasileiro e lusitano. As diferenças são encontradas, ainda, no vocabulário, pois, por exemplo, o galego apresenta castelhanismos, o português brasileiro apresenta influência indígena, já o lusitano mostra características do árabe e de suas ex-colônias. No campo fonético as falas das duas margens do rio Minho são muito parecidas entre si, entretanto a galega, em geral, está mais distanciada foneticamente da fala lisboeta que do falar paulista em relação a muitos vocalismos. Sob alguns aspectos morfológicos, como a derivação sufixal, o galego pode estar mais próximo do português de Portugal que do brasileiro; entretanto, sob aspectos sintáticos a língua galega se aproxima mais do português do Brasil que do lusitano.

\footnotetext{
${ }^{1}$ Publicado em El País Gallego, em junho de 1888.
} 
Estudo comparativo de aspectos semânticos do sufixo -ista no português e no galego.

Segundo Mattos e Silva (2002), quase todos os traços regionais do português europeu que não aparecem na língua culta do Brasil se encontram em algum ponto dialetal brasileiro, concluindo que as variedades dialetais brasileiras representam em conjunto um sincretismo das portuguesas. Pode-se generalizar dizendo que as variedades brasileiras representam um sincretismo das portuguesas e galegas, devido à semelhança com o galego, à conservação de traços do português arcaico vigentes no galego, e mesmo a influências recebidas com a grande imigração proveniente da Galiza.

Para CÂMARA JR (1976: 30-31), as diferenças da língua padrão entre Brasil e Portugal são explicadas principalmente pelo fato de a língua se achar em territórios politicamente distintos. $\mathrm{O}$ mesmo também se aplica à diferença que há entre o português brasileiro, o lusitano e o galego, os três se desenvolveram em territórios politicamente separados, a partir de um núcleo comum. De acordo com TEYSSIER (1997: 116), os brasileiros assumem uma posição bastante moderada sobre a questão das línguas, reconhecendo uma unidade dentro da língua portuguesa, mas a especificidade brasileira no sistema lingüístico do português.

Já, conforme CunHA (1981: 15):

"a distinção que as duas variantes nacionais da língua portuguesa apresentam em sua forma culta: a vigência de uma só norma em Portugal; no Brasil, a ocorrência de dualidade ou de assimetria de normas, com predominância absoluta da norma portuguesa no campo da sintaxe, o que dá a aparência de maior coesão do que a real entre as duas modalidades idiomáticas, principalmente na língua escrita”.

Para MENÉNDEZ PIDAL (1964: 228-249), a unidade da língua não exige a imposição de uma norma única, a língua se desenvolve de acordo com o seu contexto sócio-histórico, dessa maneira, a variabilidade normativa longe de atentar contra a unidade do idioma, contribuiria para estabelecer uma maior compreensão entre as diversas modalidades da língua em uso. Generalizando-se essas idéias para falares próximos, mas sem entrar no âmbito das questões lusistas $^{2}$, galeguistas ${ }^{3}$ e brasileiristas ${ }^{4}$; ao incluir o galego, deveriam ser assinaladas três

\footnotetext{
${ }^{2}$ Corrente de lingüístas que defendem o galego não como uma língua, mas como um dialeto do português. Nessa linha, também defendem que a variante brasileira é um dialeto.

${ }^{3}$ Corrente de lingüístas que defendem o galego como uma língua independente com um sistema próprio e diferente do português e do castelhano.

${ }^{4}$ Corrente de lingüistas que defendem o brasileiro como uma língua independente com um sistema próprio e diferente do português europeu.
} 
normas cultas: a portuguesa, a brasileira e a galega; bem diferenciadas entre si, mas que não impedem a mútua compreensão dos que a elas se adaptam.

De acordo com CunHA (1981: 15-18), é a história quem explica a relativa unidade existente entre a língua culta de Portugal e do Brasil e as sensíveis, por vezes profundas, diferenças da língua popular em áreas dos dois países. É o estudo histórico, de forma geral, que pode explicar também o desenvolvimento do núcleo comum do português brasileiro, lusitano e galego, bem como as suas divergências. Por isso, no primeiro capítulo, faz-se um panorama histórico, tentando evidenciar fatores sócio-culturais e circunstâncias históricas que influenciam o desenvolvimento de uma língua nos seus mais variados aspectos. Nessa direção, o estudo tenta mostrar a importância do grego ${ }^{5}$ desde o Império helênico, citando, também, a importância do latim e as influências extra-lingüísticas decorrentes de traumas históricos, geográficos, sócio-culturais sofridos durante o processo de formação e desenvolvimento das línguas portuguesa e galega, tentando, assim, justificar pelo menos em parte, o fato de que as línguas não são estáticas, sofrem várias influências, moldam-se e modificam-se de acordo com as necessidades de seus falantes. O traçado histórico começa com o grego, pois, sabe-se que o sufixo em estudo surge na cultura helênica, propagando-se pela koiné usada no período. Daí, concentra-se na expansão do Império Romano e no processo de romanização da Península Ibérica, tendo o latim como língua franca no período e, em particular, língua veicular do sufixo -ista, já importado do grego. Em seguida, traça-se um histórico da decadência do Império Romano do Ocidente juntamente com a chegada e a instalação dos assim chamados "povos bárbaros" e a sua influência na Península Ibérica. Em seguida, explica-se a expansão do Império Árabe e sua cultura nos territórios peninsulares e, segundo MENÉNDEZ PIDAL (1968: 16), o importante período da "Reconquista Cristã" para a formação dos atuais falares ibéricos. Segue-se, com a fase de formação do galego e português a partir do galego-português, um núcleo comum, e sua separação por motivos políticos. Ademais, faz-se um resumo da trajetória e do desenvolvimento da língua galega, que passou pelos Séculos Escuros quase a ponto de desaparecer principalmente no âmbito escrito, mas foi retomada pelo movimento do Rexurdimento no século XIX, entretanto, foi novamente proibida durante o período franquista (1936-1974) desenvolvendo-se com seus emigrantes e descendentes fora das terras galegas, e a partir de 1972, voltou a ser estudada na Galiza e

\footnotetext{
${ }^{5}$ Pois o sufixo -ista é proveniente do grego.
} 
Estudo comparativo de aspectos semânticos do sufixo -ista no português e no galego.

foram estabelecidos os parâmetros para a sua normatização. Mostra-se, também o desenvolvimento do português europeu durante o processo de "Reconquista" e após o reconhecimento do Reino de Portugal, como também seu comportamento diante das inovações provenientes da navegação e das colonizações ultramarinas, e os demais fatores sociais e históricos que influenciaram o português lusitano até os tempos atuais, tais como: a decadência do Império Português, a independência do Brasil, os problemas na sucessão ao trono, o período das duas grandes guerras européias, a independência de Angola e de Moçambique, a Revolução dos Cravos e o ingresso na Comunidade Européia. Como parte integrante, é feito também um traçado histórico do desenvolvimento do português no Brasil, desde a colonização, as influências indígena, africana e espanhola; o processo de povoamento do interior do país, associado também às demais influências provenientes das levas de imigrações recebidas; as políticas associadas aos ciclos econômicos; além das influências de Portugal como metrópole, França, Inglaterra e, posteriormente, Estados Unidos da América, assim como das línguas francas: o francês e o inglês. Dessa forma, mostra-se com o auxílio da história que, da mesma maneira como a sociedade e a cultura sofreram inúmeras modificações, adaptações e miscigenações, também a língua e seus componentes sintáticos e morfológicos, durante o processo de desenvolvimento, foram modificados, adaptados e miscigenados para melhor representarem o momento sócio-político e histórico que expressam.

Por outro lado, o estudo do sufixo deve envolver profundamente a derivação, pois, sabe-se que a sufixação é um processo de formação de palavras, daí a importância do segundo capítulo, no qual é feito um apanhado geral dos paradigmas atuais da teoria morfo-semântica sobre a formação de palavras nas línguas portuguesa e galega, centrando-se na derivação por sufixação e, principalmente em três classificações morfo-semânticas encontradas na literatura especializada: a classificação galega dada por FREIXEIRO MATO (1999: 228-234), a classificação brasileira oferecida por SANDMANN (1989: 32-66), e a classificação portuguesa de Rio-ToRTo (1998: 112-114), para serem usadas como uma base de apoio fundamental, nos capítulos seguintes, na análise e na proposta de uma classificação semântica própria para o sufixo -ista, a partir da classificação semântica das palavras por ele formadas, levando em conta alguns fatores relevantes como os bloqueios, a dimensão histórica e também etimológica nos estudos. 
Sabendo-se que as influências recebidas do grego nas línguas portuguesa e galega também foram recebidas em outras línguas, dados os fatores históricos apontados no capítulo primeiro, no terceiro capítulo faz-se, então, um panorama atual dos estudos sobre as características morfo-semânticas das palavras derivadas a partir das formas do sufixo estudado encontradas em várias línguas, tais como: japonês, hebraico ${ }^{6}$, basco, russo $^{7}$, polonês, alemão, inglês, francês, italiano, catalão, valenciano, castelhano, galego e português. Ao final, baseando-se no panorama, nos critérios morfo-semânticos estudados e, tendo como apoio as classificações vistas no capítulo segundo, propõe-se uma classificação genérica e simples, porém capaz de abranger as várias categorias semânticas apontadas atualmente pelos dicionários, pelas gramáticas e pelos especialistas de cada língua, para as palavras derivadas a partir das formas que o sufixo grego assume em cada uma das línguas apontadas.

Tomando como base a classificação geral obtida no terceiro capítulo e centrando-se, agora, no português e no galego, no capítulo quarto, é feito um estudo de ocorrências das formações com o sufixo -ista em corpora. Assim, inicialmente, houve uma coletânea de textos abrangente e significativa de cada período para cada caso a ser analisado de forma comparativa: o português (de Portugal e do Brasil) e o galego, através do mapeamento da semântica das palavras formadas com o sufixo -ista. Dos textos recolhidos foram extraídas todas as palavras formadas por meio do processo de sufixação através do elemento -ista, obtendo-se para cada período, uma lista de palavras; que são os dados pertinentes para o mapeamento do sufixo em corpora. Foi feita, então, uma classificação semântica das formações encontradas com o sufixo -ista, baseando-se na observação dos dados coletados bem como nas classificação obtida no segundo capítulo. Aplicando-se a classificação aos dados obtidos, pôde-se fazer uma comparação bem genérica, a título de ilustração e motivação da pesquisa, do comportamento do sufixo apresentado em corpora, no século XIX e XX, no galego, no português brasileiro e no português lusitano. Convém notar que a pesquisa feita entre os séculos XII e XIV considera o galego-português como uma língua única, e dada a escassez de formações com o sufixo no período, não foi possível dividir entre os textos da Galiza e os de Portugal. Analogamente, a pesquisa feita entre os séculos XV e XVIII considera a língua portuguesa como um todo, sem diferenciar a variante européia da americana, convém observar também que esse e é o período dos Séculos Escuros para a

\footnotetext{
${ }^{6}$ Os exemplos em hebraico foram transliterados usando-se a norma da Associação Americana de Bibliotecas.

${ }^{7}$ Os exemplos em russo foram transliterados usando-se a norma da Associação Americana de Bibliotecas.
} 
Estudo comparativo de aspectos semânticos do sufixo -ista no português e no galego.

língua galega, portanto os dados mais abundantes para o estudo somente aparecem no século XIX e XX. Deve-se ressaltar, ainda, que como o estudo é comparativo, os textos que a rigor pertencem ao século XXI, datados de 2000 a 2006, foram considerados pertencentes ao século XX. Desse modo, para os séculos XIX e XX, foram coletados textos de prosa, poesia e teatro escritos em galego, português europeu e português brasileiro, podendo-se então comparar as ocorrências das formações com -ista em cada um dos gêneros literários e dividí-las conforme a classificação semântica usada. A título de ilustração, foi usado também como corpora representativo da prosa jornalística de 2006: uma edição do jornal Galicia-Hoxe, publicado em Santiago de Compostela, para o galego; uma edição do jornal O correio da manhã, publicado em Lisboa, para o português lusitano; e uma edição do jornal $O$ Estado de São Paulo, publicado em São Paulo, para o português brasileiro.

No quinto capítulo deste trabalho, tendo como motivação o capítulo anterior, apresenta-se uma classificação semântica mais refinada. Para tal, foi usada como corpora do português uma lista com duas mil e trezentos e oitenta e cinco (2385) formações com -ista encontradas no Houaiss da Língua Portuguesa (2001), no Dicionário da Porto Editora da Língua Portuguesa, na Infopédia (2006) e na Conscienciopédia (2006); e para o galego, foi usada uma lista com mil e oitenta e três vocábulos (1083), obtida pelas formações encontradas no dicionário da Real Academia Galega (2006), no dicionário Pedagóxico da Real Academia Galega (2006), no dicionário da Lingua Galega de Freixó Cid (1999), por meio de pesquisa no TILGA (Tesouro Informatizado da Lingua Galega) e no CORGA (Corpus de Referencia do Galego Actual). Observando-se os dados de cada lista e analisando para cada um sua acepção, pôde-se separar em classes semânticas e chegar a uma classificação bem mais refinada que a encontrada no capítulo anterior. Mesmo sabendo que as paráfrases não são suficientes para explicar o processo de derivação como um todo, sempre que possível, associou-se a cada grupo proveniente da classificação morfo-semântica, uma paráfrase envolvendo o processo de derivação com o sufixo -ista e a acepção da palavra. Assim, a partir do estudo e da observação da classificação morfo-semântica das palavras formadas a partir de -ista, fez-se um traçado para um possível mapeamento do sufixo, mostrando-se a relevância dos estudos históricos e etimológicos nesse traçado, bem como nos estudos de concorrência sufixal citados a título de ilustração. Neste caso, como também em outros, as informações históricas e etimológicas são essenciais. De acordo com RIO-TORTO (1998: 140), 
há seis casos onde a descrição sincrônica de uma unidade lexical é insuficiente e as descrições históricas mostram-se úteis: na identificação do estatuto e dos tipos de constituintes lexicais, clarificação do caráter compósito das palavras, estabelecimento de tipologias de palavras de estrutura complexa, reconstituição da evolução formal e semântica das palavras, explicação das reestruturas dos sistemas afixais, determinação dos paradigmas genolexicais.

No capítulo seis é apresentado, a título de exemplo, um estudo mais aprofundado das características de uma das subclasses semânticas encontradas no capítulo anterior, a que forma as palavras gentílicas. Faz-se, então, uma comparação das formações com -ista que designam gentílicos, mostrando que na Galiza e em Portugal, atualmente tal formação não é produtiva, no entanto o é no Brasil, e possivelmente o seja no português de Angola.

Deve-se ressaltar que o castelhano - dados os fatores históricos que o conectam estreitamente com o galego e o português, "em confronto com os demais léxicos românicos, o do português apresenta, como era de esperar, um flagrante paralelismo com o castelhano" PIEL (1989: 11) - foi usado como um instrumento auxiliar no estudo, como comparativo e mediador sempre que houve dúvidas com o sufixo -ista, bem como na análise de vertentes semânticas no português, mas principalmente no galego, nos estudos feitos no capítulo quatro, cinco e seis desta dissertação.

E finalmente, chega-se às conclusões e a relevância do estudo nesta última parte, bem como às tendências de estudos e comportamentos semânticos do sufixo -ista, enlaçando todos os demais capítulos desenvolvidos. Deixando sempre em aberto a que se façam novos e mais detalhados estudos para cada proposta apresentada, uma vez que, a classificação semântica não, necessariamente, é única, conforme discussão apresentada no capítulo dois.

Dessa forma, encerra-se a introdução citando RAPOSO (1984):

"A realidade da noção de uma língua, aquilo que lhe dá uma dimensão qualitativa para além de um mero estatuto de repositório de variantes, pertence, mais do que ao domínio lingüístico, ao domínio da história, da cultura e, em última instância, da política. Na medida em que a percepção destas realidades for variando com o decorrer dos tempos e das gerações, será certamente de esperar, concomitantemente, que a extensão da noção de língua varie também." 
Estudo comparativo de aspectos semânticos do sufixo -ista no português e no galego.

\section{CAPÍTULO 1} PANORAMA HISTÓRICO

En balde veñen dias, pasan anos, E inda sigros pasarán.

Se hai abondosas fontes que se secan, Tamén as hai que eternamente manan.

(Rosalía de Castro) 


\section{A importância da língua grega}

A língua grega faz parte da família das línguas indo-européias, ainda que em seu léxico haja empréstimos que notadamente não sejam do indo-europeu. Pode-se seguir o desenvolvimento da língua grega durante um longo período: desde os primeiros traços em sua época micênica até o grego moderno, o que fornece um percurso de mais de três mil anos de uma história política e cultural, nos quais se manteve uma língua viva, que se desenvolveu até os dias de hoje, e ainda segue sua jornada de desenvolvimento.

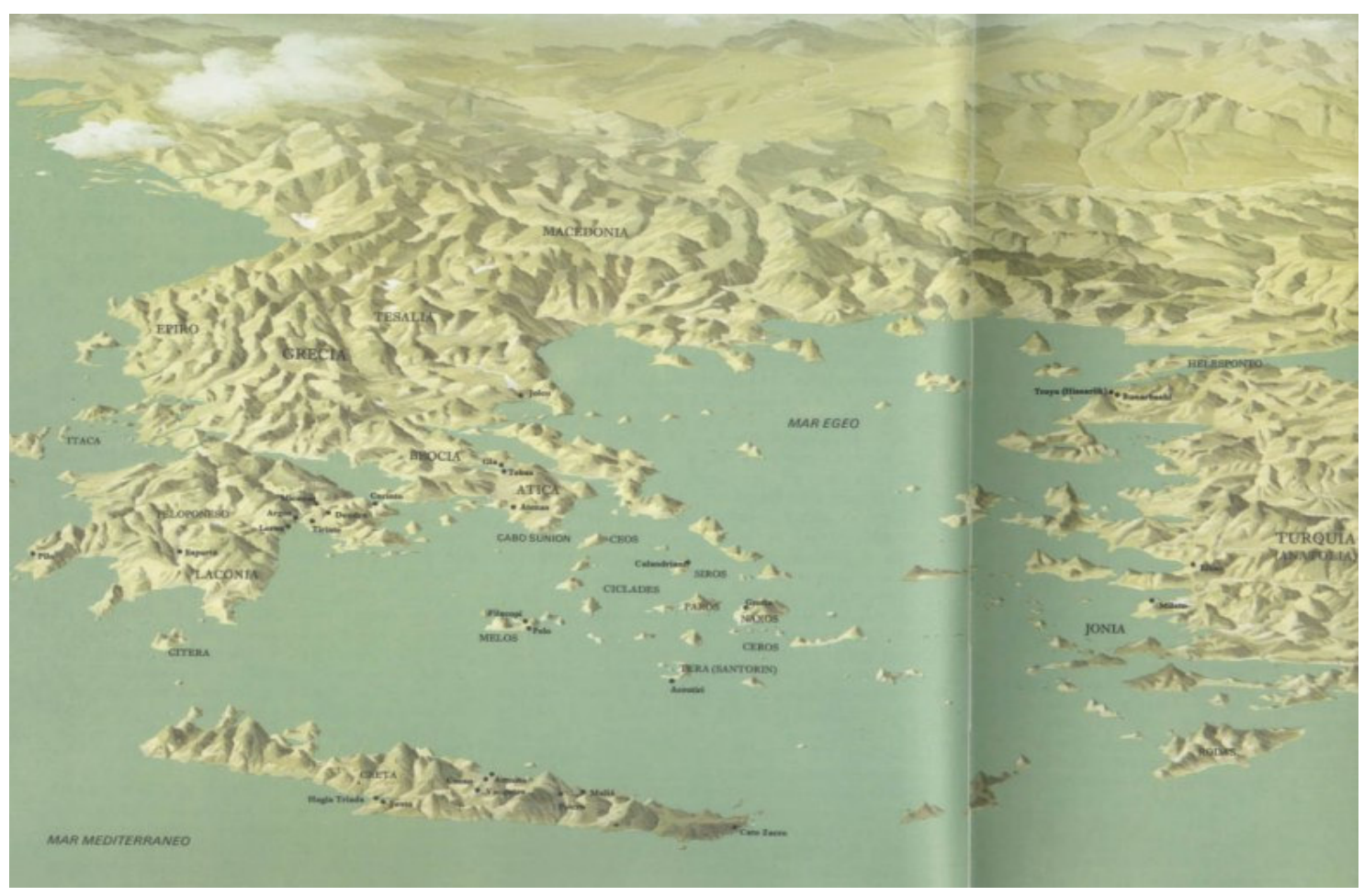

Mapa 1.1: Primeiras civilizações gregas.

De acordo com BuCK (1952: 15-16), os primeiros gregos chegaram à península helênica pelo norte, por volta de 2.000 a.C. e lá se estabeleceram, bem como em suas ilhas. Entretanto, dos povos anteriores, conhecidos pelo nome de pelasgos, pouco se sabe, ainda que seus falares devam ter influenciado traços do grego. Sabe-se que antes da invasão da Península Balcânica, os povos que mais tarde foram chamados de gregos, situavam-se ao norte desta onde tiveram contato com várias línguas indo-européias. Porém, também depois da ocupação do território, limitou-se o contato com povos de línguas similares e de fronteira, ilírios e trácios, que segundo HeRóDOTo $(5,3,1)$, era o maior povo estendendo-se desde o mar 
Estudo comparativo de aspectos semânticos do sufixo -ista no português e no galego.

Trácio até as vertentes meridionais dos Cárpatos e dali emigraram até a Ásia Menor dominando também sua costa, conforme o ilustrado no Mapa 1.1. Acredita-se que mais intensa tenha sido a influência dos povos que pertenciam ao grupo hitito-luvita do indoeuropeu na formação da língua grega, pois na Ásia Menor, com os avanços da colonização "grega" houve um contato cada vez maior com os lídios, cários, lícios, cilícios e paflagões, todos pertencentes ao grupo lingüístico anatólico ou hitito-luvita, conforme HofMANN, DEBRUNNER \& SCHERER (1986: 32-35).

Escritas em grego estão as tábuas micênicas dos séculos XV a XII a.C., feitas em argila, que documentam os arquivos de palácios minóico-micênicos como o Cnossos e que detêm grande interesse de lingüistas e historiadores. Segundo MeILlET (1930: 16-51), no século VIII a.C, introduziu-se e adotou-se o alfabeto de origem fenícia. Na mesma época, a literatura grega começou com os poemas atribuídos a Homero, que foi um grande marco, não somente grego, como da literatura ocidental com a Ilíada e a Odisséia. Desde então, as formas de expressão na cultura grega foram sendo definidas: a épica, a lírica, a prosa historiográfica, a oratória, a filosofia e os tratados científicos, o teatro, especialmente as formas clássicas: tragédia e comédia. Entretanto, a língua grega usada na escrita é complexa, pois houve uma grande variedade dialetal depois que os gregos se estabeleceram na península balcânica e confirmaram a separação de sua língua das demais indo-européias. Conforme PISANI (1954: 4-8), podem ser distinguidos quatro grandes grupos dialetais do grego: jônico-ático, eólio, arcádio-chipriota e dórico que engloba também o grego do noroeste. Os três primeiros são geralmente agrupados na categoria chamada grego aqueu. O jônico era falado na Ásia Menor, nas ilhas Cícladas e na ilha Eubéia; o ático na Ática; o eólio na Tessália, Beócia, na ilha de Lesbos e no litoral da Ásia Menor; o arcádio na Arcádia e em algumas regiões do Peloponeso; o chipriota na ilha de Chipre; o dórico na maior parte do Peloponeso, nas ilhas colonizadas pelos dórios: Creta, Rodes, Cós, Terá e outras, bem como em muitas regiões do Sul da Itália, ou Magna Grécia, e na Sicília; o grego do noroeste era falado na região mais próxima ao mar Adriático, no Epicuro e zonas próximas. Para MeILlet (1930: 73-109), o que é chamado de grego clássico é, em geral, o grego ático dos séculos V e IV a.C., ou seja, o que se usava em Atenas da época de Péricles, de Platão e dos oradores e dramaturgos. A variante ática teve um predomínio sobre as demais devido ao papel exercido por Atenas na cultura helênica, como a cidade da democracia, do teatro e da filosofia, durante a sua hegemonia política. Mesmo 
Estudo comparativo de aspectos semânticos do sufixo -ista no português e no galego.

depois de perder importância política, Atenas continuou a exercer grande influência na cultura grega. Entretanto a épica homérica e a primeira prosa grega foram escritas em jônico.

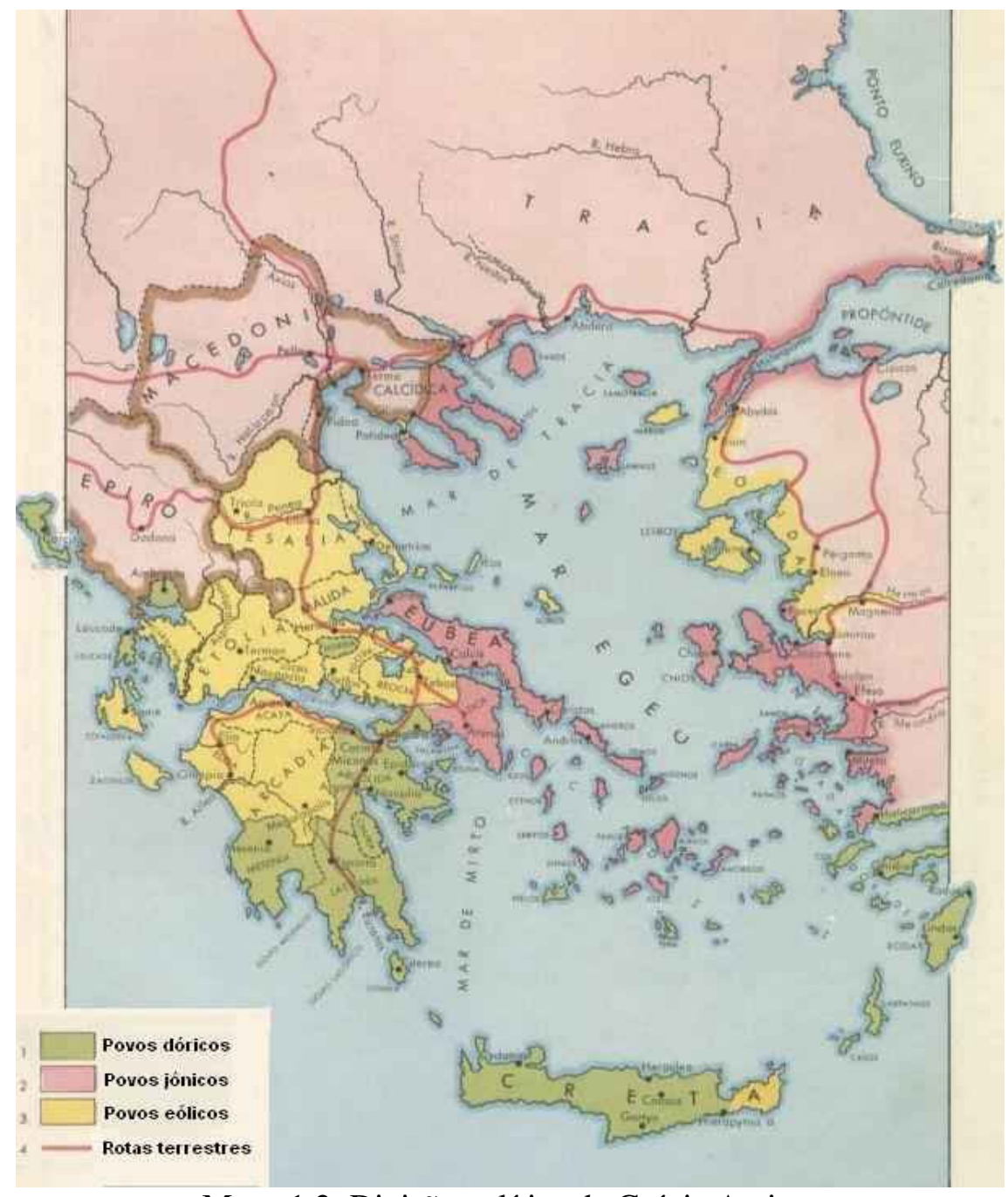

Mapa 1.2: Divisão política da Grécia Antiga.

Houve, então, uma divisão geográfica dialetal devida à distribuição dos povos gregos que colonizaram as diversas zonas helênicas, mostrada no Mapa 1.2. Entretanto, também houve a utilização das variantes de acordo com as convenções literárias, que impuseram aos vários gêneros uma ou outra forma. Por exemplo, Hesíodo era da Beócia, mas compôs os seus poemas em jônico. Píndaro, também da Beócia, compôs suas odes em dórico. Apesar das diferenças dialetais, a língua grega permitia a relação entre uns e outros gregos, mas, os dialetos acabaram desaparendo com a extensão do uso do grego no âmbito comercial e como veículo cultural e de expansão do Império. Essa língua comum grega, ou koiné, que havia 
Estudo comparativo de aspectos semânticos do sufixo -ista no português e no galego.

sido formada sobre o ático, mas com características do jônico e dórico, se consolidou como uma língua franca, de acordo com PISANI (1954: 46-70).

Sabe-se que na Antigüidade houve um período de auge helenístico com a expansão da cultura helênica e da koiné grega como língua franca, em todo o imenso domínio nas costas mediterrâneas, conforme o Mapa 1.3: no norte da África, Egito (como língua oficial) e no Oriente Médio até as fronteiras da Índia, por meio das guerras de conquistas e colonizações, promovidas em sua maior parte por Alexandre, o Grande, no final do século IV a.C. e administradas, logo depois, por seus sucessores. A criação da biblioteca de Alexandria é apenas um exemplo da grande influência exercida pela cultura dos conquistadores. Ainda que o Império Alexandrino tenha sido fragmentado, a influência do grego como cultura e língua manteve-se por muito tempo nessas regiões e pode ser considerada a maior das conquistas de Alexandre, o Grande.

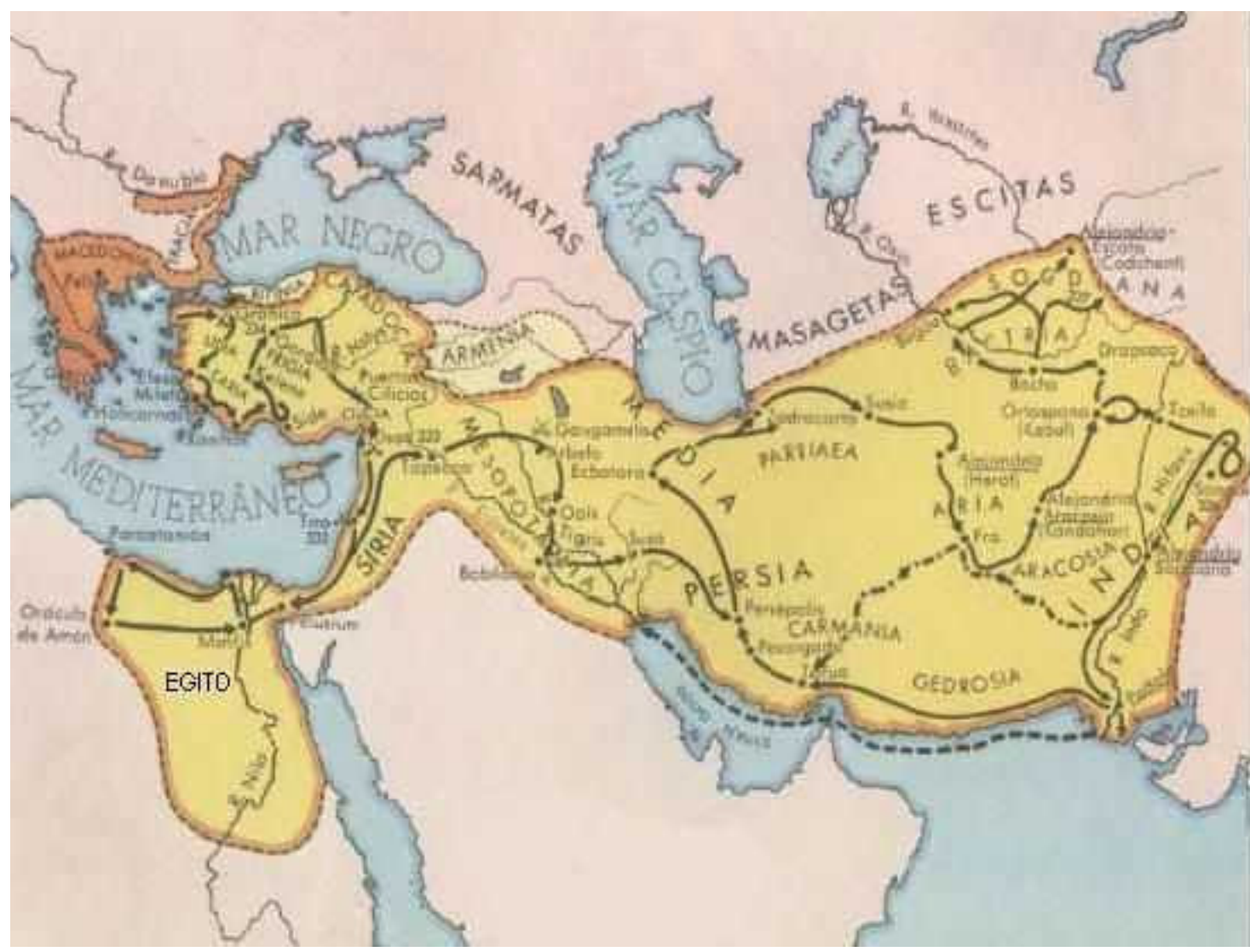

Mapa 1.3: O Império Alexandrino e suas principais rotas de expansão.

É interessante notar, que durante a colonização romana no Oriente Médio, o grego permaneceu ainda como língua franca, identificando seu poder de assimilação pelos povos 
Estudo comparativo de aspectos semânticos do sufixo -ista no português e no galego.

que ali habitavam, já que, segundo BASSETTO (2001: 89): "no Oriente a latinização foi bastante superficial". Assim se explica que os livros sagrados judaicos tenham sido escritos em aramaico e hebraico, enquanto o Novo Testamento (evangelhos, cartas dos apóstolos e apocalipse), pregado pelos cristãos, tenha sido escrito na koiné grega, e não em latim. Dessa forma, a expansão do cristianismo, juntamente com a expansão do Império Romano, como pode ser visto no Mapa 1.4, principalmente após Constantino, levou a uma forte retomada de termos do grego com o uso da bíblia mesmo depois de sua tradução para o latim. Esses termos gregos foram mantidos pela Igreja Católica até hoje por meio do latim eclesiástico.

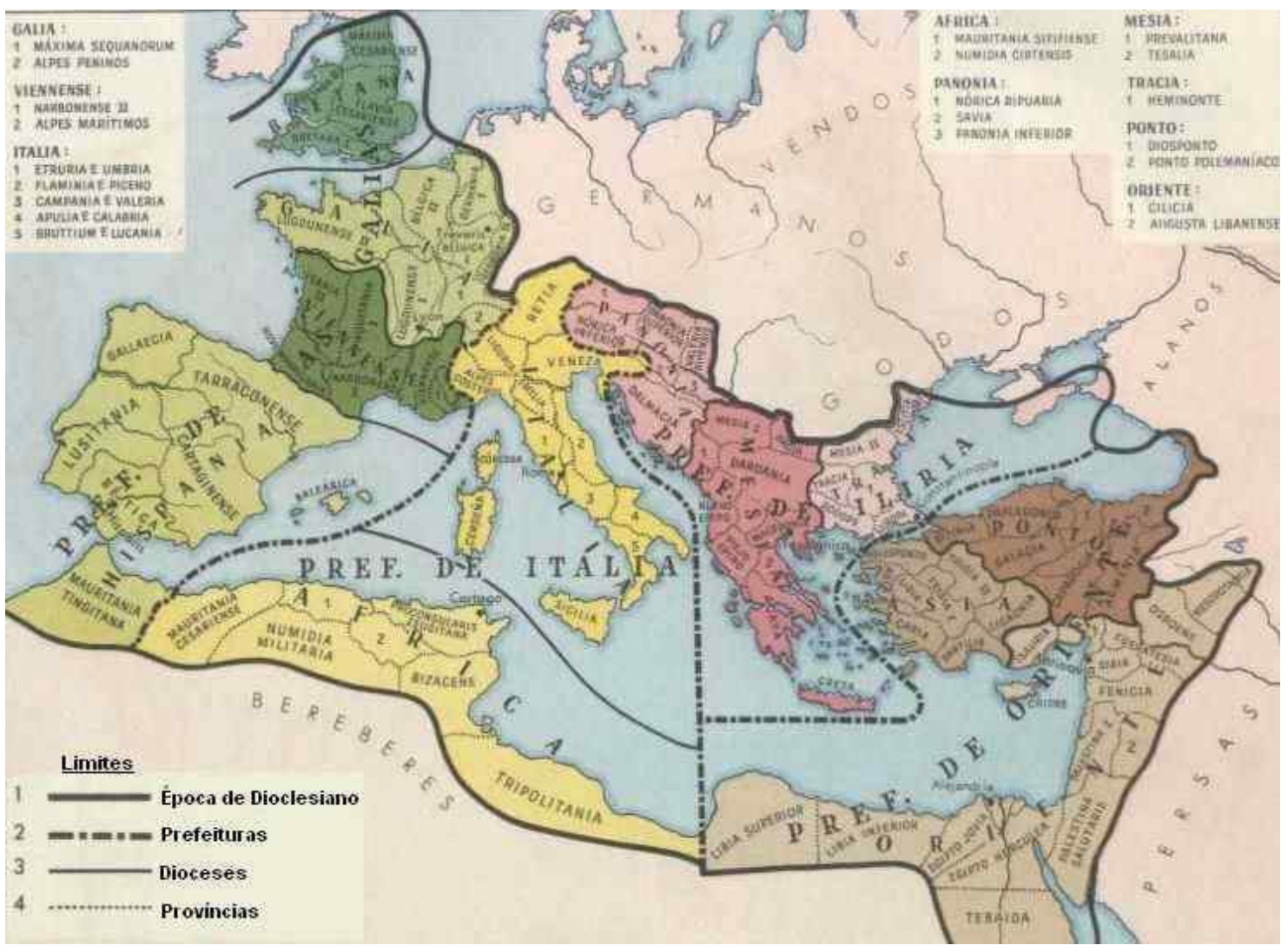

Mapa 1.4: O Império Romano.

A koiné grega também era a língua que os filósofos, mercadores e governantes do Oriente utilizavam durante o Império Romano. Mesmo os romanos escreviam em koiné na zona oriental do Império. Em Roma, estudava-se o grego nas famílias patrícias, pois era a língua da filosofia e ciência. É curioso notar que o Imperador Romano Marco Aurélio (120180) escreveu os seus Solilóquios em grego, pois era uma língua de grande prestígio, mesmo no Império Romano do Ocidente. 
Estudo comparativo de aspectos semânticos do sufixo -ista no português e no galego.

Entretanto, não só a religião e a fraca latinização do Oriente foram os responsáveis pela importância da cultura grega. Os mais diversos fatores, como por exemplo, que muitos dos escravos feitos pelos romanos eram helênicos cultos, ajudaram nessa disseminação de termos gregos no latim. A cultura grega aparece em todos os campos da civilização de Roma: na poesia, mitologia, oratória, escultura e arquitetura. Na filosofia romana também houve grande influência das idéias filosóficas gregas, com discípulos das escolas filosóficas gregas: cínicos, epicuristas, estóicos, pitagóricos, platônicos. Os romanos mais destacados sempre viajavam à Grécia para se educar, ou tinham professores gregos, como também, estudavam as artes helênicas continuando-as em versões latinas. A própria língua latina possui uma estrutura gramatical e sintática muito similar à grega. Então, de certa forma, os romanos souberam absorver e adaptar grande parte da cultura helênica na formação de seu Império, por isso o termo greco-latino, relativo à cultura. Apesar de não se usar o mesmo termo em relação à língua, houve também um determinado grau de absorção e adaptação do grego no latim.

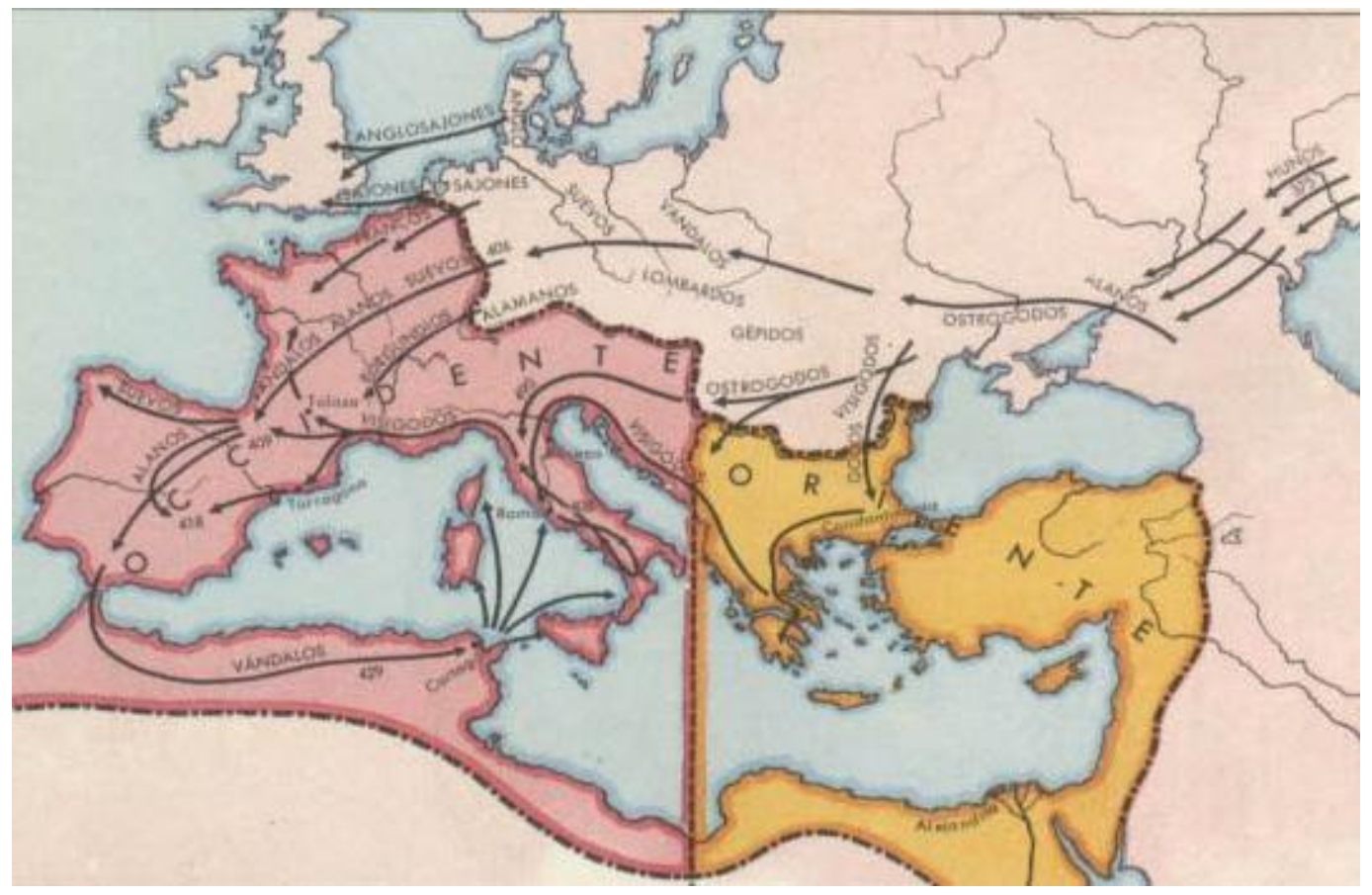

Mapa 1.5: A divisão do Império Romano e as rotas dos povos não-romanos.

Desde que Constantino mudou a capital do Império Romano para Constantinopla, em 330, até a conquista desta pelos turcos-otomanos em 1453, o centro do poder político e cultural helênico passou a ser essa capital. Depois de Teodósio, quando deixou de ser o centro de todo o Império Romano com a divisão (como está ilustrado no Mapa 1.5), para ser o centro 
Estudo comparativo de aspectos semânticos do sufixo -ista no português e no galego.

do Império Oriental, a cidade de Constantino, Constantinopla, Bizâncio ou Istambul, continuou a exercer grande influência helênica na região. Ainda depois da queda de Roma e do Império Romano do Ocidente em 476 (como está ilustrado no Mapa 1.6), o Império do Oriente ainda perdurou por quase mil anos mais, mesmo que suas fronteiras tenham sido reduzidas, suas relações com o mundo ocidental tenham sido dificultadas e a Igreja Católica, uma das fontes de iradiação do grego, tenha sido dividida em Romana e Ortodoxa.

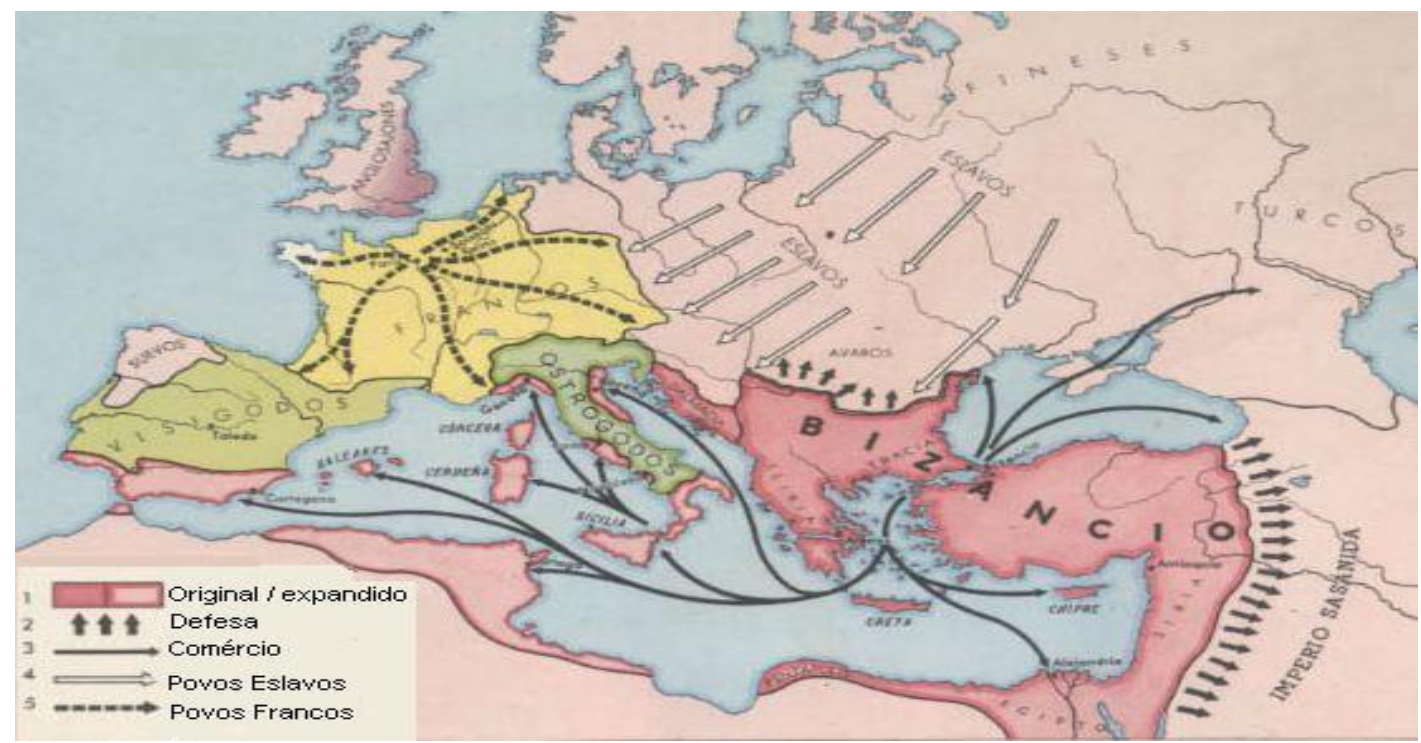

Mapa 1.6: A queda do Império Romano (do Ocidente).

Também o Império Árabe foi transmissor de parte do legado helênico, por meio de suas versões nos livros de medicina, astronomia, geometria, álgebra, ciências, e mesmo em meio à sua expansão com a "Guerra Santa", ainda que com menores proporções foi mantido o Império Bizantino, conforme mostrado no Mapa 1.7. Contudo, o grego foi praticamente esquecido no Ocidente durante a Idade Média e só retomado no Renascimento, após a tomada de Constantinopla pelos turcos-otomanos. 


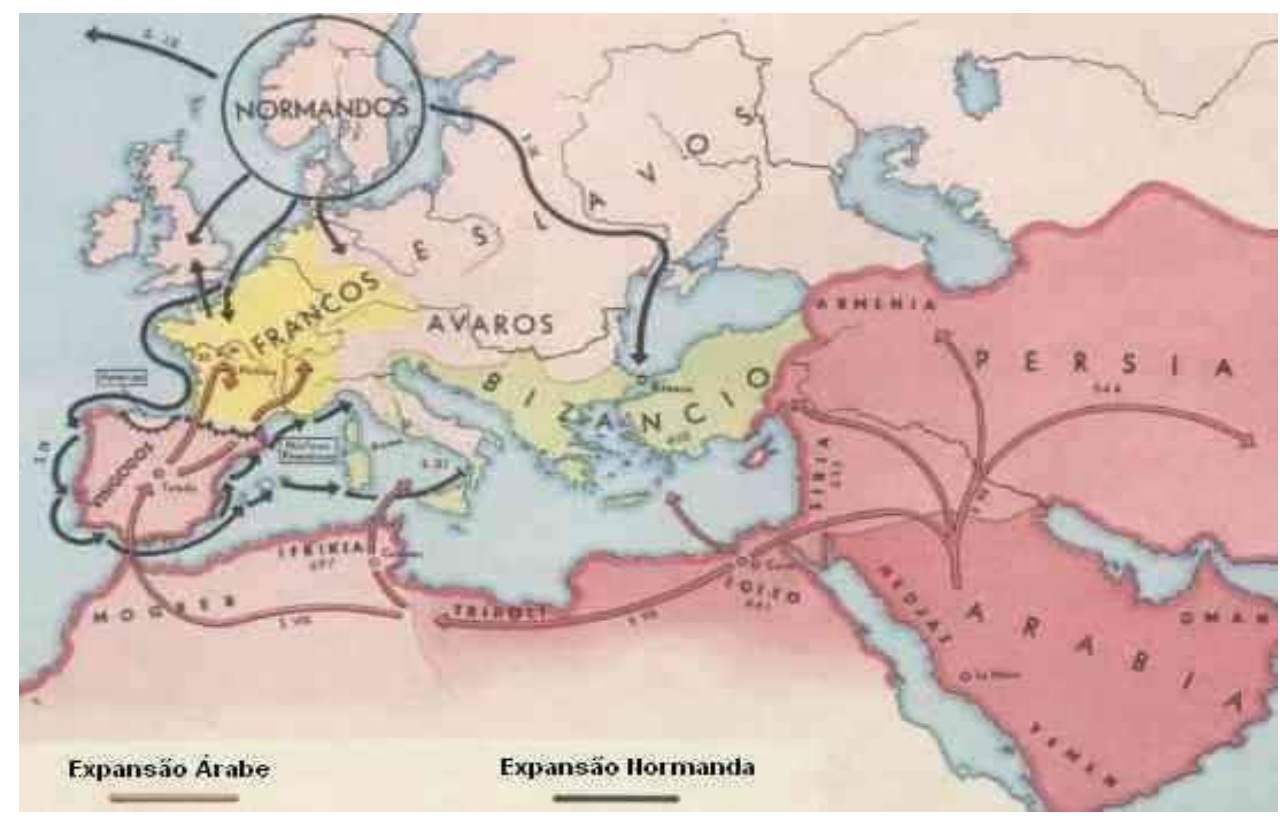

Mapa 1.7: A expansão do Império Árabe.

Constantinopla, em 1204, foi alvo das Cruzadas, organizadas inicialmente para combater a "Guerra Santa" dos islâmicos, mas ainda continuou como centro de uma civilização que conservava a tradição e, principalmente, os textos gregos da Antigüidade Clássica. Após a queda de Constantinopla, tomada pelos turcos, estes textos chegaram ao Ocidente e produziram como fruto o Renascimento. Na Europa dos séculos XIV a XVI d.C., devido às traduções e estudos dos textos gregos da Antigüidade Clássica, sobretudo na Península Itálica, nasceu o movimento Humanista Renascentista, a partir dos manuscritos levados pelos sábios que fugiram de Bizâncio com a ocupação turco-otomana. Entretanto, durante muitos séculos o Ocidente ignorou o grego, enquanto no Oriente se manteve como língua do mundo bizantino.

Depois que os turcos tomaram o poder político e instauraram sua língua em seu domínio, conforme o Mapa 1.8, os gregos continuaram falando sua língua em uma região pobre na antiga Hélade. Somente no século XIX, o grego voltou a ser a língua oficial de uma nova nação, a nova Grécia. O novo grego pode ser considerado uma continuação da koiné que perdurou e também se modificou durante o período de língua franca do Império Alexandrino e do Império do Oriente. 


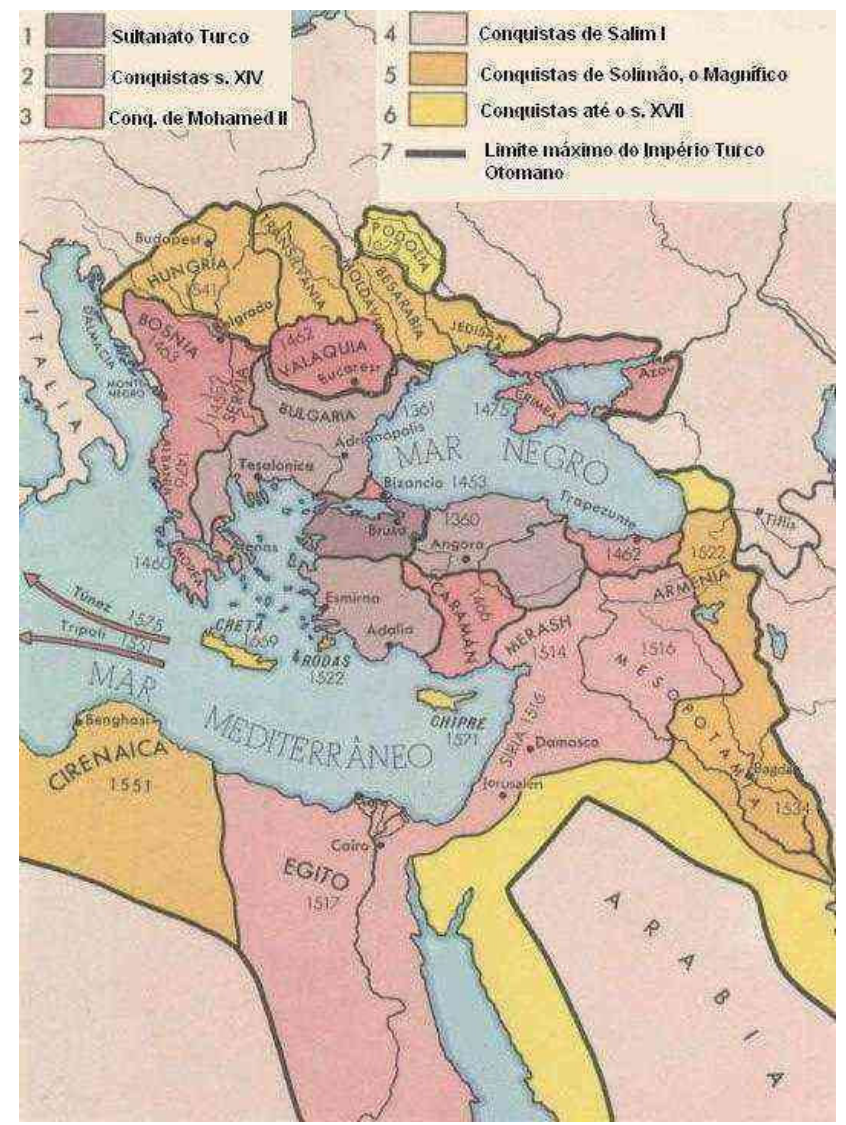

Mapa 1.8: A expansão do Império Turco.

Assim, o Humanismo recuperou no Ocidente a cultura helênica que culminou na corrida pelo saber, nas Universidades e na base para a tecnologia dos últimos séculos. Nesse afã de estudar o panorama do grego começaram os estudos de Filologia Clássica, com ensino da língua grega em centros de excelência, analisando os termos gregos, introduzidos através do latim, e declarando o quanto, segundo LÓPEZ-EIRE (2003), é imprescindível conhecer o grego para conhecer os aspectos culturais e atuais das línguas românicas.

Segundo PIEL (1989: 14), a influência do grego veiculado pelo latim foi muito mais intenso no período humanista e desde então continua até os dias de hoje com vasta importância na formação lexical "sendo porventura a língua portuguesa entre as românicas a que maior rendimento tirou e continua a tirar deste inesgotável manancial que são as línguas clássicas." 
Estudo comparativo de aspectos semânticos do sufixo -ista no português e no galego.

\section{Panorama histórico da Península Ibérica}

Sabe-se que tanto o galego-português como o castelhano e todas as demais línguas históricas e porventura faladas na Península Ibérica foram muito importantes na formação do português e do galego atuais, sob diferentes e variados aspectos, tais como: o léxico, a fonética, as estruturas sintáticas e morfológicas e algumas estruturas semânticas.

O galego, o português, o castelhano, como também a maioria das línguas da região, exceção feita ao basco, originaram-se do processo de romanização da Península aliado ao substrato indo-europeu característico de cada localidade e ainda somado aos superstratos germânicos e aos adstratos vizinhos.

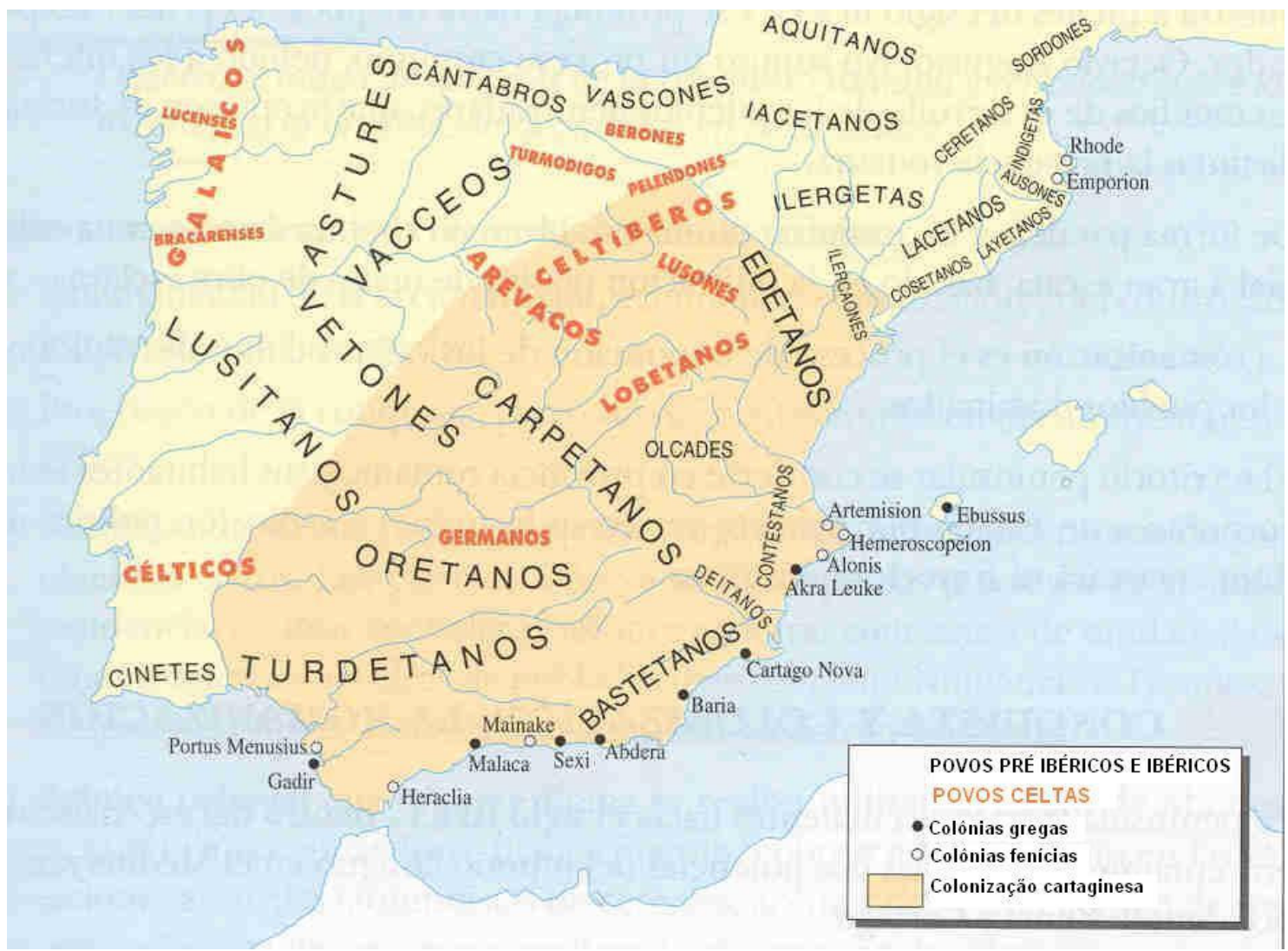

Mapa 1.9: Povos pré-romanos.

De acordo com o Mapa 1.9, podem ser notados os diferentes povos que habitaram a Península Ibérica antes da colonização do Império Romano e que devem ter contribuído decididamente com o substrato local na origem do processo de formação das línguas atuais. Por exemplo, nota-se que a região que foi o berço do galego-português era, no período pré- 
Estudo comparativo de aspectos semânticos do sufixo -ista no português e no galego.

romano, ocupada pelos povos galaicos que ali deixaram um substrato característico de seus falares como herança lingüística.

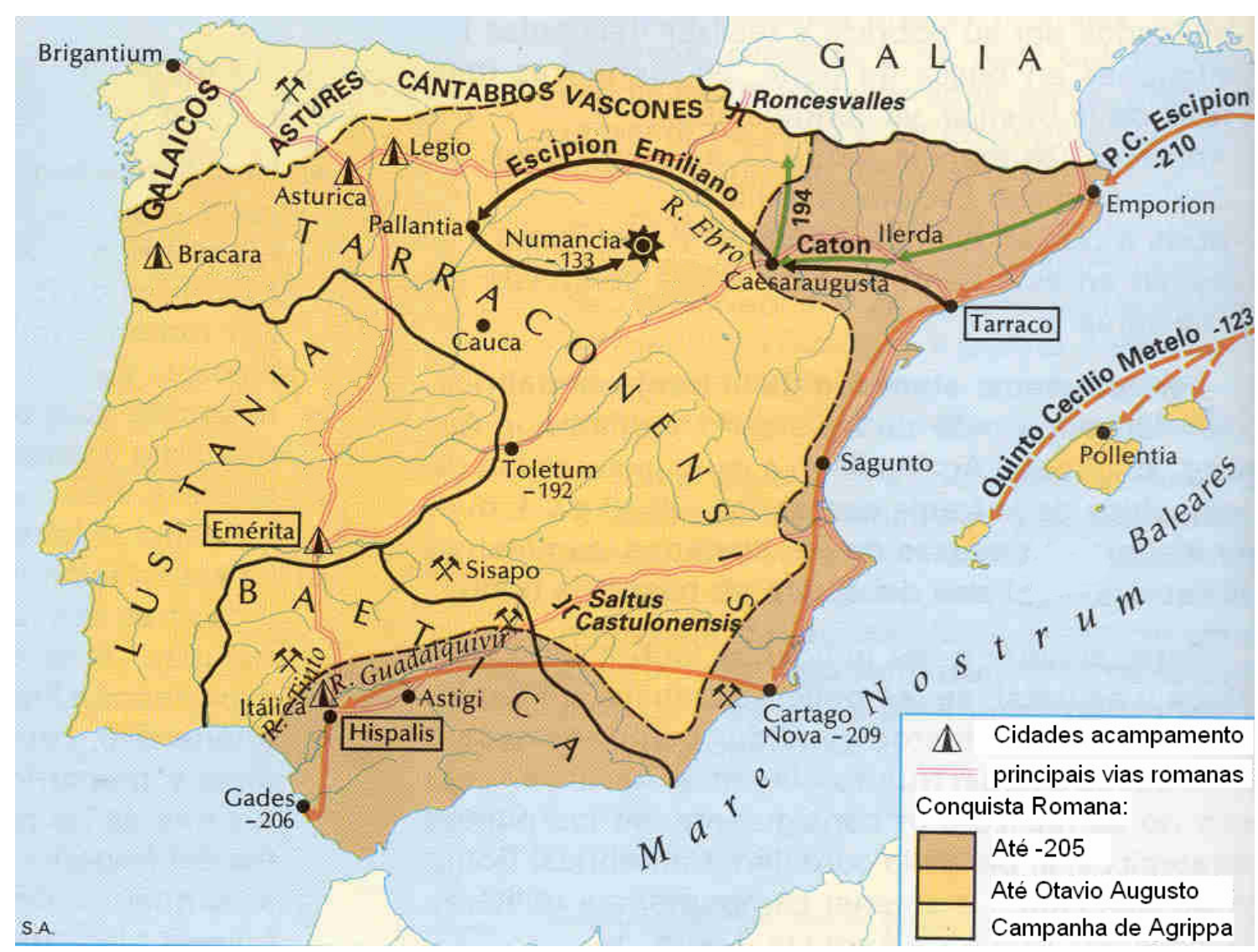

Mapa 1.10: A expansão Romana na Península Ibérica.

No ano de 210 a.C. iniciou-se a colonização da Península Ibérica como empreendimento da expansão do Império Romano, que inicialmente, conforme o Mapa 1.10, nota-se que se deteve no litoral mediterrâneo principalmente visando a estabelecer o domínio de cidades de colonização grega e fenícia. Posteriormente, de 197 a 133 a.C., durante o Império de Augusto, houve uma grande investida em direção ao interior da Península com sua quase total incorporação ao Império, ficando apenas o extremo norte povoado pelos vascones e cântabros, e extremo noroeste, povoado pelos galaicos à margem imperial. Segundo BASSETTO (2001:102), somente em 19 d.C. os povos do norte e noroeste foram romanizados, ainda que Estrabão, em sua Geografia (29 a.C.), afirme que estes povos caracterizavam-se pela "brutalidade e selvageria". 
Estudo comparativo de aspectos semânticos do sufixo -ista no português e no galego.

Durante o processo de romanização, foram introduzidos vários elementos sócioculturais desconhecidos pelos povos autóctones, tais como: o direito romano; a língua latina (processo de latinização); a organização militar, civil e política; a religião cristã (processo de cristianização); que foram assimilados pelos povos da Península conforme a estratégia de colonização aplicada a cada localidade, visando à manutenção e integridade do Império.

Como reflexo dessa romanização, nota-se no Mapa 1.11, que na evolução da divisão política, a região dos povos galaicos foi a de último interesse para o Império Romano. No ano 287, a Gallaecia, província do Império de Dioclesiano, foi descrita por geógrafos e historiadores como os territórios compreendidos desde o Mar Cantábrico até o rio Douro e, desde Finisterris (Oceano Atlântico) até a Cantábria. Suas principais cidades eram Brigantium, atual cidade d'A Corunha; Lucus Augusti, atual cidade de Lugo; Braccara Augusta, atual cidade de Braga e Portucale, atual cidade do Porto.

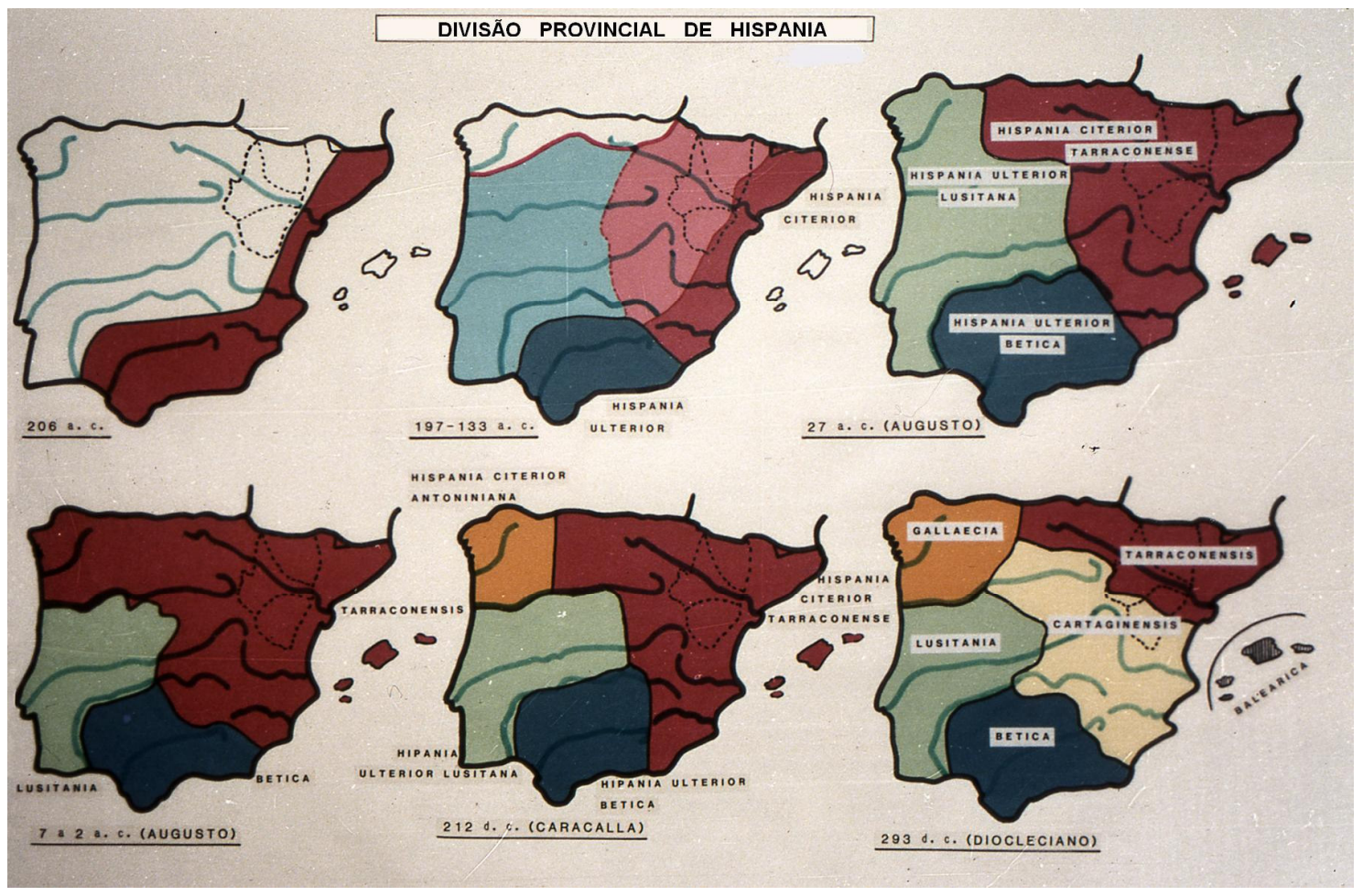

Mapa 1.11: Divisão Provincial da Península Ibérica, durante o Império Romano.

Segundo Monteagudo (1999: 62), o fatores fundamentais que contribuíram para a latinização da região noroeste da Península foram: a reorganização político administrativa com a demarcação do território, que afetou principalmente as elites locais; o exército romano, 
Estudo comparativo de aspectos semânticos do sufixo -ista no português e no galego.

que afetou diretamente os falares das classes mais baixas; a política de concessão de direitos e de cidadania romana; a criação e o crescimento das cidades; a exploração mineira; a escola de Braga; a rede viária que facilitou a mobilidade territorial e possibilitou a integração da Gallaecia ao resto da prefeitura de Hispania, promovendo também a intensificação das atividades comerciais e a imigração de latinos falantes em direção à região. É interessante notar que, se por um lado, a mobilidade no território promoveu uma grande variedade linguiística, por outro lado se apoiou no uso do latim como língua franca.

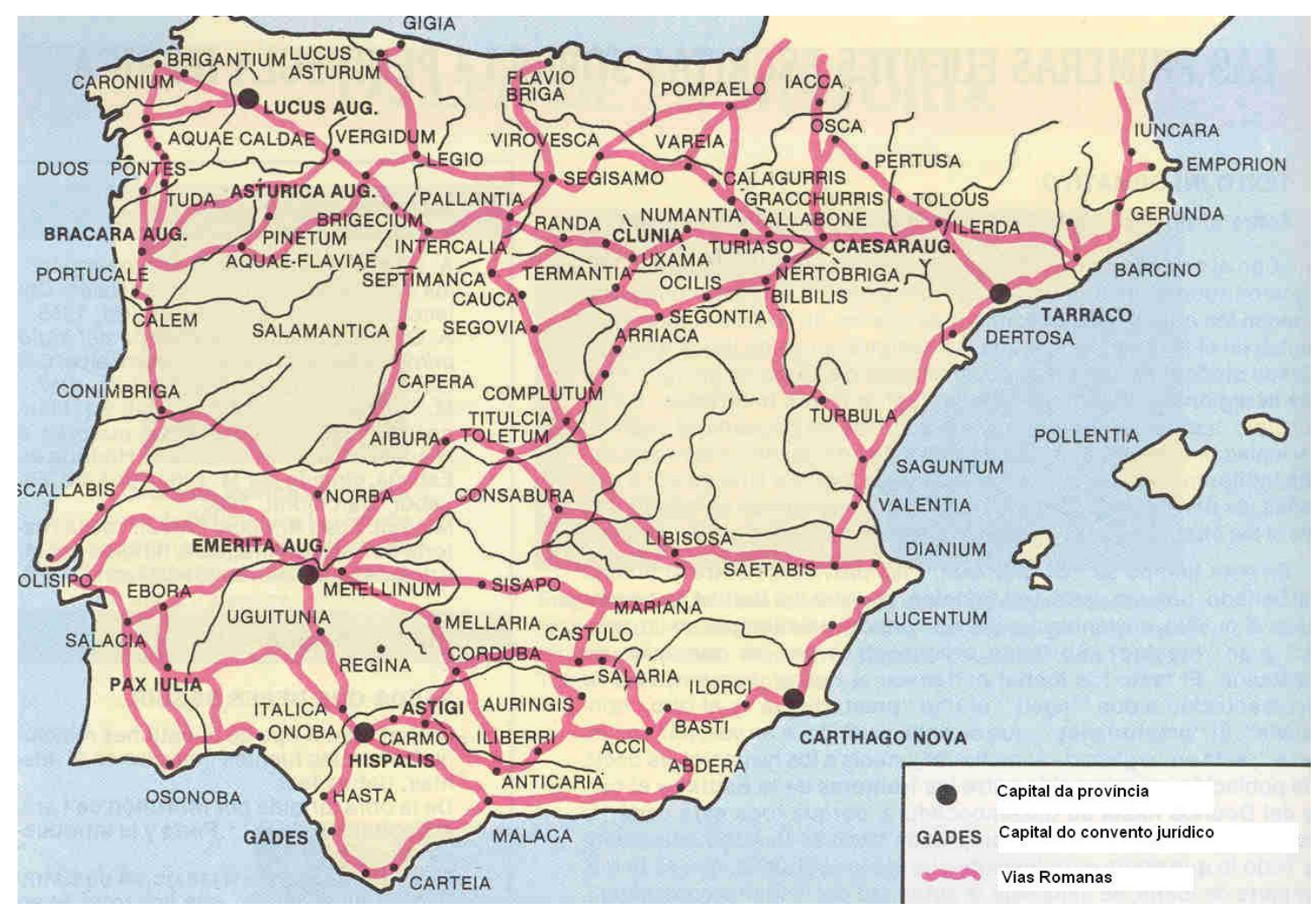

Mapa 1.12: Rede viária na Península Ibérica durante o Império de Dioclesiano.

Segundo Monteagudo (1999: 56), em termos sociolingüísticos, a diglossia proveniente da latinização acabou desencadeando um processo massivo de assimilação lingüística, que culminou com a extinção das línguas autóctones na parte ocidental do Império. Dessa maneira, o latim se sobrepôs às línguas locais e distintas em épocas diferentes na Península Ibérica, significando que, durante a romanização, nunca deve ter havido uma unidade lingüística total na região peninsular. Também é interessante notar que os distintos povos conquistados ao adotar o latim, devem ter passado a pronunciá-lo com seus próprios hábitos articulatórios e a incorporar ao seu léxico palavras autóctones, formando variedades 
Estudo comparativo de aspectos semânticos do sufixo -ista no português e no galego.

dialetais características. Com a construção das vias, conforme o Mapa 1.12, foi estimulada a maior interação entre os povos, propiciando as mais variadas interferências lingüísticas, além do contato permanente com Roma e suas variantes da língua latina. Segundo BASSETTO (2001: 110):

"a norma vulgar foi preponderante no processo de difusão e fixação do latim nas províncias, uma vez que era falada pelo exército, pelos colonos civis e militares e pelos comerciantes - que mantinham contato directo e permanente com as populações autóctones".

Assim, a Gallaecia, uma das últimas regiões a ser romanizada na Península, já moldava suas características, como fruto sociolingüístico, na assimilação do latim.

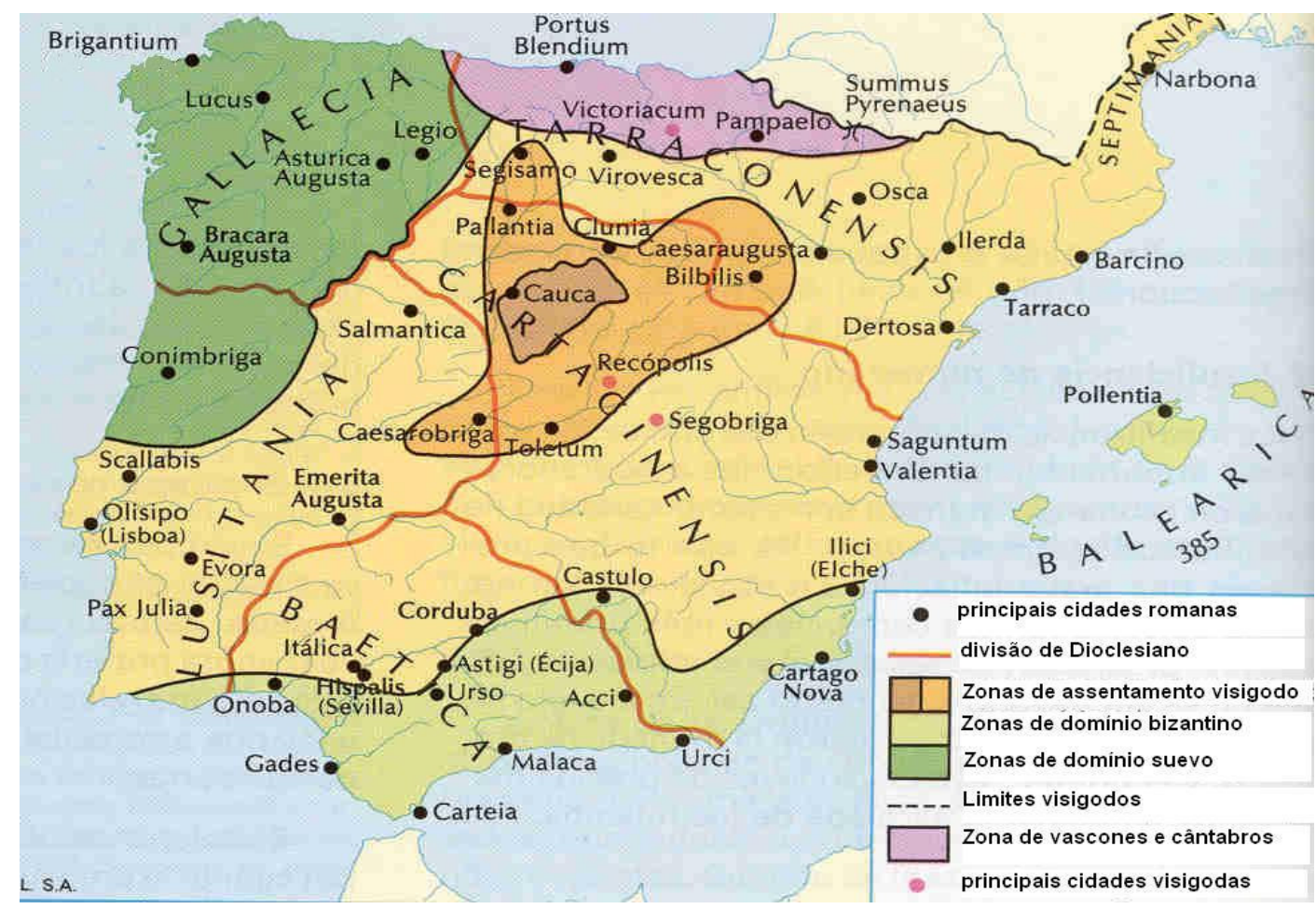

Mapa 1.13: Principais zonas de imigrações na Península Ibérica.

Com o enfraquecimento do Império Romano no final do século IV, segundo BASSETTO (2001:140-142), começaram as grandes migrações de povos não-romanos que duraram quase dois séculos. Os vândalos, povos germânicos orientais e lingüisticamente ligados ao gótico, estavam divididos em: ásdingos e sílingos; que, como aliados dos suevos (povos germânicos ocidentais) e dos alanos (de origem indo-iraniana), chegaram à Península 
Ibérica. Os suevos e ásdingos seguiram para a região da Gallaecia, os alanos (povos nãogermânicos) para a Lusitânia, e os sílingos para a Bética. Posteriormente chegaram os visigodos à Península, originários do sul da Escandinávia, que dizimaram os sílingos na Bética e perseguiram os alanos e ásdingos, obrigando-os a se fixarem na região de Vandalusia, "terra dos vândalos" (atual Andaluzia). De acordo com PAZ (1988: 59), os povos ásdingos (vândalos), que inicialmente se fixaram na Gallaecia juntamente com os suevos em 411, se deslocaram da região entre o rio Douro e Tajo, já em 419, para o sul da Bética e, posteriormente para o norte da África, sendo perseguidos pelos visigodos da Península e pelas milícias do Império Bizantino. Assim, em 534, a região de Vandalusia foi tomada pelo Império Bizantino de acordo com o empreendimento militar de destruir o reino vândalo, conforme ilustração do Mapa 1.13.

Segundo Monteagudo (1999: 69), os suevos, pouco romanizados e, inicialmente, não-cristãos, seriam os responsáveis por dar início ao particularismo da língua galegoportuguesa, ao se instalarem na Gallaecia no início do século V, em 411. A fusão dos povos galaicos-romanos e suevos, foi um processo prolongado que parece somente ter se estabilizado em 559 com a conversão destes ao catolicismo. Seu reino ocupou desde a região norte do rio Tejo e toda a província da Gallaecia com a capital em Braga, mas sucumbiu em 585 com as campanhas de expansão do reino visigodo de Leovigildo, que em 618 já dominava toda a Península Ibérica, conforme o Mapa 1.14.

Para PAZ (1998: 60), o fato de a Gallaecia permanecer durante um século e meio, ou mesmo durante os três séculos da ocupação germânica, praticamente isolada do resto da Península, favoreceu tendências de desenvolvimento que já viriam da época romana e que naquele momento encontraram uma realidade sócio-política que as alimentou. Entretanto, segundo BASSETTO (2001: 142) a superposição dos visigodos aos suevos tornou difícil distinguir as influências específicas do superstrato suevo. 


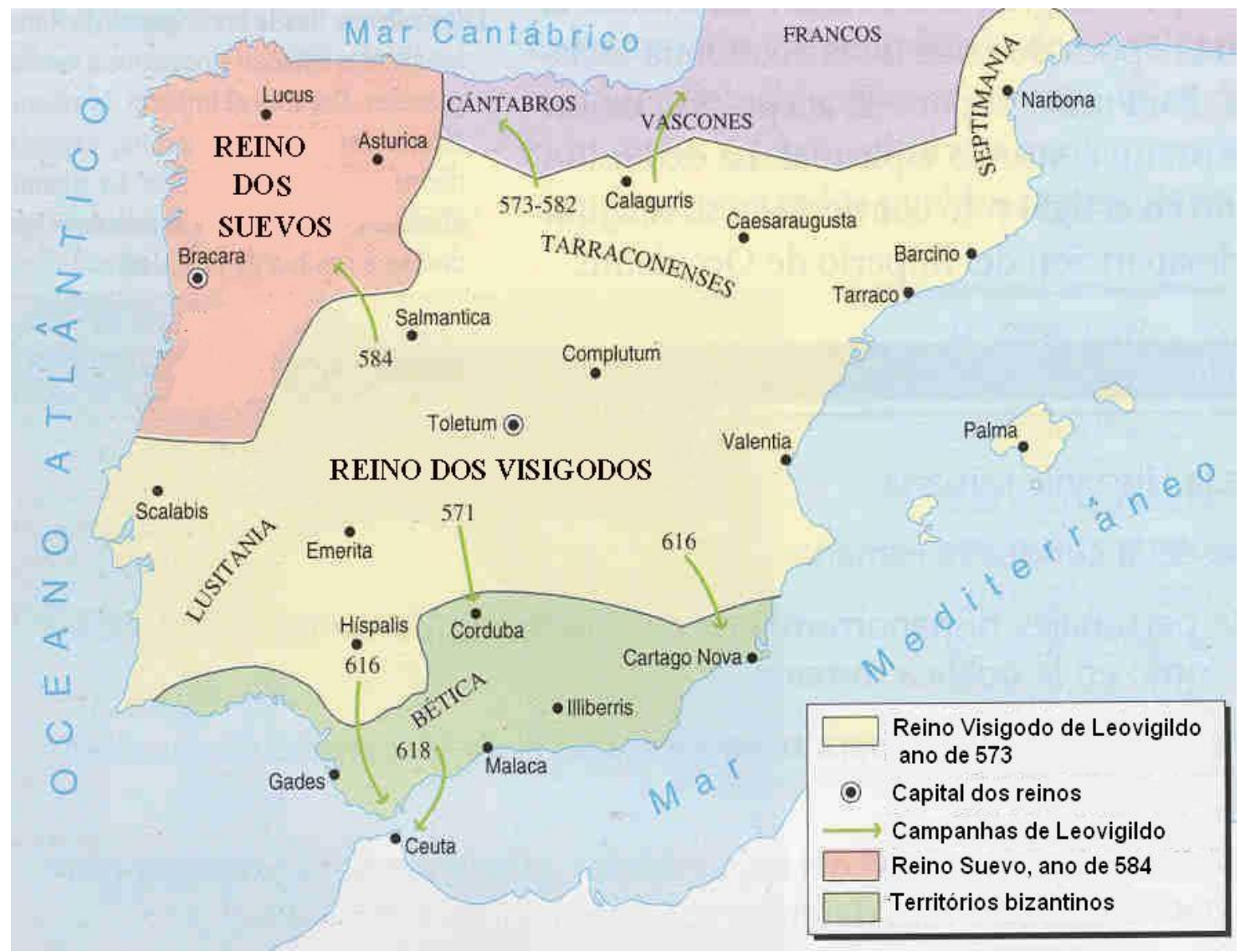

Mapa 1.14: Os reinos dos povos não-romanos na Península Ibérica.

A formação dos reinos germânicos, segundo WARTBURG (1979: 77-87), rompendo os limites do Império, influiu decididamente na formação dos espaços lingüísticos românicos, ao quebrar as linhas de comunicação com as diversas partes imperiais. No caso da Hispânia, os suevos e visigodos, segundo TEYSSIER (1987: 5) "tiveram um papel particularmente negativo: com eles a unidade romana rompe-se definitivamente e as forças centrífugas vão ponderar sobre as de coesão." No entanto, segundo PAZ (1998: 70), o analfabetismo dos povos germânicos contrastava fortemente com a tradição romana, além disso, a cristianização destes povos e a grande importância política adquirida pela Igreja Católica entre os visigodos durante os séculos VI e VII, foram os principais fatores que levaram o latim a se consolidar como língua na Península Ibérica, mesmo diante das línguas dos povos dominantes. 


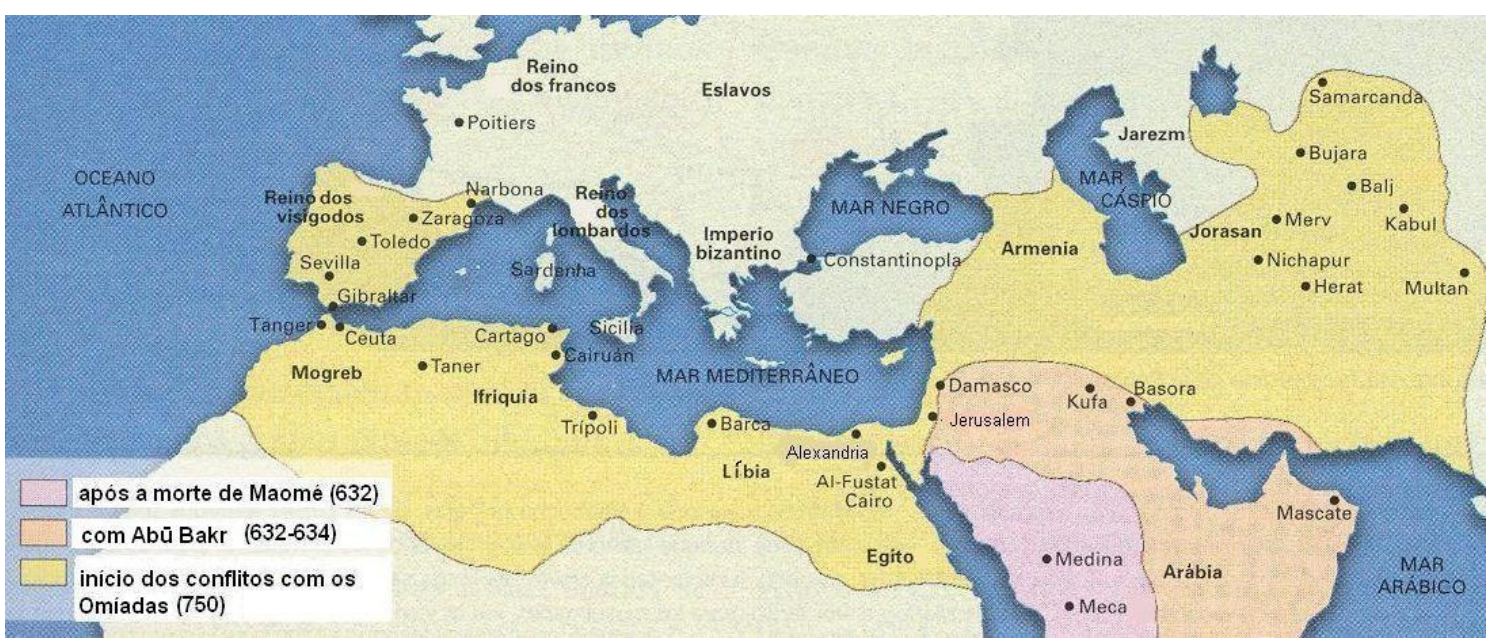

Mapa 1.15: Expansão do Império Árabe.

De acordo com BASSETTO (2001: 152), no século VI, iniciou-se uma grande expansão dos domínios árabes impulsionada, principalmente pela incipiente religião Islâmica. Após a morte de Maomé, em 632, com a Guerra Santa, em dois anos a expansão, encabeçada pelo Califa Abū Bakr, estendeu-se por toda a Península Arábica. Com o Califa 'Umar, o Império Árabe tornou-se uma teocracia administrativa e militar, na qual o comandante militar era também o governador civil, chefe religioso e juiz supremo. Em 645 o Império Árabe já dominara a Síria, a Palestina, o Egito e a Líbia, e, em 698, também toda a África do Norte, conforme ilustração do Mapa 1.15. Dessa forma, pouco mais de cem anos foi o tempo bastante para que os Árabes tivessem conseguido estender sua religião e língua bem como seu domínio político em um imenso espaço que ia desde o Oceano Índico ao Atlântico. Segundo SARAIVA (1999: 33), os fatores que explicaram essa rapidez foram a fraqueza dos impérios vizinhos: Império Persa e Império Bizantino, as ferozes lutas religiosas que então se travavam no Oriente Próximo entre judeus e cristãos, e a situação das populações oprimidas nas áreas conquistadas que em várias regiões, como por exemplo, no Norte da África e toda Península Arábica, os acolheram como libertadores. 


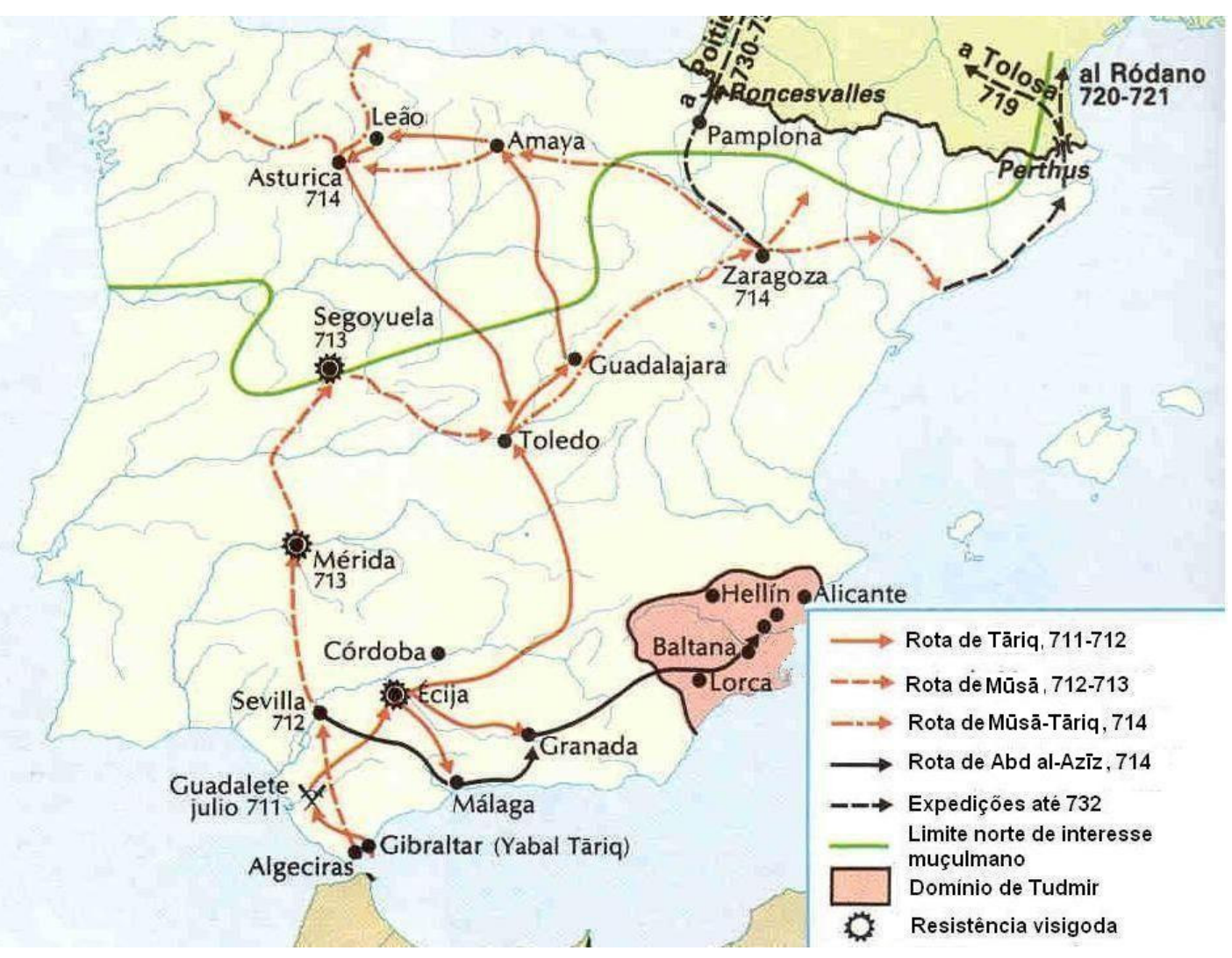

Mapa 1.16: Expansão do domínio árabe na Península Ibérica.

Devido à rapidez da conquista facilitada pelo traçado das vias romanas, em 711, a expansão do Império Árabe já se iniciava na Península Ibérica, com as conquistas de Tāriq e Mūsā, durante a dinastia dos Omíadas. Segundo BASSETTO (2001: 148), no ano seguinte, Tāriq já conseguira a conquista de Toledo, e em 732, quando já conquistara quase toda a Península, foi derrotado na batalha de Poitiers pelos Francos, conforme Mapa 1.16. De acordo com SARAiva (1999: 35-36), também a atitude dos povos visigodos da Península favoreceu o seu rápido domínio, pois a situação das populações perante o domínio árabe dependia da atitude que assumiam diante da nova religião: se a aceitavam, faziam parte da comunidade; se continuavam fiéis ao cristianismo, podiam manter suas propriedades, mas eram obrigadas a pagar tributos; se resistiam com armas eram aniquiladas. Portanto a resistência armada não foi o caso mais geral, afinal os tributos teriam que ser pagos quer o senhor fosse cristão, quer islâmico. Assim, segundo BASSETTO (2001: 149), foi a religião o fator fundamental de distanciamento entre as populações árabes e românicas, concluindo-se que também foi um fator de distanciamento entre as línguas latinas e arábicas. Como 
Estudo comparativo de aspectos semânticos do sufixo -ista no português e no galego.

conseqüência, nesse período, a população visigoda dividiu-se em: moçárabes, que permaneceram cristãos, e os muladis, que se converteram ao islamismo, porém continuaram falando a sua língua romance.

Durante o período de conquistas, os árabes ampliaram seu conhecimento através da absorção das culturas de outros povos, levando-as adiante a cada nova conquista, espalhando por seus territórios grandes nomes como, por exemplo, o de Aristóteles e de outros de destaque da antiguidade grega. A cultura árabe caracterizou-se pela construção de palácios e mesquitas com seus jardins exuberantes. Destacam-se, nestas construções, os arabescos para ilustração e decoração, nos quais houve o emprego e a disseminação da geometria e álgebra aplicadas. A literatura também teve um grande valor, com obras até hoje conhecidas no Ocidente, tais como: As mil e uma noites, As minas do rei Salomão e Ali Babá e os Quarenta Ladrões. Especificamente na Península Ibérica, assim como o Império Romano floresceu na Bética, também o Império Árabe floresceu ao sul da Península. Sevilha foi um grande centro irradiador de sua cultura, principalmente durante o século XI e XII, ali se desenvolveram a medicina, filosofia, direito, história, astronomia, teologia e as letras, com grande destaque à poesia. Como personalidades importantes culturalmente desse período, destacam-se Averróis (1126-1198) e Maimônides (1135-1204). Ainda que a cultura árabe, com sua técnica e ciência, tenha sido, sob determinados aspectos, mais desenvolvida que a dos povos românicos ali instalados, é curioso notar que a língua dos dominadores não se sobrepôs à dos dominados.

É interessante notar também que a duração do domínio árabe variou muito de região para região na Península Ibérica. Nunca chegou a ser exercido nas terras mais setentrionais, pois ao norte do Rio Ebro já retornara ao domínio cristão em 809. O Porto e Braga foram conquistadas pelos cristãos em 868, Coimbra em 1064 e Lisboa em 1147. Já Sevilha, Córdoba e Faro fizeram parte do Império Árabe durante cerca de seis séculos e Granada somente deixou de fazer parte deste domínio no final do século XV. Segundo SARAIVA (1999: 34), essas variações repercutiram diretamente na intensidade da influência da cultura árabe sobre as populações peninsulares, mas foi limitada na linguagem: não deixando vestígios na sintaxe e no léxico contribuindo com cerca de oitocentos vocábulos.

Segundo BARRAClOUgh \& PARKER (1999: 110-111), durante o Império Árabe também houve invasões na Península Ibérica de normandos, que significa "homens do norte", eram provenientes da Escandinávia, que entre o século VIII e o século XI invadiram e 
Estudo comparativo de aspectos semânticos do sufixo -ista no português e no galego.

colonizaram as costas da Europa e ilhas Britânicas. Estes povos, que manejavam muito bem as embarcações à vela, marcaram sua presença nas costas do Atlântico e, posteriormente, do Mediterrâneo ou por meio de grandes rios e seus afluentes, saqueando e incendiando as populações ribeirinhas que alcançavam. Em 844, costeando a Península Ibérica, saquearam Gijón, A Corunha, Lisboa, Beja, localidades do Algarve, Cádiz e Sevilha. Posteriormente, em 859, atacaram Valência, as Ilhas Baleares e Barcelona. No entanto, parecem ter deixado poucas influências lingüísticas em seu rastro pela Península, pois na literatura especializada nada consta neste âmbito.

Segundo SARAIVA (1999: 33-36), o que realmente teve impacto marcante na formação das atuais línguas da Península Ibérica foi o processo de Reconquista do poder dos territórios peninsulares por parte dos povos cristãos. Esse processo tem início com a ruptura do Império Árabe e seu enfraquecimento político após a crise com os Omíadas, bem como a distância entre o emirato de al-Andalus e o centro do Império na Península Arábica, além do desinteresse dos árabes pelos territórios do norte Ibérico.

Em 756, de acordo com BARRAClOUgh \& PARKER (1999: 120-121), ‘Abd ar-Rahmān, o único sobrevivente dos Omíadas na sangrenta revolução árabe que levou os Abássidas ao poder do Império, fugiu da Península Arábica e, ao chegar a al-Andalus, proclamou ali sua independência com a capital em Córdoba, tornando-se o novo califa da região. 'Abd arRahmān I, reestruturou o seu regime monárquico, baseado nas monarquias visigodas, como também modificou as instituições administrativas e fiscais adaptando-as à realidade social da região. No século VIII, Al-Hakām I (796-822) conseguiu reestruturar o exército de alAndalus, entre outras coisas, por meio de incentivos e da manutenção de um salário permanente, com o qual pode conter diversas revoltas internas e enfrentar o primeiro ataque forte dos povos cristãos do norte provenientes do reino de Astúrias de Alfonso $^{8}$ II. Nas primeiras décadas do século IX, o governo de 'Abd ar-Rahmān II, centralizado em Córdoba, promoveu uma melhoria nas condições sociais e introduziu algumas regalias aos muladis, incentivando a conversão ao Islamismo. Entretanto, a partir da segunda metade do século IX, começou a ocorrer uma grande crise política com a revolta de várias regiões que estavam submetidas ao poder central do emirado de Córdoba, conforme o Mapa 1.17. Além disso,

\footnotetext{
${ }^{8}$ Dado o grande número de ocorrências do antropônimo Afonso nomeando reis portugueses e espanhóis optouse por usar a versão do nome em português, Afonso, para designar os reis de Portugal, e a versão em castelhano, Alfonso, para os reis das demais regiões cristãs peninsulares.
} 
Estudo comparativo de aspectos semânticos do sufixo -ista no português e no galego.

nesse período ocorreram revoltas da população moçárabe e cristã, devido ao processo de hegemonia árabe, a "arabização" cultural que deixava à margem os não-muçulmanos; aliada a berberes e muladis irritados com as diferenças a favor dos árabes e sírios.

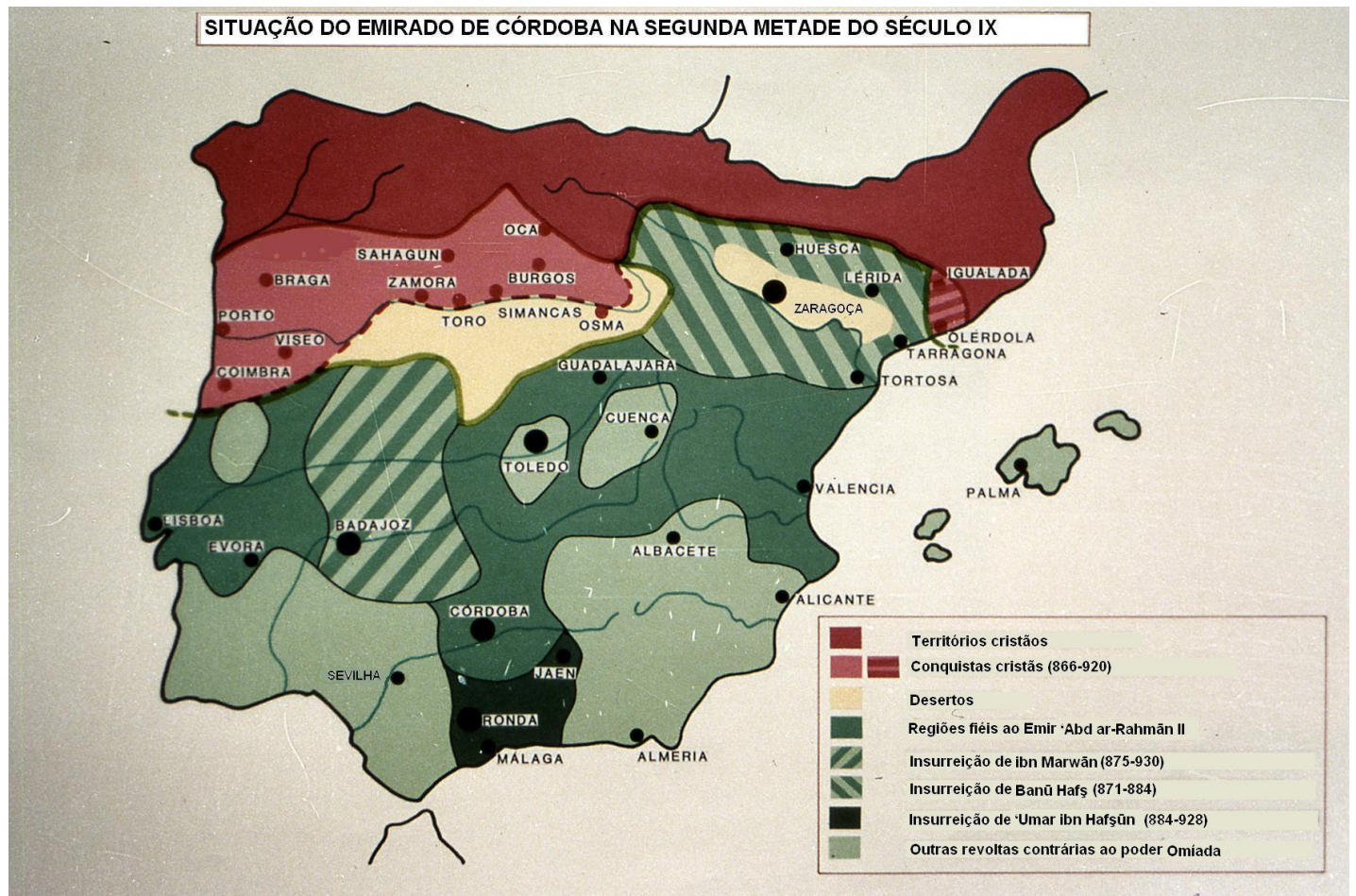

Mapa 1.17: Crise do Emirado de Córdoba.

Durante o governo de 'Abd ar-Rahmān III (912-961), o território de al-Andalus, principalmente a partir de 914, passou a sofrer com as ofensivas cada vez mais intensas dos reinos cristãos instalados ao norte da Península Ibérica, que já se organizavam ao redor de sua capital Leão; bem como, em menor medida, pelas ofensivas dos Condados Catalães. Com o fortalecimento de seu exército e diante de um regime repressivo e ofensivo, Córdoba conseguiu o apogeu político ao longo do século X, passando de Emirado a Califato, conseguido, principalmente com o prestígio alcançado pelos generais Galib, Al-Manșūr y 'Abd al-Mālik; mas também graças às diretrizes governamentais de 'Abd ar-Rahmān III, seguidas por seus sucessores Omíadas: Al-Hakām II (961-976) e Hishām II (976-1009).

Durante o século $\mathrm{X}$, houve um grande desenvolvimento das cidades e do comércio provocando um auge cultural que continuou por boa parte do século XI. Assim, alterou-se por completo a base da economia da região muçulmana produzindo, também, uma mudança 
Estudo comparativo de aspectos semânticos do sufixo -ista no português e no galego.

social considerável. Os moçárabes perderam força e diminuíram em número depois da crise do século IX, além de passarem a aceitar aspectos lingüísticos e culturais árabes. Tais mudanças atingiram o âmbito político, que não mais se respaldava no exército já enfraquecido, e o território foi dividido em reinos Taifas, cujos governadores eram supostos representantes do poder central de Córdoba. Alguns reinos Taifas foram governados por dinastias berberes, outros por muladis ou por árabes já totalmente integrados na sociedade autóctone. Os Reinos importantes absorviam os menores, principalmente na fronteira com os territórios cristãos, e ao sul, destacavam-se o Reino Taifa de Sevilha com governo andaluz e o de Granada sob o governo berbere dos zíries, conforme o ilustrado no Mapa 1.18.

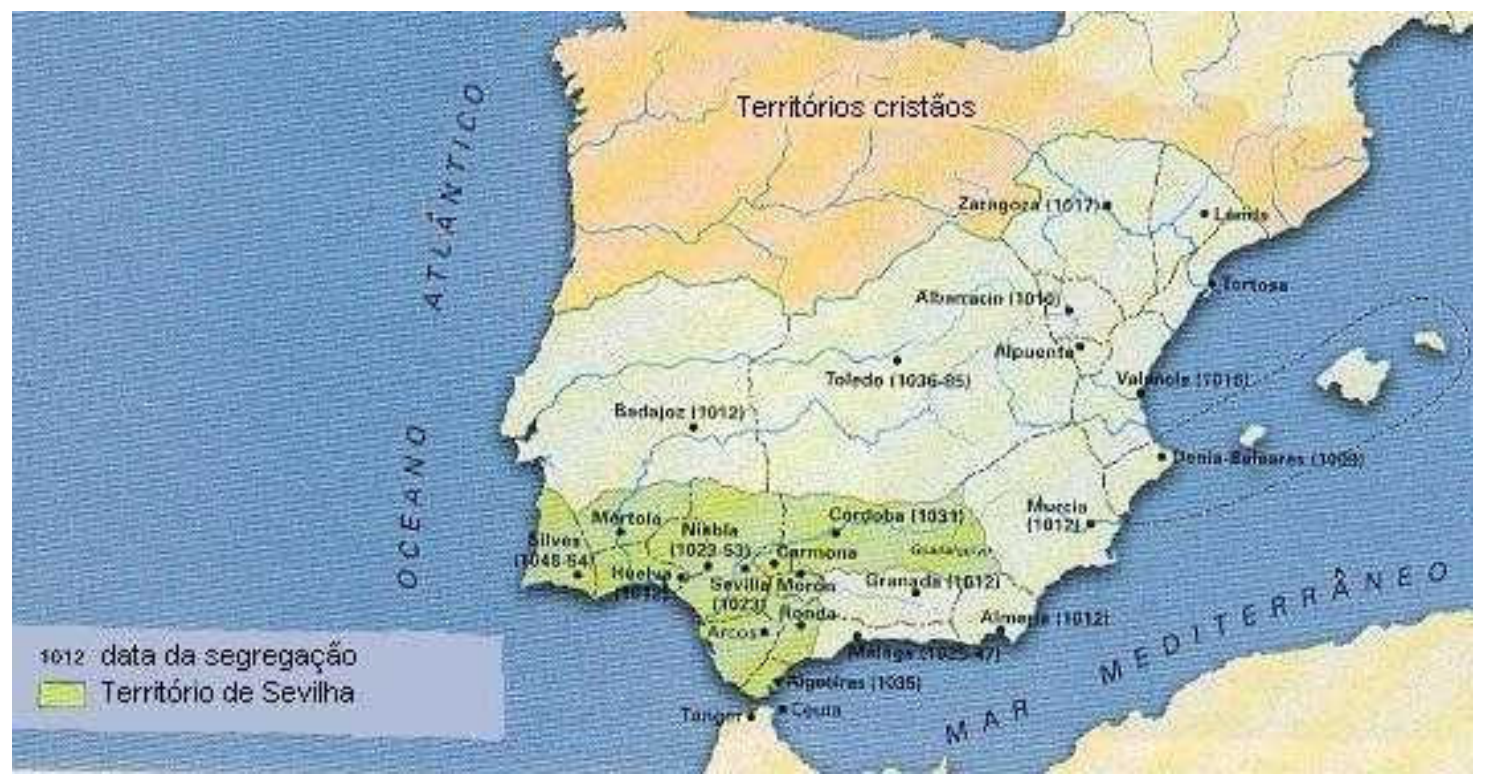

Mapa 1.18: Reinos Taifas em 1012.

Com o estabelecimento da segregação dos territórios cristãos e muçulmanos, os Taifas fronteiriços passaram a pagar impostos aos Reinos Cristãos, que aumentavam sua pressão militar e tributária. Em 1085, os cristãos conquistaram a cidade de Toledo, como conseqüência, os reinos Taifas aliaram-se militarmente aos almorávidas de Magribi, e passaram da condição de aliados à de donos do poder político. A entrada dos almorávidas norte-africanos, suas vitórias sobre os cristãos e seu domínio político em al-Andalus, freando, por algum tempo, a expansão do processo de Reconquista.

Entretanto, no início do século XII, com a intransigência, houve a perseguição e a expulsão das minorias não-muçulmanas, principalmente moçárabes e judias, que passaram a 
Estudo comparativo de aspectos semânticos do sufixo -ista no português e no galego.

se fixar em território cristão. Pouco depois, iniciou-se a decadência e as divisões internas, o que permitiu aos cristãos a retomada e o sucesso do seu empreendimento de expansão: a Reconquista.

Segundo BASSETTO (2001: 150), no contexto da Reconquista situa-se a origem de Portugal. Sabe-se que os árabes não foram além dos Montes Cantábricos, ao norte dos quais, inicialmente sob o comando de Pelaio, formou-se uma região independente de cristãos que, em 718, veio a ser o reino de Astúrias. Com Alfonso I, rei de Astúrias, e suas guerras devastadoras na Galiza contra os muçulmanos, o Rio Douro foi uma das fronteiras entre os territórios cristãos e árabes, conforme o Mapa 1.19.

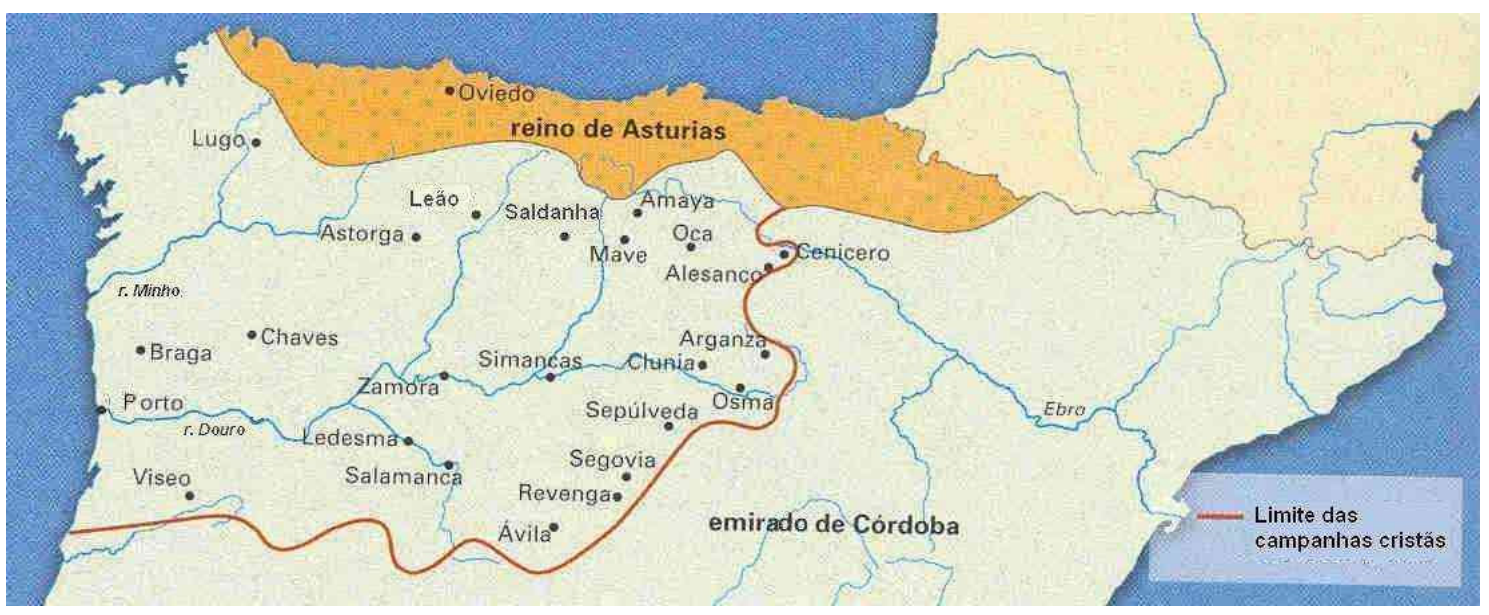

Mapa 1.19: Os territórios cristãos, no século VIII, com Afonso I.

De acordo com Alexandre Herculano, apud SARAIVA (1999: 39-40), Alfonso I reconquistou uma enorme região que incluía toda a Galiza, o Minho, o Douro e parte da atual Beira Alta, "passando os mouros a fio de espada". Entretanto, afirma SARAIVA (1999: 41) que a guerra não era por motivos religiosos, mas para apoderar-se das terras por meio das colonizações. Assim, nas terras em que o domínio árabe se desagregava com as colonizações cristãs nasciam poderes representados por chefes locais entre os quais se estabelecia uma hierarquia nem sempre bem definida, intercalada de episódios de submissão e de rebeldia. Pois, alguns nobres governavam terras por nomeação dos reis, outros por as terem, eles próprios, ocupado. Na tradição da nobreza Ibérica ficaram vestígios da nobreza que entendia nada dever aos reis. Os títulos dos governadores eram, em geral, de condes; que se caracterizavam por ser um misto de proprietários, guerreiros, governadores e salteadores. 
Estudo comparativo de aspectos semânticos do sufixo -ista no português e no galego.

Faziam a guerra quando os reis os chamavam, mas não faltam exemplos de eles próprios a fazerem entre si ou contra os seus reis, SARAIVA (1999: 42).

As colonizações deram origem aos processos de regionalização peninsular, nos quais, as antigas vias romanas foram restauradas e reutilizadas. Iniciou-se na região galega e, aos poucos, a colonização do território organizou-se em pequenos Estados independentes que puderam se aproveitar do enfraquecimento do Império Árabe no século IX, para impulsionar a expansão cristã com o empreendimento da Reconquista de Leste a Oeste, bem como em direção ao Sul, conforme o Mapa 1.20.

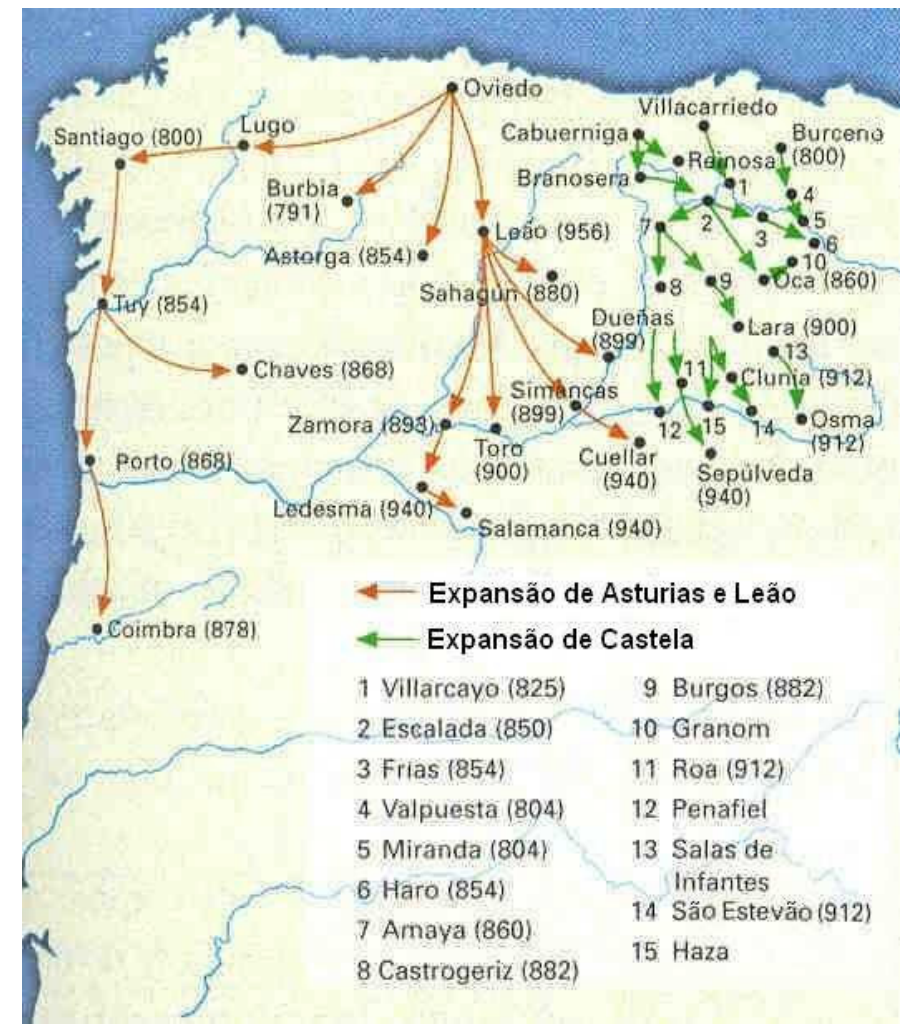

Mapa 1.20: Colonizações iniciais.

De acordo com SARAiva (1999: 42), os novos países cristãos da Península formaramse a partir de três núcleos distintos: o asturiano, que veio a originar o reino de Oviedo, de Galiza e depois de Leão e Galiza e o condado de Castela, independente durante alguns anos, depois transformado em reino e que desde 1037 andou unido ao de Leão; o pirenaico, de onde saíram os reinos de Pamplona e depois Navarra, o condado de Aragão, que logo se tornou reino, alguns condados mais ou menos independentes; e o catalão com o condado de 
Estudo comparativo de aspectos semânticos do sufixo -ista no português e no galego.

Barcelona. No Mapa 1.21, que ilustra os territórios de Sancho III, pode-se notar os três núcleos apontados por SARAIVA.

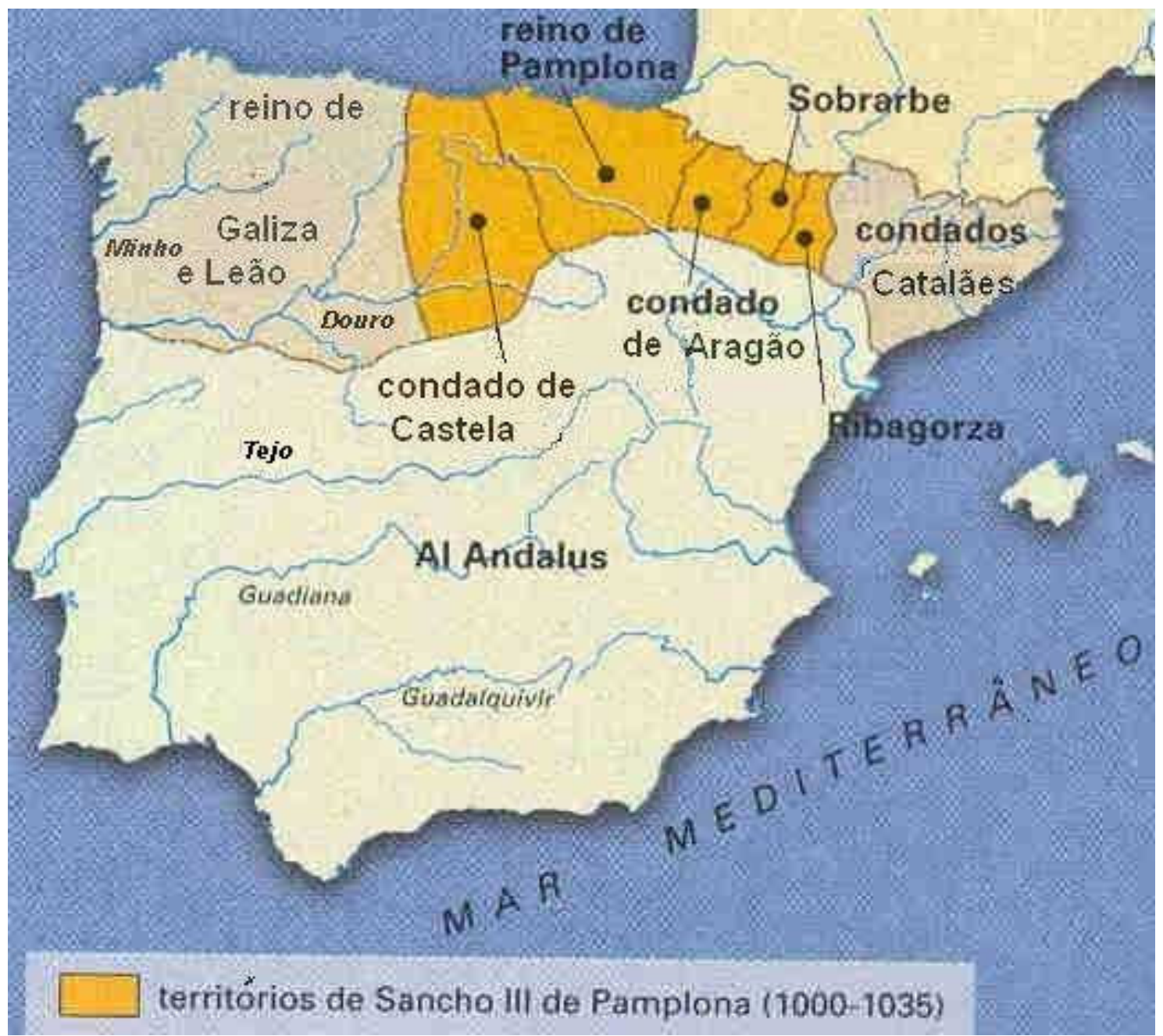

Mapa 1.21: Divisão política dos territórios cristãos no período de 1000 a 1035.

Nessa imprecisão política, aparece com freqüência o nome da Galiza, ora como reino, ora como condado. Seu limite ia até o curso do rio Douro, mas dentro dele havia outros territórios governados por condes que dependiam do reino de Leão. Nos primeiros anos da Reconquista, a importância da região galega aumentou ao se descobrir em 813 o túmulo do Apóstolo Santiago em Compostela, que junto com a Virgem de Covadonga tornaram-se os patronos da Reconquista cristã. 
Estudo comparativo de aspectos semânticos do sufixo -ista no português e no galego.

Segundo MonTEagudo (1999: 97-98), no final do século XI e durante o século XII, no mundo cristão houve uma retomada da religiosidade: com um auge de peregrinações e com a organização de Cruzadas contra aos “infiéis". Nesse contexto, o mosteiro de Cluny liderou o movimento de reforma na vida religiosa. Daí, com o fortalecimento do clero galego cuja sede é em Lugo, Santiago de Compostela tornou-se um importante centro de peregrinação.

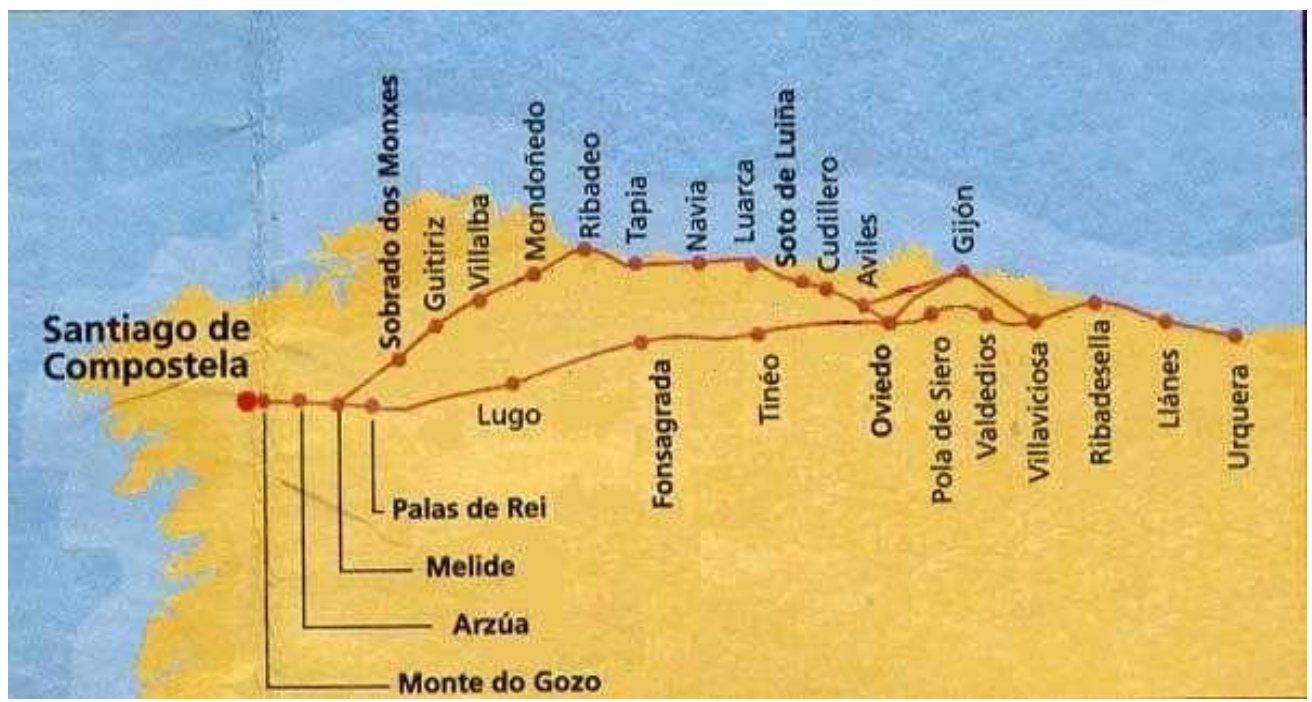

Mapa 1.22: Caminho original à Santiago de Compostela, no século IX.

Por influência de Cluny, o caminho original à Santiago foi ampliado até o reino dos francos tornando-se conhecido como a rota francesa, que no século XI foi reformada para atender a demanda de peregrinos, conforme Mapas 1.22 e 1.23.

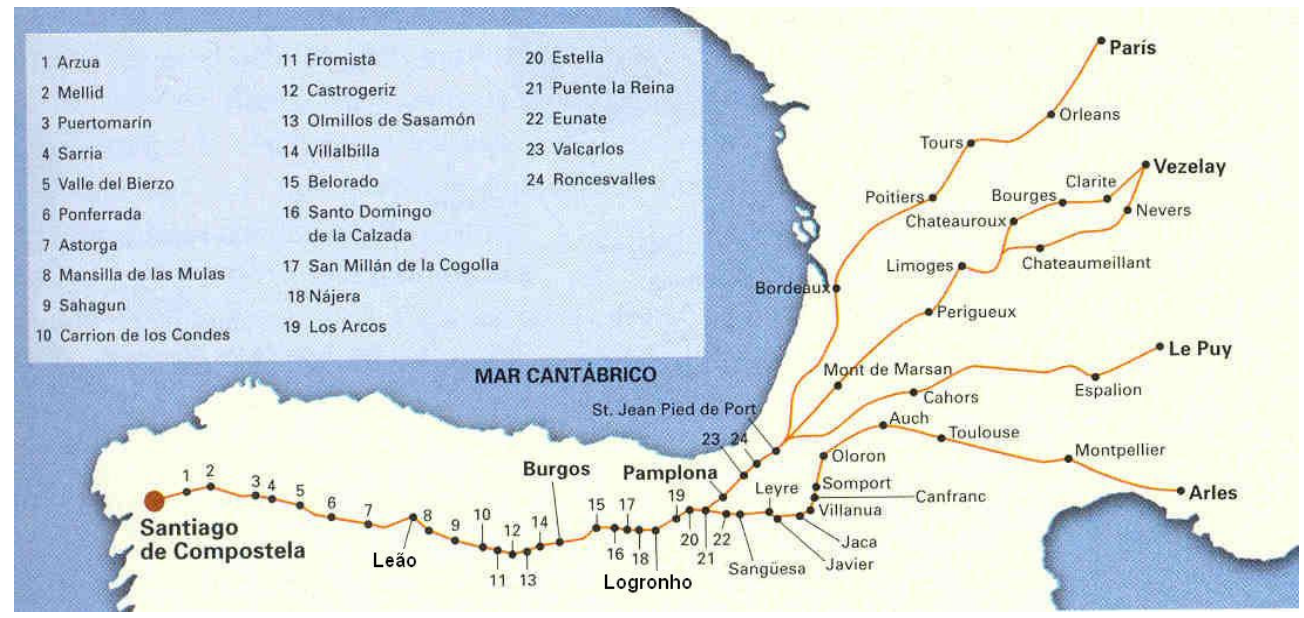

Mapa 1.23: Caminho francês de peregrinação a Santiago de Compostela. 
Estudo comparativo de aspectos semânticos do sufixo -ista no português e no galego.

Em muitos dos antigos territórios cristãos, os Caminhos de Santiago de Compostela, que em sua maioria retomavam as vias romanas, ajudaram a formar grande parte dos fenômenos de imigração e transformação da colonização cristã desde o século XI até o século XIII. Pode-se lembrar também a importância, até o século XIV, da rota portuguesa de peregrinação a Santiago, na manutenção dos territórios bem como da língua e cultura galegoportuguesa nos locais conquistados, conforme o ilustrado no Mapa 1.24.

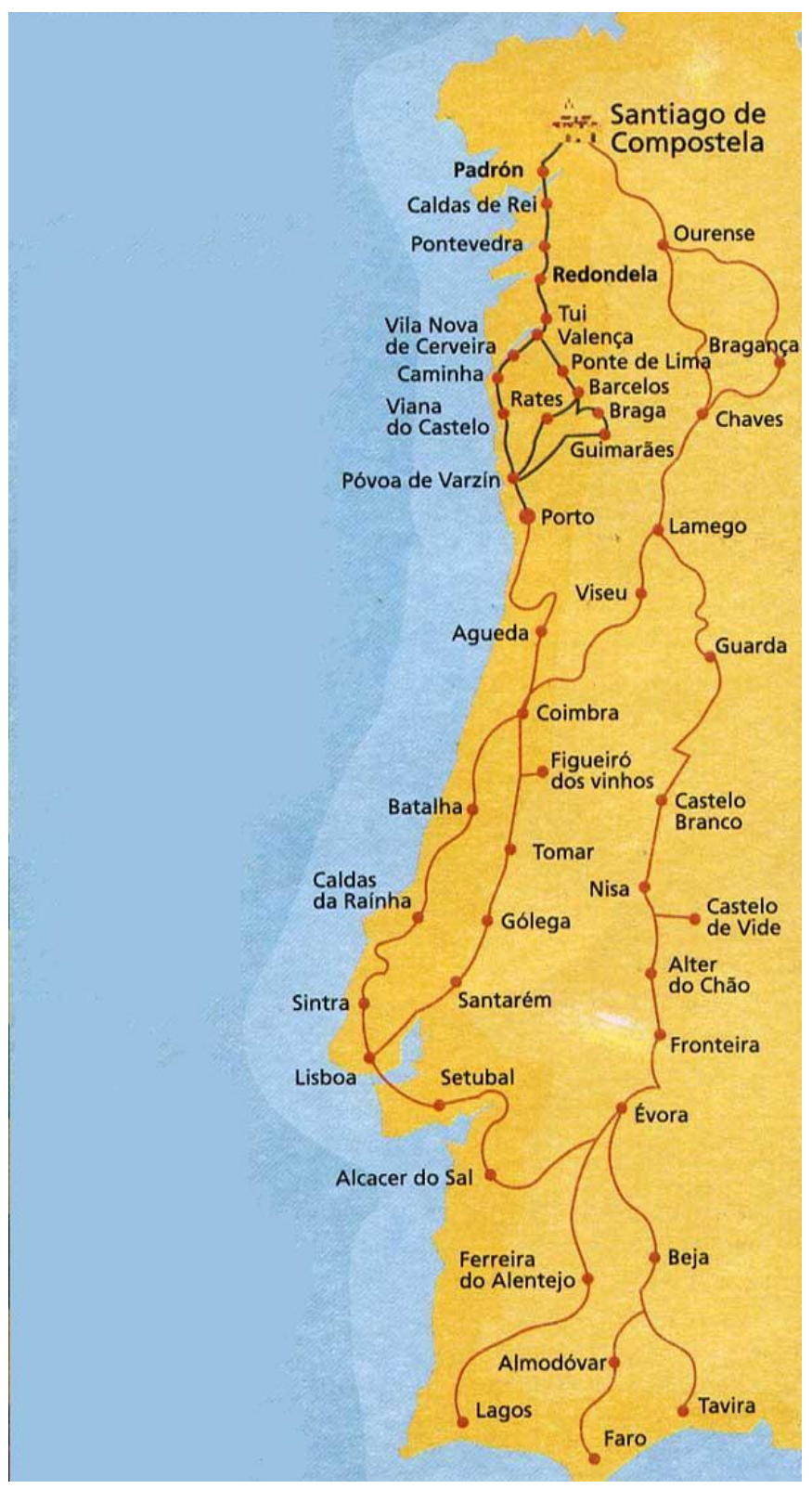

Mapa 1.24: Caminho Português de Peregrinação a Santiago de Compostela. 
Estudo comparativo de aspectos semânticos do sufixo -ista no português e no galego.

Segundo Monteagudo (1999: 97-98), desde meados do século XII, na Galiza começou-se uma grande e rápida reestruturação rural e urbana, concomitantemente na Catalunha, graças a numerosas cartas que outorgavam terras e poderes a condes, que também favoreciam o renascimento urbano e acolhiam imigrantes, provenientes de peregrinações, comerciantes e membros dos exércitos cristãos. Esse modelo de colonização e repovoamento colocava os falares românicos sobre o árabe, e a reforma de Cluny retomava o latim no âmbito religioso, espalhando-os juntamente com a Reconquista, pela Península Ibérica. Segundo BASSETTO (2001: 123), no avanço rumo ao sul, a Reconquista encontrava populações moçárabes, mais ou menos arabizadas, mas que haviam conservado, pelo menos em parte, seus falares românicos, agora associados à fé cristã. Dessa forma, em pouco tempo, as variedades de falares românicos passaram a designar a identidade dos povos.

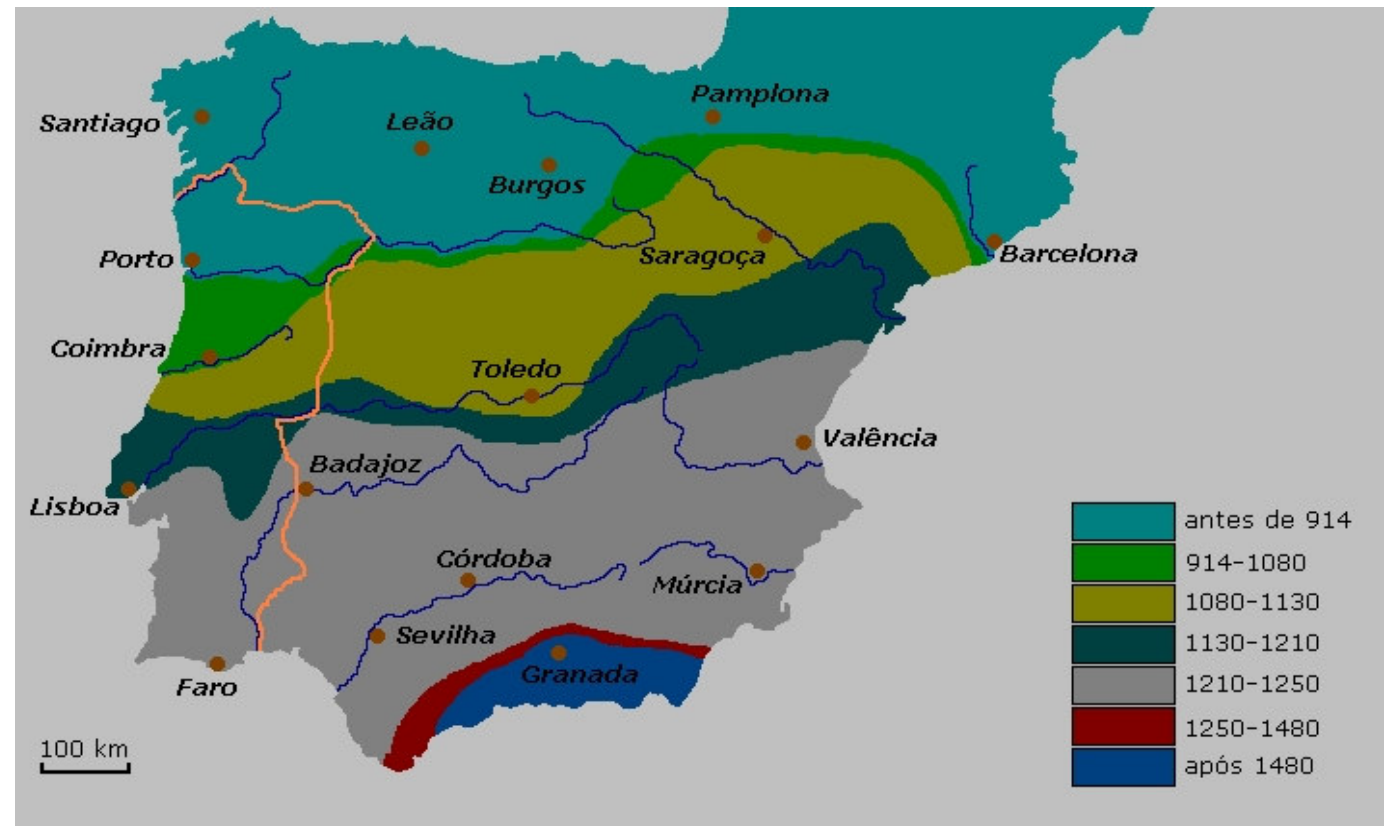

Mapa 1.25: O processo de reconquista cristã na Península Ibérica.

Apesar do Mapa 1.25 fornecer uma visão conjunta, por períodos, das conquistas cristãs sobre os territórios muçulmanos, o processo não foi tão unificado quanto possa parecer. Por volta do ano 800, Castela era apenas um condado do reino das Astúrias e, posteriormente, de Leão. Em 1029, Sancho II, rei de Navarra herdou o condado de Castela e depois dividiu o seu reino em três: Aragão, Navarra e Castela. Com Fernando I (1035-1065) o reino de Castela se uniu ao de Leão, que em conjunto com Berenguer I de Barcelona passaram a cobrar impostos do reinos Taifas. Com Alfonso VI de Castela e Leão (1065-1109) 
Estudo comparativo de aspectos semânticos do sufixo -ista no português e no galego.

houve a anexação de Toledo em 1085 e seu reino Taifa, com el Cid como herói. No reinado de Alfonso VII (1126-1157) Castela tornou-se o centro de todos os estados cristãos, enquanto o reino de Aragão e a Catalunha se uniram com Berenguer IV desde 1137 e o condado de Portugal passou a ser Reino independente desde 1139 com Afonso Henriques. Enquanto Alfonso VII completava o domínio da bacia do rio Tejo (1147), Afonso I de Portugal tomava Lisboa (1147) e Berenguer IV conquistava Tortosa, Lérida y Fraga. Com a morte de Alfonso VII, Leão e Castela separaram-se até 1230, conforme pode ser apreciado no Mapa 1.26.

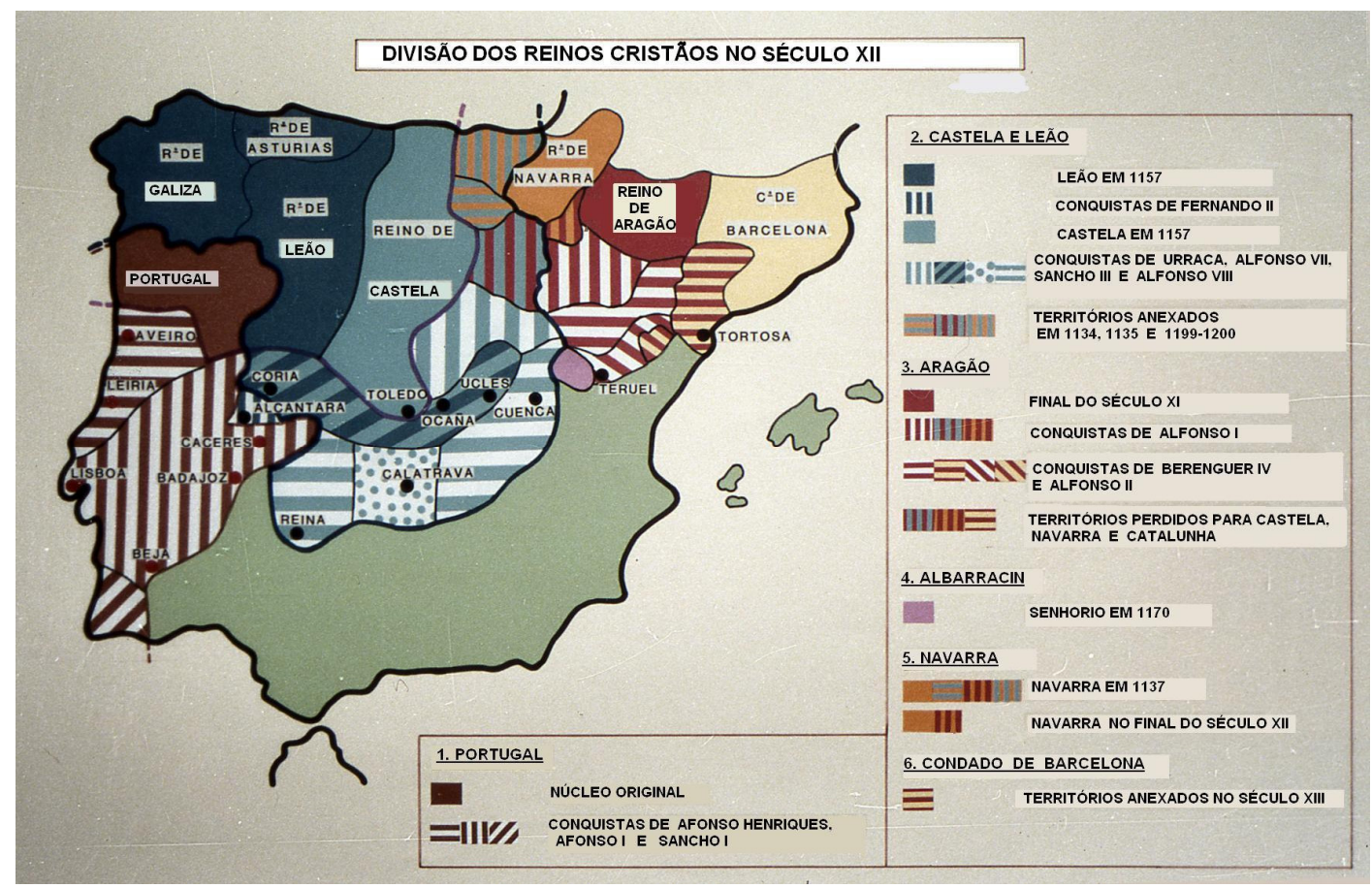

Mapa 1.26: Divisão política dos reinos cristãos no século XII.

Em 1212, Alfonso VIII de Castela, como o apoio de outros reinos cristãos conquistou Tolosa. O reino de Portugal, depois do tratado de Sabugal (1231) com Castela e Leão sobre as zonas de expansão, completou a conquista do Alentejo em 1232 e do Leste do Algarve em 1239, já definindo, praticamente, suas atuais fronteiras. Em 1230, com Fernando III, o reino de Castela e Leão voltaram a unir-se baixo a mesma coroa, aumentando seu poder político. Nesse período, com o enfraquecimento dos reinos muçulmanos, a Reconquista tomou novo impulso e avançou em direção a Valência, Ilhas Baleares e Múrcia, com Jaime I de Aragão, em 1238; e em direção à Andaluzia, com Fernando III, que conquistou, Córdoba, Jaén e Sevilha em 1248. No período de 1262 a 1263, Alfonso X (1252-1284), rei de Castela, 
Estudo comparativo de aspectos semânticos do sufixo -ista no português e no galego.

incorporou por completo as serras da baixa Andaluzia, conquistou Cádiz e Niebla em 1264. Com ajuda de Jaime I, completou o domínio de Múrcia. Entretanto, as circunstâncias políticas e econômicas puseram um fim no avanço da reconquista no final do século XIII, conforme os Mapas 1.27a e 1.27b. A capacidade defensiva do reino de Granada ao receber apoio entre 1275 e 1350, fez que resistisse até 1492, quando a força militar da união dos reinos de Castela e Aragão, com Isabel e Fernando, o anexou.

Mapa 1.27: Evolução da reconquista cristã no século XIII.

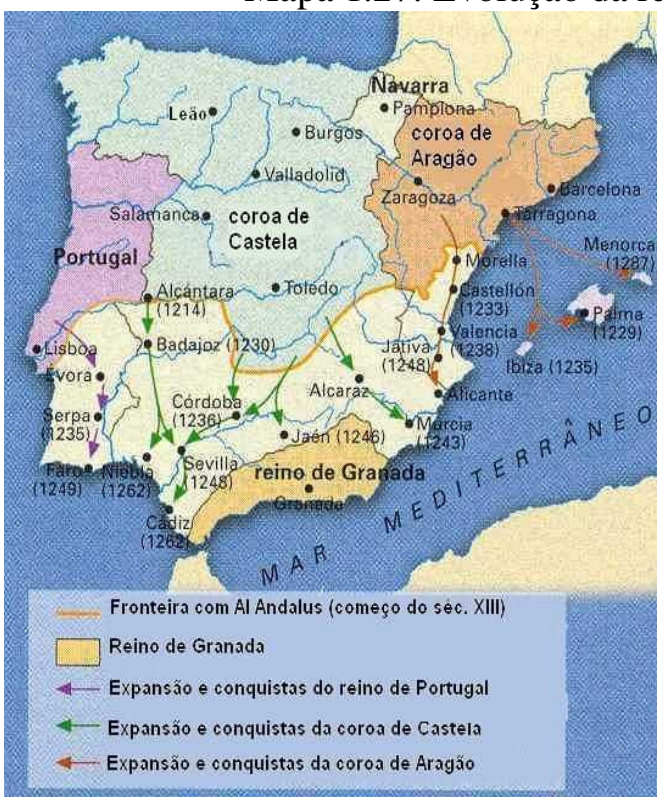

Mapa 1.27a: Início do século XIII.

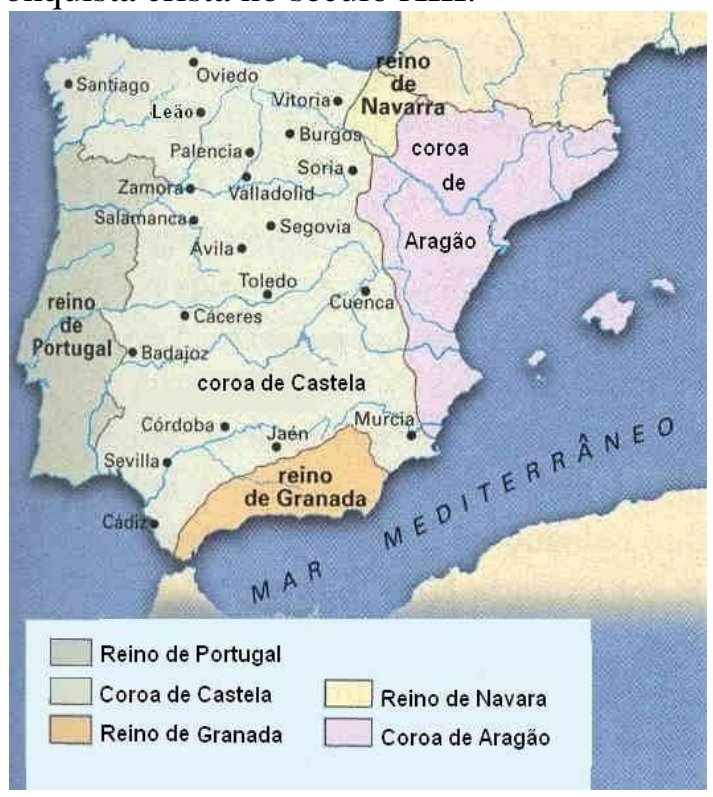

Mapa 1.27b: Meados do século XIII.

Dessa maneira, cada falar românico desenvolveu-se de acordo com o prestígio político de seu reino e sua importância dentro do contexto da Reconquista cristã. Segundo BASSETTO (2001: 235), até meados do século XI, o castelhano era apenas o falar da região de los castillos, de onde provém o nome Castela, que significa "fortificações", assim como também havia outras variantes provenientes do latim, por exemplo: leonês, aragonês, catalão e galego. Durante o reinado de Alfonso X, no século XII, o castelhano já era a língua oficial do reino de Castela e Leão, ainda que outros falares também fossem usados.

Segundo MenÉndez Pidal (1968: 16), a força política que o reino de Castela veio a exercer sobre a Península, devido à Reconquista, acabou tendo um papel fundamental na definição de seus falares. De acordo com o autor, Castela cresceu politicamente dentro da Península Ibérica, anexando os reinos a sua volta e estendeu o seu domínio político e 
Estudo comparativo de aspectos semânticos do sufixo -ista no português e no galego.

lingüístico "em forma de cunha", em direção ao sul da Península. Assim, a força política do castelhano, principalmente ao redor de seu centro de irradiação, que foi a cidade de Toledo, não deixou que outro falar se desenvolvesse, apenas em suas periferias o galego e o catalão o conseguiram diante da sua forte presença, ao passo que impediu o leonês e o aragonês, sem, contudo, conter o euskera. O português, no entanto, por representar um reino forte e independente, desenvolveu-se e irradiou-se desde seu centro cultural, para as regiões que foram conquistadas por Portugal, e, posteriormente, pelas regiões de além mar dos descobrimentos. Pode-se notar que a divisão dos reinos cristãos no século XIII, ilustrada pelo Mapa 1.27, é muito semelhante à divisão atual dos falares na Península Ibérica, que está identificada no Mapa 1.28, atestando MENÉNDEZ PidAL (1968) e BASSETTO (2001).

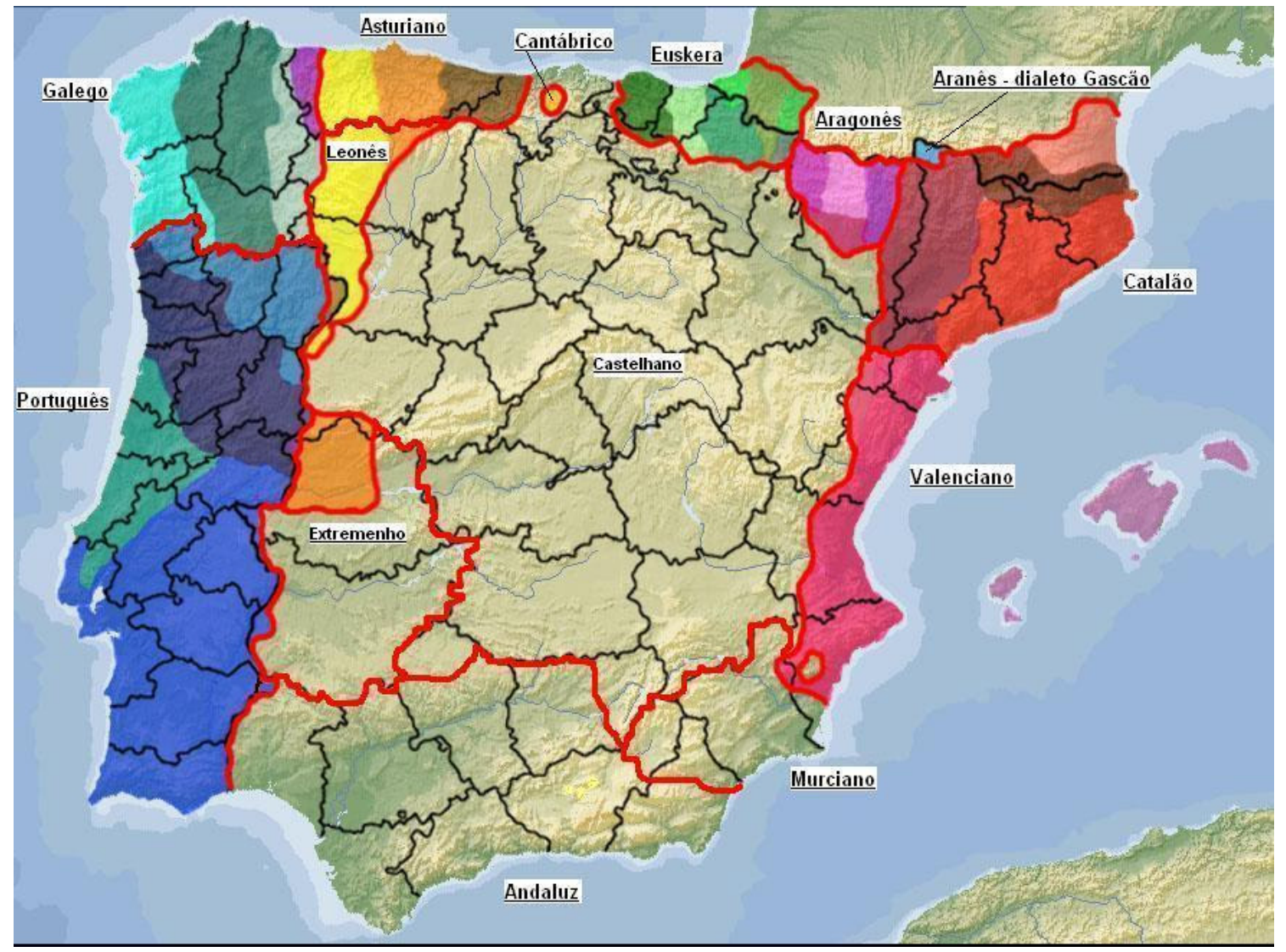

Mapa 1.28: Atual divisão dialetal da Península Ibérica. 


\section{Panorama histórico do galego-português}

Historicamente, o português e o galego têm raízes comuns, cujas origens remotam ao processo de Reconquista da Península Ibérica, entretanto, tiveram desenvolvimentos diferentes. De 1065 a 1090, a Galiza tornara-se um reinado independente sob a coroa de García I, cujos limites ao sul se estendiam às margens do rio Douro. Segundo PAZ (1999: 104), a ação de seus irmãos: Sancho II de Navarra e Alfonso VI de Castela, acabou fragmentando a unidade político-cultural galega. Assim, Alfonso VI, arrebatou a coroa de García I e dividiu o reino em dois, a fim de obter o domínio da região, alegando haver problemas com os sarracenos ao sul do rio Minho.

Ao norte do rio Minho, o rei de Castela enviou sua filha Dona Urraca, casada com Dom Raimundo de Borgonha como condes de Galiza, em 1090. A região ao sul do rio Minho foi nomeada Condado Portucalense e entregue à sua outra filha Dona Teresa casada com Dom Henrique de Borgonha, em 1093. De acordo com LoREnzo (1994: 35-36), este ato marcou definitivamente a fronteira política entre Portugal e Galiza e a fronteira lingüística entre o português e o galego, definindo o início da desagregação do bloco político-cultural galaico. Assim, a região galega ficou sob o jugo do reino centralizador de Castela, uma vez que Urraca era a herdeira direta de Alfonso VI.

A ruptura política e as mudanças da corte portuguesa desde o norte em direção ao sul, foram provocando pouco a pouco a separação das normas lingüísticas galega e portuguesa. A falta de uma unidade política e de um centro irradiador comum aumentou as diferenças, que já existiam, entre os falares do norte e do sul do rio Minho.

Se, por um lado, o condado de Galiza perdeu sua força política com o crescente aumento do poder de Castela, por outro lado, segundo SARAIVA (1999, 46-55), a região do Condado Portucalense cresceu militarmente nas batalhas de reconquista em direção ao sul, sob o comando de Dom Afonso Henriques, filho de Dom Henrique de Borgonha e Dona Teresa. Conforme TEYSSIER (1997: 25-26), o fortalecimento militar veio seguido de uma independência política e, ao se separar do reino de Leão e Castela, Portugal também se separou da Galiza e a isolou dentro dos reinos de Leão e Castela. Em 1179, Dom Afonso Henriques, posteriormente nomeado com o título de Afonso I, foi reconhecido como o rei de 
Estudo comparativo de aspectos semânticos do sufixo -ista no português e no galego.

Portugal pela Igreja Católica em Roma. Já em 1297, pelo Tratado de Alcanizes, fixaram-se as fronteiras atuais do território de Portugal.

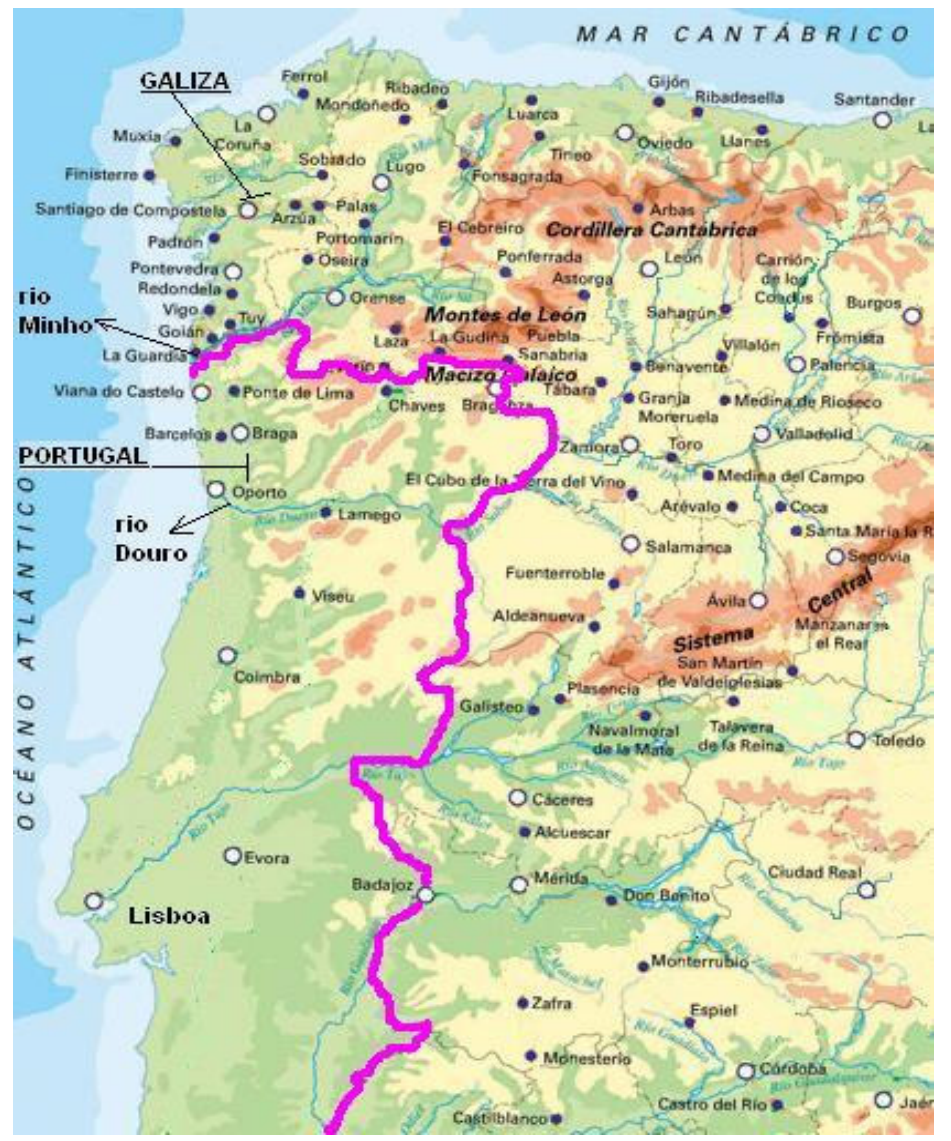

Mapa 1.29: As fronteiras entre Portugal e Galiza.

Segundo BREA (1983: 84-85), durante os séculos XIII e XIV, o galego-português teve grande importância literária na península Ibérica. Nessa época se destacaram três tipos de composições: as cantigas de amigo, as de amor e as de escárnio e maldizer, organizadas nos: Cancioneiro da Ajuda, Cancioneiro da Vaticana e Cancioneiro da Biblioteca Nacional de Lisboa. Merecem atenção as Cantigas de Santa Maria, escritas em galego-português pelo rei de Castela: Alfonso X, o Sábio. Esse período é conhecido como a fase de Esplendor Medieval da língua galego-portuguesa. É então natural, por um lado, que grande parte do léxico e das estruturas gramaticais em geral do português e do galego tenham sido inicialmente adquiridas e solidificadas a partir do galego-português proveniente dessa fase medieval destacada.

Além disso, a grande importância dos reinos de Castela e de Portugal na Península e a busca de uma União Ibérica promoveu ligações estreitas, principalmente por meio de 
matrimônios, entre as duas cortes. Houve, assim, uma notável influência do castelhano no português da corte, que se estendeu até fins do século XVII com a União Ibérica. De acordo com RUCQUOI (1995: 332-333), o primeiro rei de Portugal, D Afonso I (1140 -1185) era neto por via materna de D. Alfonso VI de Castela. Seu filho D. Sancho I (1185-1212) casou-se com Dulce de Aragão. Na sucessão, D. Afonso II (1212-1223) casou-se com Dona Urraca, filha de Alfonso IX de Castela. D. Afonso III (1247-1279) casou-se com D. Beatriz de Castela, a filha de Alfonso X, el Sábio. D. Dinis (1279-1325) casou-se com Isabel de Aragão e sua filha Constança de Portugal foi a esposa de Fernando IV de Castela. Por sua vez, D. Afonso IV (1325-1357) casou-se com D. Beatriz de Castela. Por outro lado, Dona Maria de Portugal, filha de Afonso IV, casou-se com Alfonso XI de Castela. Certamente os laços familiares da corte tiveram forte influência no falar português de prestígio, com interferências, sobretudo, do castelhano.

Entretanto, não apenas foram essas as mudanças sofridas pela língua portuguesa que a diferenciaram da galega, pois esta também sofreu mudanças. Com o processo de Reconquista a corte do reino português, que inicialmente estava em Braga, foi sendo transferida em direção ao sul conforme a expansão do território, e, com D. Afonso III, Lisboa tornou-se a capital. Certamente houve influências importantes como a do árabe, moçárabe, hebraico, provençal, francês, leonês, aragonês e, a partir das conquistas dos séculos XV e XVI, das línguas provenientes das colônias ultramarinas. Segundo BREA (1983: 83-84), a partir do século XIV, a separação política e cultural do rio Minho se intensificou e ficou marcada por duas variedades distintas. De acordo com PAZ (1999: 105), ainda que o português seja uma "criação" do sul da antiga Galiza, a sua evolução se deu no sentido da "desgaleguização", de tal forma que, ao passo que perdia o seu caráter galaico, adaptava-se ao ambiente linguí́stico moçárabe das terras centro-meridionais, pautando sua norma padrão pelos falares de Coimbra e Lisboa, que foram sede da corte. Enquanto o português veio a ser a expressão de um povo em expansão política, territorial, econômica e cultural; o galego se transformou em expressão coloquial de um povo reprimido diante do domínio castelhano, sofrendo influências deste e de outros falares trazidos pela peregrinação à Santiago de Compostela.

De acordo com SARAIVA (1999: 52-55), a toponímia conserva um vestígio da situação histórica da região nos seus nomes: castro, vila e paço ao norte e ao sul do Douro. O topônimo castro é proveniente dos castelos e fortificações celtas; vila provém da antiga 
colonização romana; o paço, proveniente de palatium, reflete a vila com a presença do novo senhor. A presença dos senhores era muito mais rara ao sul que ao norte, confirmado pela localização dos castros e das beetrias. A beetria é um tipo de organização intermediária entre o concelho e o senhorio feudal. Os moradores da aldeia dependiam de um nobre, mas tinham o direito de o eleger. Os castros e beetrias, numerosas na Galiza, já são bem mais raros na região do Minho e, ao sul do Douro, os castros já não existem e as beetrias são raríssimas. Esta coexistência de uma zona predominantemente senhorial, onde as populações viviam em situações de dependência pessoal e a regra era a servidão, e as zonas onde existiam os concelhos e a situação mais freqüente era a da liberdade, não pode deixar de ser considerada como um fator social da independência portuguesa. Por outro lado, a organização municipal proporcionou ao rei de Portugal a organização de forças militares, que tornaram possível o seu grande fortalecimento e sua hegemonia no governo.

Sabe-se que a separação política consumada na primeira metade do século XII não produziu diferenças lingüísticas imediatas entre os falares usados ao norte e ao sul do rio Minho, mas aos poucos foram criadas as condições para que cada região cultivasse as suas diferenças. Portanto, segundo PAZ (1999: 107), quando na segunda metade do século XIII começou-se a escrever regularmente na língua romance galego-português, entre os textos produzidos ao norte e ao sul do rio Minho, existiam já diferenças que em alguns casos eram a manifestações dialetais e em outros podem ter sido produzidas pelas distintas tradições escriturárias dos escrivãos de cada localidade. Entretanto, fato é que essas diferenças se aguçaram e se consolidaram nos séculos XIV e XV, a partir dos quais já existem duas línguas diferentes que se desenvolveram com dois rumos totalmente distintos.

De acordo com PAZ (1999: 129), no início existiu uma unidade lingüística galaica e, ao final, os acontecimentos históricos conduziram a que se produzisse um reagrupamento independente dos falares portugueses e galegos, desembocando na constituição de duas línguas próximas, porém distintas. A independência portuguesa e a pouca comunicação política e cultural entre as duas regiões, mesmo com as peregrinações à Santiago de Compostela, acabaram formando dois idiomas diferentes a partir do que eram inicialmente apenas diferenças dialetais. 


\section{Panorama histórico da Galiza}

Segundo SARAIVA (1999: 44), no final do século IX, as condições políticas de Leão e Castela tinham mudado; a administração foi aperfeiçoada; a influência dos cluniacenses fezse sentir, principalmente ao introduzir modificações nos cultos cristãos e nos escritos eclesiásticos em latim. Assim, Alfonso VI de Leão e Castela conquistou grande prestígio na Europa cristã, fornecendo uma considerável parte dos recursos para a construção de Cluny III, um templo majestoso para a época. Dessa ligação com Cluny, Alfonso VI casou suas duas filhas com duques de Borgonha, membros da alta nobreza do reino franco. E como tal, entregou-lhes à Dona Urraca, casada com Dom Raimundo de Borgonha o governo da Galiza e à sua filha Dona Teresa, casada com Dom Henrique de Borgonha, o condado Portucalense. O rei Alfonso VI havia conseguido impor o seu grande poder à maior parte da Península Ibérica. Os solenes títulos que usou: Imperator super omnes Spaniae nationes, em 1087, e Hispaniae Imperator, em 1091; traduzem sua intenção de acabar com as fronteiras na Península e conduzi-la a uma unidade política, sob seu poder. De acordo com SARAIVA (1999: 45), as nomeações da Galiza e de Portucale tiveram a intenção de refrear as tendências de autonomias, mais de uma vez reveladas nas regiões mais afastadas do centro da coroa castelhana, substituindo nelas o governo de famílias locais pelos membros da família real. Entretanto, quando Alfonso VI morreu, em 1109, desencadeou-se uma reação generalizada contra o crescente poder de Leão e Castela. A herdeira do trono, a rainha Urraca, disputou durante anos com o rei de Aragão a chefia política da Península cristã e discutiu também com o arcebispo de Compostela a autoridade sobre a Galiza. O conde de Astúrias revoltou-se e, vencido, refugiou-se em Portucale. É desse período também, o cerco de Guimarães, revolta liderada por Dom Afonso Henriques, filho de Dona Teresa de Portucale.

Conforme Monteagudo (1999: 99-100), o filho de Dona Urraca seguia pelo caminho natural de se converter o rei de Galiza, entretanto, em 1135, fez-se coroar rei de toda a Espanha, na Catedral de Leão, sob o nome de Alfonso VII, fixando-se nos interesses da coroa de Castela. Nesse período a influência franca no norte da Península aumentou avassaladoramente, bem como o número de fundações monásticas da ordem de Cluny, facilitado, em parte, pela peregrinação a Santiago de Compostela, daí a importância do caminho de peregrinação francês ilustrado no mapa 1.23 (página 55). Nesse período, começou 
a despontar o crescimento urbano na Galiza, bem como a importância das cidades episcopais e Compostela como centros irradiadores de cultura. A cargo da criação dos filhos dos reis cristãos, estava, em geral, o clero de Santiago de Compostela, onde ocorreu uma elevação de nível cultural, dada também a influência francesa. Com a morte de Alfonso VII, em 1157, houve a divisão dos reinos de Leão e Castela, de forma que Sancho ficou com Castela e Fernando herdou Leão, Astúrias e Galiza. Apesar de nesse período haver uma divisão das forças políticas e militares, no que concerne ao processo de Reconquista cristã, continuou havendo uma grande importância da cidade de Santiago de Compostela no âmbito cultural, assim, seus educadores clericais passaram a estudar filosofia e teologia na Universidade de Paris, por meio da concessão de bolsas. Segundo MonTEAGUdo (1999: 114-115), em 1230, as coroas de Castela e Leão uniram-se novamente com o rei Fernando III, que incorporou totalmente, as regiões e reinos de Astúrias, Galiza e Leão, introduzindo de forma maciça o uso do castelhano por meio das classes dirigentes nesses locais. Assim, de acordo com LORENZO (1994), a penetração de nobres de fala castelhana na região da Galiza foi intensa, e na aliança que ainda se mantinha com a antiga classe nobre e dirigente galega, era requisito indispensável falar castelhano para a comunicação. A "desgaleguização" se produziu, em princípio, nos âmbitos mais formais e posteriormente no campo familiar da nobreza. Os cargos civis e eclesiásticos mais importantes também foram concedidos a pessoas nãogalegas, e por estes e outros motivos o galego deixou de ser a língua das classes sociais mais altas, ficou reduzido ao âmbito de língua de uso popular, rural e para as classes trabalhadoras e restrito à sua forma oral contribuindo para o seu total desprestígio social. Esse processo se intensificou com Alfonso X, o mesmo rei que escreveu as Cantigas de Santa Maria em galego-português nomeou o abade de Valladolid como arcebispo de Santiago de Compostela.

Segundo LORENZO (1994), em meados do século XIV, na disputa pela coroa de Castela, de 1366 a 1369, os nobres galegos apoiaram Dom Pedro I, mas quem subiu ao trono foi Dom Henrique II, o que fez com que, a Galiza fosse desprestigiada e seus dirigentes gradativamente substituídos por dirigentes de confiança do rei, em geral castelhanos. No entanto, a "desgaleguização" culminou no século XV, novamente na disputa pela coroa de Castela, a Galiza apoiou Joana, mas quem se tornou rainha foi Isabel, a Católica, que, durante seu reinado, exerceu uma grande repressão contra a Galiza, dando início aos Séculos Escuros para o galego e toda a sua literatura. De acordo com PAZ (1999: 264), o estereótipo da 
personagem do galego imigrante pobre e rústico, já existente no período medieval, se popularizou a partir do século XV e se espalhou por toda a Península Ibérica, tomando como traço característico o seu falar e contribuindo para o desprestígio total da língua galega.

Assim, inicialmente na segunda metade do século XII, o galego disputava sua autonomia como língua enfrentando o latim da igreja, o notarial e o literário. A partir do século XIII, o castelhano já começava a se impor como a língua de uma nação, se sobrepondo ao latim no campo notarial e literário. Com os reis católicos e a expansão marítima, o castelhano se sobrepôs às demais línguas espanholas. Mas, somente no século XVI, com o humanismo, o castelhano se impôs totalmente ao latim no campo literário, como também às outras línguas espanholas, e em particular ao galego.

Entretanto, de acordo com MonTEAGUdo (1999: 117-121), a atividade literária não desapareceu totalmente. Encontra-se uma importante quantidade de mostras da literatura popular, elaborada anonimamente e divulgada na forma oral. Também se recolheram muitos versos que se cantavam por toda a península no tempo de Natal, e ainda, se conhecem alguns autores que deixaram parte de seu trabalho poético em galego. Um exemplo é o Soneto Renascentista de Isabel de Castro e Andrade, Condessa de Altamira, composto no último terço do século XVI. São importantes também, os autores Gómez Tonel e Vazquez Neira com suas homenagens à rainha Dona Margarida de Áustria, que datam de 1611. Assim como os decassílabos escritos por Martín Torrado.

Segundo PAZ (1999: 317-327), a situação de desprestígio começou a ser combatida somente no final do século XVIII, graças ao trabalho de alguns ilustrados que defendiam os direitos de uso do galego como qualquer outra língua. A figura mais relevante foi o Frade Martín Sarmiento, que não só se preocupou com o estudo da língua galega, como também denunciou a sua marginalização no âmbito educacional, administrativo e eclesiástico. A partir de Sarmiento, alguns outros ilustrados, como o Padre Sobreira e José Cornide, passaram também a estudá-la e a defendê-la.

De acordo com Monteagudo (1999: 292-295), a invasão Napoleônica do início do século XIX contribuiu para despertar a consciência galega, pois abriu as portas para a circulação de textos escritos na língua popular da região. Ademais, a reação pós-napoleônica favoreceu as ideologias nacionalista e regionalista, respaldadas no crescente poder da 
burguesia. A consciência da Galiza diferenciada do resto da Espanha foi aumentando progressivamente e esta procura de identidade manifestou-se por meio de publicações nas quais os escritores e políticos valorizavam a sua cultura e região diante da opressão externa. Em 1848, houve o banquete de Conxo, no qual se confraternizaram estudantes e trabalhadores, e onde o "galeguismo" tomou características revolucionárias. Nesse contexto, começou a reivindicação do direito de Galiza administrar os seus próprios recursos e eleger seus próprios representantes. Em 1853 publicou-se o primeiro livro escrito em galego do século XIX: A gaita galega. O seu autor, Xoán Manuel Pinto, junto com Francisco Añón, Manuel Murguía e outros deram o primeiro passo para a normalização do galego e são conhecidos como o Grupo dos Precursores. Logo em seguida veio a fase chamada Rexurdimento, ou seja, renascimento do galego, e é marcada pela publicação do livro Cantares Gallegos em 1863 de Rosalía de Castro, que fez renascer a cultura lírica e popular, juntamente com outros escritores importantes da época, dentre eles: Curros Enríquez (Aires da Miña Terra, 1880) e Eduardo Pondal (Queixumes dos Pinos, 1886), restauraram a plenitude literária.

Nos primeiros anos do século XX houve uma retomada de consciência sobre o galego por parte de diversas associações que conseguiram que a língua chegasse a ser normalizada não somente no campo literário. Entre elas: as Irmandades da Fala, a Xeración Nós e o Seminario de Estudos Galegos. As Irmandades da Fala foram constituídas em 1916, seu ideal foi difundido pela publicação da revista A Nosa Terra, e contemplava a defesa e habilitação do galego, com sua presença na escola e na administração pública. A partir daí o galego começou a ser habitual nos atos públicos e discursos políticos. A Xeración Nós realizava o trabalho de estudo e fortalecimento da cultura galega, defendendo o uso da língua em todos os campos, inclusive no científico. Criado em 1923, o Seminário de Estudos Galegos reunia muitos universitários para, em conjunto, publicarem os seus trabalhos em galego.

Entretanto nesse período, principalmente no que se refere aos primeiros anos do século XX, a situação lingüística do galego era muito diversificada. Vivendo na oralidade por tanto tempo produziu uma grande variedade dialetal e passou a ser designada como uma língua rural e rústica, própria das classes camponesas e do operariado exportado pelo campo galego. No âmbito urbano, prestes a desaparecer em favor do castelhano nas classes da elite, porém vista como a língua dos operários, segundo GARCíA BLANCO, apud MonTEAGUdo (1999: 
332). Em relação ao mesmo período, Vilar Ponte, apud Monteagudo (1999: 332), afirma que ainda que já não fosse mais a língua da classe média, esta classe também não deixava de utilizar o galego, mesmo em ambiente familiar. Em julho de 1888, José Leite de Vasconcelos afirmou, em artigo publicado em El País Gallego, que o galego era um co-dialeto do português, já que carecia de uma literatura suficientemente desenvolvida e não era o idioma de um país independente, apud PAZ (1999: 461).

Durante a Segunda República Espanhola, o movimento político nacionalista galego conseguiu um considerável desenvolvimento, figurando entre as suas reivindicações a do reconhecimento para a Galiza de seus direitos idiomáticos. Em junho de 1936 foi aprovado o Estatuto de Autonomia de Galiza, que no seu artigo 40 estabelecia a oficialidade do galego. Com a eclosão da Guerra Civil Espanhola, todo o processo ficou paralisado, segundo MonTEAGUdo (1999: 385-435).

A ditadura franquista foi um entrave para o desenvolvimento social e cultural na Galiza. Iniciou-se um duro período de repressão conhecido como a "longa noite de pedra". O galego sobreviveu na Espanha, na clandestinidade, no contexto oral, na fala familiar e camponesa, e graças ao trabalho de associações culturais clandestinas como $O$ Galo em Santiago de Compostela e $O$ Facho n'A Corunha. Mas, também sobreviveu na fala dos galegos que emigraram, em particular os que foram para Buenos Aires, na Argentina, onde formaram grandes e importantes comunidades, associações culturais e filantrópicas que publicavam obras literárias e jornais em galego.

Depois da morte de Franco, o galego, que tivera o uso proibido durante os quarenta anos de seu governo, voltou ao estado diglóssico semelhante ao que se encontrava no final do século XIX. Entretanto, como resultado da Constituição de 1978, a Galiza recebeu um Estatuto de Autonomia, aprovado em 21 de dezembro de 1980, no qual se reconheceu e se legitimou o galego como língua oficial em toda a região. Iniciou-se, então, um resgate do galego por meio dos emigrantes e das comunidades que o falavam livremente fora de Espanha. Em 1983, a Xunta de Galicia promulgou a Lei de Normalización Lingüística a fim de favorecer a normalização e garantir a igualdade com o castelhano na administração pública, no ensino, na imprensa etc. Apesar dos progressos do galego em diversos campos, ainda há grandes lacunas no seu uso e, em certos contextos, ainda se pode notar seu desprestígio. 


\section{Panorama histórico de Portugal}

Desde fins do século IX começaram a aparecer referências a um condado Portucalense, de fronteiras muito imprecisas, mas que abrangia terras ao sul do rio Minho até ao sul do rio Douro, conforme SARAIVA (1999: 42-49). A designação provinha da povoação Portucale, próxima à foz do rio Douro, conquistada dos muçulmanos e repovoada nos meados do século IX, pelo conde Vimara Peres. As regiões mais ao sul formavam também um condado com sede em Coimbra, cujo governo foi exercido por uma família portucalense, até, novamente, cair em domínio muçulmano e voltar ao domínio cristão em 1064. Em 1093, o rei Alfonso VI de Castela e Leão, entregou o condado Portucalense à sua filha Dona Teresa, casada com Dom Henrique de Borgonha. Em 1128, Dom Afonso Henriques, filho de Dona Teresa de Portucale, liderou o cerco de Guimarães, uma revolta na qual se opunha à reintegração de terras do Condado Portucalense à Galiza, contrariamente às pretensões de sua mãe, Dona Teresa, de se apoderar do Reino de Galiza enquanto Dona Urraca se ocupava do reino de Leão e Castela. Em 1135, Dom Alfonso VII proclamou-se rei de Toda Espanha, e começaram as guerras com seu primo Dom Afonso Henriques de Portucale apoiado pelos barões portucalenses e pelos bispos de Braga e Coimbra que queriam obter a independência de suas dioceses. Já, em 1143, em carta ao papa Inocêncio II, Dom Afonso Henriques proclamou-se rei de Portugal, por meio de um censo pago à Cúria Romana. Entretanto, somente em 1179 tal ato foi reconhecido pelo Vaticano. Nesse período já não havia o rei da Espanha e a força que impelia a unidade peninsular não evitara a fragmentação, de acordo com tendências feudais. Dessa forma, em 1179, Afonso Henriques era um dos vários reis cristãos existentes na Península Ibérica.

A fronteira do novo reino, quando Dom Afonso Henriques começou a intitular-se rei, passava um pouco ao sul de Coimbra, conforme o ilustrado no Mapa 1.30. O primeiro grande passo para o aumento do território verificou-se em 1147 com as conquistas de Santarém e de Lisboa, junto com a qual também a de Sintra. A última conquista foi a do Faro, em 1249. Durou, portanto, pouco mais de um século o período de expansão do território, tempo que comporta longos intervalos de paz e períodos de guerras em conseqüência de contra-ofensivas muçulmanas. 
Estudo comparativo de aspectos semânticos do sufixo -ista no português e no galego.

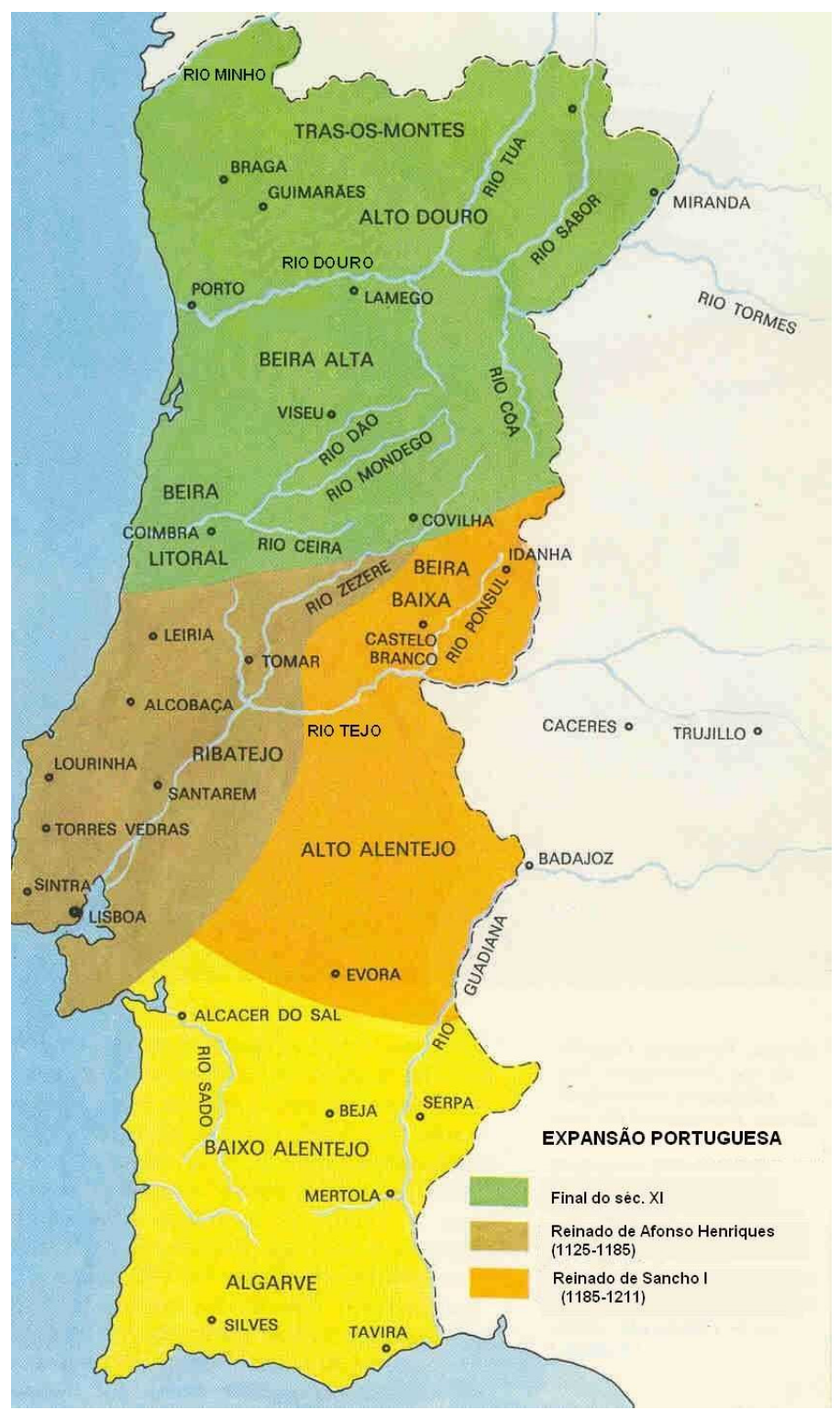

\section{Mapa 1.30: A reconquista cristã portuguesa.}

De acordo com SARAIVA (1999: 52-55), apesar das divisões e fraqueza interna dos principados islâmicos (reinos Taifas), as forças militares portuguesas eram poucas, e foi, várias vezes, necessário recorrer à ajuda das tropas cruzadas vindas do Norte da Europa a caminho da Palestina quando faziam suas escalas nos portos portugueses. Os diplomatas encarregados de propor a colaboração guerreira eram bispos, que deviam convencer os chefes dos cruzados que tão santa era a guerra contra os "infiéis" da Península Ibérica como a cruzada para libertar o Santo Sepulcro e ao mesmo tempo ofereciam, como pagamento, o saque das cidades que caíssem em seu poder. Desse modo, Dom Afonso Henriques 
Estudo comparativo de aspectos semânticos do sufixo -ista no português e no galego.

conquistou Lisboa, em 1147, Dom Sancho I conquistou Alvor e Silves, em 1187, e Dom Afonso II dominou Alcácer do Sal, em 1217.

A conquista do território prosseguiu ao longo de toda a primeira metade do século XIII, com as numerosas expedições guerreiras no reinado de Sancho II. Parte das conquistas no Alentejo e no Algarve foi feita pelas ordens monásticaas, especialmente a dos cavaleiros de Santiago. O rei as recompensou com grandes doações de tipo semi-feudal, nas quais a administração era entregue às ordens, que se tornavam proprietárias e organizavam o arrendamento de terras a lavradores estrangeiros. Assim, já no final do século XIII, fixaram-se os limites do que é hoje o território peninsular de Portugal.

Sabe-se que, a partir de 1255, na chancelaria do rei Afonso III de Portugal, a par do latim já se usava o português nos diplomas oficiais, de acordo com MATTOS E SiLVA (1999). Dessa forma, na última década do século XIII, o rei Dom Dinis legalizou a língua portuguesa como a oficial do reino, seguindo também nisso o modelo de seu avô, o rei Alfonso X de Leão e Castela, que institui o castelhano como língua oficial.

Entretanto, para SARAIVA (1999: 52), foi a tomada, em 1147, de Lisboa, que veio a ter importância decisiva no destino de Portugal e da língua portuguesa. O centro do país deslocou-se em direção ao sul, sem, entretanto, deixar de se localizar no litoral. Assim, os velhos interesses agrícolas foram substituídos pelos marítimos e mercantis, com cujo apoio se pos fim na dinastia de Borgonha na segunda metade do século XIV, com a subida ao trono do Mestre de Avis, filho de D. Pedro I, contrariamente ao ensejo da nobreza (fiel à herdeira de Borgonha). Houve, também o surgimento de uma nova classe social: a burguesia de comerciantes e armadores de navios. Quando Portugal se lançou aos Descobrimentos marítimos, não apenas se destacou Lisboa, também o Algarve teve um importante papel com a Escola de Navegação de Sagres do Infante D. Henrique o Navegador, e a de Lagos dos armadores de navios e da Casa da Guiné.

Estes fatores histórico-sociais tiveram as suas repercussões lingüísticas. É este provavelmente o período em que, pelos hábitos articulatórios próprios das populações moçárabes do Sul, o galaico-português importado do Norte transformou-se em uma língua foneticamente bem distinta do galego. A decadência a partir de 1350 da lírica galaicoportuguesa, que contribuíra à formação de uma imagem de unidade lingüística no oeste da 
Península, e o florescimento, sobretudo em Portugal, da prosa didática e histórica, gênero típico da época dos primeiros reis da Dinastia de Avis em que se reflete um pouco mais a língua falada, também fazem com que a ruptura entre as duas variantes lingüísticas: a do norte e a do sul do rio Minho se note mais nitida e profundamente. Segundo o Instituto Camões ${ }^{9}$, ao contrário do que acontecia no caso das cantigas, as diferenças existentes no que diz respeito à língua, entre obras portuguesas como a Crônica Geral de 1344, os Livros de Linhagens, o Livro da Montaria de D. João I, o Leal Conselheiro do rei D. Duarte, a Demanda do Santo Graal e as Crônicas de Fernão Lopes e de Azurara, por um lado, e as galegas como a Crônica Troyana e a tradução da Crônica Geral de 1404, por outro, são bastante consideráveis.

Os séculos XVI e XVII, de acordo com SARAIVA (1999: 193-217), culturalmente foram uma época áurea das letras e artes portuguesas, e desde o ponto de vista lingüístico, o instante em que o português conseguiu uma maior difusão no mundo, dada as colonizações, bem como os contatos portugueses com as demais potências, motivo pelo qual, numerosas palavras exóticas penetraram no francês, italiano, inglês ou alemão por via portuguesa, mas também a existência nessas línguas de alguns lusitanismos puros que datam deste período, bem como vários neologismos de origem estrangeira que incidiram no português.

$\mathrm{Na}$ Idade Média tinham sido o francês e o provençal os idiomas que contribuíram em maior grau para o enriquecimento do léxico português, nos séculos XVI e XVII foram o italiano e o espanhol. A Itália como expoente durante o Renascimento explica a abundância de italianismos introduzidos no português por esta época, enquanto que os espanholismos devem ser atribuídos não tanto aos sessenta anos de anexação a Espanha como à atração que a literatura, a cultura exerceram sobre a Europa durante os Séculos de Ouro das artes espanholas.

De maneira análoga a como Nebrija tinha feito na Espanha, alguns gramáticos começam sistematicamente a comparar as formas portuguesas com as latinas para eleger dentre as distintas variantes usuais de cada palavra aquelas mais "adequadas" à língua. Os primeiros gramáticos portugueses dessa linha são Fernão de Oliveira com a Gramática da linguagem portuguesa, em 1536, e João de Barros com a Gramática da língua portuguesa, em 1540, mas sucedem-se muitos outros através de todo o século XVI, XVII, primeira metade

\footnotetext{
${ }^{9}$ http://www.instituto-camoes.pt/cvc/linguistica.html
} 
do XVIII, e no século XIX. O século XVIII português, contudo, foi mais crítico que criador e manteve-se como o marco da fixação da língua. As modificações fonéticas posteriores não vieram a ser registradas pela ortografia e, muitas das vezes, não foram adotadas pela fala culta do Brasil.

Do século XVIII é também a Academia das Ciências de Lisboa, fundada em 1779, contribuindo para a "purificação" e fixação da língua, por meio do primeiro Vocabulário Português e Latino em dez volumes, publicado entre 1712 e 1727, de autoria do francês Bluteau. De finais do mesmo século data o Dicionário de Morais Silva, considerado como um dos mais ricos para o estudo do português da época.

Já no século XIX, e durante o Romantismo, a perfeição do estilo é sacrificada ao vigor da expressão e o uso de palavras estrangeiras torna-se lícito. Assim, abundam os galicismos e algumas estruturas sintáticas do francês. Da mesma maneira, há uma nova entrada de espanholismos, determinada pela atração que exerce Espanha como pitoresca e heróica devido à resistência a Napoleão. Também a Itália contribuiu para o enriquecimento do léxico português neste tempo, ao passo que entraram no idioma a primeira leva de anglicismos, de acordo com informações do Instituto Camões.

Com o movimento realista e a entrada do século XX, houve uma abertura maior para a utilização de palavras vulgares e quotidianas, que até então estavam reclusas no ambiente familiar e popular. Entretanto, segundo SARAIVA (1999: 357- 366), a ditadura de Salazar, de 1933 a 1974, foi um período de repressão não apenas político, como também cultural, refletindo-se no desenvolvimento conservador da língua, pois nesses quarenta anos, o país praticamente ficou isolado, não só geográfica, mas culturalmente. Nesse período houve a emigração, em massa para vários países europeus, bem como para Canadá e Estados Unidos. Com a Revolução dos Cravos, em 1974, além de haver uma mudança política no país, ocorreram também mudanças sócio-culturais. Muitos emigrantes retornaram trazendo consigo já uma influência estrangeira. Nessa época também Portugal perdeu suas colônias africanas e recebeu, em contrapartida, uma grande quantidade de luso-descendentes foragidos das guerras, promovendo uma retomada das influências lingüísticas africanas.

Segundo SARAIVA (1999: 375), em junho de 1985, com a adesão e a integração de Portugal à Comunidade Européia, houve mudanças profundas sob muitos aspectos da vida e 
Estudo comparativo de aspectos semânticos do sufixo -ista no português e no galego.

da cultura portuguesa, que provocou influências lingüísticas, principalmente no léxico, com a entrada de palavras globais. Assim, Portugal atraiu a imigração proveniente das suas excolônias, recebendo então, influências diretas dos falares africanos e brasileiros. A influência brasileira ocorre também pelos meios de comunicação como: revistas, livros, programas de televisão, em particular pelas telenovelas e entrevistas com jogadores de futebol.

Dessa maneira, ainda que o português seja uma unidade lingüística, nele há uma grande variedade. Assim como a Espanha tem a sua divisão de falares provenientes do processo de Reconquista, em Portugal também pode-se traçar um paralelo com o processo de Reconquista, associando-o ao reconhecimento de áreas dialetais, conforme o Mapa 1.31.

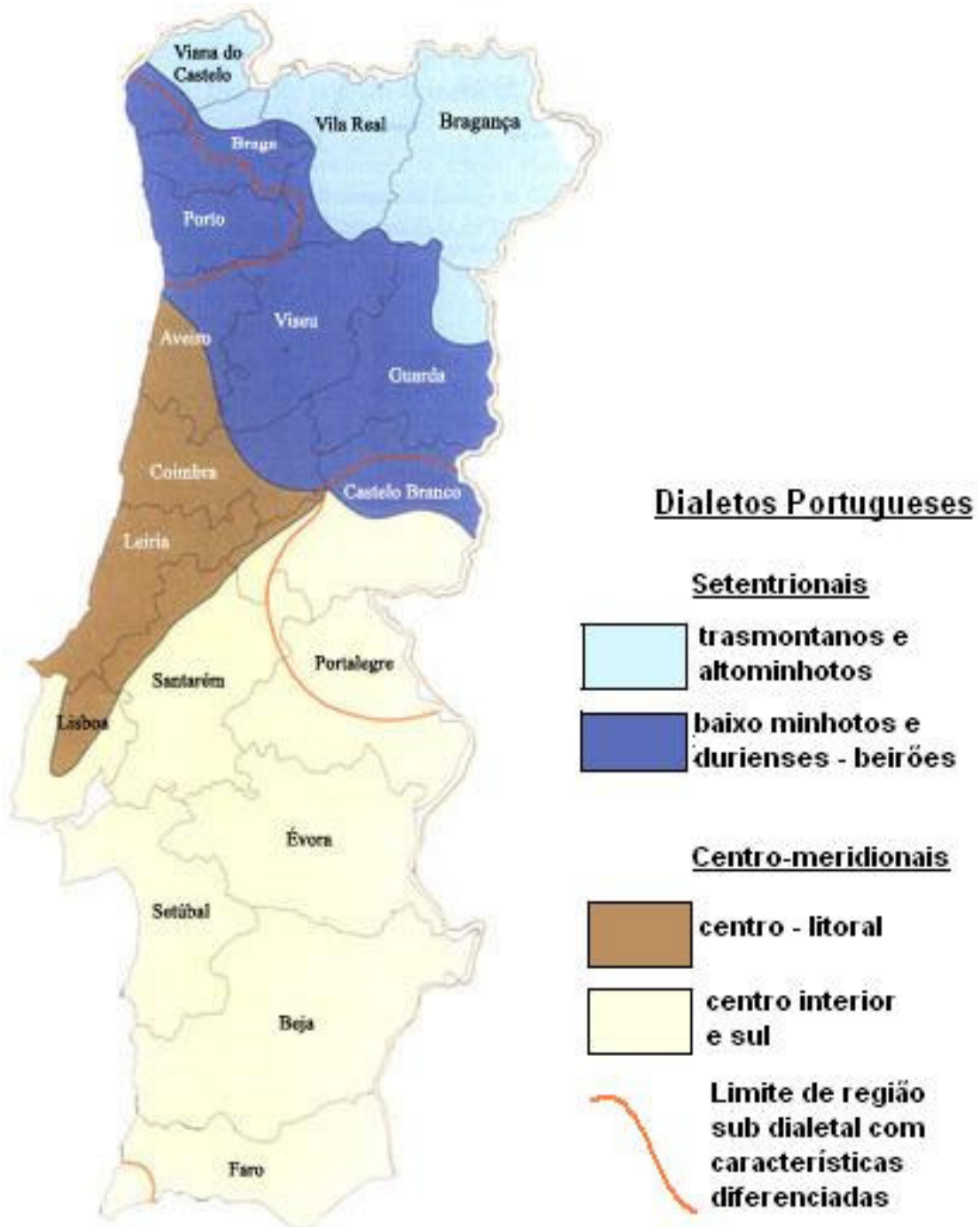

Mapa 1.31: Divisão dialetal em Portugal. 
Estudo comparativo de aspectos semânticos do sufixo -ista no português e no galego.

Segundo o Instituto Camões, nas zonas setentrionais conservam-se tipos léxicos arcaicos, alguns deles quase totalmente desaparecidos no resto da România, bem como, ao norte, ainda há um contato com o galego, enquanto que nas zonas centro-meridionais encontram-se tipos lexicais do centro da Espanha.

É interessante notar que, depois do espanhol, a língua portuguesa é o idioma românico que tem maior número de falantes, cerca de 117 milhões de pessoas, como conseqüência dos descobrimentos marítimos. Assim, corresponde à Lusitânia, ou seja, espaço geolingüístico ocupado pelo português, conforme definição de Elia (1989: 16-17), além de Portugal; na África, o arquipélago de Cabo Verde, Guiné Bissau, São Tomé e Príncipe, Angola e Moçambique; Diu, Damão, Goa, Timor-Leste e Macau, no Oriente; e, na América do Sul, o Brasil, conforme o Mapa 1.32.

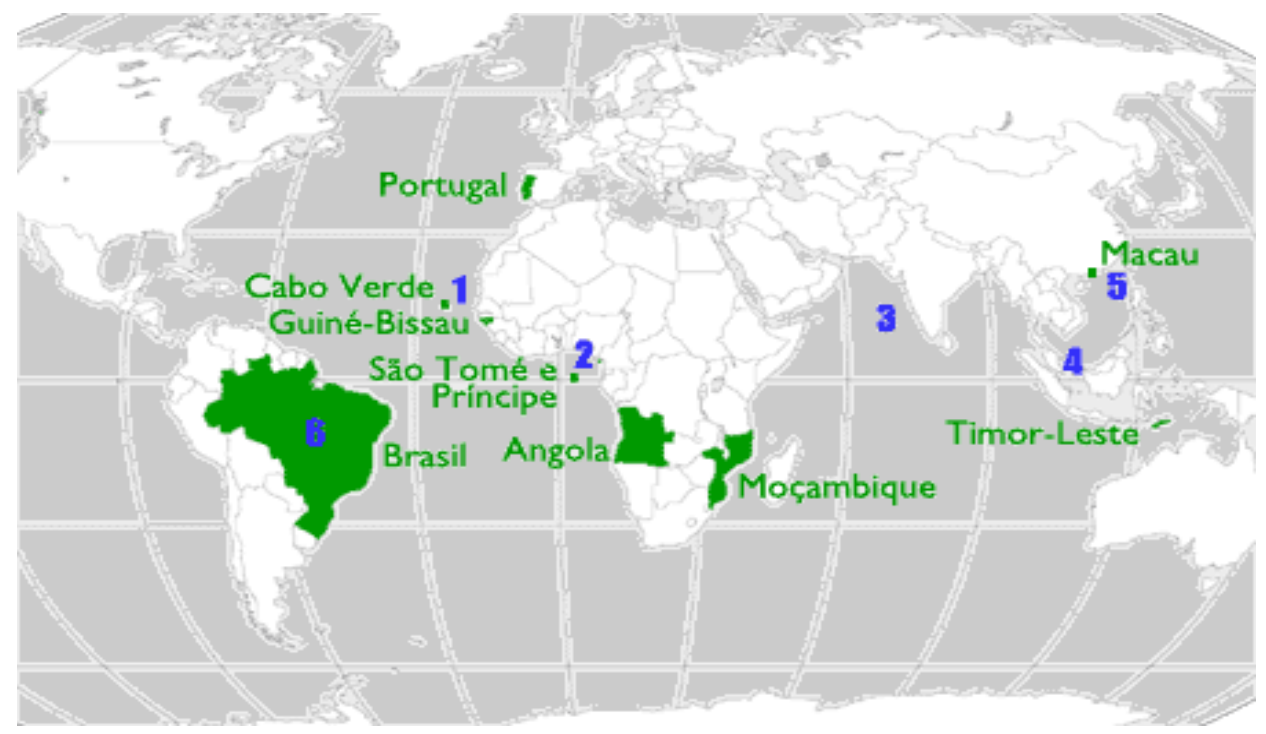

Mapa 1.32: A língua portuguesa no mundo.

A emigração para a América, já em época moderna, de trabalhadores portugueses determinou a existência de núcleos portugueses não só no Brasil, mas também nos países de fala espanhola ou inglesa. Nos primeiros, dada a semelhança são absorvidos lingüisticamente, mas na América do Norte, mantêm-se um português, ainda, com poucas influências do inglês. Uma das mais recentes colônias formou-se nos Estados Unidos com cerca de um milhão de portugueses, dos quais cerca de dois terços vivem na Califórnia e Massachussets, conforme o Instituto Camões. 


\section{Panorama histórico do Brasil}

Segundo o Prof. Dr. Aryon D. Rodrigues, da Universidade de Brasília (UnB), quando os portugueses chegaram ao Brasil, em 1500, havia mais de 1.000 línguas no país, faladas por índios. Assim, a língua portuguesa no Brasil passou a ser praticada em uma relação de espaço e tempo diferentes dos de Portugal, relacionando-se com as línguas indígenas como um traço inovador em relação ao português lusitano.

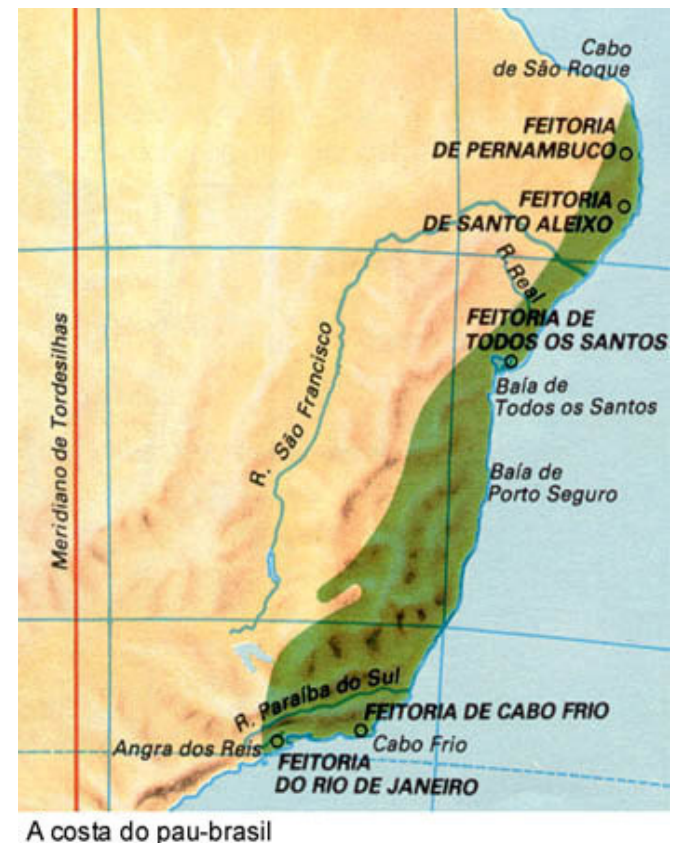

Mapa 1.33: As atividades portuguesas no litoral brasileiro, no século XVI.

A colonização portuguesa no Brasil começou pelo litoral, a partir de 1532, com a fundação de São Vicente e Piratininga, para a exploração de pau-brasil e a criação de engenhos de cana-de-açúcar. Nesse período, diversas comunidades de falantes de línguas da família Tupi habitavam o litoral entre o Maranhão e o Paraná, havendo entre elas uma grande proximidade lingüística. A partir do tronco tupi, criou-se uma língua geral comum a índios e não-índios, sendo referida por viajantes e missionários como a língua dos índios, língua brasílica, língua da terra, língua do Brasil, ou linguagem paulista; uma língua franca da costa brasileira, que foi documentada pelos jesuítas, por exemplo, em a Arte de gramática da língua mais usada na costa do Brasil, do padre José de Anchieta (1595). No século XVII, quando da colonização das regiões do Maranhão e Amazonas, usou-se outra língua-geral, conhecida 
Estudo comparativo de aspectos semânticos do sufixo -ista no português e no galego.

como linguagem amazônica, usada ainda hoje, mas de forma restrita. Entretanto, a língua oficial do Estado era o português. Convém ressaltar que durante o século XVI e XVII, a língua portuguesa passou a sofrer concorrência direta com outras línguas oficiais: o holandês no nordeste e o francês no litoral sudeste, que também deixaram suas influências.

Com a saída dos holandeses, em 1654, intensificou-se o processo português de colonização. A população, cuja maioria era de índios, passou a receber um número cada vez maior de escravos africanos e de portugueses que chegavam com o status de senhores. $\mathrm{O}$ tráfico de escravos começou com o cultivo da cana-de-açúcar em São Vicente, no Recôncavo Baiano e em Pernambuco, aumentando no século XVII. Segundo CÂMARA JR. (1976: 30-31), os escravos acabaram aprendendo o português pela necessidade de se comunicar com os senhores, mas também se adaptaram à língua geral, que era a mais falada entre os colonos. De 1502 a 1860, foram introduzidos cerca de 3.600 .000 africanos, de origem variada e em períodos diversos, CÂMARA JR.(1976: 30-31). Assim, a relação lingüística no Brasil passou a ser fundamentalmente entre o português de várias regiões de Portugal, as diversas línguas africanas, as diferentes línguas indígenas e a língua geral.

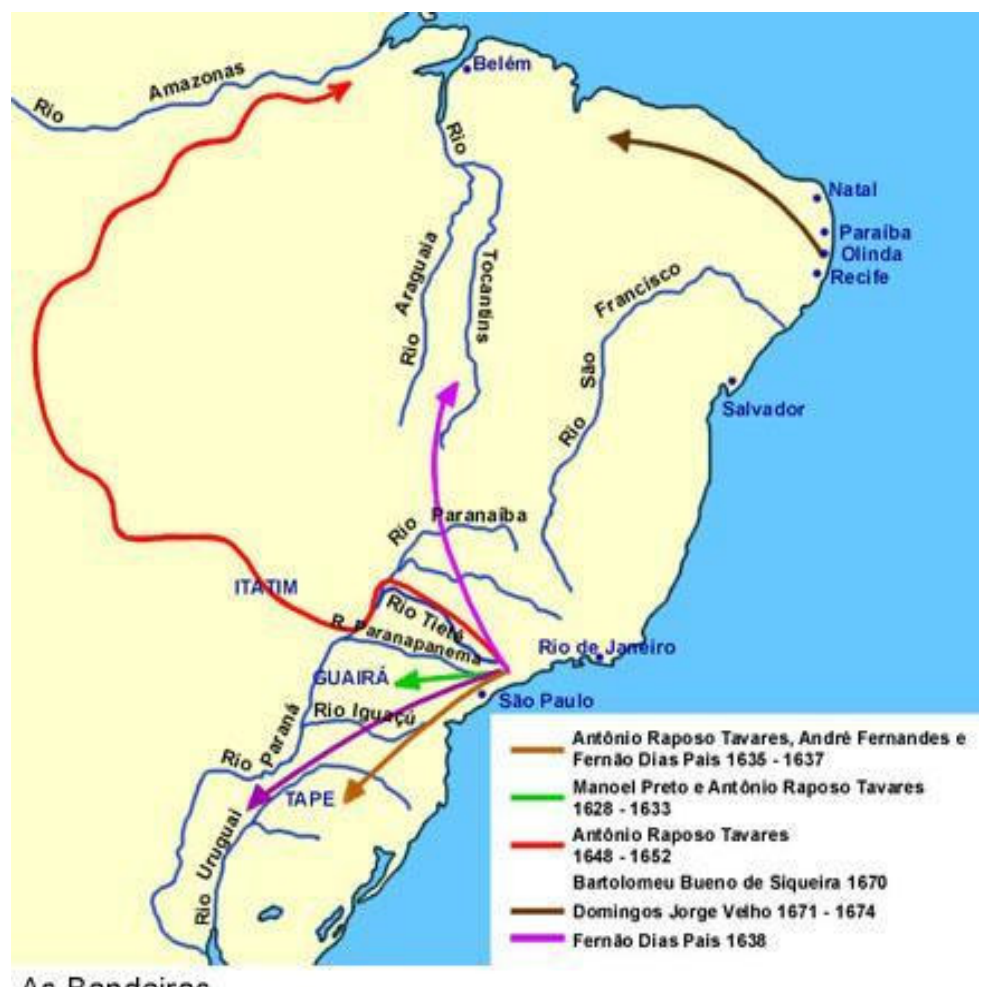

As Bandeiras

Mapa 1.34: As expedições bandeirantes do século XVIII. 
Estudo comparativo de aspectos semânticos do sufixo -ista no português e no galego.

Com as atividades econômicas do século XVII, houve um considerável aumento no número de portugueses que emigraram ao Brasil para se aventurar nos centros em expansão, como bandeirantes. Por um lado, o papel destes foi fundamental na expansão territorial e na disseminação da língua geral, conforme Mapa 1.34; bem como pelo contato com o castelhano das missões no sul. Por outro, foi responsável pela diminuição das populações indígenas, e com elas a importância de suas línguas em seus territórios.

Pode-se notar que a ocupação territorial do Brasil caminhou paralelamente com as atividades econômicas em cada período, conforme o Mapa 1.35. Assim, no século XVI, restringiu-se ao litoral do nordeste e sudeste, com o ciclo do pau-brasil e da cana-de-açúcar. No século XVII, houve o ciclo do ouro em Minas Gerais e ao longo do rio São Francisco, bem como a criação de gado no: sertão nordestino, sul de Minas Gerais e sul de São Paulo, e a criação de búfalos ao longo do rio Amazonas. No século XIX, a importação do gado zebu contribuiu para a o aumento das áreas dedicadas à pecuária no nordeste e centro-oeste; houve a expansão no oeste paulista com o ciclo do café; e um aumento na ocupação da bacia amazônica com a extração da borracha.

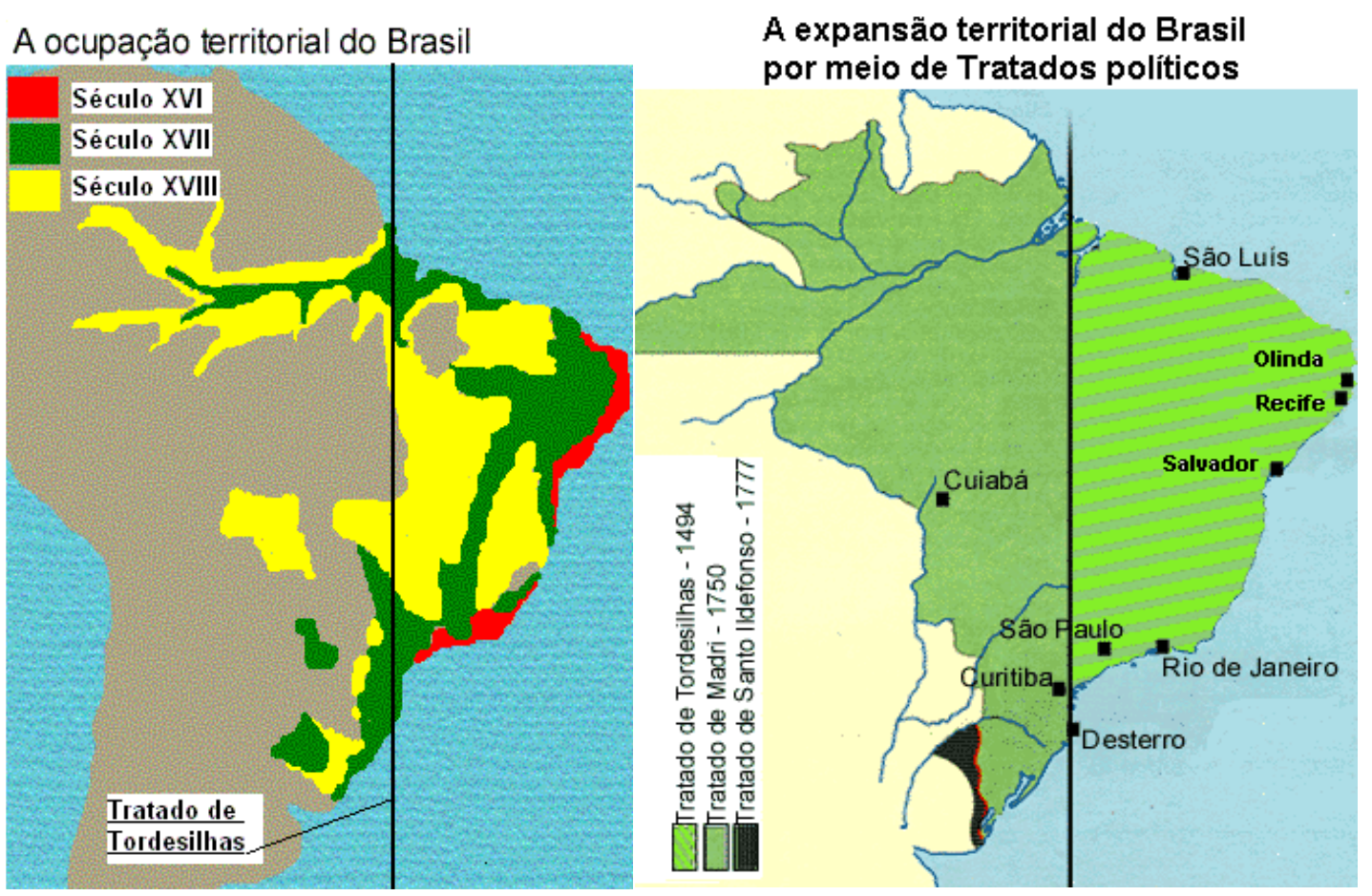

Mapa 1.35: A expansão da colonização e a expansão territorial do Brasil. 
Estudo comparativo de aspectos semânticos do sufixo -ista no português e no galego.

Dessa forma, a variedade das atividades econômicas que ocorreu em períodos diferentes, em contato com povos de procedências distintas, bem como as grandes diferenças geográficas, contribuíu para uma variedade dialetal na língua, ainda que houvesse um traço comum dado pela língua geral.

A predominância do uso do português no Brasil em relação à língua geral começou a ocorrer a partir da segunda metade do século XVIII e se consolidou definitivamente no início do século XIX, com a instalação da família real e da corte portuguesa no Rio de Janeiro. Por meio de um decreto do Marquês de Pombal, em 17 de agosto de 1758, a língua portuguesa tornou-se o idioma oficial do Brasil, proibindo-se o uso das demais línguas, inclusive a língua geral. Entretanto, quando foi decretada a obrigatoriedade do uso do português, os falantes brasileiros já haviam incorporado traços característicos da língua geral, com mais de dois séculos de sua utilização. O português, além de língua oficial do Estado, passou a ser a língua mais falada, devido também ao aumento do número de portugueses, procedentes das mais variadas regiões. Assim, a língua passou a conviver no Brasil em um mesmo espaço com variedades que em Portugal não tinham esta relação direta, pois, ali conviviam como dialetos de regiões diferentes. Estes aspectos certamente contribuíram para diferenças específicas entre o português americano e o europeu. Segundo TEYSSIER (1997: 95-96), no final do século XVIII, o brasileiro aparece no teatro português como uma personagem cuja característica é a peculiaridade de seu falar.

Com a trasnferência da família real portuguesa, em 1808, para o Brasil, houve a rápida transformação do Rio de Janeiro em Capital do Império que trouxe novos aspectos para as relações sociais da, até então, colônia. Logo de início, Dom João VI criou a imprensa no Brasil e fundou a Biblioteca Nacional, mudando o quadro da vida cultural, e dando à língua, no solo americano, um instrumento direto de circulação. Estes fatos certamente contribuíram para que o português se tornasse uma língua de prestígio no Brasil, favorecendo-a como a língua nacional do Império quando da independência, e a língua oficial do Estado Brasileiro desde então. Nesse período, a influência do inglês cresceu dado as relações com a Inglaterra, e as atividades comerciais e de construção civil exercidas pelos ingleses. Entretanto, a língua da cultura ainda era o francês, exercendo grande influência sobre o português.

Como reflexo das revoluções européias ocorridas, especialmente no século XIX, o Brasil passou por várias mudanças sociais e políticas, que atuaram na cultura e na língua. $\mathrm{O}$ 
processo de independência do Brasil é uma das conseqüências da influência do nacionalismo europeu transplantado ao solo da América. Após a independência política houve um grande número de discussões sobre a gramática da "língua nacional”, que abriu espaços importantes tanto na literatura quanto na constituição do conhecimento sobre o português no Brasil. Por exemplo, o estilo da escrita de José de Alencar provocou debates com gramáticos portugueses. Desta maneira, marcou-se uma variedade da língua portuguesa proveniente de sua relação com as condições brasileiras, cuja história de convivência com outras línguas como as indígenas, a língua geral, as africanas, bem como a convivência com as línguas européias e veiculares de cultura: o francês, italiano, inglês e alemão, a modificou de forma específica.

Convém notar que, com as mudanças ocorridas no século XIX, o tráfico de escravos africanos diminuiu, até cessar por volta de 1850. As grandes extensões territoriais a ser povoadas no sul do Brasil, a necessidade de mão-de-obra para as lavouras e as políticas racistas do século XIX de "branqueamento" da população, facilitaram o processo de imigração, principalmente de europeus. Assim, além das línguas indígenas autóctones e das africanas, completa-se o quadro geral do multilingüismo com a chegada dos emigrantes europeus e asiáticos, sobretudo a partir do século XIX. Segundo a Wikipedia ${ }^{10}$, o processo de imigração deixou fortes marcas de mestiçagem e hibridismo cultural, que foi mais intenso no Sul e Sudeste do país. De acordo com KreUTZ (2000: 351), a partir de 1824, formou-se a primeira corrente imigratória com os alemães, seguida de 1.513.151 italianos, que vieram a partir de 1870, 1.462 .111 portugueses, 598.802 espanhóis, 188.622, japoneses, 123.724 russos, 94.453 austríacos, 79.509 sírio-libaneses, 50.010 poloneses e 349.354 de diversas nacionalidades.

Convém notar que, nesse período, houve dois tipos bem diferenciados de imigração: a destinada ao povoamento de áreas estratégicas, por exemplo, na região Sul do Brasil, com a formação de colônias fechadas que utilizavam a língua de seu país de origem; para abastecer a mão-de-obra da cultura cafeeira, que culminou com o êxodo dos colonos para as cidades atuando na área de serviços ou na indústria incipiente, principalmente na cidade de São Paulo. Segundo a Enciclopédia de línguas no Brasil $^{11}$, devido à imigração do século XIX, houve

\footnotetext{
${ }^{10} \mathrm{http}: / /$ pt.wikipedia.org/wiki/Brasil

${ }^{11} \mathrm{http}: / / \mathrm{www}$.labeurb.unicamp.br/elb/
} 
influências no português brasileiro de línguas como: alemão e seus dialetos, árabe, castelhano (e demais línguas da Espanha), hebraico, holandês, iídiche, inglês, italiano e seus dialetos, japonês, línguas eslavas, novas variantes do português europeu. Já no século XX, além da continuidade da maioria das correntes migratórias, houve também, entre outros, a entrada do chinês, coreano e do castelhano da América, bem como das variantes africanas do português.

Com relação à imigração galega no Brasil, segundo CORBACHO QUINTELA (2002), foi muito numerosa entre as duas últimas décadas do século XIX e as três primeiras do século XX. Inicialmente os imigrantes foram enviados à formação de colônias agrícolas no Pará e Amazonas, cujo fracasso destinou-os às cidades de Manaus, Belém e Salvador, como também à Santos, São Paulo e Rio de Janeiro. Segundo GonZÁleZ (2000: 250-251), os imigrantes da Galiza distinguiram-se pela preferência em se estabelecerem nos núcleos urbanos dedicandose ao trabalho liberal. A influência galega no português brasileiro encontra-se principalmente no léxico. Por exemplo, a palavra galego, no Brasil, designa um indivíduo muito branco e loiro, pois assim eram os primeiros imigrantes galegos em relação à população local.

Assim, o contato do português brasileiro com outras línguas foi um dos fatores que acentuou a tendência de variedades dos falares regionais, que já havia desde a colonização, ainda que, segundo Serafim da Silva Neto, as delimitações dialetais espaciais não são tão marcantes como as isoglossas da România Antiga. Mas, para TEYSSIER (1997: 98): "as divisões 'dialetais` no Brasil são menos geográficas que sócio-culturais”. Pois, de acordo com MATtos E Silva (1999), o fato é decorrente da conjunção da histórica demográfica brasileira, o tipo de transmissão lingüística irregular, ao longo dos séculos XVI ao XIX, e a quase ausência de escolarização nesses séculos.

O português brasileiro para MATTOS E SILVA (1999) resultou do contato entre falantes do português europeu, língua hegemônica de dominação, com os falantes das numerosas línguas indígenas autóctones, com os das línguas gerais, e ainda do contato com os africanos, de várias línguas, e seus descendentes e, a partir do século XIX, com os falantes dos mais diversos grupos de imigrantes, que ainda continuam a chegar e na língua hão de imprimir alguma característica. Os variados percursos na história lingüística brasileira, que envolvem não só a língua portuguesa, mas todas as demais, as que já estavam no Brasil e as que chegaram, constituíram, e continuam a constituir, o português brasileiro dentro de um complexo contexto multilingüístico. 


\section{O léxico português e galego}

O léxico das línguas é um organismo vivo, complexo, produto de uma elaboração multissecular através de inúmeras gerações que transmitem a herança lingüística inicial. Assim, a constituição do léxico português e galego foi o resultado da acumulação e seleção do vocabulário que se formou gradualmente ao longo de vinte séculos, influenciado por diferentes condições sócio-culturais, históricas e sócio-lingüísticas.

Se por um lado, em uma língua a massa lexical é o produto de uma seleção que, no transcurso do tempo, o registro culto e literário se encarrega de realizar. Por outro, apesar do léxico português e galego proceder em grande parte do latim, também se caracteriza por uma relativa heterogeneidade produzida por elementos que já a língua dos conquistadores romanos teve que incorporar, bem como as demais aquisições pelo processo contínuo de recepção de empréstimos e formação de palavras novas que, a partir da aparição do galego-português na sua forma escrita, chegaram com maior ou menor intensidade à língua atual.

Assim, segundo FerReIro (2001:13-14), pode-se considerar o latim como elemento fundamental, cuja adaptação da estrutura fonológica e morfológica aos termos populares criou os padrões lexicais dos atuais português e galego. Diante do latim, o substrato de línguas autóctonas da Gallaecia, ilustrado no mapa 1.9 (página 39), não modificou seus aspectos fundamentais, tendo maior influência na toponímia, e no nome de utensílios, animais e plantas. Por exemplo, em português: lastra ${ }^{12}$, veiga ${ }^{13}$, robalo ${ }^{14}$, beiço, buraco, berço,

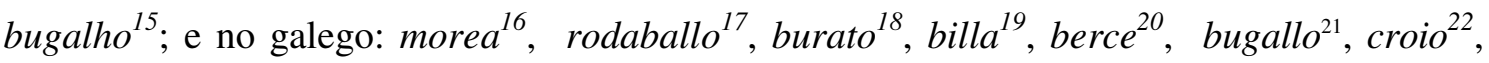
procedem de línguas anteriores ao latim. Desse modo, a história do português e galego tem como marco a romanização da Gallaecia, conforme os mapas 1.10 e 1.11. (páginas 40 e 41).

\footnotetext{
12 Ferida.

${ }^{13}$ Várzea fértil.

${ }^{14}$ Variedade de peixe.

${ }^{15}$ Fruto do carvalho.

16 Tradução: "grupo de objetos".

17 Tradução: "robalo (variedade de peixe)".

18 Tradução: "buraco".

19 Tradução: "chave de passagem de água, torneira".

20 Tradução: "berço".

21 Tradução: "bugalho".

22 Tradução: "seixo".
} 
Acredita-se que o léxico latino era formado pelo latim vulgar frente ao latim literário, que na Gallaecia devia apresentar diferenças em relação ao latim das demais regiões da península. Diversos fatores, como a cronologia da romanização - a Gallaecia foi romanizada dois séculos depois que a Bética, mapa 1.11 (página 41) - a sua situação marginal em relação à România, assim como a corrente de colonização proveniente da Bética, a zona romanizada mais conservadora da Hispânia, apontam para características particulares de um latim vulgar galego-português que, segundo PIEL (1989: 55-60), no campo lexical se manifesta com traços próprios. As diferenças regionais do latim e a sua evolução se acentuaram com a desintegração do Império Romano a partir do século V d.C. e a criação de unidades políticas autônomas, bem como com as migrações de povos suevos, vândalos, alanos e, posteriormente, visigodos, que estabelecerem o seu domínio na Península Ibérica, conforme os mapas 1.13 e 1.14 (páginas 43 e 45). Desses povos se originaram as palavras no galego: branco $^{23}$, gardar $^{24}$, roupa ${ }^{25}$, chuzo $^{26}$; e no português: branco, guardar, roupa, espetar. Segundo BASSETTO (2001: 142-143), devido ao subjugo dos povos suevos pelos visigodo, é difícil atribuir a influência, exercida por aqueles, mas, sabe-se que certas estruturas morfológicas são herança direta dos visigodos, tais como os sufixos -arde, -ardo e -engo que hoje aparecem em palavras como: covarde, galhardo e mulherengo. Para TEYSSIER (1997: 21) a influência dos suevos e visigodos se sobressai no léxico em determinados campos semânticos, tais como os da guerra: guerra, roubar e espiar; da indumentária: fato e ataviar; nomes de animais: ganso e marta; na antroponímia: Fernando, Rodrigo, Gonçalo; e na toponímia: Guitiriz, Gondomar, Sendim, Guimarães.

No século VIII, com a formação do Império Árabe, conforme mapas 1.15 e 1.15 (páginas 46 e 47), houve uma grande influência lexical, pois são arabismos as palavras do galego: azucre $^{27}$, aceite $e^{28}$, acelga ${ }^{29}$, alfinete $^{30}$, alfombra $^{31}$ e a interjeição oxala $^{32}$; e no atual português, segundo SARAIVA (1999: 34), são numerosos para designar produtos hortícolas:

\footnotetext{
23 Tradução: "branco".

${ }^{24}$ Tradução: "guardar".

${ }^{25}$ Tradução: "roupa".

26 Tradução: "espeto".

${ }^{27}$ Tradução: "açúcar".

${ }^{28}$ Tradução: "azeite".

29 Tradução: "acelga".

${ }^{30}$ Tradução: "alfinete".

31 Tradução: "tapete".

32 Proveniente de "in šā' Allah".
} 
Estudo comparativo de aspectos semânticos do sufixo -ista no português e no galego.

açafrão, acelga, açúcar, albarrã, alface, alfarroba, alfazema, alfobre, azeite, azeitona, cenoura, cherivia, estragão, laranja, limão, maçaroca; termos relacionados com a água: alvanel, albufeira, alverca, almargem, almácega, algeroz, alcatruz, chafariz, azenha; termos ligados ao comércio: almoeda, armazém, almude, arroba, arrátel, fanga, quilate, calibre, quintal, rima, resma, maravedi, ceitil, mitical, fardo; ligados à ciência: álcool, algarismo, almanaque, alfarrábio, álgebra, zero, zênite, azimute, elixir, xarope. Entretanto, as diferenças linguiísticas e culturais contribuíram para a superposição do romance galego-português sobre o moçárabe durante a Reconquista. Convém lembrar que, PIEL (1965: 1267), no galego não há praticamente arabismos que não apareçam ao mesmo tempo em português, em castelhano, ou até mesmo em ambas, sugerindo que tenham entrado no galego por via destas.

Segundo GARCÍA (2003), a presença de palavras de origem provençal é bem menor do que seria de se esperar, apesar da longa convivência do português com essa língua, concentrando-se, basicamente, em vocábulos relacionados com a vida nas cortes, tais como: alba, balada, bedel, coxim, cadafalso, estandarte, homenagem, jogral, justa, paliçada, refrão, sirventês, trova, truão, tropel, vassalo e vianda. Como também, algumas palavras de uso mais geral: alegre, anel, artilharia, salitre, rouxinol, hospedagem e viagem. Logo depois da aparição do galego-português na forma escrita, no final do século XII, já eram registrados os primeiros empréstimos de galo-romance; do francês: pelos contatos com as peregrinações, a presença de ordens monásticas de origem francesa e ainda pela influência francesa na corte portuguesa; e do provençal, da importância de sua literatura no movimento trovadoresco galego-português. No final do período medieval, foram documentados também os castelhanismos, principalmente nas traduções de obras castelhanas, que influenciarão diretamente o galego a partir dos Séculos Escuros. Segundo TEYSSIER (1997: 88), da metade do século XV até o final do século XVII, constatou-se um bilingüismo luso-espanhol não só na corte portuguesa, mas também na literatura da época, fator este que certamente produziu fortes influências no desenvolvimento da língua portuguesa de prestígio. No caso da Galiza, deve-se levar em conta a sua condição sociolingüística diglóssica desde a Idade Média, favorecendo o castelhanismo. O período dos descobrimentos marítimos e a ascensão de Portugal como potência européia, favoreceu uma posição de destaque à língua portuguesa e também trouxe uma grande contribuição ao seu léxico, bem como ao léxico galego e de outras línguas da Europa, enriquecendo-as, dado o contato com produtos, povos, culturas e línguas 
Estudo comparativo de aspectos semânticos do sufixo -ista no português e no galego.

diferentes e originários das regiões mais diversas: África, Ásia, América e Oceania. De acordo com TEYSSIER (1997: 86), nesse período também houve uma nova injeção de palavras árabes provenientes da África do Norte, da África do Leste e do Oceano Índico.

A importância do latim e do grego literário na aquisição de cultismos acentuou-se no século XVI e XVII no período do Renascimento, momento no qual, também houve uma forte influência do italiano nos campos literário, artístico e lingüístico. Os autores adeptos do movimento Renascentista, recriaram os recursos de ampliação vocabular nos moldes dos clássicos antigos. Assim, segundo Silva (2004), encontram-se vários exemplos em Luís Vaz de Camões, o marco inicial do português moderno: Tágide, significa ninfa do Tejo, pelo latim Tagus, - $i$ + sufixo -ide, variante de -ida: Ilíada, Eneida e Os Lusíadas, que indica filiação. A título de ilustração, é interessante notar que na Grécia Antiga, estruturada no patriarcalismo, era comum o patronímico, assim como no mundo germânico. No mundo ibérico, formou-se este patronímico com o sufixo -ici, que significa "relativo ao que foi gerado", cuja terminação $-i$ é um genitivo. A evolução dessa forma veio a dar, em castelhano e no galego -ez, que manteve a designação filho de, como em: Fernández, González, Rodríguez; e em português es, por exemplo em: Álvares, Gonçalves, Henriques.

Já a partir do século XVIII a cultura francesa exerceu grande influência na Europa e suas colônias, assim como a importância vocabular do francês como língua franca. Daí muitas palavras virem para o português e galego por veiculação do francês. Por exemplo, no português há: restaurante, greve, bombom; e no galego: chaminea ${ }^{33}$, champaña $^{34}$, modista ${ }^{35}$. Segundo TEYSSIER (1997: 91), no português os empréstimos provenientes de outras línguas européias "foram e continuam a ser numerosos", principalmente do francês, influência que já se nota no português desde a sua origem, mas que se intensificou a partir do século XVIII.

Paralelamente à importância do francês, no século XIX já era de se notar uma influência do inglês, sobretudo britânico, em várias áreas, como, por exemplo, no campo de jogos e esportes com palavras como bridge, futebol, handebol no português e no galego com fútbol $^{36}$, handicap ${ }^{37}$ e o decalque baloncesto ${ }^{38}$. Depois da Segunda Guerra Mundial, na

\footnotetext{
33 Tradução: "chaminé”.

34 Tradução: "champanha".

${ }^{35}$ Tradução: "modista".

${ }^{36}$ Tradução: "futebol".

${ }^{37}$ Competição na qual se impõe desvantagens ou obstáculos aos melhores participantes.
} 
Estudo comparativo de aspectos semânticos do sufixo -ista no português e no galego.

segunda metade do século $\mathrm{XX}$, a grande influência da cultura francesa veio a ser substituída pela estadunidense, tornando-se o inglês, a língua veicular do período. Dessa influência há, como exemplo, em português: delivery, esnobismo, lobby; e em galego: autostop ${ }^{39}$, express $^{40}$, barbacoa $^{41}$.

Sabe-se que, na área da música, o italiano sempre exerceu uma grande influência, principalmente com o advento das grandes óperas. Mas, é interessante notar que, na nomenclatura musical, continua a exercer grande influência, pois muitos dos instrumentos e aparatos musicais de uma orquestra têm seu nome proveniente do italiano: celo, címbalo, violoncelo; como também, os compassos temporais de uma partitura: presto, andante, piano.

No campo da nomenclatura técnica e científica, a formação de palavras novas baseouse nas raízes do latim e do grego para designar termos e conceitos provenientes das idéias geradas pelos séculos XVIII ao XX, continuando a formação de palavras por meio de termos eruditos, como por exemplo: telefone, automóvel, televisão, endocrinologia. Segundo TEYSSIER (1997: 91), “o vocabulário do português enriqueceu-se, como o de todas as línguas européias, com um número considerável de termos que designam conceitos e objetos relativos à civilização científica e técnica."

Por outro lado, no Brasil, houve também influências importantes das línguas indígenas e africanas. De acordo com AmARAL (1920: 35-41), a influência indígena recebida pelo português no Brasil é predominantemente de origem tupi, centrando-se na imensidão vocabular, como a nomenclatura de topônimos: Canindé, Pacaembu, Butantã; fenômenos naturais: piracema, pororoca; nomes de animais: sucuri, sussuarana, tamanduá; nomes de vegetais: abacate, abacaxi, carnaúba, ipê; utensílios: arapuca, peteca, samburá; alimentos: pamonha, muqueca, pipoca, paçoca; adjetivos: pangaré, jururu, pururuca; crendices: saci, caipora, curupira; e doenças como catapora. Para GARcíA (2003), a influência africana é pequena e nota-se, principalmente, no léxico brasileiro, tal como ocorre com palavras de uso da religião: macumba, mandinga, candomblé, babalaô e orixá; na nomenclatura de comidas: tutu, angu, cachaça e vatapá; utensílios: agogô, maracatu e ganzá; nomes de doenças: caxumba, calombo e calundu; objetos de uso pessoal: cachimbo, carimbo, miçanga e tanga;

\footnotetext{
38 Tradução: "bola ao sesto."

39 Tradução: "carona".

${ }^{40}$ Modalidade rápida de transporte.

${ }^{41}$ Tradução: "churrasqueira".
} 
Estudo comparativo de aspectos semânticos do sufixo -ista no português e no galego.

animais: camundongo e marimbondo; plantas: inhame, chuchu, jiló e quiabo; locatícia: mocambo, quilombo e senzala; designação pessoal: moleque, mисата, e dengo.

Convém notar que, para MatTos E SiLva (2002), a designação de novos objetos e descobertas criou palavras novas e diferentes, nas distantes regiões: em Portugal, no Brasil, como também na Galiza. Por exemplo: ônibus (Brasil), autocarro (Portugal) e autobus (Galiza); trem (Brasil), comboio (Portugal) e tren (Galiza); bonde (Brasil), eléctrico (Portugal) e tran (Galiza); geladeira (Brasil), frigorífico (Portugal) e neveira (Galiza) ${ }^{42}$.

Segundo MatTos E SiLVA (2002), ocorrem, com frequiência, no português brasileiro, derivações a partir de radicais que existiam já na antiga língua da metrópole, mas que ainda não haviam desenvolvido suas possibilidades léxicas, por exemplo: vaquejada ${ }^{43}$ proveniente

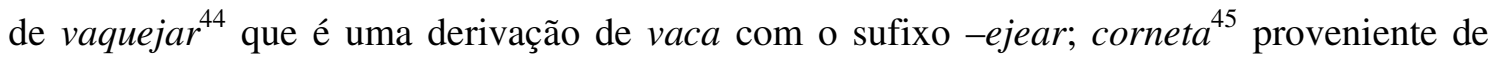
corno por analogia com maneta e perneta; ruivor $^{46}$ proveniente de ruivo calcado sobre o modelo de verdor; vaqueirama ${ }^{47}$ proveniente de vaqueiro calcado sobre o modelo de moirama $^{48} ;$ retirante $^{49}$ que é uma derivação do verbo retirar com o sufixo -nte.

Sabe-se, então, que os empréstimos sempre foram numerosos no desenvolvimento do português e do galego. Entretanto, o léxico do português e do galego não sofreu apenas o processo de empréstimo de outras línguas, mas, sobretudo, sofreu processos internos, complexos e fundamentais de ampliação e modernização, por meio da formação de palavras e pela modificação semântica das já existentes.

\footnotetext{
${ }^{42}$ Xeladeira é a forma usada pelos galegos que emigraram para o Brasil, Argentina e Uruguai.

${ }^{43}$ Rodeio.

${ }^{44}$ Lidar com vacas.

${ }^{45}$ Touro ou vaca com um único corno.

${ }^{46}$ Claridade avermelhada que fica no horizonte depois do pôr do sol.

${ }^{47}$ Reunião de vaqueiros.

${ }^{48}$ Reunião de mouros.

${ }^{49}$ Quem emigra das regiões castigadas pela seca.
} 
Estudo comparativo de aspectos semânticos do sufixo -ista no português e no galego.

CAPÍTULO 2 A FORMAÇÃO DE PALAVRAS

Quero enredar coa Palabra, darlle outro senso distinto, teimar porque a cuncha se abra, penetrar no labirinto.

(Miro Villar) 


\section{A formação de palavras}

O léxico de uma língua é variável e está sujeito a constantes mudanças, pois algumas palavras vão deixando de ter uso na língua oral e/ou escrita e outras vão aparecendo a cada período produzindo uma renovação léxica das línguas vivas. Essa renovação é feita por meio de um conjunto de mecanismos que proporciona um alto grau de liberdade ao falante ou ao escritor. Assim, a formação das palavras é um processo normal de enriquecimento do léxico, por meio da acomodação da expressão oral e escrita, através de empréstimos externos e internos, mudanças de significado, construções fraseológicas, expressões equivalentes às palavras e/ou abreviações e reduções de expressões.

Na descrição de uma língua há fenômenos relacionados com a formação de palavras e que não podem ser explicados somente baseados na sintaxe, morfologia, semântica ou léxico. Assim, se o estudo de processos de formação de palavras privilegiar a análise, o resultado será uma análise morfológica e/ou semântica das unidades léxicas; se privilegiar o aspecto regular e produtivo, ou seja, derivação de estruturas formativas a partir de estruturas mais simples, o resultado será descritivo-gerativo. Entretanto há ainda a criatividade lingüística do falante, as propriedades específicas da formação de palavras e as relações com a gramática normativa. Desse modo, no estudo da variação lexical, deve-se considerar: o processo formativo e os seus elementos (bases e afixos); a combinação destes e seu efeito; as modificações das condições de uso das palavras; o empréstimo e o decalque; e o impacto de situar as variações dentro de seu devido âmbito histórico, social e cultural.

Para a gramática normativa, a formação de palavras contém uma lista finita de regras de derivação que especificam a construção a partir de uma lista finita de itens lexicais ou bases e outra lista também finita de afixos. Estas regras estão ligadas a todos os constituintes da gramática: morfologia, pois especifica como é formada a nova palavra a partir dos elementos de base; fonologia, pois explica as eventuais transformações fonéticas que podem ocorrer entre as bases e os afixos; a sintaxe, pois relaciona as propriedades sintáticas da palavra base com as da nova palavra; a semântica, pois explica o significado das palavras novas ou o modo de construir a partir do significado dos elementos-base.

Sabe-se que para CoSERIU (1977: 105-107) a formação lexical é basicamente o resultado de transformações semânticas. Para alguns gramáticos, como FrEIXEIRO MATO 
Estudo comparativo de aspectos semânticos do sufixo -ista no português e no galego.

(1999: 161), a formação de palavras é feita a partir de uma estrutura paradigmática reportada a uma base sintagmática, marcada pelo conteúdo, mas diferindo da morfologia e da sintaxe.

\section{Os procedimentos de formação de palavras}

A formação de palavras e a sintaxe têm muito em comum, pois ambas são formas de expressão da criatividade lingüística. A sintaxe permite ao falante produzir um conjunto muito grande de combinações com um inventário finito de elementos e regras, e a formação de palavras permite ao falante criar designações lexicais correspondentes a novas situações a partir de elementos já existentes na língua. Ou seja, a formação de palavras e as combinações sintáticas são produzidas de acordo com certas regras que podem ser combinadas entre si. Assim, uma cláusula relativa pode combinar-se com outra cláusula e de um substantivo pode formar-se um adjetivo, por exemplo, em português: posição $\rightarrow$ posicional; em galego: orella $^{50} \rightarrow$ orelludo $^{51}$. Além disso, as regras podem ser aplicadas de forma recursiva e combinadas entre si abrindo uma grande gama, tanto na sintaxe quanto na formação de palavras. Entretanto, as irregularidades no processo de formação de palavras são tão importantes quanto as regularidades.

De qualquer maneira, a formação de palavras e a análise de sua estrutura interna também constituem objeto de estudo da morfologia. Assim, as palavras que possuem uma estrutura interna complexa, na qual se destacam bases e afixos, são consideradas como resultado da aplicação de regras de formação de palavras. Estas regras são parcialmente definidas como instâncias dos procedimentos morfológicos: flexão, derivação e composição. Cada um destes processos é caracterizado em função do tipo de alteração que processa na palavra que toma como base, podendo ou não alterar a classificação da palavra obtida como produto.

Do ponto de vista morfológico, de acordo com FrEIXEIRO MATO (1999: 161) as palavras podem ser construídas a partir de uma base invariável, morfema radical ou lexema, e elementos variáveis que se adicionam ao lexema. Segundo a morfologia, o lexema é portador do significado básico da palavra e os morfemas podem especializar ou especificar esse

\footnotetext{
${ }^{50}$ Tradução: "orelha".

51 Tradução: "orelhudo".
} 
significado e classificar a palavra em uma determinada categoria gramatical. Os morfemas podem ser: flexionais, quando apenas contêm indicações e significações de tipo gramatical; e lexicais ou derivativos, também chamados de afixos, e que, em geral, modificam a base com determinações e especificações de tipo lexical.

Os procedimentos de formação das palavras podem ser tradicionalmente divididos em dois tipos principais e mais ligados às características morfológicas: a derivação, dividida em afixal - prefixal e sufixal -, parassintética, regressiva e imprópria; e a composição que se divide em justaposição e aglutinação. Além da derivação e da composição existem outros procedimentos formadores de palavras tais como a onomatopéia, a abreviação ou redução de palavras, bem como a importação e o decalque de termos estrangeiros, que podem não ser necessariamente morfológicos.

Segundo FreIXEIRO MATO (1999: 314) a importação de palavras procedentes de outras línguas é um dos procedimentos mais antigos de criação lexical. Qualquer empréstimo de outra língua que é preciso para nomear novos objetos ou conceitos, cuja designação na língua receptora é inexistente, é um empréstimo necessário. Por exemplo, no português as palavras: restaurante, software, leitmotiv, batuta e shampoo, provenientes do francês, inglês, alemão, italiano e inglês, respectivamente; assim como no galego, as palavras: hotel $^{52}$, marketing ${ }^{53}$, búnker $^{54}$, partitura $^{55}$ e futbol $l^{56}$, provenientes do francês, inglês, alemão, italiano e inglês, respectivamente. Entretanto, as palavras importadas nem sempre correspondem às necessidades onomásticas, podem servir a outros interesses, tais como: culturais, políticos e modismos, passando a ser concorrentes com as palavras da língua receptora. Por exemplo, no português: futebol e ludopédio, delivery e em domicílio, hall e vestíbulo; assim como no galego: crêpe $^{57}$ e filloa ${ }^{58}$ chaminea $^{59}$ e fumeira $^{60}$ calle $^{61}$ e rúa ${ }^{62}$. Dentro dos empréstimos estrangeiros, podem-se considerar também os decalques provenientes de outras línguas, por

\footnotetext{
52 Tradução: "hotel".

53 Tradução: "marketing".

54 Tradução: "abrigo de grande proteção".

55 Tradução: "partitura”, na área da música.

56 Tradução: "futebol".

57 Tradução: "panqueca", proveniente do francês.

58 Tradução: "panqueca".

59 Tradução: "chaminé”, proveniente do francês.

60 Tradução: "chaminé”.

61 Tradução: "rua", proveniente do castelhano.

${ }^{62}$ Tradução: "rua".
} 
Estudo comparativo de aspectos semânticos do sufixo -ista no português e no galego.

exemplo, em português há cachorro-quente formado como decalque proveniente do inglês hot-dog, em galego há cosmovisión ${ }^{63}$, do alemão Weltanschauung ${ }^{64}$.

Um procedimento bem criativo na produção de palavras é a redução de vocábulos já existentes na língua, formando uma nova palavra. Conforme BASíLIO (2004: 37), a palavra formada é sempre sinônima da palavra derivante, e é usada, na maioria das vezes, em um registro menos formal. Por exemplo, em português cinematógrafo e cinema; motocicleta e moto, quilograma e quilo, José e Zé, Ernestina e Tina; assim como em galego: cinema $^{65}$ e cine $^{66}$, televisión $^{67}$ e tele ${ }^{68}$, colexio $^{69}$ e cole ${ }^{70}$ Xoán $^{71}$ e Xan $^{72}$, Antonio $^{73}$ e Antón ${ }^{74}$ ou Toño ${ }^{75}$. A acronímia também é um procedimento de redução, na qual a união dos extremos de várias palavras dá origem a um novo vocábulo. A título de ilustração, em certas regiões do Brasil é comum o uso de acronímia do nome dos pais para formar o do filho, por exemplo: Linda + Adolfo $\rightarrow$ Lindolfo, José + Cacilda $\rightarrow$ Josilda, José + Maria $\rightarrow$ Josimar, Ademir + Hilda $\rightarrow$ Ademilda. Mas não só no campo da antroponímia esse recurso pode ser utilizado, como por exemplo, no português há: português + espanhol $\rightarrow$ portunhol; e no galego: cantante $^{76}+$ autor $^{77} \rightarrow$ cantautor $^{78}$. A abreviação é outro procedimento de redução e consiste na representação escrita de uma palavra mediante uma ou várias de suas letras. A abreviação simples é quando se reduz apenas uma palavra, por exemplo, em português: professor $\rightarrow$ Prof., Dona $\rightarrow$ D., avenida $\rightarrow$ av.; e em galego: Presidente ${ }^{79} \rightarrow$ Pte. $^{80}$, Don $^{81} \rightarrow D^{82}$, avenida $^{83} \rightarrow$ avda. $^{84} \mathrm{~A}$ abreviação composta ou a formação de siglas consiste na

\footnotetext{
63 Tradução: “cosmovisão", "visão mundial” ou "visão de mundo".

${ }^{64}$ Idem.

65 Tradução: "cinema".

66 Tradução: "cine”.

67 Tradução: "televisão".

68 Tradução: "tv".

69 Tradução: "colégio".

${ }^{70}$ Equivale a redução do nome colégio, usado coloquialmente.

71 Tradução: "João".

${ }^{72}$ Equivale ao apelido usual do nome próprio "João", como por exemplo, "Jô" em português.

73 Tradução: "Antônio" em português brasileiro e "António" em português lusitano.

${ }^{74}$ Equivale ao apelido usual do nome próprio "Antônio" ou "António", por exemplo, "Antão" em português.

${ }^{75}$ Equivale ao apelido usual do nome próprio "Antônio" ou "António", por exemplo, "Tonho" ou "Toni”.

76 Tradução: "cantor".

77 Tradução: "autor".

${ }^{78}$ Equivale a "cantor e, ao mesmo tempo, autor de uma canção".

79 Tradução: "presidente".

${ }^{80}$ Abreviatura do título Presidente.

${ }^{81}$ Tradução: "Dom".

${ }^{82}$ Abreviatura do título honorífico Don.

${ }^{83}$ Tradução: "avenida".
} 
Estudo comparativo de aspectos semânticos do sufixo -ista no português e no galego.

representação gráfica e fonética de várias palavras, permanecendo a primeira letra de cada uma delas, por exemplo, em português: USP $\rightarrow$ Universidade de São Paulo, IA $\rightarrow$ Inteligência Artificial, Bradesco $\rightarrow$ Banco Brasileiro de Descontos; e em galego: USC $\rightarrow$ Universidade de Santiago de Compostela, SOGAMA $\rightarrow$ Sociedade Galega do Medio Ambiente; TVG $\rightarrow$ Televisión de Galiza. Segundo GuILBERT (1975: 276), o processo de transformação de uma sigla em uma nova palavra é essencialmente sociolingüístico, pois resulta da difusão dentro de uma comunidade com adaptações fonéticas, entretanto também é lingüístico quando a sigla se transforma em uma base de derivação, por exemplo, sufixal. A título de ilustração há, em português: $U D N^{85} \rightarrow$ udenista e em galego: $P_{S G}^{86} \rightarrow$ peseguista ${ }^{87}$.

A onomatopéia, conforme FrEIXEIRO MATO (1999: 307-308), é o procedimento que consiste na criação de palavras novas por meio da imitação fônica de vozes ou sons da natureza. Por exemplo, em português: uivar, cocoricó $^{88}$, bem-te-vi ${ }^{89}$; em galego: ouvear ${ }^{90}$; chascarraschás $^{91}$, paspallao $^{92}$.

É possível também criar novas palavras por meio do procedimento de composição, ou seja, da união de duas ou mais bases. Segundo BASílio (2004: 29), na composição não há elementos fixos, nem funções pré-determinadas para os elementos componentes, sendo definida pela sua estrutura, por exemplo, em português: plano + alto $\rightarrow$ planalto; e em

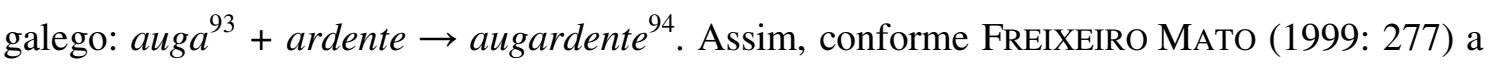
palavra composta é o resultado da união de pelo menos duas bases independentes na língua, de forma que funcionam como uma única palavra, ainda que o seu significado não necessariamente seja, olhando sincronicamente e sem o auxílio da etimologia, a soma do

\footnotetext{
${ }^{84}$ Tradução: “av.”, abreviatura de "avenida".

${ }^{85}$ União Democrática Nacional - antigo partido político brasileiro.

${ }^{86}$ Partido Socialista Galego - antigo partido político galego.

${ }^{87}$ Membro ou militante do partido político PSG.

${ }^{88}$ É o cantar dos galos, equivale ao "cacaracá" no português lusitano e ao "quiquiriquí" no galego.

${ }^{89}$ Segundo o dicionário Houaiss, é uma ave da família dos tiranídeos, cujo canto parece repetir as sílabas de que se compõe seu nome.

90 Tradução: "uivar".

${ }^{91}$ É o ruído produzido por instrumentos musicais populares do tipo "reco-reco".

${ }^{92}$ Tradução: "codorna”, seu canto parece repetir as sílabas de que se compõe seu nome.

93 Tradução: "água”.

94 Tradução: "aguardente".
} 
Estudo comparativo de aspectos semânticos do sufixo -ista no português e no galego.

significado unitário de cada componente, por exemplo, em português: pé-de-moleque ${ }^{95}$; e em galego: arco da vella ${ }^{96}$.

Já, o termo derivação, de acordo com FreiXEIRO MATO (1999: 166), refere-se a um conjunto de diversos procedimentos para a formação de novas palavras a partir de um único radical, ao qual se unem afixos, prefixos ou sufixos, com o objetivo de se obter um novo significante. Assim, o processo de derivação pode ser classificado em: prefixação, sufixação ou ainda em outras formas, tais como: derivação parassintética, derivação regressiva e derivação imprópria.

Chama-se derivação imprópria ao procedimento de alteração da classe da palavra, sem alterações estruturais, mas com uma nova significação como resulltado. Segundo BASÍLIO (2004: 60), o termo "conversão", usado pela maioria das gramáticas normativas, é mais adequado para designar o procedimento. A título de exemplo, tanto no português quanto no galego, a palavra burro, designa como substantivo um mamífero quadrúpede, mas, também pode ser empregada como adjetivo na designação de qualquer pessoa a que se queira referir por sua inépcia. Um exemplo típico do português é a palavra oliveira, substantivo comum que designa uma planta, mas que pode se transformar em um substantivo próprio, como sobrenome de família: Oliveira. Já no galego, um exemplo análogo é a palavra cerdeira ${ }^{97}$, que designa uma planta e um sobrenome de família: Cerdeira. Segundo FreIXEIRo Mato (1999: 251) a substantivação de uma palavra, verbo ou adjetivo, é a forma mais comum desse procedimento. Por exemplo, em português: amanhecer (verbo) $\rightarrow$ o amanhecer (substantivo), rico (adjetivo) $\rightarrow$ o rico (substantivo); em galego: atardecer $^{98}$ (verbo) $\rightarrow$ o atardecer (substantivo), nugallao $^{99}$ (adjetivo) $\rightarrow$ o nugallao (substantivo).

A derivação regressiva é o procedimento de criação de novas palavras, no qual a palavra formada sofre a perda de elementos da sua forma original. Este procedimento ocorre, sobretudo, na formação de substantivos deverbais, ainda que, segundo BASílIO (2004: 38), também possa haver derivação regressiva denominal. Por exemplo, em português: atraso

\footnotetext{
${ }^{95}$ Segundo o didionário Houaiss, "doce feito de rapadura com grãos de amendoim” no português brasileiro.

96 Tradução: "arco íris".

97 Tradução: "cerejeira”, há como variante a forma cirdeira.

98 Tradução: "entardecer".

99 Tradução: "preguiçoso".
} 
Estudo comparativo de aspectos semânticos do sufixo -ista no português e no galego.

atrasar, debate $\leftarrow$ debater, troco $\leftarrow$ trocar; e em galego: trouleo $^{100} \leftarrow$ troulear $^{101}$, agarimo ${ }^{102}$ $\leftarrow$ agarimar $^{103}$, babuxa $^{104} \leftarrow$ babuxar $^{105}$. De acordo com FREIXEIRO MATO (1999: 248), as formas regressivas são concorrentes diretas das formações por sufixação, em geral com mento, -ura, no galego: -ción e no português: -ção; diferenciando-se pelo seu uso estilístico ou por critérios semânticos, por exemplo, em português há abafar $\rightarrow$ abafo, abafação, abafamento, abafadura e abafado; analogamente, em galego há abafar ${ }^{106} \rightarrow$ abafo $^{107}$, abafamento $^{108}$, abafadura $^{109}$ e abafado ${ }^{110}$.

Derivação por prefixação é o procedimento de formação de palavras a partir do acréscimo de afixos antes dos radicais, criando novas palavras que pertencem à mesma classe gramatical da base. Por exemplo, a partir da palavra destinar, em português, pode-se formar uma outra palavra por derivação prefixal: predestinar, na qual o prefixo pre- indica um sentido de anterioridade. Um exemplo análogo em galego consegue-se a partir de: facer $^{111}$, formando-se: refacer $^{112}$, com o sufixo re- com valor iterativo; convém notar que com: lucir ${ }^{113}$ pode-se formar: relucir ${ }^{114}$, na qual o prefixo re- adquire um valor intensificador. Assim, para FreiXeiro MAto (1999: 254), os prefixos são afixos lexicais com um significado claro e constante, geralmente de origem grega ou latina, que são colocados antes do lexema e estão presentes nas palavras cultas de muitas línguas ocidentais. A título de ilustração, na tabela 2.1 estão dispostos alguns prefixos de origem grega e latina que apresentam praticamente o mesmo significado.

\footnotetext{
100 Tradução: "farra"ou "bagunça”.

101 Tradução: "divertir-se, em geral, de forma ruidosa" ou "fazer travessuras".

102 Tradução: "carinho".

103 Tradução: "tratar com carinho".

104 Tradução: "garoa".

105 Tradução: "garoar".

106 Tradução: "abafar".

107 Tradução: "abafo" ou "abafado".

108 Tradução: "abafamento" ou "abafação".

109 Tradução: "abafamento" ou "abafadura”.

110 Tradução: “abafado".

111 Tradução: "fazer".

112 Tradução: "refazer".

113 Tradução: "brilhar".

114 Tradução: "brilhar muito", no sentido figurado: "destacar-se demasiadamente".
} 


\begin{tabular}{|c|c|c|c|c|}
\hline $\begin{array}{l}\text { PREFIXOS } \\
\text { GREGOS }\end{array}$ & $\begin{array}{l}\text { PREFIXOS } \\
\text { LATINOS }\end{array}$ & SIGNIFICADO & \multicolumn{2}{|c|}{$\begin{array}{l}\text { EXEMPLOS } \\
\text { português, galego / português, galego }\end{array}$} \\
\hline$a-, a n-$ & in- & Negação & 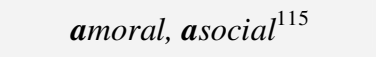 & infeliz, inimaxinábel ${ }^{116}$ \\
\hline ana- & $d i s-, d i-$ & Separação & anagrama, analoxía $a^{117}$ & dissidente, distensión $n^{118}$ \\
\hline epi- & super-, supra- & Acima de & epílogo, epígrafe $e^{119}$ & supracitar, superficie $e^{120}$ \\
\hline hipo- & sub-, sob- & Para baixo & hipotensão, hipoalérxico ${ }^{121}$ & sub-solo, subestimar ${ }^{122}$ \\
\hline pro- & pré- & Anterioridade & profecia, prólogo ${ }^{123}$ & prevenção, prexulgar ${ }^{124}$ \\
\hline
\end{tabular}

Tabela 2.1: Alguns prefixos gregos e latinos.

Já a derivação por sufixação é o procedimento de formação de novas palavras a partir do acréscimo de sufixos, que, segundo FrEIXEIRO MATO (1999: 166), são afixos lexicais colocados depois do lexema para a criação de novas palavras especializando o significado da base, a partir da significação dada pelo sufixo. Por exemplo, no português, a partir da palavra real, pode-se formar por derivação sufixal: realismo, com o sufixo -ismo, que denota um dado sistema de idéias filosóficas, literárias e das artes plástica. A partir da mesma palavra, real, pode-se formar por sufixação: realista, com o sufixo -ista, que pode denotar vários sentidos: relativo ou próprio do realismo, aquele que é partidário do realismo, ou aquele que age com realismo. Ainda, a partir da palavra, real, pode-se formar por derivação: realístico, com o sufixo -ístico; relativo ou próprio de quem é realista. Analogamente, em galego, a partir da palavra humor $^{125}$, pode-se formar: humorismo ${ }^{126}$ com o sufixo -ismo, humorista ${ }^{127}$ com o sufixo-ista e humorístico ${ }^{128}$ com o sufixo-ístico.

É interessante notar que, por um lado, verifica-se que um mesmo sufixo pode apresentar vários significados. Por exemplo, em português o sufixo - eiro designa agente em:

\footnotetext{
115 Tradução: “não-social”.

116 Tradução: “não-imaginável”.

117 Tradução: "analogia".

118 Tradução: "distensão".

119 Tradução: "epígrafe".

${ }^{120}$ Tradução: "superfície".

121 Tradução: "hipoalérgico".

122 Tradução: "subestimar".

123 Tradução: "prólogo".

124 Tradução: "julgar previamente".

125 Tradução: "humor".

126 Tradução: "humorismo".

127 Tradução: "humorista".

128 Tradução: "humorístico".
} 
Estudo comparativo de aspectos semânticos do sufixo -ista no português e no galego.

batateiro, mas indica uma planta em: limoeiro; analogamente na língua galega, para os exemplos: pataqueiro ${ }^{129}$ (agente) e castiñeiro $^{130}$ (planta). Por outro, sufixos diferentes podem apresentar o mesmo significado, por exemplo, em português: estudante, lenhador, balconista, engenheiro, e em galego: tratante $^{131}$, vendedor $^{132}$, maquinista $^{133}$, cociñeiro $^{134}$; nos quais os diferentes sufixos: -nte, -or, -ista e -eiro, apresentam o mesmo significado: agente.

A título de ilustração, na tabela 2.2 estão dispostos alguns sufixos de origem grega e latina, seguidos de exemplos em português e em galego, bem como uma de suas noções.

\begin{tabular}{|c|c|c|c|c|c|}
\hline $\begin{array}{l}\text { SUFIXOS } \\
\text { LATINOS }\end{array}$ & $\begin{array}{c}\text { EXEMPLOS } \\
\text { português / galego }\end{array}$ & NOÇÃO & $\begin{array}{l}\text { SUFIXOS } \\
\text { GREGOS }\end{array}$ & $\begin{array}{c}\text { EXEMPLOS } \\
\text { português / galego }\end{array}$ & NOÇÃO \\
\hline$-a d a$ & martelada, patada ${ }^{135}$ & Ação & $-i a$ & filosofia, xeografía ${ }^{136}$ & Ciência \\
\hline -aria, -eria & livraria, frutería ${ }^{137}$ & Local & -ite & sinusite, colite $^{138}$ & Inflamação \\
\hline -eiro & toureiro, troiteiro $^{139}$ & Agente & $-i t a$ & saudita, israelita ${ }^{140}$ & Procedência \\
\hline$-o r$ & catador, pintor $^{141}$ & Agente & -ismo & nazismo, cubismo ${ }^{142}$ & Ideologia \\
\hline -mente & claramente, ricamente $^{143}$ & Modo & -ista & artista, terrorista ${ }^{144}$ & Agente \\
\hline
\end{tabular}

Tabela 2.2: Alguns sufixos gregos e latinos.

Segundo FreiXEIRO MATO (1999: 269) a derivação parassintética é um procedimento complexo que corresponde a uma estrutura ternária, composta de prefixo, base e sufixo, no qual a prefixação e a sufixação atuam simultaneamente na formação de uma nova palavra. De acordo com BASílio (2004: 44), existem palavras que apresentam prefixo e sufixo, mas não

\footnotetext{
129 Tradução: "batateiro".

130 Tradução: "castanheiro".

${ }^{131}$ Tradução: comerciante que faz qualquer tipo de negócio que lhe seja vantajoso.

132 Tradução: "vendedor".

133 Tradução: "maquinista".

134 Tradução: "cozinheiro".

135 Tradução: "chute" ou "pontapé".

136 Tradução: "geografia".

137 Tradução: "quitanda".

138 Tradução: "colite" ou inflamação do intestino.

139 Tradução: "pescador de trutas".

140 Tradução: "israelita".

141 Tradução: "pintor".

142 Tradução: "cubismo".

143 Tradução: "ricamente".

144 Tradução: "terrorista".
} 
Estudo comparativo de aspectos semânticos do sufixo -ista no português e no galego.

são formadas por parassíntese, pois o que caracteriza o procedimento não é a ocorrência simultânea dos afixos, mas a estrutura que exige a utilização simultânea de prefixos e sufixo no procedimento. Por exemplo, em português: alma $\rightarrow$ desalmado (des- + alma +- ado $)$, dia $\rightarrow$ adiar $(a-+$ dia +- ar $)$, triste $\rightarrow$ entristecer $($ en -+ triste +- ecer $)$; em galego: diñeiro ${ }^{145}$ $\rightarrow$ adiñeirado $^{146}(a-+$ diñeiro +- ado $)$, noite $^{147} \rightarrow$ anoitecer $^{148}(a-+$ noite +- ecer $)$, vello ${ }^{149}$ $\rightarrow$ envellar ${ }^{150}($ en- + vello $+-a r)$.

Pode-se notar que existe uma grande proximidade entre os procedimentos de flexão e derivação, pois ambos são de natureza afixal, mas as gramáticas geralmente afirmam que a flexão dá origem a formas de uma mesma palavra e a derivação origina novas palavras. No entanto, esta é uma definição na qual há posições controversas, por exemplo, no caso de sufixos avaliativos: diminutivos, aumentativos, intensificadores e pejorativos, pode-se questionar se de fato é uma derivação ou uma flexão, pois não se considera o produto resultante do processo como uma palavra nova, mas como uma variação da palavra tomada como base. Por exemplo, em português: cedo (advérbio) $\rightarrow$ cedinho (advérbio), claro (adjetivo) $\rightarrow$ claríssimo (adjetivo); em galego: pequeno ${ }^{151}$ (adjetivo) $\rightarrow$ pequeniño ${ }^{152}$ (adjetivo), $\operatorname{tarde}^{153}$ (advérbio) $\rightarrow$ tardísimo $^{154}$ (advérbio). Por outro lado também há a proposta de CÂMARA JR. (1978: 61) de que a flexão ocupa uma posição mais fixa e opera dentro de regras mais previsíveis, por exemplo, em português: senhor $\rightarrow$ senhores, flor $\rightarrow$ flores; e no galego: home $\rightarrow$ homes $^{155}$, muller $\rightarrow$ mulleres $^{156}$; enquanto a derivação oferece mais possibilidades combinatórias e liberdade construtiva. Por exemplo, em português: reconstituir (re- + constituir), reconstituinte (re- + constituir $+-n t e)$, constituinte (constituir $+-n t e)$, constituição (constituir $+-c ̧ \tilde{a} o)$, reconstituição $(r e-+$ constituir $+-c ̧ \tilde{a} o)$, constitucional (constituir $+-c ̧ \tilde{a} o+-a l)$, constitucionalismo $($ constituir $+-c ̧ \tilde{a} o+-a l+-$ ismo), constitucionalista (constituir $+-c ̧ \tilde{a} o+-a l+-i s t a)$, constitucionalistamente (constituir

\footnotetext{
145 Tradução: "dinheiro".

${ }^{146}$ Pessoa que tem muito dinheiro.

147 Tradução: "noite".

148 Tradução: "anoitecer".

149 Tradução: "velho".

${ }^{150}$ Tradução: "envelhecer".

151 Tradução: "pequeno".

152 Tradução: "pequenino".

153 Tradução: "tarde".

154 Tradução: "tardíssimo".

155 Tradução: "homem" e sua forma em plural "homens".

156 Tradução: "mulher" e sua forma em plural "mulheres".
} 
$+-c ̧ \tilde{a} o+-a l+-i s t a+-m e n t e)$, evangelisteiro (evangelho $+-i s t a+-$ eiro); em galego: xurdimento $^{157}$ (xurdir +- mento $)$, rexurdimento ${ }^{158}$ (re- + xurdir +- mento $^{5}$, nacional ${ }^{159}$ $($ nación $+-a l)$, nacionalista ${ }^{160}$ (nación $\left.+-a l+-i s t a\right)$, nacionalizar ${ }^{161}($ nación $+-a l+-$ izar), nacionalización ${ }^{162}$ (nación + -al + -izar + -ción), renacionalizar ${ }^{163}($ re -+ nación + $a l+-i z a r), \quad$ renacionalización ${ }^{164}(r e-+$ nación $+-a l+-i z a r+-$ ción $)$, desnacionalizar ${ }^{165}$ $($ des -+ nación $+-a l+-i z a r)$, desnacionalización ${ }^{166}($ des -+ nación $+-a l+-i z a r+-$ ción $)$.

Conclui-se, pelo apresentado até então que, apesar de novas palavras se formarem mediante o acréscimo de afixos sujeitos aos condicionamentos morfológicos das classes das palavras-base e de si próprios, não existe uma associação única entre os processos formais (prefixação, sufixação, composição) e os tipos de funções presentes nas palavras formadas, pois diferentes processos podem ter a mesma função. Por exemplo, a função de acúmulo pode ser verificada em um processo de composição ou num de derivação por sufixação, em português: poliglota indica o acúmulo de línguas e cabeleira indica o acúmulo de cabelos; analogamente no galego: polideportivo ${ }^{167}$ sugere o acúmulo de desportos e neboeiro ${ }^{168}$ sugere o acúmulo de neboa ${ }^{169}$. Também pode haver concorrência de funções em um mesmo processo, mas com afixos diferentes, por exemplo, tanto o sufixo - eiro quanto o sufixo -ista podem indicar profissão, no português há: manobreiro, manobrista, engenheiro, balconista; no galego há: camioneiro ${ }^{170}$, camionista $^{171}$, enxeñeiro ${ }^{172}$, recepcionista ${ }^{173}$. Por outro lado, um mesmo processo pode ser heterogêneo funcionalmente, ou seja, dar origem a significações semânticas de classes totalmente distintas. Por exemplo, o sufixo -eiro pode apresentar várias funções diferentes, a título de ilustração em português: padeiro indica profissão, pitangueira é

\footnotetext{
157 Tradução: "surgimento".

158 Tradução: "ressurgimento".

159 Tradução: "nacional".

160 Tradução: "nacionalista".

161 Tradução: "nacionalizar".

162 Tradução: "nacionalização".

163 Tradução: "renacionalizar".

164 Tradução: "renacionalização".

165 Tradução: "desnacionalizar".

166 Tradução: “desnacionalização".

167 Tradução: “ ginásio poli-esportivo”.

168 Tradução: "nevoeiro".

169 Tradução: "névoa".

170 Tradução: "caminhoneiro" ou "motorista de caminhão".

${ }^{171}$ Idem

172 Tradução: "engenheiro".

173 Tradução: "recepcionista".
} 
uma árvore, galinheiro indica um local, cobreiro é uma doença, saleiro é um recipiente, fofoqueiro é a qualidade de uma pessoa, nevoeiro é o acúmulo de névoa; já em galego, na sufixação com -eiro: cueiro $^{174}$ é uma peça de roupa, carniceiro $^{175}$ é uma profissão, pexegueiro $^{176}$ é uma planta, capoeira ${ }^{177}$ é o local onde se criam os capós $^{178}$, papeira $^{179}$ é uma ${\text { doença, } \text { maseira }^{180} \text { é um recipiente, mixiriqueiro }}^{181}$ é a qualidade de uma pessoa, chuvisqueiro $^{182}$ é o acúmulo de chuvisco $^{183}$.

Por outro lado, é interessante notar que a afixação promove regras de formação de palavras com alta produtividade lexical, isso, em parte, devido à conotação semântica envolvida nos afixos que podem favorecer uma produção em série. Por exemplo, com o sufixo-ense e partindo de uma palavra que designa localidade, ou seja, um topônimo, formase mecanicamente os habitantes dessa localidade. A título de ilustração, em português: Porto Velho $^{184} \rightarrow$ porto-velhense, Almada ${ }^{185} \rightarrow$ almadense, Ourinhos ${ }^{186} \rightarrow$ ourinhense; em galego: Lalín $^{187} \rightarrow$ lalinense, Vigo ${ }^{188} \rightarrow$ viguense $^{189}$, Santiago $^{190} \rightarrow$ santiaguense $^{191}$. Outro exemplo de produtividade é o prefixo $a$-, de origem grega, que denota uma negação da base, e com o qual, muitas palavras podem ser produzidas, por exemplo, em português: amoral, anormal, ateu; e em galego: apolítico ${ }^{192}$, atípico ${ }^{193}$, acientífico ${ }^{194}$. Convém ressaltar que, ainda assim, a afixação é um processo complexo e a semântica das palavras resultantes nem sempre segue um princípio sistemático.

${ }^{174}$ Tradução: "fralda".

${ }^{175}$ Tradução: "açougueiro".

${ }^{176}$ Tradução: "pessegueiro".

177 Tradução: "galinheiro".

${ }^{178}$ Tradução: "galos".

${ }^{179}$ Tradução: "bócio".

${ }^{180}$ Equivale a um baú de madeira no qual se deixa a massa de fazer pão a fermentar.

${ }^{181}$ Tradução: "fofoqueiro".

${ }^{182}$ Tradução: "garoa intensa".

${ }^{183}$ Tradução: "chuvisco".

${ }^{184}$ Cidade brasileira no estado de Rondônia.

${ }^{185}$ Cidade portuguesa.

${ }^{186}$ Cidade brasileira no estado de Minas Gerais.

${ }^{187}$ Povoado da província de Pontevedra, na Galiza.

${ }^{188}$ Cidade da província de Pontevedra, na Galiza.

${ }^{189}$ Forma concorrente com vigués.

${ }^{190}$ Santiago de Compostela, capital da Galiza.

${ }^{191}$ Forma concorrente com: compostelano e santiagués.

${ }^{192}$ Tradução: "não-político".

193 Tradução: "não-típico".

${ }^{194}$ Tradução: "não-científico". 
Em resumo, o processo de formação de palavras tem como função o enriquecimento lexical mediante a mudança de classe ou a modificação semântica das palavras já existentes na língua. Assim, do ponto de vista do conteúdo da base, as novas palavras formadas podem corresponder a uma grande mudança semântica em relação ao léxico primário.

\section{A sufixação}

Conforme o que foi visto anteriormente, dentro da formação de palavras, além dos procedimentos mais especificamente morfológicos - derivação por sufixação e prefixação, parassíntese, derivação regressiva, derivação imprópria, composição - pode-se considerar outros procedimentos não necessariamente morfológicos como a onomatopéia, as abreviações, os estrangeirismos. No entanto, a maior parte dos mecanismos de formação de palavras é de caráter morfológico e se refere às diferentes maneiras de como se combinam os morfemas lexicais: lexemas e afixos, e, de acordo com SAID ALI (1930: 15), a sufixação mostra-se como o procedimento mais produtivo na formação de palavras.

Existe uma série de sufixos que alteram semanticamente a base de um modo subjetivo, mas que, muitas vezes, não modificam sua categoria gramatical. Estes sufixos podem ser chamados, segundo a maioria das gramáticas, de avaliativos, apreciativos, valorativos, expressivos ou afetivos e, em geral, são os sufixos aumentativos, diminutivos, intensificadores e pejorativos. Já, os sufixos considerados semanticamente mais objetivos e que alteram de modo fundamental o significado da base são chamados de nocionais e, freqüentemente, possuem a capacidade de efetuar uma modificação na sua categoria sintática e/ou semântica. Entretanto, classificar um sufixo em avaliativo ou nocional pode ser difícil, já que um mesmo sufixo pode ser avaliativo em alguns casos e nocional em outros. Por exemplo, em português, $-\tilde{a} o$ é um sufixo aumentativo, mas em: porta $\rightarrow$ portão ou caixa $\rightarrow$ caixão, o significado da base já está bastante alterado. Analogamente em galego, -ón é um sufixo aumentativo, mas em colcha ${ }^{195} \rightarrow$ colchón $^{196}$ ou perdiz ${ }^{197} \rightarrow$ perdigón $^{198}$, o significado já foi bastante especializado. Daí, o ponto de vista subjetivo ou a avaliação

\footnotetext{
195 Tradução: "colcha”.

196 Tradução: “colchão".

197 Tradução: "perdiz" (um tipo de ave).

198 Tradução: "perdigão" (macho da perdiz).
} 
emotiva na sufixação não são exclusivos necessariamente do número reduzido de morfemas classificados habitualmente como avaliativos ou nocionais. E dentro do repertório dos sufixos avaliativos, apesar de se classificar cada um deles no grupo dos diminutivos, aumentativos, intensificadores e pejorativos, na prática esta distinção não é tão clara, pois em muitas ocasiões o valor do sufixo dependerá do contexto e/ou da intenção do falante. Além disso, pela recursividade de aplicações de regras de derivação pode-se ter construções de novas palavras com uso de um sufixo diminutivo seguido de um aumentativo e vice-versa. O que na forma estrutural constitui um paradoxo, na língua, muitas vezes, pode ser usado sem qualquer problema. Por exemplo, no português: livro $\rightarrow$ livreto (livro +- eto $) \rightarrow$ livretão (livro +eto $\left.^{199}+-\tilde{a} o^{200}\right)$ e porta $\rightarrow$ portão $($ porta $+-\tilde{a} o) \rightarrow$ portãozinho; como no galego: porta ${ }^{201} \rightarrow$ portiña $^{202}($ porta $+-i \tilde{n} a) \rightarrow$ portiñola $^{203}($ porta $+-i \tilde{n} a+-$ ola $) \rightarrow$ portiñolón $^{204}($ porta +$\left.i \tilde{n} a^{205}+-o l a^{206}+-o n^{207}\right)$.

Considerando-se, por exemplo, o conjunto de sufixos diminutivos, o valor que atribuem à base excede em muito o valor propriamente diminuidor. Ou seja, o valor dos sufixos diminutivos varia desde o propriamente diminuidor com bases substantivas, por exemplo, no português: casa $\rightarrow$ casinha $($ casa $+-i n h a)$ e livro $\rightarrow$ livrinho (livro + -inho), analogamente no galego: $\operatorname{casa}^{208} \rightarrow \operatorname{casiñ}^{209}($ casa $+-i \tilde{n} a)$ e $\operatorname{libro}^{210} \rightarrow$ libriño $^{211}($ libro + iño); o ponderativo ou atenuante sobre bases adjetivas, por exemplo, no português: chato $\rightarrow$ chatinho (chato +- inho), analogamente no galego: aburrido ${ }^{212} \rightarrow$ aburridiño $^{213}$ (aburrido + $-i \tilde{n} o)$; o intensificador de pronomes ou advérbios, por exemplo, no português: perto $\rightarrow$ pertinho (perto +- inho), analogamente no galego: pouco $^{214} \rightarrow$ pouquiño $^{215}($ pouco +- iño); o

\footnotetext{
${ }^{199}$ Sufixo diminutivo em português.

${ }^{200}$ Sufixo aumentativo em português.

201 Tradução: "porta".

202 Tradução: "portinha".

203 Tradução: "cancela".

204 Tradução: "cancela grande".

${ }^{205}$ Sufixo diminutivo em galego.

${ }^{206}$ Idem.

${ }^{207}$ Sufixo aumentativo em galego.

208 Tradução: "casa".

209 Tradução: "casinha" ou "casa pequena".

210 Tradução: "livro".

211 Tradução: "livrinho" ou "livro pequeno".

212 Tradução: "chato".

213 Tradução: "chatinho".

214 Tradução: "pouco".

215 Tradução: "pouquinho".
} 
valor afetivo, por exemplo, no português: filho $\rightarrow$ filhinho (filho +- inho), analogamente no galego: neno ${ }^{216} \rightarrow$ neniño ${ }^{217}($ neno $+-i \tilde{n} o)$ e $n a i^{218} \rightarrow$ naiciña $^{219}($ nai $+-i \tilde{n} a)$; e mesmo o valor pejorativo, por exemplo, no português: mulher $\rightarrow$ mulherzinha (mulher + -inha), analogamente no galego: fraco $^{220} \rightarrow$ fracuxo $^{221}\left(\right.$ fraco $\left.+-u x o^{222}\right)$.

Além dos sufixos diminutivos, aumentativos e intensificadores caracterizarem os falantes do português e galego sob várias possibilidades semântico-estilísticas, dependendo do entorno sócio-cultural, da procedência rural ou urbana e até mesmo do sexo; também, segundo LAPA (1979:106): “como somos, porém, gente apaixonada, e facilmente vamos de um extremo ao outro, não é de surpreender que o mesmo sufixo evoque em nós sentimentos depreciativos. A pequenez física pode traduzir insuficiência moral.” É interessante notar que, como intensificador de uma idéia, o acúmulo de sufixos diminutivos pode funcionar como uma exacerbação da noção fornecida pela base, por exemplo, em português: fraco $\rightarrow$ fracote $($ fraco +- ote $) \rightarrow$ fracotinho $($ fraco +- ote +- inho $)$; analogamente em galego: fraco ${ }^{223} \rightarrow$ fracuxo $^{224}($ fraco +- uxo $) \rightarrow$ fracuxiño $^{225}($ fraco +- uxo $+-i \tilde{n} o)$. Praticamente as mesmas idéias desenvolvidas para os sufixos diminutivos valem para os sufixos aumentativos, ressaltando que tanto os sufixos aumentativos quanto os diminutivos podem funcionar como intensificadores e/ou como pejorativos.

Assim, a sufixação nocional corresponde ao processo que modifica de forma substancial o conteúdo semântico da base. Enquanto os sufixos avaliativos, em geral, salvo as observações feitas nos parágrafos anteriores, estão semanticamente subordinados à base, que funciona como núcleo lexical, os nocionais funcionam como núcleo semântico e sintático que podem modificar totalmente o conteúdo da base e sua categoria semântica. Por exemplo, em português: um sapatinho é um sapato (mesma categoria semântica), mas um sapateiro é uma pessoa, uma sapataria é um local, uma sapatada é um golpe e sapatear é uma ação;

\footnotetext{
${ }^{216}$ Forma carinhosa de designar "menino".

${ }^{217}$ Forma carinhosa de designar "menininho".

218 Tradução: "mãe".

219 Tradução: "mãezinha".

${ }^{220}$ Tradução: "fraco".

221 Tradução: "fracote".

${ }^{222}$ Sufixo diminutivo em galego.

223 Tradução: "fraco".

224 Tradução: "fracote".

${ }^{225}$ Tradução: "fracotinho".
} 
analogamente em galego: um zoquiño $o^{226}$ é um zoco ${ }^{227}$, mas um zoqueiro ${ }^{228}$ é uma pessoa, uma zocada $^{229}$ é um golpe e zoquear ${ }^{230}$ é uma ação.

Assim, o exemplo anterior e as noções de sufixação revistas neste trabalho contrariam alguns gramáticos, como BECHARA (1969: 206) e RoCHA LIMA (1972: 108), ao afirmarem em suas obras, que os sufixos são elementos apenas de valor morfológico na formação de série de palavras e que são semanticamente mais vazios de significado que os prefixos. Muito ao contrário, segundo SANDMANN (1989: 30-31), “os sufixos não são vazios de significado (...) nem são mais vazios que os prefixos (...) e correspondem até semanticamente muitas vezes a lexemas". Daí a possibilidade real de um mapeamento e classificação do valor semântico apresentado pelos sufixos.

\section{A classificação dos sufixos}

Sabe-se que o número de sufixos nocionais é muito maior que de sufixos avaliativos tanto no português quanto no galego, tornando-se mais difícil estabelecer uma classificação entre eles. Normalmente, o critério semântico combinado ao critério de mudança de classes é o mais utilizado, embora haja muitas dificuldades devido à polissemia e à sinonímia dos sufixos. Assim, uma forma usual de fazê-la, é a divisão em relação às classes das palavras formadoras, ou palavras-base na sufixação: substantivos, adjetivos, verbos e advérbios. Outra forma é baseando-se nas classes semânticas das palavras formadas e suas respectivas subdivisões. Entretanto, a classificação não deixa de ser uma tarefa problemática do ponto de vista semântico devido, principalmente, à grande diversidade de significados produzidos pela derivação, bem como pela concorrência e cruzamentos semânticos que há entre os sufixos.

Além de sufixos nominais, verbais e adverbiais, segundo a classe de palavras que formam, respectivamente: substantivos/adjetivos, verbos ou advérbios; os sufixos nominais podem ser, segundo classificação de FERREIRO (2001: 115), diferenciados em sufixos nocionais ou referenciais, e sufixos apreciativos. No caso dos sufixos referenciais nominais há

\footnotetext{
226 Tradução: "tamanquinho".

227 Tradução: "tamanco".

${ }^{228}$ É o artesão que faz e conserta tamancos.

${ }^{229}$ Golpe com tamanco.

${ }^{230}$ Equivale a sapatear, mas calçando tamancos.
} 
a possibilidade de subdividi-los segundo a categoria de suas bases: nominais (substantivos ou adjetivos) e verbais, nas quais, também, aparecem os fenômenos de concorrência e cruzamentos. Os sufixos nominais são os formadores de substantivos que, juntamente com os sufixos formadores de adjetivos, atuam no fenômeno da nominalização. De acordo com a classificação dada acima, grosso modo, podem ser: desubstantivais, como em piano $\rightarrow$ pianista, em português, e camión ${ }^{231} \rightarrow$ camionista $^{232}$, em galego; deadjetivais, como em cômodo $\rightarrow$ comodista, em português, e sensual ${ }^{233} \rightarrow$ sensualista $^{234}$, em galego; deverbais, como em batizar $\rightarrow$ batista, em português, e fumar ${ }^{235} \rightarrow$ fumista $^{236}$, em galego. Convém ressaltar que a estreita relação entre substantivos e adjetivos também é um fator problemático na classificação semântica, dado que ambos constituem a classe nominal e, às vezes, uma mesma palavra pode desempenhar as duas funções. Na língua portuguesa o fenômeno de conversão, ou seja, a transposição de uma palavra de uma classe para outra sem a alteração de sua forma, é especialmente comum e verificado, principalmente, entre substantivos e adjetivos, conforme comprovação feita nos estudos de BASÍLIO (2002: 75). Em resumo, segundo VIARO (2003): “o mesmo sufixo pode adquirir significações distintas. Uma classificação semântica há de prever essa situação. Além dessa classificação, é possível separar os sufixos dependendo do seu ponto de partida e seu ponto de chegada".

Segundo FreIXEIRO MATO (1999: 228-234), os sufixos formadores de substantivos podem ser classificados, segundo critérios semânticos tais como:

1. Coletivos ou conjuntos. Por exemplo, o sufixo -al: portal (português) e $\operatorname{areal}^{237}$ (galego); -ario: glossário (português) e formulario ${ }^{238}$ (galego); -agem: folhagem (português) e axe: ramaxe $^{239}$ (galego); -ada: bicharada (português) e mullerada ${ }^{240}$ (galego); -ado: aglomerado (português) e profesorado ${ }^{241}$ (galego); -edo: arvoredo (português) e viñedo ${ }^{242}$

\footnotetext{
231 Tradução: "caminhão".

232 Tradução: "caminhoneiro".

233 Tradução: "sensual".

${ }^{234}$ Tradução: "sensualista”.

235 Tradução: "fumar".

236 Tradução: "fumante" em português brasileiro e "fumador" em português lusitano.

${ }^{237}$ Tradução: local onde há muita area $=$ areia.

238 Tradução: "formulário".

${ }^{239}$ Tradução: "ramagem".

${ }^{240}$ Tradução: : muitas mulheres juntas.

241 Tradução: "professorado".

242 Tradução: "vinhedo".
} 
(galego); -ura: urdidura $^{243}$ (português), dentadura ${ }^{244}$ (galego); -aria: confraria (português) e pedraria ${ }^{245}$ (galego); -eiro(a): nevoeiro (português), esterqueira (português), romanceiro ${ }^{246}$ (galego) e xesteira ${ }^{247}$ (galego); -mento: ornamento (português) e armamento $^{248}$ (galego); -io: vozerio $^{249}$ (português) e -ío: mullerío ${ }^{250}$ (galego).

2. Quantitativos (quantidade que cabe no objeto designado pela base). Por exemplo, -ada: baciada (português) e cullerada ${ }^{251}$ (galego).

3. Locativos:

3.1. Lugar no qual abundam. Por exemplo, -al: cafezal (português) e toxal ${ }^{252}$ (galego); edo: castanhedo $^{253}$ (português) e laxedo ${ }^{254}$ (galego); -eiro(a): carvoeira (português), borralheiro $^{255}$ (português), clareira $^{256}$ (galego) e pulgueiro ${ }^{257}$ (galego).

3.2. Lugar no qual se cultiva. Por exemplo, -al: batatal (português), patacal ${ }^{258}$ (galego); eiro(a): arrozeira (português) e centeeiro ${ }^{259}$ (galego);

3.3. Lugar no qual se realiza uma atividade. Por exemplo, -douro: embarcadouro (português), abatedouro (português); -doiro: embarcadoiro ${ }^{260}$ (português), abatedoiro $^{261}$ (português), miradoiro ${ }^{262}$ (galego) e comedoiro $^{263}$ (galego); -eiro:

\footnotetext{
${ }^{243}$ Segundo o dicionário Houaiss, significa o conjunto de fios disposto no tear.

244 Tradução: "dentadura”.

245 Tradução: muitas pedras juntas.

${ }^{246}$ Tradução: "romanceiro".

${ }^{247}$ Tradução: local onde abundam as xestas = planta leguminosa de flores amarelas.

248 Tradução: "armamento".

${ }^{249}$ Segundo o dicionário Houaiss, significa o som de muitas vozes juntas.

${ }^{250}$ Tradução: : muitas mulheres juntas.

251 Tradução: "colherada".

252 Tradução: “tojal”.

${ }^{253}$ Segundo o dicionário Houaiss, significa o mesmo que "castanhal” (área onde abundam castanheiros).

254 Tradução: "lajeado".

${ }^{255}$ Segundo o dicionário Houaiss, significa o mesmo que "borralheira".

256 Tradução: "clareira".

${ }^{257}$ Tradução: o local infestado de pulgas.

${ }^{258}$ Tradução: "batatal".

259 Tradução: o local de plantio de centeio.

${ }^{260}$ Segundo o dicionário Houaiss, significa o mesmo que "embarcadouro".

${ }^{261}$ Segundo o dicionário Houaiss, significa o mesmo que "abatedouro".

262 Tradução: "mirante".

263 Tradução: "sala de jantar" nas casas e "refeitório" em empresas, escolas e hospitais.
} 
fiadeiro ${ }^{264}$ (galego) e lavadeiro ${ }^{265}$ (galego); -ório: observatório (português) e -orio: dormitorio $^{266}$ (galego).

3.4. Lugar sob uma jurisdição. Por exemplo, -ado: emirado (português) e ducado ${ }^{267}$ (galego); -ato: tabelionato (português) e califato $^{268}$ (galego); -io: senhorio (português) e-io: señorío ${ }^{269}$ (galego).

3.5. Lugar no qual se desenvolve uma atividade profissional. Por exemplo, -aria: perfumaria (português) e -aría: cafetaría ${ }^{270}$ (galego); -ado: almoxarifado (português) e xulgado ${ }^{271}$ (galego); -oria: corregedoria (português) e -oría: promotoría $^{272}$ (galego).

3.6. Lugar ou construção onde se guarda algo ou utilizado por seres vivos. Por exemplo, -ário: berçário (português) e -ario: vestiario ${ }^{273}$ (galego); -eiro(a): formigueiro (português), coelheira (português), galiñeiro ${ }^{274}$ (galego) e palleira $^{275}$ (galego).

4. Temporais (duração ou época em que se desenvolve uma atividade). Por exemplo, -ado: sultanado ${ }^{276}$ (português) e reinado ${ }^{277}$ (galego); -ia: chefia (português) e -ía: invernía ${ }^{278}$ (galego).

5. Ações:

5.1. Ações ou efeitos. Por exemplo, -ame: esparrame (português) e desparrame ${ }^{279}$ (galego); -agem: postagem (português) e -axe: lavaxe $^{280}$ (galego); -aço: cansaço (português) e -azo: cansazo $^{281}$ (galego); -ncia: inadimplência (português) e

\footnotetext{
264 Tradução: "tear" ou local onde se fia.

265 Tradução: "lavanderia" ou "tanque".

266 Tradução: "dormitório".

${ }^{267}$ Região dirigida por, ou pertencente a, um duque.

${ }^{268}$ Região dirigida por, ou pertencente a, um califa.

${ }^{269}$ Região dirigida por, ou pertencente a, um senhor feudal.

${ }^{270}$ Tradução: "bar" em português brasileiro e "café (local)" em português lusitano.

${ }^{271}$ Tradução: "tribunal regional" em português brasileiro.

272 Tradução: "promotoria”.

273 Tradução: "vestiário".

274 Tradução: "galinheiro".

275 Tradução: "palheiro".

${ }^{276}$ Segundo o dicionário Houaiss, significa o mesmo que "sultanato".

277 Tradução: "reinado".

278 Tradução: "invernia".

279 Tradução: "esparrame”.

${ }^{280}$ Tradução: "lavagem".

281 Tradução: "cansaço".
} 
observancia $^{282}$ (galego); -nça: desavença (português) e -nza: crenza ${ }^{283}$ (galego) ; $a d o(a)$ : achado (português) e mirada ${ }^{284}$ (galego); -ido(a): partido (português) e dormida 285 (galego); -ção: atuação (português), partição (português) e -ción: actuación $^{286}$ (galego), partición ${ }^{287}$ (galego); -mento: entupimento (português) e seguimento $^{288}$ (galego); -ura: fervura (português), abertura (português), fervedura ${ }^{289}$ (galego) e salpicadura ${ }^{290}$ (galego).

5.2. Ações características. Por exemplo, -ria: grosseria (português) e tontaria ${ }^{291}$ (galego), -ada: bagaçada (português) e burrada ${ }^{292}$ (galego); -eira: besteira (português) e asneira $^{293}$ (galego).

5.3. Ações violentas que produzem ferimentos ou golpes ou praticadas de repente. Por exemplo, -aço: panelaço ${ }^{294}$ e -azo: estacazo $^{295}$ (galego); -ada: facada (português) e patada $^{296}$ (galego); -ão: empurrão (português) e -ón: escorregón ${ }^{297}$ (galego).

6. Agentes:

6.1. Objetos que servem para realizar uma ação. Por exemplo, -douro: bebedouro (português); -doiro: bebedoiro ${ }^{298}$ (português) e varredoiro $^{299}$ (galego); -eiro(a): carpideira (português) e munxideira ${ }^{300}$ (galego); -nte: absorvente (português) e

\footnotetext{
282 Tradução: “observância”.

${ }^{283}$ Tradução: "crença".

284 Tradução: "olhada".

285 Tradução: "dormida".

286 Tradução: "atuação".

287 Tradução: "partição".

288 Tradução: "seguimento".

289 Tradução: "fervura".

${ }^{290}$ É o ato ou efeito de "salpicar".

${ }^{291}$ É a ação característica de um "tonto", o mesmo que "tolice".

292 Tradução: "burrada".

293 Tradução: "asneira".

${ }^{294}$ Segundo o dicionário Houaiss, significa grande ruído percutindo em panelas.

${ }^{295}$ Golpes dados como uma "estaca".

296 Tradução: "chute" ou "pontapé".

${ }^{297}$ Tradução: "escorregão".

${ }^{298}$ Segundo o dicionário Houaiss, significa o mesmo que "bebedouro".

299 Tradução: "vassoura grande".

300 Tradução: “ordenhadeira”.
} 
calmante $^{301}$ (galego); -or(a): abridor (português) e pasador ${ }^{302}$ (galego); -ura: fechadura (português) e pechadura ${ }^{303}$ (galego).

6.2. Pessoa que realiza uma ação. Por exemplo, -nte: agente (português) e contribuinte ${ }^{304}$ (galego); -or(a): agressor (português) e saltador ${ }^{305}$ (galego).

7. Ocupacionais:

7.1. Profissionais. Por exemplo, -ão(ã): sacristão (português) e -án(a): $\operatorname{capelán}^{306}$ (galego); -ário(a): boticário (português) e -ario(a): bibliotecario ${ }^{307}$ (galego); eiro(a): açougueiro (português) e carteiro $^{308}$ (galego); -ista: pianista (português) e dentista $^{309}$ (galego); -iz: aprendiz (português) e actriz ${ }^{310}$ (galego); -nte: gerente (português) e cantante $^{311}$ (galego); -or(a): governador (português) e labrador $^{312}$ (galego).

7.2. Especialidades profissionais. Por exemplo, -aria: ourivesaria (português) e -aría: xardinaría $^{313}$ (galego); -ato: celibato (português) e artesanato $^{314}$ (galego); -ado: bacharelado (português) e secretariado ${ }^{315}$ (galego); -ia: engenharia (português) e ía: advocacía $^{316}$ (galego); -ção: administração (português) e -ción: administración ${ }^{317}$ (galego); -ismo: turismo (português) e xornalismo ${ }^{318}$ (galego); -ura: advocatura $^{319}$ (português) e arquitectura $^{320}$ (galego).

\footnotetext{
301 Tradução: "calmante".

302 Tradução: "trava" ou "fecho" instalado do lado de dentro das portas.

303 Tradução: "fechadura".

304 Tradução: "contribuinte".

305 Tradução: "saltador" ou "saltitante".

306 Tradução: "capelão".

307 Tradução: "bibliotecário".

308 Tradução: "carteiro".

309 Tradução: “dentista".

310 Tradução: "atriz".

311 Tradução: "cantor" ou "cantora".

312 Tradução: "lavrador".

313 Tradução: "jardinagem".

314 Tradução: "artesanato".

315 Tradução: "secretariado".

316 Tradução: "advocacia".

317 Tradução: "administração".

318 Tradução: "jornalismo".

${ }^{319}$ Segundo o dicionário Houaiss, é uma profissão e significa a função do advogado.

320 Tradução: "arquitetura".
} 
8. Caracterizadores (qualidades). Por exemplo, -dade: humildade (português) e lealdade lin $^{321}$ (galego); -ácia: audácia (português) e -acia: falacia ${ }^{322}$ (galego); -ícia: delícia (português) e -icia: malicia $^{323}$ (galego); -ície: imundície (português) e -icie: calvicie $^{324}$ (galego); -ez: altivez (português) e vellez ${ }^{325}$ (galego); -eza: dureza (português) e beleza ${ }^{326}$ (galego); -ice: chatice (português) e vellice ${ }^{327}$ (galego); -ncia: arrogância (português) e ignorancia $^{328}$ (galego); -nça: esperança (português) e -nza: temperanza ${ }^{329}$ (galego); -ia: energia (português) e -ía: alegría ${ }^{330}$ (galego); -or: clamor (português) e amargor $^{331}$ (galego);-ude: virtude (português) e quietude ${ }^{332}$ (galego);-ume: pesadume ${ }^{333}$ (português) e negrume ${ }^{334}$ (galego); -ura: brancura (português), achatadura (português), frescura ${ }^{335}$ (galego) e curvatura $^{336}$ (galego).

9. Femininos (referidos a atividades e/ou qualidades no âmbito feminino). Por exemplo, com -eira: trabalhadeira (português) e cantadeira ${ }^{337}$ (galego); -esa: baronesa (português); essa: condessa (português) e -esa: abadesa $^{338}$ (galego); -ina: arlequina $^{339}$ (português) e heroina $^{340}$ (galego); -inha: abobrinha (português) e -iña: galiña ${ }^{341}$ (galego); -isa: poetisa (português) e papisa ${ }^{342}$ (galego); -iz: embaixatriz (português) e actriz ${ }^{343}$ (galego).

\footnotetext{
${ }^{321}$ Tradução: "lealdade".

322 Tradução: "falácia”.

323 Tradução: "malícia".

324 Tradução: "calvície".

325 Tradução: "velhice".

326 Tradução: "beleza".

327 Tradução: "velhice".

328 Tradução: "ignorância".

329 Tradução: "temperança", ou pessoa comedida.

330 Tradução: "alegria".

331 Tradução: "amargor".

332 Tradução: "quietude".

${ }^{333}$ Segundo o dicionário Houaiss, significa sentimento de tristeza ou desgosto.

334 Tradução: "negrume".

335 Tradução: "frescura".

336 Tradução: "curvatura".

337 Tradução: "cantadora”.

338 Tradução: "abadessa”.

${ }^{339}$ Segundo o dicionário Houaiss, personagem feminina da commedia dell'arte que corresponde ao Arlequim.

340 Tradução: "heroína".

341 Tradução: "galinha".

342 Tradução: "papisa".

343 Tradução: “atriz".
} 
Estudo comparativo de aspectos semânticos do sufixo -ista no português e no galego.

10. Vegetais: árvores, arbustos e plantas. Por exemplo, -eiro(a): goiabeira (português), limoeiro (português), roseira ${ }^{344}$ (galego) e pexegueiro ${ }^{345}$ (galego); -ácea(o): herbácea (português) e rosácea ${ }^{346}$ (galego).

11. Animais. Por exemplo, -ácea(o): cetáceo (português) e galinácea ${ }^{347}$ (galego); -ídeo: aracnídeo (português) e colibrideo ${ }^{348}$ (galego).

12. Recipientes:

12.1. No qual se guarda algo. Por exemplo, -ário: incensário $^{349}$ (português) e -ario: relicario $^{350}$ (galego); -eiro(a): charuteira (português) e moedeiro ${ }^{351}$ (galego).

12.2. No qual se serve algo. Por exemplo, -eiro(a): manteigueira (português), galheteiro (português), sopeira ${ }^{352}$ (galego) e saleiro ${ }^{353}$ (galego).

12.3. No qual se realiza uma atividade. Por exemplo, -douro: bebedouro (português); doiro: bebedoiro ${ }^{354}$ (português) e lavadoiro ${ }^{355}$ (galego).

\section{Doenças:}

13.1. Inflamações. Por exemplo, -ite: conjuntivite (português) e meninxite ${ }^{356}$ (galego).

13.2. Acúmulos. Por exemplo, -ose: tuberculose (português) e trombose ${ }^{357}$ (galego).

14. Bebidas, comidas ou preparados. Por exemplo, -ada: limonada (português), feijoada (português), laranxada ${ }^{358}$ (galego), allada $^{359}$ (galego).

15. Ciências. Por exemplo, -ística: balística (português) e lingüística ${ }^{360}$ (galego), -ia: filosofia (português) e -ía: xeografía ${ }^{361}$ (galego).

\footnotetext{
344 Tradução: "roseira".

345 Tradução: "pessegueiro".

346 Tradução: "rosácea" (nome botânico da família da planta).

347 Tradução: "galinácea" (nome da família da ave).

348 Tradução: "ofídio" ou "ofióideo" (serpentes e cobras).

${ }^{349}$ Segundo o dicionário Houaiss, o mesmo que "turíbulo" (recipiente em cujo interior se queima incenso).

350 Tradução: "relicário".

351 Tradução: "porta-moedas".

352 Tradução: "sopeira".

353 Tradução: "saleiro".

${ }^{354}$ Segundo o dicionário Houaiss, significa o mesmo que "bebedouro".

355 Tradução: "lavanderia" ou "tanque".

356 Tradução: "meningite".

357 Tradução: "trombose".

358 Tradução: "laranjada".

359 Tradução: "alheira".
} 
Estudo comparativo de aspectos semânticos do sufixo -ista no português e no galego.

16. Tendências ideológicas (linhas de pensamento, filosóficas, ideológicas, religiosas ou doutrinárias). Por exemplo, -ismo: nacionalismo (português), budismo (português), impresionismo $^{362}$ (galego) e catolicismo ${ }^{363}$ (galego).

E os sufixos formadores de adjetivos podem ser classificados, segundo critérios semânticos, como:

\section{Caracterizadores:}

1.1. Indicam qualidades que caracterizam pessoas ou coisas. Por exemplo, $-a c o(a)$ : cardíaco (português) e maniaco $^{364}$ (galego); -aico(a): onomatopaico (português) e prosaico $^{365}$ (galego); -al: causal (português) e persoal ${ }^{366}$ (galego); -átil: retrátil (português) e vibrátil ${ }^{367}$ (galego); -az: mordaz (português) e ricaz ${ }^{368}$ (galego); -vel: admirável (português) e -bel: amábel ${ }^{369}$ (galego); -bundo(a): meditabundo (português) e vagabundo ${ }^{370}$ (galego); -ado(a): penado (português) e barbado ${ }^{371}$ (galego); -ido(a): deprimido (português) e dolorido ${ }^{372}$ (galego); -douro(a): duradouro (português) e -doiro(a): duradoiro ${ }^{373}$ (galego); -or(a): falador (português) e encantador ${ }^{374}$ (galego); -eiro(a): cabreiro (português) e preguiceiro ${ }^{375}$ (galego);-ento(a): bexiguento (português) e balorento ${ }^{376}$ (galego);-enho(a): sedenho (português) e -eño(a): rouqueño ${ }^{377}$ (galego); -ico(a): básico (português) e alcólico ${ }^{378}$ (galego): -ático(a): hepático (português) e aromático $^{379}$ (galego); -il: civil

\footnotetext{
360 Tradução: "lingüística".

361 Tradução: "geografia".

362 Tradução: "impressionismo".

363 Tradução: "catolicismo".

364 Tradução: "maníaco".

365 Tradução: "prosaico".

366 Tradução: "pessoal”.

367 Tradução: "vibrátil".

368 Tradução: "rico".

369 Tradução: "amável”.

370 Tradução: "vagabundo".

371 Tradução: "barbado".

372 Tradução: "dolorido".

373 Tradução: "duradouro".

374 Tradução: "encantador".

375 Tradução: "preguiçoso".

376 Tradução: "embolorado".

377 Tradução: "rouco".

378 Tradução: "alcoólico".

379 Tradução: "aromático".
} 
Estudo comparativo de aspectos semânticos do sufixo -ista no português e no galego.

(português) e febril $^{380}$ (galego); -ino(a): albino (português) e cristalino $^{381}$ (galego): io(a): vadio (português) e -ío(a): $\operatorname{tardio~}^{382}$ (galego); -ivo(a): festivo (português) e intensivo $^{383}$ (galego); -iço(a): chovediço (português) e -izo(a): sombrizo $^{384}$ (galego); -nte: fulgurante (português) e brillante ${ }^{385}$ (galego); -onho(a): risonho (português) e oño(a): medoño ${ }^{386}$ (galego); -ório(a): migratório (português) e -orio(a): meritorio ${ }^{387}$ (galego);-oso(a): afetuoso (português) e desexoso ${ }^{388}$ (galego); -sco(a): carnavalesco (português) e libresco ${ }^{389}$ (galego).

1.2. Expressam semelhança na qualidade. Por exemplo, -áceo(a): galináceo (português) e azuláceo $^{390}$ (galego); -alho(a): crisalho $^{391}$ (português) e -allo(a): grisallo ${ }^{392}$ (galego); -ado(a): azulado (português) e nacarado ${ }^{393}$ (galego); -ento(a): carvoento (português) e cincento $^{394}$ (galego); -enho(a): triguenho (português) e -eño(a): ferreño ${ }^{395}$ (galego); -eo(a): vítreo (português) e róseo ${ }^{396}$ (galego); -óide: burróide (português) e esferóide $^{397}$ (galego); -ório(a): giratório (português) e -orio(a): rotatorio $^{398}$ (galego).

1.3. Caracterizam pejorativamente. Por exemplo, -ão(ã): fanfarrão (português) e -án(a): cacholán $^{399}$ (galego); -as: balholas ${ }^{400}$ (português) e baldragas ${ }^{401}$ (galego); -udo(a): lanfranhudo $^{402}$ (português) e peludo ${ }^{403}$ (galego).

${ }^{380}$ Tradução: "febrill".

${ }^{381}$ Tradução: "cristalino".

382 Tradução: "tardio".

${ }^{383}$ Tradução: "intensivo".

${ }^{384}$ Tradução: "sombroso".

385 Tradução: "brilhante".

386 Tradução: "medonho".

${ }^{387}$ Tradução: "meritório".

${ }^{388}$ Tradução: "desejoso".

${ }^{389}$ Tradução: "livresco".

${ }^{390}$ Tradução: "azulado".

${ }^{391}$ Segundo o dicionário Houaiss, o mesmo que grisalho.

392 Tradução: "grisalho".

393 Tradução: "perolado".

${ }^{394}$ Tradução: "cinzento".

${ }^{395}$ Tradução: "ferrenho".

${ }^{396}$ Tradução: "rosado".

${ }^{397}$ Tradução: "esferóide".

${ }^{398}$ Tradução: "rotatório".

${ }^{399}$ Tradução: "cabeça de vento".

${ }^{400}$ Segundo o dicionário Houaiss, aquele que denota falta de inteligência, idiota.

${ }^{401}$ Tradução: "fanfarrão".

${ }^{402}$ Segundo o dicionário Houaiss, desajeitado.

${ }^{403}$ Tradução: "peludo". 


\section{Virtuais:}

2.1. Podem indicar potencialidade. Por exemplo, -vel: inesquecível (português) e -bel: críbel $^{404}$ (galego); -átil: volátil (português) e portátil ${ }^{405}$ (galego).

2.2. Facilidade em algo. Por exemplo, -iço(a): quebradiço (português) e -izo(a): esquecedizo $^{406}$ (galego); -io(a): escorregadio (português) e -ío(a): fuxidio ${ }^{407}$ (galego).

2.3. Futuridade. Por exemplo, -bundo(a): furibundo ${ }^{408}$ (português) e moribundo ${ }^{409}$ (galego);-douro(a): vindouro (português) e-doiro(a): vindoiro $^{410}$ (galego).

3. Relacionais (relativo ou pertencente a). Por exemplo, -aico(a): pirenaico ${ }^{411}$ (português) e xudaico $^{412}$ (galego); -al: celestial (português) e espacial ${ }^{413}$ (galego);-ano(a): republicano (português) e rosaliano ${ }^{414}$ (galego); -ar: ocular (português) e escolar $^{415}$ (galego); ário(a): diário (português) e -ario: dentario $^{416}$ (galego); -engo(a): abadengo (português) e realengo $^{417}$ (galego); -eno(a): extraterreno (português) e -eño(a): terreño $^{418}$ (galego); ense: circense (português) e hortense ${ }^{419}$ (galego); - estre: silvestre (português) e campestre $^{420}$ (galego); -exo(a): castrexo $^{421}$ (galego); -ício(a): advocatício (português) e icio(a): alimenticio $^{422}$ (galego); -ico(a): cartográfico (português) e $x^{2}$ ografico ${ }^{423}$ (galego); -il: têxtil (português) e táctil $^{424}$ (galego); -ino(a): caprino (português) e uterino ${ }^{425}$

\footnotetext{
404 Tradução: "acreditável”.

405 Tradução: "portátil".

406 Tradução: "esquecido".

407 Tradução: que tende a fugir.

${ }^{408}$ Segundo o dicionário Houaiss, enfurecido ou prestes a ser tomado pela fúria.

${ }^{409}$ Tradução: "moribundo".

410 Tradução: "vindouro".

${ }^{411}$ Segundo o dicionário Houaiss, relativo à região do Pireneus.

412 Tradução: "judaico".

413 Tradução: “espacial”.

${ }^{414}$ Relativo à Rosalía de Castro.

415 Tradução: "escolar".

416 Tradução: "dentário".

417 Tradução: "realengo".

418 Tradução: "terreno".

419 Tradução: "hortense".

${ }^{420}$ Tradução: "campestre".

${ }^{421}$ Relativo ao "castro".

422 Tradução: "alimentício".

423 Tradução: "geográfico".

424 Tradução: "táctill".

425 Tradução: "uterino".
} 
Estudo comparativo de aspectos semânticos do sufixo -ista no português e no galego.

(galego); -inho(a): marinho (português) e -iño(a): setemesiño $^{426}$ (galego); -ístico(a): humorístico (português) e estilístico ${ }^{427}$ (galego); -tório(a): declamatório (português) e torio(a): natatorio $^{428}$ (galego); -sco $(a)$ : animalesco (português) e trobadoresco ${ }^{429}$ (galego); -um(una): cabrum $^{430}$ (português), -uno(a): gatuno (português) e -ún(a): vacún ${ }^{431}$ (galego).

4. Gentílicos (origem ou procedência). Por exemplo, -aco(a): polaco (português) e austríaco $^{432}$ (galego); -ão(ã): alemão (português) e -án(a): vilán ${ }^{433}$ (galego); -ano(a):

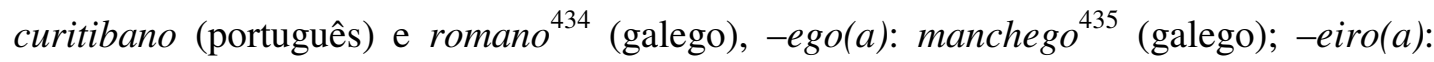
mineiro (português) e brasileiro ${ }^{436}$ (galego); -enho(a): açorenho $^{437}$ (português) e -eño(a): portorriqueño $^{438}$ (galego); -ense: estadunidense (português) e cretense ${ }^{439}$ (galego); - $\hat{e}$ (a): português (português) e -és(a): noruegués ${ }^{440}$ (galego); -eu(a): galileu $^{441}$ (português) e europeu (galego); -í: israeli $^{442}$ (galego), -ico(a): pérsico ${ }^{443}$ (galego); -ino(a): argentino (português) e marroquino ${ }^{444}$ (galego); -inho(a): biscainho $^{445}$ (português) e -iño(a): bizcaíno $^{446}$ (galego); -io(a): armênio (português) e -ío(a): algarvío ${ }^{447}$ (galego); -ista: santista (português) e paulista ${ }^{448}$ (galego); -ita: israelita (português) e saudita ${ }^{449}$ (galego);

\footnotetext{
${ }^{426}$ Bebê prematuro, que nasce aos sete meses de gestação.

427 Tradução: "estilístico".

428 Tradução: "natatório".

429 Tradução: "trovadoresco".

${ }^{430}$ Segundo o dicionário Houaiss, relativo aos caprinos.

431 Tradução: "vacuno".

432 Tradução: "austríaco".

433 Tradução: "vilão".

${ }^{434}$ Tradução: "romano".

435 Originário de La Mancha.

${ }^{436}$ Originário do Brasil, empréstimo do português.

${ }^{437}$ Segundo o dicionário Houaiss, significa o mesmo que açoriano.

438 Tradução: "portorriquenho".

439 Tradução: "cretense".

440 Tradução: "norueguês".

${ }^{441}$ Segundo dicionário Houaiss, originário da Galiléia.

${ }^{442}$ Originário de Israel.

${ }^{443}$ Originário da Pérsia.

444 Tradução: "marroquino".

445 Originário de Biscaia.

${ }^{446}$ Originário de Bizcaia.

${ }^{447}$ Originário do Algarve.

${ }^{448}$ Originário do estado de São Paulo, empréstimo do português.

${ }^{449}$ Tradução: "saudita”.
} 
$-o l(a):$ reinol $^{450}$ (português) e español ${ }^{451}$ (galego); -oto(a): paivoto ${ }^{452}$ (português) e miñoto $^{453}$ (galego).

5. Tendências (ideológicas, artísticas, filosóficas, religiosas ou doutrinárias). Por exemplo, -ano(a): luterano (português) e cristiano $^{454}$ (galego); -ista: cubista (português) e neotrobadorista ${ }^{455}$ (galego).

Os sufixos formadores de verbos podem ser classificados, segundo critérios semânticos, como:

1. Freqüência (repetição ou realização freqüente de uma ação). Por exemplo, -ear: golpear (português) e cabecear $^{456}$ (galego); -ejar: pestanejar (português) e -exar: gotexar $^{457}$ (galego); -icar: claudicar (português) e choricar $^{458}$ (galego); -inhar: dorminhar $^{459}$ (português) e -iñar: chuviñar ${ }^{460}$ (galego); -iscar: chuviscar (português) e namoriscar $^{461}$ (galego); -mingar: choramingar (português) e choramingar (galego).

2. Modificativos (mudança de estado, ou de qualidade). Por exemplo, -ear: clarear (português) e rarear $^{462}$ (galego); -ecer: anoitecer (português) e oscurecer $^{463}$ (galego); -ejar: alvejar (português) e -exar: branquexar ${ }^{464}$ (galego); -ificar: solidificar (português) e clarificar $^{465}$ (galego); -itar: debilitar (português) e habilitar ${ }^{466}$ (galego); -izar: humanizar (português) e axilizar $^{467}$ (galego); - ezar: afortalezar ${ }^{468}$ (português) e embelezar $^{469}$ (galego).

\footnotetext{
${ }^{450}$ Segundo o dicionário Houaiss, significa indivíduo natural do reino.

451 Tradução: "espanhol".

452 Originário de Castelo de Paiva em Portugal.

453 Tradução: "minhoto" em português, originário da região do rio Minho.

${ }^{454}$ Tradução: "cristão".

455 Tradução: "neotrovadorista".

456 Tradução: "cabecear".

457 Tradução: "gotejar".

458 Tradução: "choramingar".

${ }^{459}$ Segundo o dicionário Houaiss, significa dormir aos poucos ou por um curto período.

460 Tradução: "chuviscar".

461 Tradução: "namoricar",

462 Tradução: "tornar raro", rarefazer.

463 Tradução: "escurecer".

464 Tradução: "branquear".

465 Tradução: "clarear".

466 Tradução: "habilitar".

467 Tradução: "agilizar".

${ }^{468}$ Segundo o dicionário Houaiss, dar ou tomar aspecto de fortaleza, fortalecer.

469 Tradução: "embelezar".
} 
Já, segundo o autor, o único sufixo formador de advérbios é -mente, por exemplo, em português: claramente e em galego: axeitadamente ${ }^{470}$; e, portanto, não lhe atribui classificação semântica alguma. Nessa mesma linha, SANDMANN (1989: 77) afirma que mente é o único sufixo no português com o qual se formam advérbios.

SANDMANN (1989: 32), assim como FreiXEIRO MATO, propõe sua classificação partindo de: formação de substantivos, formação de adjetivos, formação de verbos e formação de advérbios (sufixo -mente), e então apresenta suas subclassificações, dadas sufixo a sufixo, mas restrito ao seu corpus. Assim, segundo SANDMANN (1989: 32-55), os sufixos formadores de substantivos podem ser classificados como:

1. Substantivos derivados de substantivos.

1.1. $-a c ̧ o . ~(-a z o$, em galego). Com as seguintes funções:

1.1.1. Aumentativa. Por exemplo: barulhaço (português) e ruidazo ${ }^{471}$ (galego).

1.1.2. Golpe forte. Por exemplo: joelhaço, em português, é um golpe forte com o joelho; em galego, martelazo $^{472}$ é um golpe forte com o martelo ${ }^{473}$.

1.1.3. Expressiva. Por exemplo: mulheraça em português, tanto pode significar uma grande e forte mulher, como uma mulher muito interessante; partidazo, em galego, significa uma excelente partida de futebol.

1.2. - agem (-axe, em galego). Com a função de expressar uma ação. Por exemplo: panfletagem, em português, é a redação de um texto em forma de panfleto; aprendizaxe $^{474}$, em galego, é a ação cujo foco é o aprendiz.

1.3. -ão. (-ón ou -án, em galego). Com as seguintes funções:

1.3.1. Aumentativa. Por exemplo: casarão, em português, é uma casa grande; e narizón ${ }^{475}$, em galego, é um nariz grande.

1.3.2. Expressiva. Por exemplo: em português, dinheirão significa muito dinheiro e calçadão é uma via destinada exclusivamente aos pedestres; em galego,

\footnotetext{
${ }^{470}$ Tradução: “jeitosamente".

${ }^{471}$ Tradução: ruído muito alto.

472 Tradução: "golpe forte com o martelo".

473 Tradução: "martelo".

474 Tradução: "aprendizagem".

475 Tradução: "narigão".
} 
memorión $^{476}$ significa uma memória extraordinária e faldrón ${ }^{477}$, não é uma faldra $^{478}$ grande, mas um pano (em geral de linho) com o qual se enrolam os nenês e as crianças pequenas da cintura para baixo.

1.4. - aria (-aría, em galego). Com a função de designar lugar onde algo se encontra ou onde se produz algo. Por exemplo: em português, ferramentaria ${ }^{479}$ é o local onde se fabricam ferramentas; e, em galego, libraría $^{480}$ é o local onde se encontram os $\operatorname{libros}^{481}$ à venda.

1.5. -ário (-ario, em galego). Com a função agentiva (profissional). Por exemplo: em português metroviário; em galego, comisario $^{482}$.

1.6. -ado e -ato. Com a função de formação de substantivos abstratos. Por exemplo: em português proletariado e campesinato ${ }^{483}$; em galego: bispado $^{484}$ e liderato $^{485}$.

1.7. - eira. Com a função de designar local onde se encontra algo. Por exemplo: em português, arrozeira $^{486}$; e em galego sementeira ${ }^{487}$.

1.8. - eiro. Com as seguintes funções:

1.8.1. Agentiva. Por exemplo: em português, motoqueiro é quem conduz uma moto; em galego coroceiro $^{488}$ é quem faz corozas ${ }^{489}$.

1.8.2. Locativa. Por exemplo: em português, atoleiro é o local onde se atola; em galego palleiro $^{490}$ é o lugar onde se guarda a palla ${ }^{491}$.

1.9. - ete. Com a função diminutiva. Por exemplo: em português, cartazete é um diminutivo de cartaz; e em galego rapacete ${ }^{492}$ é o diminutivo de rapaz $^{493}$.

\footnotetext{
476 Tradução: "memória extraordinária”.

${ }^{477}$ É um pano com o qual se enrolam os nenês e as crianças pequenas da cintura para baixo.

478 Tradução: "saia".

${ }^{479}$ Segundo o dicionário Houaiss, é o local onde se fabricam ou se vendem ferramentas.

480 Tradução: "livraria".

481 Tradução: "livros".

482 Tradução: "delegado de polícia".

${ }^{483}$ Segundo o dicionário Houaiss, significa a condição camponesa.

${ }^{484}$ Tradução: "bispado".

485 Tradução: "liderança".

${ }^{486}$ Segundo o dicionário Houaiss, significa o mesmo que "arrozal".

${ }^{487}$ Tradução: "local onde se plantam as sementes".

${ }^{488}$ Artesão que faz as corozas (capas de palha).

${ }^{489}$ Capa de palha que se usa no campo para se abrigar da chuva.

490 Tradução: "palheiro".

491 Tradução: "palha".
} 
1.10. -ia (-ía, em galego). Com a função de formação de substantivos abstratos. Por exemplo, em português: reitoria; em galego: invernía ${ }^{494}$.

1.11. -ica. Com a função de formação de substantivos abstratos. Por exemplo, em português: robótica; em galego: óptica ${ }^{495}$.

1.12. -inho (-iño, em galego). Com as seguintes funções:

1.12.1. Diminutiva. Por exemplo: em português, livrinho é um diminutivo de livro; e em galego neniño ${ }^{496}$ é o diminutivo de $n e n o^{497}$.

1.12.2. Expressiva. Por exemplo: em português, caixinha é um sinônimo de gorjeta; e em galego señoriñ ${ }^{498}$ é o título de uma mulher solteira.

1.13. -ismo. Com a função de designar orientações, doutrinas e teorias filosóficas, religiosas, políticas, sociais, artísticas, comportamentais, etc. Por exemplo, em português: iluminismo, protestantismo, presidencialismo, feudalismo, romantismo, individualismo; e em galego: cartesianismo $^{499}$, $_{\text {catolicismo }}{ }^{500}$, monarquismo $^{501}$, comunismo $^{502}$, $^{\text {cubismo }}{ }^{503}$, optimismo ${ }^{504}$.

1.14. - ista. Com as seguintes funções:

1.14.1. Adepto das idéias de um político. Por exemplo, em português, Malufista é o adepto das idéias do ex-governador paulistano Paulo Maluf; em galego Franquista $^{505}$ é o adepto das idéias do General Francisco Franco.

1.14.2. Membro de um partido político. Por exemplo: em português, udenista era o membro do antigo partido brasileiro $U D N^{506}$; em galego um ppista ${ }^{507}$ é membro do $P P^{508}$.

\footnotetext{
492 Tradução: "menino pequeno".

493 Tradução: "menino".

494 Tradução: "invernia".

495 Tradução: "ótica”, no sentido da ciência.

496 Tradução: "menininho".

497 Tradução: "menino".

498 Tradução: "senhorita".

499 Tradução: "cartesianismo".

500 Tradução: "catolicismo".

501 Tradução: "monarquismo".

502 Tradução: "comunismo".

503 Tradução: "cubismo".

504 Tradução: "otimismo".

${ }^{505}$ Seguidor ou simpatizante do General e Caudilho Francisco Franco.
} 
Estudo comparativo de aspectos semânticos do sufixo -ista no português e no galego.

1.14.3. Fã de um clube esportivo ou torcedor de um time de futebol. Por exemplo, em português, santista é o torcedor do Santos Futebol Clube; em galego deportivista ${ }^{509}$ é o torcedor do Deportivo de La Coruña ${ }^{510}$.

1.14.4. Emprego ou ocupação. Por exemplo: em português, vitrinista; em galego, pianista $^{511}$.

1.14.5. Adepto de orientações, doutrinas e teorias filosóficas, religiosas, políticas, sociais, artísticas, comportamentais, etc. Por exemplo, em português: iluminista, hinduísta, presidencialista, capitalista, impressionista, individualista; e em galego: constructivista ${ }^{512}$, budista $^{513}$, monarquista ${ }^{514}$, comunista ${ }^{515}$, cubista ${ }^{516}$, optimista $^{517}$.

1.15. - -ite. Com as seguintes funções:

1.15.1. De designar inflamações. Por exemplo: em português, conjuntivite; em galego, apendicite $^{518}$.

1.15.2. Expressiva. Por exemplo: em português exclusivamente brasileiro, paixonite $^{519}$, indicando metaforicamente uma paixão exagerada e passageira.

1.16. - oca. Com a função diminutiva, e com sentido de desapreço. Por exemplo: motoca ou belezoca, em português; e casoca ${ }^{520}$ em galego.

2. Substantivos derivados de adjetivos.

2.1. - $\hat{e}$ (-és, em galego). Com a função de designar uma língua ou uma variedade dela. Por exemplo: economês ${ }^{521}$, em português; internetés ${ }^{522}$, em galego.

\footnotetext{
${ }^{506}$ UDN é a sigla de União Democrática Nacional, partido brasileiro extinto em 1965.

${ }^{507}$ Membro ou seguidor do PP.

${ }^{508}$ PP é a sigla do Partido Popular, atualmente um dos partidos políticos da Espanha.

${ }^{509}$ Torcedor do time de futebol galego: Deportivo de La Coruña

${ }^{510}$ Clube e time de futebol galego.

511 Tradução: "pianista".

512 Tradução: "construtivista".

513 Tradução: "budista".

514 Tradução: "monarquista".

515 Tradução: "comunista".

516 Tradução: "cubista".

517 Tradução: "otimista".

518 Tradução: "apendicite".

${ }_{520}^{519}$ Segundo o dicionário Houaiss, significa uma intensa paixão amorosa, regionalismo brasileiro.

520 Tradução: "casebre".
} 
2.2. -eza. Com a função de formação de substantivos abstratos. Por exemplo: em português: dureza; em galego: beleza ${ }^{523}$.

2.3. -ice. Com a função de formação de substantivos abstratos. Por exemplo: em português: burrice; em galego: tolice ${ }^{524}$.

2.4. -dade. Com a função de formação de substantivos abstratos. Por exemplo: em português: competitividade; em galego: lealdade ${ }^{525}$.

3. Substantivos derivados de verbos.

3.1. - ada. Com a função de designar ações. Por exemplo: em português: olhada; em galego: rabuñada ${ }^{526}$.

3.2. - agem (-axe, em galego). Com a função de designar ações ou efeitos. Por exemplo: em português: lavagem; em galego: rodaxe $^{527}$.

3.3. -ção (-ción, -sión, -zón, em galego). Com a função de designar ações ou efeitos. Por exemplo: em português: penalização; em galego: doazón ${ }^{528}$.

3.4. $-\operatorname{or}(a)$. Com as seguintes funções:

3.4.1. Agentivo. Por exemplo: em português: velejador; em galego: nadador $^{529}$.

3.4.2. Instrumento. Por exemplo: em português: misturador; em galego: abridor ${ }^{530}$.

3.4.3. Máquina. Por exemplo: em português: secadora; em galego: lavadora ${ }^{531}$.

3.5. - ura. Com a função de designar ações ou efeitos. Por exemplo: em português: laqueadura; em galego: varredura ${ }^{532}$.

3.6. -mento. Com a função de designar ações ou efeitos. Por exemplo: em português: gerenciamento; em galego: movemento ${ }^{533}$.

\footnotetext{
${ }^{521}$ Segundo dicionário Houaiss, a linguagem pejada de tecnicidades do jargão dos economistas.

${ }^{522}$ A linguagem usada nas comunicações via internet.

523 Tradução: "beleza".

524 Tradução: "tolice".

525 Tradução: "lealdade".

${ }^{526}$ Tradução: "unhada" (ato de ferir com as unhas).

527 Tradução: "rodagem".

528 Tradução: "doação".

529 Tradução: "nadador".

530 Tradução: "abridor".

531 Tradução: "lavadora".

532 Tradução: o ato ou efeito de varrer.
} 
Os sufixos formadores de adjetivos, para SANDMANN (1989: 55-66), são:

4. Adjetivos derivados de substantivos.

4.1. -al. Por exemplo: em português: ambulatorial; em galego: policial $^{534}$.

4.2. - ar. Por exemplo: em português: familiar; em galego: escolar ${ }^{535}$.

4.3. -ável. Por exemplo: em português: presidenciável.

4.4. -eiro. Por exemplo: em português: alcooleiro $^{536}$; em galego: gandeiro $^{537}$.

4.5. -engo. Por exemplo: em português: verdoengo; em galego: mullerengo $^{538}$.

4.6. - ense. Usado na formação de gentílicos. Por exemplo: em português: catarinense $^{539}$; em galego: lalinense $e^{540}$.

4.7. -sco. Por exemplo: em português: carnavalesco; em galego: mourisco $^{541}$.

4.8. -iano. Por exemplo: em português: uspiano $^{542}$; em galego: rosaliano ${ }^{543}$.

4.9. -ico. Por exemplo: em português: botânico; em galego: xeográfico ${ }^{544}$.

4.10. -ino. Por exemplo: em português: natalino; em galego: cristalino $^{545}$.

4.11. -ivo. Por exemplo: em português: automotivo; em galego: tempestivo ${ }^{546}$.

4.12. -oso. Por exemplo: em português: preconceituoso; em galego: orgulloso ${ }^{547}$.

5. Adjetivos derivados de adjetivos.

5.1. -ão (-ón, -án, em galego). Por exemplo: em português: covardão; em galego: solteirón ${ }^{548}$.

\footnotetext{
533 Tradução: "movimento".

534 Tradução: "policial".

535 Tradução: "escolar".

${ }^{536}$ Segundo o dicionário Houaiss, significa relativo à álcool.

537 Tradução: relativo ao gado.

538 Tradução: "mulherengo".

${ }^{539}$ Originário do estado de Santa Catarina, no Brasil.

${ }^{540}$ Originário de Lalín, povoado da província de Pontevedra na Galiza.

541 Tradução: "mourisco".

${ }^{542}$ Derivado de USP, abreviação de Universidade de São Paulo.

${ }^{543}$ Relativo à Rosalía de Castro.

544 Tradução: "geográfico".

545 Tradução: "cristalino".

${ }^{546}$ Relativo à tempestade.

547 Tradução: "orgulhoso".
} 
5.2. -inho (-iño, em galego). Por exemplo: em português: amarelinho; em galego: toliño ${ }^{549}$

5.3. -íssimo (-ísimo, em galego). Por exemplo: em português: altíssimo; em galego: grandísimo $^{550}$.

6. Adjetivos derivados de verbos.

6.1. -nte. Por exemplo: em português: desgastante; em galego: contribuinte ${ }^{551}$.

6.2. -vel (-bel, em galego). Por exemplo: em português: suprimível; em galego: agradábel ${ }^{552}$.

6.3. -tório. Por exemplo: em português: contestatório; em galego: rotatório ${ }^{553}$.

De maneira diferente, RIO-TORTO (1998: 112-114) oferece uma classificação baseada na regra de formação de palavras $(R F P)$ e suas características semânticas, sem, no entanto, ser exaustiva no detalhamento dos sufixos envolvidos. Para tanto, Rio-ToRTO (1998: 112-11) faz uso da seguinte notação de categorias operatórias:

$A$ - adjetivo, $A b$ - adjetivo de base, $A d$ - adjetivo derivado;

$N$ - nome, $N b$ - nome de base, $N d$ - nome derivado;

$X$ - variável que representa uma unidade lexical e aquilo que ela denota, $X b$ - unidade de base, $X d$ - produto derivacional,

$V$ - verbo, $V b$ - verbo de base, $V d$ - verbo derivado.

Assim, segundo RIO-TORTO (1998: 112-114), tem-se a classificação a seguir:

1. Produtos deverbais

1.1. Ação/processo de $V$ e/ou resultado da ação/processo de $V$. Por exemplo, em português: acolhimento (-mento), arremetida (-ida), atropelo (-elo), contagem (agem), entrada (-ada), fundição (-ção), mordedura (-ura), tropeção (-ão),

\footnotetext{
${ }^{548}$ Tradução: "solteirão".

${ }_{550}^{549}$ Tradução: "tolinho".

${ }^{550}$ Tradução: "grandíssimo".

${ }^{551}$ Tradução: "contribuinte".

${ }_{553}^{552}$ Tradução: "agradável".

${ }^{553}$ Tradução: "rotatório".
} 
Estudo comparativo de aspectos semânticos do sufixo -ista no português e no galego.

vingança (-nça), zombaria (-ia); em galego: movemento ${ }^{554}$ (-mento), xemido ${ }^{555}$ (-ido), limpadela ${ }^{556}(-$ ela $)$, aterraxe $^{557}$ (-axe), rabuñada ${ }^{558}(-a d a)$, expedir ${ }^{559}{ }_{(-}$ ción), doazón ${ }^{560}$ (-zón), varredura ${ }^{561}$ (-ura), esvarón ${ }^{562}$ (-ón), crenza ${ }^{563}(-n z a)$, borracheira $^{564}(-e i r a)$.

1.2. Que V. Por exemplo, em português: aldrabão ${ }^{565}$ (-ão), dançarino (-ino), desenhador $^{566}$ (-or), desenhista (-ista), ouvinte (-nte), queixoso (-oso), enfadonho (-onho); em galego: bailarino ${ }^{567}$ (-ino), pintor ${ }^{568}$ (-or), deseñista ${ }^{569}{ }_{(-}$ ista), cantante $^{570}(-n t e)$, baboso $^{571}$ (-oso), enfadoño ${ }^{572}$ (-oño).

1.3. Aquilo com que se $V$; instrumento com que (se) $V$. Por exemplo, em português: aspirador (-or), enceradeira (-eira), esfregão (-ão); em galego: abridor ${ }^{573}$ (-or), munxideira $^{574}$ (-eira), fregona ${ }^{575}$ (-ón, -ona ).

1.4. Local onde se $V$. Por exemplo, em português: albergaria (-aria), consultório (ório), miradouro ${ }^{576}$ (-douro), bebedoiro ${ }^{577}$ (-doiro); em galego: refinaría ${ }^{578}$ (aria), dormitorio ${ }^{579}$ (-orio), miradoiro ${ }^{580}$ (-doiro), fregadeiro ${ }^{581}$ (-eiro).

554 Tradução: "movimento".

555 Tradução: "gemido".

556 Tradução: "limpezinha".

557 Tradução: "aterragem".

${ }^{558}$ Ato ou efeito de ferir usando as unhas.

559 Tradução: "expedir".

560 Tradução: "doação".

561 Tradução: "varrição".

562 Tradução: "escorregão".

563 Tradução: "crença".

564 Tradução: "bebedeira".

${ }^{565}$ Segundo o dicionário Houaiss, indivíduo atrapalhado (aldrabar = trancar). Regionalismo de Portugal.

${ }^{566}$ Segundo o dicionário Houaiss, o mesmo que "desenhista".

567 Tradução: "bailarino".

568 Tradução: "pintor".

569 Tradução: "desenhista”.

570 Tradução: "cantor".

571 Tradução: "aquele ou aquilo que se baba".

572 Tradução: “enfadonho".

573 Tradução: "abridor".

574 Tradução: “ordenhadeira” (máquina para ordenhar).

575 Tradução: "esfregão".

${ }^{576}$ Segundo o dicionário Houaiss, o mesmo que "mirante".

${ }^{577}$ Segundo o dicionário Houaiss, o mesmo que "bebedouro".

578 Tradução: "refinaria".

579 Tradução: "dormitório".

580 Tradução: "mirante" em português brasileiro.

581 Tradução: "pia de cozinha”. 
1.5. Que pode ser $V$-do. Por exemplo, em português: adorável (-ável), combustível (ível), solúvel (-úvel); em galego: amábel ${ }^{582}$ (-ábel), críbel $^{583}$ (-íbel), insolúbel ${ }^{584}$ (-úbel).

2. Produtos verbais

2.1. Transformar em / tornar(-se) Nb. Por exemplo, em português: deificar ${ }^{585}$ (-ificar), endeusar (-ar), favelizar ${ }^{586}$ (-izar), entardecer (-ecer); em galego: escurecer $^{587}$ (-ecer), humanizar ${ }^{588}$ (-izar), solidificar ${ }^{599}$ (-ificar), formar ${ }^{590}$ (-ar).

2.2. Afetar $N b$. Por exemplo: em português: açucarar (-ar), encerar (-ar), vacinar (ar); em galego: envarnizar ${ }^{591}$ (-ar), adozar $^{592}$ (-ar), limar $^{593}$ (-ar).

2.3. Causar Nb. Por exemplo, em português: aterrorizar (-izar), danificar (-ificar), enraivecer (-ecer), esfomear (-ar); em galego: fastidiar ${ }^{594}$ (-ar), horrorizar ${ }^{595}$ (izar), amedrontar ${ }^{596}$ (-ntar), damnificar ${ }^{597}$ (-ificar).

2.4. Transformar em / tornar(-se) Ab. Por exemplo, em português: amadurecer (ecer), dignificar (-ificar), entristecer (-ecer), esvaziar (-ar), facilitar (-itar); em galego: enriquecer ${ }^{598}$ (-ecer), envellar ${ }^{599}$ (-ar), clarexar $^{600}$ (-exar), dignificar ${ }^{601}$ (-ificar), axilizar $^{602}$ (-izar), debilitar ${ }^{603}$ (-itar).

\footnotetext{
582 Tradução: "amável”.

583 Tradução: "acreditável".

584 Tradução: "insolúvel”.

${ }^{585}$ Segundo o dicionário Houaiss, significa atribuir(-se) natureza divina; endeusar(-se), divinizar(-se).

${ }^{586}$ Segundo o dicionário Houaiss, dar ou tomar o aspecto de favela. Regionalismo brasileiro.

587 Tradução: "escurecer”.

588 Tradução: "humanizar".

589 Tradução: "solidificar".

590 Tradução: "formar".

591 Tradução: "envernizar".

592 Tradução: "adoçar".

593 Tradução: "limar".

594 Tradução: "aborrecer".

595 Tradução: "horrorizar".

596 Tradução: "causar medo".

597 Tradução: "danificar".

598 Tradução: "enriquecer".

${ }^{599}$ Tradução: "envelhecer".

600 Tradução: "clarear".

601 Tradução: "dignificar”.

602 Tradução: "agilizar".

603 Tradução: "debilitar".
} 
3. Nomes não deverbais

3.1. Evento relacionado com $N b$. Por exemplo, em português: abrilada ${ }^{604}$ (-ada), belenzada ${ }^{605}(-a d a)$; em galego: muiñada ${ }^{606}(-a d a)$.

3.2. Conjunto de $N b$ ou (grande) quantidade de $N b$. Por exemplo, em português: berreiro (-eiro), casario (-io), enfermaria (-aria), folhagem (-agem), papelada (-ada), passaredo (-edo), pedraria (-aria), penugem (-ugem), vasilhame (-ame); em galego: $\operatorname{areal}^{607}(-$ al $)$, formulario $^{608}(-$ ario $)$, ramaxe $^{609}(-$ axe $)$, mullerada $^{610}(-$ ada), profesorado ${ }^{611}$ (-ado), dentadura ${ }^{612}$ (-ura), pedraría ${ }^{613}$ (-aria), romanceiro $^{614}$ (-eiro), armamento $^{615}$ (-mento), mullerío ${ }^{616}(-i o)$.

3.3. Local de grande quantidade de $N b$. Em português, há: vinhedo (-edo); laranjal (al), canil (-il); em galego: arboredo ${ }^{617}$ (-edo), toxal $^{618}(-a l)$.

3.4. Local relacionado com $\mathrm{Nb}$, ou local onde se exerce atividade relacionada com $\mathrm{Nb}$. Por exemplo, em português: livraria (-aria); em galego: zapateria $^{619}$ (-eria).

3.5. Atividade / ocupação, cargo, estatuto, relacionado com $N b$. Por exemplo, em português: advocacia (-ia), generalato (-ato); em galego: xardinaría ${ }^{620}$ (-aría), celibato $^{621}$ (-ato): enxeñería ${ }^{622}(-i ́ a)$.

\footnotetext{
${ }^{604}$ Segundo dicionário Houaiss, revolta de abril de 1824, em Lisboa, quando o infante D. Miguel liderou movimento pela abdicação de seu pai, D. João VI.

${ }^{605}$ Segundo dicionário Houaiss, movimento revolucionário ocorrido em Portugal a 4 de novembro de 1836 contra a rainha D. Maria II, na Torre de Belém.

${ }^{606}$ Relativo ao muiño (moinho). Reunião de gente no moinho.

${ }^{607}$ Tradução: local onde há muita area =areia.

${ }^{608}$ Tradução: "formulário".

${ }^{609}$ Tradução: "ramagem”.

${ }^{610}$ Tradução: : muitas mulheres juntas.

611 Tradução: "professorado".

612 Tradução: "dentadura".

613 Tradução: muitas pedras juntas.

614 Tradução: "romanceiro".

615 Tradução: "armamento".

${ }^{616}$ Tradução: : muitas mulheres juntas.

617 Tradução: "arvoredo".

618 Tradução: “tojal”.

619 Tradução: "sapataria".

${ }^{620}$ Tradução: "jardinagem”.

621 Tradução: "celibato".

${ }^{622}$ Tradução: "engenharia".
} 
Estudo comparativo de aspectos semânticos do sufixo -ista no português e no galego.

3.6. Aquele que exerce uma atividade relacionada com $N b$. Por exemplo, em português: empresário (-ário), ferreiro (-eiro), maquinista (-ista); em galego: bibliotecario $^{623}$ (-ario), zoqueiro $^{624}$ (-eiro), violinista $^{625}$ (-ista).

3.7. $N d$ (objeto, vegetal) relacionado com $N b$. Por exemplo, em português: chuveiro (eiro), galinheiro (-eiro), telheiro (-eiro), limoeiro (-eiro); em galego: capoeira $^{626}$ (-eira), palleiro $^{627}$ (-eiro), nogueira ${ }^{628}$ (-eira).

3.8. Produto relacionado com $N b$, produto preparado a base de $N b$. Por exemplo, em português: laranjada (-ada), marmelada (-ada); em galego: laranxada ${ }^{629}$ (-ada), mariscada ${ }^{630}(-a d a)$.

3.9. Produto derivado ou extraído de $N b$. Por exemplo, em português: cafeína (-ina) e em galego: cafeina $^{631}$ (-ina).

3.10. (O que é / o que pode ser) continente de $N b$. Por exemplo, em português: cinzeiro (-eiro), dedal (-al), dedeira (-eira), relicário (-ário), vestiário (-ário); em galego: maseira ${ }^{632}$ (-eira), xoieiro ${ }^{633}$ (-eiro), dedal ${ }^{634}(-a l)$, relicario ${ }^{635}{ }_{(-}$ ario).

3.11. Porção contida em $N b$. Por exemplo, em português: carrada ${ }^{636}$ (-ada) e em galego: cullerada ${ }^{637}(-a d a)$.

3.12. Doença relacionada com $N b$. Por exemplo, em português: bronquite (-ite), neurose (-ose), cobreiro (-eiro); em galego: artrite 638 $^{63}$ (-ite), escoliose es $^{639}$ (-ose), papeira $^{640}(-$ eira).

\footnotetext{
623 Tradução: "bibliotecário".

${ }^{624}$ É o artesão que faz zocos (tamancos).

625 Tradução: "violinista".

626 Tradução: "galinheiro".

627 Tradução: "palheiro".

628 Tradução: "nogueira".

629 Tradução: "laranjada".

${ }^{630}$ Comida feita a base de mariscos.

631 Tradução: "cafeína".

${ }^{632}$ Ucha na qual se deixa a massa de fazer pão para fermentar.

${ }^{633}$ Tradução: "porta-jóias".

${ }^{634}$ Tradução: "dedal".

635 Tradução: "relicário".

${ }^{636}$ Segundo o dicionário Houaiss, carga que um carro transporta ou pode transportar de uma só vez.

${ }^{637}$ Tradução: "colherada".

638 Tradução: "artrite”.
} 
3.13. Sistema científico, filosófico, ideológico relacionado com $X b$. Por exemplo, em português: budismo (-ismo), darwinismo (-ismo), hegelianismo ${ }^{641}(-i s m o)$, judaísmo (-ismo), luteranismo (-ismo), messianismo (-ismo), sandinismo ${ }^{642}$ (- $_{\text {- }}$ ismo); em galego: cartesianismo $^{643}$, $_{\text {catolicismo }}^{644}$, $_{\text {monarquismo }}^{645}$, comunismo $^{646}$, $^{\text {cubismo }}{ }^{647}$, franquismo ${ }^{648}$.

3.14. O fato de ser A. Em português: firmeza (-eza), brancura (-ura), imundície (ície), arrogância (-ncia), humildade (-dade), virtude (-ude), solidão (-idão), solidez (-ez); em galego: lealdade ${ }^{649}$ (-dade), falacia $^{650}$ (-acia), malicia ${ }^{651}$ (icia), calvicie ${ }^{652}$ (-icie), vellez ${ }^{653}$ (-ez), beleza ${ }^{654}$ (-eza), vellice $e^{655}$ (-ice), ignorancia $^{656}(-n c i a)$, temperanza ${ }^{657}(-n z a)$, amargor $^{658}(-o r)$, quietude $^{659}$ (-ude), negrume $^{660}$ (-ume), frescura ${ }^{661}$ (-ura).

4. Adjetivos não deverbais

4.1. Originário / proveniente de $N b$. Em português: algarvio $^{662}$ (-io), austríaco (-aco), beirão (-ão), mineiro (-eiro), chileno (-eno), galileu (-eu), francês (-ês),

${ }^{639}$ Tradução: "escoliose".

${ }^{640}$ Tradução: "bócio".

${ }^{641}$ Segundo o dicionário Houaiss, filosofia do alemão Georg Friedrich Hegel (1770-1831), segundo a qual o universo é uma totalidade integrada, sujeita a um movimento gerado por sucessivas contradições, a dialética, e orientada para uma finalidade última, que equivale à realização plena de sua essência espiritual.

${ }^{642}$ Segundo o dicionário Houaiss, conjunto de idéias nacionalistas e antiimperialistas inspiradas na ação do líder revolucionário nicaragüense César Augusto Sandino (1893-1934).

643 Tradução: "cartesianismo".

644 Tradução: "catolicismo".

645 Tradução: "monarquismo".

646 Tradução: "comunismo".

647 Tradução: “cubismo”.

648 Tradução: "franquismo".

${ }^{649}$ Tradução: "lealdade".

${ }^{650}$ Tradução: "falácia".

${ }^{651}$ Tradução: "malícia”.

${ }^{652}$ Tradução: "calvície".

653 Tradução: "velhice”.

654 Tradução: "beleza”.

655 Tradução: "velhice".

656 Tradução: "ignorância”.

${ }^{657}$ Tradução: "temperança”, ou pessoa comedida.

${ }^{658}$ Tradução: "amargor”.

${ }^{659}$ Tradução: "quietude".

660 Tradução: "negrume".

661 Tradução: "frescura”.

${ }^{662}$ Segundo o dicionário Houaiss, relativo ao Algarve (região ao Sul de Portugal) ou o que é seu natural ou habitante; tem como forma concorrente: algarviense. 
israelita (-ita), judaico (-aico), lisboeta (-eta), londrino (-ino), paivoto ${ }^{663}$ (-oto), peruano (-ano), portuense ${ }^{664}$ (-ense), santista (-ista); em galego: polaco ${ }^{665}{ }_{(-}$ aco), alemán ${ }^{666}(-a ́ n)$, brasileiro ${ }^{667}$ (-eiro), europeu ${ }^{668}(-e u)$, noruegués ${ }^{669}(-e ́ s)$, saudita $^{670}$ (-ita), marroquino ${ }^{671}$ (-ino), miñoto ${ }^{672}$ (-oto), romano ${ }^{673}$ (-ano), cretense $^{674}$ (-ense), paulista ${ }^{675}(-$ ista $)$, israeli $^{676}(-\hat{\imath})$, galego $^{677}(-$ ego $)$, portorriqueño $^{678}(-e \tilde{n} o)$, pérsico ${ }^{679}(-i c o)$, bizcaíño $^{680}(-i \tilde{n} o)$, español $^{681}(-o l)$.

4.2. Relativo a $N b$. Por exemplo, em português: artesanal (-al), cervejeiro (-eiro), complementar (-ar), forense (-ense); em galego: espacial ${ }^{682}(-a l)$, castrexo $^{683}(-$ exo), escolar ${ }^{684}$ (-ar), hortense ${ }^{685}$ (-ense).

4.3. Que pertence a $N b$. Por exemplo, em português: artesanal (-al), familiar (-ar), infernal (-al), oceânico (-ico), partidário (-ário); em galego: celestial ${ }^{686}(-a l)$, campestre $^{687}$ (-estre), escolar ${ }^{688}(-$ ar $)$.

4.4. Que tem $N b$. Por exemplo, em português: metódico (-ico), barbado (-ado), barrento (-nto), brioso (-oso), febril (-il), maníaco (-aco), sortudo (-udo); em

\footnotetext{
${ }^{663}$ Originário de Castelo de Paiva em Portugal.

${ }^{664}$ Segundo o dicionário Houaiss, relativo à cidade do Porto ou o que é seu natural ou habitante.

665 Tradução: "polonês".

666 Tradução: "alemão".

${ }^{667}$ Originário do Brasil, empréstimo do português.

668 Tradução: "europeu”.

${ }^{669}$ Tradução: "norueguês".

670 Tradução: "saudita".

671 Tradução: "marroquino".

672 Tradução: "minhoto", originário da região do rio Minho.

673 Tradução: "romano".

${ }^{674}$ Tradução: "cretense".

${ }^{675}$ Originário do estado de São Paulo, empréstimo do português brasileiro.

${ }^{676}$ Originário de Israel.

${ }^{677}$ Originário da Galiza.

678 Tradução: "portorriquenho".

${ }^{679}$ Originário da Pérsia.

${ }^{680}$ Originário de Bizcaia.

${ }^{681}$ Tradução: "espanhol".

682 Tradução: “espacial”.

${ }^{683}$ Relativo ao "castro".

684 Tradução: "escolar".

${ }^{685}$ Tradução: "hortense".

686 Tradução: “celestial”.

${ }^{687}$ Tradução: "campestre".

688 Tradução: "escolar".
} 


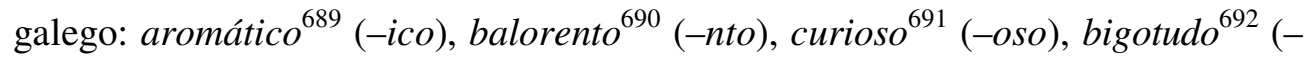
udo), listrado $^{693}(-$ ado $)$, brillante $^{694}(-n t e)$.

4.5. Que é adepto de $N b$. Em português: budista (-ista), republicano (-ano); em galego: ecoloxista ${ }^{695}$ (-ista), presbiteriano ${ }^{696}$ (-ano).

4.6. Que causa, que provoca $N b$. Por exemplo, em português: medonho (-onho), terrorista (-ista); em galego: asqueroso ${ }^{697}(-$ oso $)$, noxento $^{698}(-n t o)$.

4.7. Que tem semelhança com $N b$, que evoca $N b$. Por exemplo, em português: cristalino (-ino), dantesco (-sco), senhoril (-il), solarengo ${ }^{699}$ (-engo); em galego: azuláceo $^{700}$ (-áceo), nacarado ${ }^{701}$ (-ado), esferóide ${ }^{702}$ (-óide).

5. Nomes isocategoriais

5.1. Pequeno Nb. Por exemplo, em português: $\operatorname{aranhiço}^{703}$ (-iço), barbicha (-icha), chibato (-ato), farolete (-ete), farolim ${ }^{704}$ (-im), ilhéu (-éu), ilhota (-ota), livrinho (-inho), lugarejo (-ejo), papelucho (-ucho), rapazelho ${ }^{705}$ (-elho), rapazito ${ }^{706}{ }_{(-}$ ito), riacho (-acho), ruela (-ela), sacola (-ola), saleta (-eta); em galego: barrigola $^{707}$ (-ola), regato ${ }^{708}$ (-ato), rapazote ${ }^{709}$ (-ote), banqueta ${ }^{710}$ (-eta),

\footnotetext{
${ }^{689}$ Tradução: "aromático".

690 Tradução: "embolorado".

691 Tradução: "curioso".

692 Tradução: "bigodudo".

693 Tradução: "listrado".

694 Tradução: "brilhante".

695 Tradução: "ecologista".

696 Tradução: "presbiteriano".

697 Tradução: "asqueroso".

698 Tradução: "nojento".

${ }^{699}$ Segundo o dicionário Houaiss, relativo a ou próprio de solar ('casa nobre').

700 Tradução: "azulado".

701 Tradução: "perolado".

702 Tradução: "esferóide".

${ }^{703}$ Segundo o dicionário Houaiss, aranha pequena.

${ }^{704}$ Segundo o dicionário Houaiss, pequeno farol que geralmente serve à navegação costeira.

${ }^{705}$ Segundo o dicionário Houaiss, o mesmo que "rapazote".

${ }^{706}$ Tradução: "rapazinho", regionalismo de Portugal.

${ }^{707}$ Diminutivo de "barriga".

${ }^{708}$ Diminutivo de "rego".

${ }^{709}$ Diminutivo de "rapaz".

${ }^{710}$ Diminutivo de "banco".
} 
naiciña $a^{711}(-i \tilde{n} a)$, librete $^{712} \quad(-$ ete $)$, rabixo $^{713} \quad(-\mathrm{ixo})$, burrico $^{714} \quad(-i c o)$, ventanuxo $^{715}(-$ uxo $)$.

5.2. Grande $N b$. Por exemplo, em português: barcaça (-aça), bocarra (-arra); cabeçorra (-orra), carrão (-ão), copázio (-ázio), dentuça (-uça); homenzarrão (-arrão), moscardo (-ardo), pratarraz (-rraz), ricalhão ${ }^{716}$ (-alhão); em galego: pescozón $^{717}$ (-ón), patarra ${ }^{718}$ (-arra), mulleraza ${ }^{719}$ (-aza), penedo ${ }^{720}$ (-edo).

\section{Adjetivos isocategoriais}

6.1. Ab em grau de intensidade reduzido. Por exemplo, em português: doentinho (inho), doentito ${ }^{721}$ (-ito), grandinho (-inho), grandito $^{722}$ (-ito); em galego: tristiño $^{723}$ (-iño), tristote $^{724}$ (-ote), baixiño ${ }^{725}$ (-iño), baixote ${ }^{726}$ (-ote).

6.2. Bastante $A b, A b$ em grau de intensidade elevada. Por exemplo, em português: bonzão (-ão), mansarrão ${ }^{727}$ (-arrão), ricaço (-aço), tristonho (-onho); em galego: tristón $^{728}$ (-ón), tristeiro ${ }^{729}$ (-eiro), ricazo ${ }^{730}(-a z o)$.

6.3. Muito $A b, A b$ em grau de intensidade muito elevada. Por exemplo, em português: altíssimo (-íssimo), humílimo (-ílimo), paupérrimo (-érrimo); em galego: formosísimo $^{731}$ (-ísimo), misérrimo ${ }^{732}$ (-érrimo).

\footnotetext{
711 Tradução: “mãezinha”.

712 Diminutivo de libro (livro).

713 Diminutivo de "rabo".

${ }^{714}$ Diminutivo de "burro".

${ }^{715}$ Diminutivo de ventana (janela).

${ }^{716}$ Segundo o dicionário Houaiss, o mesmo que "ricaço".

717 Aumentativo de pescozo (pescoço).

${ }^{718}$ Aumentativo de "pata".

${ }^{719}$ Aumentativo de muller (mulher).

${ }^{720}$ Aumentativo de "pena".

721 Tradução: "doentinho", regionalismo de Portugal.

722 Tradução: "grandinho”, regionalismo de Portugal.

${ }^{723}$ Tradução: "tristezinho".

${ }^{724}$ Idem.

725 Tradução: "baixinho".

${ }^{726}$ Idem.

${ }^{727}$ Segundo o dicionário Houaiss, que ou aquele que é excessivamente sossegado, calmo, sem pressa.

${ }^{728}$ Tradução: "muito triste".

${ }^{729}$ Idem.

${ }^{730}$ Tradução: "muito rico".

731 Tradução: "formosíssimo".

732 Tradução: "misérrimo".
} 
7. Verbos isocategoriais

7.1. $V$ - praticar, exercer, executar a ação designada por $V$ - em grau de intensidade reduzido e/ou de forma iterativa e/ou menos perfeita. Por exemplo, em português: saltitar (-itar), chuviscar (-iscar), cuspinhar (-inhar), versalhar ${ }^{733}$ (-alhar); em galego: cantarexar $^{734}$ (-exar), dormiñar ${ }^{735}$ (-iñar), namoriscar ${ }^{736}$ (-iscar).

\section{As paráfrases semânticas e as regras de formação de palavras}

Tais classificações, quando são semânticas, levam, inicialmente, a elaboração de paráfrases genéricas para dar conta dos grandes grupos semânticos, como se pode notar na classificação de RiO-TORTO e de FREIXEIRO MATO, já que, segundo SANDMANN (1989: 31), os sufixos correspondem a lexemas, ou seja, uma sufixação equivale semanticamente a um grupo sintático definido por uma paráfrase (semântica) do processo específico daquela derivação. Naturalmente, a capacidade de incluir elementos do mundo extralingüístico surge como uma reserva relativa à paráfrase. RIO-TORTO (1998: 110) considera as paráfrases como uma simplificação das acepções dos dicionários. Do mesmo modo, BossIER (1998: 22):

"paráfrases semânticas, ou seja, definições plausíveis, à maneira lexicográfica, estão muito próximas da consciência do falante. Quando este reflete no conteúdo de uma palavra sufixada, fá-lo com base na palavra primitiva, de um modo bastante similar ao dos lexicógrafos, apenas de um modo mais tosco".

No entanto, para COSERIU (1987: 181), nada impede o uso de designações, desde que conexas às significações e RiO-TORTO (1998: 110) afirma que a formulação de paráfrases é uma primeira etapa no levantamento das regularidades derivacionais que aparecem entre a palavra final e seus constituintes; e na análise das operações semântico-categoriais. Da mesma forma, BOSSIER (1998: 23):

“a plausibilidade das definições sempre é suscetível de melhoramento, depurada de qualquer circularidade ou ainda de sinonímia usada como sucedâneo de uma

\footnotetext{
${ }^{733}$ Segundo o dicionário Houaiss, compôr versos mal feitos ou de má qualidade poética.

734 Tradução: "cantarolar".

735 Tradução: "dorminhar".

${ }^{736}$ Tradução: "namoricar".
} 
verdadeira definição. Tudo isso não impede extrair das definições lexicais, numa segunda operação, fórmulas de índole mais gramatical ou mais semântica”.

Pode-se notar, então, que há três tipos de semântica envolvidos na formação de palavras por sufixação: a semântica da palavra sufixada, a semântica da base e a semântica do sufixo, Viaro (2005). Nota-se, também, que as três classificações dadas anteriormente: Freixeiro Mato, Sandmann e Rio-Torto; centram-se na semântica da palavra formada auxiliada pela palavra base e pelo sufixo.

Desse modo, pode-se concluir que a formulação de paráfrases é uma etapa preliminar do processo de sistematização na formação de palavras na língua, pois por meio delas encontram-se as regularidades, fazem-se as generalizações e especificações necessárias, bem como se eliminam as redundâncias e, assim, chega-se às suas regras de formação de palavras, em particular, do sistema de sufixação.

\section{A produtividade e suas restrições}

De acordo com SANDMANN (1991: 44-45): “da competência lexical do usuário de uma língua fazem parte tanto a capacidade de formar e entender palavras novas como a de atribuir estrutura às palavras já integrantes do léxico”. Isto significa que há algumas etapas interligadas no processo de formação de palavras para o falante de uma língua: numa primeira fase, o falante entende as palavras novas e equivale a formação de paráfrases; numa segunda fase, o falante reconhece os elementos envolvidos no processo de formação de uma palavra nova, que equivale ao reconhecimento das regras de formação de palavras; numa terceira fase, o falante produz palavras novas aplicando o mesmo processo reconhecido na segunda etapa, que equivale à aplicação das regras de formação de palavras. A terceira fase desse processo, isto é, a aplicação das regras e a produção efetiva de palavras novas irá indicar a produtividade da regra de formação de palavras, e em particular, a produtividade de uma vertente semântica associada a um determinado sufixo no processo de formação de palavras.

Segundo Viaro (2005), a produtividade abrange dois casos: a de um elemento prolífico, quando por meio dele se obtêm muitas palavras; e a de um elemento que produz muitos neologismos. O autor ressalta: "um sufixo prolífico não é, necessariamente, produtivo 
(pode ter deixado de formar neologismos após criar muitas palavras) e um não-prolífico pode trazer uma força produtiva subestimada se nos pautamos somente nos dicionários".

Entretanto, o principal problema surge no momento de definir o critério a ser adotado para medir a produtividade. O critério, em geral, mais usado é o cômputo da freqüência das palavras formadas a partir de um dado sufixo em um determinado corpus. Para ARONOFF (1976: 35), a produtividade lexical não deve ser confundida com elevado nível de ocorrência, pois tal engano leva a definir uma regra como mais ou menos produtiva de acordo com a listagem maior ou menor que apresentam no léxico, quando em realidade o que deve definir uma regra como produtiva é o fato de se prestar à formação de novos itens lexicais. Embora haja uma grande controvérsia em relação a esse critério de medida da produtividade, que envolve também a escolha do corpus e sua representatividade do sistema, convém citar BOSSIER (1998: 8): “produtividade é uma verificação que pode constar da investigação, num grau variável, mas nunca deve ser um critério eliminatório previamente estabelecido".

De acordo com HALLE (1973: 9-10):

"The list of morphemes and the rules of word formation together define the potential words of language. The set of actual words is obtained from that the potential words by applying to the latter the modifications indicated in the filter", ${ }^{237}$.

Segundo SANDMANN (1991: 59): "é de sua própria natureza que regras tenham limitações, que elas tenham campos específicos de aplicação". Assim, para o autor, as limitações próprias das regras de formação de palavras funcionam como filtros que limitam ou disciplinam a formação de palavras, por isso, em sua obra dispõe vários tipos de restrições no processo de produção lexical, no intuito de mostrar o escopo de tais operações. Citando BAUER (1983) apud SANDMANN (1991: 59 - 60), são descritas duas restrições de caráter pragmático: a existência do objeto a ser designado e sua nomeabilidade. Em relação às bases de derivações, o autor descreve restrições fonológicas, morfológicas, semânticas e sintáticas.

De acordo com SANDMANN (1991: 61), “a repetição de sons iguais na mesma palavra contraria, de maneira geral, princípios estéticos de eufonia”. Assim dentro das palavras potenciais em português cuja base é a palavra estressar, há: estressamento e *estressação,

\footnotetext{
${ }^{737}$ Tradução: “A lista de morfemas e as regras de formação de palavras (RFP) definem juntas as palavras em potencial de um sistema lingüístico. Mas, o subconjunto das palavras usadas é obtido pela filtragem do conjunto de palavras potenciais".
} 
entretanto a primeira forma é preferida em relação à segunda, pois o filtro fonológico, neste caso, é a repetição de sons iguais seguidos na mesma palavra. Analogamente, um exemplo em galego: considerando-se enfraquecer ${ }^{738}$, há as palavras potenciais: enfraquecimento ${ }^{739}$ e *enfraquezación, e a primeira é preferida em relação à segunda, pois o filtro fonológico é o mesmo. Porém, há exceções: cassação (português) e sombreireiro ${ }^{740}$ (galego).

Convém notar também que o processo de recursividade e concatenação de regras sufixais não é tão aleatório quanto possa parecer, pois ocorre em função das estruturas lexicais paradigmáticas, que se por um lado cristaliza determinadas formas, por outro lado promove restrições morfológicas. De acordo com ARONOFF (1976: 62) e SANDMANN (1991: 62-64), o grau de produtividade de uma regra de formação de palavras está ligado aos tipos específicos de bases morfológicas em que a regra opera. Assim, verbos formados com o sufixo -ecer, geralmente selecionam o sufixo -mento (e não o sufixo -cão / -ción) para formar nomes de ação, por exemplo: aquecer $\rightarrow$ aquecimento (português) e crecer $^{741} \rightarrow$ crecemento $^{742}$ (galego). Os verbos formados com o sufixo -izar, geralmente selecionam o sufixo -ção em português e -ción em galego para formar nomes de ação, por exemplo: nacionalizar $\rightarrow$ nacionalização (português) e legalizar ${ }^{743} \rightarrow$ legalización $^{744}$ (galego). Porém, há exceções: deslizar $\rightarrow$ deslizamento (português) e enraizar ${ }^{745} \rightarrow$ enraizamento $^{746}$ (galego).

Segundo ARONOFF (1976: 65), existe uma estreita e importante relação entre coerência semântica e produtividade. Do mesmo modo para SANDMANN (1991: 64), quando o sufixo é restritivo quanto a aspectos puramente semânticos, como a conotação da base, então a restrição será de natureza semântica. Por exemplo, o sufixo -udo tomando como base $X$ pertencente ao conjunto das partes externas do corpo humano ou animal, significa: "que tem ou é provido de $X$ grande”. Assim, em português há: barrigudo e chifrudo; em galego há: panzudo $^{747}$ e cornudo ${ }^{748}$. Entretanto, o mesmo sufixo pode designar também as qualidades

\footnotetext{
738 Tradução: "enfraquecer”.

739 Tradução: "enfraquecimento".

${ }^{740}$ Tradução: : pessoa que fabrica ou comercializa "sombreiros" (chapéus).

741 Tradução: "crescer".

742 Tradução: "crescimento".

743 Tradução: "legalizar".

744 Tradução: "legalização".

745 Tradução: "enraizar".

746 Tradução: "enraizamento".

747 Tradução: "barrigudo".

748 Tradução: "chifrudo".
} 
morais ou características permanentes de personalidade, por exemplo: sisudo (português) e sortudo $^{749}$ (galego), e neste caso significa: “que tem muito $X$ ”; mas não pode se associar, devido à sua característica semântica, a bases substantivas mais concretas como: casa $\rightarrow$ *casudo para designar "que tem casa grande" ou que "tem muitas casas", então atesta-se que há uma limitação de natureza semântica.

Para SANDMANN (1991: 67 -68) "é de natureza sintática o fato de muitos sufixos se unirem, exclusivamente ou preferencialmente, a bases pertencentes à determinada categoria gramatical ou a uma classe de palavras e não a outras". Por exemplo, o sufixo -nte associa-se a verbos na formação de adjetivos de natureza dinâmica; como em português: frustrar $\rightarrow$ frustrante e em galego: crecer $^{750} \rightarrow$ crecente $^{751}$, mas não atua em bases adverbiais (perto $\rightarrow$ *pertonte) ou nominais (caneta $\rightarrow *$ canetante).

Além disso, em particular, parece haver interessantes aspectos das restrições lexicais, chamados de bloqueios, ou seja, quando a ocorrência da formação de uma palavra é impedida pela existência de outra forma que já preenche o seu papel no léxico, nas palavras de ARONOFF (1976: 55): "Blocking prevents the listing of synonyms in a single stem. An affix which is productive with a given morphological class will thus block the attachment of rival affixes to that class"752. Segundo SANDMANN (1991: 75), "está-se frente a uma situação de conflito entre o sistema e o uso; o sistema permite mais de uma forma, o uso, porém, consagra e privilegia uma". Por exemplo, em português, como já existe a palavra estudo não se pode formar *estudagem ou *estudamento; analogamente em galego como já existe a palavra agarimo $^{753}$ não se forma a palavra *agarimagem ou *agarimento.

Em relação aos bloqueios, SANDMANN (1991: 78 - 80) faz duas ressalvas interessantes: "a especialização de sentido de uma palavra - forma de lexicalização - pode levar à anulação do bloqueio de formas com outros sufixos de função igual”, por exemplo: em português há salvação e salvamento, e em galego há ensino ${ }^{754}$ e ensinamento ${ }^{755}$ cada qual

\footnotetext{
749 Tradução: "sortudo".

750 Tradução: "crescer".

751 Tradução: "crescente".

752 Tradução: "O bloqueio impede a formação de uma lista de sinônimos em derivações. Pois, um afixo produtivo para a formação de uma dada classe morfológica bloqueará a atuação de afixos concorrentes para a formação desta mesma classe."

753 Tradução: "carinho".

754 Tradução: "ensino".

755 Tradução: "ensinamento".
} 
com sua especificidade semântica, não gerando o bloqueio entre elas; e "o despeito a determinados bloqueios de regras de formação de palavras pode assumir caráter estilístico". Para Rio-ToRTo (1998: 63), "o léxico tem sido encarado como um acervo que pode incluir uma secção que corporize a sua dimensão criativa". Um bom exemplo em português é a obra de Guimarães Rosa, na qual aparecem termos, tais como: pobrepérrimo, tristoso, severoso, severista, ricoso, mortemente, depoismente, comfomemente.

E em galego, um bom exemplo, está em Rosalía de Castro:

Ando buscando meles e frescura

Para meus labios secos,

I non sei como atopo nin por donde,

\section{Queimores e amarguexos.}

(XIX, Follas novas)

Em contrapartida, também se encontram formas concorrentes derivadas de uma mesma base, por exemplo: manobreiro e manobrista são, em português, agentivos que designam a pessoa que manobra carros; camioneiro $^{756}$ e camionista $^{757}$ são, em galego, agentivos que designam a pessoa que dirige um caminhão. Um exemplo bem ilustrativo é a concorrência entre as formas: fumante ${ }^{758}$, fumador $^{759}$ e fumista ${ }^{760}$, no português e no galego, são agentivos que designam a pessoa que fuma; mas sabe-se que fumante é a forma mais usada no Brasil, ao passo que fumador é a forma mais usada na Galiza e em Portugal, e fumista é uma forma que pode ser encontrada em textos sobre tabagismo e também em alguns textos literários das três regiões, no entanto é pouco usada no Brasil, em Portugal e na Galiza.

Assim, deve-se levar em conta também os mais variados fatores e condições que podem interferir no processo de formação de palavras, de acordo com BASíliO (2004: 80), "a formação de palavras pode ter uma função exclusivamente cognitiva, como categorização. Mas, em termos de comunicação, a palavra se forma também em função do enunciado". Ou seja, as funções não estão isoladas e exclusivas na formação da palavra diante da

\footnotetext{
756 Tradução: “caminhoneiro” ou "motorista de caminhão".

${ }^{757}$ Idem.

${ }^{758}$ Segundo o dicionário Houaiss, significa que o quem fuma; fumador, fumista.

${ }^{759}$ Segundo o dicionário Houaiss, significa o mesmo que "fumante".

${ }^{760}$ Segundo o dicionário Houaiss, significa o mesmo que "fumante".
} 
comunicação, assim, não há apenas uma função semântica ou morfológica, mas um misto de funções que associa os mais variados fatores ao enunciado e à expressão.

Desse modo, segundo BAsílio (1993: 370):

"a função de sufixos como -ista e -ano, formadores de nomes, que ocorrem em construções como budista, maoísta, maometano e machadiano. Do ponto de vista da competência lexical, -ista e -ano podem formar nomes a partir de nomes próprios, mas são as condições socioculturais que elevam certos nomes próprios à condição base possível para esse tipo de formação, uma vez satisfeita a condição de um mínimo de status sociocultural".

\section{A dimensão histórica}

Apesar das controvérsias e de determinados fatores problemáticos, é interessante notar que, seguindo apenas as regras de formação de palavras pode-se construir um algoritmo passível de implementação computacional. De fato, a Teoria Minimalista, segundo RIOTORTO (1998: 57), "preconiza que a formação de palavras (...) está a cargo de um sistema computacional que (...) tem a capacidade de gerar as estruturas morfolexicais da língua”. Entretanto, nota-se também que uma língua não se desenvolve de forma tão regular. Convém citar RiO-TORTO (1998: 132): "a análise do sistema derivacional do português não se esgota na identificação das coordenadas semântico-categoriais por que se define cada regra de formação de palavras (...) envolve diversas outras dimensões". Ainda, segundo Rio-ToRTo (1998: 82):

“a plurivocidade de dimensões semânticas que os produtos lexicais convocam não deixa margens para dúvidas acerca da multipolaridade e da interactividade por que necessariamente se define a formação de palavras e o domínio em torno dela configurado. Não é, pois, legítimo, continuar a reduzir este domínio a uma só dimensão, subsumindo-o no léxico ou na morfologia”.

De acordo com SAID ALI (1930:3):

"parece cousa extremamente facil distinguir palavras derivadas de palavras primitivas quando se trata de exemplos (...) que não requerem especial cultivo da intelligencia 
Estudo comparativo de aspectos semânticos do sufixo -ista no português e no galego.

(...) São entretanto numerosos os casos em que transparece menos lucida a relação entre o termo derivado e o derivante, sendo necessario algum estudo para se perceber a filiação. Outras vezes tem havido tal evolução de forma e sentido, que surge um curioso conflicto entre o pensamento geral do vulgo e o facto encarado à luz da pesquisa scentifica".

De fato, segundo VIARO (2004): "é inegável que haja derivação, no entanto, o estudo estritamente sincrônico desse capítulo gramatical se revela, no mínimo, um contra-senso”. Da mesma maneira, Rio-TORTO (1998: 133-148) sustenta que a história da língua é insubstituível na análise de determinados aspectos da formação de palavras, nos quais se nota que o presente é em larga medida herdeiro do passado, por exemplo: a) na identificação do estatuto e dos tipos de constituintes lexicais; b) na clarificação do caráter compósito das palavras; c) no estabelecimento de tipologias de palavras de estrutura complexa; d) na reconstituição da evolução formal e semântica das palavras; e) na explicação de algumas das reestruturações dos sistemas afixais; f) na determinação dos paradigmas genolexicais.

Assim, RIO-TORTO (1998: 148) conclui:

"Mais do que observar que há / pode haver insuficiências no tratamento sincrônico / contemporâneo da componente lexical que só uma abordagem histórica pode suprir, importa chamar a atenção para a consubstancial incorporação do passado no presente que todo o sistema lexical atesta, e que nenhuma análise sincrónica pode subestimar".

Dessa forma, nota-se que as polaridades por si só não dão conta do sistema como um todo. Ou seja, um estudo estritamente sincrônico mostra-se insuficiente diante de vários fatores, como também um estudo estritamente diacrônico apontará suas insuficiências. Entretanto, em detrimento do pensamento ortodoxo polar, acredita-se que ponderar os estudos complementando com uma metodologia o que a outra deixa a desejar é, segundo RIO-TORTO (1998: 134), "atitude de complementaridade entre análise histórica e sincrônica". 
Estudo comparativo de aspectos semânticos do sufixo -ista no português e no galego.

\section{CAPÍTULO 3}

\section{PANORAMA DO SUFIXO -ISTA}

Sigamos estas deusas e vejamos Se fantásticas são, se verdadeiras.

(Luís de Camões) 


\section{Panorama do sufixo -ista}

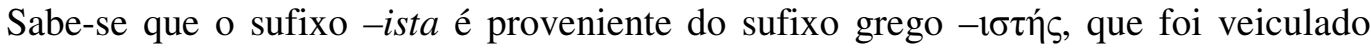
pelo latim sob a forma -istēs, e incorporado às línguas românicas, por exemplo: no francês sob a forma -iste; e no italiano, catalão, espanhol, galego e português sob a forma -ista. Sabese também que, não apenas nas línguas românicas, mas muitas outras com as quais o latim e o grego mantiveram contato o sufixo aparece.

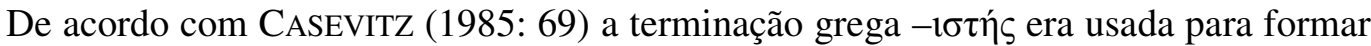
nomes de agentes a partir de verbos terminados em $-\zeta \omega$ no dialeto jônico-ático e acabou sendo incorporado à koiné a partir do século III a.C., (mapas 1.1, 1.2 e 1.3 nas páginas 31, 32

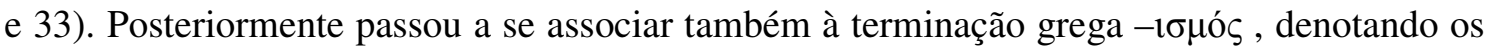
agentes para a mesma base. Com essa mesma conotação semântica foi importado para o latim sob a forma -istēs, e, com o processo de expansão do Império Romano (mapa 1.4 na página 34), totalmente incorporado às línguas românicas.

Segundo SAID Ali (1930: 20), -ista está associado ao sufixo -ismo, e sua primeira conotação semântica surge para designar os adeptos de doutrinas e sistemas formados pelo sufixo ao qual se associa; perdurando tal uso até a atualidade na língua portuguesa. Segundo o autor, na modernidade, o sufixo continua a criar nomes ou os importá-los do estrangeiro para designar pessoas com ocupação relacionada ao objeto que serve como base da derivação.

Em relação ao sufixo -ismo, SAID ALI (1930: 19) explica que as palavras mais antigas formadas por esse sufixo na língua portuguesa devem-se ao latim da Idade Média, algumas formadas de empréstimos diretamente do grego e outras já formadas analogicamente. De acordo com o autor, o fato inicial de popularização dessas palavras deve-se à ação da Igreja Católica, e ressalta que, ainda que tenham sido difundidas no vulgo, não apresentaram produtividade na formação de novos derivados. Esta disposição só veio a mudar nos séculos XVIII e XIX, sob influência dos movimentos intelectuais franceses, e então muitas palavras não só foram formadas e importadas do estrangeiro, mas também se iniciou a sua formação a partir de bases próprias do português. Assumindo essa relação entre -ismo e -ista, por analogia, o que ocorreu a um, em termos de produtividade, deve ter ocorrido ao outro sufixo.

Já FERREIRO (2001: 132-133) argumenta que inicialmente os sufixos -ismo e -ista tiveram um importante desenvolvimento na língua galega associado à expansão do 
cristianismo, diretamente do grego, ou por meio do latim, na maior parte dos casos através do latim tardio e medieval. Segundo o autor, posteriormente, principalmente nos séculos XIX e $\mathrm{XX}$, os dois sufixos tiveram um grande desenvolvimento nas línguas usadas como veículos de movimentos culturais, das quais o galego tomou como empréstimo um número muito grande de palavras, por exemplo: do francês empiriste ${ }^{761}>$ empirista $^{762}$, do inglês labourist $^{763}>$ laborista $^{764}$ e do italiano fascista ${ }^{765}>$ fascista $^{766}$.

Pode-se notar que a associação do -ista ao sufixo -ismo não aparece apenas em SAID Ali (1930) e FERREIRo (2001), mas também é explícita na maioria das obras que tratam do sufixo de origem grega, sejam das línguas românicas ou não. Por exemplo: em STARETS \& VoInOVA (1986) e em ZALIZNIAK (1986), WAHRIG (1999), HORNBY (1995), MifFLIN (1996), Le Robert (1985), GuÉHo (2003), Glachant \& Robert (2002), Zingarelli (1990), García De Diego (1951), SAntiago Lacuesta (2000), Diccionário de la Real Academia Española (2001), BASílio (1995), dicionário HoUAISS (2001), como também em SANDMANN (1989: 42 e 45-46). Entretanto, nesses dois últimos aparece também como sufixo associado o -ístico que, segundo o dicionário HoUAISS (2001), é dado por: -ista + -ico "formando uma constelação sufixal em que a ocorrência de um deles tem função paradigmática com a dos outros numa cognação; isso, entretanto, não quer dizer que a constelação -ismo / -ista / ístico tenha existência concomitante e automática”, ou seja, se por um lado há heroísmo, mas não há um correspondente com -ista; por outro lado há balconista, mas não há o correspondente com o sufixo-ismo; e analogamente com -ístico.

Fazendo-se um panorama da extensão da forma que a terminação grega $-1 \sigma \mu$ ó $\varsigma$, ou o sufixo -istēs, adquiriu nas línguas atuais, observou-se que em árabe, segundo os especialistas e falantes, o sufixo não é usado, portanto não é produtivo e tampouco há palavras importadas que o tenham em sua formação. Pois, na língua árabe já há um elemento próprio para a formação de agentivos que o supre totalmente nas formações denominais, o elemento ${ }^{767}$, como por exemplo, em: ${ }^{769}$. É interessante notar que o mesmo elemento

\footnotetext{
761 Tradução: "empirista”, adepto do empirismo.

762 Tradução: "empirista", adepto do empirismo.

763 Tradução: "laborista", membro do Partido Trabalhista Inglês.

764 Tradução: "laborista", adepto das idéias políticas do Partido Trabalhista Inglês.

765 Tradução: "fascista”, adepto do fascismo (regime político criado por Benito Mussolini na Itália).

${ }^{766}$ Tradução: "fascista”, adepto ou simpatizante do fascismo.

767 Transliteração: $\bar{\imath}$.

768 Tradução: "Marx”. Transliteração: Marks.
} 
formador de nomes de agentes, ${ }^{770}$, é o formador dos nomes gentílicos na língua árabe, como por exemplo: لبنان ${ }^{771} \rightarrow$ لبناني De fato nada foi encontrado com o sufixo -ista no dicionário árabe: the concise OXFORD (1982).

Já, em dicionários da língua japonesa foram encontrados apenas três exemplos de palavras formadas com o sufixo イスト ${ }^{773}$ (-ista), com caráter de empréstimos das línguas ocidentais: ヌーディスト ${ }^{774}$, エゴィスト ${ }^{775}$ e ピノニスト ${ }^{776}$, ainda que haja palavras próprias no japonês sinônimas: 裸体主義者 ${ }^{777}$, 利己主義者 ${ }^{778} \mathrm{e}$ ピアノ者 ${ }^{779}$. Acreditase, então, que o sufixo イスト ${ }^{780}$ (-ista) apareça pouco em japonês, pois a língua tem suas próprias estruturas para designar as conotações semânticas que são dadas por aquele. Assim, para formar gentílicos na língua japonesa há a terminação 人 $^{781}$, por exemplo: ブラジル ${ }^{782}$ $\rightarrow$ ブラジル人 ${ }^{783}$ e 日本 ${ }^{784} \rightarrow$ 日本人 ${ }^{785}$; para designar agentivos ou profissionais existe a terminação 者 $^{786}$ : 歯医 ${ }^{787} \rightarrow$ 歯医者 ${ }^{788}$, 消費 ${ }^{789} \rightarrow$ 消費者 ${ }^{790}$ e ピアノ ${ }^{791} \rightarrow ヒ^{\circ}$ アノ者 ${ }^{792}$; para designar seguidores de ideologias existe a terminação 徒 ${ }^{793}$ : 仏教 ${ }^{794} \rightarrow$ 仏教徒 ${ }^{795}$, é interessante notar que nestes casos também há o agentivo associado à ideologia, que designa o sacedote para atividades religiosas, por exemplo: 仏教 ${ }^{796} \rightarrow$ 仏教者 ${ }^{797}$. Dessa forma, conclui-se que o sufixo -ista como tal é, por hora, pouco usado no japonês.

\footnotetext{
${ }^{769}$ Tradução: “marxista”. Transliteração: Marksī.

${ }^{770}$ Transliteração: $\bar{l}$.

${ }^{771}$ Tradução: "Líbano". Transliteração: Lubnān.

772 Tradução: "libanês". Transliteração: lubnānī.

773 Tradução: “-ista”. Transliteração: isuto.

774 Tradução: "nudista”. Transliteração: $n \bar{u}$ disuto.

775 Tradução: "egoísta”. Transliteração: egoisuto.

776 Tradução: "pianista”. Transliteração: pianisuto.

777 Tradução: "nudista". Transliteração: rataishugisha.

778 Tradução: "egoísta”. Transliteração: rikoshugisha.

779 Tradução: "pianista”. Transliteração: pianosha.

780 Tradução: “-ista”. Transliteração: isuto.

${ }^{781}$ Transliteração: jin.

782 Tradução: "Brasil”. Transliteração: Burajiru.

783 Tradução: "brasileiro". Transliteração: burajirujin.

784 Tradução: "Japão". Transliteração: Nihon.

785 Tradução: “japonês”. Transliteração: nihonjin.

786 Transliteração: sha.

787 Tradução: "dente". Transliteração: $h a$.

788 Tradução: "dentista”. Transliteração: haisha.

${ }^{789}$ Tradução: "consumir". Transliteração: shōhi.

790 Tradução: "consumidor” ou "consumista”. Transliteração: shōhisha.

791 Tradução: "piano". Transliteração: piano.

792 Tradução: "pianista”. Transliteração: pianosha.

793 Transliteração: to.

794 Tradução: "budismo”. Transliteração: Bukkyō.

795 Tradução: "budista”. Transliteração: bukkyōto.

796 Tradução: "budismo”. Transliteração: Bukkyō.
} 
De acordo com ZlochevSKY (1988), em hebraico o sufixo vo (-ist) é muito raro, mas aparece em palavras importadas principalmente via inglês, francês e alemão, e iídiche; pode, ou não, aparecer associado ao -ism nas suas duas formas variantes: ${ }^{798}$ e ${ }^{799}$ יזם Entetanto, o hebraico tem suas próprias estruturas para designar agentes, uma delas é por meio da terminação ${ }^{800}$, como em: ${ }^{801}$, ou seja, pessoa que trabalha em: pessoa que pratica בפורטיט ${ }^{803}$. Com essa terminação também se formam os gentílicos, por exemplo: עברי ${ }^{805}$. Outra terminação usada na formação de agentivos é $\}^{806}$ : trabalha em ספריה ${ }^{808}$, e כרטים ${ }^{810}$ é quem trabalha distribuindo dicionários pesquisados foram encontradas apenas 19 palavras o sufixo יסט (-ist):

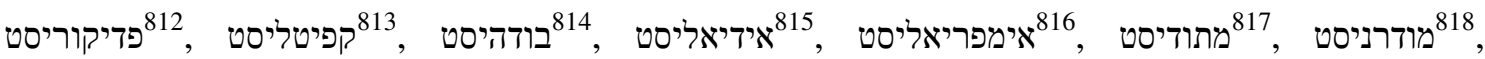

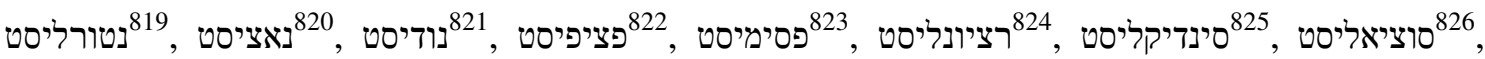
סוריאליסט ${ }^{827}$, טרוריסט ${ }^{829}$, Segundo os falantes da língua, em âmbitos mais

${ }^{797}$ Tradução: "budista” (sacerdote). Transliteração: bukkyōsha.

${ }^{798}$ Transliteração: ism.

${ }^{799}$ Transliteração: $i z m$.

${ }^{800}$ Transliteração: $i$.

${ }^{801}$ Tradução: "banqueiro". Transliteração: bankai.

${ }^{802}$ Tradução: "banco". Transliteração: bank.

${ }^{803}$ Tradução: "esportista". Transliteração: sportai.

${ }^{804}$ Tradução: "esporte". Transliteração: sport.

${ }^{805}$ Tradução: "hebreu". Transliteração: ibri.

${ }^{806}$ Transliteração: an.

${ }^{807}$ Tradução: "bibliotecário". Transliteração: safran.

${ }^{808}$ Tradução: "biblioteca". Transliteração: sifriá.

${ }^{809}$ Tradução: "bilheteiro". Transliteração: kartissan.

${ }^{810}$ Tradução: "bilhetes". Transliteração: kartis.

811 Tradução: "absolutista". Transliteração: absolutist.

${ }^{812}$ Tradução: "pedicuro". Transliteração: pedikurist.

${ }^{813}$ Tradução: "capitalista". Transliteração: kapitalist.

${ }^{814}$ Tradução: "budista". Transliteração: budist.

${ }^{815}$ Tradução: "idealista". Transliteração: idealist.

${ }^{816}$ Tradução: "imperialista". Transliteração: imperialist.

${ }^{817}$ Tradução: "metodista". Transliteração: metodist.

${ }^{818}$ Tradução: "modernista". Transliteração: modernist.

${ }^{819}$ Tradução: "naturalista". Transliteração: naturalist.

${ }^{820}$ Tradução: "nazista". Transliteração: natzist.

${ }^{821}$ Tradução: "nudista". Transliteração: nudist.

${ }^{822}$ Tradução: "pacifista". Transliteração: patzifist.

${ }^{823}$ Tradução: "pessimista". Transliteração: pessimist.

${ }^{824}$ Tradução: "racionalista". Transliteração: ratzionalist.

${ }^{825}$ Tradução: "sindicalista". Transliteração: sindicalist.

${ }^{826}$ Tradução: "socialista". Transliteração: sotzialist.

${ }^{827}$ Tradução: "surrealista". Transliteração: sureialist.

${ }^{828}$ Tradução: "terrorista". Transliteração: terorist.

${ }^{829}$ Tradução: "universalista". Transliteração: unibersalist. 
específicos como o artístico ou científico, eventualmente podem ser encontradas algumas outras palavras. No entanto, o sufixo יסט (-ist) não se mostra produtivo na língua hebraica, pois não há formações a partir de nomes hebraicos e este sufixo, restringindo-se apenas às palavras já sufixadas que a ele chegam por meio de empréstimos estrangeiros.

Segundo a EUKALTZAindiA ${ }^{830}$ (2006), na lingua basca, assim como no hebraico, o sufixo -ista chega sob a forma de empréstimos de outras línguas, tais como: latim, castelhano, francês ou inglês; entretanto não é produtivo na língua basca, pois não há palavras formadas a partir de um lexema basco e o sufixo -ista. Os empréstimos com o sufixo -ista são termos muito raros em basco já que existem outros sufixos que o suprem na função agentiva, por exemplo: -tzaile em aho-artatzaile ${ }^{831}$; -gile em harreragile ${ }^{832}$ e nobelagile $^{833}$; -ari em tren-

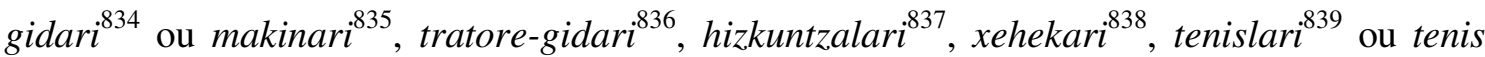
jokari $^{840}$, opera-kantari $^{841}$, Ebanjelari ${ }^{842}$; -dun em pensiodun ${ }^{843} ;$-zain em igogailuzain ${ }^{844}$. Outras palavras que em muitas línguas são terminadas em -ista, têm formas próprias na lingua como por exemplo: ezkor ${ }^{845}$ ou ukakor $^{846}$, zorro-lapur ${ }^{847}$. Apesar de estar rodeada por língua latinas, a influência destas sobre a língua basca se mostra muito pequena em relação ao sufixo -ista, que por hora não é produtivo na língua e os poucos empréstimos de palavras que

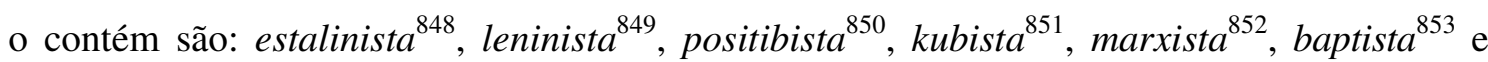
terrorista $^{854}$.

\footnotetext{
${ }^{830}$ Real Academia da Língua Basca.

${ }^{831}$ Tradução: "dentista".

832 Tradução: "recepcionista".

833 Tradução: "novelista".

834 Tradução: "maquinista".

835 Tradução: "maquinista".

836 Tradução: "tractorista".

${ }^{837}$ Tradução: "lingüista".

${ }^{838}$ Tradução: "detalhista".

${ }^{839}$ Tradução: "tenista".

840 Tradução: "tenista".

841 Tradução: "operista”.

${ }^{842}$ Tradução: "evangelista".

${ }^{843}$ Tradução: "pensionista".

${ }^{844}$ Tradução: "ascensorista".

845 Tradução: "optimista”.

846 Tradução: "optimista”.

847 Tradução: "carteirista".

848 Tradução: "estalinista".

${ }^{849}$ Tradução: "leninista".

${ }^{850}$ Tradução: "positivista".

${ }^{851}$ Tradução: "cubista".

852 Tradução: "marxista".
} 
É interessante notar que no russo, o sufixo masculino proveniente do grego $-1 \sigma \tau \eta \dot{s}$, assume duas formas distintas no processo de derivação de substantivos: $-u c m^{855} \mathrm{e}-u c m \kappa a^{856}$, uma na formação de palavras masculinas e outra na formação das femininas (ambas no nominativo singular). Segundo StaRets \& VoinOVa (1986) e ZALIZNiaK (1986), o sufixo é formador de: a) nomes de profissionais, por exemplo: артист $^{857}$ e артистка $^{858}$, машинист $^{859}$ е машинистка ${ }^{860}$, журналист ${ }^{861}$ е журналистка ${ }^{862}$, лингвист ${ }^{863}$ e лингвистка ${ }^{864}$, гитарист $^{865}$ е гитаристка ${ }^{866}$ парашютист $^{867}$ e парашютистка $^{868}$, пианист $^{869}$ е пианистка ${ }^{870}$, тракторист ${ }^{871}$ е трактористка ${ }^{872}$; виолончелист ${ }^{873}$ e виолончелистка ${ }^{874}$, юурист ${ }^{875}$ е юуристка ${ }^{876}$, теннисист $^{877}$ e теннисистка ${ }^{878}$, футболист $^{879}$ е футболистка ${ }^{880}$; b) nomes expressos pela mesma base de uma palavra formada com o sufixo $-и з M^{881}$, designando adeptos de uma ideologia ou que se dedicam a uma atividade, por exemplo: активизм ${ }^{882} \leftrightarrow$ активист $^{883}$ е активистка ${ }^{884}$; коммунизм ${ }^{885}$

\footnotetext{
853 Tradução: "batista".

854 Tradução: "terrorista".

855 Transliteração: ist.

${ }^{856}$ Transliteração: istka.

857 Tradução: "ator". Transliteração: artist.

${ }^{858}$ Tradução: "atriz". Transliteração: artistka.

${ }^{859}$ Tradução: "maquinista". Transliteração: mashinist.

${ }^{860}$ Tradução: na forma feminina significa "datilógrafa". Transliteração: mashinistka.

${ }^{861}$ Tradução: "jornalista” (masculino). Transliteração: zhurnalist.

${ }^{862}$ Tradução: “jornalista” (feminina). Transliteração: zhurnalistka.

863 Tradução: "lingüista" (masculino). Transliteração: lingvist.

${ }^{864}$ Tradução: "lingüista" (feminino). Transliteração: lingvistka.

${ }^{865}$ Tradução: "guitarrista” (masculino). Transliteração: gitarist.

866 Tradução: "guitarrista” (feminino). Transliteração: gitaristka.

867 Tradução: "pára-quedista" (masculino). Transliteração: parashyutist.

${ }^{868}$ Tradução: "pára-quedista" (feminino). Transliteração: parashyutistka.

${ }^{869}$ Tradução: "pianista" (masculino). Transliteração: pianist.

${ }^{870}$ Tradução: "pianista" (feminino). Transliteração: pianistka.

${ }^{871}$ Tradução: "tratorista" (masculino). Transliteração: traktorist.

872 Tradução: "tratorista" (feminino). Transliteração: traktoristka.

${ }^{873}$ Tradução: "violoncelista" (masculino). Transliteração: violonchelist.

${ }^{874}$ Tradução: "violoncelista" (feminino). Transliteração: traktoristka.

875 Tradução: "advogado" (masculino). Transliteração: yuurist.

876 Tradução: "advogado" (feminino). Transliteração: yuuristka.

877 Tradução: "tenista" (masculino). Transliteração: tenisist.

878 Tradução: "tenista" (feminino). Transliteração: tenisistka.

${ }^{879}$ Tradução: "futebolista" (masculino). Transliteração: futbolist.

${ }^{880}$ Tradução: "futebolista" (feminino). Transliteração: futbolistka.

881 Transliteração: izm.

882 Tradução: “ativismo". Transliteração: aktivizm.

883 Tradução: "ativista" (masculino). Transliteração: aktivist.

${ }^{884}$ Tradução: "ativista" (feminino). Transliteração: aktivistka.

885 Tradução: "comunismo”. Transliteração: kommunizm.
} 
$\leftrightarrow$ коммунист $^{886}$ е коммунистка ${ }^{887} ;$ империализм $^{888} \leftrightarrow$ империалист $^{889}$ е империалистка $^{890} ;$ ленинизм $^{891} \leftrightarrow$ ленинист $^{892}$ е ленинистка ${ }^{893}$; марксизм $^{894} \leftrightarrow$ марксист $^{895}$ е марксистка ${ }^{896} ;$ материализм $^{897} \leftrightarrow$ материалист $^{898}$ е материалистка ${ }^{899}$; милитаризм $^{900} \leftrightarrow$ милитарист $^{901}$ е милитаристка ${ }^{902} ;$ оптимизм $^{903} \leftrightarrow$ оптимист $^{904} \mathrm{e}$ оптимистка $a^{905} ;$ социализм $^{906} \leftrightarrow$ социалист $^{907}$ е социалистка ${ }^{908} ;$ сталинизм $^{909} \leftrightarrow$ сталинист $^{910}$ е сталинистка ${ }^{911} ;$ туризм ${ }^{912} \leftrightarrow$ турист $^{913}$ е туристка ${ }^{914}$. Entretanto, a incidência de formações com o sufixo parece ser pequena na língua russa, apenas foram encontradas as vinte e três palavras acima, tomadas como exemplo, de um total de sete mil vocábulos listados por STARETS \& VOINOVA (1986), ou seja, 0,003\%. Na pesquisa também foram encontrados outros sufixos concorrentes na formação de nomes agentivos, como por exemplo: $-о p^{915},-о в н и \kappa^{916},-щ и \kappa^{917},-{ }^{17}{ }^{918}{ }^{918}$, em suas formas nominativas masculinas. Segundo falantes nativos da língua, o sufixo: $-u c m^{919}\left(-u c m \kappa a^{920}\right)$ não é muito comum no

\footnotetext{
${ }^{886}$ Tradução: "comunista" (masculino). Transliteração: kommunist.

${ }^{887}$ Tradução: "comunista” (feminino). Transliteração: kommunistka.

${ }^{888}$ Tradução: "imperialismo". Transliteração: imperializm.

${ }^{889}$ Tradução: "imperialista” (masculino). Transliteração: imperialist.

${ }^{890}$ Tradução: "imperialista” (feminino). Transliteração: imperialistka.

891 Tradução: "leninismo". Transliteração: leninizm.

${ }^{892}$ Tradução: "leninista" (masculino). Transliteração: leninist.

${ }^{893}$ Tradução: "leninista" (feminino). Transliteração: leninistka.

${ }^{894}$ Tradução: "marxismo". Transliteração: marksizm.

895 Tradução: "marxista" (masculino). Transliteração: marksist.

${ }^{896}$ Tradução: "marxista" (feminino). Transliteração: marksistka.

897 Tradução: "materialismo". Transliteração: materializm.

${ }^{898}$ Tradução: "materialista" (masculino). Transliteração: materialist.

899 Tradução: "materialista" (feminino). Transliteração: materialistka.

900 Tradução: "militarismo". Transliteração: militarizm.

901 Tradução: "militarista" (masculino). Transliteração: militarist.

902 Tradução: "militarista" (feminino). Transliteração: militaristka.

903 Tradução: "otimismo". Transliteração: optmizm.

904 Tradução: "otimista” (masculino). Transliteração: optmist.

905 Tradução: “otimista” (feminino). Transliteração: optmistka.

906 Tradução: "socialismo". Transliteração: sotsializm.

907 Tradução: "socialista" (masculino). Transliteração: sotsialist.

908 Tradução: "socialista" (feminino). Transliteração: sotsialistka.

909 Tradução: "stalinismo". Transliteração: stalinizm.

910 Tradução: "stalinista” (masculino). Transliteração: stalinist.

911 Tradução: "stalinista" (feminino). Transliteração: stalinistka.

912 Tradução: "turismo". Transliteração: turizm.

913 Tradução: "turista" (masculino). Transliteração: turist.

914 Tradução: "turista” (feminino). Transliteração: turistka.

915 Transliteração: or.

916 Transliteração: ovnik.

917 Transliteração: shchik.

918 Transliteração: tel'.

919 Transliteração: ist.
} 
vulgo, mas pode aparecer na literatura mais específica ou técnica, como acadêmica e musical, pois as palavras por ele formadas, na sua grande maioria, são de procedência estrangeira para a língua, exceção feita aos dois únicos exemplos construídos com nomes próprios russos: ленинист ${ }^{921}$ е сталинист $^{922}$. Desse modo, acredita-se que a formação com o sufixo estudado seja bem pouco produtiva na língua russa.

Assim como no russo, no polonês o sufixo assume duas formas: -ista para o masculino e -istka para o feminino. De acordo como os exemplos encontrados em STANISŁAWSKI (1969), o sufixo pode assumir duas características semânticas: a) formador de nomes de profissionais, por exemplo: artysta e artystka ${ }^{923}$, dentysta e dentystka ${ }^{924}$, futbolista $^{925}$ para designar o jogador de futbol $^{926}$, maszynista $^{927}$ e maszynistka ${ }^{928}$, pianista e pianistka $^{929}$ para designar o profissional que toca piano ${ }^{930}$, recepcjonista e recepcjionistka ${ }^{931}$, tenista e tenistka ${ }^{932}$ para designar o jogador de tenis ${ }^{933}$, wiolonczelista e wiolonczelistka ${ }^{934}$ para designar o profissional que toca wiolonczela ${ }^{935}$; b) formador de nomes de agentes expressos pela mesma base de uma palavra formada com o sufixo -izm, designando seguidores de uma ideologia ou que se dedicam a uma atividade, por exemplo: abolicjonizm $\leftrightarrow$ abolicjonista e abolicjonistka ${ }^{936}$, buddyzm $\leftrightarrow$ buddysta e buddystka ${ }^{937}$, darwinizm $\leftrightarrow$ darwinista e darwinistka ${ }^{938}$, komunizm $\leftrightarrow$ komunista e komunistka ${ }^{939}$, maksymalizm $\leftrightarrow$ maksymalista e maksymalistka ${ }^{940}$, populizm $\leftrightarrow$ populista e populistka ${ }^{941}$, turyzm $\leftrightarrow$ turysta $e$

\footnotetext{
${ }^{920}$ Transliteração: istka.

921 Tradução: "leninista" (masculino). Transliteração: leninst.

922 Tradução: "stalinista" (masculino). Transliteração: stalinist.

923 Tradução: "ator" e "atriz”, respectivamente.

924 Tradução: "dentista”, nas formas masculina e feminina, respectivamente.

925 Tradução: "futebolista", apenas foi encontrada a forma masculina.

926 Tradução: "futebol".

927 Tradução: "maquinista”, condutor da máquina do trem - apenas na forma masculina.

928 Tradução: "datilógrafa”, apenas na forma feminina.

${ }^{929}$ Tradução: "pianista", nas formas masculina e feminina, respectivamente.

930 Tradução: "piano".

931 Tradução: "recepcionista", nas formas masculina e feminina, respectivamente.

932 Tradução: "tenista”, nas formas masculina e feminina, respectivamente.

933 Tradução: "tênis".

934 Tradução: "violoncelista”, nas formas masculina e feminina, respectivamente.

935 Tradução: "violoncelo".

936 Tradução: "abolicionismo" ↔ "abolicionista”, nas formas masculina e feminina, respectivamente.

937 Tradução: "budismo" $\leftrightarrow$ "budista", nas formas masculina e feminina, respectivamente.

938 Tradução: "darwinismo" ↔ "darwinista", nas formas masculina e feminina, respectivamente.

939 Tradução: "comunismo" $\leftrightarrow$ "comunista”, nas formas masculina e feminina, respectivamente.

940 Tradução: "maximalismo" $\leftrightarrow$ "maximalista”, nas formas masculina e feminina, respectivamente.

941 Tradução: "populismo" $\leftrightarrow$ "populista”, nas formas masculina e feminina, respectivamente.
} 
turystk $a^{942}$. Foram encontrados vários outros sufixos concorrentes na formação de nomes agentivos na língua polonesa, dentre eles: -owy. Assim como no russo, os falantes nativos da língua declaram que o sufixo não é muito comum, pois afirmam que as palavras por ele formadas são de origem estrangeira. Na pesquisa também não foram encontradas palavras formadas a partir do sufixo -ista e um lexema polonês; dessa forma, acredita-se que sua produtividade na língua polonesa, senão for nula, é muito escassa.

Também no alemão, assim como no russo e polonês, o sufixo estudado assume duas formas distintas no processo de derivação substantiva: -ist e -istin, para o nominativo singular masculino e feminino, respectivamente. Segundo WAHRIG (1999), pode ser classificado como um sufixo formador de nomes: a) de agentes profissionais, por exemplo: Cellist e Cellistin ${ }^{943}$, Dentist e Dentistin ${ }^{944}$, Florist e Floristin ${ }^{945}$, Kopist e Kopistin ${ }^{946}$, Maschinist $^{947}$, Modistin $^{948}$, Pianist e Pianistin $^{949}$; b) especialistas em cultura, política ou sociedade de um determinado povo ou local: amerikanisch $\leftrightarrow$ Amerikanist e Amerikanistin $^{950}$, hellenisch $\leftrightarrow$ Hellenist e Hellenistin ${ }^{951}$, nordisch $\leftrightarrow$ Nordist e Nordistin ${ }^{952}$; c) adeptos de uma ideologia ou uma atividade, expressa pelo sufixo -ismus, por exemplo: Ageismus ${ }^{953} \leftrightarrow$ Ageist $^{2}$ e Ageistin ${ }^{954}$, Anarchismus $\leftrightarrow$ Anarchist e Anarchistin ${ }^{955}$, Darwinismus $\leftrightarrow$ Darwinist e Darwinistin $^{956}$, Journalismus $\leftrightarrow$ Journalist e Journalistin ${ }^{957}$, Klassizismus $\leftrightarrow$ Klassizist e Klassizistin ${ }^{958}$, Optmismus $\leftrightarrow$ Optmist e Optmistin ${ }^{959}$, Rassismus $\leftrightarrow$ Rassist e Rassistin ${ }^{960}$,

\footnotetext{
942 Tradução: "turismo" ↔ "turista”, nas formas masculina e feminina, respectivamente.

943 Tradução: "violoncelista", nas formas masculina e feminina, respectivamente.

944 Tradução: "dentista", nas formas masculina e feminina, respectivamente. Ainda que, as formas mais usuais em alemão sejam: Zahnartz e Zahnartzin.

945 Tradução: "florista", nas formas masculina e feminina, respectivamente. Ainda que, as formas mais usuais em alemão sejam: Blumenhärdler e Blumenhärdlerin.

946 Tradução: "copista”, nas formas masculina e feminina, respectivamente.

947 Tradução: "maquinista”, somente na forma masculina. Também existe a forma masculina: Lokomotivführer.

948 Tradução: "modista", só aparece na forma feminina.

949 Tradução: "pianista", nas formas masculina e feminina, respectivamente. Ainda que, em alemão também exista a forma masculina: Klavierspielmann.

950 Tradução: "americano" $\leftrightarrow$ "americanista", nas formas masculina e feminina, respectivamente.

951 Tradução: "helênico" $\leftrightarrow$ "helenista", nas formas masculina e feminina, respectivamente.

952 Tradução: "nórdico" $\leftrightarrow$ "nordista” (especialista em assuntos nórdicos), nas formas masculina e feminina, respectivamente.

953 Tradução: discriminação fundamentada na idade.

954 Tradução: quem discrimina fundamentado na idade, formas: masculina e feminina, respectivamente.

955 Tradução: "anarquismo" $\leftrightarrow$ "anarquista”, nas formas masculina e feminina, respectivamente.

956 Tradução: "darwinismo" ↔ "darwinista", nas formas masculina e feminina, respectivamente.

957 Tradução: "jornalismo" $\leftrightarrow$ "jornalista”, nas formas masculina e feminina, respectivamente.

958 Tradução: "classicismo" $\leftrightarrow$ "classicista", nas formas masculina e feminina, respectivamente.

959 Tradução: "otimismo" $\leftrightarrow$ "otimista”, nas formas masculina e feminina, respectivamente.

960 Tradução: "racismo" ↔ "racista", nas formas masculina e feminina, respectivamente.
} 
Sexismus $\leftrightarrow$ Sexist e Sexistin ${ }^{961}$, Terrorismus $\leftrightarrow$ Terrorist e Terroristin ${ }^{962}$. É interessante notar que os nomes expressos em (a) são, em geral, palavras estrangeiras na língua alemã, pois para designar agentivos a língua já dispõe do sufixo - er (-erin). No entanto, ainda que o sufixo - er (-erin) seja o mais utilizado em alemão na formação de nomes agentivos, o sufixo -ist (-istin) possui uma grande produtividade principalmente na formação de nomes expressos em (b) e (c). Mas, convém ressaltar que nem sempre existe a associação entre -ist e -ismus, por exemplo: quem se dedica a Alkoholismus ${ }^{963}$ é Alkoholiker ${ }^{964}$ e o seguidor de Katholizismus $^{965}$ é Katholisch ${ }^{966}$. É interessante notar que, diferentemente do inglês, o sufixo -ist não é utilizado em alemão para designar especialidades médicas ou científicas, para tanto geralmente utiliza-se o sufixo -ologe, por exemplo: Dermatologe $e^{967}$ e Kardiologe K68 $^{960 \text { Pe-se }}$ observar que no alemão o sufixo -er (-erin), bem como a composição com o termo Schriftsteller ${ }^{969}$ são as maneiras de formar nomes que designam autores especializados em escrever determinado tipo de obra, por exemplo: Romancier ${ }^{970}$ ou Romanschriftsteller ${ }^{971}$. Observa-se também que em alemão a formação de agentes que praticam esportes é, em geral, uma composição com a palavra Spieler ${ }^{972}$, por exemplo: Tennisspieler e Tennisspielerin ${ }^{973}$, Fußballspieler e Fußballspielerin ${ }^{974}$; de maneira diferente às outras línguas que utilizam o sufixo -ista para a formar o nome do agente que pratica o esporte.

Sabe-se que o sufixo -ist em inglês, diferentemente do alemão e russo, é comum para os dois gêneros: masculino e feminino na formação de palavras. Segundo a classificação morfológica do dicionário HoRnBY (1995), o sufixo -ist é, essencialmente, um formador de nomes a partir de: a) verbos terminados em -ize, como por exemplo: antagonize $\leftrightarrow$ antagonist $^{975}$, generalize $\leftrightarrow$ generalist $^{976}$, plagiarize $\leftrightarrow$ plagiarist $^{977}$, specialize $\leftrightarrow$

\footnotetext{
961 Tradução: "sexismo" $\leftrightarrow$ "sexista”, nas formas masculina e feminina, respectivamente.

962 Tradução: "terrorismo" $\leftrightarrow$ "terrorista", nas formas masculina e feminina, respectivamente.

963 Tradução: "alcoolismo".

964 Tradução: "alcoólatra" ou "alcoolista".

965 Tradução: "catolicismo".

966 Tradução: "católico".

967 Tradução: "dermatologista” ou médico especializado em dermatologia.

968 Tradução: "cardiologista" ou médico especializado em cardiologia.

969 Tradução: escritor e autor.

970 Tradução: "romancista".

971 Tradução: "romancista".

972 Tradução: jogador, praticante, ou pessoa que toca algum instrumento musical.

973 Tradução: "tenista”, na forma masculina e feminina, respectivamente.

974 Tradução: "futebolista”, na forma masculina e feminina, respectivamente.

975 Tradução: "contrariar" ↔ "antagonista” (adversário).
} 
Estudo comparativo de aspectos semânticos do sufixo -ista no português e no galego.

specialist ${ }^{978}$; b) nomes terminados em -ism, por exemplo: Buddhism $\leftrightarrow$ Buddhist ${ }^{979}$, Darwinism $\leftrightarrow$ Darwinist $^{980}$, Marxism $\leftrightarrow$ Marxist $^{981}$, terrorism $\leftrightarrow$ terrorist $^{982}$; c) nomes substantivos comuns, por exemplo: art $\leftrightarrow$ artist $^{983}$, science $\leftrightarrow$ scientist $^{984}$, conservation $\leftrightarrow$ conservationist ${ }^{985}$, orchard $\leftrightarrow$ orchardist ${ }^{986}$, violin $\leftrightarrow$ violinist $^{987}$. Observa-se que muitas palavras possuem, além da forma verbal terminadas em -ize, também a forma em -ism, por exemplo: antagonize $\leftrightarrow$ antagonism e antagonist ${ }^{988}$, generalize $\leftrightarrow$ generalism e generalist ${ }^{989}$, plagiarize $\leftrightarrow$ plagiarism e plagiarist ${ }^{990}$, o que torna esta classificação não-unívoca.

Já no dicionário LONGMAN (1987), é dada uma classificação semântica das palavras formadas em inglês pelo sufixo -ist: a) nomes e adjetivos que designam adeptos de uma religião ou um conjunto de princípio ou idéias, por exemplo: Brahmanist ${ }^{91}$ adepto do brahmanism $^{992}$, $_{\text {cubist }}{ }^{993}$ pintor adepto dos princípios do cubism $^{994}$, optimist $^{995}$ adepto dos ideais do optimism ${ }^{996}$, pacifist ${ }^{997}$ adepto das idéias do pacifism $^{998}$; b) nomes que designam alguém que estuda, produz, toca ou opera algo, por exemplo: linguist $t^{999}$ alguém que estuda languages $^{1000}$, novelist ${ }^{1001}$ alguém que escreve novels ${ }^{1002}$, guitarist ${ }^{1003}$ alguém que toca

${ }^{976}$ Tradução: "generalizar" $\leftrightarrow$ "generalista”.

977 Tradução: "plagiar" $\leftrightarrow$ pessoa que faz plágio.

${ }^{978}$ Tradução: "especializar" $\leftrightarrow$ "especialista".

979 Tradução: "budismo" $\leftrightarrow$ "budista".

980 Tradução: "darwinismo" $\leftrightarrow$ "darwinista".

981 Tradução: "marxismo" $\leftrightarrow$ "marxista".

982 Tradução: "terrorismo" $\leftrightarrow$ "terrorista".

983 Tradução: "arte" $\leftrightarrow$ "artista".

984 Tradução: "ciência" $\leftrightarrow$ "cientista".

985 Tradução: "conservação" $\leftrightarrow$ "conservacionista".

${ }^{986}$ Tradução: "pomar" $\leftrightarrow$ pessoa que cuida do pomar

987 Tradução: "violino" $\leftrightarrow$ "violinista".

${ }^{988}$ Tradução: "contrariar" ↔ "antagonismo" e "antagonista" (adversário).

989 Tradução: "generalizar" ↔ "generalismo" e "generalista".

990 Tradução: "plagiar" $\leftrightarrow$ ato ou efeito de plagiar e pessoa que faz plágio.

991 Tradução: "bramanista".

992 Tradução: "bramanismo" - religião oriental que segue Brahma.

${ }^{993}$ Tradução: "cubista".

${ }^{994}$ Tradução: "cubismo" - movimento artístico dado, principalmente, na pintura.

${ }^{995}$ Tradução: "otimista".

996 Tradução: "otimismo".

997 Tradução: "pacifista".

${ }^{998}$ Tradução: "pacifismo".

${ }^{999}$ Tradução: "lingüista".

${ }^{1000}$ Tradução: línguas e idiomas.

1001 Tradução: "romancista".

1002 Tradução: "romances".

${ }^{1003}$ Tradução: "violonista", quem toca violão; "guitarrista" 
guitar $^{1004}$, machinist ${ }^{1005}$ alguem que opera uma machine ${ }^{1006}$ - e, no caso de profissões médicas ou científicas, o sufixo pode aparecer sob a forma -ologist, por exemplo: psychologist ${ }^{1007}$ alguém que estuda psychology ${ }^{1008}$, cardiologist ${ }^{1009}$ alguém que estuda cardiology ${ }^{1010}$, physicist $^{1011}$ alguém que estuda physics $^{1012}$; c) nomes e adjetivos de alguém que faz discriminação de pessoas, por exemplo: ageist ${ }^{1013}$ alguém que discrimina por age $e^{1014}$, racist ${ }^{1015}$ alguém que faz discriminação baseado em race ${ }^{1016}$, sexist ${ }^{1017}$ alguém que faz discriminação baseado em sex ${ }^{1018}$, ou seja, pode discriminar pessoas simplesmente por pertencerem ao sexo feminino ou ao masculino. Convém notar que também no inglês o sufixo designa um agente especialista em aspectos da cultura (inclusive língua) e/ou sociedade de um povo ou de um país, por exemplo: brazilianist ${ }^{1019}$ é um especialista em aspectos da cultura e/ou sociedade do Brasil, africanist ${ }^{1020}$ é um especialista em aspectos da cultura e/ou sociedade da África, hebrewist ${ }^{1021}$ é um especialista em hebraico e jewist ${ }^{1022}$ é um especialista em cultura judaica, helenist ${ }^{1023}$ é um especialista na cultura helênica e grecist $^{1024}$ é um especialista em grego, latinist $^{1025}$ é um especialista em latim.

De acordo com Mifflin (1996), o sufixo -ist forma nomes agentivos, ou seja, nomes que denotam alguém que faz algo, freqüentemente proveniente de verbos terminados em -ize ou nomes terminados em -ism. Segundo o autor, o principal concorrente do -ist é o sufixo er, e, em muitos casos, os concorrentes podem ser intercambiáveis entre si, por exemplo:

\footnotetext{
1004 Tradução: "violão", “guitarra”.

1005 Tradução: "maquinista".

1006 Tradução: "máquina”.

1007 Tradução: "psicólogo".

1008 Tradução: "psicologia".

1009 Tradução: "cardiologista".

1010 Tradução: "cardiologia”.

1011 Tradução: "físico".

1012 Tradução: "física".

1013 Tradução: quem faz discriminação de pessoas pela idade.

1014 Tradução: "idade".

1015 Tradução: "racista".

1016 Tradução: "raça".

1017 Tradução: quem faz discriminação de pessoas baseado no sexo.

1018 Tradução: "sexo".

1019 Tradução: "brasileirista".

1020 Tradução: "africanista”.

1021 Tradução: "hebraísta".

1022 Tradução: "judaísta”.

1023 Tradução: "helenista".

1024 Tradução: "grecista".

1025 Tradução: "latinista".
} 


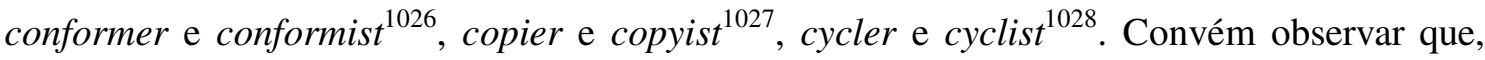
ainda que haja algumas palavras sufixadas com -ist que designam os praticantes de determinados esportes, por exemplo: arquerist ${ }^{1029}$ e rugbyist ${ }^{1030}$; em inglês o mais comum é o uso da forma composta com a palavra player $^{1031}$, por exemplo: tennis player $^{1032}$, basketball player $^{1033}$ e football player ${ }^{1034}$.

É interessante notar que no inglês também existe o sufixo -ista que, segundo o dicionário da WIKIPEDIA (2006), foi incorporado à língua inglesa por influência do português. Semanticamente denota o adepto de idéias ou princípios, geralmente políticos, por exemplo: Marxista $^{1035}$, Blairista ${ }^{1036}$, Bushista ${ }^{1037}$ e Clintonista ${ }^{1038}$. Entretanto, freqüentemente o sufixo -ista pode denotar uma idéia obsessiva, por exemplo: fashionista é alguém obcecado por fashion $^{1039}$. Assim, comunista ${ }^{1040}$ possui uma conotação muito mais forte que comunist ${ }^{1041}$, analogamente com as palavras: ageista e ageist ${ }^{1042}$, racista e racist ${ }^{1043}$, sexista e sexist ${ }^{1044}$. Dessa forma, as palavras formadas com o sufixo -ista, no inglês, têm uma conotação marcada pejorativamente, mesmo para designar o adepto de um princípio, sua carga semântica assume uma força mais pejorativa que as palavras formadas com o sufixo -ist.

No francês, o sufixo proveniente do grego $-\imath \sigma \tau \eta ́ c$, assume a forma -iste, tanto para o gênero feminino como para o masculino. Segundo o dicionário da Wikipedia, é utilizado para formar nomes agentivos que correspondem semanticamente a um especialista, por exemplo: dermatologiste $^{1045}$ e hebraïste ${ }^{1046}$; um adepto de uma atividade, por exemplo: illusioniste $e^{1047} e$

\footnotetext{
1026 Tradução: “conformista”.

1027 Tradução: "copista".

1028 Tradução: "ciclista".

1029 Tradução: praticante de archery (arco e flecha), "arqueiro(a)".

1030 Tradução: praticante de rugby, jogador(a) de rugby.

1031 Tradução: "jogador".

1032 Tradução: "tenista”.

1033 Tradução: "basquetebolista", jogador(a) de basketball.

1034 Tradução: "futebolista”, jogador(a) de futebol.

1035 Tradução: adepto das idéias de Carl Marx.

1036 Tradução: adepto das idéias do primeiro ministro inglês Tony Blair.

1037 Tradução: adepto das idéias do Presidente dos EUA George W. Bush.

1038 Tradução: adepto das idéias do Presidente dos EUA Bill Clinton.

1039 Tradução: "moda".

1040 Tradução: "comunista".

1041 Tradução: "comunista".

1042 Tradução: pessoa que faz discriminação baseada na idade.

1043 Tradução: "racista".

1044 Tradução: pessoa que faz discriminação baseada no sexo.

1045 Tradução: “dermatologista”, médico especializado em dermatologia.
} 
hippiste $^{1048}$; de uma ideologia ou de uma teoria, por exemplo: évolutionniste ${ }^{1049} \mathrm{e}$ communiste $^{1050}$; um músico instrumentista, por exemplo: flûtiste ${ }^{1051}$ e trompiste $^{1052}$; determinados esportistas, por exemplo: tenniste ${ }^{1053}$, surfiste ${ }^{1054}$ e rugbiste ${ }^{1055}$. Já, em LE ROBERT (1985), encontra-se que o sufixo serve à formação de substantivos que, geralmente, designam pessoas e adjetivos, correspondendo a um derivado em -isme formado por uma base de nome concreto ou abstrato. Assim, as palavras formadas com -iste, indicam um profissional, o exercício de uma atividade ou uma especialidade, e ainda, adesão de uma pessoa a um grupo, uma facção ou um sistema de idéias. Por exemplo, tomando como base um nome próprio, designam "os adeptos de": gaulliste $^{1056}$, castriste $^{1057}$, titiste ${ }^{1058}$, péroniste $^{1059}$ - tendo, neste caso, o sufixo -ien como concorrente; tomando como base o nome de um grupo ou sistema: communiste ${ }^{1060}$, structuraliste ${ }^{1061}$. Atualmente, este sentido tem se generalizado abrangendo outras formações a partir de nomes, por exemplo, tomando como base nomes tirados das marcas ou modelos de automóveis, passam do significado de "adeptos de" ao de "amantes de" e "aficcionados por". Como ilustração, os dois exemplos a seguir (recolhidos de L'express, 18 de setembro de 1972): um lanciaïste é um amante de veículos da marca Lancia; um kawasakiste é uma pessoa aficcionada por motos da marca Kawasaki.

Ainda que já houvesse algumas palavras no francês com o sufixo -iste, a sua produtividade começou a partir do século XVI com as traduções gregas, mas a maioria das palavras formadas com o sufixo é proveniente do século XIX como também do século XX. De acordo com LE LigueR (2005), em dicionários da língua francesa com aproximadamente sessenta mil palavras, em média, 1,3\% delas é formada com -iste, mostrando que atualmente é muito produtivo, especialmente na formação de agentes que estudam as novas ciências e,

\footnotetext{
1046 Tradução: "hebraísta”, especialista na língua hebraica.

1047 Tradução: "ilusionista", quem pratica o ilusionismo.

1048 Tradução: "hipista", que pratica hipismo.

1049 Tradução: "evolucionista".

1050 Tradução: "comunista".

1051 Tradução: "flautista”, instrumentista especializado em tocar flauta.

1052 Tradução: "trompista", instrumentista especializado em tocar trompa.

1053 Tradução: "tenista".

1054 Tradução: "surfista".

1055 Tradução: jogador(a) de rugby.

1056 Tradução: adepto das idéias do general, político e presidente da Francês: Charles A.M.J. de Gaulle.

1057 Tradução: adepto das idéias do estadista cubano Fidel Castro.

1058 Tradução: adepto das idéias do estadista iugoslavo Josip Broz mais conhecido como Tito.

1059 Tradução: adepto das idéias do presidente da Argentina Juan Domingo Perón.

1060 Tradução: "comunista".

1061 Tradução: "estruturalista”.
} 
também, para designar médicos especialistas, por exemplo, o termo urgentiste ${ }^{1062}$ apareceu em 1986 para indicar o profissional médico especializado em serviços de urgence $^{1063}$. Essa noção semântica de especialista, dada pelo sufixo -iste, se estendeu para outros campos menos científicos, porpularizando-se no processo de formação de novas palavras, por exemplo: bédéiste ${ }^{1064} \mathrm{em}$ 1974, véliplanchiste ${ }^{1065}$ em 1980, galeriste ${ }^{1066}$ em 1985, vacanciste $^{1067}$ e voyagiste ${ }^{1068}$ apareceram depois de 1980.

Também segundo GuÉHO (2003), o sufixo -iste é especialmente produtivo em francês. Atualmente, ao lado de formas não concretas como pompiste ${ }^{1069}$, o sufixo também pode ser aplicado a uma atividade bem material, como por exemplo: antenniste ${ }^{1070}$ é uma pessoa que fabrica ou instala antennes de télévision ${ }^{1071}$, bagagiste ${ }^{1072}$ é uma pessoa que fabrica, vende ou se ocupa de bagages $^{1073}$ em um aeroporto. O sufixo pode dar uma noção um pouco mais intelectual, como por exemplo: nutritionniste ${ }^{1074}$ é um técnico em nutrition ${ }^{1075}$, tiersmondiste ${ }^{1076}$ é um especialista em Tiers-Monde $e^{1077}$. E neste caso o sufixo -iste é concorrente com com o sufixo -ier, formador de agentes. Por outro lado, o sufixo -iste também pode indicar adeptos de idéias: no campo político, religioso, filosófico, científico, artístico, etc, por exemplo: mitterrandiste ${ }^{1078}$, lamaïste ${ }^{1079}$, rationaliste ${ }^{1080}$, évolutionniste ${ }^{1081}$, impressionniste ${ }^{1082}$; que normalmente estão associados aos sistemas de idéias expressos pelo sufixo -isme: mitterrandisme ${ }^{1083}$, lamaïsme ${ }^{1084}$, rationalisme $e^{1085}$, évolutionnisme ${ }^{1086}$,

1062 Tradução: médico emergencista.

1063 Tradução: emergência, pronto atendimento, pronto socorro.

1064 Tradução: autor especializado em bédés (proveniente de B.D.)

1065 Tradução: especialista em véliplanche (windsurfe).

1066 Tradução: gerente especializado em galeries (galeria de exposições, em geral, artísticas).

1067 Tradução: profissional especializado em organizar atividades de vacances (férias).

1068 Tradução: profissional especializado em organizar viagens.

1069 Tradução: muito pomposo.

1070 Tradução: "antenista".

1071 Tradução: antenas de televisão.

1072 Tradução: "bagagista".

1073 Tradução: "bagagens".

1074 Tradução: "nutricionista".

1075 Tradução: "nutrição".

1076 Tradução: "terceiro-mundista".

1077 Tradução: "terceiro-mundo".

1078 Tradução: adepto da política promovida pelo ex-presidente francês François Mitterand.

1079 Tradução: "lamaísta”, adepto do lamaísmo.

1080 Tradução: "racionalista".

1081 Tradução: "evolucionista".

1082 Tradução: "impressionista".

1083 Tradução: sistema de idéias políticas promovidas pelo ex-presidente francês François Mitterand.

1084 Tradução: "lamaísmo", religião que segue os preceitos de um Dalai-Lama. 
impressionnisme $^{1087}$. Por analogia há também: terrorisme ${ }^{1088}$, racisme $^{1089}$, sexisme $e^{1090} \mathrm{e}$ âgisme ${ }^{1091}$, e seus adeptos: terroriste ${ }^{1092}$, raciste $^{1093}$, sexiste $^{1094}$ e âgiste ${ }^{1095}$. Este último grupo incorpora uma carga semântica pejorativa que já está associada ao sufixo -iste em francês.

Segundo Glachant \& RoBert (2002), na maioria dos casos em que a palavra-base é um nome próprio de pessoa, o sufixo -iste pode ser trocado pela preposição pour ${ }^{1096}$ ou pelo prefixo pro-, por exemplo, quando o sufixo expressa a defesa de uma doutrina política ou religiosa: trotskistes ${ }^{1097}$ significa o mesmo que pour Trotski ${ }^{1098}$ ou pro-Trotski, pétainiste ${ }^{1099}$ significa o mesmo que pour Pétain ${ }^{1100}$ ou pro-Pétain ${ }^{1101}$. Também há em francês o sufixo ien, muito produtivo para designar adeptos políticos, por exemplo: giscardienne ${ }^{1102}$, chiraquienne $^{1103}$. Segundo a teoria dos autores, o sufixo -ien, geralmente, se refere à pessoa designada pela base, por exemplo: Hitler ${ }^{1104} \rightarrow$ hitlerien $^{1105}$; ao passo que o sufixo -iste, em geral, se refere às idéias ou ao sistema proposto pela pessoa designada pela base e expresso por meio do sufixo -isme, por exemplo: Lénin ${ }^{1106} \rightarrow$ léninisme $^{1107} \rightarrow$ léniniste $^{1108}$. Entretanto, a fronteira semântica entre os dois sufixos pode se mostrar bastante tênue, por exemplo, no caso das palavras: voltairien ${ }^{1109}$ e rousseauiste ${ }^{1110}$ quando se referem às suas escolas literárias.

\footnotetext{
1085 Tradução: "racionalismo".

1086 Tradução: "evolucionismo".

1087 Tradução: "impressionismo".

1088 Tradução: "terrorismo".

1089 Tradução: "racismo".

1090 Tradução: "sexismo".

1091 Tradução: atitude de discriminação fundamentada na idade.

1092 Tradução: "terrorista".

1093 Tradução: "racista".

1094 Tradução: "sexista".

1095 Tradução: quem faz discriminação fundamentada na idade.

1096 Tradução: "para”.

1097 Tradução: "trotskistas".

1098 Tradução: revolucionário russo Lev Davidovitch Bronstein, dito Trotski (1879-1940).

1099 Tradução: adepto das idéias Philippe Pétain, chefe do regime de Vichy (França) e morto em agosto de 1945.

${ }^{1100}$ Idem.

${ }^{1101}$ Ibidem.

1102 Tradução: adepto político do presidente francês Valéry Giscard d'Estaing.

1103 Tradução: adepto político do presidente francês Jacques Chirac.

1104 Tradução: governante da Alemanha Adolph Hitler (1889-1945).

1105 Tradução: "hitleriano".

1106 Tradução: estadista russo Vladimir Ilitch Ulianov (1870-1924), dito Lénin (1879-1940).

1107 Tradução: "leninismo".

1108 Tradução: "leninista".

1109 Tradução: "voltairiano", estudioso ou entusiasta de Voltaire (1694-1778).

1110 Tradução: "rousseanista”, estudioso ou entusiasta do filósofo Jean Jacques Rousseau (1712-1778).
} 
Já na língua italiana, conforme TEKAČVIĆ (1972: 42), o sufixo estudado é bem particular, pois distingue o gênero no plural, mas não no singular. Assim assume a forma -ista para masculino e feminino singular, -isti para masculino plural e -iste para feminino plural. Na língua italiana popular, o sufixo também assume a distinção de gênero no singular, sendo a forma -ista para o feminino e -isto para o masculino, por exemplo: socialista ${ }^{1111}$, socialisto $^{1112}$, socialiste ${ }^{1113}$ e socialisti ${ }^{1114}$ são as formas populares para o feminino e masculino singular e plural da palavra socialista.

De acordo com ZiNGARELli (1990) o sufixo -ista é formador de nomes agentivos por meio da associação a palavras formadas com o sufixo -ismo e comutando-se os sufixos, por exemplo: impressionismo e impressionista ${ }^{1115}$, cubismo e cubista ${ }^{1116}$, razzismo e razzista ${ }^{1117}$, sessismo e sessista ${ }^{1118}$, ciclismo e ciclista ${ }^{1119}$. Também, por analogia, forma outros substantivos indicando atividade profissional, por meio de derivações diversas, por exemplo:

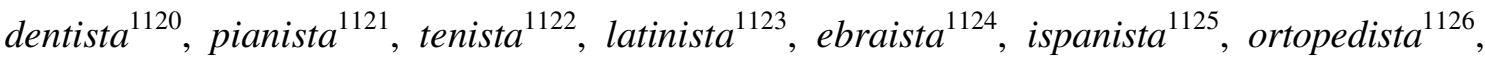
cardiologista $^{1127}$.

Para REAle (2004) o sufixo -ista pode apresentar uma variedade muito grande de significados, como a seguir: a) indicar um profissional, por exemplo: $\operatorname{dentista}^{1128}$, giornalista $^{1129}$; b) uma particular habilidade, por exemplo: calcista $^{1130}$, violinista $^{1131}$, ciclista $^{1132}$; c) adepto a um movimento religioso, político, literário, etc, por exemplo:

1111 Tradução: "socialista", forma feminina e singular.

1112 Tradução: "socialista", forma masculina e singular.

1113 Tradução: "socialista", forma feminina e plural.

1114 Tradução: "socialista”, forma masculina e plural.

1115 Tradução: "impressionismo" e "impressionista".

1116 Tradução: "cubismo e cubista".

1117 Tradução: "racismo e racista".

1118 Tradução: "sexismo e sexista".

1119 Tradução: "ciclismo e ciclista".

1120 Tradução: "dentista".

1121 Tradução: "pianista".

1122 Tradução: "tenista”.

1123 Tradução: "latinista".

1124 Tradução: "hebraísta".

1125 Tradução: "hispanista".

1126 Tradução: "ortopedista”.

1127 Tradução: "cardiologista”.

1128 Tradução: "dentista".

1129 Tradução: "jornalista”.

1130 Tradução: "futebolista".

1131 Tradução: "violinista".

1132 Tradução: "ciclista". 
calvinista $^{1133}$, socialista ${ }^{1134}$, marinista ${ }^{1135}$, realista ${ }^{1136}$; d) pertinência a uma época, por exemplo: cinquecentista $^{1137}$; e) estudioso de determinado campo, por exemplo: ispanista ${ }^{1138}$, latinista $^{1139}$; f) membro da torcida de algum time de esportes; g) aficionado por algo; etc. Dessa forma, a multiplicidade de significados da base, somado à multiplicidade de significados do sufixo -ista, dá lugar a vários fenômenos e a incerteza quanto ao significado da palavra formada. Assim, palavras formadas com bases de mesmo tipo e o sufixo -ista terão classes de significação e paráfrases totalmente diferentes, por exemplo: petrarchista ${ }^{1140}$ é um adepto do estilo poético de Francesco Petrarca (1304-1374) e dantista ${ }^{1141}$ é um estudioso do escritor e poeta Dante Alighieri (1265-1321). Também algumas palavras podem pertencer a várias classes de significação e estar associadas a várias paráfrases, por exemplo, a palavra romanista ${ }^{1142}$ significa: a) católico partidário da supremacia de Roma (do Papa), papista; b) advogado especialista em Direito Romano; c) estudioso de Filologia Neolatina; d) aficcionado pela cidade de Roma e sua memória; e) membro da torcida do time Società Sportiva Roma.

Segundo MARTIGNON (2004), como formador de agentivos, o sufixo -ista tem muitos concorrentes no italiano, tais como: -aio, -aro, -ario, -aiolo, mas hoje sua produtividade é muito grande, principalmente no âmbito científico. De acordo com MigLIORINI (1956), o sufixo -ista tem como grandes concorrentes as formações com -logo no campo semântico da designação de profissionais altamente especializados em alguma ciência ou nova técnica, entretanto -ista é muito mais produtivo na língua italiana, atualmente, principalmente na construção de novas palavras dessa classe semântica. Por exemplo, italianista ${ }^{1143}$ é preferido à italianologo $^{1144}$, linguista $^{1145}$ é preferido à glottologo ${ }^{1146}$. Segundo ADAMO (1996), um exemplo interessante é a palavra accatiemmellista, substantivo formado sobre a base do

\footnotetext{
1133 Tradução: "calvinista".

1134 Tradução: "socialista".

1135 Tradução: "marinista”, adepto do estilo literário do poeta italiano Gianbattista Marino (1569-1625).

1136 Tradução: "realista".

1137 Tradução: "quinhentista".

1138 Tradução: "hispanista".

1139 Tradução: "latinista".

1140 Tradução: "petrarquista".

1141 Tradução: "dantiano".

1142 Tradução: "romanista".

1143 Tradução: estudioso da língua italiana.

1144 Tradução: estudioso da língua italiana.

1145 Tradução: "lingüista".

1146 Tradução: "glotólogo".
} 
acrônimo HTML e o sufixo -ista, para designar o especialista na disposição gráfica e informática de documentos destinados à internet.

Para FleCHIA (1996), pode-se encontrar no italiano um número muito grande de palavras substantivas derivadas a partir do sufixo -ista, e, dada sua alta produtividade, é praticamente ilimitada a formação de novas palavras com o seu uso, "potendo ognuno coniarne quanti voglia"1147.

Na língua catalã, o sufixo -ista, segundo GDLC (1998), em geral, pode assumir duas classes semânticas: a) a que designa profissionais, por exemplo: pianista $^{1148}$, dentista $^{1149}$; b) a que designa seguidor de teoria ou doutrina correspondente em -isme, por exemplo: optimista $^{1150}$, comunista $^{1151}$. Conforme BADIA I MARGARIT (1962: 313), o sufixo -ista, que é comum para os dois gêneros: masculino e feminino, e associado ao sufixo -isme, é usado para designar adeptos de doutrinas expressas pelo sufixo -isme ou adeptos de determinadas posições, por exemplo: racionalisme $\leftrightarrow$ racionalista ${ }^{1152}$, materialisme $\leftrightarrow$ materialista $^{1153}$; também expressas pelo -isme, mas também é usado para designar agentes de profissões diversas, por exemplo: dentista ${ }^{154}$, modista $^{1155}$; e muitos dos substantivos formados também são usados como adjetivos. Da mesma forma, para RUAIX (1987: 31), -ista forma derivados substantivos e/ou adjetivos de duas classes semânticas: a) pessoa que exerce uma profissão ou atividade, por exemplo: florista ${ }^{1156}$, dentista ${ }^{1157}$, modista ${ }^{1158}$; b) pessoa adepta de uma doutrina ou ideologia, por exemplo: budista $^{1159}$, capitalista $^{1160}$, absolutista ${ }^{1161}$.

De acordo com GINER I FERRANDO (s.d.), na língua valenciana o sufixo -ista apresenta as mesmas classes semânticas do catalão, mas assume uma forma diferenciada de acordo com o gêneros, ou seja, -iste para o masculino e -ista para o feminino, e tal característica é uma

\footnotetext{
1147 Tradução: podendo-se criar tudo quanto se deseja.

1148 Tradução: "pianista".

1149 Tradução: "dentista”.

1150 Tradução: "otimista".

1151 Tradução: "comunista".

1152 Tradução: "racionalismo $\leftrightarrow$ racionalista".

1153 Tradução: "materialismo $\leftrightarrow$ materialista".

1154 Tradução: "dentista".

1155 Tradução: "modista".

1156 Tradução: "florista".

1157 Tradução: "dentista".

1158 Tradução: "modista".

1159 Tradução: "budista".

1160 Tradução: "capitalista".

1161 Tradução: "absolutista”.
} 
Estudo comparativo de aspectos semânticos do sufixo -ista no português e no galego.

das que, juntamente com outras, reforça as posições de diferenciação e separação entre as línguas catalã e valenciana.

Já, na visão de RULL I MURUZABAL (2000), a diferenciação entre masculino e feminino é uma variação dialetal provocada por fatores fonéticos. Além disso, RULL I MURUZABAL (2000), não apenas associa os sufixos -ista e -isme, como também propõe um paradigma no qual são duas variantes de um mesmo sufixo, ou seja, um sufixo -is $X$, com $X$ podendo assumir $t$ ou $m$, de acordo com o papel gramatical da base a que se acopla, e com uma acomodação vocálica final. Ainda, sustentando que sejam o mesmo sufixo, RULL I MuRUZABAL (2000), propõe uma classificação semântica mais específica que o encontrado nas gramáticas e dicionários da língua, abrangendo, por exemplo, a categoria de: ofícios: modista $^{1162}$, nutricionista ${ }^{1163}$, florista ${ }^{164}$; esportes, por exemplo: futbolista $^{1165}$, pingponguista $^{1166}$, surfista $^{1167}$; interpretação musical, por exemplo: baixista ${ }^{1168}$, $_{\text {flautista }}{ }^{169}$, violinista $^{1170}$; condução de veículos, por exemplo: motorista $^{1171}$, escuterista $^{1172}$,

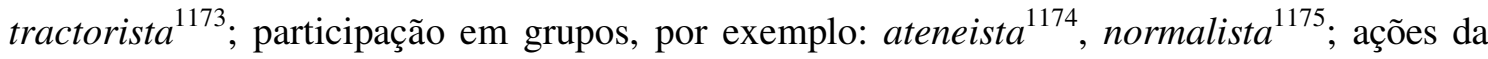
religião católica, por exemplo: exorcista ${ }^{1176}$, baptista $^{1177}$; tendências ou atitudes humanas, por exemplo: heroísme ${ }^{1178}$, vandalisme $e^{1179}$, altruisme ${ }^{1180}$; torcida de times de futebol, por exemplo: barcelonista ${ }^{1181}$, valencianista ${ }^{1182}$, mallorquista $^{1183}$; fenômenos lingüísticos, por exemplo: barbarisme ${ }^{1184}$, iotacisme ${ }^{1185}$, lambdacisme ${ }^{1186}$; estados patológicos, por exemplo:

1162 Tradução: "modista".

1163 Tradução: "nutricionista".

1164 Tradução: "florista".

1165 Tradução: "futebolista".

1166 Tradução: Jogador de pingue-pongue.

1167 Tradução: "surfista".

1168 Tradução: "baixista".

1169 Tradução: "flautista".

1170 Tradução: "violinista".

1171 Tradução: condutor de moto.

1172 Tradução: condutor de scooter.

1173 Tradução: condutor de trator.

1174 Tradução: quem cursa um ateneu.

1175 Tradução: "normalista".

1176 Tradução: "exorcista".

1177 Tradução: "batista".

1178 Tradução: "heroísmo".

1179 Tradução: "vandalismo".

1180 Tradução: "altruísmo".

1181 Tradução: membro da torcida do time Fútbol Club Barcelona.

1182 Tradução: membro da torcida do time Valencia Club de Fútbol.

1183 Tradução: membro da torcida do time Real Club Deportivo Mallorca.

1184 Tradução: "barbarismo". 
raquitisme ${ }^{1187}$, traumatisme $e^{1188}$, artritisme $e^{1189}$; fenômenos físicos; conjuntos que formam sistemas, por exemplo: mecanisme ${ }^{1190}$, organisme ${ }^{1191}$, metabolisme ${ }^{1192}$ : doutrinas do tipo político e religioso, por exemplo: aznarisme ${ }^{1193}$ comunisme $^{1194}$, deisme $^{1195}$, budisme $^{1196}$.

No castelhano, o sufixo -ista é comum de dois gêneros, ou seja assume a mesma forma no masculino e no feminino. Entretanto, popularmente encontra-se, em alguns casos a foma -isto para o masculino, ainda que não seja gramaticalmente aceita. Por exemplo: modisto $^{1197}$ e recepcionisto ${ }^{1198}$, para indicar uma profissão geralmente feminina e exercida por alguém do sexo masculino; novelisto ${ }^{1199}$ e violinisto ${ }^{1200}$, para indicar certo grau de desprezo pelo modo como um agente masculino exerce sua atividade.

Para GARCíA DE DiEGo (1951), o sufixo -ista denota, no castelhano, ofício, partido ou escola, e é aplicado com grande liberdade a nomes próprios, formando por exemplo: carlista $^{1201}$ e orleanista ${ }^{1202}$; a substantivos comuns: rentista ${ }^{1203}$, fumista $^{1204}$, ebanista $^{1205}$, pancista $^{1206}$; a adjetivos: realista ${ }^{1207}$, idealista ${ }^{1208}$; a determinantes e pronomes: altruísta ${ }^{1209}$, egoísta $^{1210}$; a nomes compostos: panteísta ${ }^{1211}$; e também a partículas: ergotista ${ }^{1212}$. Já, o Diccionario de Lengua Española de la Real Academia (2001), apresenta o sufixo -ista como

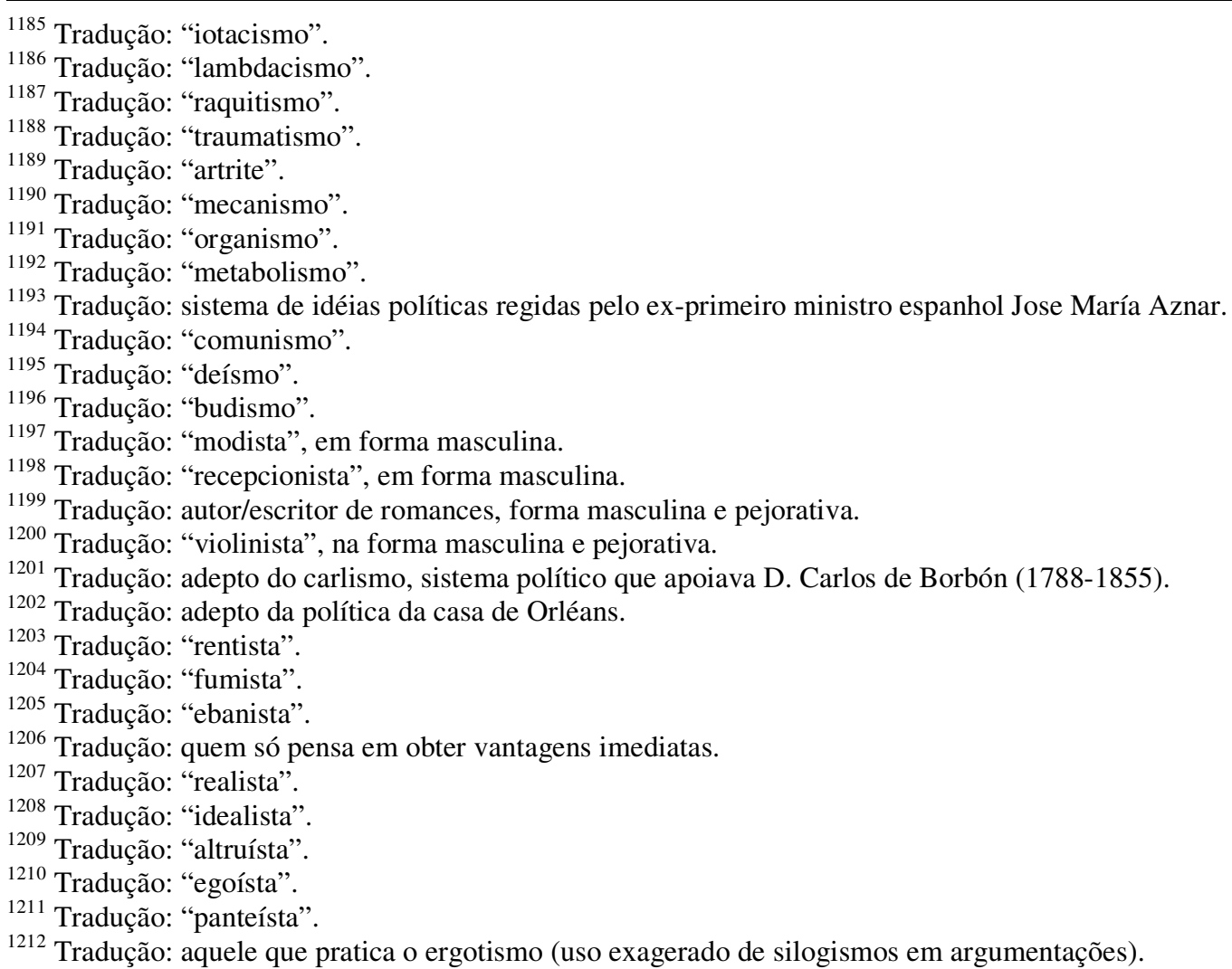


formador por derivação de: a) adjetivos que usualmente se transformam em substantivos e que costumam significar "adepto de" ou "inclinado a" do que é expresso pela mesma raiz mas com o sufixo -ismo, que a sua vez indica: a1) doutrinas, sistemas, escolas ou movimentos (socialismo $^{1213}$, platonismo ${ }^{1214}$, impresionismo ${ }^{1215}$ ), a2) atitudes $\left(\right.$ egoísmo $^{1216}$, individualismo $^{1217}$, puritanismo ${ }^{1218}$ ), a3) atividades esportivas (atletismo ${ }^{1219}$, alpinismo ${ }^{1220}$, ciclismo $^{1221}$ ) e a4) termos científicos (tropismo, ${ }^{1222}$ astigmatismo $^{1223}$, leísmo $^{1224}$ ), por exemplo: comunista $^{1225}$, europeísta ${ }^{1226}$, optimista ${ }^{1227}$; b) substantivos que designam geralmente a pessoa que tem determinada ocupação, profissão ou oficio, por exemplo: almacenista $^{1228}$, periodista ${ }^{1229}$, $_{\text {axista }}{ }^{1230}$.

Para BARTOŠ (1997), o sufixo -ista é muito usado na língua espanhola e é um dos sufixos mais produtivos na formação de nomes substantivos e adjetivos referente à pessoas designando os adeptos ou membros de partidos, movimentos políticos e sociais, por exemplo, aparece nos seguintes neologismos: centrista $^{1231}$, bipartidista $^{1232}$, laborista $^{1233}$, monetarista $^{1234}$, pluralista $^{1235}$, occidentalista ${ }^{1236}$, segregacionista ${ }^{1237}$, ecologista ${ }^{1238}$; alguns adjetivos referem-se ao mundo do esporte: colista $^{1239}$, velocista $^{1240}$, centrocampista $^{1241}$.

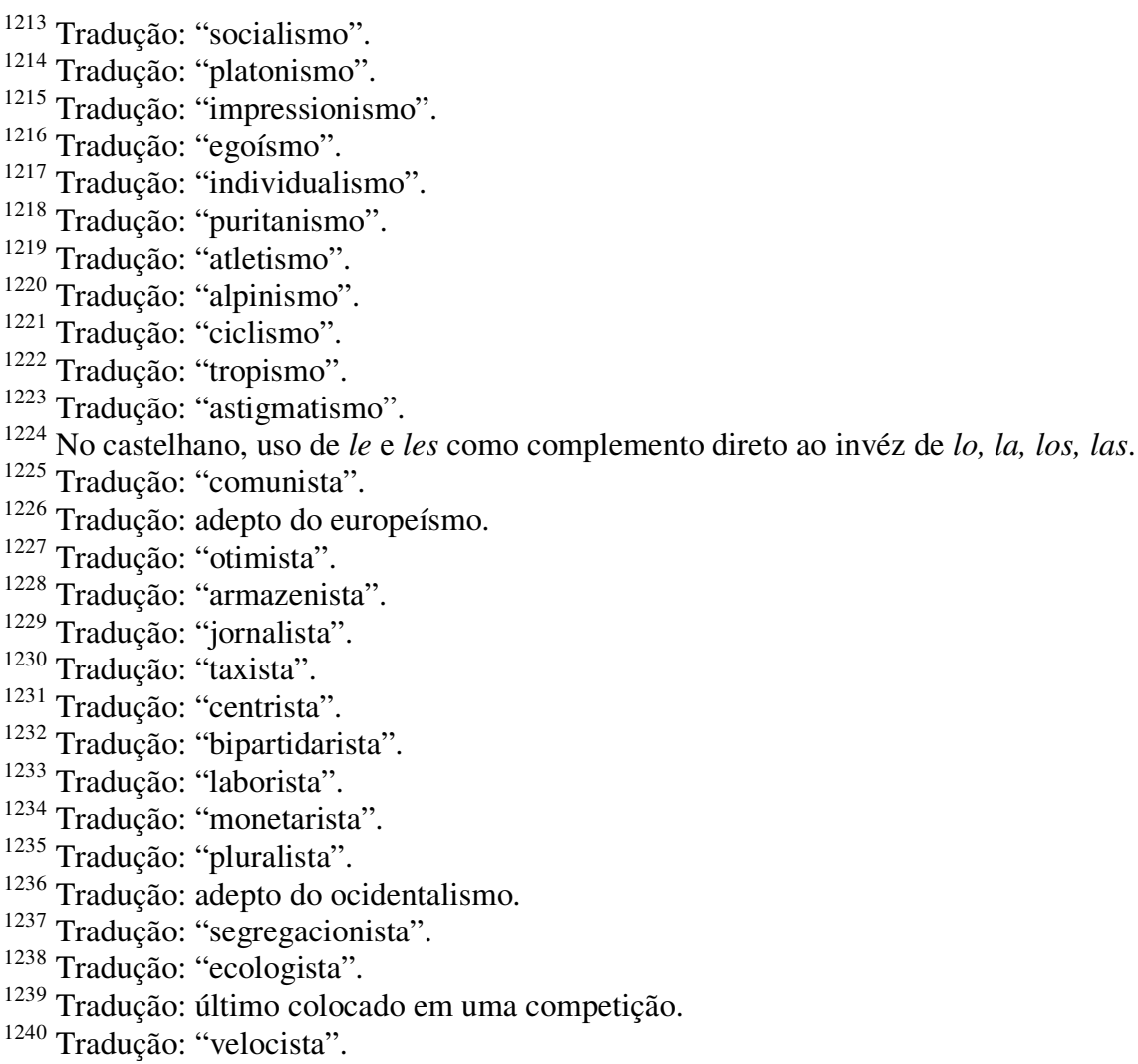


De acordo com Moliner (2002), junto a nomes de instrumentos de música e de algunos esportes, o sufixo -ista forma nomes que indicam a pessoa cuja profisssão é tocar esse instrumento ou praticar esse esporte, por exemplo: pianista (piano) ${ }^{1242}$, guitarrista (guitarra) $)^{1243}$, futbolista (fútbol) ${ }^{1244}$, tenista (tenis) $)^{1245}$. Este sufixo também pode indicar a pessoa que tem como profisssão viver do indicado pela base, por exemplo: telefonista $(\text { teléfono })^{1246}$, recepcionista (recepción) $)^{1247}$, taxista (taxi) ${ }^{1248}$. O sufixo -ista é especialmente produtivo para formar nomes e adjetivos, tomando como base um nome cuja terminação se dê com o sufixo -ismo. A base geralmente pode indicar uma ideologia ou uma corrente artística e a forma derivada com -ista significa "adepto de $X$ " ou "partidário de $X$ " , por exemplo: cubista $(\text { cubismo })^{1249}$, comunista $(\text { comunismo })^{1250}$, realista $(\text { realismo })^{1251}$, pesimista $(\text { pesimismo })^{1252}$. Os substantivos e adjetivos formados com este sufixo servem tanto para o masculino como para o feminino. Dependendo das referencias regionais, -ista também pode ser susbtituído pelo sufixo - ero, por exemplo, camionista $^{1253}$ e camionero $^{1254}$. Na medicina, é particularmente abundante o número de substantivos que designam profissão formados com o sufixo -ista, por exemplo: anestesista ${ }^{1255}$, oculista ${ }^{1256}$, psicoanalista $^{1257}$, dentista $^{1258}$.

Segundo SAntiago Lacuesta \& Bustos Gisbert (2000), ainda que seja difícil estabelecer limites estritos, pode-se agrupar os derivados de -ista em quatro grandes classes: a) designações profissionais que podem ser praticamente de todo tipo, por exemplo, música (organista $^{1259}$, acordeonista $^{1260}$, solista $^{1261}$, fagotista $^{1262}$ ), literatura ou imprensa (novelista ${ }^{1263}$,

\footnotetext{
1241 Tradução: "centro-campista".

1242 Tradução: "pianista" (piano).

1243 Tradução: "violonista” (violão).

1244 Tradução: "futebolista" (futebol).

1245 Tradução: "tenista" (tênis).

1246 Tradução: "telefonista" (telefone).

1247 Tradução: "recepcionista" (recepção).

1248 Tradução: "taxista” (táxi).

1249 Tradução: "cubista” (cubismo).

1250 Tradução: "comunista" (comunismo)

1251 Tradução: "realista" (realismo).

1252 Tradução: "pessimista" (pessimismo).

1253 Tradução: condutor de caminhão.

1254 Tradução: condutor de caminhão.

1255 Tradução: "anestesista".

1256 Tradução: "oculista”.

1257 Tradução: "psicoanalista”.

1258 Tradução: "dentista".

1259 Tradução: "organista".

1260 Tradução: "acordeonista".

1261 Tradução: "solista".
} 
Estudo comparativo de aspectos semânticos do sufixo -ista no português e no galego.

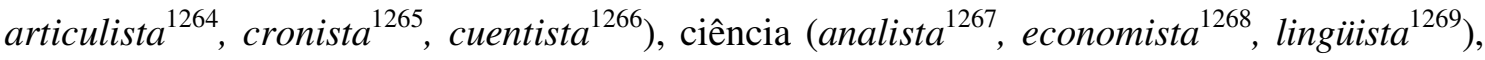
economia (accionista ${ }^{1270}$, cambista $^{1271}$, $_{\text {agiotista }}{ }^{1272}$, contratista $^{1273}$, economista ${ }^{1274}$ ), trabalhos manuais (ceramista $^{1275}$, ebanista ${ }^{1276}$, electricista ${ }^{1277}$ ), bandidos e marginais (perista ${ }^{1278}$, espadista $^{1279}$, contrabandista ${ }^{1280}$, carterista $^{1281}$ ), mundo do espetáculo e do esporte (equilibrista $^{1282}$, transformista $^{1283}$, contorsionista ${ }^{1284}$, ajedrecista ${ }^{1285}$, deportista ${ }^{1286}$, futbolista $^{1287}$, surfista $\left.{ }^{1288}\right)$; b) convicções políticas (abolicionista ${ }^{1289}$, $_{\text {centrista }}{ }^{1290}$, derechista $^{1291}$, regionalista ${ }^{1292}$, terrorista ${ }^{1293}$ ), religiosas ou filosóficas (budista $^{1294}$, existencialista $^{1295}$, humanista ${ }^{1296}$ ) científicas (conductista ${ }^{1297}$, estructuralista ${ }^{1298}$, generativista $^{1299}$ ), artísticas (dadaísta ${ }^{1300}$, expresionista ${ }^{1301}$, conceptista ${ }^{1302}$ ); c) descrições do

1262 Tradução: "fagotista".

1263 Tradução: "novelista".

1264 Tradução: escritor de artigos.

1265 Tradução: "cronista".

1266 Tradução: "contista”.

1267 Tradução: "analista".

1268 Tradução: "economista".

1269 Tradução: "lingüista".

1270 Tradução: "acionista".

1271 Tradução: "cambista".

1272 Tradução: "agiota".

1273 Tradução: "contratista".

1274 Tradução: "economista".

1275 Tradução: "ceramista".

1276 Tradução: "ebanista”.

1277 Tradução: "eletricista”.

1278 Tradução: pessoa que negocia objetos roubados.

${ }^{1279}$ Tradução: ladrão que utiliza chaves falsas para abrir as casas e rouba-las.

1280 Tradução: "contrabandista".

1281 Tradução: "carteirista”, batedor de carteiras.

1282 Tradução: "equilibrista".

1283 Tradução: "transformista".

1284 Tradução: "contorsionista".

1285 Tradução: "enxadrista”, "xadrezista”.

1286 Tradução: "desportista", "esportista".

1287 Tradução: "futebolista”.

1288 Tradução: "surfista”.

1289 Tradução: "abolicionista".

1290 Tradução: "centrista".

1291 Tradução: "direitista".

1292 Tradução: "regionalista".

1293 Tradução: "terrorista".

1294 Tradução: "budista".

1295 Tradução: "existencialista".

1296 Tradução: "humanista".

1297 Tradução: "condutista".

1298 Tradução: "estruturalista".

1299 Tradução: "gerativista".

1300 Tradução: "dadaísta”. 
carácter de uma pessoa, na maioria das vezes com uma orientação pejorativa: alarmista ${ }^{1303}$, camorrista $^{1304}$, cobista ${ }^{1305}$, cuentista $^{1306}$, juerguista ${ }^{1307}$, ventajista ${ }^{1308}$, sablista $^{1309}$, bromista $^{1310}$, detallista ${ }^{1311}$; d) designações de participantes ou membros de um grupo: asambleísta $^{1312}$, ateneísta ${ }^{1313}$, congresista ${ }^{1314}$, corista ${ }^{1315}$, cursillista $^{1316}$; em particular, membros de torcida de times de futebol: madridista ${ }^{1317}$, sevillista ${ }^{1318}$ e albacetista $^{1319}$; e pertencentes a um partido político: PSOEista $^{1320}$ e PPista ${ }^{1321}$. Na maioria dos exemplos citados anteriormente, a transparência semântica do derivado é muito relativa e isso é devido, basicamente, a duas possíveis razões: a) a base de derivação possui um significado metafórico como, por exemplo, em espadista ${ }^{1322}$ (espada $\left.{ }^{1323}\right)$, sablista ${ }^{1324}\left(\right.$ sable $\left.^{1325}\right)$, cuentista $^{1326}$ $\left(\right.$ cuento $\left.^{1327}\right)$. b) o derivado possui uma especialização semântica que foge do padrão da derivação com o sufixo, fugindo do significado da base e do sufixo, ou dos demais componentes, e não se encaixando explicitamente em possíveis paráfrases. Por exemplo: solista $^{1328}$, arreglista $^{1329}$, accionista $^{1330}$, seminarista $^{1331}$, abolicionista $^{1332}$, $^{1}$ rrorista $^{1333}$.

\footnotetext{
1301 Tradução: "expressionista".

1302 Tradução: "conceptista”, adepto do conceptismo (barroco nascido na Espanha nos séc. XVI e XVII).

1303 Tradução: "alarmista".

1304 Tradução: "encrenqueiro", provocador de brigas.

1305 Tradução: "bajulador".

1306 Tradução: "vigarista".

1307 Tradução: "farrista".

${ }^{1308}$ Tradução: "oportunista".

1309 Tradução: "caloteiro", "calotista".

1310 Tradução: "trocista".

1311 Tradução: "detalhista".

1312 Tradução: pessoa que participa de assembléia.

1313 Tradução: pessoa que estuda em ateneu.

1314 Tradução: "congressista".

1315 Tradução: "corista".

1316 Tradução: aluno de curso de curta duração.

1317 Tradução: membro da torcida do Real Madrid Club de Fútbol.

1318 Tradução: membro da torcida do Sevilla Fútbol Club.

1319 Tradução: membro da torcida do Albacete Fútbol Sala.

${ }^{1320}$ Tradução: pertencente ao PSOE - Partido Socialista Obrero Español.

1321 Tradução: pertencente ao PP - Partido Popular.

${ }^{1322}$ Tradução: ladrão que utiliza chaves falsas para abrir as casas e rouba-las.

1323 Tradução: "espada”.

1324 Tradução: "caloteiro", "calotista".

1325 Tradução: "sabre”, espada curta usada como arma.

1326 Tradução: "vigarista”.

1327 Tradução: "conto".

1328 Tradução: "solista", indivíduo que executa um solo.

1329 Tradução: indivíduo que faz um arranjo musical.

1330 Tradução: "acionista”, pessoa titular que detém ações de uma empresa.

1331 Tradução: "seminarista”, aluno de um seminário.

1332 Tradução: "abolicionista”, adepto do abolicionismo.
} 
Estudo comparativo de aspectos semânticos do sufixo -ista no português e no galego.

Já no galego, segundo LUGRís FREIRE (1931: 18), o sufixo -ista designa apenas um profissional ou agente que desempenha um ofício, ilustrado pelos seguintes exemplos: telegrafista $^{1334}$, retratista ${ }^{1335}$. Na classificação semântica dada pelo Instituto da Lengua Galega (1974: 196-197), o sufixo -ista aparece associado apenas a duas categorias: a) à categoria profissional, por exemplo: xornalista ${ }^{1336}$, dentista ${ }^{1337}$, futbolista ${ }^{1338}$; b) à categoria de adepto do que é expresso pela mesma raiz mas com o sufixo -ismo, por exemplo: budista $^{1339}$, franquista $^{1340}$, socialista ${ }^{1341}$.

Segundo Álvares, Monteagudo \& Regueira (1995: 112), no galego o sufixo -ista é semanticamente classificado como um sufixo caracterizador e como um sufixo profissional. Segundo os autores, o sufixo -ista como caracterizador, forma normalmente adjetivos, em geral a partir de bases nominais, que ressaltam alguma característica ou qualidade de uma pessoa, por exemplo: anarquista ${ }^{1342}$, franquista ${ }^{1343}$, trampista $^{1344}$. Já como um sufixo profissional, Álvares, MonTEAGUdo \& REgUEIRA (1995: 114, 120-121) afirmam que as formações a partir de -ista geralmente têm um substantivo como base e indicam cargo, emprego, profissão, título, função, ocupação; por exemplo: almacén ${ }^{1345} \rightarrow$ almacenista $^{1346}$, arte $^{1347} \rightarrow$ artista $^{1348}$, carteira $^{1349} \rightarrow$ carteirista $^{1350}$, comentario $^{1351} \rightarrow$ comentarista $^{1352}$, copia $^{1353} \rightarrow$ copista $^{1354}$, crónica $^{1355} \rightarrow$ cronista $^{1356}$, dente $^{1357} \rightarrow$ dentista $^{1358}$, ébano $^{1359} \rightarrow$

\footnotetext{
1333 Tradução: "terrorista", aquele que propaga o terror, pessoa que pratica atos de terrorismo.

1334 Tradução: "telegrafista".

1335 Tradução: "retratista".

1336 Tradução: "jornalista".

1337 Tradução: "dentista”.

1338 Tradução: "futebolista".

1339 Tradução: "budista".

1340 Tradução: “franquismo”. Adepto do regime político do espanhol Francisco Franco (1892-1975).

1341 Tradução: "socialista".

1342 Tradução: "anarquista”, adepto dos ideais da anarquia.

1343 Tradução: adepto dos ideais do Caudilho espanhol General Francisco Franco.

1344 Tradução: "trapaceiro", pessoa caracterizada por fazer trampas (trapaças).

1345 Tradução: "armazém".

1346 Tradução: "armazenista”, pessoa que trabalha em armazém.

1347 Tradução: "arte".

1348 Tradução: "artista", pessoa que trabalha com arte.

1349 Tradução: "carteira”.

1350 Tradução: "carteirista”, pessoa que furta carteiras.

1351 Tradução: "comentário”.

1352 Tradução: "comentarista", pessoa que faz/escreve comentários.

1353 Tradução: "cópia”.

1354 Tradução: “copista”, pessoa que faz cópias.

1355 Tradução: "crônica".

1356 Tradução: "cronista”, pessoa que faz/escreve crônicas.
} 
ebanista $^{1360}$ flor $^{1361} \rightarrow$ florista $^{1362}$, moda $^{1363} \rightarrow$ modista $^{1364}$, novela $^{1365} \rightarrow$ novelista $^{1366}$, oficina $^{1367} \rightarrow$ oficinista $^{1368}$, órgano $^{1369} \rightarrow$ organista $^{1370}$, piano $^{1371} \rightarrow$ pianista $^{1372}$, $^{13 \text { elefono }}{ }^{1373}$

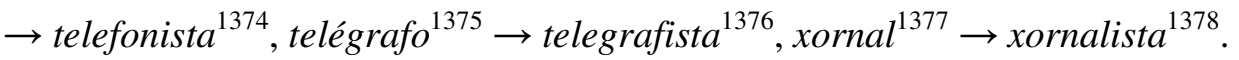

Na classificação semântica de GONZÁles REFOXo \& RÁBADE CASTIÑEIRA (1995: 48, 50), o sufixo -ista aparece como ocupacional e como um sufixo de tendências. Como sufixo ocupacional, o -ista se mostra nas formações de nomes substantivos agentivos que designam geralmente profissionais e se encaixam nas paráfrases: "pessoa que trabalha em/com X", "pessoa que pratica X" ou "pessoa que se ocupa de X"; por exemplo: armacenista ${ }^{1379}$, ciclista $^{1380}$ e maquinista ${ }^{1381}$. Como sufixo de tendências, o -ista se mostra nas formações de nomes adjetivos que caracterizam geralmente adeptos ou simpatizantes e se encaixam nas paráfrases: "pessoa adepta (ou que simpatiza com) a ideologia, a teoria, as idéias ou a doutrina X", por exemplo: cubista $^{1382}$ e budista ${ }^{1383}$.

Quanto à forma, GonZÁles ReFoxo \& RÁBADE CASTIÑEIRA (1995: 38-39, 41-42), classificam a terminação -ista como um sufixo referencial formador de nomes substantivos,

\footnotetext{
1357 Tradução: "dente”.

1358 Tradução: "dentista”, especialista no tratamento de dentes.

1359 Tradução: "ébano",

1360 Tradução: "ebanista”, pessoa que trabalha com ébano.

1361 Tradução: "flor".

1362 Tradução: "florista”, pessoa que comercializa flores.

1363 Tradução: "moda".

1364 Tradução: "modista", pessoa que trabalha com moda.

1365 Tradução: "romance".

1366 Tradução: "romancista", pessoa que faz/escreve novelas (romances).

1367 Tradução: "escritório".

1368 Tradução: pessoa que trabalha em uma oficina (escritório).

1369 Tradução: “órgão”, instrumento musical.

1370 Tradução: “organista”, pessoa que toca o instrumento musical: órgão.

1371 Tradução: "piano".

1372 Tradução: "pianista”, pessoa que toca o instrumento musical: piano.

1373 Tradução: "telefone".

1374 Tradução: "telefonista", pessoa que trabalha na operação de telefones.

1375 Tradução: "telégrafo".

1376 Tradução: "telegrafista”, pessoa que trabalha na operação de telégrafos.

1377 Tradução: “jornal”.

1378 Tradução: "jornalista”, especialista na elaboração de matérias de jornais.

1379 Tradução: pessoa que trabalha em armacén (armazém).

1380 Tradução: pessoa que pratica ciclismo.

1381 Tradução: pessoa que se ocupa da máquina do trem, responsável pela máquina do trem.

1382 Tradução: pessoa que segue ideologia artística do cubismo.

1383 Tradução: pessoa que segue a doutrina religiosa do Budismo.
} 
por exemplo: armacenista ${ }^{1384}$, pianista $^{1385}$, xornalista ${ }^{1386}$; e formador de nomes adjetivos, por exemplo: federalista ${ }^{1387}$, paulista $^{1388}$, vanguardista $^{1389}$.

GONZÁLEZ FERNÁNDEZ (1976: 240-241) classifica semanticamente as formações do sufixo -ista em três tipos. O primeiro tipo designa indivíduos adeptos, simpatizantes ou membros, de seitas, doutrinas ou sistemas, por exemplo: absolutista ${ }^{1390}$, aislacionista $^{1391}$, aperturista $^{1392}$, ateista $^{1393}$, autonomista $^{1394}$, budista $^{1395}$, alvinista $^{1396}$, arlista $^{1397}$, celtista $^{1398}$, comunista $^{1399}$, darvinista ${ }^{1400}$, evanxelista ${ }^{1401}$, falanxista ${ }^{1402}$, fascista ${ }^{1403}$, federalista ${ }^{1404}$,

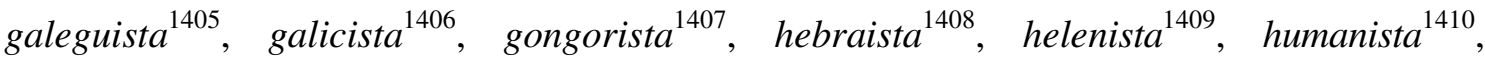
iluminista $^{1411}$, imperialista ${ }^{1412}$, izquierdista ${ }^{1413}$, kantista ${ }^{1414}$, laborista ${ }^{1415}$, maoista ${ }^{1416}$, materialista $^{1417}$, modernista ${ }^{1418}$, monopolista ${ }^{1419}$, naturalista $^{1420}$, nominalista $^{1421}$,

\footnotetext{
1384 Tradução: "armazenista”.

1385 Tradução: "pianista”.

1386 Tradução: "jornalista".

1387 Tradução: "federalista".

1388 Tradução: "paulista”, originário do estado de São Paulo, no Brasil.

1389 Tradução: "vanguardista".

1390 Tradução: "absolutista".

1391 Tradução: "isolacionista".

1392 Tradução: "aberturista”.

1393 Tradução: "ateísta”.

1394 Tradução: "autonomista".

1395 Tradução: "budista".

1396 Tradução: "calvinista".

1397 Tradução: “carlista”, adepto do sistema que apoiava D. Carlos de Borbón (1788-1855), da Espanha.

1398 Tradução: membro da torcida do time de futebol galego do Real Club Celta de Vigo,

1399 Tradução: "comunista".

1400 Tradução: "darwinista”.

1401 Tradução: "evangelista".

1402 Tradução: membro ou adepto da Falange espanhola (partido fascista espanhol).

1403 Tradução: "fascista".

1404 Tradução: "federalista".

1405 Tradução: indivíduo que utiliza galeguismos. Adepto dos ideais que representam os interesses e direitos relativos à Galiza. Especialista em cultura galega.

1406 Tradução: "galicista".

1407 Tradução: "gongorista”.

1408 Tradução: "hebraísta".

1409 Tradução: "helenista".

1410 Tradução: "humanista".

1411 Tradução: "iluminista".

1412 Tradução: "imperialista".

1413 Tradução: "esquerdista”.

1414 Tradução: "kantista".

1415 Tradução: "laborista".

1416 Tradução: "maoísta".

1417 Tradução: "materialista".

1418 Tradução: "modernista".

1419 Tradução: "monopolista”.
} 
positivista $^{1422}$, racista $^{1423}$, realista $^{1424}$, romanticista ${ }^{1425}$, simbolista $^{1426}$, socialista $^{1427}$, sofista ${ }^{1428}$, triunfalista ${ }^{1429}$. O segundo tipo designa indivíduos com determinada profissão, ofício ou ocupação, por exemplo: almacenista ${ }^{1430}$, artista $^{1431}$, callista $^{1432}$, $_{\text {cambista }}{ }^{1433}$, coplista $^{1434}$, cronista $^{1435}$, cupletista $^{1436}$, electricista ${ }^{1437}$, estadista ${ }^{1438}$, fabulista $^{1439}$, guitarrista $^{1440}$, maquinista ${ }^{1441}$, marmolista ${ }^{1442}$, modista $^{1443}$, novelista ${ }^{144}$, oficinista $^{1445}$, organista $^{1446}$, perfumista ${ }^{1447}$, pianista ${ }^{1448}$, proverbista $^{1449}$, tallista $^{1450}$, telefonista ${ }^{1451}$, telegrafista $^{1452}$, xornalista ${ }^{1453}$. Ao terceiro tipo pertencem os qualificativos, ou seja, adjetivos caracterizadores ou relativos à base, por exemplo: cerealista ${ }^{1454}$, egoista ${ }^{1455}$, optimista $^{1456}$, partidista $^{1457}$, palabrista $^{1458}$, pensionista $^{1459}$, rentista $^{1460}$, velocista $^{1461}$.

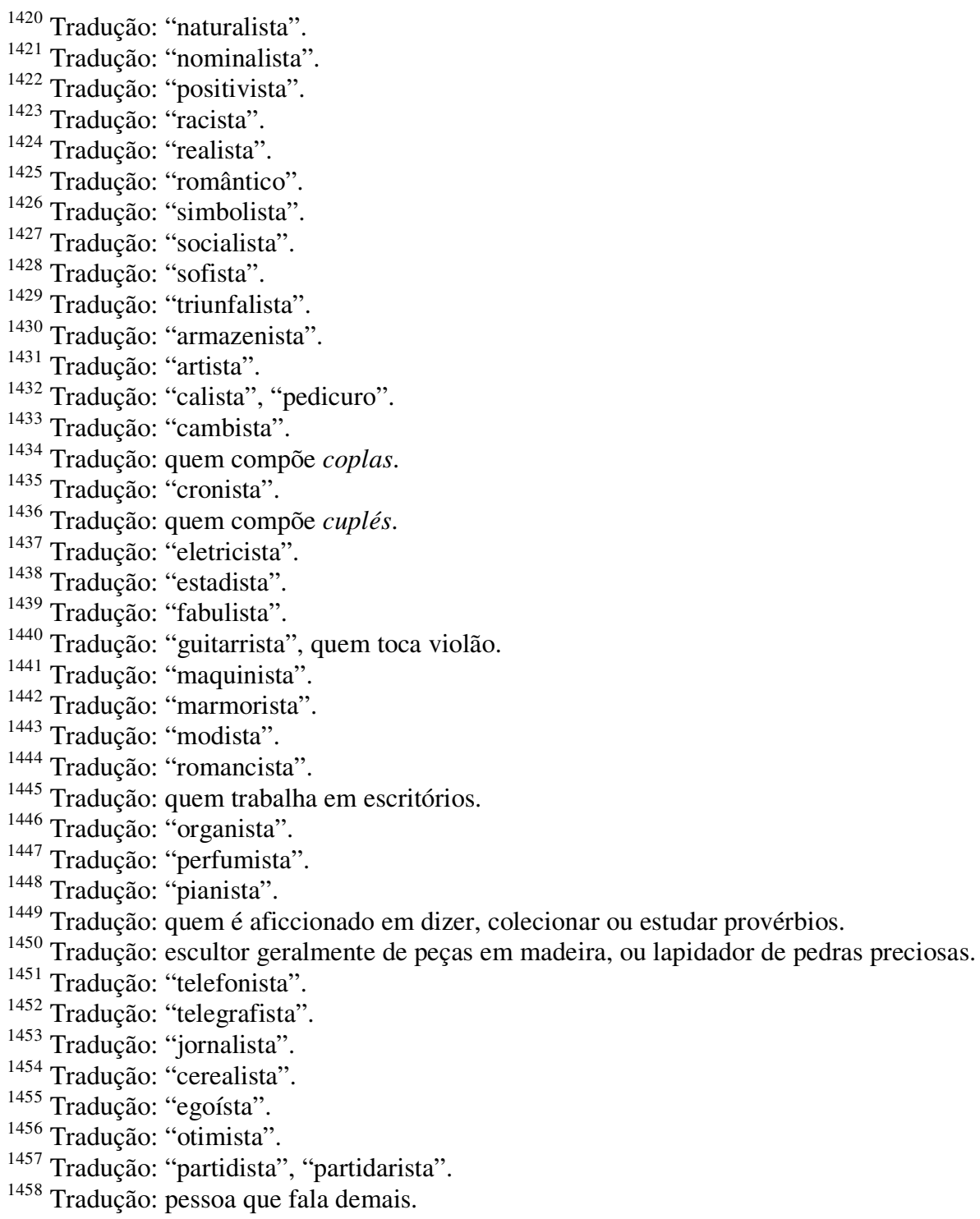


Na classificação de FreiXeIRo MATO (1999: 225-226, 229-232), o sufixo -ista pode ser um formador de substantivos a partir de substantivos com a designação de "ocupação profissional”, por exemplo: dentista (dente) $)^{1462}$ e pianista (piano) ${ }^{1463}$. Entretanto, segundo o autor, sua principal função é a formar adjetivos a partir de substantivos, com a designação de adepto de tendências ideológicas, artísticas ou doutrinárias, por exemplo: castrista (Fidel Castro) $)^{1464}$ e vangardista (vangarda) ${ }^{1465}$; ou ainda com a designação gentílica, por exemplo: paulista $^{1466}$.

Já, Segundo Ferreiro (2001: 156), o sufixo -ista forma adjetivos facilmente substantiváveis, geralmente, a partir de bases nominais, entretanto também pode forma-los a partir de bases verbais, por exemplo: arrendar ${ }^{1467} \rightarrow$ arrendista $^{1468}$. Conforme o autor, as formações com -ista podem significar: "ocupação", "profissão" ou "ofício", casos nos quais a maioria dos adjetivos já está consolidada na forma substantiva, por exemplo: accionista $(\text { acción }+-i s t a)^{1469}$, conferencista $(\text { conferencia }+-i \text { sta })^{1470}$, estadista $(\text { estado }+-i s t a)^{1471}$, latinista $(\text { latin }+-i \text { sta })^{1472}$. As formações com $-i s t a$, podem também significar "adeptos de doutrinas ou sistemas políticos, filosóficos, artísticos e/ou religiosos"; e nestes casos, há uma relação paradigmática com o sufixo -ismo, por exemplo: comunista (común $+-i s t a$,

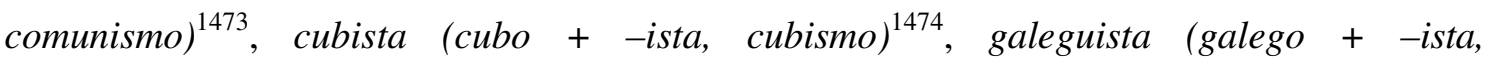

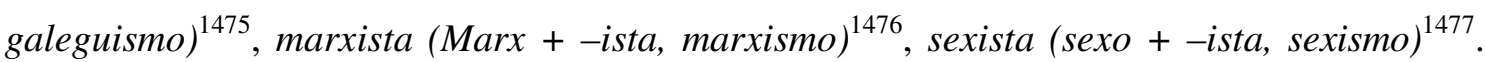
Segundo o autor, os adjetivos com -ista que simplesmente apresentam a noção mais geral de

\footnotetext{
1459 Tradução: "pensionista".

1460 Tradução: "rentista".

1461 Tradução: "velocista".

1462 Tradução: "dentista (dente)".

1463 Tradução: "pianista (piano)".

1464 Tradução: "castrista (Fidel Castro)".

1465 Tradução: "vanguardista (vanguarda)".

1466 Tradução: "pualista”, natural ou habitante do Estado de São Paulo - Brasil.

1467 Tradução: "arrendar".

1468 Tradução: “arrendador", "locador".

1469 Tradução: "acionista (ação + -ista)".

1470 Tradução: "conferencista (conferência + -ista)".

1471 Tradução: "estadista (estado + -ista)".

1472 Tradução: "latinista (latim + -ista)".

1473 Tradução: "comunista (comum $+-i$ sta, comunismo)".

1474 Tradução: "cubista (cubo + -ista, cubismo)".

1475 Tradução: "galeguista (galego + -ista, galeguismo)", indivíduo que utiliza galeguismos.

1476 Tradução: "marxista (Marx + -ista, marxismo)".

1477 Tradução: "sexista (sexo + -ista, sexismo)".
} 
"relativo a" ou "próprio de"; por exemplo: bolsista $(\text { bolsa }+-i \text { ista })^{1478}$, faunista (fauna + $i s t a)^{1479}$, paisaxista (paisaxe $\left.+-i s t a\right)^{1480}$; são escassos na língua galega, pois é preferida a formação multissufixal com -ístico $(-i s t a+-i c o)$, tais como: bolsístico $(a)^{1481}$, faunístico $(a)^{1482}$, paisaxístico $(a)^{1483}$. Por outro lado, o autor ressalta que os gentílicos que apresentam o sufixo -ista em galego são empréstimos do português brasileiro, por exemplo: paulista $^{1484}$ e santista ${ }^{1485}$.

Na língua Portuguesa, de acordo com SAndmann (1989: 45), -ista é um sufixo muito produtivo, prestando-se às mais variadas funções substantivas e adjetivas. Em seu corpus de pesquisa encontrou 49 formações novas com o sufixo, ressaltando que alguns exemplos ocorrem com maior frequiência na função adjetiva: liquidacionista e exclusivista; enquanto outros exemplos destacam-se mais na função substantiva: aparista e pratista; entretanto, a maioria pode desempenhar ambas as funções: os europeístas brasileiros e a política europeísta. Segundo BASílio (2004: 61-62) a conversão de adjetivos em substantivos é bastante comum na língua portuguesa, pois o adjetivo tem função de caracterizar, enquanto o substantivo tem a função de designar, e uma maneira eficiente de designar é por meio da caracterização. Além disso, BASílio (2006: 79-92) afirma que há mecanismos de mútua conversão entre as duas classes, assim como a possibilidade de extensão de propriedades de uma classe para a outra, tornando a classificação e a distinção entre adjetivos e substantivos tênue e complexa.

No corpus de pesquisa, SANDMANN (1989: 43-45) afirma ter encontrado vários tipos de significações semânticas para as formações com -ista e destaca seis delas. Dessa maneira, com o significado de "profissional" ou "ocupação", apresenta como exemplos extraídos de seu corpus: aparista ${ }^{1486}$, pratista $^{1487}$ e quadrinista ${ }^{1488}$. Com o significado de "especialista",

\footnotetext{
1478 Tradução: "bolsista (bolsa $+-i s t a)$ ".

1479 Tradução: "fauniano".

1480 Tradução: "paisagista (paisagem + -ista)".

1481 Tradução: "relativo à bolsa de estudos".

1482 Tradução: "faunístico(a)".

1483 Tradução: "paisagístico(a)".

1484 Tradução: "paulista", natural ou habitante do Estado de São Paulo - Brasil.

1485 Tradução: "santista”, natural ou habitante da cidade de Santos - Brasil.

1486 Comerciante ou coletor de aparas.

${ }^{1487}$ Músico que toca pratos, fabricante ou comerciante de produtos em prata.

${ }^{1488}$ Autor de histórias em quadrinhos.
} 
apresenta a palavra brasilianista ${ }^{1489}$. Com o significado geral de "adepto de uma doutrina ou orientação política, sociológica, literária ou filosófica", apresenta como exemplos extraídos do corpus: bom-mocista ${ }^{1490}$, clientelista, desenvolvimentista, detalhista, diretista ${ }^{1491}$, emancipacionista, emendista, europeísta, historicista, indiretista ${ }^{1492}$, preservacionista, prorrogacionista $^{1493}$, reducionista ${ }^{1494}$, tenentista. Com o significado de "seguidor ou simpatizante de um político", ilustra com os seguintes exemplos: amaralista, andreazzista, aurelianista, castilhista, gonzaguista, macielista, malufista, robertista, tancredista, virgilista. Com o significado de "membro de um partido político", expõe os seguintes exemplos do corpus: frentista (Frente Liberal), pedessista (PDS), pedetista (PDT), peemedebista (PMDB), pessedista (PSD), petista (PT). Com o significado de "fã de um clube esportivo", apresenta como exemplos do corpus: gremista (Grêmio de Futebol Porto-Alegrense) e flamenguista (Clube de Regatas Flamengo).

Conforme VILELA (1994: 76), o sufixo -ista é muito freqüente e abrange as mais variadas áreas da realidade extralingüística na formação de nomes agentivos, por exemplo, em: criminologista, tenista, malabarista, dentista, garagista, recepcionista, dermatologista, filatelista. Assim, o afixo -ista orienta a base semanticamente para designar o agente desde as profissões: dentista, ascensorista; as atividades: ciclista, ocultista; até nas opiniões e/ou ideologias: comunista, darwinista, budista.

Segundo Miranda (1980: 62), atualmente, o processo morfológico de formação de agentivos por meio de derivação com o sufixo -ista é altamente produtivo, no entanto a formação com este sufixo aparentemente mostra-se de grande opacidade, tanto semântica quanto funcional. Em seu trabalho, MiRANDA (1980: 62-63), em lugar de considerar a formação de agentivos com -ista como uma operação única, estabelece dois processos morfológicos distintos, na tentativa de tornar a formação com o sufixo mais transparente, ainda que a característica comum dos agentivos formados seja apresentar sempre o traço [+humano].

\footnotetext{
${ }^{1489}$ Empréstimo do inglês brazilianist que significa "especialista em assuntos do Brasil", nos EUA.

1490 Segundo o Aurélio, apud Sandmann (1989:44), bom-moço significa “indivíduo hipócrita" ou "fingidor", daí bom-mocismo significa "hipocrisia" ou "fingimento".

1491 Adepto das eleições diretas.

1492 Adepto das eleições indiretas.

1493 Adepto do prolongamento do mandato do Presidente João Figueiredo.

${ }^{1494}$ Adepto do mandato presidencial mais breve.
} 
Dessa maneira, MiRANDA (1980: 63-66) divide as formações agentivas com -ista em dois grandes grupos. O primeiro grupo é composto por agentivos que podem funcionar como substantivos ou adjetivos, que se incluem em uma relação paradigmática geral: X-ista / Xismo, trazendo um sentido de "partidarismo", "adesão" e podem ser descritos pelas seguintes paráfrases: "adepto de X-ismo", para os substantivos e "relativo a X-ismo" para os adjetivos. Por exemplo: absolutista / absolutismo, simbolista / simbolismo, futurista / futurismo, marxista / marxismo, getulista / getulismo. Neste caso, as bases, adjetivos ou substantivos, são marcadas pelos traços: $[-$ concreto $],[-$ comum $]$, segundo a autora.

Já o segundo grupo é composto por agentivos que somente podem funcionar como substantivos e traz o sentido de "ocupação", "ofício", "profissão". No entanto é um grupo mais complexo, pois a paráfrase proposta pela autora: "especialista em X", cobre apenas uma parte do grupo, em geral, a que se inclui em uma relação paradigmática: X-ista / X-ia, por exemplo: neurologista e neurologia, meteorologista e meteorologia, oceanografista e oceanografia, economista e economia, ortopedista e ortopedia. Outros agentivos, entretanto, apresentam especificações de sentido decorrentes de características sintático-semânticas de suas bases, ainda que o sentido geral de "ocupação", "ofício", "profissão" seja mantido, por exemplo: pianista é "aquele que toca piano", tratorista é "aquele que dirige o trator", tenista é "aquele que joga tênis", romancista é "aquele que escreve romances", figurinista é "aquele que desenha figurinos". Neste caso, segundo a autora, as bases, que são substantivos, estão marcadas pelos traços: $[+$ concreto $]$ ou $\left[[- \text { concreto }]^{\wedge}[+\right.$ especialidade $\left.]\right]$.

No entanto, a complexidade das formações com -ista é tal que o estudo oferecido pela autora não abrange casos como: manobrista é "aquele que manobra carros", recepcionista é "aquele que recebe as pessoas", veranista é "aquele que veraneia", fumista é "aquele que fuma", nos quais a base é um verbo, já que, segundo CASEVITZ (1985: 69), originalmente o sufixo era usado para formar nomes de agentes a partir de bases verbais na língua grega. Além disso, o estudo não contempla agentes que não pertençam aos dois grupos da divisão proposta, ou seja, não estão associados ao sufixo -ismo e tampouco designam "profissão" ou "ocupação", tais como: asneirista é "aquele que diz muitas asneiras", badernista é "aquele que faz muita baderna", vegetarista é "aquele que só come vegetais". Ademais, seu trabalho centra-se em agentivos, excluindo também outros casos como: caturrista é "aquele que é muito caturra", catonista é "aquele que é muito catão", clarista é "o religioso que pertence à 
ordem de Santa Clara", petista é "aquele que pertence ao PT (Partido dos Trabalhadores)"; assim como as formações gentílicas com -ista, por exemplo: sulista, paulista, santista; que, segundo MIRANDA (1980:101), são improdutivas na língua portuguesa.

Centrando-se também em agentivos está a classificação das formações com -ista dada por BASÍLIO (2006: 74), segundo a qual há basicamente três tipos: agentividade plena, agentividade indireta e agentividade mental ou abstrata. Assim, os agentes plenos são as formações com -ista caracterizadas pela sua base, ou seja, o agente tem relação direta com o nome designado pela base e a utiliza (a faz) designando a sua função agentiva. Por exemplo: flautista é aquele que toca flauta, futebolista é aquele que joga futebol, tratorista é aquele que dirige o trator, sambista é aquele que faz sambas, contista é aquele que escreve contos, florista é aquele que vende flores, perfumista é aquele que fabrica perfumes. No segundo caso, na agentividade indireta, a base designa entidades passíveis de estudo ou especializações e os agentes indiretos, ou seja, as formações com -ista designam indivíduos como especialistas nas entidades. Por exemplo: economista é um especialista em economia, dermatologista é um especialista em dermatologia, lingüista é um especialista em estudos das línguas, hebraísta é um especialista em hebraico. No último caso da classificação, o agente é definido apenas pela sua atitude mental de adesão, ou seja, nesse tipo de formação, a construção com -ista designa um ser caracterizado por sua adesão ao conceito denotado ou sugerido pela base, que pode ser tanto a sigla de um partido como um nome próprio, um substantivo abstrato; representando um dado conceito ou posição teórica, ideológica, religiosa; como objeto de adesão mental. Segundo BASÍlıO (2006: 76): “em alguns casos, essas formações se baseiam em conceitos expressos por bases adjetivas ou verbais, envolvendo, portanto, mudança de classe. Isso ocorre porque, nestas formações, o relevante é o conceito, não importando a classe da base". Por exemplo: PT - petista, Marx - Marxista, estrutural - estruturalista, continuar - continuista, evolução - evolucionista. Entretanto, a complexidade das formações com o sufixo é tal que a fronteira entre os três tipos descritos pela autora pode ser tênue, como é ilustrado em: Cervantes - cervantista, Camões camonista, nos quais as formações com -ista não indicam seres caracterizados pela adesão ao conceito denotado ou sugerido pela base, como nos exemplos de adesão mental: Marx marxista e Darwin - darwinista; mas indicam "o estudioso da obra de", ou seja, um cervantista é um estudioso da obra de Cervantes, analogamente um camonista é um estudioso 
da obra de Camões. Além disso, existem formações com -ista cuja base é obscura, por exemplo: ciclista; no entanto, a idéia semântica de agente é transmitida pelo sufixo derivacional.

Pode-se notar, então, que as opiniões dos gramáticos e dos lingüistas especificamente sobre o sufixo divergem em alguns pontos. A respeito do tema, SAID ALI (1930: 20) afirma que o sufixo -ista, atualmente na língua portuguesa, se mostra como formador de palavras com as seguintes noções semânticas: a) adeptos de doutrinas e sistemas cujos nomes são formados a partir de sufixação com -ismo; b) indivíduos cuja ocupação se relaciona com o objeto a que se refere o termo derivante. Segundo CÂMARA JR. (1975: 221) o sufixo -ista é do tipo que designa proveniência de uma dada região ou pessoas caracterizadas por suas atividades sociais, ou seja, "deriva de preferência nomes relacionados a uma atividade artística ou científica (violinista, cientista, psicologista) e ainda nomes gentílicos (no Brasil, Campista: referente à cidade de Campos) como uma variante, já não mais produtiva: -it(a) (jesuíta: de Jesus; cenobita: de Cenóbio)”. De acordo com BASílio (2006: 74), os agentivos em -ista são classificados em três grupos que: a) expressam agentividade direta caracterizada pela base: artista, pianista; b) apresentam agentividade indireta; a base designa entidades passíveis de estudo, prática ou especialização; daí o sufixo designa indivíduos como especialistas, teóricos ou práticos, em relação ao elemento especificado na base: anestesista, lingüista, oculista; c) apresentam agentividade abstrata e mental, especificada apenas em termos de adesão: darwinista, petista, espiritualista, evolucionista. Já, MiRANDA (1980: 6366) divide as formações agentivas com -ista em dois grupos: a) as que designam adeptos e se encaixam na paráfrase "adepto de X-ismo" para os substantivos e "relativo a X-ismo" para os adjetivos; b) as que designam agente profissional ou ocupacional e se encaixam na paráfrase “especialista em X”. Para SANDMANN (1989: 43-46), atualmente no português brasileiro o sufixo -ista se tem mostrado bastante produtivo na formação de nomes que, na maioria das vezes, podem desempenhar a função adjetiva ou substantiva, e cuja base de derivação é, em geral, um substantivo. Conforme observação em corpus, o autor oferece a seguinte classificação semântica: a) emprego ou ocupação; b) especialista; c) adepto de uma doutrina ou orientação política, sociológica, literária ou filosófica; d) seguidor ou simpatizante de um político; e) membro de um partido; f) fã de um clube esportivo. 
No HouAISS (2001), dicionário da língua portuguesa, indica-se que o sufixo -ista é um formador de substantivos dos dois gêneros (masculino e feminino) com a função semântica, associada ao sufixo -ismo, de designar o adepto, aderente, seguidor, ou partidário. Segundo o dicionário Melhoramentos (1963), o sufixo apresenta a idéia de agente (balconista, dicionarista, propagandista), ou de adepto de sistema filosófico, religioso ou político (budista, integralista, kantista). No dicionário Aurélio (1999) aparece a seguinte classificação semântica do sufixo -ista: a) adepto ou sectário de doutrina, escola, seita, teoria ou princípio artístico, filosófico, político ou religioso, por exemplo: budista, classicista, socialista, moralista; b) que pratica certo ofício ou que tem certa ocupação, por exemplo: balconista, cinegrafista, eletricista; c) especialista, por exemplo: alergista, pneumologista; d) que toca certo instrumento musical, geralmente com talento e/ou dedicação, por exemplo: organista, violinista; e) que pratica determinada modalidade ou tem certo hábito, ou conduta, por exemplo: boxista, enxadrista, blefista, calculista, cigarrista; f) aluno (de determinado ano escolar), por exemplo: primeiranista, terceiranista; g) nomes gentílicos, por exemplo: paulista, sulista. No dicionário da WIKIPEDIA (2006) parece uma divisão em quatro classes: a) quem segue um princípio, por exemplo: budista, comunista; b) quem é estudioso ou profissional de um assunto, por exemplo: latinista, cientista; c) quem usa algo: flautista, maquinista; d) quem tem uma visão preconceituosa: racista, sexista.

Quanto à forma relativa ao gênero, o sufixo -ista é bem peculiar, apresenta difenciação no russo, polonês, alemão, valenciano e italiano popular, bem como no castelhano popular; característica essa que já se apresentava no grego e no latim. Na língua inglesa, cuja estrutura já não dá margem a tal diferenciação, o sufixo não apresenta formas distintas para os gêneros. Entretanto, é pelo menos curioso que tal diferenciação não se dê nas línguas francesa, catalã, galega normativa, portuguesa e castelhana normativa, pois os demais concorrentes do sufixo -ista, na formação de nomes agentivos ou adjetivos nestas línguas destacam os gêneros masculino e feminino. A título ilustrativo, é interessante notar que na língua galega e portuguesa dos séculos XII e XIII, o sufixo -or, proveniente do latim e, atualmente, um dos principais concorrentes do sufixo -ista na formação de agentes, também, na maioria dos casos, não possuía distinção para a forma feminina, porém com a sua alta produtividade e sua popularização acabou por formar essa distinção, em muitos dos casos, em - ora. Como se sabe, o sufixo -ista é mais moderno em relação à sua produtividade, que se 
refere aos séculos XIX e XX no português e no galego. Eventualmente, com sua popularização crescente e alta produtividade, poderá se desenvolver tal diferenciação, assim como no italiano e castelhano populares a diferença entre os gêneros já aparece.

Também, pode-se constatar depois dessas descrições do sufixo -ista que, a maioria dos dicionários ou gramáticas das línguas consultadas apresentam os mais diversos critérios para a classificação das palavras formadas por meio da derivação com o sufixo em estudo, ou seja, alguns autores utilizam critérios morfológicos; outros critérios semânticos e outros, ainda, uma combinação de critérios, mas não há uma classificação única. Observou-se que, de maneira geral, o sufixo -ista forma nomes agentivos com característica muito humana. Notou-se também que, a maioria dos casos converge para uma classificação semântica genérica, na qual, distinguem-se dois grandes grupos: 1) formador de nomes de profissões e ocupações; 2) formador de nomes de adeptos a ideologias cujos nomes provêm da derivação com o sufixo -ismo.

Ao pesquisar as palavras em dicionários, pode-se refinar um pouco mais a classificação geralmente encontrada e propor, ainda de forma bastante ampla e genérica, a seguinte classificação para o sufixo -ista:

1. Formador de agentividade direta e indireta, segundo classificação de BASíLIO (2006: 74). Por exemplo, no inglês: copyist ${ }^{1495}$; no alemão: Modistin $^{1496}$, no hebraico: no basco: terrorista ${ }^{1498}$.

1.1. Profissional que dirige ou opera determinado equipamento. Por exemplo, no russo: машинист ${ }^{1499}$ е машинистка ${ }^{1500}$; no catalão: escuterista ${ }^{1501}$.

1.2. No âmbito da música em geral. Por exemplo, no italiano: solista ${ }^{1502}$; no castelhano: arreglista $^{1503}$.

\footnotetext{
1495 Tradução: "copista”.

1496 Tradução: "modista”, só aparece na forma feminina.

1497 Tradução: "pedicuro". Transliteração: pedikurist.

1498 Tradução: "terrorista".

1499 Tradução: “maquinista”. Transliteração: mashinist.

1500 Tradução: "datilógrafa”. Transliteração: mashinistka.

1501 Tradução: condutor de scooter.

1502 Tradução: "solista".

1503 Tradução: quem faz arranjos musicais.
} 
1.2.1. Músico que toca determinado instrumento. Por exemplo, no polonês: wiolonczelista e wiolonczelistka ${ }^{1504}$; no russo: гumapucm $^{1505}$ е гитаристка ${ }^{1506}$.

1.3. No âmbito dos jogos e esportes em geral. Por exemplo, no valenciano: deportiste e deportista $^{1507}$ e no catalão: centrocampista ${ }^{1508}$.

1.3.1. Jogador de determinada modalidade lúdico-esportiva. Por exemplo, no italiano: calcista $^{1509}$; no polonês: tenista e tenistka ${ }^{1510}$.

1.4. No âmbito artístico em geral. Por exemplo, no português: trapezista e contorsionista.

1.4.1.1.Escritor de determinado gênero. Por exemplo, no inglês: novelist ${ }^{1511}$; no castelhano: cuentista $^{1512}$.

1.5. Profissional especializado em:

1.5.1. Ciências Biológicas. Por exemplo, em inglês: biologist ${ }^{1513}$.

1.5.1.1. Medicina. Por exemplo: em francês: dermatologiste ${ }^{1514}$.

1.5.2. Ciências Exatas. Por exemplo, em inglês: physicist ${ }^{1515}$.

1.5.3. Ciências Humanas. Por exemplo, em russo: лингвист ${ }^{1516}$ е лингвистка ${ }^{1517}$; em francês: hebraïste ${ }^{1518}$.

1.5.4. Determinado período histórico. Por exemplo, no italiano: cinquecentista $^{1519}$; no castelhano: ochocentista ${ }^{1520}$.

1.6. Outros agentivos. Por exemplo, no castelhano: fumista ${ }^{1521}$.

1504 Tradução: “violoncelista", nas formas masculina e feminina, respectivamente.

1505 Tradução: "guitarrista", quem toca violão (masculino). Transliteração: gitarist.

1506 Tradução: "guitarrista”, quem toca violão (feminino). Transliteração: gitaristka.

1507 Tradução: "esportista”, nas formas masculina e feminina, respectivamente.

1508 Tradução: "centro-campista".

1509 Tradução: jogador de futebol.

${ }^{1510}$ Tradução: "tenista", nas formas masculina e feminina, respectivamente.

1511 Tradução: escritor de romances.

1512 Tradução: escritor de contos.

1513 Tradução: "biólogo".

1514 Tradução: "dermatologista", médico especializado em dermatologia.

1515 Tradução: "físico".

1516 Tradução: "lingüista" (masculino). Transliteração: lingvist.

1517 Tradução: "lingüista" (feminino). Transliteração: lingvistka.

1518 Tradução: "hebraísta”, especialista na língua hebraica.

1519 Tradução: "quinhentista".

1520 Tradução: "oitocentista". 
2. Formador de nomes que designam adesão mental, segundo classificação dada por BASÍLIO (2006: 74), ou seja, adeptos de ideologias cujos nomes podem ou não ser provenientes de derivação com o sufixo -ismo. Por exemplo, em russo: ленинист ${ }^{1522}$ е ленинистка ${ }^{1523}$.

2.1. No âmbito da religião. Por exemplo, em polonês: buddysta e buddystka ${ }^{1524}$; em inglês: brahmanist ${ }^{1525}$.

2.2. No âmbito artístico. Por exemplo, em basco: kubista ${ }^{1526}$; em hebraico: סוריאליסט

2.3. No âmbito político. Por exemplo, em alemão: Anarchist e Anarchistin ${ }^{1528}$; em inglês: blairist $^{1529}$.

2.4. No âmbito científico e filosófico. Por exemplo, no francês: évolutionniste ${ }^{1530}$; no polonês: darwinista e darwinistka ${ }^{1531}$.

2.5. No âmbito comportamental e de movimentos sociais. Por exemplo, em castelhano: marxista ${ }^{1532}$; em galego: feminista ${ }^{1533}$.

2.6. No âmbito da discriminação. Por exemplo, em alemão: Rassist e Rassistin ${ }^{1534}$; no francês: âgiste ${ }^{1535}$.

3. Formador de nomes que dão a noção de pertinência em geral

3.1. Gentílicos. Por exemplo, no português: paulista.

3.2. Partidos políticos. Por exemplo, no castelhano: PSOEista ${ }^{1536}$.

3.3. Entidades e associações. Por exemplo, em francês: sorbonniste ${ }^{1537}$.

1521 Tradução: "fumante".

1522 Tradução: "leninista" (masculino). Transliteração: leninist.

${ }^{1523}$ Tradução: "leninista" (feminino). Transliteração: leninistka.

1524 Tradução: "budista”, nas formas masculina e feminina, respectivamente.

1525 Tradução: "bramanista".

1526 Tradução: "cubista”.

1527 Tradução: "surrealista”. Transliteração: sureialist.

1528 Tradução: "anarquista", nas formas masculina e feminina, respectivamente.

${ }^{1529}$ Tradução: adepto dos princípios do primeiro ministro inglês Tony Blair.

1530 Tradução: "evolucionista".

1531 Tradução: "darwinista", nas formas masculina e feminina, respectivamente.

1532 Tradução: "marxista".

1533 Tradução: "feminista".

1534 Tradução: "racista", nas formas masculina e feminina, respectivamente.

1535 Tradução: quem faz discriminação fundamentada na idade.

1536 Tradução: pertencente ao PSOE - Partido Socialista Obrero Español.

1537 Tradução: Segundo o dicionário Houaiss, "sorbonista” designa o estudante da Universidade de Sourbonne. 
3.4. Torcidas de times esportivos. Por exemplo, no catalão: barcelonista $^{1538}$.

4. Formador de nomes qualificativos, ou seja, que identificam, caracterizam e qualificam em geral com valores físicos, morais, psíquicos e/ou de conduta. Por exemplo, em português: egoísta e caturrista, em castelhano: pancista $^{1539}$.

Convém notar que nem todas as línguas nas quais o sufixo -ista se manifesta terá presente todas as categorias da classificação, pois normalmente outros mecanismos da língua poderão supri-las. Entretanto, apesar da generalidade da classificação, casos de ocorrências de novas formações com -ista são por ela cobertos, pois, em geral, a produtividade do sufixo se dá nas áreas semânticas mais comuns. Por exemplo, o vocábulo espanhol muychiquitista inventado pela protagonista Mafalda na vinheta argentina de Quino (figura 3.1), encaixa-se na categoria de formador de nomes que designam adesão mental, ainda que tal palavra não seja encontrada em dicionários.
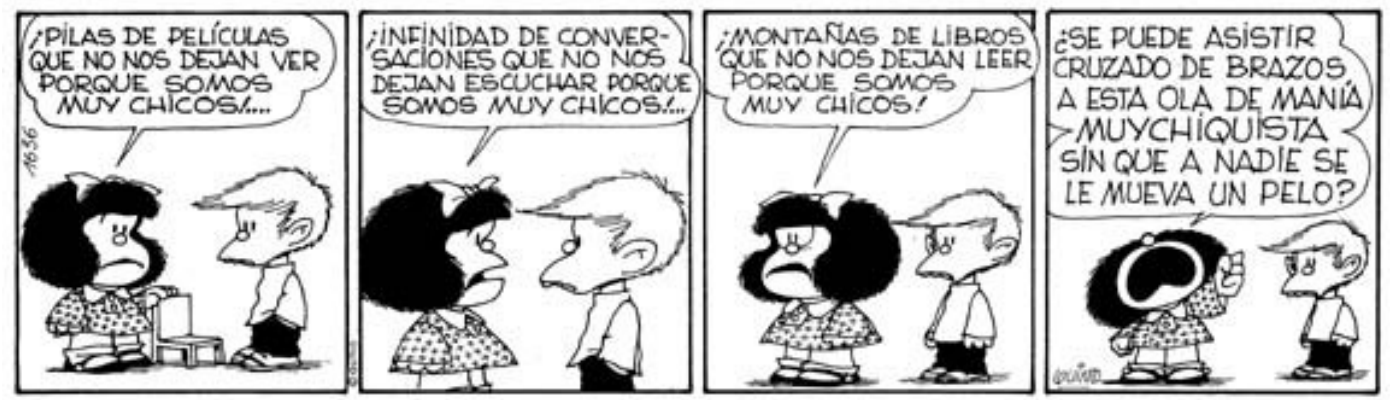

Figura 3.1. Mafalda e o sufixo -ista.

É interessante notar também que, ao se fazer um estudo um pouco mais detalhado sobre as palavras formadas pelo sufixo -ista, em algumas línguas pode-se encontrar uma variedade semântica bem mais diversa e complexa que a apontada apenas por essa classificação, é o caso dos estudos franceses, italianos, catalães, castelhanos, galegos e da língua portuguesa, supracitados.

\footnotetext{
1538 Tradução: membro da torcida do time Fútbol Club Barcelona.

1539 Tradução: quem só pensa em obter vantagens imediatas.
} 


\section{Nunca me esquecerei que no meio do caminho tinha uma pedra tinha uma pedra no meio do caminho no meio do caminho tinha uma pedra.}

(Carlos Drummond de Andrade) 


\section{Ocorrências do sufixo -ista em corpora}

Inicialmente, para fazer o estudo das ocorrências de formações com o sufixo -ista, foi feito um levantamento de textos de cada período para cada caso a ser analisado de forma comparativa: no português de Portugal, no do Brasil e no galego. Dos textos recolhidos foram extraídas todas as palavras formadas por meio do processo de sufixação com -ista, obtendo-se para cada período, uma lista de palavras; que são os dados pertinentes usados no estudo das formações com o sufixo em corpora.

Entretanto, na pesquisa de ocorrências do sufixo -ista, para o período do século XII ao século $\mathrm{XV}$, da formação do galego-português e dos grandes processos de transformação das línguas estudadas, não se usou distinção entre o português e o galego, pois, devido à escassez de formações com o sufixo no período, não foi possível dividir entre os textos da Galiza e os de Portugal. Convém ressaltar que além do sufixo -ista, cujas ocorrências nesse período são muito raras, anotaram-se também as poucas ocorrências do sufixo -ismo no mesmo período, pois, segundo SAID ALI (1930: 20) e FERREIRO (2001: 132-133), um sufixo está paradigmaticamente ao outro associado. Na língua portuguesa, do século XV ao século XVIII, também não foi feita distinção entre as formas brasileira e lusitana, pois as ocorrências de palavras formadas com o sufixo em questão mostraram-se tímidas. Convém notar, ainda, que no galego ocorre uma quebra da sequiência temporal durante os Séculos Escuros, finais da Idade Média (século XV) até o começo do século XIX, no qual a língua manteve-se praticamente na forma oral, portanto as pouquíssimas obras escritas à disposição foram analisadas sem que fosse encontrada uma única ocorrência de formações com o sufixo -ista.

Já nos séculos XIX e XX, abundam textos, bem como o número de ocorrências com o sufixo é significativa e pôde-se analisar separadamente no galego, no português brasileiro e no português europeu. Para cada período e língua, foram analisados por volta de trinta e cinco obras, dividas nos gêneros: prosa, poesia e teatro. Para o século XX colocou-se a título de ilustração uma única publicação de jornal, para a constatação da presença de formações com ista na prosa jornalística representativa de cada local: Galicia Hoxe (Santiago de Compostela) como representante do galego; O Correio da Manhã (Lisboa) como representante do português lusitano e $O$ Estado de São Paulo como representante do português brasileiro. Assim, foram analisadas as ocorrências das palavras formadas com o sufixo -ista, nos séculos 
XIX e XX, na Galiza, em Portugal e no Brasil, de acordo com o gênero da obra e tais ocorrências foram comparadas.

Dando prosseguimento à pesquisa em corpora, aproveitou-se também para estudar os aspectos semânticos das ocorrências das formações com o sufixo -ista, como justificativa das características de gênero encontradas. Para tanto, seguiu-se a classificação semântica genérica, proposta no capítulo anterior, dividida em quatro grandes grupos:

3. agentividade direta e indireta, por exemplo: recepcionista;

4. agentividade por adesão mental, por exemplo: absolutista;

5. noção de pertinência em geral, por exemplo: seminarista;

6. qualificativos, por exemplo: egoísta.

Entretanto, tal classificação não foi satisfatória para os dados obtidos em corpora, pois algumas ocorrências semânticas em seu contexto não se encaixavam em nenhuma das quatro categorias, havendo, então, a necessidade da elaboração de uma quinta categoria. Por outro lado, notou-se também que mais de noventa e cinco por cento das ocorrências classificadas como agentividade indicavam profissionais ou agentes ocupacionais, daí a primeira categoria foi especializada. Então, obteve-se e usou-se a classificação semântica a seguir:

8. agentes profissionais ou ocupacionais, por exemplo: maquinista;

9. indivíduos adeptos de doutrinas ou sistemas, por exemplo: budista;

10. indivíduos pertencentes a grupos, por exemplo: reservista;

11. qualificativos, por exemplo: narcisista;

12. outros, por exemplo: Batista.

Desse modo, obteve-se uma classificação semântica para as formações encontradas em corpora, que contempla cinco categorias: 1) ocupação ou profissão, 2) adesão mental, 3) qualidade característica, 4) pertinência a grupos, 5) outros. Mais detalhes da classificação em corpora estão dispostos no Anexo I deste trabalho.

Convém lembrar que a análise aqui usada restringe-se apenas à semântica da palavra formada e não à semântica do sufixo, já que apresentam um interessante e complexo comportamento polissêmico no contexto das ocorrências em corpora. 


\section{Ocorrências dos sufixos -ista e-ismo em corpora medieval}

Nos dois famosos documentos antigos do galego-português - A notícia de fiadores de Paio Soares Romeu, datado de 1175; e a cantiga Ora faz ost'o senhor de Navarra de Joam Soares de Paiva, escrito no ano 1196 - não há ocorrência alguma de palavras formadas a partir dos sufixos -ista ou -ismo. De acordo com análise feita em três documentos notariais da segunda metade do século XII encontrados no CIPM $^{1540}$ (Corpus Informatizado do Português Medieval), da região do litoral do Douro, sendo dois documentos escritos por Moreira e um escrito por Pedroso, também não se evidenciaram ocorrências de palavras formadas a partir dos sufixos -ista e -ismo.

Segundo Viaro (2003), nas Cantigas de Santa Maria do Rei Afonso X, escritas no século XIII em galego-português, aparece uma única ocorrência de palavra formada com o sufixo -ismo: batismo; como também uma única ocorrência a partir do sufixo -ista: evangelista. Entretanto, observa-se que também a palavra evangelisteiro, encontrada na obra, tem em sua concatenação sufixal a presença do sufixo -ista. Além disso, foram analisados sete documentos pertencentes ao CIPM que remetem a Vidas de Santos do Manuscrito Alcobacense, que datam do final do século XIII e início do século XIV, que compõe narrativas de cunho religioso sobre vidas de santos: vida de Tarsis, vida de uma monja, vida de Santa Pelágia, morte de S. Jeronimo, visão de Tundalo, vida de Eufrosina, vida de Santa Maria Egipcíaca. No documento vida de Santa Pelágia foi encontrada a palavra baptismo (formada com o sufixo -ismo); no documento morte de S. Jeronimo foi encontrada a palavra Baptista (formada com o sufixo -ista) como referência a Sam Joham; em vida de Santa Maria Egipcíaca foram encontradas as palavras baptismo (formada com o sufixo -ismo) e Bautista (formada com o sufixo -ista) como uma variação ortográfica e, fonética de Baptista, proveniente do galego-português e que está efetiva e vigente na língua galega atual. Já em Milagros de Nuestra Señora de Gonzalo de Berceo, também escrita no século XIII, mas em língua castelhana, não aparece palavra alguma formada a partir do sufixo -ismo, entretanto aparecem duas ocorrências com o sufixo -ista: organista e evangelistas.

De acordo com os arquivos do CIPM, encontrou-se a ocorrência da palavra baptismo (formada por meio do sufixo -ismo) no documento Foro Real, de Afonso X, com data

${ }^{1540}$ http://cipm.fcsh.unl.pt/ 
aproximada de 1280, na região da Beira Alta. Nos arquivos de Documentos Notariais in Clítico da História do Português, do CIPM encontraram-se duas ocorrências da palavra batista, referindo-se a São João; uma delas sob a forma bautista em documento do Mosteiro de Vilarinho na região do Minho, datado de 1296, referindo-se ao dia de São João Batista. A outra ocorrência se dá sob a forma de bbatista em documento do Mosteiro de Pedroso, na região do Minho, datado de 1261, referindo-se à festa de São João Batista como marco para uma data. Nos arquivos de Textos Notariais in História do Galego-Português encontraram-se também duas ocorrências da palavra batista, referindo-se a São João Batista; uma delas sob a forma Bautjsta em documento de doação de bens ao Mosteiro de Santa Maria do Sobrado, no povoado de Quiroga situado na província galega de Lugo, datado de 1281, referindo-se ao dia de São João Batista. A outra ocorrência se dá sob a forma de Baptista em documento de 1281, da igreja de Bayona situada na província galega de Pontevedra, também se referindo ao dia de São João Batista.

Os demais documentos do CIPM pertencentes ao século XIII analisados foram: Notícia de Torto; Testamento de D. Afonso II; 59 Textos Notariais in História do GalegoPortuguês; 65 Textos Notariais in Clíticos na História do Português; 21 Textos Notariais do Arquivo de Textos do Português Antigo (Oxford); 49 Documentos Notariais; 34 documentos da Chancelaria D. Afonso III; 7 documentos do Foros de Garvão; 10 documentos de Tempos dos Preitos de, aproximadamente, 1280, em Beira Alta; Dos Costumes de Santarém, de1294 em Alentejo; e 403 cantigas de escárnio e mal dizer, dentre as quais, muitas de autoria do Rei Afonso X. Da Biblioteca Virtual Galega, foram consultadas: 210 Cantigas de amor e 219 cantigas de amigo; porém, nestes documentos não se evidenciaram ocorrências de formações com os sufixos -ista e -ismo. Tampouco foi possível encontra-las no TILGA ${ }^{1541}$ (Tesouro Medieval Informatizado da Lingua Galega), nos séculos XII a XIV.

Já, na obra completa de Gil Vicente escrita em português no século XIV, observam-se apenas duas ocorrências de palavras formadas com o sufixo -ista: evangelista(s) e Baptista; e duas ocorrências com o sufixo-ismo: mourismo ${ }^{1542}$, e baptismo, em seus autos religiosos.

\footnotetext{
1541 http://www.ti.usc.es/tilg/.

${ }^{1542}$ De acordo com o Dicionário da Língua Portuguesa da Porto Editora, significa o mesmo que moirismo, ou seja, um substantivo masculino que indica o que é proveniente de Mouros; (De mouro+-ismo).
} 
Evidenciou-se, então, que nos textos do século XIII, em sua maioria escritos em mosteiros ou igrejas, a palavra formada a partir do sufixo -ista que ocorre com frequiência é batista, referindo-se a São João, assim como ao sacramento do batismo, como palavra formada com o sufixo -ismo. Já nas Cantigas de Santa Maria, escritas na Corte de Afonso X, aparecem, além da palavra batismo, as palavras evangelista e evangelisteiro. Assim, pode-se constatar que as palavras formadas a partir dos sufixos -ista e -ismo estavam restritas a textos leigos de referência religiosa - pois, sabe-se que os textos oficiais da Igreja eram escritos em latim eclesiástico, nesse período - e eram usadas como empréstimos do grego veiculado pelo latim. Pode-se notar também que, por não aparecerem nas cantigas de escárnio e aparecem com uma freqüência quase nula em outros tipos de texto que não tratam da temática religiosa, como, por exemplo, nos textos notariais, essas palavras não se mostram populares, nesse período, fora do contexto religioso. Vale a pena ressaltar que quando aparecem nos textos notariais, referem-se a topônimos ou a datas, que muitas vezes tomavam como base argumentos religiosos. Convém notar que a grande influência do poder da Igreja Católica na época abrangia vários campos; como por exemplo, a educação era feita por monges; a divisão político-administrativa era feita por paróquias e os documentos civis e jurídicos eram elaborados em igrejas ou mosteiros; portanto era natural usar os marcos religiosos, como os dias de homenagem a santos, nomes religiosos associados a topônimos e os nomes próprios atribuídos aos recém nascidos eram, geralmente, referências religiosas.

Nesse contexto religioso de palavras formadas por meio do sufixo -ista, a ressalva se faz para a palavra organista encontrada no castelhano, que, ainda que indique o músico que toca o órgão, convém lembrar que esse instrumento musical também estava associado aos cultos da Igreja. Seria interessante analisar textos de latim desse período em busca de palavras com os sufixos em questão, para um melhor esclarecimento do contexto e de seus usos.

É interessante notar que nos textos do século XIV, na obra completa de Gil Vicente, poucas palavras apareceram formadas a partir dos sufixos analisados, o que mostra sua pequena produtividade e pouca circulação entre o vulgo neste período, entretanto é curioso notar a formação a partir do sufixo -ismo, da palavra mourismo onde já desponta uma produção fora do contexto religioso. Nos textos notariais galegos e portugueses do século XIV também não foi possível encontrar formações com os sufixos -ista e -ismo. 
Estudo comparativo de aspectos semânticos do sufixo -ista no português e no galego.

Utilizando como corpus o dicionário Houaiss (2001) da Língua Portuguesa os pesquisadores $^{1543}$ Dr. Zwinglio de Oliveira Guimarães Filho e Leandro Mariano obtiveram o gráfico 4.1, valendo-se das datações das palavras formadas com os sufixos -ista e -ismo. Assim, pelo gráfico pode-se observar que há um paralelismo no comportamento das formações com os dois sufixos no decorrer dos séculos. Observa-se também que a produtividade dos dois sufixos aumenta vertiginosamente a partir do século XVIII, ao passo que na Idade Média eram quase improdutivos.

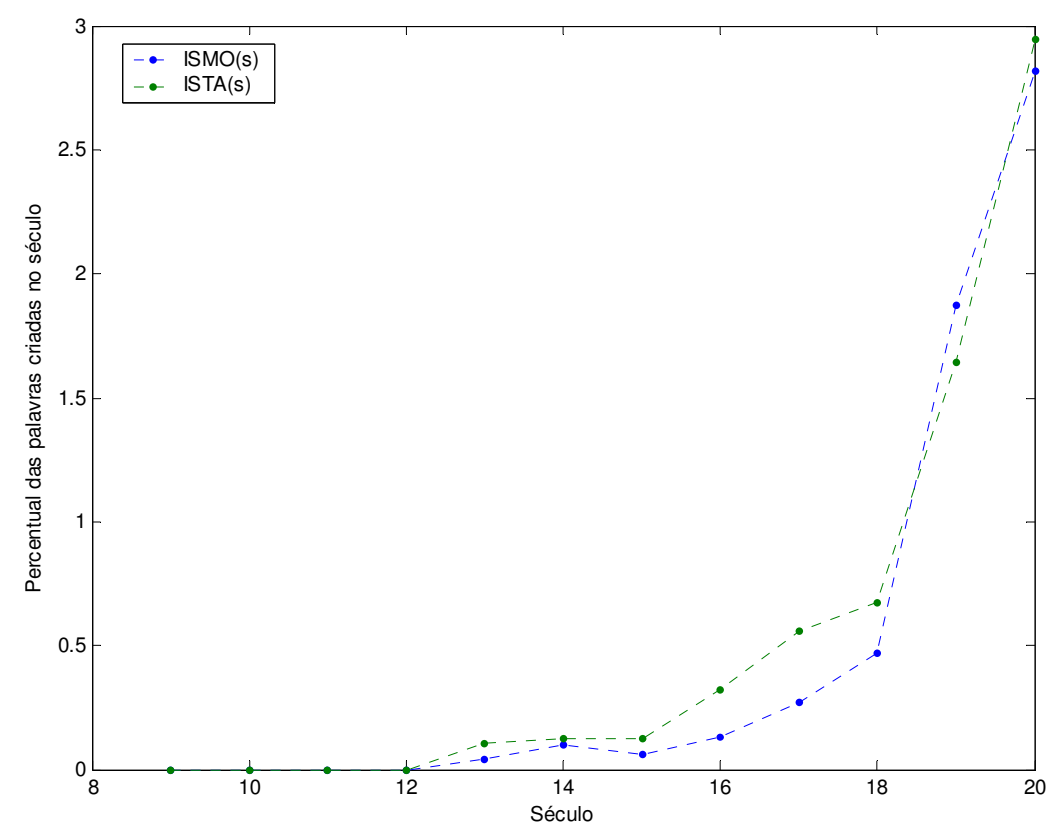

Gráfico 4.1. Produtividade dos sufixos -ista e -ismo por século.

A título de ilustração, as atestações mediante corpora, por um lado confirmam as posições de SAID Ali (1930: 19-20) e FERREIRO (2001: 132-133) ao associar os sufixos -ista e -ismo em formações paradigmáticas, ressaltando que a produtividade efetiva de tais sufixos nas formações de palavras começa nos séculos XVIII e XIX sob influência dos movimentos intelectuais franceses. Assim como confirmam a posição de VILELA (1994: 74), segundo a qual a relação -ista e -ismo data do século XIX, com o vocabulário político e social, passando posteriormente a aplicar-se também a outros domínios, por exemplo: esportes, movimentos artísticos e literários, comportamento humano, estudos lingüísticos.

\footnotetext{
${ }^{1543}$ Do Instituto de Física da Universidade de São Paulo e membros do GMHP - Grupo de Morfologia Histórica do Português, cadastrado no CNPq sob coordenação do Prof. Dr. Mário Eduardo Viaro.
} 


\section{Ocorrências do sufixo -ista na língua galega}

Pertencente ao século XV, nada foi encontrado na Biblioteca Virtual Galega, como também no TMILG ${ }^{1544}$ (Tesouro Medieval Informatizado da Lingua Galega), que ilustrasse os usos dos sufixos -ista e/ou -ismo. Tampouco as obras analisadas dos Séculos Escuros Galegos ${ }^{1545}$ : Composicións Galegas (século XVIII) de Xosé Cornide, Composicións Galegas (século XVIII) do Cura de Fruíme, Colóquio de 24 galegos rústicos (século XVIII) do Padre Sarmiento, e a obra de teatro: A contenda dos labradores de Caldelas (1671) de Gabriel Freixó de Araúxo; apresentaram ocorrências dos sufixos -ista ou-ismo.

Já, pertencentes aos séculos XIX e XX foram analisadas setenta e uma obras galegas, das quais trinta e cinco pertencem ao século XIX, mais precisamente à segunda metade do século, e trinta e seis pertencem ao século XX, detalhadas no Anexo I deste trabalho. A título de ilustração do gênero da prosa jornalística, tomou-se também como corpus o jornal Galicia Hoxe, publicado em Santiago de Compostela no dia 26 de junho de 2006 (segunda-feira). Nas obras pertencentes ao século XIX foram encontradas quarenta e cinco formações com o sufixo -ista e no século XX foram encontradas cento e oitenta e seis. No gráfico seguinte está ilustrado o crescimento do uso de formações com o sufixo -ista, com o qual pode-se observar que no século XX houve um crescimento de mais de quatrocentos por cento $(413,3 \%)$, ou seja, um vertiginoso aumento do uso das formações com -ista em galego.

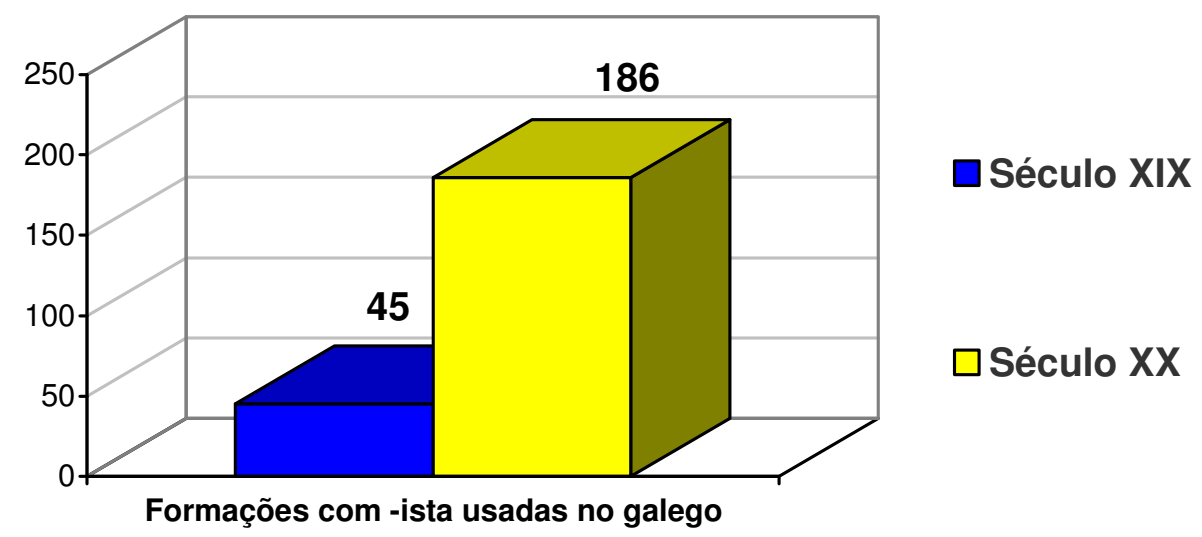

Gráfico 4.2. Ocorrências do sufixo -ista em corpora galego.

\footnotetext{
1544 http://corpus.cirp.es/tmilg/

${ }^{1545}$ Período compreendido entre os séculos XV, XVI, XVII e XVIII, no qual o uso da língua galega, por motivos políticos, esteve ausente de seu uso oficial e marginalizada em prol do uso da língua castelhana.
} 
Em termos quantitativos por gênero da obra analisada, no levantamento feito em corpora galego do século XIX foram encontradas quarenta e cinco formações com o sufixo ista, das quais vinte e duas apareceram na prosa, vinte e uma nas obras poéticas e quinze nas obras teatrais. Dessa maneira, pode-se concluir que as formações com -ista foram mais utilizadas nos gêneros prosaico e poético que no teatral nesse período, de tal modo que nos dois primeiros se mostra muito próxima. Assim, em valores absolutos, tal distribuição nos gêneros da escrita do século XIX está ilustrada no gráfico seguinte.

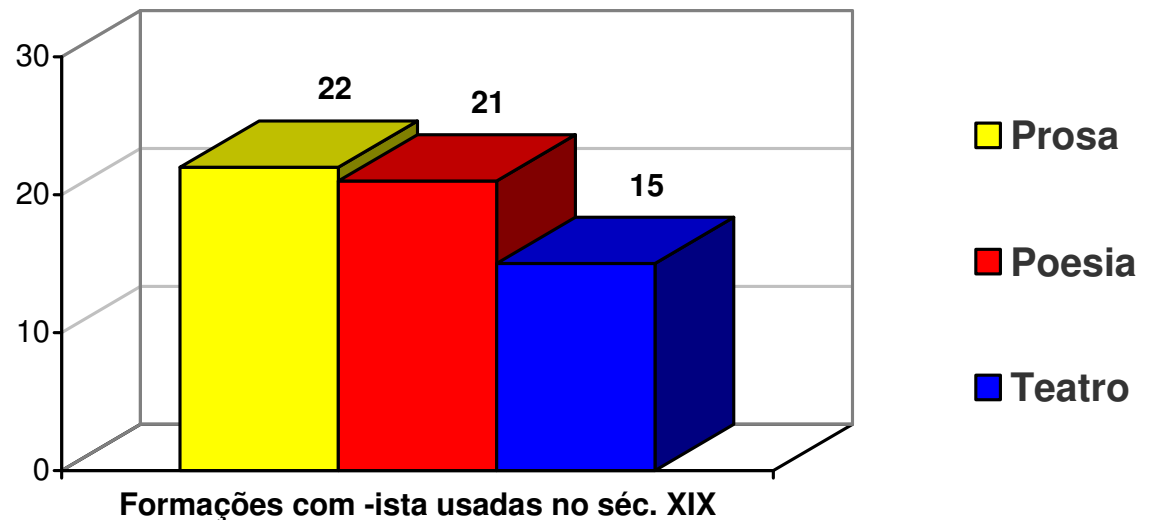

Gráfico 4.3. Distribuição nos gêneros da escrita em corpora galego do século XIX.

Sabe-se que, em geral, o gênero prosaico é o mais usado na escrita, no entanto, o século XIX das letras galegas foi marcado pela grande produção poética, abrangendo desde os temas coloquiais e regionais até eruditos e científicos. É interessante notar que o período do Rexurdimento, (vide capítulo 1, página 68) no qual houve uma grande busca pelas raízes galegas latentes desde os Séculos Escuros, resgatou palavras já usadas no período medieval como: evanxelista ${ }^{1546}$ (avanxelista ${ }^{1547}$ ) e bautista ${ }^{1548}$ (boutista $^{1549}$ ), ao lado das de datação provavelmente mais recente, como: ramista ${ }^{1550}$ e funcionista ${ }^{1551}$, mas ainda com cunho religioso. Por outro lado, o século XIX galego esteve aberto às inovações provenientes do resto da Europa, sobretudo da França, trazendo consigo a experimentação de novos temas em variantes dos gêneros consagrados com inúmeros estrangeirismos, alguns dos quais entraram no galego com o sufixo -ista, e já totalmente fora do âmbito religioso.

\footnotetext{
1546 Tradução: "evangelista”.

1547 Variação ortográfica de evanxelista.

1548 Tradução: "batista".

${ }^{1549}$ Variação ortográfica de bautista.

${ }^{1550}$ Pessoa encarregada de organizar a festa da paróquia.

${ }^{1551}$ Pessoa que paga a função religiosa em obséquio de algum santo.
} 
Estudo comparativo de aspectos semânticos do sufixo -ista no português e no galego.

Em termos quantitativos por gênero da obra analisada, em corpora galego do século $\mathrm{XX}$ foram encontradas cento e oitenta e seis formações com o sufixo -ista, das quais cento e trinta e cinco apareceram no gênero prosa, trinta e duas na poesia, dezenove no teatro e quarenta e uma em uma única publicação de jornal. Pode-se notar, então, que em corpora galego analisado do século XX a formação estudada ocorre muito mais na prosa que nos demais gêneros da escrita. Assim, em valores absolutos, tal distribuição nos gêneros da escrita do século XX está ilustrada no gráfico seguinte.

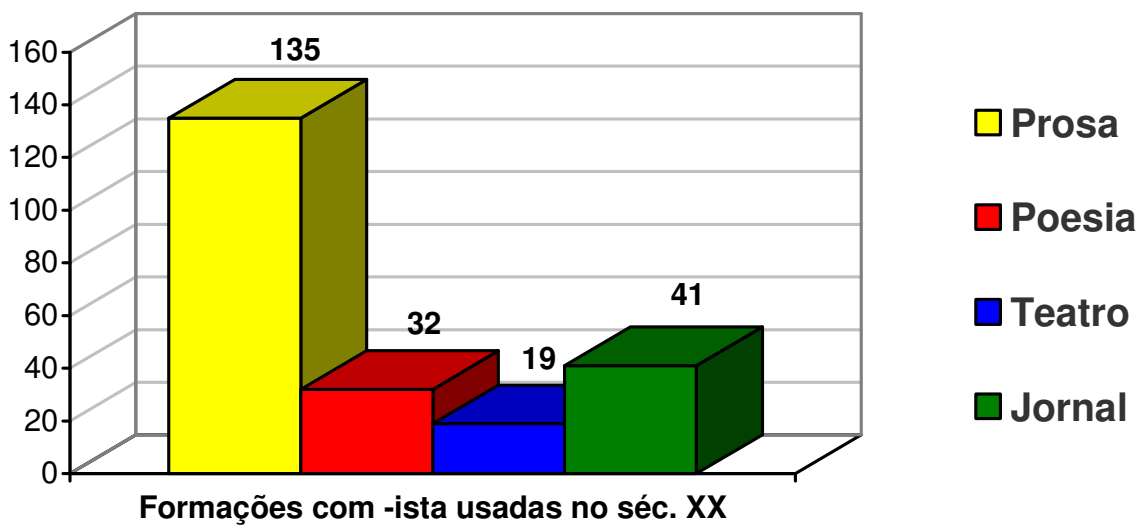

Gráfico 4.4. Distribuição nos gêneros da escrita em corpora galego do século XX.

Acredita-se, então que, a partir do século XX, passou a haver uma maior propensão ao uso de formações com o sufixo -ista no gênero prosaico da escrita (romances, ensaios, relatos, cartas, documentos) devido à grande maleabilidade de tal gênero, bem como sua grande veiculação determinada pelo seu abrangente uso. Convém lembrar também que o segundo gênero no qual a formação mais se apresenta é a prosa jornalística por meio da publicação de jornal, veículo bem popular na Galiza para a divulgação de informações. Tal constatação leva a crer que muitas das formações com o sufixo não se apresentam somente no âmbito científico, religioso, político, filosófico e/ou artístico, mas estejam presentes também na expressão do âmbito popular e cotidiano da língua galega.

Ao se confrontar a distribuição do uso de formações com o sufixo -ista no galego, em números absolutos, encontrada em corpora do uso das formações com -ista entre os três gêneros da escrita no século XIX e no século XX, obteve-se a tabela e o gráfico seguintes. 


\section{DISTRIBUIÇÄO EM CORPORA GALEGO DAS FORMAÇÕES COM O SUFIXO -ISTA \\ GÊNERO SÉCULO XIX SÉCULO XX

$\begin{array}{lll}\text { PROSA } & 22 & 135\end{array}$ \\ $\begin{array}{lll}\text { POESIA } & 21 & 32\end{array}$ \\ $\begin{array}{lll}\text { TEATRO } & 15 & 19\end{array}$}

Tabela 4.1. Ocorrências do sufixo -ista nos gêneros da escrita em corpora galego.

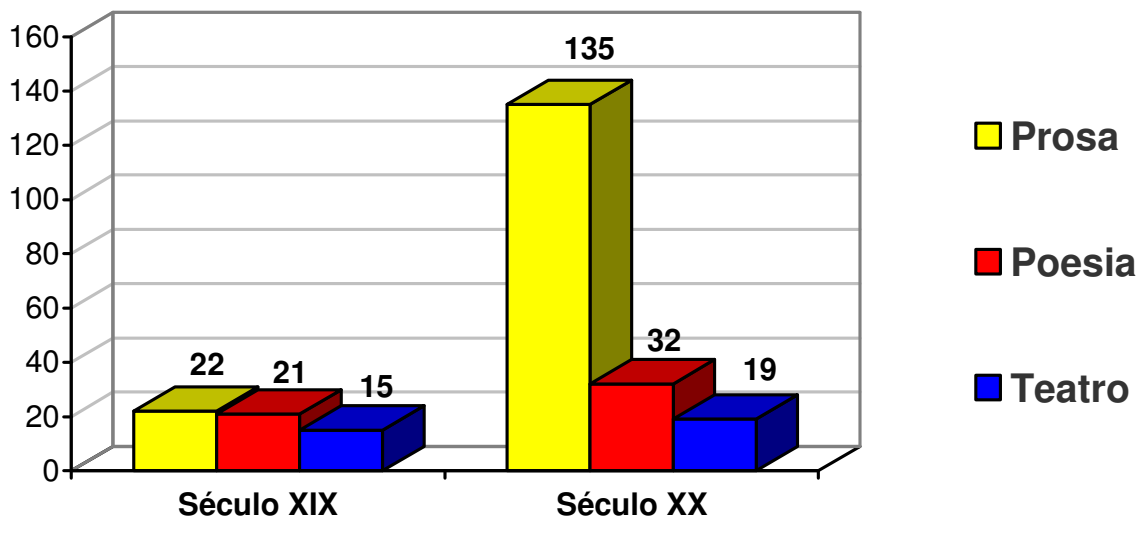

Gráfico 4.5. Ocorrências do sufixo -ista nos gêneros da escrita em corpora galego.

Analisando-se as confrontações quantitativas das distribuições observa-se nitidamente que o uso de formações com -ista cresceu no século XX em valores absolutos, comparativamente com o século XIX, nos três gêneros observados. Entretanto, computandose seus valores percentuais de formações encontradas em cada gênero relativa ao número total de formações com o sufixo em cada período, obtêm-se a tabela e os gráficos seguintes.

\begin{tabular}{|c|c|c|c|c|c|}
\hline \multirow{3}{*}{ GÊNERO } & \multicolumn{5}{|c|}{ OCORRÊNCIAS DE FORMAÇÕES COM O SUFIXO -ISTA EM CORPORA GALEGO } \\
\hline & \multicolumn{2}{|c|}{ SÉCULO XIX } & \multicolumn{2}{|c|}{ SÉCULO XX } & \multirow[b]{2}{*}{ CRESCIMENTO } \\
\hline & $\begin{array}{l}\text { Valores } \\
\text { absolutos }\end{array}$ & $\begin{array}{c}\text { Valores } \\
\text { percentuais }\end{array}$ & $\begin{array}{l}\text { Valores } \\
\text { absolutos }\end{array}$ & $\begin{array}{c}\text { Valores } \\
\text { percentuais }\end{array}$ & \\
\hline PROSA & 22 & $38 \%$ & 135 & $73 \%$ & $35 \%$ \\
\hline POESIA & 21 & $36 \%$ & 32 & $17 \%$ & $-19 \%$ \\
\hline TEATRO & 15 & $26 \%$ & 19 & $10 \%$ & $-16 \%$ \\
\hline
\end{tabular}

Tabela 4.2. O sufixo -ista nos gêneros da escrita em corpora galego em valores absolutos e em valores percentuais. 


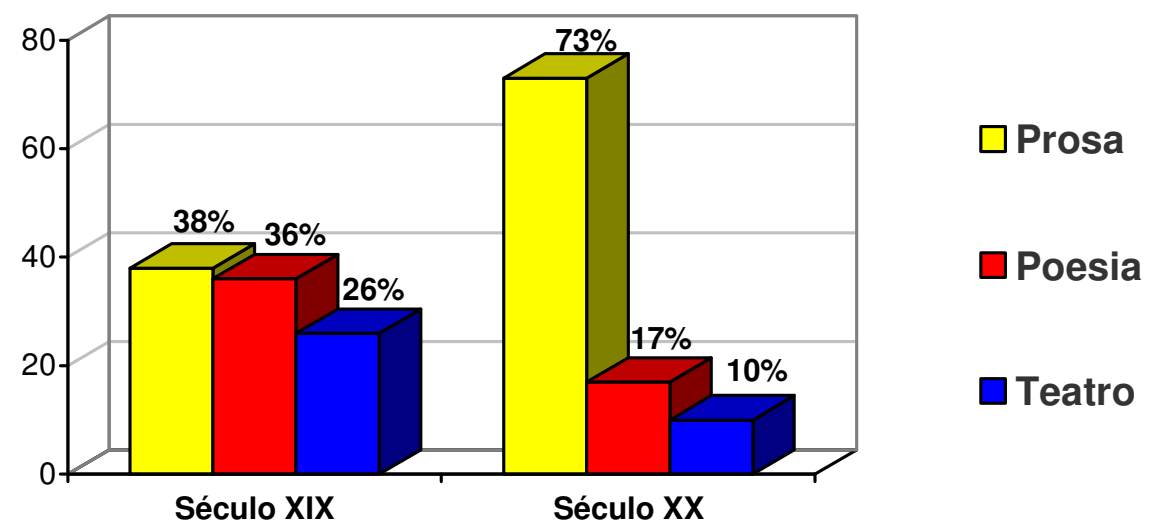

Gráfico 4.6. Valores percentuais nos gêneros da escrita em corpora galego (I).
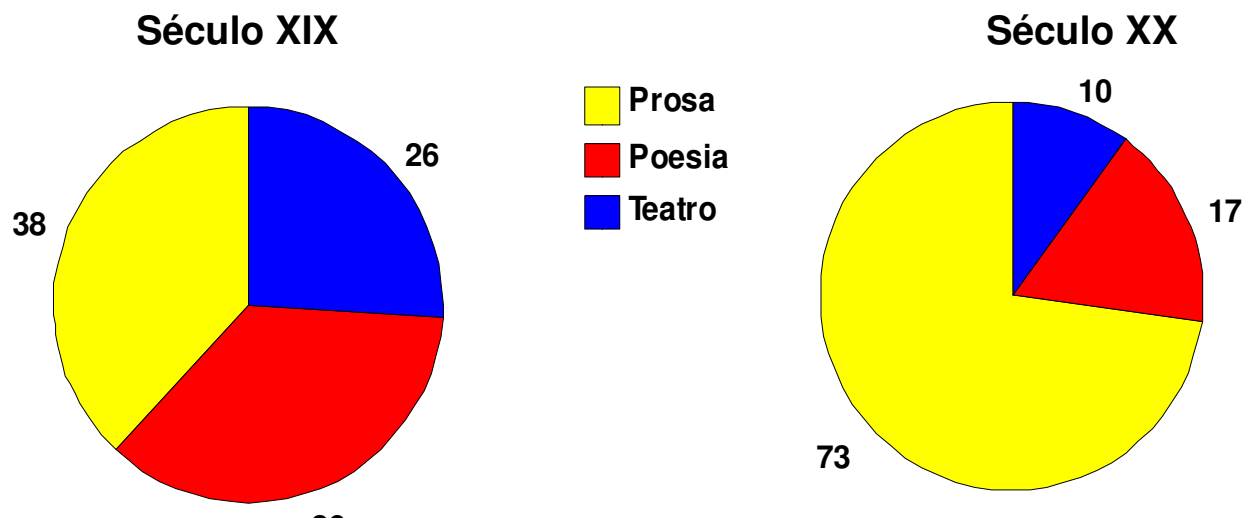

Gráfico 4.7. Valores percentuais nos gêneros da escrita em corpora galego (II).

Pode-se, então, observar que em corpora galego do século XIX analisado as ocorrências de palavras com o sufixo -ista dividem-se quase que igualmente entre os três gêneros: prosa, poesia e teatro, ainda que o gênero que mais apresente as formações seja a prosa, com trinta e oito por cento $(38 \%)$ do total das palavras com -ista no período e o gênero menos favorecido para o uso das formações seja o teatro, com vinte e seis por cento (26\%). Assim, pode-se concluir que, em corpora galego do século XIX analisado, o uso das palavras formadas com o sufixo -ista, mostra-se distribuido praticamente de forma indiscriminada entre os três gêneros estudados, evidenciando uma característica eclética de uso das formações.

Observa-se, também que, no corpora galego do século XX analisado, as ocorrências de palavras com o sufixo -ista mostram-se muito mais abundantes no gênero da prosa que nos 
demais gêneros estudado. Ou seja, setenta e três por cento (73\%) das formações com o sufixo foram encontradas no gênero da prosa, em detrimento do gênero da poesia, no qual verificouse dezessete por cento (17\%) das formações, e no teatro, no qual verificou-se apenas dez por cento (10\%) das formações. Assim, pode-se concluir que, em corpora galego do século XX analisado, o uso das palavras formadas com o sufixo -ista perdeu a sua característica poética e teatral, evidenciando uma característica nitidamente prosaica de uso.

Conclui-se, então, que as ocorrências do uso de formações com o sufixo -ista em corpora galego passaram a mostrar um caráter muito mais prosaico de uso no século $\mathrm{XX}$, comparativamente com o século XIX, cujo caráter de uso mostrava-se equilibrado e eclético entre os três gêneros estudados.

Tentando justificar a observação notada em corpora galego com relação à característica de gênero adquiridas pelas ocorrências do uso de formações com o sufixo -ista, resolveu-se estudar o seu comportamento semântico no contexto encontrado e classificá-lo de acordo com o âmbito inserido, no século XIX e no século XX.

Assim, para uma análise e classificação semântica dos usos das formações com -ista nesses dois séculos foi necessário, inicialmente, observar cada uma das designações das formações encontradas em seu contexto em corpora, em cada século e posteriormente dividilas conforme a classificação proposta no início deste capítulo. A divisão em classes das palavras formadas com o sufixo -ista encontrada em corpora galego está detalhada no Anexo I deste trabalho.

Dessa forma, para as formações galegas com o sufixo -ista encontradas em corpora do século XIX, vinte e três ocorrências foram classificadas semanticamente como "ocupação ou profissão", nove ocorrências como "adesão mental", onze ocorrências como "qualidade característica", uma única ocorrência como "pertinência a grupos" e também uma única ocorrência classificada na categoria "outros". Convém observar que esta única ocorrência refere-se à palavra Bautista ${ }^{1552}$, pois nos contextos em que foi encontrada designa o sobrenome de uma pessoa, e dessa forma, não se encaixou nas classes semânticas de "ocupação ou profissão", "adesão mental", "qualidade característica" ou "pertinência a grupos".

1552 Tradução: "Batista”. 
Estudo comparativo de aspectos semânticos do sufixo -ista no português e no galego.

Analogamente, para as formações galegas com o sufixo -ista encontradas em corpora do século XX, setenta e sete ocorrências foram classificadas semanticamente como "ocupação ou profissão", setenta e duas ocorrências como "adesão mental", vinte e seis ocorrências como "qualidade característica", doze ocorrências como "pertinência a grupos" e nenhuma ocorrência foi registrada dentro da categoria "outros". Conforme está ilustrado na tabela e no gráfico seguintes.

$\begin{array}{ccc}\text { CLASSIFICAÇÄO SEMÂNTICA DAS FORMAÇÕES COM O SUFIXO -ISTA EM CORPORA GALEGO } \\ \text { ClASSE } & \text { SÉCULO XIX } & \text { SÉCULO XX } \\ \text { OCUPAÇÃO } & 23 & 77 \\ \text { ADESÃO } & 9 & 72 \\ \text { QUALIIDADE } & 11 & 26 \\ \text { PERTINÊNCIA } & 1 & 12 \\ \text { OUTROS } & 1 & 0\end{array}$

Tabela 4.3. Classificação semântica das ocorrências do sufixo -ista em corpora galego.

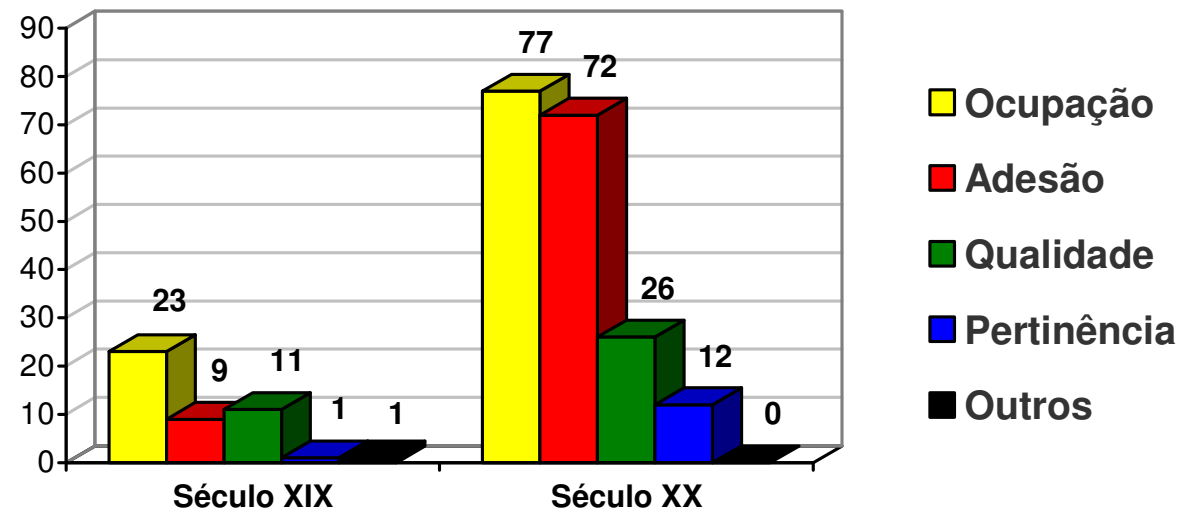

Gráfico 4.8. Classificação semântica das ocorrências do sufixo -ista em galego.

Com os dados obtidos da classificação semântica feita, pode-se notar, em termos absolutos, que todas as quatro primeiras classes semânticas no século XX tiveram um aumento no uso de formações com o sufixo -ista, comparativamente ao século XIX, consideradas isoladamente. Entretanto, para que realmente se possa identificar o comportamento das classes semânticas entre um século e outro a análise deve ser feita em termos percentuais do total de formações usadas em cada século, conforme a tabela e gráficos seguintes. 
Estudo comparativo de aspectos semânticos do sufixo -ista no português e no galego.

\begin{tabular}{|c|c|c|c|c|c|}
\hline \multirow{3}{*}{ Classe } & \multicolumn{5}{|c|}{ CLASSIFICAÇÃO DE FORMAÇÕES COM O SUFIXO -ISTA EM CORPORA GALEGO } \\
\hline & \multicolumn{2}{|c|}{ SÉCULO XIX } & \multicolumn{2}{|c|}{ SÉCULO XX } & \multirow[b]{2}{*}{ CRESCIMENTO } \\
\hline & $\begin{array}{l}\text { Valores } \\
\text { absolutos }\end{array}$ & $\begin{array}{c}\text { Valores } \\
\text { percentuais }\end{array}$ & $\begin{array}{l}\text { Valores } \\
\text { absolutos }\end{array}$ & $\begin{array}{l}\text { Valores } \\
\text { percentuais }\end{array}$ & \\
\hline OCUPAÇÃO & 23 & $51 \%$ & 77 & $42 \%$ & $-9 \%$ \\
\hline ADESÃO & 9 & $20 \%$ & 72 & $38 \%$ & $18 \%$ \\
\hline QUALIDADE & 11 & $25 \%$ & 26 & $14 \%$ & $-11 \%$ \\
\hline PERTINÊNCIA & 1 & $2 \%$ & 12 & $6 \%$ & $4 \%$ \\
\hline OUTROS & 1 & $2 \%$ & 0 & 0 & $-2 \%$ \\
\hline
\end{tabular}

Tabela 4.4. Classificação semântica das ocorrências do sufixo -ista em corpora galego com os valores absolutos e com os valores percentuais obtidos.

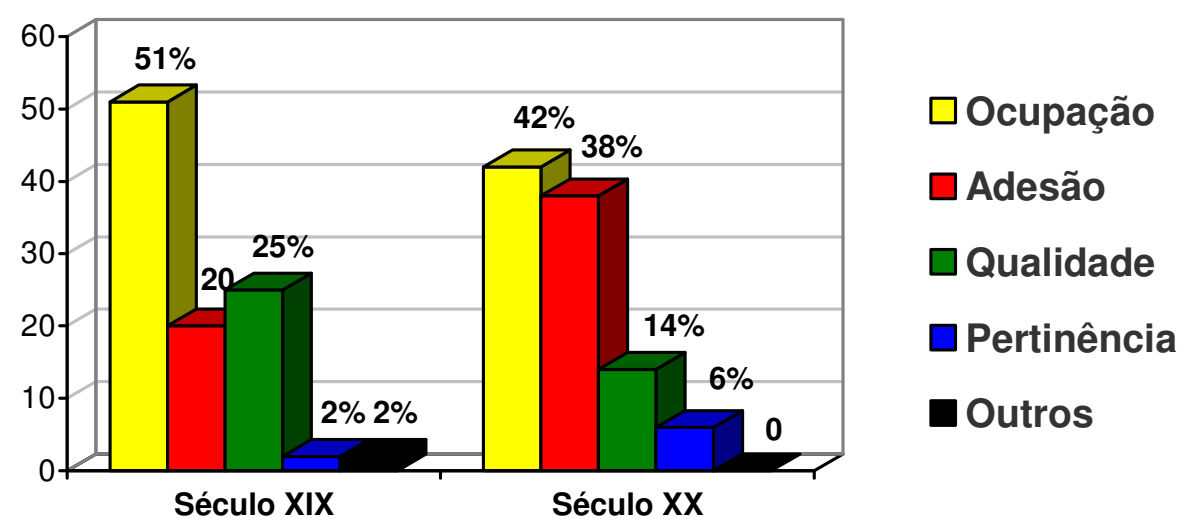

Gráfico 4.9. Valores percentuais da classificação semântica obtida em galego (I).

Século XIX

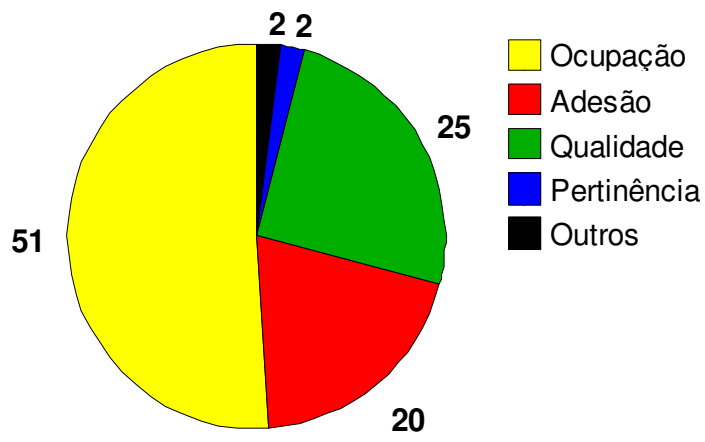

Século XX

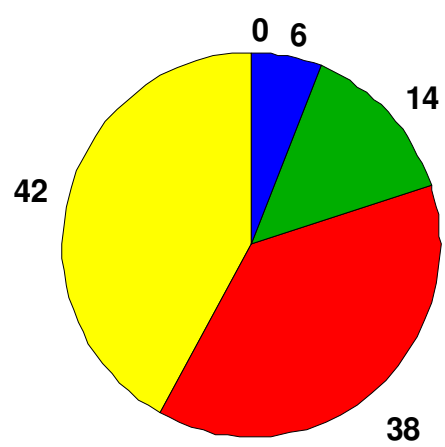

Gráfico 4.10. Valores percentuais da classificação semântica obtida em galego (II). 
Analisando-se a tabela e os gráficos das categorias semânticas das formações com ista em termos percentuais, comparativos do século XIX e XX, pode-se constatar em corpora utilizado que a categoria semântica mais utilizada é a "ocupação ou profissão", com cinqüenta e um por cento $(51 \%)$ das ocorrências encontradas no século XIX, e com quarenta e dois por cento $(52 \%)$ das ocorrências encontradas no século XX. A categoria de "adesão mental" passou a ser a segunda mais utilizada no século XX, com trinta e oito por cento (38\%), enquanto no século XIX contava com vinte por cento (20\%) e era a terceira categoria mais usada. A categoria "qualidade característica", que era a segunda mais usada no século XIX com vinte e cinco por cento (25\%), passou a ser a terceira no século XX, com quatorze por cento $(14 \%)$ das ocorrências encontradas. A categoria "pertinência a grupos" mostrou-se a quarta categoria tanto no século XIX com dois por cento (2\%) das ocorrências, quanto no século XX com seis por cento $(6 \%)$ de uso das formações -ista. A categoria semântica menos utilizada é "outros", representando apenas dois por cento $(2 \%)$ das ocorrências no século XIX e nem aparecendo no século XX.

Dessa maneira, comparando-se os séculos XIX e XX constatou-se em corpora que houve um pequeno decréscimo de nove por cento (9\%) no uso da categoria "ocupação ou profissão". Já na categoria "adesão mental" houve um aumento de dezoito por cento (18\%) no século XX em relação ao XIX. Na categoria "qualidade característica" houve uma diminuição de onze por cento (11\%) no século XX em relação ao XIX. Na categoria "pertinência a grupos" houve um aumento de quatro por cento (4\%) no século XX em relação ao XIX. Em outras palavras, no século XX, no galego, passou-se a se utilizar mais formações com o sufixo -ista que designam "adesão mental" e "pertinência a grupos", aumentando o seu uso comparativamente às demais categorias semânticas. Entretanto, as categorias semânticas que mais se destacam nas ocorrências de formações com -ista em corpora galego e com representação significativa, somando mais de noventa por cento, tanto no século XIX quanto no século XX, foram: "ocupação ou profissão", "adesão mental" e "qualidade característica". Dessa maneira, acredita-se que as formações com o sufixo estudado e classificadas como: "ocupação ou profissão", "adesão mental” e "qualidade característica", que representavam um cunho estilístico eclético em seu uso no século XIX, passaram, no século XX, a adquirir um cunho estilístico majoritariamente prosaico na língua galega. 


\section{Ocorrências do sufixo -ista no português}

No século XV, na Demanda do Santo Graal, foi encontrada a palavra evangelista. No Livro da ensinança de bem cavalgar toda a sela, Historia dos reis de Portugal in crônica geral de Espanha, e nos textos notariais do Corpus Informatizado do Português Medieval, nenhuma palavra com o sufixo - ista foi encontrada.

Na obra completa de Luis Vaz de Camões, do século XVI, também não foram observadas palavras com o sufixo em estudo. Nos sermões do Padre Vieira do século XVII: Sermão Quinta Dominga de Quaresma: evangelista; Sermão do Bonsucesso de Portugal contra Holanda: calvinista; Sermão de Santo Antonio: cronista e evangelista; nos três sermões de Maria Rosa Mística: evangelista e batista. Nas poesias de Gregório de Matos, no século XVI, somente foram encontradas: paulista e coronista. Na obra completa de teatro do Padre Anchieta, encontrou-se a palavra artista.

No século XVIII, em O Uraguai, de Basílio da Gama, nada se encontrou; em Cartas chilenas, de Tomás Antônio Gonzaga, encontrou-se camarista, rigorista, rabequista; em Poemas, de Cláudio Manuel da Costa, encontrou-se: paulista; em Sonetos e outros Poemas, de Bocage, encontrou-se: versista, artista, em Guerra do alecrim e da manjerona (1737), de Antonio José da Silva, o judeu, encontrou-se: cronista, cupidista, antagonista, alecrinista, majeronista. Em outras fontes do século XVIII pesquisadas, como o Diário da Navegação, de Teotônio José Juzarte e a Descrição da Ilha de Itaparica, de Manuel de Santa Maria, nenhuma palavra formada com o sufixo -ista foi evidenciada.

Assim, as formações com o sufixo -ista encontradas, entre o séculos XV e XVIII em corpora são escassas, mas o seu uso em corpora aumenta nos séculos XVII e XVIII, conforme está ilustrado na tabela seguinte.

$\begin{array}{ccc}\text { SÉCULO } & \text { NÚMERO } & \text { FORMAÇÕES COM O SUFIXO -ISTA ENCONTRADAS } \\ \text { XV } & 1 & \text { evangelista. } \\ \text { XVI } & 0 & \text { artista, Batista, calvinista, coronista, cronista, evangelista, paulista. } \\ \text { XVII } & 7 & \begin{array}{l}\text { alecrinista, antagonista, artista, camarista, cronista, cupidista, } \\ \text { majeronista, paulista, rigorista, rabequista, versista. }\end{array}\end{array}$

Tabela 4.5. Ocorrências do sufixo -ista em corpora do português medieval. 


\section{Ocorrências do sufixo -ista no português europeu}

Pertencentes aos séculos XIX e XX foram analisadas sessenta e oito obras portuguesas, das quais trinta e quatro pertencem ao século XIX, mais precisamente à segunda metade do século, e trinta e quatro são pertencentes ao século XX. A título de ilustração de prosa jornalística foi usado como corpus $O$ correio da manhã, de 24 de julho de 2006, editado em Lisboa. Nas obras do século XIX foram encontradas oitenta e oito formações com -ista e, no século XX, foram encontradas cento e sessenta, observando-se um crescimento de cento e oitenta e dois por cento (182\%), conforme o gráfico seguinte.

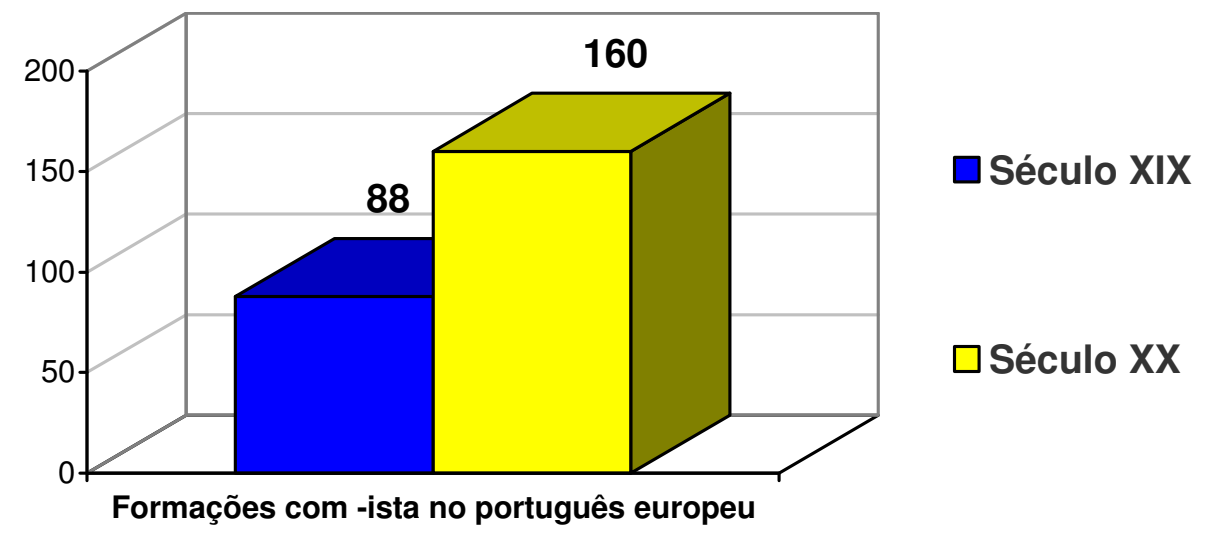

Gráfico 4.11. Ocorrências do sufixo -ista em corpora lusitano.

Em termos quantitativos por gênero da obra analisada, em corpora português do século XIX, foram obtidas oitenta e uma formações com o sufixo -ista no gênero da prosa, quatorze ocorrências na poesia e dezesseis ocorrências no teatro, conforme o gráfico seguinte.

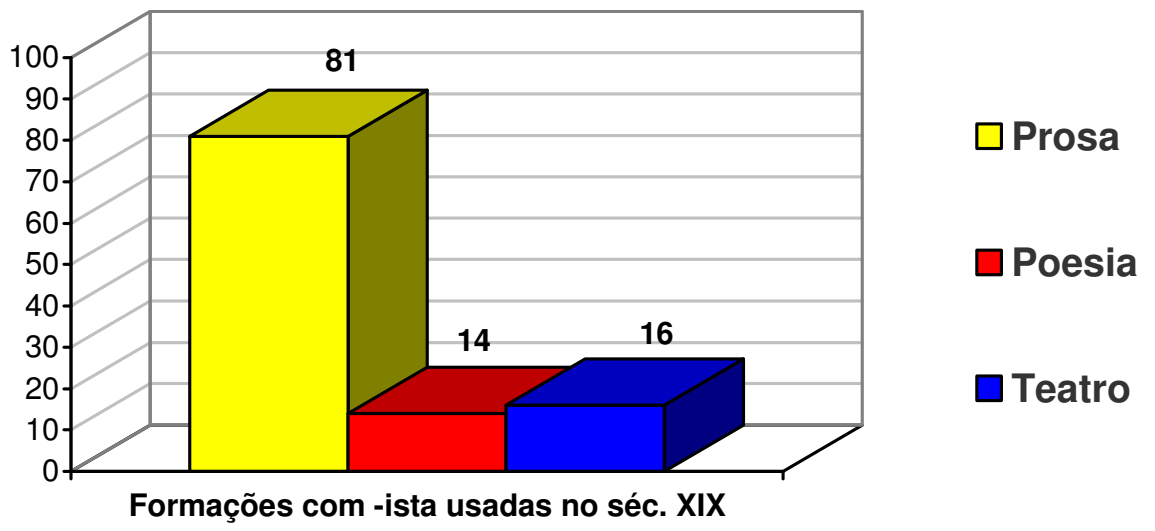

Gráfico 4.12. Distribuição nos gêneros da escrita em corpora lusitano do século XIX. 
Estudo comparativo de aspectos semânticos do sufixo -ista no português e no galego.

Em termos quantitativos por gênero da obra analisada, em corpora português do século XX foram encontradas cento e cinco formações com o sufixo -ista no gênero da prosa, dezesseis ocorrências no gênero da poesia, trinta e sete ocorrências no teatro e sessenta e quatro ocorrências em uma única edição do jornal: O Correio da Manhã. Conforme a distribuição do uso de formações com o sufixo nos gêneros da escrita, no século XX, que está ilustrada no gráfico seguinte.

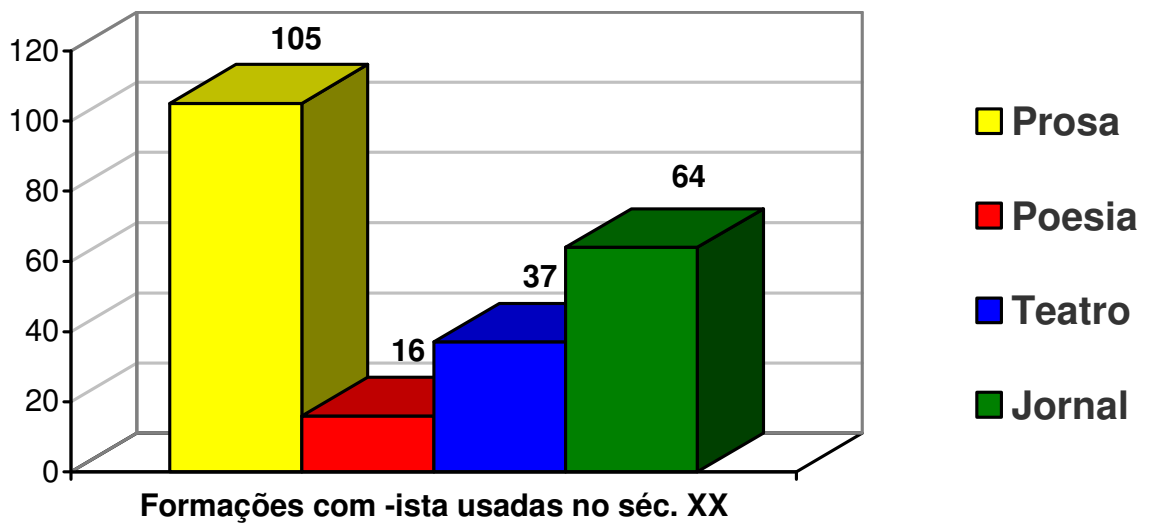

Gráfico 4.13. Distribuição nos gêneros da escrita em corpora lusitano do século XX.

Dessa maneira, pode-se perceber que as formações com -ista, foram mais utilizadas nos gêneros prosaico do que nos gêneros poético e teatral, de tal modo que a distribuição se mostra muito tendenciosa à prosa. E pode-se perceber que motra tendência à prosa jornalística, pois há sessenta e quatro ocorrências em uma única edição de jornal.

Ao se confrontar a distribuição do uso de formações com o sufixo -ista no português europeu, em número absolutos, encontrada em corpora do uso das formações com -ista entre os três gêneros da escrita no século XIX e no século XX, obteve-se a tabela e o gráfico seguintes.

DISTRIBUIÇÄO EM CORPORA PORTUGUÊS DAS FORMAÇÕES COM O SUFIXO -ISTA

GÊNERO SÉCULO XIX SÉCULO XX

$\begin{array}{lcc}\text { PRosa } & 81 & 105 \\ \text { PoEsia } & 14 & 16 \\ \text { TEATRO } & 16 & 37\end{array}$

Tabela 4.6. Ocorrências do sufixo -ista nos gêneros da escrita em corpora lusitano. 


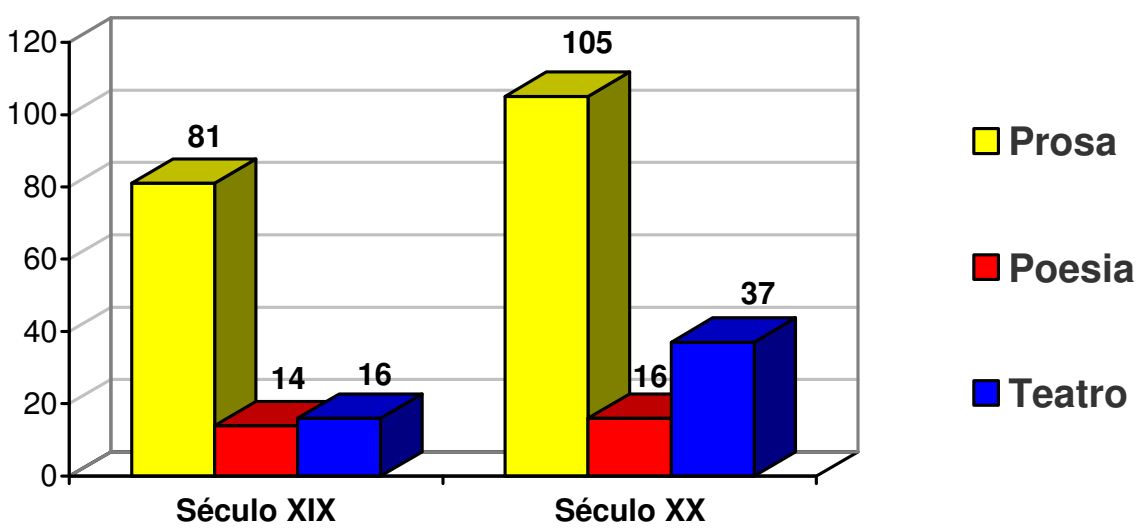

Gráfico 4.14. Ocorrências do sufixo -ista nos gêneros da escrita em corpora lusitano.

Analisando-se as confrontações quantitativas das distribuições nos três gêneros obtidas em corpora, observa-se nitidamente que o uso das formações com -ista cresceu no século XX, comparativamente com o seu uso no século XIX, nos três gêneros da escrita observados isoladamente e em valores absolutos. Pode-se notar, claramente, que o gênero teatral no século XX, comparativamente com o século XIX, mostrou um crescimento maior, em valores absolutos, que os demais gêneros.

Entretanto, computando-se seus valores percentuais de formações encontradas em cada gênero relativo ao número total de formações com o sufixo em cada período, obtêm-se a tabela e os gráficos seguintes.

\begin{tabular}{|c|c|c|c|c|c|}
\hline \multirow{3}{*}{ GÊNERO } & \multicolumn{5}{|c|}{ OCORRÊNCIAS DE FORMAÇÕES COM O SUFIXO -ISTA EM CORPORA PORTUGUÊS } \\
\hline & \multicolumn{2}{|c|}{ SÉCULO XIX } & \multicolumn{2}{|c|}{ SÉCULO XX } & \multirow[b]{2}{*}{ CRESCIMENTO } \\
\hline & $\begin{array}{l}\text { Valores } \\
\text { absolutos }\end{array}$ & $\begin{array}{c}\text { Valores } \\
\text { percentuais }\end{array}$ & $\begin{array}{l}\text { Valores } \\
\text { absolutos }\end{array}$ & $\begin{array}{c}\text { Valores } \\
\text { percentuais }\end{array}$ & \\
\hline PROSA & 81 & $73 \%$ & 105 & $66 \%$ & $-7 \%$ \\
\hline POESIA & 14 & $12 \%$ & 16 & $10 \%$ & $-2 \%$ \\
\hline TEATRO & 16 & $15 \%$ & 37 & $24 \%$ & $9 \%$ \\
\hline
\end{tabular}

Tabela 4.7. O sufixo -ista nos gêneros da escrita em corpora português em valores absolutos e em valores percentuais. 


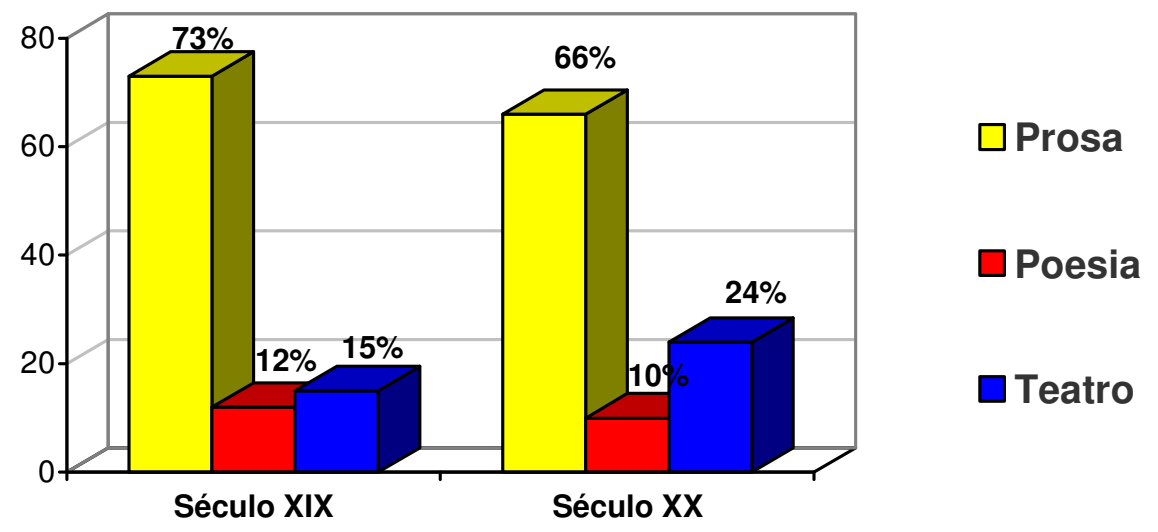

Gráfico 4.15. Valores percentuais nos gêneros da escrita em corpora português (I).

Século XIX

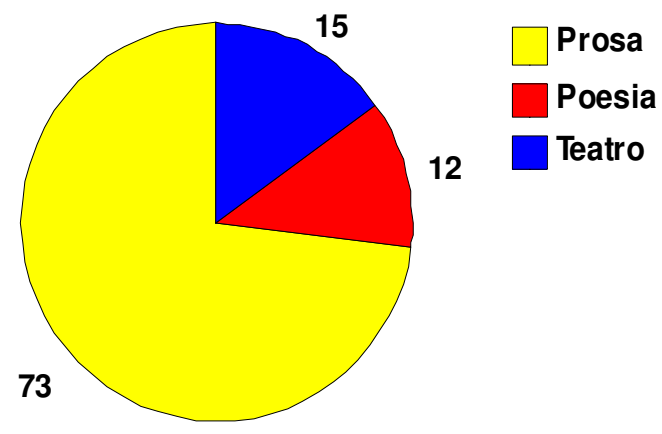

Século XX

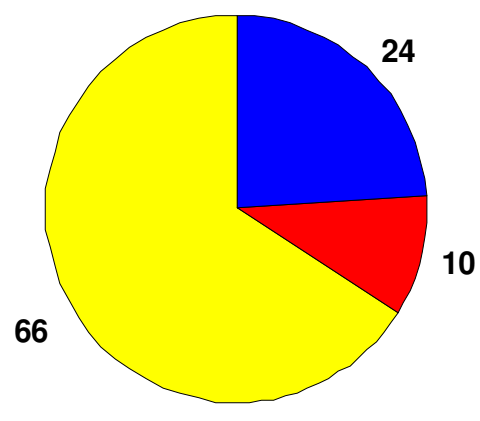

Gráfico 4.16. Valores percentuais nos gêneros da escrita em corpora português (II).

Pode-se, então, observar que em corpora português do século XIX analisado as ocorrências de palavras com o sufixo -ista dividem-se de forma bem diferente entre os três gêneros: prosa, poesia e teatro. A prosa mostra-se como o gênero que mais apresenta as formações, com quase três quartos das ocorrências encontradas, ou seja, setenta e três por cento $(73 \%)$ do total das palavras com -ista no período. O pouco mais de um quarto restante, divide-se entre o gênero do teatro, com quinze por cento (15\%) do total das palavras com -ista no período, e o gênero da poesia, com doze por cento (12\%) do total das palavras com -ista no período. Assim, pode-se concluir que, em corpora português do século XIX analisado, o uso das palavras formadas com o sufixo -ista, evidencia-se sobretudo no gênero prosaico.

Convém lembrar que no século XIX as letras portuguesas sofreram influência direta da literatura francesa, sobretudo na prosa, que estava em voga na França, com os mais variados 
temas desde os coloquiais e regionais até os eruditos e os científicos, tanto no Romantismo quanto no Realismo e Naturalismo. Observou-se, também, que os movimentos literários Realismo e Naturalismo concentraram mais o uso das formações com o sufixo -ista que o movimento Romântico, por exemplo, nas obras de Alexandre Herculano pertencente ao Romantismo quase não se encontraram formações com o sufixo -ista, no entanto, nas obras pertencentes ao Realismo, como as de Eça de Queiroz, abundam os usos das formações com o sufixo -ista. É interessante notar que, o teatro português da época, com grande influência do Romantismo, fez uma volta às temáticas medievais e aos temas de Gil Vicente com a exaltação do período áureo das navegações, dificultando o uso de formações com -ista, dada a temática centrada em um vocabulário mais próximo ao medieval. Em relação ao gênero da poesia, diferentemente do que ocorre na língua galega, as ocorrências de formações com o sufixo -ista mostraram-se muito escassas em corpora português, indicando que a expressão no gênero poético, dentro do período não se mostrou propícia para o uso do sufixo -ista.

Observa-se, também que, em corpora português do século $\mathrm{XX}$, as ocorrências de formações com o sufixo -ista mostram-se muito mais abundantes no gênero da prosa que nos demais gêneros estudados, com quase dois terços das ocorrências encontradas, ou seja, sessenta e seis por cento (66\%) do total das palavras com -ista no período. Do restante, praticamente um quarto do total das ocorrências encontradas verificam-se no gênero teatral, ou seja, vinte e quatro por cento (24\%). Já o gênero poético é o que menos apresenta ocorrências de palavras com o sufixo, apenas dez por cento (10\%).

Comparando-se os dados do século XIX com os dados do século XX, nota-se que, o uso das palavras formadas com o sufixo -ista evidencia uma forte característica prosaica, apresentando quase três quartos (73\%) das formações no século XIX e dois terços (66\%) das formações no século XX. Observa-se, então, que houve um decréscimo de sete por cento (7\%) no uso de formações com o sufixo -ista no gênero prosaico, do século XIX comparativamente com o século XX. O gênero da poesia mostrou-se o menos propenso ao uso das palavras formadas com o sufixo -ista, tanto no século XIX, com doze por cento (12\%) das formações, quanto no século XX, com dez por cento (10\%) delas. Nota-se, também, que houve um pequeno decréscimo de dois por cento (2\%) no uso de formações com o sufixo -ista no gênero poético, do século XIX comparativamente com o século XX. Já o gênero do teatro, apesar de se mostrar pouco propenso ao uso das palavras formadas com o sufixo -ista, tanto 
Estudo comparativo de aspectos semânticos do sufixo -ista no português e no galego.

no século XIX, com quinze por cento $(15 \%)$ das formações, quanto no século XX, com vinte e quatro por cento $(24 \%)$ delas, foi o único gênero que apresentou crescimento, nove por cento (9\%), no uso das formações, do século XIX comparativamente com o século XX.

Conforme foi visto, o teatro português do século XIX sofreu grande influência do Romantismo voltando às temáticas do período medieval e, portanto com poucas ocorrências de formações com -ista, quizá menos que o esperado para o período. Entretanto, o teatro português do século XX é muito heterogêneo e influenciado, por um lado pelo Realismo e Naturalismo (no início do século XX) e por outro lado pelos movimentos modernistas e de vanguarda portugueses, propiciando os experimentos e as inovações na temática, como também no léxico, abrangendo as áreas filosóficas, políticas, científicas, religiosas, assim como as temáticas populares. Dessa forma, constata-se um maior uso de formações com o sufixo estudado no século XX e, dado que no século XIX a ocorrência de formações foi menor que o esperado, é natural que o gênero do teatro seja o que apresente o maior crescimento percentual de uso de formações com o sufixo -ista.

Convém notar que o gênero prosa jornalística no século $\mathrm{XX}$, mostrou-se muito propenso ao uso das formações, apresentando sessenta e quatro ocorrências de palavras formadas com o sufixo -ista, o que leva a crer que o uso das formações também se dá em âmbito mais popular da escrita.

Conclui-se, então, que as ocorrências do uso de formações com o sufixo -ista em corpora português, tanto no século XX, quanto no século XIX, apresentam-se mais no gênero da prosa, seguido pelo gênero teatral e poético. Assim pode-se afirmar que em corpora português o gênero da prosa apresentou uma característica muito propensa ao uso das formações com o sufixo -ista. Verificou-se também que, ainda que tenha crescido seu uso no âmbito teatral, o teatro não se mostrou um gênero característico do uso das formações, assim como também a poesia não se evidenciou como um gênero característico do uso das formações com o sufixo -ista, em corpora português.

Tentando justificar a observação notada em corpora português com relação à característica de gênero das ocorrências de formações com o sufixo -ista, resolveu-se estudar o seu comportamento semântico no contexto encontrado e classificá-lo de acordo com o âmbito inserido, no século XIX e no século XX. 
Estudo comparativo de aspectos semânticos do sufixo -ista no português e no galego.

Analogamente ao que foi feito em corpora galego, em corpora português fez-se uma análise e uma classificação semântica dos usos das formações com -ista no século XIX e no século XX, observando as designações das formações encontradas em seu contexto em corpora, em cada século e posteriormente dividindo-as em categorias semânticas, detalhado no Anexo I deste trabalho.

Assim, para as formações portuguesas com o sufixo -ista encontradas em corpora do século XIX, quarenta e nove ocorrências foram classificadas semanticamente como “ocupação ou profissão", dezessete ocorrências como "adesão mental”, dezenove ocorrências como "qualidade característica", quinze ocorrências como "pertinência a grupos" e duas ocorrências classificadas na categoria "outros". Convém observar que estas duas ocorrências são: Batista e reliquista. Batista, nos contextos em que foi encontrada, designa um antropônimo, e a palavra reliquista ${ }^{1553}$, apesar de ser um agente, não é uma ocupação, por isso foram encaixadas na classe "outros".

Analogamente, para as formações portuguesas com o sufixo -ista encontradas em corpora do século XX, oitenta e três ocorrências foram classificadas semanticamente como "ocupação ou profissão", quarenta e duas ocorrências como "adesão mental", dezessete ocorrências como "qualidade característica", quinze ocorrências como "pertinência a grupos" e quatro ocorrências foram classificadas na categoria "outros", que são: Batista, correntista, onanista, pensionista; E foram assim classificadas pois, correntista designa quem possui conta-corrente; onanista designa quem freqüentemente pratica o onanismo ${ }^{1554}$; e pensionista $^{1555}$ designa, nos contextos encontrados, ora quem se hospeda em pensões, ora quem recebe aposentadoria ou pensão; ou seja, não se encaixam nas categorias: “ocupação ou profissão", “adesão mental”, “qualidade característica” ou "pertinência a grupos”.

A divisão semântica das ocorrências de -ista está ilustrada na tabela seguinte.

\footnotetext{
${ }^{1553}$ Segundo o Dicionário Houaiss, quem coleciona relíquias, tanto no sentido concreto quanto no abstrato.

1554 Segundo o Dicionário da Porto Editora, "masturbação".

${ }^{1555}$ Segundo o Dicionário da Porto Editora: 1. que ou pessoa que recebe uma pensão; 2. que ou pessoa que paga uma pensão.
} 
Estudo comparativo de aspectos semânticos do sufixo -ista no português e no galego.

\section{CLASSIFICAÇÄO SEMÂNTICA DAS FORMAÇÕES COM O SUFIXO -ISTA EM CORPORA PORTUGUÊS \\ Classe \\ SÉCULO XIX \\ SÉCULO XX}

OCUPAÇÃO

ADESÃO

QUALIDADE

PERTINÊNCIA

Outros
49

17

19

3

2
83

42

17

15

4

Tabela 4.8. Classificação semântica das ocorrências de -ista em corpora lusitano.

Pode-se notar, em termos absolutos, pelos dados da tabela 4.8, que todas as categorias semânticas no século XX tiveram um aumento no uso das formações, comparativamente ao século XIX, conforme está ilustrado no gráfico seguinte.

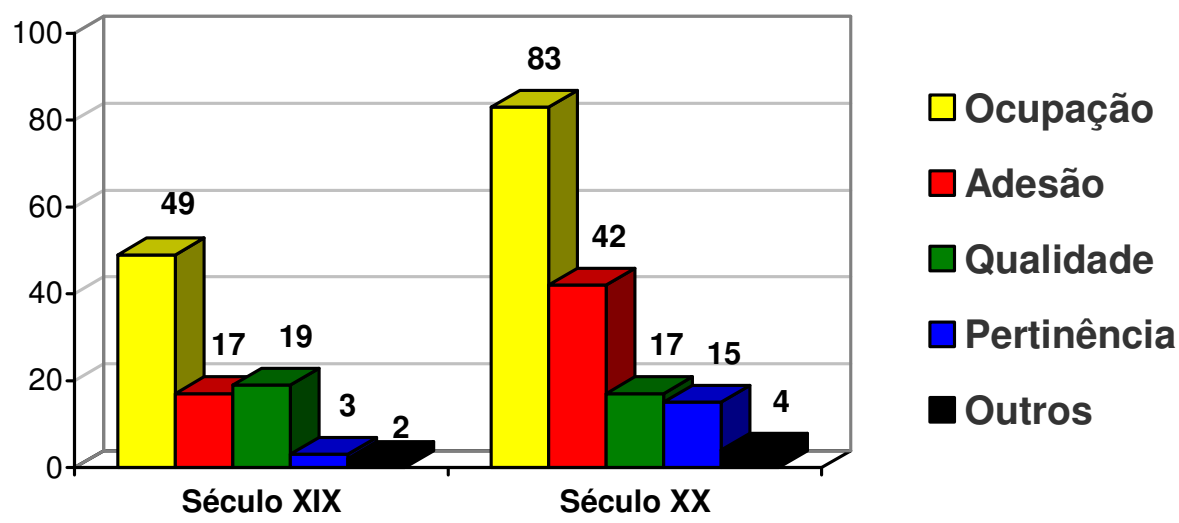

Gráfico 4.17. Classificação semântica das ocorrências de -ista em português lusitano.

Entretanto, os dados absolutos mostram apenas uma realidade pontual e para que realmente se possa identificar e analisar crescimentos é necessário que sejam feitos os cálculos dos valores percentuais referentes a cada categoria semântica, para compará-los entre si dentro de um mesmo padrão. Tais valores percentuais foram calculados e dispostos na tabela seguinte. 
Estudo comparativo de aspectos semânticos do sufixo -ista no português e no galego.

\begin{tabular}{|c|c|c|c|c|c|}
\hline \multirow{3}{*}{ ClaSSE } & \multicolumn{5}{|c|}{ CLASSIFICAÇÃO DE FORMAÇÕES COM O SUFIXO -ISTA EM CORPORA PORTUGUÊS } \\
\hline & \multicolumn{2}{|c|}{ SÉCULO XIX } & \multicolumn{2}{|c|}{ SÉCULO XX } & \multirow[b]{2}{*}{ CRESCIMENTO } \\
\hline & $\begin{array}{c}\text { Valores } \\
\text { absolutos }\end{array}$ & $\begin{array}{c}\text { Valores } \\
\text { percentuais }\end{array}$ & $\begin{array}{l}\text { Valores } \\
\text { absolutos }\end{array}$ & $\begin{array}{c}\text { Valores } \\
\text { percentuais }\end{array}$ & \\
\hline OCUPAÇÃO & 49 & $55 \%$ & 83 & $52 \%$ & $-3 \%$ \\
\hline ADESÃO & 17 & $19 \%$ & 42 & $26 \%$ & $7 \%$ \\
\hline QUALIDADE & 19 & $21 \%$ & 17 & $11 \%$ & $-10 \%$ \\
\hline PERTINÊNCIA & 3 & $3 \%$ & 15 & $9 \%$ & $6 \%$ \\
\hline OUTROS & 2 & $2 \%$ & 4 & $2 \%$ & 0 \\
\hline
\end{tabular}

Tabela 4.9. Classificação semântica das ocorrências do sufixo -ista em corpora português com os valores absolutos e com os valores percentuais obtidos.

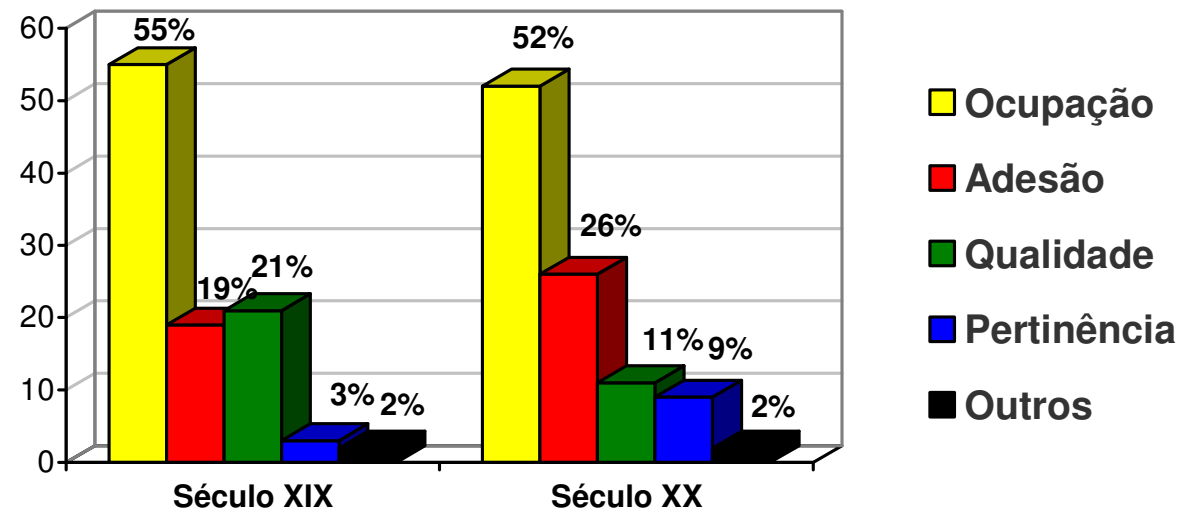

Gráfico 4.18. Valores percentuais da classificação semântica no português lusitano (I).

\section{Século XIX}

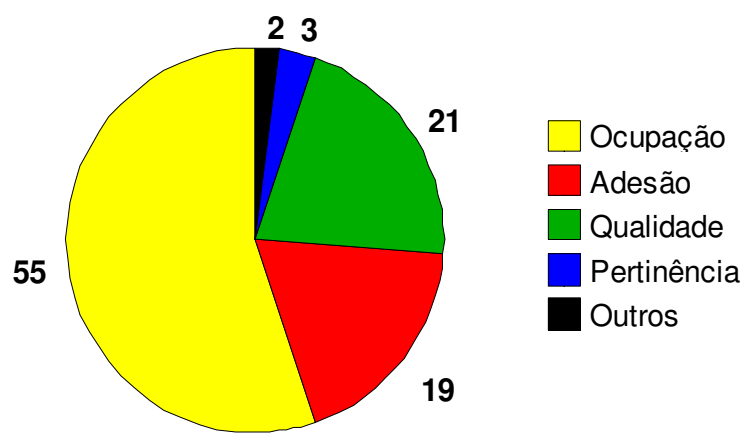

Século XX

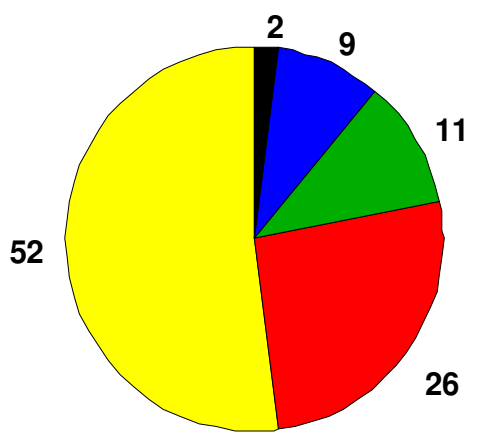

Gráfico 4.19. Valores percentuais da classificação semântica no português lusitano (II).

Analisando-se a tabela e os gráficos das categorias semânticas das formações com ista, em termos percentuais, pode-se constatar em corpora utilizado que a categoria semântica 
mais utilizada é a "ocupação ou profissão", com cinqüenta e cinco por cento (55\%) das ocorrências encontradas no século XIX, e com cinqüenta e dois por cento (52\%) das ocorrências encontradas no século XX. A categoria de "adesão mental" passou a ser a segunda mais utilizada no século XX, com vinte e seis por cento (26\%), enquanto no século XIX contava com dezenove por cento (19\%) e era a terceira categoria mais usada. A categoria "qualidade característica", que era a segunda mais usada no século XIX com vinte e um por cento $(21 \%)$, passou a ser a terceira no século XX, com onze por cento (11\%) das ocorrências encontradas. A categoria "pertinência a grupos" e a quarta categoria tanto no século XIX com três por cento $(3 \%)$ das ocorrências, quanto no século XX com nove por cento $(9 \%)$ de uso das formações com -ista. A categoria semântica menos utilizada é "outros", representando dois por cento (2\%) das ocorrências no século XIX e XX.

Dessa maneira, comparando-se os séculos XIX e XX constatou-se em corpora que houve um pequeno decréscimo de três por cento (3\%) no uso da categoria "ocupação ou profissão", ou seja, no século XIX contava com cinqüenta e cinco por cento (55\%), e no século XX passou para cinqüenta e dois por cento (52\%). Já na categoria "adesão mental" houve um aumento de sete por cento $(7 \%)$ no século XX em relação ao XIX. Na categoria "qualidade característica" houve uma diminuição de dez por cento (10\%) no século XX em relação ao XIX. Na categoria "pertinência a grupos" houve um aumento de três por cento (3\%) no século XX em relação ao XIX. Em outras palavras, no século XX, no português europeu, passou-se a se utilizar mais formações com o sufixo -ista que designam semanticamente "adesão mental" e "pertinência a grupos".

Entretanto, a conclusão a que se chega é que o uso de formações com o sufixo -ista em corpora utilizado cresceu do século XIX para o século XX no português europeu, apresentando-se principalmente nas categorias semânticas: "ocupação ou profissão", "adesão mental" e "qualidade característica", bem como o seu uso estilístico apresentou -se marcado pelo gênero prosaico. 


\section{Ocorrências do sufixo -ista no português brasileiro}

Pertencentes aos séculos XIX e XX foram analisadas setenta e uma obras brasileiras, das quais trinta e cinco pertencem ao século XIX, e trinta e seis são pertencentes ao século XX. A título de ilustração, tomou-se também como corpus o jornal O Estado de São Paulo, publicado no dia 08 de junho de 2006. Nas obras do século XIX foram encontradas cento e duas formações com o sufixo -ista e no século XX foram encontradas duzentas e sessenta e nove formações com o sufixo. Observando-se no século XX um crescimento de duzentos e sessenta e quatro por cento (264\%), conforme está ilustrado no gráfico seguinte.

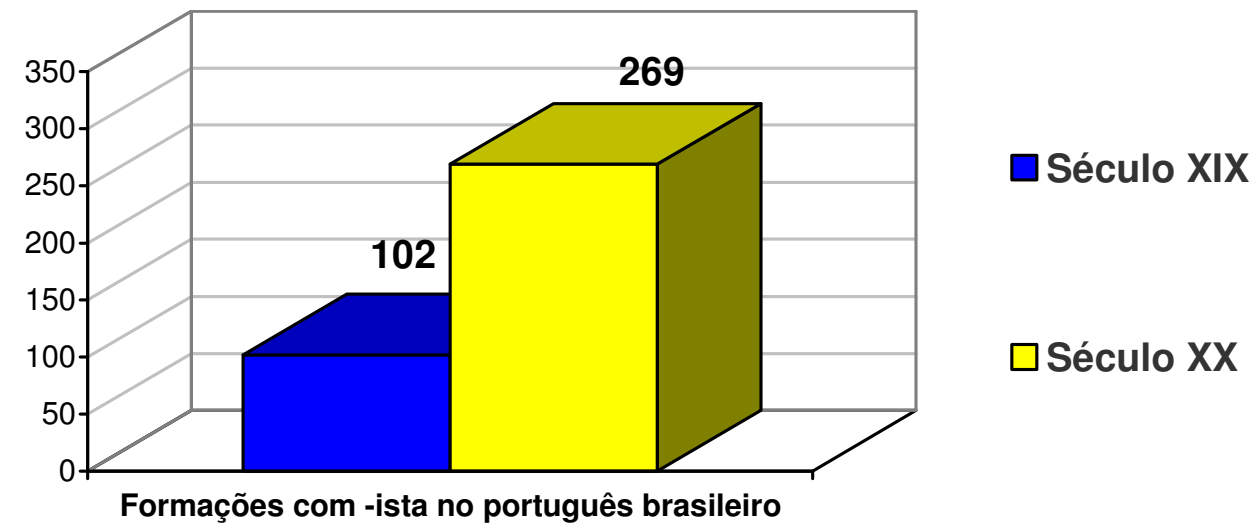

Gráfico 4.20. Ocorrências do sufixo -ista em corpora brasileiro.

Em termos quantitativos por gênero da obra no século XIX foram obtidas oitenta e cinco formações com o sufixo - ista no gênero da prosa, quatorze no gênero da poesia e trinta e uma no teatro. Conforme está ilustrado no gráfico seguinte.

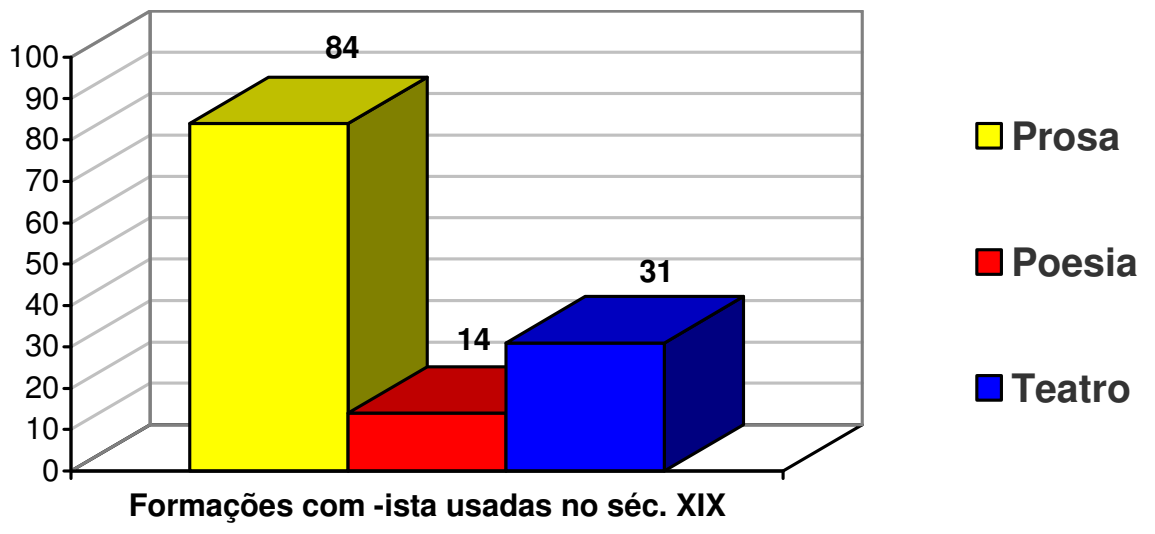

Gráfico 4.21. Distribuição nos gêneros da escrita em corpora brasileiro do século XIX. 
Estudo comparativo de aspectos semânticos do sufixo -ista no português e no galego.

Assim, pode-se perceber que, em valores absolutos, as formações com -ista foram muito mais utilizadas no gênero prosaico do que nos gêneros poético e teatral. Sabe-se que, normalmente, o gênero prosaico é o mais utilizado na escrita, e, portanto, é natural que apresente uma maior concentração em números absolutos da formação procurada. Convém lembrar que no século XIX as letras brasileiras sofreram grande influência das letras francesas, sobretudo na prosa, tanto no Romantismo quanto no Realismo e Naturalismo.

Em termos quantitativos por gênero da obra analisada do século XX foram obtidas cento e sessenta e sete ocorrências com o sufixo -ista no gênero da prosa, trinta e uma na poesia, quarenta e nove no teatro e noventa e oito ocorrências na edição de jornal. Conforme está ilustrado no gráfico seguinte.

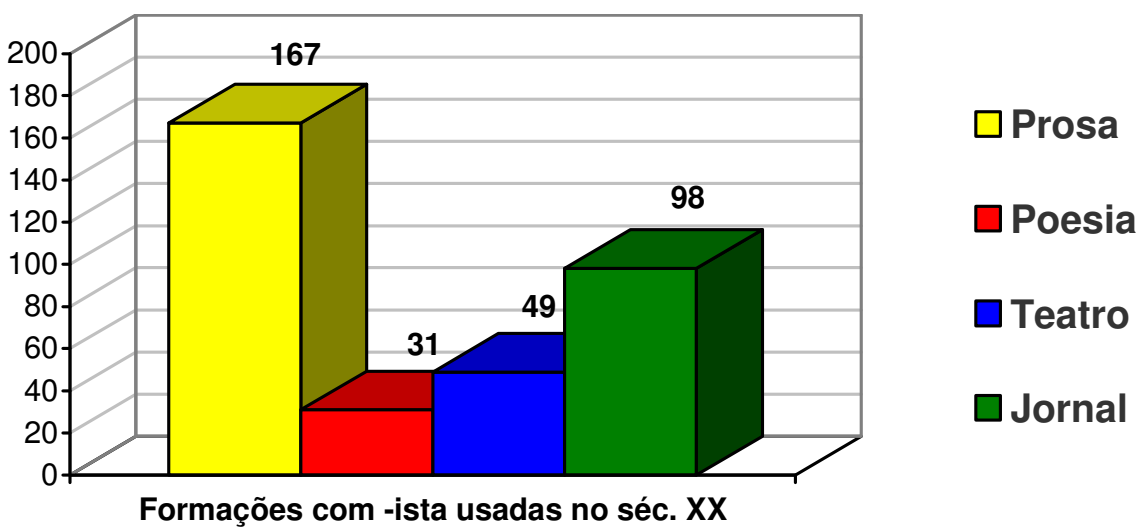

Gráfico 4.22. Distribuição nos gêneros da escrita em corpora brasileiro do século XX.

Na tabela seguinte estão dispostos os dados referente à distribuição nos gêneros da escrita no século XIX e XX, em corpora brasileiro.

DISTRIBUIÇÄO EM CORPORA BRASILEIRO DAS FORMAÇÕES COM O SUFIXO -ISTA

GÊNERO

SÉCULO XIX

84

14

31
SÉCULO XX

167

31

49

Tabela 4.10. Ocorrências do sufixo -ista nos gêneros da escrita em corpora brasileiro. 
Estudo comparativo de aspectos semânticos do sufixo -ista no português e no galego.

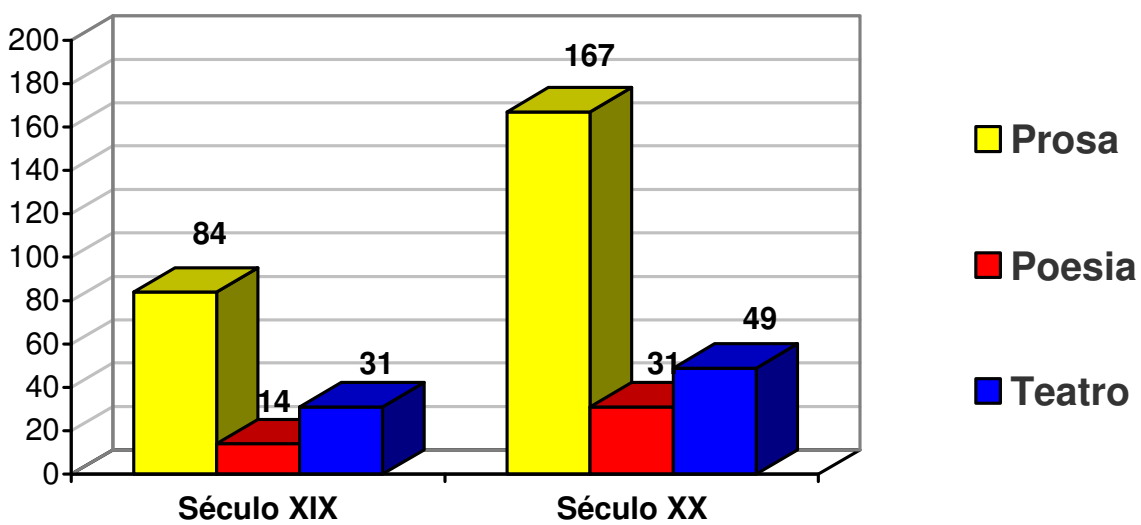

Gráfico 4.23. Ocorrências do sufixo -ista nos gêneros da escrita em corpora brasileiro.

Observando-se a tabela 4.10 e gráfico 4.23 , nota-se que o uso das formações com -ista cresceu no século XX, comparativamente com o século XIX. Entretanto, computando-se os valores percentuais em cada gênero relativo ao número total de formações com o sufixo em cada período, obteve-se a tabela e os gráficos seguintes.

\begin{tabular}{|c|c|c|c|c|c|}
\hline \multirow{3}{*}{ GÊNERO } & \multicolumn{5}{|c|}{ OCORRÊNCIAS DE FORMAÇÕES COM O SUFIXO -ISTA EM CORPORA BRASILEIRO } \\
\hline & \multicolumn{2}{|c|}{ SÉCULO XIX } & \multicolumn{2}{|c|}{ SÉCULO XX } & \multirow[b]{2}{*}{ CRESCIMENTO } \\
\hline & $\begin{array}{l}\text { Valores } \\
\text { absolutos }\end{array}$ & $\begin{array}{c}\text { Valores } \\
\text { percentuais }\end{array}$ & $\begin{array}{l}\text { Valores } \\
\text { absolutos }\end{array}$ & $\begin{array}{l}\text { Valores } \\
\text { percentuais }\end{array}$ & \\
\hline PROSA & 84 & $65 \%$ & 167 & $68 \%$ & $3 \%$ \\
\hline POESIA & 14 & $11 \%$ & 31 & $12 \%$ & $1 \%$ \\
\hline TEATRO & 31 & $24 \%$ & 49 & $20 \%$ & $-4 \%$ \\
\hline
\end{tabular}

Tabela 4.11. O sufixo -ista nos gêneros da escrita em corpora brasileiro em valores absolutos e em valores percentuais.

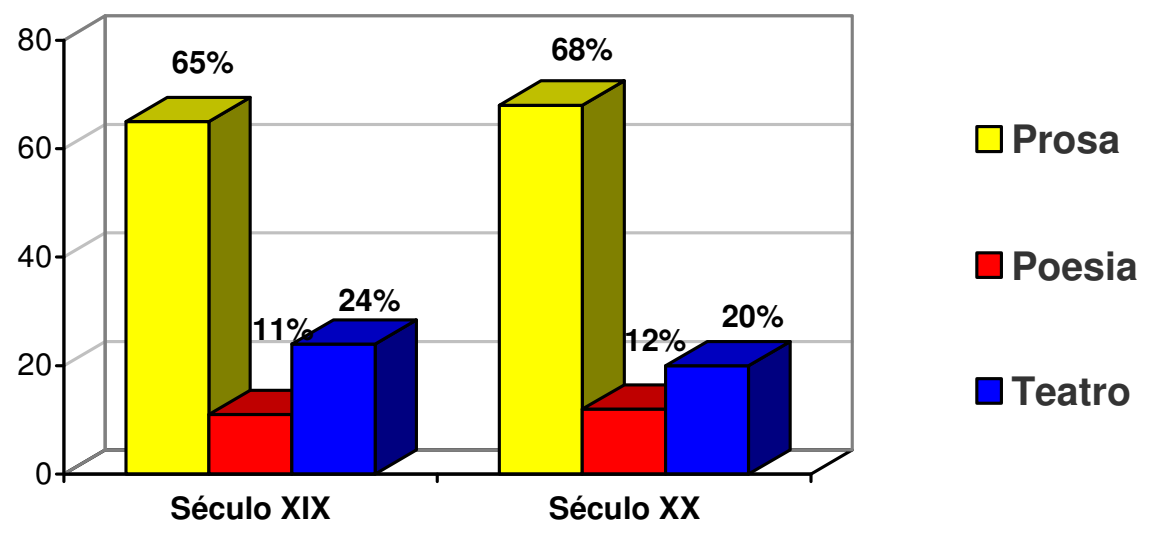

Gráfico 4.24. Valores percentuais nos gêneros da escrita em corpora brasileiro (I). 

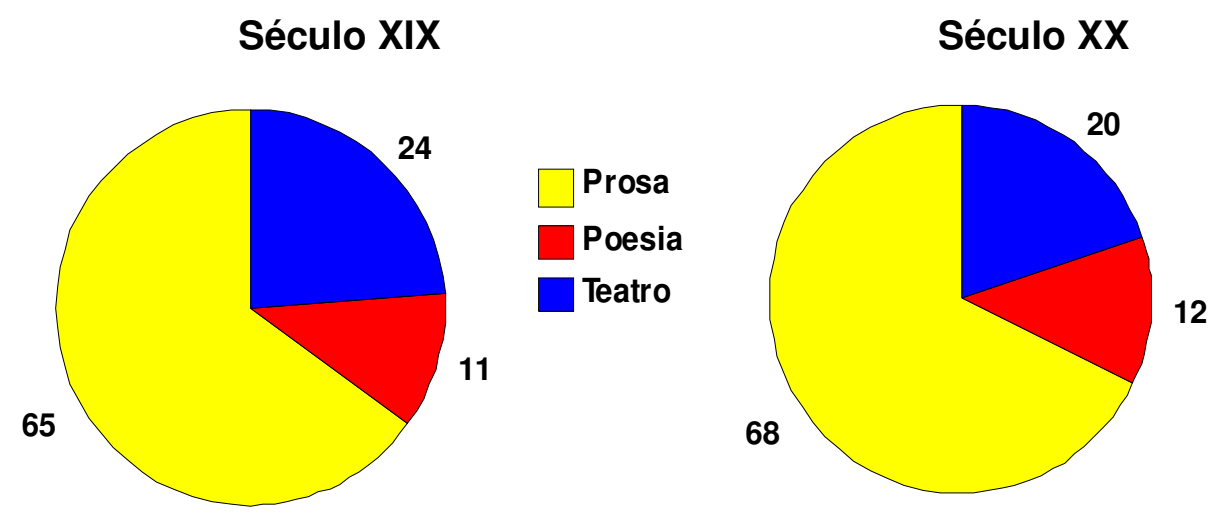

Gráfico 4.25. Valores percentuais nos gêneros da escrita em corpora brasileiro (II).

Pode-se, então, observar que em corpora brasileiro do século XIX analisado as ocorrências de palavras com o sufixo -ista dividem-se de forma bem diferente entre os três gêneros: prosa, poesia e teatro. A prosa mostra-se como o gênero que mais apresenta as formações, com quase dois terços das ocorrências encontradas, ou seja, sessenta e cinco por cento $(65 \%)$ do total das palavras com -ista no período. O pouco mais de um terço restante, divide-se entre o gênero do teatro, com quase um quarto do total das palavras com -ista no período, ou seja, vinte e quatro por cento (24\%), e o gênero da poesia, com onze por cento (11\%) do total das palavras com -ista no período. Assim, pode-se concluir que, em corpora brasileiro do século XIX analisado, o uso das palavras formadas com o sufixo -ista, evidencia-se sobretudo no gênero prosaico.

Observa-se, também que, em corpora brasileiro do século $\mathrm{XX}$, as ocorrências de formações com o sufixo -ista mostram-se muito mais abundantes no gênero da prosa que nos demais gêneros estudados, com mais de dois terços das ocorrências encontradas, ou seja, sessenta e oito por cento (68\%) do total das palavras com -ista no período. Do restante, vinte por cento $(20 \%)$ do total das ocorrências encontradas verificam-se no gênero teatral, e apenas doze por cento (12\%) verificam-se no gênero poético, que apresenta a menor ocorrência de palavras com o sufixo.

Comparando-se os dados do século XIX com os dados do século XX, nota-se que, o uso das palavras formadas com o sufixo -ista evidencia uma forte característica prosaica, apresentando quase dois terços $(65 \%)$ das formações no século XIX e mais de dois terços (68\%) das formações no século XX. Observa-se, então, que houve um aumento de três por 
Estudo comparativo de aspectos semânticos do sufixo -ista no português e no galego.

cento (3\%) no uso de formações com o sufixo -ista no gênero prosaico, do século XIX para o século XX. O gênero da poesia mostrou-se o menos propenso ao uso das palavras formadas com o sufixo -ista, tanto no século XIX, com onze por cento (11\%) das formações, quanto no século XX, com doze por cento $(12 \%)$ delas. Nota-se, também, que houve um pequeno aumento de apenas um por cento (1\%) no uso de formações com o sufixo -ista no gênero poético, do século XIX para o século XX, comparativamente. Já o gênero do teatro, apesar de não se mostrar muito propenso ao uso das palavras formadas com o sufixo -ista, tanto no século XIX, com quase um quarto do total das formações (24\%), quanto no século XX, com um quinto (20\%) delas, foi o único gênero que apresentou decréscimo, quatro por cento (4\%), no uso das formações, do século XIX para o século XX.

Sabe-se que o teatro brasileiro do século XIX, diferentemente do teatro português, sofreu uma grande influência do Realismo francês com várias ocorrências de formações com -ista. Já o teatro do século XX é muito heterogêneo e varia de autor para autor, por exemplo, na obra completa de Nelson Rodrigues consultada, somente em Toda nudez será castigada, foram encontradas formações com o sufixo estudado. Analogamente, nas obras de Dias Gomes consultadas, somente em $O$ pagador de promessas foi encontrada uma única ocorrência com o sufixo -ista: fetichista. Já nas obras de Millôr Fernandes abundam as formações derivadas com -ista. Assim é natural que o número de ocorrências de formações com -ista tenha diminuído no século XX ao se comparar com o XIX.

Notou-se, também, que na prosa do século XIX os movimentos literários Realismo e Naturalismo concentraram mais formações com o sufixo -ista que o movimento do Romantismo. Por exemplo, em $O$ guarani, de José de Alencar, pertencente ao Romantismo, foram encontradas apenas quatro formações com o sufixo estudado, ao passo que nas obras Senhora e Guerra dos Mascates, pertencentes ao final do Romantismo e já com algumas influências e características do Realismo, as formações com o sufixo -ista tornam-se bem mais abundantes, assim como nas obras de Machado de Assis.

Convém notar que o gênero prosa jornalística, assim como no galego e no português europeu, no século XX, mostrou-se muito propenso ao uso das formações, apresentando noventa e oito ocorrências de palavras formadas com o sufixo -ista encontradas em uma única edição de jornal e cinqüenta e oito formações encontradas no livro $O$ complô que elegeu 
Estudo comparativo de aspectos semânticos do sufixo -ista no português e no galego.

Tancredo (1985), prosa jornalística organizada por Ricado Noblat, o que aponta para o uso das formações também no âmbito popular da escrita.

Quanto à poesia brasileira no século XIX, acredita-se que, por estar muito presa à forma e a uma temática mais tradicional, o uso de formações com -ista era algo mais raro, ao passo que no século XX, com o Movimento Literário Modernista, a experimentação com novas formas, temas e vocabulário justificam o grande aumento do uso das formações com o sufixo em números absolutos, no entanto frente ao número total de ocorrências obtido em corpora, devido principalmente ao abundante uso na prosa, o gênero poético não se destaca como característico do uso de formações com -ista.

Conclui-se, então, que, de maneira similar ao encontrado em corpora português, as ocorrências do uso de formações com o sufixo -ista em corpora brasileiro, tanto no século $\mathrm{XX}$, quanto no século XIX, apresentam-se mais no gênero da prosa, seguido pelo gênero teatral e poético. Assim pode-se afirmar que em corpora brasileiro o gênero da prosa apresentou uma característica muito propensa ao uso das formações com o sufixo -ista. Verificou-se também que o teatro não se mostrou um gênero característico do uso das formações, assim como também a poesia não se evidenciou como um gênero característico do uso das formações com o sufixo -ista, em corpora brasileiro.

Analogamente ao que foi feito em corpora galego e português, em corpora brasileiro fez-se uma análise e uma classificação semântica dos usos das formações com -ista no século XIX e no século XX, observando as designações das formações encontradas em seu contexto em corpora, em cada século e posteriormente dividindo-as em categorias semânticas, detalhado no Anexo I deste trabalho.

Assim, para as formações com o sufixo -ista encontradas em corpora brasileiro do século XIX, cinqüenta e três ocorrências foram classificadas semanticamente como "ocupação ou profissão", treze ocorrências como "adesão mental", vinte e duas ocorrências como "qualidade característica", onze ocorrências como "pertinência a grupos" e três classificadas na categoria "outros". Convém observar que estas três ocorrências são: Batista, fumista e tabaquista. Batista designa um antropônimo, e as palavras fumista e tabaquista apesar de designar agentes, não designam ocupação, por isso foram encaixadas na classe "outros". 
Estudo comparativo de aspectos semânticos do sufixo -ista no português e no galego.

Analogamente, para as formações com o sufixo -ista encontradas em corpora brasileiro do século XX, cento e trinta e nove ocorrências foram classificadas semanticamente como "ocupação ou profissão", sessenta e nove ocorrências como "adesão mental”, quarenta e sete ocorrências como "qualidade característica", treze ocorrências como "pertinência a grupos" e cinco ocorrências foram classificadas na categoria "outros", que são: Batista, correntista, pensionista, rapezista e vegetarista; E foram assim classificadas pois, correntista designa quem possui conta-corrente; pensionista designa, nos contextos encontrados, ora quem se hospeda em pensões, ora quem recebe aposentadoria ou pensão; ou seja, não se encaixam nas categorias: "ocupação ou profissão","adesão mental”, "qualidade característica" ou "pertinência a grupos". Conforme está ilustrado na tabela seguinte.

\section{CLASSIFICAÇÄO SEMÂNTICA DAS FORMAÇÕES COM O SUFIXO -ISTA EM CORPORA BRASILEIRO \\ Classe \\ OCUPAÇÃO \\ ADESÃO \\ QUALIDADE \\ PERTINÊNCIA \\ OUTROS \\ SÉCULO XIX \\ 53 \\ 13 \\ 22 \\ 11 \\ 3 \\ SÉCULO XX \\ 13 \\ 5}

Tabela 4.12. Classificação semântica das ocorrências de -ista em corpora brasileiro.

Pode-se notar, em termos absolutos, que todas as categorias semânticas no século XX tiveram um aumento comparativamente ao século XIX, conforme o gráfico seguinte.

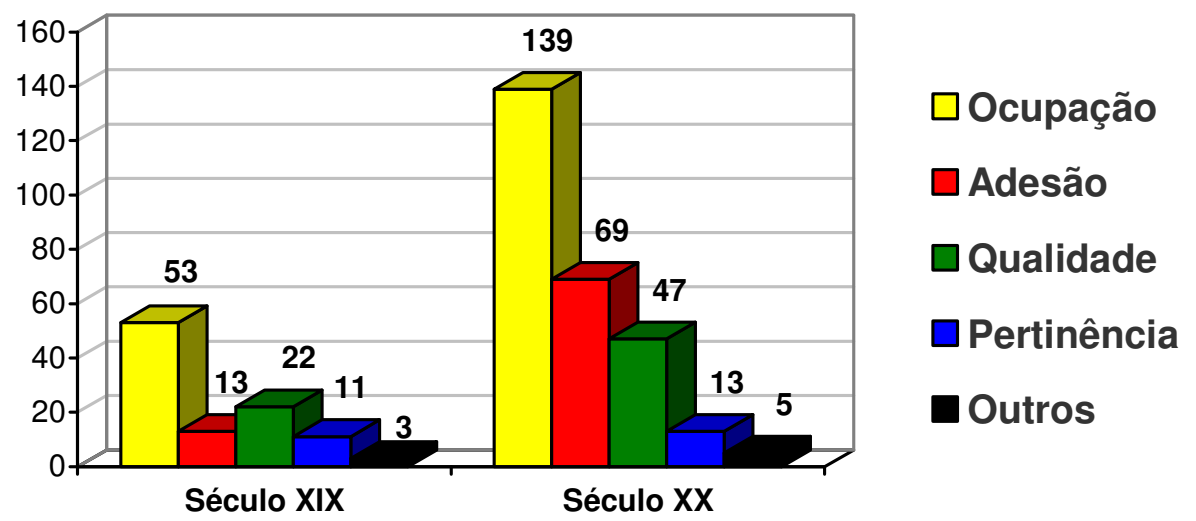

Gráfico 4.26. Classificação semântica das ocorrências de -ista em português brasileiro. 
Estudo comparativo de aspectos semânticos do sufixo -ista no português e no galego.

Ao calcular os percentuais, foram obtidos: a tabela e os gráficos seguintes.

\begin{tabular}{|c|c|c|c|c|c|}
\hline \multirow{3}{*}{ Classe } & \multicolumn{5}{|c|}{ CLASSIFICAÇÃO DE FORMAÇÕES COM O SUFIXO -ISTA EM CORPORA } \\
\hline & \multicolumn{2}{|c|}{ SÉCULO XIX } & \multicolumn{2}{|c|}{ SÉCULO XX } & \multirow[b]{2}{*}{ CRESCIMENTO } \\
\hline & $\begin{array}{l}\text { Valores } \\
\text { absolutos }\end{array}$ & $\begin{array}{c}\text { Valores } \\
\text { percentuais }\end{array}$ & $\begin{array}{l}\text { Valores } \\
\text { absolutos }\end{array}$ & $\begin{array}{c}\text { Valores } \\
\text { percentuais }\end{array}$ & \\
\hline OCUPAÇÃO & 53 & $52 \%$ & 139 & $52 \%$ & 0 \\
\hline ADESÃO & 13 & $13 \%$ & 69 & $25 \%$ & $12 \%$ \\
\hline QUALIDADE & 22 & $21 \%$ & 47 & $17 \%$ & $-4 \%$ \\
\hline PERTINÊNCIA & 11 & $11 \%$ & 13 & $4 \%$ & $-7 \%$ \\
\hline OUTROS & 3 & $3 \%$ & 5 & $2 \%$ & $-1 \%$ \\
\hline
\end{tabular}

Tabela 4.13. Classificação semântica das ocorrências do sufixo -ista em corpora brasileiro com os valores absolutos e com os valores percentuais obtidos.

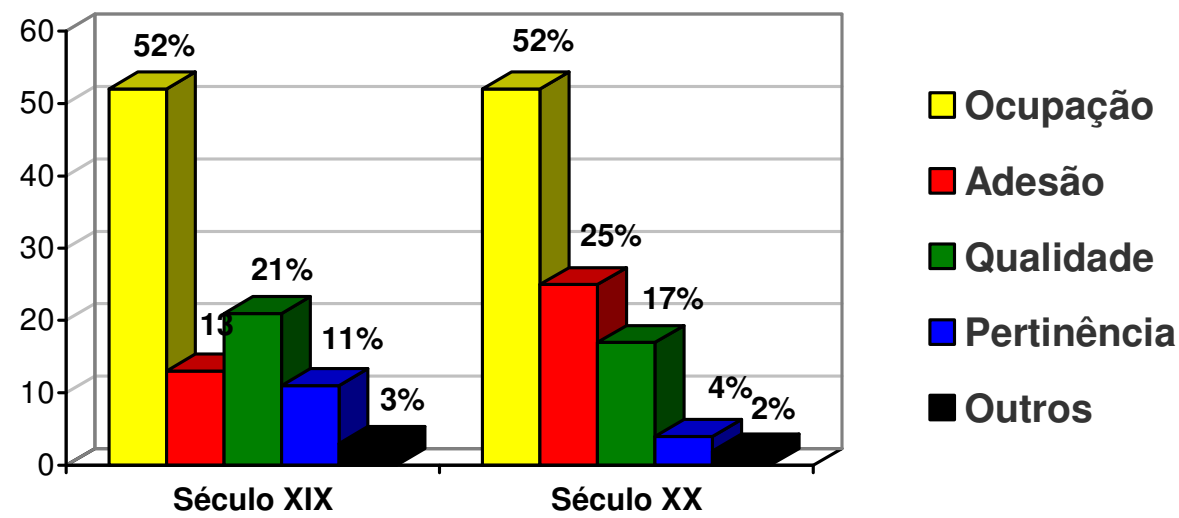

Gráfico 4.27. Valores percentuais da classificação semântica no português do Brasil (I).

\section{Século XIX}

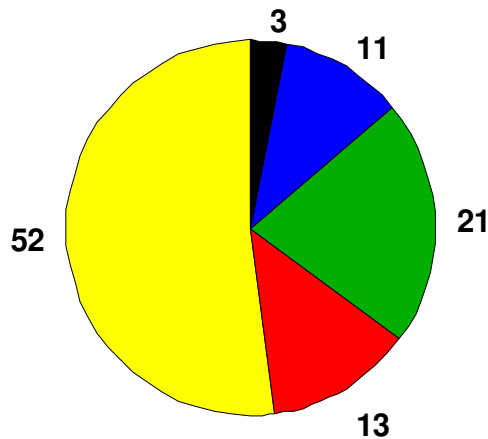

Século XX

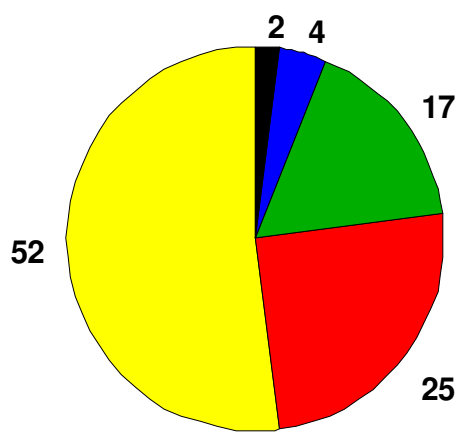

Gráfico 4.28. Valores percentuais da classificação no português do Brasil (II). 
Estudo comparativo de aspectos semânticos do sufixo -ista no português e no galego.

Analisando-se a tabela e os gráficos das categorias semânticas das formações com ista, em termos percentuais, comparativos do século XIX e XX, pode-se constatar em corpora utilizado que tanto no século XIX quanto no século XX, a categoria semântica mais utilizada é "ocupação ou profissão", com cinqüenta e dois por cento (52\%) das ocorrências encontradas. A categoria "adesão mental" passou a ser a segunda mais utilizada no século $\mathrm{XX}$, com vinte e cinco por cento (25\%), enquanto no século XIX contava com treze por cento (13\%) e era a terceira categoria mais usada. A categoria "qualidade característica", que era a segunda mais usada no século XIX com vinte e um por cento (21\%), passou a ser a terceira no século XX, com dezessete por cento (17\%) das ocorrências encontradas. A categoria "pertinência a grupos" mostrou-se a quarta categoria tanto no século XIX com onze por cento (11\%) das ocorrências, quanto no século XX com quatro por cento (4\%) de uso das formações com -ista. A categoria semântica menos utilizada é "outros", representando três por cento (3\%) das ocorrências no século XIX e dois por cento (2\%) no século XX.

Dessa maneira, comparando-se os séculos XIX e XX constatou-se em corpora que houve manutenção nos números encontrados no uso da categoria "ocupação ou profissão". Já na categoria "adesão mental" houve um aumento de doze por cento (12\%) no século XX em relação ao XIX; nas demais categorias semânticas houve uma diminuição no século XX em relação ao XIX. Na categoria "qualidade característica" houve uma diminuição de quatro por cento (4\%); na categoria "pertinência a grupos" houve uma diminuição de sete por cento (7\%) e na categoria "outros" houve uma diminuição de um por cento (1\%). Em outras palavras, no século XX, no português brasileiro, passou-se a utilizar mais formações com o sufixo -ista que designam semanticamente "adesão mental" e a utilizar menos formações que designam semanticamente "qualidade característica" e "pertinência a grupos".

Entretanto, conclui-se que o uso de formações com o sufixo -ista em corpora cresceu do século XIX para o século XX no português brasileiro, apresentando-se principalmente nas categorias semânticas: "ocupação ou profissão", "adesão mental" e "qualidade característica", bem como o seu uso estilístico apresentou-se marcadamente no gênero prosaico. 


\section{Comparação de usos entre o galego e o português}

Com os dados anteriormente obtidos, podem ser feitas várias comparações do uso das formações com -ista, no galego, no português do Brasil e no português de Portugal. Com relação ao número total de palavras com o sufixo -ista encontradas nas três variedades idiomáticas, comparando-se os séculos XIX e XX, pode-se notar que nas três houve um crescimento, em números absolutos, do uso de derivações com o sufixo, apresentando-se de maneira mais arrojada no galego e no português brasileiro, com um índice de crescimento superior a duzentos e cinqüenta por cento, e de maneira mais conservadora no português lusitano, com um índice de crescimento inferior a duzentos por cento. De tal forma que no galego houve o maior crescimento absoluto do uso das formações, mais de quatrocentos por cento $(413 \%)$, seguido do português brasileiro com crescimento de mais de duzentos por cento (264\%) e do português lusitano que apresentou um crescimento de cento e oitenta e um por cento (181\%), conforme está disposto na tabela e gráficos seguintes.

\begin{tabular}{|c|ccc|}
\multicolumn{4}{c}{ TOTAL DE FORMAÇÕES USADAS COM O SUFIXO -ISTA } \\
VARIEDADE IDIOMÁtICA & SÉCULO XIX & SÉCULO XX & CRESCIMENTO \\
GALEGO & 45 & 186 & $413 \%$ \\
PORTUGUÊS BRASILEIRO & 102 & 269 & $264 \%$ \\
PORTUGUÊS LUSITANO & 88 & 160 & $181 \%$ \\
TOTAL & $\mathbf{2 3 5}$ & $\mathbf{6 1 5}$ & $\mathbf{2 6 2 \%}$
\end{tabular}

Tabela 4.14. Uso de formações com o sufixo -ista.

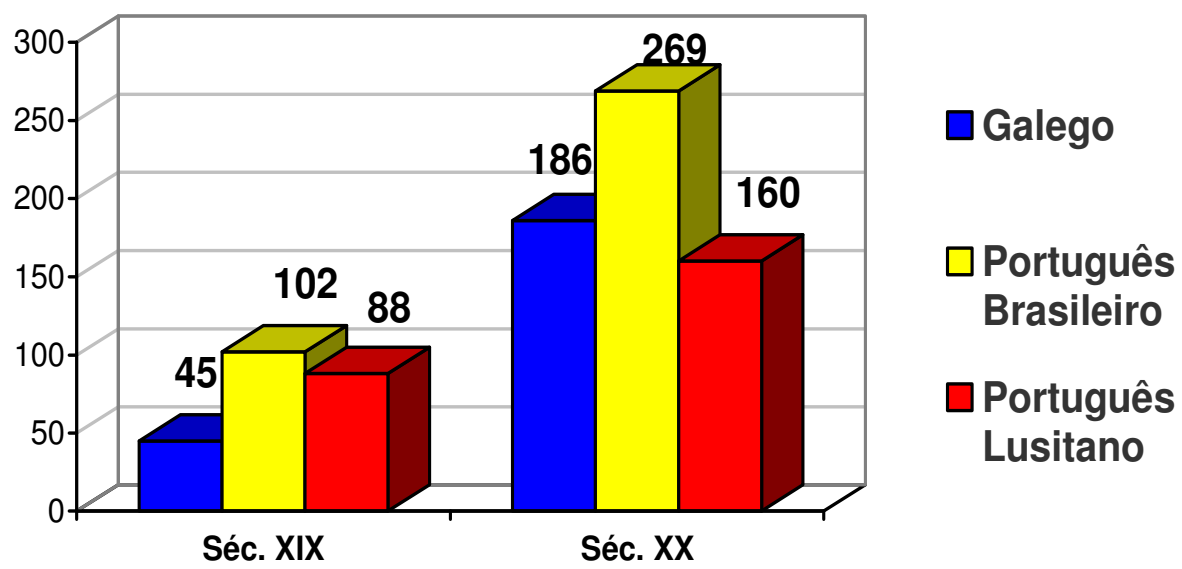

Gráfico 4.29. Formações usadas com o sufixo -ista, em números absolutos. 
Estudo comparativo de aspectos semânticos do sufixo -ista no português e no galego.

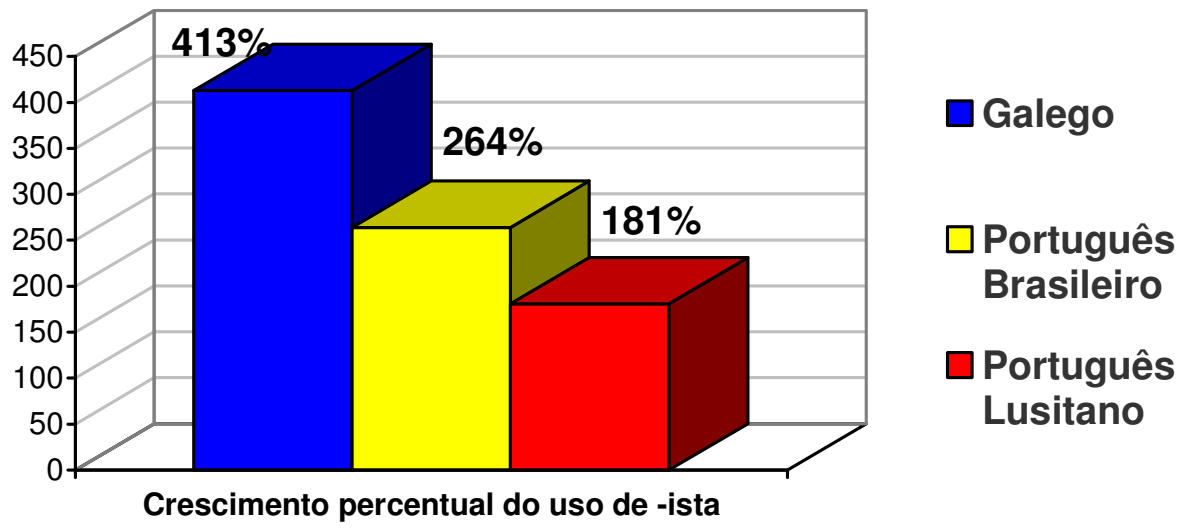

Gráfico 4.30. Crescimento do uso de formações com o sufixo -ista.

Pode-se notar também que em corpora total do século XIX, a variedade brasileira da língua portuguesa apresentou o maior índice de ocorrências com o sufixo -ista: quarenta e três por cento (43\%), seguida da variedade lusitana que apresentou um índice de trinta e oito por cento (38\%), e a língua galega apresentou o menor índice: apenas dezenove por cento (19\%). No século XX, a variedade brasileira continuou a apresentar o maior índice de ocorrências: quarenta e quatro por cento (44\%), seguida do galego com trinta por cento (30\%), e variedade lusitana, com vinte e seis por cento (26\%). Conforme o gráfico seguinte.

Século XIX

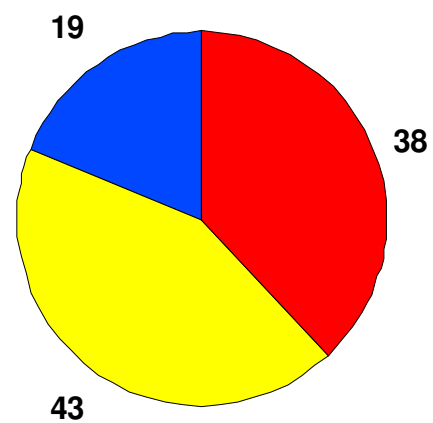

Século XX

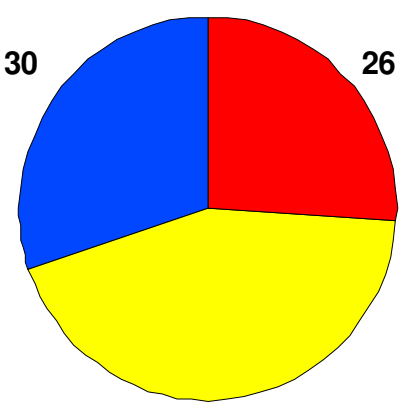

44

Gráfico 4.31. Uso de formações com o sufixo -ista nas três variedades idiomáticas.

Segundo Vilela (1994: 74), o sufixo -ista torna-se relevante na língua portuguesa a partir do século XIX, com o vocabulário político e social, passando posteriormente a outros âmbitos, sendo, portanto, o seu uso uma característica inovadora. 
Estudo comparativo de aspectos semânticos do sufixo -ista no português e no galego.

Assim, quanto ao uso de formações com o sufixo -ista, de modo geral, pode-se dizer que o galego mostrou-se mais conservador no século XIX e mais arrojado no $\mathrm{XX}$. Observando-se o português, nota-se que a variedade brasileira mostrou-se a mais arrojada tanto no século XIX quanto no XX, entretanto a lusitana mostrou-se arrojada no século XIX e um pouco mais conservadora no XX.

Comparando-se o século XIX e XX, nos três gêneros da escrita, com relação ao uso de formações com -ista, verificou-se que em corpora das três variedades idiomáticas a distribuição de valores é bem diversa, entretanto, nota-se claramente que é a prosa o gênero no qual se mostra a maioria das ocorrências. De acordo com a tabela seguinte.

\begin{tabular}{|c|c|c|c|c|c|c|}
\hline \multirow{3}{*}{ GÊNERO } & \multicolumn{6}{|c|}{ OCORRÊNCIAS DAS FORMAÇÕES COM O SUFIXO -ISTA } \\
\hline & \multicolumn{3}{|c|}{ SÉCULO XIX } & \multicolumn{3}{|c|}{ SÉCULO XX } \\
\hline & GALEGO & $\begin{array}{l}\text { PORTUGUÊS } \\
\text { BRASILEIRO }\end{array}$ & $\begin{array}{c}\text { PORTUGUÊS } \\
\text { LUSITANO }\end{array}$ & GALEGO & $\begin{array}{l}\text { PORTUGUÊS } \\
\text { BRASILEIRO }\end{array}$ & $\begin{array}{l}\text { PORTUGUÊS } \\
\text { LUSITANO }\end{array}$ \\
\hline PROSA & $\begin{array}{c}22 \\
(38 \%)\end{array}$ & $\begin{array}{c}84 \\
(65 \%)\end{array}$ & $\begin{array}{c}81 \\
(73 \%)\end{array}$ & $\begin{array}{c}136 \\
(73 \%)\end{array}$ & $\begin{array}{c}167 \\
(68 \%)\end{array}$ & $\begin{array}{c}105 \\
(66 \%)\end{array}$ \\
\hline POESIA & $\begin{array}{c}21 \\
(36 \%)\end{array}$ & $\begin{array}{c}14 \\
(11 \%)\end{array}$ & $\begin{array}{c}14 \\
(12 \%)\end{array}$ & $\begin{array}{c}32 \\
(17 \%)\end{array}$ & $\begin{array}{c}31 \\
(12 \%)\end{array}$ & $\begin{array}{c}16 \\
(10 \%)\end{array}$ \\
\hline TEATRO & $\begin{array}{c}15 \\
(26 \%)\end{array}$ & $\begin{array}{c}31 \\
(24 \%)\end{array}$ & $\begin{array}{c}16 \\
(15 \%)\end{array}$ & $\begin{array}{c}19 \\
(10 \%)\end{array}$ & $\begin{array}{c}49 \\
(20 \%)\end{array}$ & $\begin{array}{c}37 \\
(24 \%)\end{array}$ \\
\hline $\begin{array}{c}\underset{1556}{\text { TOTAL }} \\
(100 \%)\end{array}$ & 58 & 129 & 111 & 187 & 247 & 158 \\
\hline
\end{tabular}

Tabela 4.15. Ocorrência de formações com o sufixo -ista nos gêneros da escrita.

\begin{tabular}{cccccc}
\hline \multicolumn{5}{c}{ FORMAÇÕES USADAS COM O SUFIXO-ISTA } \\
\hline $\begin{array}{c}\text { GÊNERO } \\
\text { PROSA }\end{array}$ & \multicolumn{2}{c}{ SÉCULO XIX } & \multicolumn{2}{c|}{ SÉCULO XX } \\
& $\begin{array}{c}\text { VALORES } \\
\text { ABSOLUTOS }\end{array}$ & $\begin{array}{c}\text { VALORES } \\
\text { PERCENTUAIS }\end{array}$ & $\begin{array}{c}\text { VALORES } \\
\text { ABSOLUTOS }\end{array}$ & $\begin{array}{c}\text { VALORES } \\
\text { PERCENTUAIS }\end{array}$ & CRESCIMENTO \\
\hline GALEGO & 22 & $38 \%$ & 135 & $73 \%$ & $35 \%$ \\
\hline $\begin{array}{c}\text { PORTUGUÊS } \\
\text { BRASILEIRO }\end{array}$ & 84 & $65 \%$ & 167 & $68 \%$ & $3 \%$ \\
\hline $\begin{array}{c}\text { PORTUGUÊS } \\
\text { LUSITANO }\end{array}$ & 81 & $73 \%$ & 105 & $66 \%$ & $-7 \%$ \\
\hline
\end{tabular}

Tabela 4.16. Uso de formações com o sufixo -ista no gênero prosaico.

\footnotetext{
${ }^{1556}$ Nota-se que os totais apresentados na Tabela 4.14 diferem destes, pois aqui, na Tabela 4.15, cada ocorrência pode ser computada até três vezes, uma em cada gênero: na prosa, poesia e teatro. .
} 
Estudo comparativo de aspectos semânticos do sufixo -ista no português e no galego.

Observando-se a Tabela 4.16, específica do gênero prosaico, e comparando-se os séculos XIX e XX, pode-se notar que em todas as variedades mostrou-se um aumento nos números absolutos de ocorrências das formações com -ista. Nota-se também que na língua galega houve o maior crescimento do uso das formações derivadas com o sufixo -ista: trinta e cinco por cento (35\%), seguido da variedade brasileira da língua portuguesa e da variedade lusitana, com um decréscimo de sete por cento (7\%) no uso das formações com o sufixo. Conforme o gráfico seguinte.

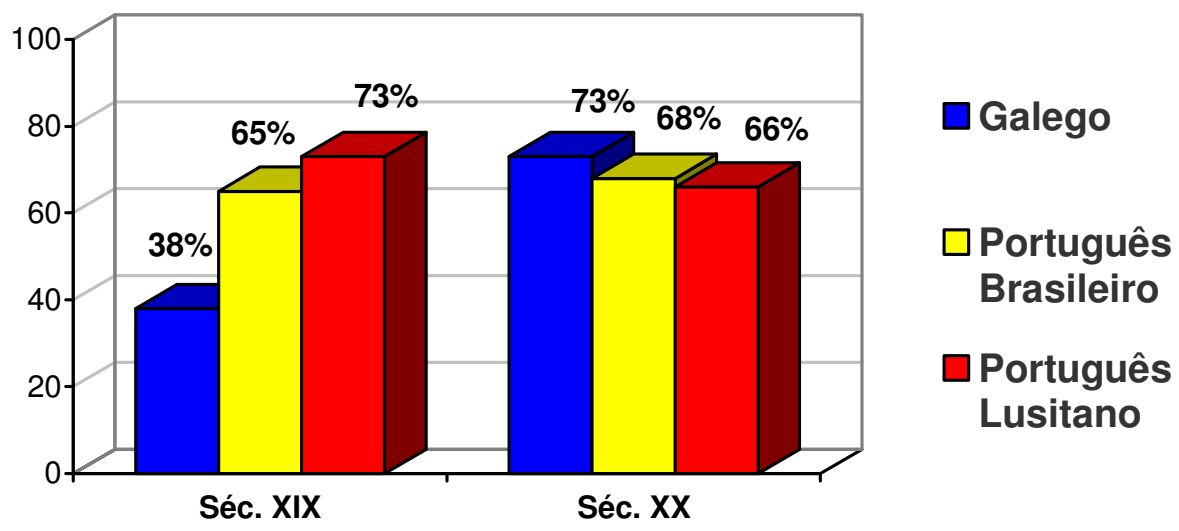

Gráfico 4.32. Uso de formações com o sufixo -ista na prosa, valores percentuais.

Observando-se os valores percentuais na tabela 4.16 e no gráfico 4.32 nota-se que trinta e oito por cento (38\%) das formações com o sufixo -ista encontradas em corpora galego do século XIX, mostram-se no gênero prosaico, e no século XX, esse número aumenta vertiginosamente para setenta e três por cento (73\%). No português brasileiro do século XIX, observa-se que sessenta e cinco por cento (65\%) das formações com o sufixo ocorrem no gênero da prosa, e no século XX a proporção praticamente se mantém com um pequeno acréscimo. Analogamente, no português lusitano do século XIX, observa-se que setenta e três por cento $(73 \%)$ das formações com o sufixo ocorrem no gênero da prosa, e no século XX há um decréscimo, passando a sessenta e seis por cento $(66 \%)$ na prosa.

Assim, pode-se afirmar que, do século XIX para o século XX, o galego aumentou sensivelmente o uso de formações com -ista no gênero da prosa, passando de trinta e oito por cento $(38 \%)$ para setenta e três por cento $(73 \%)$, ou seja, no galego do século XX as palavras com -ista adquiriram uma característica mais prosaica de uso. Além disso, pela observação dos valores em percentuais no século XX, pode-se afirmar que no galego, o uso das formações com o sufixo mostra-se muito mais propenso à prosa que nas variedades brasileira 
Estudo comparativo de aspectos semânticos do sufixo -ista no português e no galego.

e lusitana da língua portuguesa, cujo uso praticamente se manteve, com um pequeno aumento ou decréscimo, próximo ao do século XIX. Conforme o gráfico seguinte.

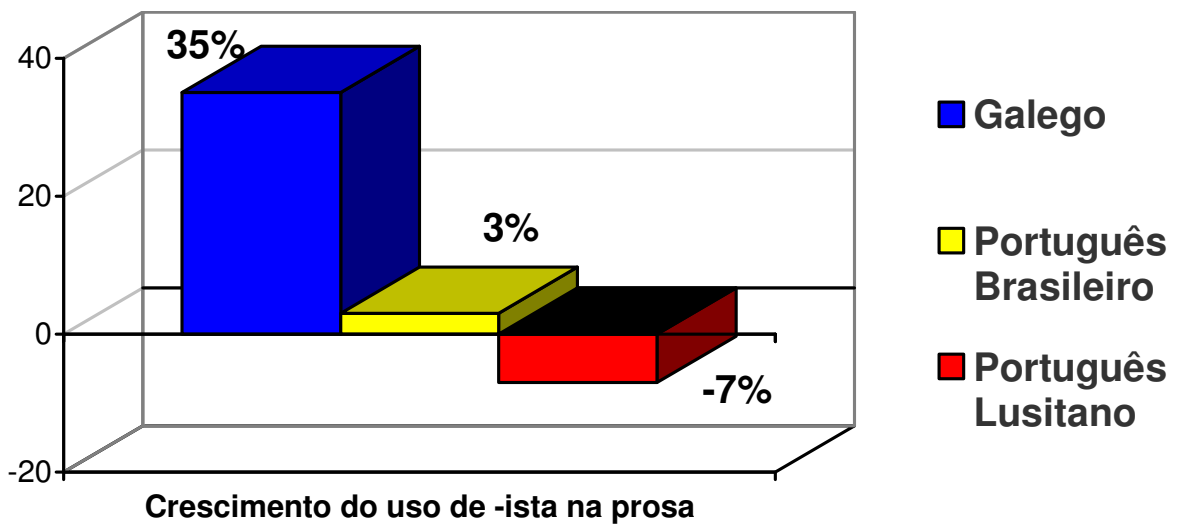

Gráfico 4.33. Crescimento do uso de formações com o sufixo -ista na prosa.

Com relação ao uso de formações com -ista no gênero poesia encontradas nas três variedades idiomáticas, comparando-se os séculos XIX e XX, pode-se notar que no galego houve o maior decréscimo do uso das formações, dezenove por cento (19\%), ao passo que no português lusitano houve um decréscimo de dois por cento (2\%) e no português brasileiro houve um pequeno crescimento de apenas um por cento $(1 \%)$. Na tabela e gráficos seguintes está disposta a distribuição do sufixo -ista no gênero poético, nas três variedades idiomáticas.

\begin{tabular}{|c|c|c|c|c|c|}
\hline \multirow{3}{*}{$\begin{array}{l}\text { GÊNERO } \\
\text { POESIA }\end{array}$} & \multicolumn{5}{|c|}{ FORMAÇÕES USADAS COM O SUFIXO -ISTA } \\
\hline & \multicolumn{2}{|c|}{ SÉCULO XIX } & \multicolumn{2}{|c|}{ SÉCULO XX } & \multirow{2}{*}{ CRESCIMENTO } \\
\hline & $\begin{array}{c}\text { VALORES } \\
\text { ABSOLUTOS }\end{array}$ & $\begin{array}{c}\text { VALORES } \\
\text { PERCENTUAIS }\end{array}$ & $\begin{array}{c}\text { VALORES } \\
\text { ABSOLUTOS }\end{array}$ & $\begin{array}{c}\text { VALORES } \\
\text { PERCENTUAIS }\end{array}$ & \\
\hline GALEGO & 21 & $36 \%$ & 32 & $17 \%$ & $-19 \%$ \\
\hline $\begin{array}{l}\text { PORTUGUÊS } \\
\text { BRASILEIRO }\end{array}$ & 14 & $11 \%$ & 31 & $12 \%$ & $1 \%$ \\
\hline $\begin{array}{c}\text { PORTUGUÊS } \\
\text { LUSITANO }\end{array}$ & 14 & $12 \%$ & 16 & $10 \%$ & $-2 \%$ \\
\hline
\end{tabular}

Tabela 4.17. Uso de formações com o sufixo -ista no gênero poético.

Observando-se a Tabela 4.17, pode-se notar que, no século XIX, o número de ocorrências com o sufixo -ista encontrado na poesia é igual no português brasileiro e no 
Estudo comparativo de aspectos semânticos do sufixo -ista no português e no galego.

lusitano, mas bem maior no galego. Já no século XX, o número de ocorrências é praticamente igual no português brasileiro e no galego, sendo menor na variedade lusitana. Nota-se, também, que, em valores absolutos, houve um aumento do número de ocorrências com o sufixo -ista nas três variedades idiomáticas, comparando-se o século XIX com o século XX, no gênero poético.

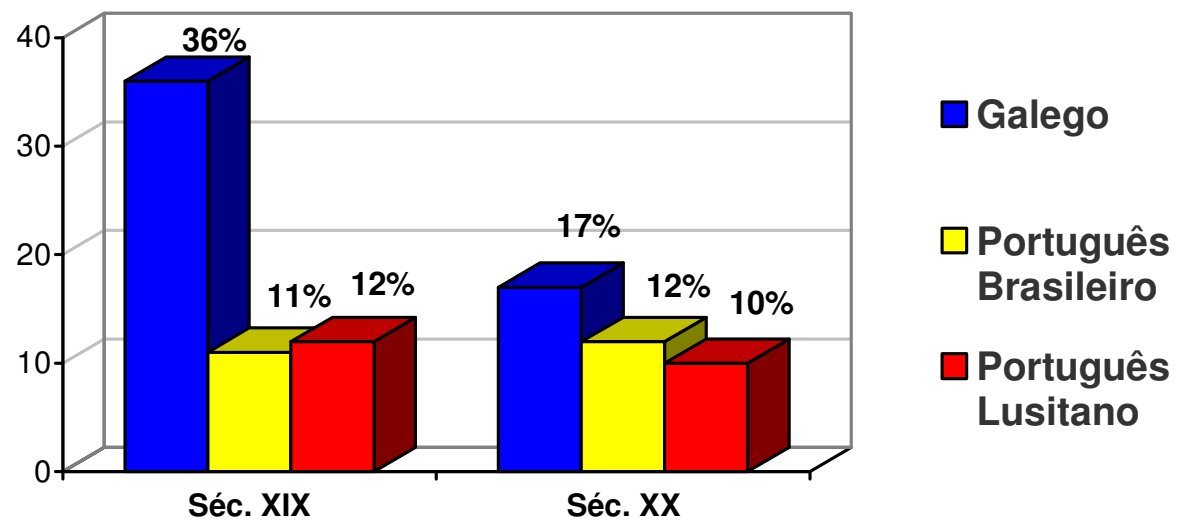

Gráfico 4.34. Uso de formações com o sufixo -ista na poesia, valores percentuais.

Apesar do visível aumento, no século $\mathrm{XX}$, em números absolutos das ocorrências de formações com o sufixo -ista na poesia, de acordo com o gráfico 4.34, em valores percentuais registra-se uma acentuada diminuição de ocorrências na língua galega: de trinta e seis por cento $(36 \%)$ no século XIX para dezessete por cento (17\%) no século XX. Nota-se também que tal diminuição já era esperada, pois é compatível com o aumento das ocorrências de formações com -ista verificado no gênero da prosa. Verifica-se ainda que no português brasileiro do século XIX, onze por cento (11\%) das formações com o sufixo ocorrem no gênero da poesia, e no século XX a proporção praticamente se mantém com um pequeno acréscimo, passando a doze por cento (12\%). Analogamente, no português lusitano do século XIX, observa-se que doze por cento (12\%) das formações ocorrem no gênero da poesia, e no século XX há um pequeno decréscimo, passando a dez por cento (10\%) na poesia.

Assim, pode-se afirmar que, do século XIX para o século XX, no galego verificou-se a sensível diminuição no uso de formações com -ista no gênero da poesia, ou seja, no galego do século $\mathrm{XX}$ as palavras com -ista adquiriram uma característica menos poética de uso, que do século XIX. Ainda assim, pela observação dos valores em percentuais no século XX, pode-se afirmar que no galego, o uso das formações com o sufixo mostra-se mais propenso à 
Estudo comparativo de aspectos semânticos do sufixo -ista no português e no galego.

poesia que no português brasileiro e lusitano, cujo uso se manteve próximo ao do século XIX, com um pequeno aumento ou decréscimo. Conforme o gráfico seguinte.

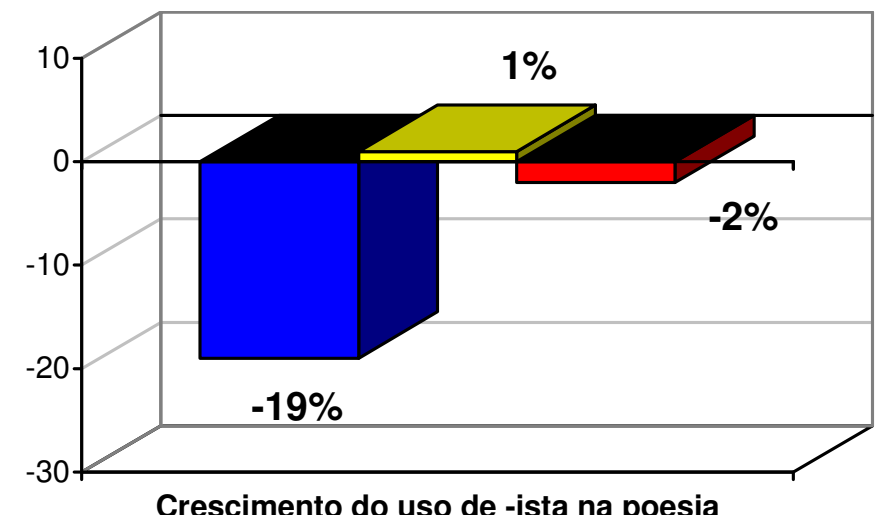

Crescimento do uso de -ista na poesia
- Galego

Português

Brasileiro

Português

Lusitano

Gráfico 4.35. Crescimento do uso de formações com o sufixo -ista na poesia.

Com relação ao uso de formações com -ista no gênero teatral encontradas nas três variedades idiomáticas, comparando-se os séculos XIX e XX, pode-se notar que só há crescimento do uso das formações no português lusitano com nove por cento (9\%), no português brasileiro há um pequeno decréscimo de quatro por cento (4\%) no uso das formações e no galego mostra-se um decréscimo significativo de dezesseis por cento (16\%). Na tabela e gráficos seguintes estão dispostos os dados referentes ao uso de formações com o sufixo -ista no teatro, em valores absolutos, percentuais, bem como seu índice de crescimento para cada uma das três variedades idiomáticas estudadas.

\begin{tabular}{|c|c|c|c|c|c|}
\hline \multirow{3}{*}{$\begin{array}{l}\text { GÊNERO } \\
\text { TEATRO }\end{array}$} & \multicolumn{5}{|c|}{ FORMAÇÕES USADAS COM O SUFIXO -ISTA } \\
\hline & \multicolumn{2}{|c|}{ SÉCULO XIX } & \multicolumn{2}{|c|}{ SÉCULO XX } & \multirow{2}{*}{ CRESCIMENTO } \\
\hline & $\begin{array}{l}\text { VALORES } \\
\text { ABSOLUTOS }\end{array}$ & $\begin{array}{c}\text { VALORES } \\
\text { PERCENTUAIS }\end{array}$ & $\begin{array}{l}\text { VALORES } \\
\text { ABSOLUTOS }\end{array}$ & $\begin{array}{c}\text { VALORES } \\
\text { PERCENTUAIS }\end{array}$ & \\
\hline GALEGO & 15 & $26 \%$ & 19 & $10 \%$ & $-16 \%$ \\
\hline $\begin{array}{l}\text { PORTUGUÊS } \\
\text { BRASILEIRO }\end{array}$ & 31 & $24 \%$ & 49 & $20 \%$ & $-4 \%$ \\
\hline $\begin{array}{c}\text { PORTUGUÊS } \\
\text { LUSITANO }\end{array}$ & 16 & $15 \%$ & 37 & $24 \%$ & $9 \%$ \\
\hline
\end{tabular}

Tabela 4.18. Uso de formações com o sufixo -ista no gênero teatral. 


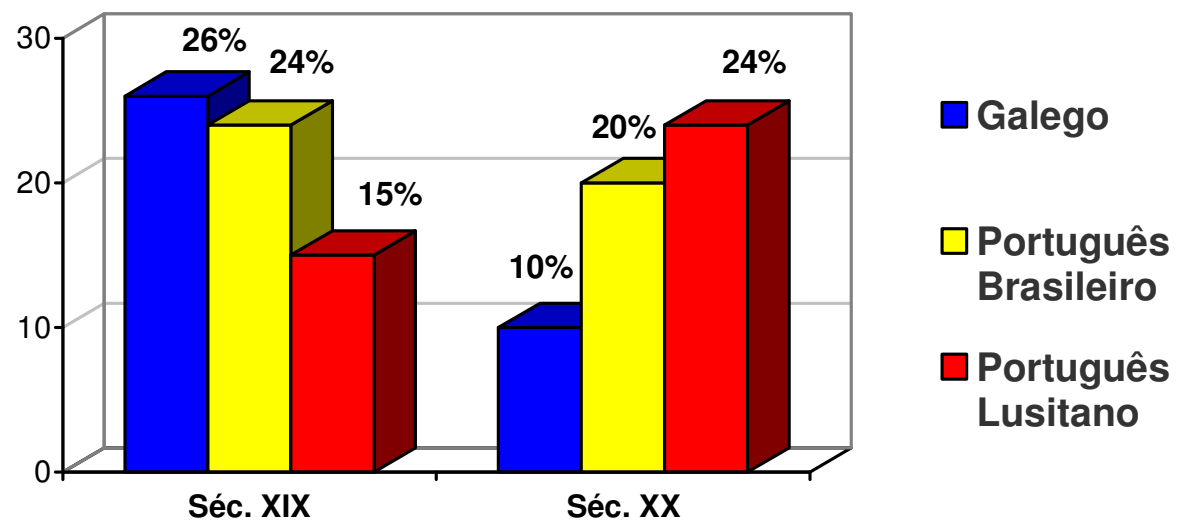

Gráfico 4.36. Uso de formações com o sufixo -ista no teatro, valores percentuais.

Apesar do aumento, no século XX, em números absolutos das ocorrências de formações com o sufixo -ista no gênero teatral, de acordo com o gráfico 4.36 dos valores percentuais registra-se uma significativa diminuição de ocorrências na língua galega: de vinte e seis por cento (26\%) no século XIX para dez por cento (10\%) no século XX. Nota-se também que tal diminuição já era esperada, pois é compatível com o grande aumento das ocorrências de formações com -ista verificado no gênero da prosa. Verifica-se ainda que no português brasileiro do século XIX, vinte e quatro por cento (24\%) das formações com o sufixo ocorrem no gênero do teatro, e no século XX há um pequeno decréscimo, passando a vinte por cento (20\%). Já, o português lusitano é a única variedade idiomática que apresenta um crescimento do uso de formações com o sufixo -ista no gênero teatral: no século XIX, observa-se que há quinze por cento $(15 \%)$ de ocorrências, aumentando, no século XX, para vinte e quatro por cento $(24 \%)$ de ocorrências das formações no teatro.

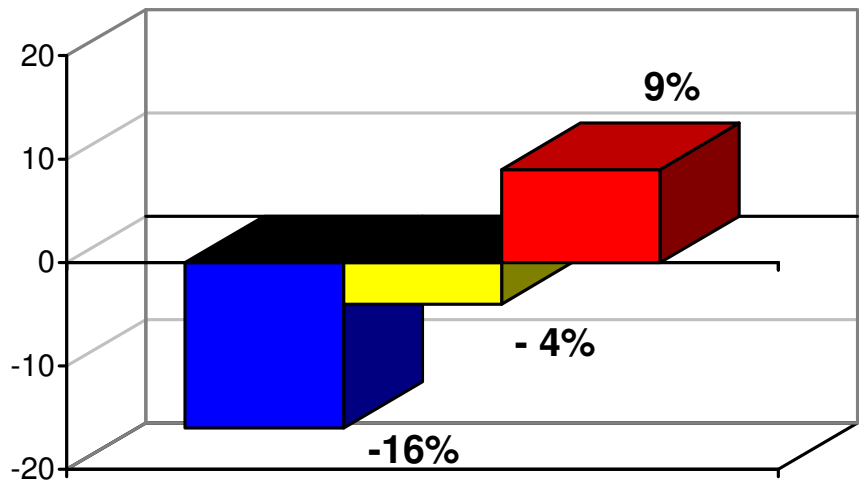

Crescimento do uso de -ista no teatro $\square$ Galego

Português

Brasileiro

Português

Lusitano

Gráfico 4.37. Crescimento do uso de formações com o sufixo -ista no teatro. 
Estudo comparativo de aspectos semânticos do sufixo -ista no português e no galego.

Assim, pode-se afirmar que, do século XIX para o século XX, no galego verificou-se uma sensível diminuição no uso de formações com -ista no gênero teatral, ou seja, no galego do século $\mathrm{XX}$ as palavras com -ista adquiriram uma característica menos teatral de uso, que do século XIX. Nota-se também, pela observação dos valores em percentuais no século XIX, que no galego (26\%), o uso das formações com o sufixo mostrava-se mais propenso ao teatro que no português brasileiro (24\%) e no português lusitano (15\%). No entanto, a distribuição de uso das formações modifica-se totalmente no século $\mathrm{XX}$, mostrando-se o português lusitano (24\%) mais propenso ao uso das formações com o sufixo, seguido do português brasileiro (20\%) e do galego (10\%).

Assim, quanto ao crescimento geral do uso das formações com -ista, no século XX em relação ao século XIX, pode-se notar que em número total de formações usadas, o maior crescimento foi no galego, seguido do português brasileiro e português lusitano. Dividindo-se em gêneros da escrita; obteve-se na prosa o maior crescimento no galego, seguido do português brasileiro e um decréscimo no português lusitano; na poesia houve um grande decréscimo no galego e basicamente uma estabilidade no português brasileiro e lusitano; no teatro o maior crescimento foi do português lusitano, havendo um pequeno decréscimo no português brasileiro e um decréscimo significativo no galego. Conforme está disposto na tabela seguinte.

\begin{tabular}{|c|c|c|c|c|c|c|c|c|c|}
\hline \multirow{3}{*}{ GÊNERO } & \multicolumn{9}{|c|}{ CRESCIMENTO DO USO DO SUFIXO -ISTA } \\
\hline & \multicolumn{3}{|c|}{ GALEGO } & \multicolumn{3}{|c|}{ PORTUGUÊS BRASILEIRO } & \multicolumn{3}{|c|}{ PORTUGUÊS LUSITANO } \\
\hline & XIX & XX & ÍNDICE & XIX & XX & ÍNDICE & XIX & XX & ÍNDICE \\
\hline PROSA & $38 \%$ & $73 \%$ & $35 \%$ & $65 \%$ & $68 \%$ & $3 \%$ & $73 \%$ & $66 \%$ & $-7 \%$ \\
\hline POESIA & $36 \%$ & $17 \%$ & $-19 \%$ & $11 \%$ & $12 \%$ & $1 \%$ & $12 \%$ & $10 \%$ & $-2 \%$ \\
\hline TEATRO & $26 \%$ & $10 \%$ & $-16 \%$ & $24 \%$ & $20 \%$ & $-4 \%$ & $15 \%$ & $24 \%$ & $9 \%$ \\
\hline
\end{tabular}

Tabela 4.19. Crescimento do uso do sufixo -ista nos gêneros da escrita.

Analisando-se a tabela 4.19, pode-se notar, ainda, que o gênero "prosa" é, em absoluto, o mais propenso para o uso de formações com o sufixo -ista nas três variedades idiomáticas, tanto no século XIX quanto no século XX. Em segundo lugar, na língua portuguesa destaca-se o uso do sufixo no gênero teatro, ao passo que na língua galega destaca-se o uso do sufixo no gênero poesia. 


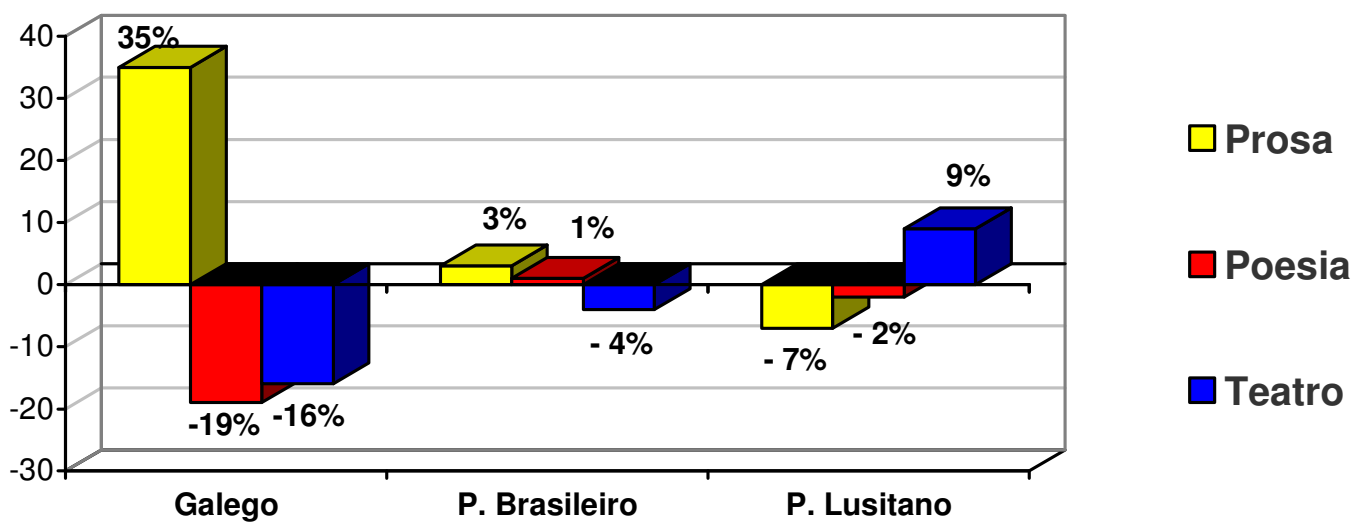

Gráfico 4.38. Índice de crescimento do uso do sufixo -ista nos gêneros da escrita.

No gráfico 4.38 está ilustrado o índice de crescimento das distribuições uso do sufixo -ista nos gêneros da escrita, no século XX comparativamente com o século XIX. De acordo com o gráfico, nota-se que no português brasileiro houve a menor variação dos índices, indicando que a distribuição do uso do sufixo manteve-se muito semelhante entre os séculos XIX e XX. Analogamente, pode-se considerar que no português lusitano houve uma pequena variação, inferior a dez por cento (10\%), indicando também que a distribuição do uso manteve-se similar entre os dois séculos. Entretanto, no galego nota-se uma grande variação nos índices, indicando que a distribuição do sufixo sofreu alterações significativas de uso do século XIX para o século XX , marcando, então, uma diferença de comportamento da língua galega, em relação ao uso do sufixo -ista, com as demais variedades lingüísticas estudadas.

Assim, analisando-se os três gráficos de distribuição: 4.39, 4.40 e 4.41, constata-se que no galego do século XIX o uso das formações com o sufixo mostra-se praticamente indiscriminado quanto aos três gêneros da escrita, já no século $\mathrm{XX}$, destaca-se o gênero da prosa para o uso das formações. Nota-se, então, que no século XX, a distribuição percentual entre os gêneros passa a ser muito similar no galego, português brasileiro e lusitano. Entretanto, o português, tanto brasileiro quanto lusitano, difere do galego em relação à proporção de uso nos gêneros teatro e poesia, no século XX. Convém notar também que, no século XX, a distribuição de uso do sufixo no galego está mais próxima da distribuição verificada no português brasileiro que da distribuição lusitana. 
Século XIX

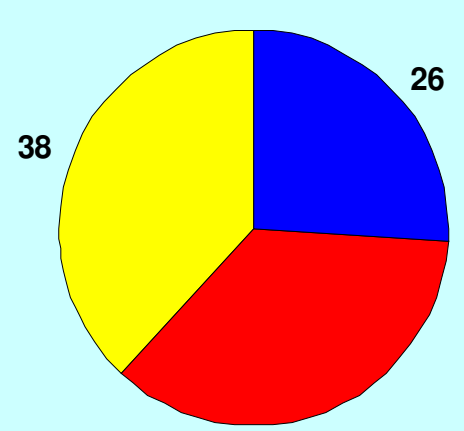

36

\section{Século XX}
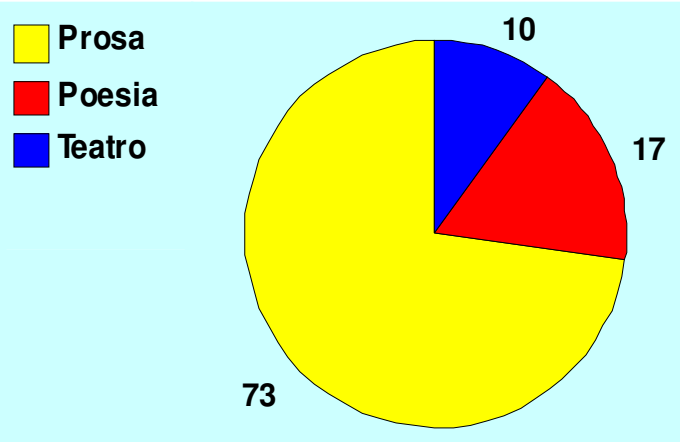

Gráfico 4.39. Valores percentuais nos gêneros da escrita em corpora galego.
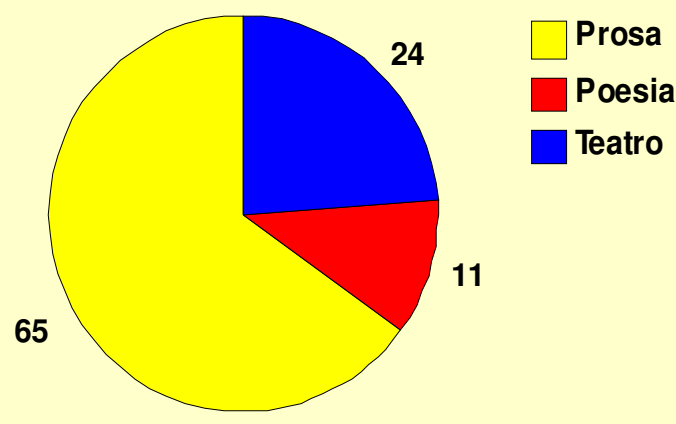

11

68

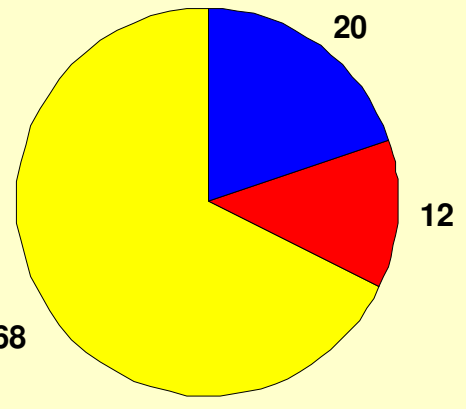

Gráfico 4.40. Valores percentuais nos gêneros da escrita em corpora brasileiro.

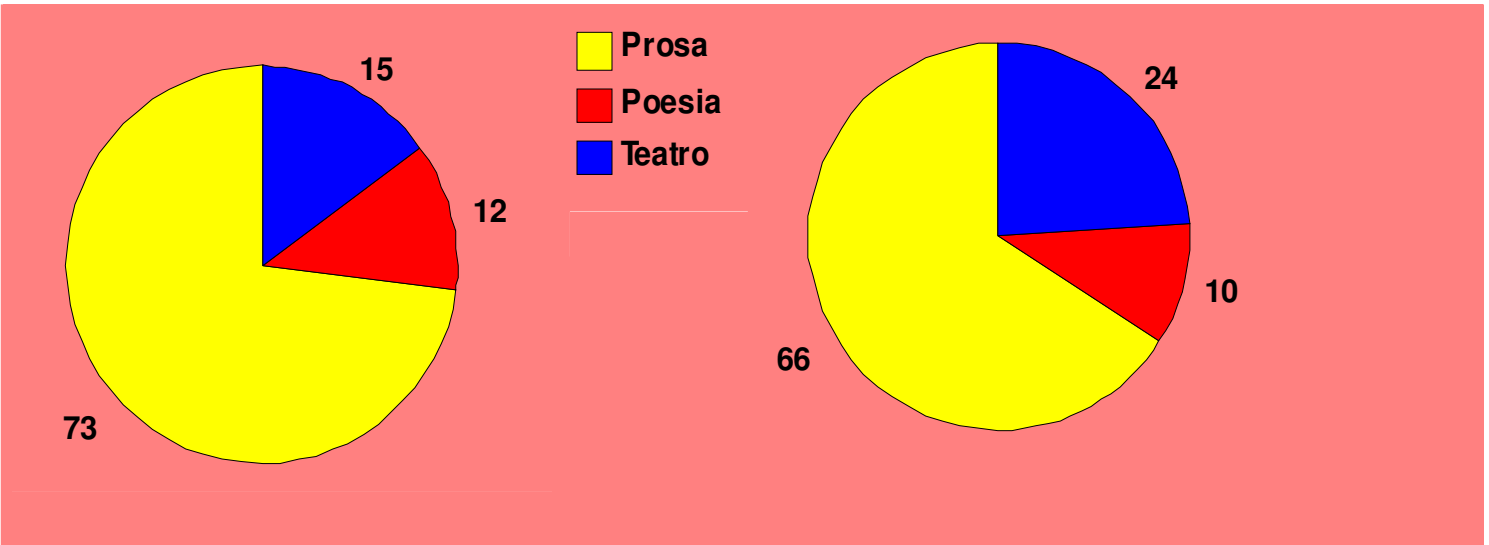

Gráfico 4.41. Valores percentuais nos gêneros da escrita em corpora português. 
Estudo comparativo de aspectos semânticos do sufixo -ista no português e no galego.

Desse modo, pode-se afirmar que houve uma mudança de comportamento da língua galega em relação ao sufixo -ista em corpora do século XIX, no qual sua característica de uso era praticamente indiscriminada entre os gêneros, comparativamente com o século $\mathrm{XX}$, em que o sufixo assume uma característica nitidamente prosaica de uso. Pode-se afirmar, então, que a língua galega no século XX aproximou-se à língua portuguesa, quanto à característica principal de emprego do sufixo nos gêneros da escrita, entretanto, em relação ao segundo maior uso, as línguas continuam diferindo: no galego é poético, e no português é teatral, porém com uma similar distribuição geral. Acredita-se que tal fato possa refletir fenômenos específicos de cada região que atuaram no desenvolvimento da língua quanto ao uso das palavras sufixadas com -ista nos gêneros da escrita.

De modo geral, conclui-se que a característica predominante de uso das palavras formadas com o sufixo -ista é prosaica, principalmente no século XX, nas três variedades idiomáticas estudadas.

Infelizmente não foi possível a verificação do crescimento do uso de palavras com o sufixo -ista na prosa jornalística, mas somente a comparação em termos de valores absolutos no século XX, bem como de valores percentuais em relação ao total de ocorrências no século, para uma única edição de jornal em cada variedade idiomática estudada. Desse modo, foram consultados três exemplares de jornal pertencentes ao ano de 2006. No entanto, pode-se notar que no português brasileiro, em números absolutos, houve noventa e oito ocorrências, seguido do português lusitano com sessenta e quatro e do galego com quarenta e duas, conforme está disposto na tabela e gráfico seguintes.

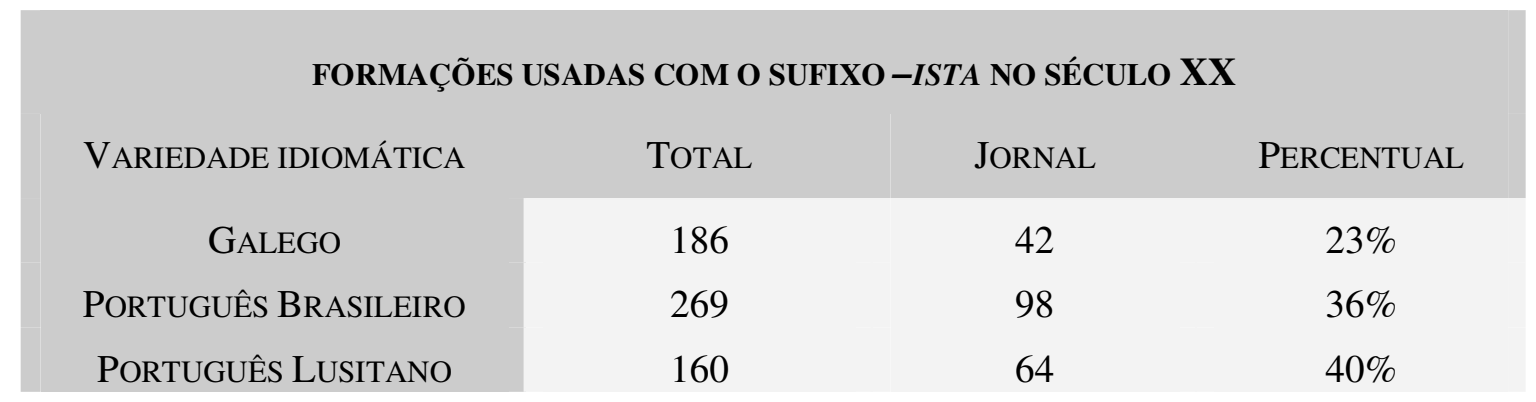

Tabela 4.20. Uso de formações como sufixo -ista em uma única edição de jornal. 


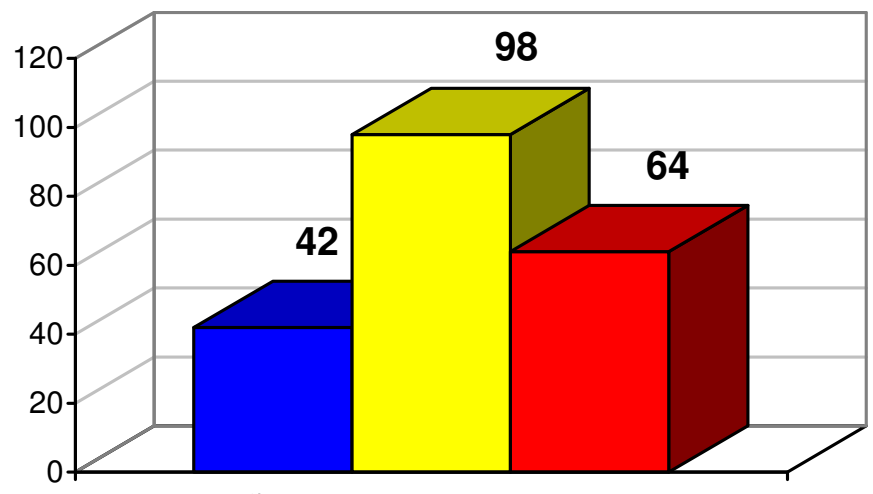

Formações com -ista usadas em jornais
Galego

Português

Brasileiro

Português

Lusitano

Gráfico 4.42. Uso de formações como sufixo -ista em uma única edição de jornal.

Convém notar que o jornal que representa o português brasileiro, O Estado de São Paulo, é pertencente à São Paulo, uma cidade muito maior que Lisboa, representada pelo $O$ Correio da Manhã, que por sua vez é muito maior que Santiago de Compostela, representada pelo jornal Galicia Hoxe, justificando a distribuição em valores absolutos. Já a distribuição em termos percentuais mostra-se maior no português lusitano com quarenta por cento (40\%), seguida pelo português brasileiro que apresenta trinta e seis por cento (36\%) das formações e do galego com apenas vinte e três por cento (23\%), conforme está disposto no gráfico seguinte.

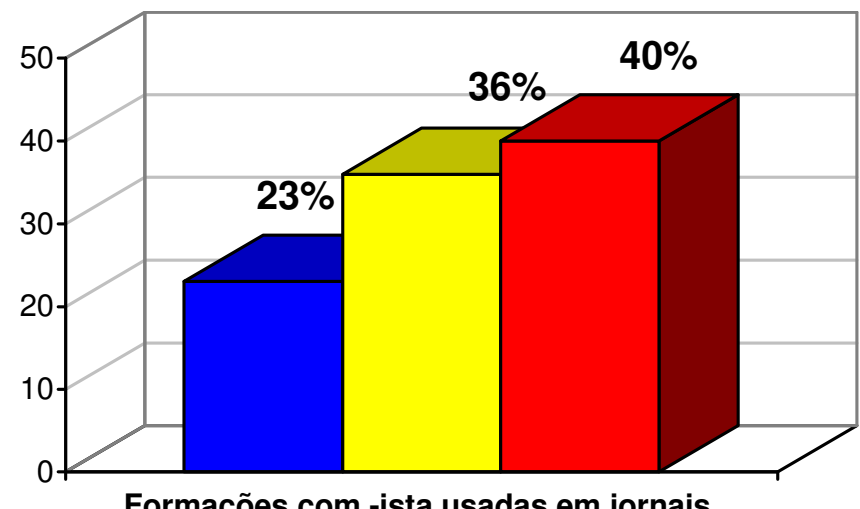

Formações com -ista usadas em jornais $\square$ Galego

Português

Brasileiro

Português

Lusitano

Gráfico 4.43. Uso de -ista em uma única edição de jornal, valores percentuais.

Assim pôde-se observar que, no corpora utilizado, a prosa jornalística, comparando-se os dados percentuais obtidos nas três variedades idiomáticas com apenas uma edição de jornal, evidencia-se como um subgênero da prosa mais propenso ao uso do sufixo -ista, que os gêneros poesia ou teatro.

Feita a classificação semântica das palavras com -ista na edição de jornal das três variedades idiomáticas, que está detalhada no Anexo I deste trabalho, obteve-se a tabela 
Estudo comparativo de aspectos semânticos do sufixo -ista no português e no galego.

seguinte com os valores absolutos e percentuais, bem como obteve-se o gráfico 4.44 comparativo da distribuição semântica em cada edição de jornal analisada.

\begin{tabular}{|c|c|c|c|c|c|c|}
\hline \multirow{3}{*}{ Classe } & \multicolumn{6}{|c|}{ FORMAÇÕES USADAS COM O SUFIXO -ISTA NO JORNAL } \\
\hline & \multicolumn{2}{|c|}{ GALEGO } & \multicolumn{2}{|c|}{ PORTUGUÊS BRASILEIRO } & \multicolumn{2}{|c|}{ PORTUGUÊS LUSITANO } \\
\hline & $\begin{array}{c}\text { VALOR } \\
\text { ABSOLUTO }\end{array}$ & $\begin{array}{c}\text { VALOR } \\
\text { PERCENTUAL }\end{array}$ & $\begin{array}{c}\text { VALOR } \\
\text { ABSOLUTO }\end{array}$ & $\begin{array}{c}\text { VALOR } \\
\text { PERCENTUAL }\end{array}$ & $\begin{array}{c}\text { VALOR } \\
\text { ABSOLUTO }\end{array}$ & $\begin{array}{c}\text { VALOR } \\
\text { PERCENTUAL }\end{array}$ \\
\hline OCUPAÇÃO & 18 & $44 \%$ & 68 & $70 \%$ & 35 & $55 \%$ \\
\hline ADESÃO & 15 & $36 \%$ & 15 & $15 \%$ & 13 & $20 \%$ \\
\hline QUALIDADE & 2 & $5 \%$ & 4 & $4 \%$ & 4 & $6 \%$ \\
\hline PERTINÊNCIA & 6 & $15 \%$ & 9 & $9 \%$ & 9 & $14 \%$ \\
\hline OUTROS & 0 & - & 2 & $2 \%$ & 3 & $5 \%$ \\
\hline TOTAL & 41 & & 98 & & 64 & \\
\hline
\end{tabular}

Tabela 4.21. Classificação semântica das palavras com -ista na edição de jornal.

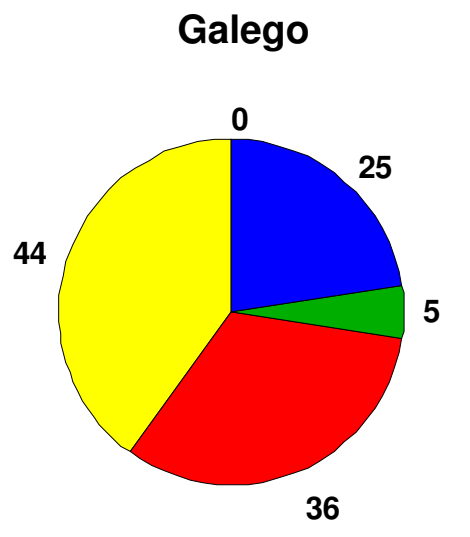

Português Brasileiro

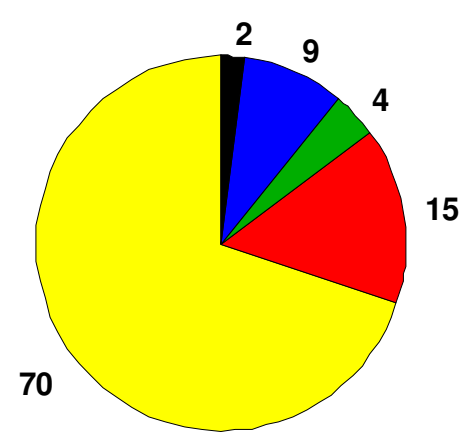

Português Lusitano

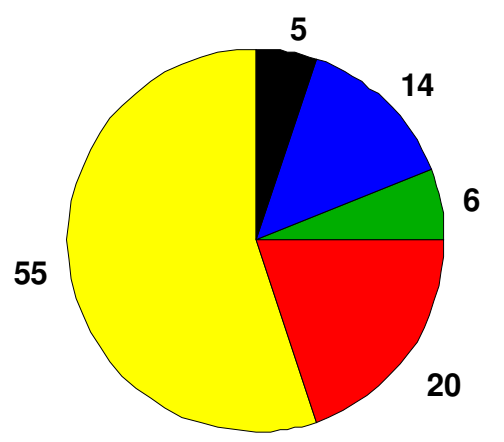

Gráfico 4.44. Classificação semântica das palavras com -ista nos três jornais.

Observando-se o gráfico 4.44, nota-se que a categoria semântica "ocupação ou profissão" é a que mais ocorrências apresenta nos três idiomas, entretanto mostra-se muito maior no português brasileiro, seguido da variedade lusitana e do galego. Já as categorias 
"adesão mental" e "pertinência a grupos" mostram-se mais significativas no galego, seguidas do português lusitano e, por último, do português brasileiro. Tal observação reflete, não apenas o interesse e preocupações da população de cada região, mas também a linha de redação de cada jornal.

A maioria das formações encontradas no jornal brasileiro refere-se a profissões no caderno de classificados de emprego, o que justifica a grande representatividade da categoria semântica "ocupação ou profissão". No jornal português e no galego, também a maioria das formações encontradas refere-se profissões e foram localizadas, não no caderno de classificados (que nestes jornais mostrou-se muito pequeno), mas principalmente nos de: notícias locais, ciência, educação, programação cultural e esportes.

Em relação à categoria semântica "adesão mental”, a maioria das formações do jornal galego a ela pertencentes referem-se a ideais políticos, assim como nos demais jornais e foram encontradas principalmente nos cadernos de política local, nacional e internacional. Entretanto, no jornal galego, estes cadernos mostraram-se maiores e mais detalhados, principalmente o caderno local e nacional, justificando a sua grande representatividade.

Em relação à categoria semântica "pertinência a grupos", a maioria das formações do jornal galego e português a ela pertencentes referem-se a: membros de times esportivos (especificamente de futebol) ou de suas torcidas e foram encontradas principalmente no caderno de esportes. Já, a maioria das palavras do jornal brasileiro pertencentes à categoria "pertinência a grupos" referem-se a membros de partidos políticos e foram encontradas principalmente no caderno de política nacional.

É interessante notar também que as acepções de algumas das palavras sufixadas com ista encontradas nos jornais não foram encontradas em dicionários, por exemplo: cadista $^{1557}$ no jornal brasileiro, sportinguista ${ }^{1558}$ no jornal português, e deportivista ${ }^{1559}$ no jornal galego. Em sua grande maioria designam: novas especialidades profissionais, membros de times esportivos ou suas torcidas, membros de partidos políticos, adeptos de ideais em geral designados por antropônimos. Dessa forma pode-se inferir que o sufixo apresenta uma fácil e recente produção, indicando sua produtividade nas variedades idiomáticas.

\footnotetext{
${ }^{1557}$ Profissional especializado na manipulação do software $C A D$.

${ }^{1558}$ Membro da torcida do time Sporting Club.

${ }^{1559}$ Membro da torcida do time Real Club Deportivo de La Coruña.
} 
Estudo comparativo de aspectos semânticos do sufixo -ista no português e no galego.

Considerando-se como prosa em corpora majoritariamente a prosa literária, detalhada no Anexo I desta dissertação, foram obtidos: a tabela 4.22 com os valores absolutos e percentuais e os gráficos 4.45, 4.46 e 4.47 comparativos da distribuição semântica prosaica em corpora nas três variedades idiomáticas nos século XIX e XX.

\begin{tabular}{|c|c|c|c|c|c|c|}
\hline \multirow{3}{*}{ Classe } & \multicolumn{6}{|c|}{ FORMAÇÕES USADAS COM O SUFIXO -ISTA NA PROSA } \\
\hline & \multicolumn{2}{|c|}{ GALEGO } & \multicolumn{2}{|c|}{ PORTUGUÊS BRASILEIRO } & \multicolumn{2}{|c|}{ PORTUGUÊS LUSITANO } \\
\hline & SÉC. XIX & SÉC. XX & SÉC. XIX & SÉC. XX & SÉC. XIX & SÉC. XX \\
\hline OCUPAÇÃO & $\begin{array}{c}64 \% \\
14\end{array}$ & $\begin{array}{c}39 \% \\
53\end{array}$ & $\begin{array}{c}50 \% \\
42\end{array}$ & $\begin{array}{c}47 \% \\
78\end{array}$ & $\begin{array}{c}57 \% \\
47\end{array}$ & $\begin{array}{c}51 \% \\
54\end{array}$ \\
\hline ADESÃO & $\begin{array}{c}13 \% \\
3\end{array}$ & $\begin{array}{c}39 \% \\
53\end{array}$ & $\begin{array}{c}14 \% \\
12\end{array}$ & $\begin{array}{c}28 \% \\
47\end{array}$ & $\begin{array}{c}17 \% \\
14\end{array}$ & $\begin{array}{c}29 \% \\
30\end{array}$ \\
\hline QUALIDADE & $\begin{array}{c}18 \% \\
4\end{array}$ & $\begin{array}{c}18 \% \\
25\end{array}$ & $\begin{array}{c}19 \% \\
16\end{array}$ & $\begin{array}{c}18 \% \\
29\end{array}$ & $\begin{array}{c}20 \% \\
17\end{array}$ & $\begin{array}{c}13 \% \\
14\end{array}$ \\
\hline PERTINÊNCIA & $\begin{array}{c}5 \% \\
1\end{array}$ & $\begin{array}{c}4 \% \\
5\end{array}$ & $\begin{array}{c}13 \% \\
11\end{array}$ & $\begin{array}{c}5 \% \\
9\end{array}$ & $\begin{array}{c}4 \% \\
3\end{array}$ & $\begin{array}{c}4 \% \\
4\end{array}$ \\
\hline OUTROS & - & - & $\begin{array}{c}4 \% \\
3\end{array}$ & $\begin{array}{c}2 \% \\
4\end{array}$ & $\begin{array}{c}2 \% \\
2\end{array}$ & $\begin{array}{c}3 \% \\
3\end{array}$ \\
\hline TOTAL & 22 & 136 & 84 & 167 & 81 & 105 \\
\hline
\end{tabular}

Tabela 4.22. Classificação semântica das palavras com -ista na prosa.

Observando-se os gráficos seguintes pode-se notar que as classes semânticas com representação significativa são: "ocupação ou profissão", "adesão mental" e "qualidade característica". Destaca-se a classe "ocupação ou profissão", com cerca de cinquienta por cento $(50 \%)$ das ocorrências na língua portuguesa, e, no galego, com mais de sessenta por cento $(60 \%)$ no século XIX. Verificou-se também que o número de ocorrências de "ocupação ou profissão" diminuiu no século XX no galego e no português, tanto brasileiro como lusitano, comparativamente com o século XIX, no gênero prosa. Em contrapartida, o número de ocorrências da classe "adesão mental" aumentou no século XX, com relação ao XIX nas três variedades idiomáticas, e a classe "qualidade característica" praticamente manteve-se estável. É interessante observar que a classe "pertinência a grupos" não se mostrou expressiva na prosa, ao passo que no jornal mostra-se significativa. Verificou-se, ainda, que a distribuição semântica da prosa do galego do século XIX está mais próxima do português lusitano, ao passo que no século XX mostra-se mais próxima do português brasileiro. 


\section{Classificação semântica das palavras formadas com -ista na Prosa Século XIX \\ Século XX}
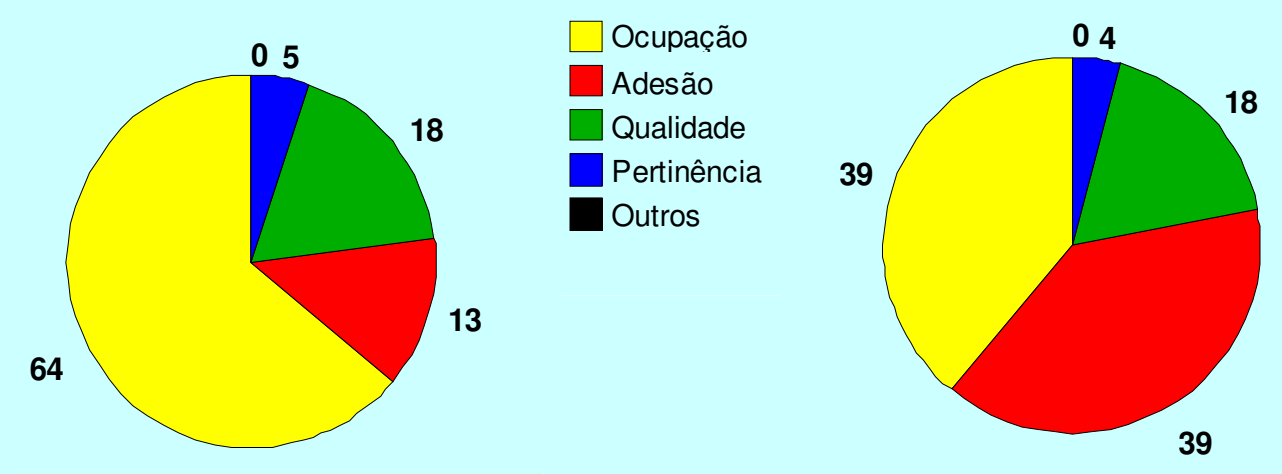

Gráfico 4.45. Classificação semântica das palavras com -ista na prosa galega.
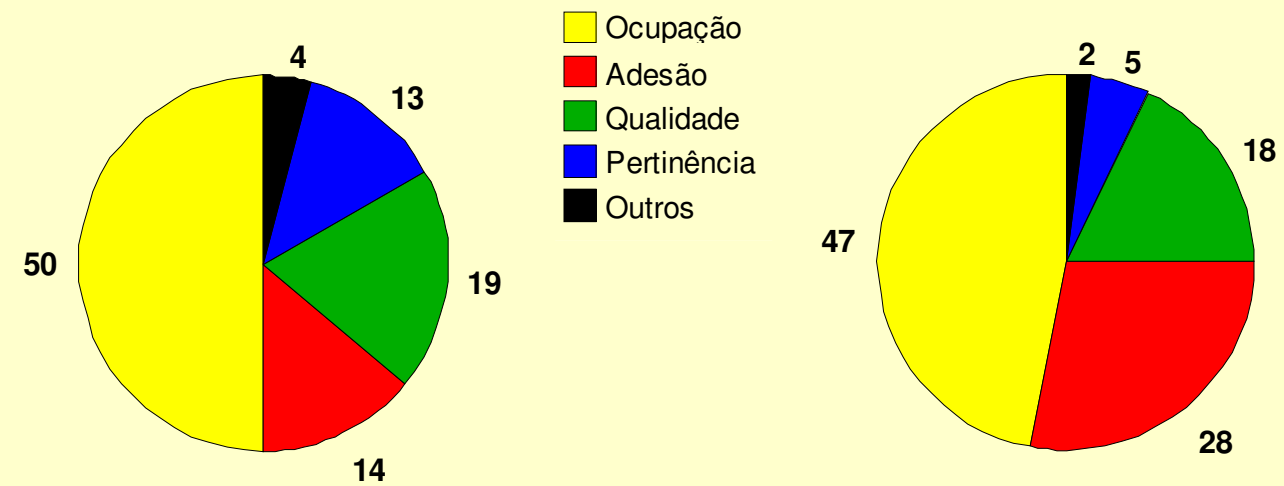

Gráfico 4.46. Classificação semântica das palavras com -ista na prosa brasileira.

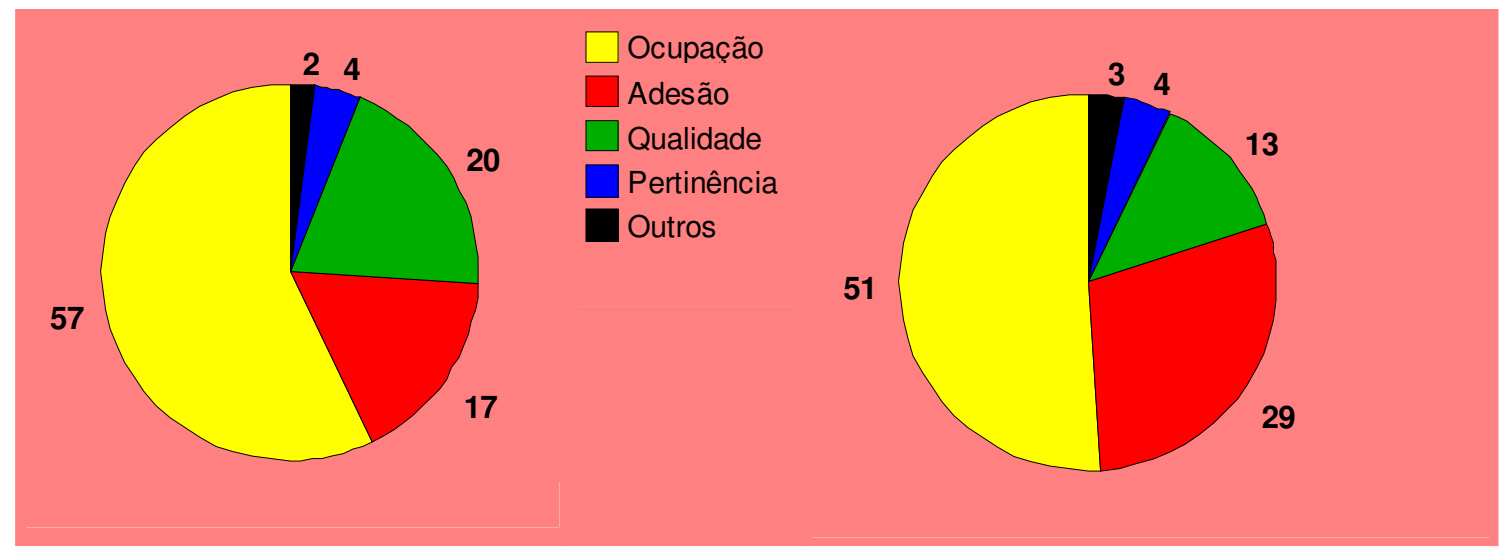

Gráfico 4.47. Classificação semântica das palavras com -ista na prosa portuguesa. 
Estudo comparativo de aspectos semânticos do sufixo -ista no português e no galego.

Para o gênero poesia, foram obtidos: a tabela 4.23 com os valores absolutos e percentuais e os gráficos 4.48, 4.49 e 4.50 comparativos da distribuição semântica de corpora nas três variedades idiomáticas nos século XIX e XX, detalhada no Anexo I.

\begin{tabular}{|c|c|c|c|c|c|c|}
\hline \multirow{3}{*}{ Classe } & \multicolumn{6}{|c|}{ FORMAÇÕES USADAS COM O SUFIXO -ISTA NA POESIA } \\
\hline & \multicolumn{2}{|c|}{ GALEGO } & \multicolumn{2}{|c|}{ PORTUGUÊS BRASILEIRO } & \multicolumn{2}{|c|}{ PORTUGUÊS LUSITANO } \\
\hline & SÉC. XIX & SÉC. XX & SÉC. XIX & SÉC. XX & SÉC. XIX & SÉC. XX \\
\hline OCUPAÇÃO & $\begin{array}{c}48 \% \\
10\end{array}$ & $\begin{array}{c}47 \% \\
15\end{array}$ & $\begin{array}{c}50 \% \\
7\end{array}$ & $\begin{array}{c}52 \% \\
16\end{array}$ & $\begin{array}{c}93 \% \\
13\end{array}$ & $\begin{array}{c}63 \% \\
10\end{array}$ \\
\hline ADESÃO & $\begin{array}{c}29 \% \\
6\end{array}$ & $\begin{array}{c}38 \% \\
12\end{array}$ & $\begin{array}{l}- \\
0\end{array}$ & $\begin{array}{c}23 \% \\
7\end{array}$ & $\begin{array}{l}- \\
0\end{array}$ & $\begin{array}{c}25 \% \\
4\end{array}$ \\
\hline QUALIDADE & $\begin{array}{c}19 \% \\
4\end{array}$ & $\begin{array}{c}9 \% \\
3\end{array}$ & $\begin{array}{c}43 \% \\
6\end{array}$ & $\begin{array}{c}23 \% \\
7\end{array}$ & $\begin{array}{c}7 \% \\
1\end{array}$ & $\begin{array}{c}6 \% \\
1\end{array}$ \\
\hline PERTINÊNCIA & - & $\begin{array}{c}6 \% \\
2\end{array}$ & - & $\begin{array}{c}2 \% \\
1\end{array}$ & - & $\begin{array}{c}6 \% \\
1\end{array}$ \\
\hline OUTROS & $\begin{array}{c}4 \% \\
1\end{array}$ & - & $\begin{array}{c}7 \% \\
1\end{array}$ & - & - & - \\
\hline TOTAL & 21 & 32 & 14 & 31 & 14 & 16 \\
\hline
\end{tabular}

Tabela 4.23. Classificação semântica das palavras com -ista na poesia.

Observando-se os gráficos seguintes nota-se que, no século XIX, as ocorrências com o sufixo -ista na poesia brasileira estão praticamente divididas entre duas classes semânticas: “ocupação ou profissão" e "qualidade característica". Na poesia portuguesa do século XIX, concentram-se na classe "ocupação ou profissão". Já, na poesia galega do século XIX, quase cinqüenta por cento (50\%) das ocorrências pertencem à classe "ocupação ou profissão", e as demais se dividem entre a classe "adesão mental" e "qualidade característica". No século XX verifica-se uma aproximação da língua portuguesa à galega quanto às classes semânticas na poesia, pois tanto na variedade lusitana quanto na brasileira, surgem ocorrências significativas pertencentes à classe "adesão mental". Nota-se, ainda, que no século XX há uma diminuição das ocorrências pertinentes à classe "qualidade característica". É interessante notar que na poesia quase não há ocorrências com o sufixo -ista classificadas semanticamente como "pertinência a grupos". Assim, pode-se inferir, que as ocorrências com o sufixo na poesia do século XX estão marcadas semanticamente pelas classes: "ocupação ou profissão ", "adesão mental" e "qualidade característica". 


\section{Classificação semântica das palavras com -ista na Poesia}

Século XIX

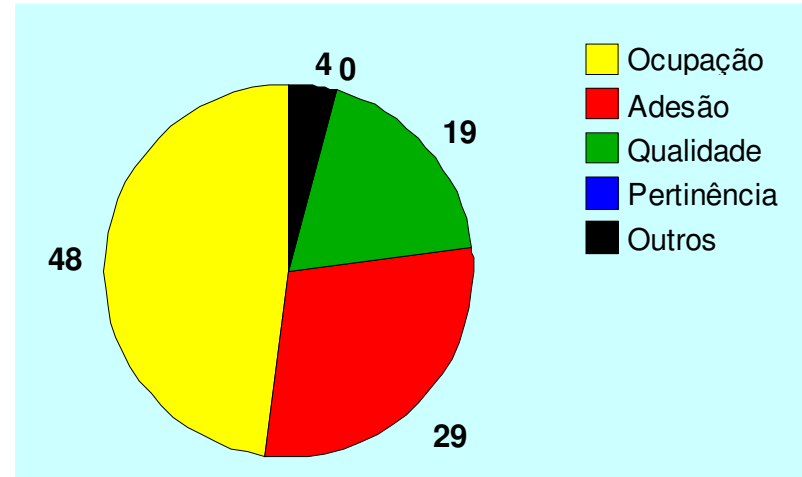

\section{Século XX}

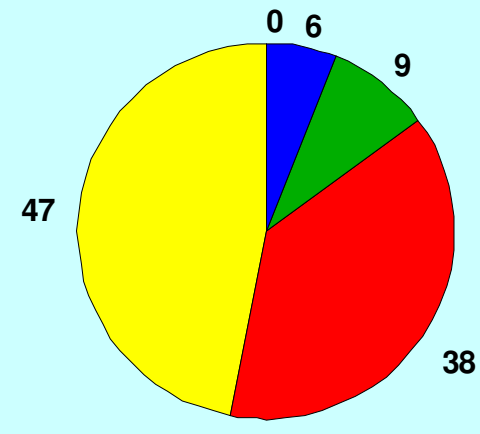

Gráfico 4.48. Classificação semântica das palavras com -ista na poesia galega.

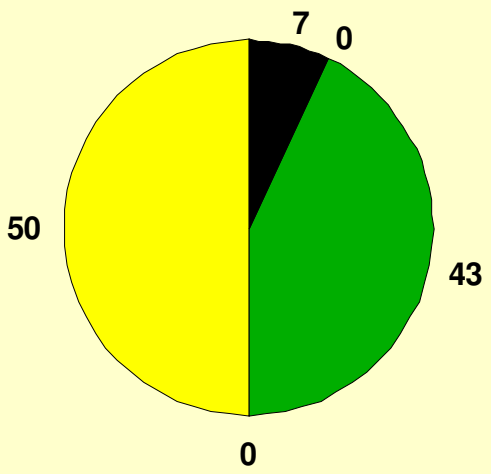

Ocupação

Adesão

Qualidade

Pertinência

Outros

43

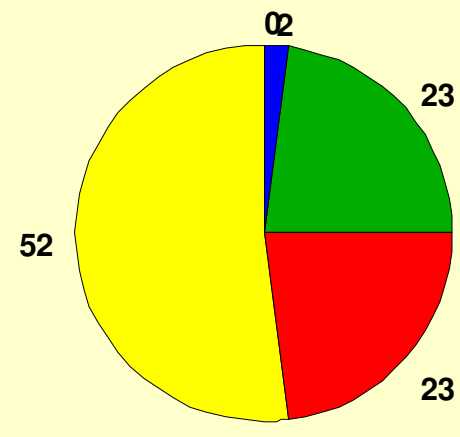

Gráfico 4.49. Classificação semântica das palavras com -ista na poesia brasileira.
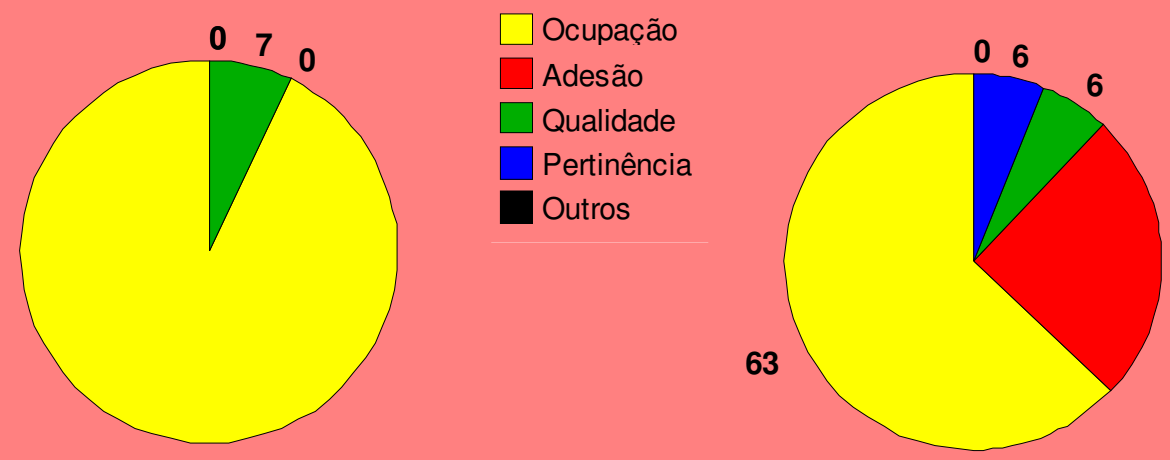

25

93

Gráfico 4.50. Classificação semântica das palavras com -ista na poesia portuguesa. 
Estudo comparativo de aspectos semânticos do sufixo -ista no português e no galego.

Para o gênero teatral, foram obtidos: a tabela 4.24 e os gráficos $4.51,4.52$ e 4.53 da distribuição semântica nos século XIX e XX, detalhada no Anexo I.

\begin{tabular}{|c|c|c|c|c|c|c|}
\hline \multirow{3}{*}{ CLASSE } & \multicolumn{6}{|c|}{ FORMAÇÕES USADAS COM O SUFIXO -ISTA NO TEATRO } \\
\hline & \multicolumn{2}{|c|}{ GALEGO } & \multicolumn{2}{|c|}{ PORTUGUÊS BRASILEIRO } & \multicolumn{2}{|c|}{ PORTUGUÊS LUSITANO } \\
\hline & SÉC. XIX & SÉC. XX & SÉC. XIX & SÉC. XX & SÉC. XIX & SÉC. XX \\
\hline OCUPAÇÃO & $\begin{array}{c}54 \% \\
8\end{array}$ & $\begin{array}{c}53 \% \\
10\end{array}$ & $\begin{array}{c}61 \% \\
19\end{array}$ & $\begin{array}{c}33 \% \\
16\end{array}$ & $\begin{array}{c}50 \% \\
8\end{array}$ & $\begin{array}{c}62 \% \\
23\end{array}$ \\
\hline ADESÃO & $\begin{array}{c}20 \% \\
3\end{array}$ & $\begin{array}{c}21 \% \\
4\end{array}$ & $\begin{array}{c}19 \% \\
6\end{array}$ & $\begin{array}{c}30 \% \\
15\end{array}$ & $\begin{array}{c}12 \% \\
2\end{array}$ & $\begin{array}{c}24 \% \\
9\end{array}$ \\
\hline QUALIDADE & $\begin{array}{c}26 \% \\
4\end{array}$ & $\begin{array}{c}26 \% \\
5\end{array}$ & $\begin{array}{c}12 \% \\
4\end{array}$ & $\begin{array}{c}33 \% \\
16\end{array}$ & $\begin{array}{c}38 \% \\
6\end{array}$ & $\begin{array}{c}8 \% \\
3\end{array}$ \\
\hline PERTINÊNCIA & - & - & $\begin{array}{c}4 \% \\
1\end{array}$ & $\begin{array}{c}2 \% \\
1\end{array}$ & - & $\begin{array}{c}6 \% \\
2\end{array}$ \\
\hline OUTROS & - & - & $\begin{array}{c}4 \% \\
1\end{array}$ & $\begin{array}{c}2 \% \\
1\end{array}$ & - & - \\
\hline TOTAL & 15 & 19 & 31 & 49 & 16 & 37 \\
\hline
\end{tabular}

Tabela 4.24. Classificação semântica das palavras com -ista no teatro.

Observando-se os gráficos seguintes nota-se que, as classes semânticas que se destacam nas obras teatrais, tanto no século XIX quanto no XX, são: "ocupação ou profissão", "adesão mental" e "qualidade característica", modificando-se sua distribuição em cada período e língua estudados. Pode-se perceber que a classe que mais se destaca é “ocupação ou profissão”. Entretanto, nota-se, também, que no teatro, assim como na poesia, quase não há ocorrências com o sufixo -ista na classe "pertinência a grupos". Observa-se que no teatro galego a distribuição manteve-se praticamente similar nos dois períodos estudados. No teatro brasileiro do século XX houve uma considerável diminuição na classe "ocupação ou profissão" e um aumento nas classes "qualidade característica" e "adesão mental", comparado ao século XIX. Já, o gênero teatral português do século XX mostrou um aumento efetivo nas classes: "ocupação ou profissão" e "adesão mental", ao passo que apresentou uma sensível diminuição na classe "qualidade característica", comparando-se com o século XIX.

Assim, conclui-se que as ocorrências no gênero teatral estão marcadas pelas classes semânticas: "ocupação ou profissão", "adesão mental” e "qualidade característica". 


\section{Classificação semântica das palavras com -ista no Teatro Século XIX \\ Século XX}
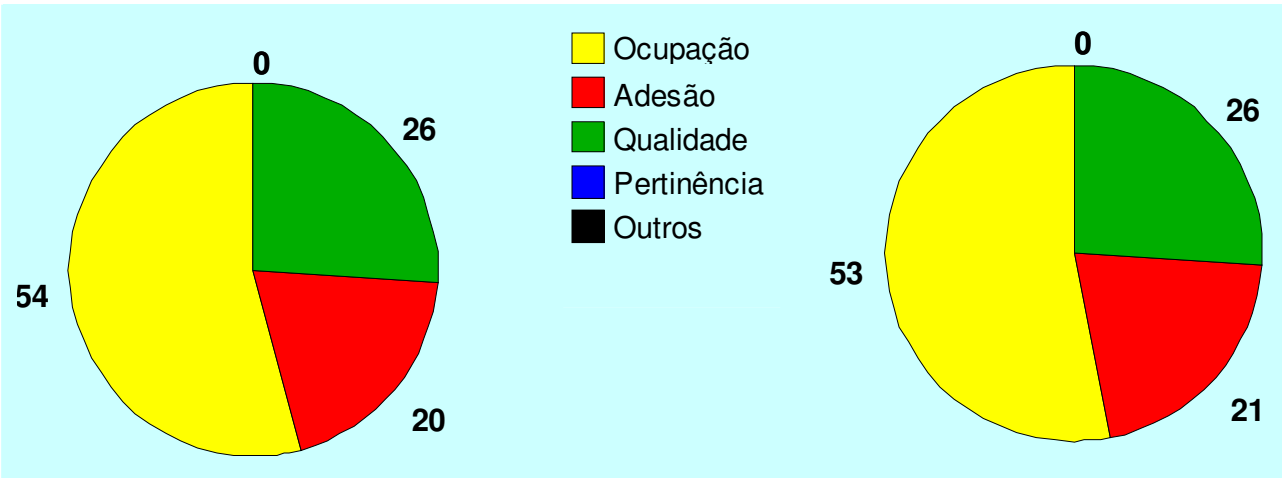

Gráfico 4.51. Classificação semântica das palavras com -ista no teatro galego.
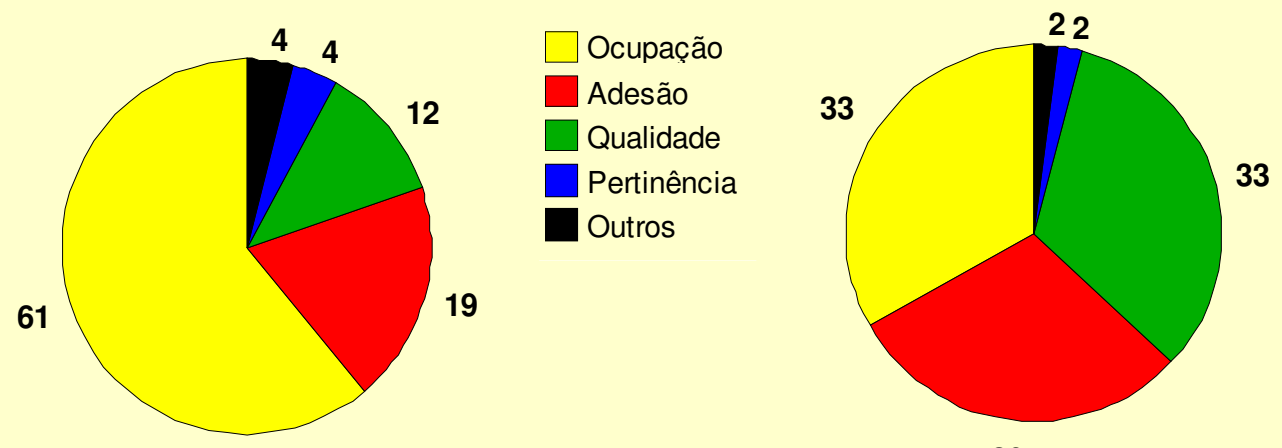

30

Gráfico 4.52. Classificação semântica das palavras com -ista no teatro brasileiro.

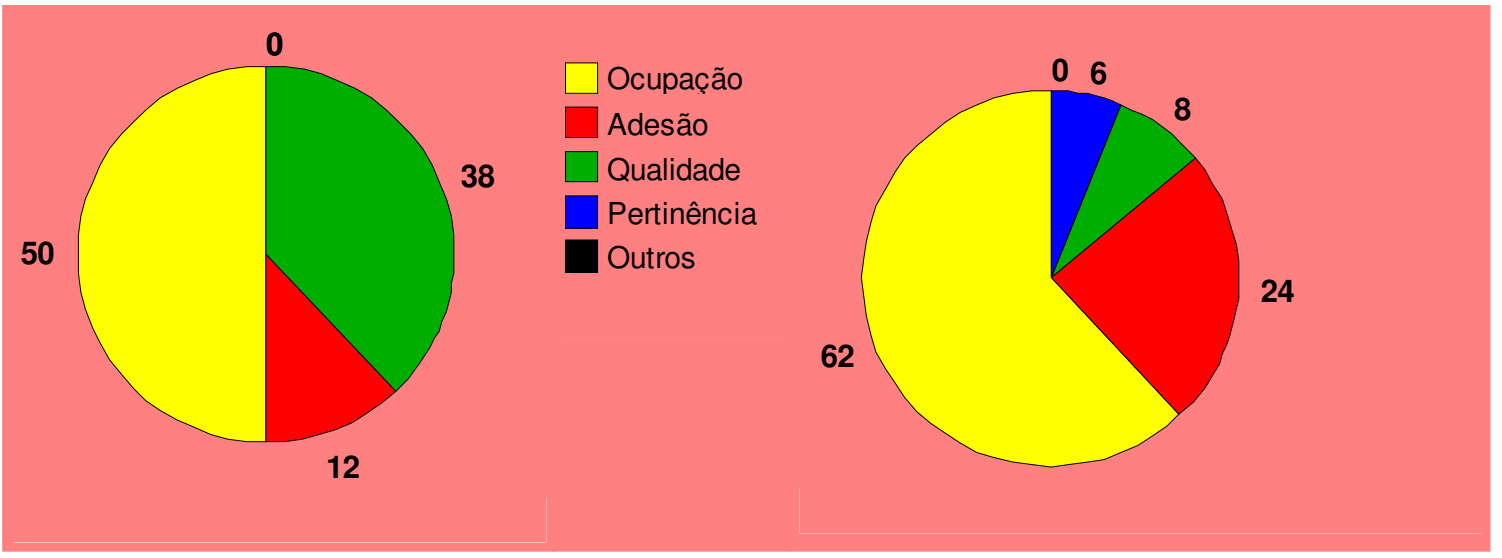

Gráfico 4.53. Classificação semântica das palavras com -ista no teatro português. 
Estudo comparativo de aspectos semânticos do sufixo -ista no português e no galego.

Para a classificação semântica geral, foram obtidos: a tabela 4.25 e o gráfico 4.54 com os índices de crescimento de cada classe semântica e os gráficos 4.55, 4.56 e 4.57 comparativos da distribuição semântica geral nos séculos XIX e XX, detalhada no Anexo I.

\begin{tabular}{|c|c|c|c|c|c|c|c|c|c|}
\hline \multirow{3}{*}{ Classe } & \multicolumn{9}{|c|}{ CRESCIMENTO DO USO DO SUFIXO -ISTA NA CLASSIFICAÇÃO SEMÂNTICA } \\
\hline & \multicolumn{3}{|c|}{ GALEGO } & \multicolumn{3}{|c|}{ PORTUGUÊS BRASILEIRO } & \multicolumn{3}{|c|}{ PORTUGUÊS LUSITANO } \\
\hline & XIX & $X X$ & ÍNDICE & XIX & $X X$ & ÍNDICE & XIX & $\mathrm{XX}$ & ÍNDICE \\
\hline OCUPAÇÃO & $51 \%$ & $42 \%$ & $-9 \%$ & $52 \%$ & $52 \%$ & 0 & $55 \%$ & $52 \%$ & $-3 \%$ \\
\hline ADESÃO & $20 \%$ & $38 \%$ & $18 \%$ & $13 \%$ & $25 \%$ & $12 \%$ & $19 \%$ & $26 \%$ & $7 \%$ \\
\hline QUALIDADE & $25 \%$ & $14 \%$ & $-11 \%$ & $21 \%$ & $17 \%$ & $-4 \%$ & $21 \%$ & $11 \%$ & $-10 \%$ \\
\hline PERTINÊNCIA & $2 \%$ & $6 \%$ & $4 \%$ & $11 \%$ & $4 \%$ & $-7 \%$ & $3 \%$ & $9 \%$ & $6 \%$ \\
\hline OUTROS & $2 \%$ & $0 \%$ & $-2 \%$ & $3 \%$ & $2 \%$ & $-1 \%$ & $2 \%$ & $2 \%$ & 0 \\
\hline
\end{tabular}

Tabela 4.25. Classificação semântica geral das formações usadas com o sufixo -ista.

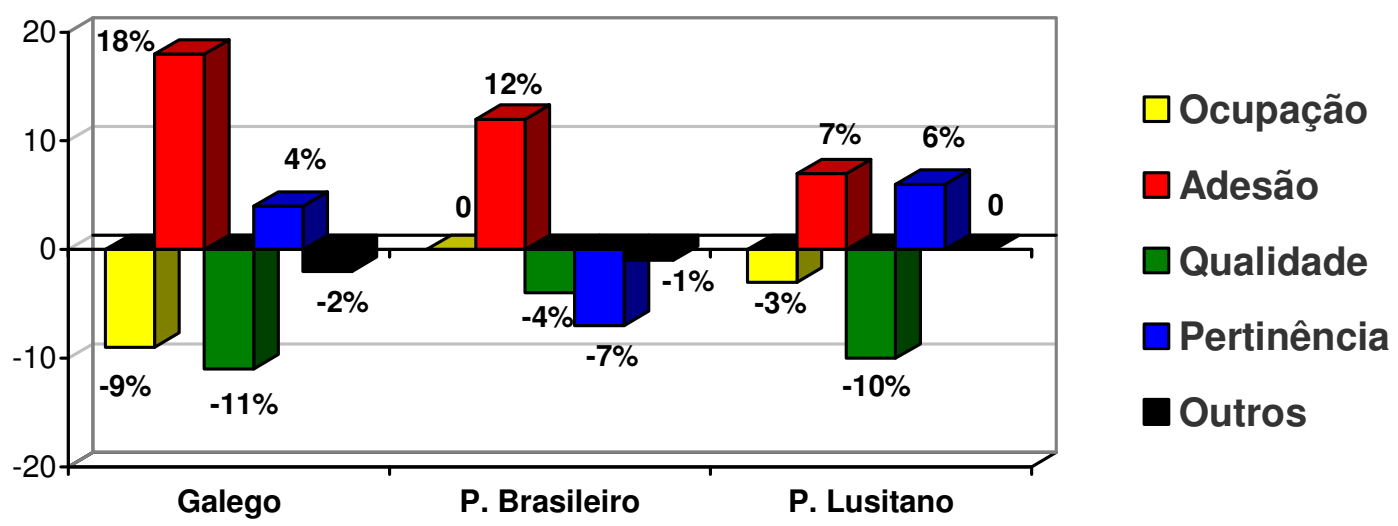

Gráfico 4.54. Índice de crescimento das classes semânticas de palavras com -ista.

Observando-se a tabela 4.25 e o gráfico 4.54, ao comparar o século XIX e XX, verifica-se que a classe "adesão mental" é a única que apresentou crescimento nas três variedades idiomáticas e a "qualidade característica" é a única que apresentou decréscimo em todas as variedades idiomáticas. A classe "ocupação ou profissão" apresentou decréscimo no galego e no português lusitano, mas manteve-se estável no português brasileiro. Já, a classe "pertinência a grupos" apresentou crescimento no galego e no português lusitano, mas mostrou decréscimo no português brasileiro. 


\section{Classificação semântica geral das palavras com o sufixo -ista}

Século XIX

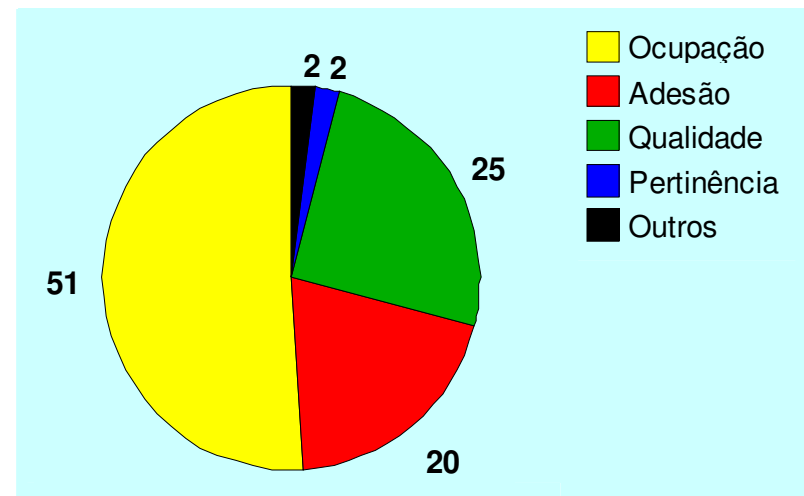

\section{Século $X X$}

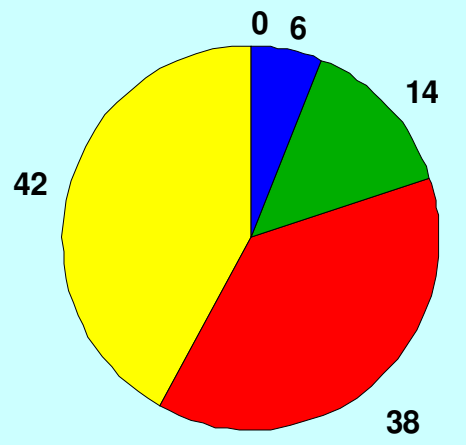

Gráfico 4.55. Valores percentuais da classificação semântica obtida em galego.
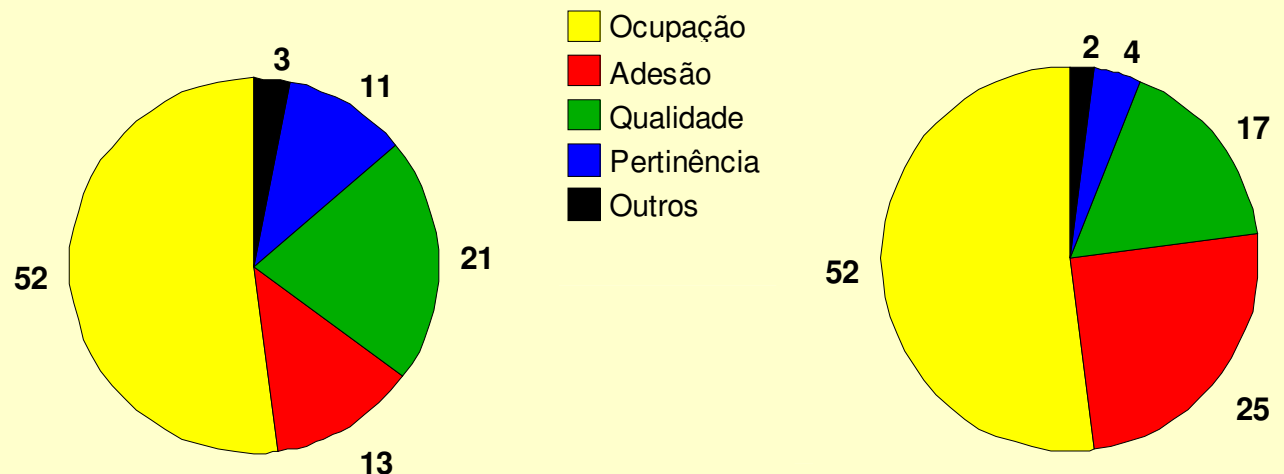

Gráfico 4.56. Valores percentuais da classificação no português do Brasil.

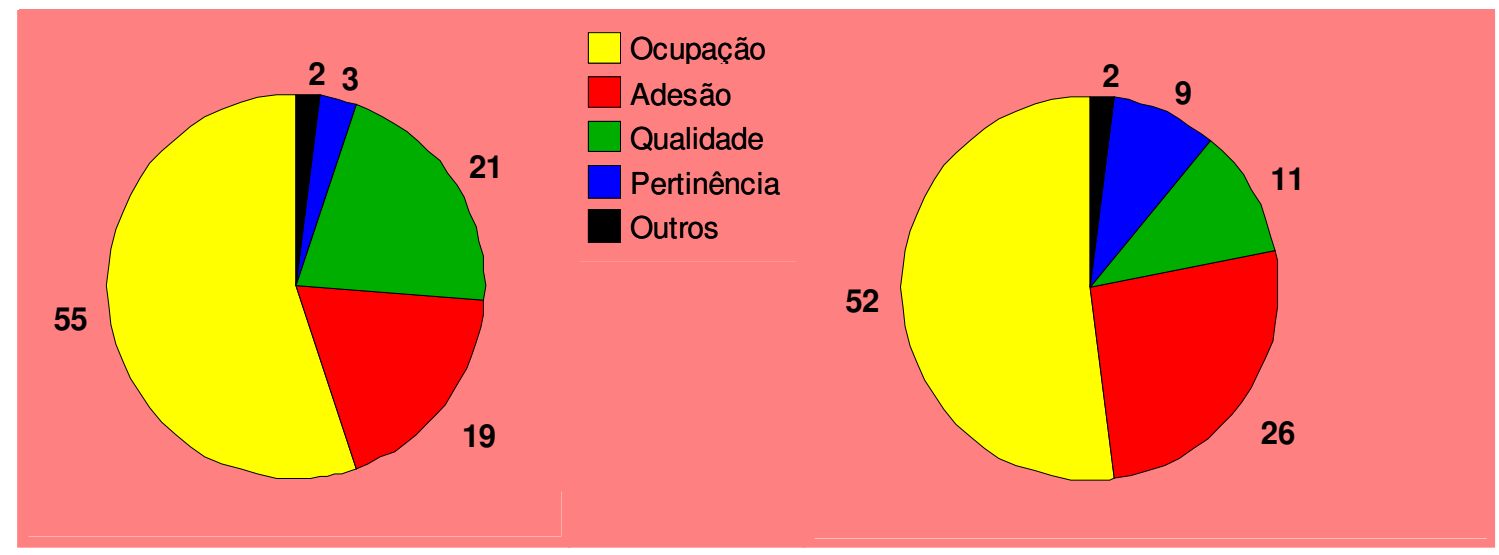

Gráfico 4.57. Valores percentuais da classificação semântica no português lusitano. 
Estudo comparativo de aspectos semânticos do sufixo -ista no português e no galego.

Observando-se os gráficos 4.55, 4.56 e 4.57 da classificação semântica geral, pode-se inferir que a categoria "ocupação ou profissão" é a mais representada pelas formações com o sufixo -ista nas três variedades idiomáticas, tanto no século XIX como XX. Também é possível observar que no século XIX a segunda categoria semântica mais representada é "qualidade característica", seguida da categoria "adesão mental"; no entanto, no século XX nota-se a inversão destas, ou seja, a segunda categoria semântica mais representada passa a ser "adesão mental", seguida pela categoria semântica "qualidade característica".

Observa-se, ainda, que na classificação semântica geral a categoria semântica "pertinência a grupos" apresenta-se com pouca relevância, entretanto nos textos de jornal estudados sua relevância foi significativa superando a categoria semântica "qualidade característica", conforme o gráfico 4.44. Tal fenômeno foi verificado, pois na prosa jornalística abundaram as ocorrências de: "membros de partidos políticos", por exemplo: pneuvista ${ }^{1560}$ no jornal galego e petista ${ }^{1561}$ no jornal brasileiro; "membros de torcidas de times de futebol", por exemplo: deportivista ${ }^{1562}$ no jornal galego e portista ${ }^{1563}$ no jornal português; "membros de grupos de seleção", por exemplo: semifinalista no jornal galego, mundialista no jornal português e finalista no jornal brasileiro; "gentílicos" principalmente no jornal brasileiro, por exemplo: paulista ${ }^{1564}$.

Verifica-se, também, que as distribuições da classificação semântica geral são muito parecidas às distribuições encontradas no gênero prosa, pois, segundo constatação feita em corpora as palavras formadas com o sufixo -ista apresentam uma forte característica prosaica de uso, principalmente no século XX.

É interessante observar que as classes semânticas encontradas para as formações com o sufixo -ista: "ocupação ou profissão", "adesão mental", "qualidade característica" e "pertinência a grupos", possuem como característica marcante o traço [+animado] e o traço [+humano], quando usadas como substantivos e na maioria das vezes que são utilizadas como adjetivos.

\footnotetext{
${ }^{1560}$ Membro do partido político PNV (Partido Nacionalista Vasco).

1561 Membro do partido político PT (Partido dos Trabalhadores).

1562 Tradução: membro da torcida do time Real Club Deportivo de La Coruña.

${ }^{1563}$ Membro da torcida ou do Clube de Futebol do Porto.

${ }^{1564}$ Natural ou habitante do Estado de São Paulo.
} 
É interessante notar também que algumas das palavras sufixadas com -ista em corpora não foram encontradas em dicionários, outras foram encontradas com acepção diferente da usada em contexto, que em sua grande maioria designam: "novas especialidades profissionais", por exemplo: fotoxornalista ${ }^{1565}$ em corpora galego, cadista ${ }^{1566}$ em corpora brasileiro e saxosambista ${ }^{1567}$ em corpora português; "membros de partidos políticos", por exemplo: pneuvista ${ }^{1568}$ em corpora galego e ex-udenista ${ }^{1569}$ em corpora brasileiro; "membros de torcidas de times esportivos", por exemplo: deportivista ${ }^{1570}$ em corpora galego e benfiquista ${ }^{1571}$ em corpora português; "adeptos à ideais" e principalmente formados a partir de um substantivo que designa antropônimos como base, por exemplo: zapaterista ${ }^{1572} \mathrm{em}$ corpora galego e tancredista ${ }^{1573}$ em corpora brasileiro; “qualidade característica", por exemplo: orellista ${ }^{1574}$ em corpora galego e trustkista ${ }^{1575}$ em corpora brasileiro. Embora não encontradas em dicionários, as palavras existem em seu contexto e evidenciam o quanto o sufixo é significativo e produtivo na formação de novas palavras dentro dos períodos e variedades lingüísticas estudados. Tais constatações, juntamente com a observação feita que as ocorrências com -ista cresceram muito na prosa literária principalmente após o movimento do Realismo, evidenciam também a característica inovadora das palavras formadas por derivação com o sufixo -ista.

Convém notar que a acentuada ocorrência de formações com o sufixo -ista na prosa jornalística evidencia que a característica inovadora das formações aparece, não somente no âmbito erudito, filosófico e científico, como também no âmbito popular da escrita.

Deve-se ressaltar, ainda, que os dados e resultados obtidos neste capítulo estão em função de corpora pesquisado, podendo mudar de configuração ao se alterar as obras analisadas.

\footnotetext{
${ }^{1565}$ Quem trabalha com fotojornalismo.

${ }^{1566}$ Profissional especializado na manipulação do software $C A D$.

${ }^{1567}$ Quem toca saxofone em arranjos de sambas.

${ }^{1568}$ Membro do partido político PNV (Partido Nacionalista Vasco).

${ }^{1569}$ Ex-membro do antigo partido político UDN (União Democrática Nacional).

1570 Tradução: membro da torcida do time Real Club Deportivo de La Coruña.

${ }^{1571}$ Membro da torcida ou do Clube de Futebol de Benfica.

1572 Tradução: adepto das idéias políticas de José Luis Rodríguez Zapatero (primeiro ministro da Espanha).

1573 Adepto dos ideais políticos de Tancredo Neves.

1574 Tradução: quem tem o hábito de escutar à espreita.

${ }^{1575}$ Refere-se aos que se dizem trotskistas, mas jogam trust e não abandonam seus hábitos burgueses.
} 
Estudo comparativo de aspectos semânticos do sufixo -ista no português e no galego.

CAPÍTULO 5 UMA CLASSIFICAÇÃO SEMÂNTICA

Em vão me tento explicar, os muros são surdos. Sob a pele das palavras há cifras e códigos.

(Carlos Drummond de Andrade) 


\section{Proposta de classificação para derivações com -ista}

No capítulo anterior foi feito, a título de ilustração, um estudo das ocorrências das palavras formadas com o sufixo -ista em corpora, apontando características interessantes do uso das formações com o sufixo nas variedades lingüísticas abordadas. No entanto, tal estudo se mostrou insuficiente para a elaboração de uma classificação semântica, pois esta estaria baseada somente em ocorrências detectadas e totalmente dependentes da escolha de corpora e não, propriamente, do léxico das línguas em questão, pois, muitas palavras há na língua que não aparecem nas pesquisas de comprovação em corpora. Assim, para elaborar uma classificação semântica das palavras formadas com o sufixo -ista consistente e coerente é preciso trabalhar com outro tipo de corpora, que seja representativo e que se comporte como um inventário indicando, se não todas, pelo menos a maioria das formações com o sufixo a serem estudas para cada uma das línguas.

Desde essa ótica, foram coletadas todas as palavras pertencentes à língua galega terminadas com -ista encontradas no dicionário da Real Academia Galega (2006), no dicionário Pedagóxico da Real Academia Galega (2006), no dicionário da Língua Galega organizado por Freixó Cid (1999), no TILGA ${ }^{1576}$ (Tesouro Informatizado da Língua Galega) e no CORGA $^{1577}$ (Corpus de Referencia do Galego Actual). Analogamente, foram coletadas todas as palavras pertencentes à língua portuguesa terminadas com -ista encontradas no dicionário Houaiss da Língua Portuguesa (2001), no dicionário da Porto Editora da Língua Portuguesa, na Infopédia ${ }^{1578}$ (Enciclopédia Multimédia em Língua Portuguesa, 2006) e na Conscienciopédia ${ }^{1579}$ (Enciclopédia Digital da Conscienciologia, 2006).

Primeiramente, foram analisados e selecionados todos os vocábulos das duas listas obtidas: para a língua galega e para a língua portuguesa, e nelas foram encontradas e removidas palavras, tais como: conquista, crista, entrevista, ista ${ }^{1580}$, lista, mista, revista e vista; que não são derivações com o sufixo -ista. Também foram encontradas e depuradas das duas listas as variações ortográficas de uma mesma palavra, tais como: iansenista ${ }^{1581}$,

\footnotetext{
1576 http://www.ti.usc.es/tilg/

${ }^{1577} \mathrm{http}: / /$ corpus.cirp.es/corga/

$1578 \mathrm{http}: / /$ www.infopedia.pt/

1579 http://pt.conscienciopedia.ceaec.org.br/lista_de_ista/

1580 Tradução: "esta” (pronome demonstrativo feminino).

1581 Tradução: jansenista.
} 
Estudo comparativo de aspectos semânticos do sufixo -ista no português e no galego.

jansenista $^{1582}$, e xansenista ${ }^{1583}$ no galego; ativista e activista no português, mantendo-se nelas uma única forma ortográfica para cada palavra encontrada em cada uma das línguas. Assim, foram obtidas duas listas de palavras: a primeira totalizando mil e oitenta e três (1083) vocábulos galegos, e a segunda totalizando dois mil e trezentos e oitenta e cinco (2385) vocábulos brasileiros e portugueses, detalhadas no Anexo II da dissertação como corpora deste capítulo.

Inicialmente, já se pode notar uma grande diferença entre o galego e português na quantidade de vocábulos encontrados nas duas listas com o sufixo -ista: 1083 vocábulos da língua galega e 2385 vocábulos da língua portuguesa. Observa-se que na língua portuguesa o número de vocábulos é pelo menos duas vezes ${ }^{1584}$ maior que os encontrados na língua galega. Essa diferença reflete, por um lado, a situação histórica de repressão, descrita no capítulo 1 (páginas: 67 a 69), que a língua galega sofreu, restringindo e interrompendo seu desenvolvimento, em particular, no campo léxico. Por outro, reflete a necessidade de expressão da língua portuguesa em manter mais vocábulos formados com o sufixo -ista que na língua galega, indicando que esta deve suprir, pelo menos em parte, a sua necessidade de expressão com outras estruturas lingüísticas. A diferença quantitativa entre as duas listas, galega e da língua portuguesa, de vocábulos derivados com o sufixo -ista está ilustrada no gráfico a seguir.

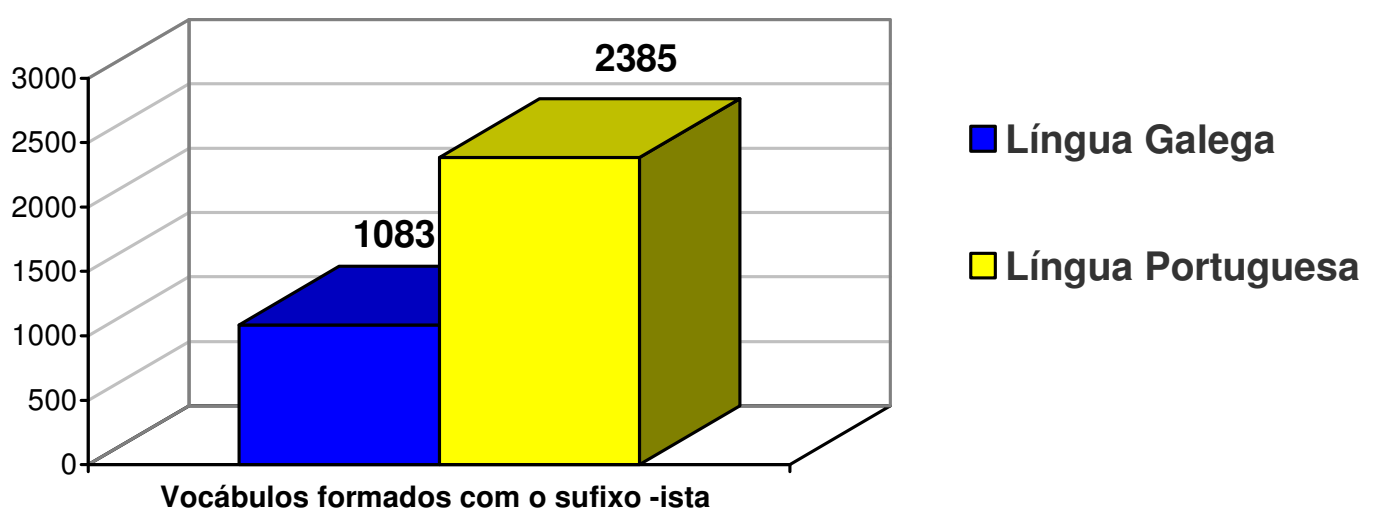

Gráfico 5.1. Número de palavras formadas com o sufixo -ista no português e no galego.

\footnotetext{
1582 Tradução: jansenista.

1583 Tradução: jansenista.

1584 O número de vocábulos derivados com o sufixo -ista pertencentes à lista da língua portuguesa é exatamente 2,2 vezes maior que o número de vocábulos encontrados na lista da língua galega.
} 
Posteriormente à etapa de levantamento de vocábulos derivados com o sufixo -ista na língua portuguesa e galega, foram feitas várias análises e classificações com as listas designadas como corpora a fim de detectar fatos relevantes para estudos morfológicos e semânticos das formações. Em um estudo preliminar fez-se uma classificação associada à base da formação; em outro foi feita uma divisão baseada no âmbito semântico a qual representa ou pertence cada uma das formações com o sufixo -ista, por exemplo: âmbito da música, dos esportes, especialidades médicas, etc; em outro estudo, ainda, a classificação foi feita de acordo com a letra inicial das palavras formadas com -ista. Entretanto, tais classificações mostraram-se insuficientes para um mapeamento semântico do sufixo -ista. A título de ilustração, as duas listas de palavras derivadas com -ista no português e no galego foram divididas em ordem alfabética, evidenciando uma distribuição das formações de acordo com a letra inicial, com a qual pôde-se notar uma similaridade entre as distribuições das palavras pertencentes à língua galega e das formações pertencentes ao português, indicando que a maioria dos vocábulos derivados com -ista, tanto na língua galega quanto na portuguesa, iniciam-se com as letras: $a, c, e, m, p, s$ e $t$. No entanto, este resultado em nada contribui para uma classificação semântica.

Conforme foi visto nos capítulos anteriores, sabe-se da dificuldade na elaboração de uma classificação, dada a complexidade semântica das palavras formadas por derivações. Dessa maneira, notou-se que o ponto de partida não poderia ser a categoria da base da formação, ainda que refinada, pois uma mesma base gera as mais variadas classes semânticas de vocábulos. Por exemplo, uma base toponímica pode gerar uma categoria semântica de gentílico, mas também, de religioso, de pertencente a uma torcida ou time esportivo, de adesão, de especialidade, de qualidade ou de ocupação; a título de ilustração: a base toponímica São Paulo gera a formação paulista, que pode ser o gentílico de São Paulo ou o religioso pertencente à ordem de São Paulo; a base Santos gera a formação santista, que pode ser o gentílico da cidade de Santos ou o torcedor do time esportivo Santos Futebol Clube; a base Porto gera a formação portista, que indica um membro da torcida ou do time esportivo Clube de Futebol do Porto; a base Sião gera a formação sionista, que indica o adepto de uma ideologia; a base Vaticano gera a formação vaticanista, que indica o especialista em assuntos do local; a base Alpes gera a formação alpinista, que indica um agente em modalidade ocupacional esportiva; analogamente a base Maraton gera a formação maratonista; a base 
Estudo comparativo de aspectos semânticos do sufixo -ista no português e no galego.

Malabar gera a formação malabarista, que, em princípio, indicava a qualidade em se parecer aos habitantes de Malabar na prática de brincadeiras, posteriormente passou a indicar o agente com habilidade em tais brincadeiras.

Assim, o passo inicial foi estudar as várias acepções de todos os vocábulos das duas listas de palavras formadas com o sufixo e, construir categorias semânticas gerais o bastante para abranger as acepções encontradas, usando como instrumento auxiliar, principalmente para o galego, as acepções e etimologias dadas por outros dicionários da língua galega e dicionários de castelhano, tais como o dicionário da Real Academia Española (2001) e o dicionário Básico da Língua da editora Anaya (1999), assim como o Corominas (1954) e o dicionário Houaiss (2001), para uma noção da história, datação e etimologia das palavras, tanto galegas quanto pertencentes à língua portuguesa, ainda que não tenha sido possível encontrar a datação e etimologia de grande parte dos vocábulos das duas listas. Convém observar que não foi possível encontrar a datação das palavras galegas, uma vez que não se encontrou uma obra que determinasse tal estudo específico. Já, o estudo etimológico das palavras galegas foi calcado nas obras de etimologia da língua espanhola e língua portuguesa consultadas.

Entretanto, apenas o uso de dicionários mostrou-se insuficiente, pois muitos dos vocábulos, principalmente da lista galega usada como corpora, não foram neles encontrados. Além disso, conforme foi visto no capítulo 4, as acepções dadas pelos dicionários nem sempre são coerentes com as acepções encontradas em contexto. Por exemplo, a acepção da palavra colecionista dada pelo dicionário Houaiss (2001) é "quem coleciona objetos", no entanto em contexto a acepção encontrada foi "quem sofre de transtorno obsessivo e compulsivo de colecionar objetos", conforme está detalhado no Anexo III desta dissertação. Assim, usando a internet como instrumento auxiliar, foi necessário também procurar as acepções de cada vocábulo das duas listas em contexto. Dessa forma, ao coletar todas as acepções dos vocábulos das listas encontradas em dicionários e em contexto, em particular para as palavras galegas, criou-se parte do glossário galego-português disposto no Anexo IV deste trabalho, completado, posteriormente, com os demais vocábulos galegos que não são derivações com o sufixo -ista, mas que foram usados como exemplos nesta dissertação.

A etapa seguinte foi fazer uma análise de todas as acepções das palavras derivadas com o sufixo -ista que foram coletadas, dividindo-as semanticamente em classes. Assim, para 
Estudo comparativo de aspectos semânticos do sufixo -ista no português e no galego.

fazer a divisão em classes foi usada, inicialmente, a classificação geral proposta no final do capítulo 3 (páginas: 178 a 181):

1) Agentividade.

2) Nomes que designam adesão mental, segundo classificação de BASíLIO (2006:74).

3) Nomes que dão a noção de pertinência a grupos.

4) Nomes qualificativos.

Entretanto, nas duas listas usadas como corpora foram encontrados muitos vocábulos cujas acepções não se enquadravam nessas quatro grandes classes semânticas propostas no capítulo 3, conforme já previsto no próprio capítulo, no final da página 181. Dessa forma, as acepções semânticas de tais vocábulos foram estudadas, conforme as classificações de FREIXEIRO MATO (1999: 228-234), SANDMANN (1989: 32) e RIO-TORTO (1998: 112-114) descritas no capítulo 2 (páginas: 106 a 133) e divididas semanticamente em mais quatro grandes classes. Assim, no procedimento da etapa de classificação das palavras derivas foram encontradas, ao todo, oito grandes classes semânticas que abrangem todas as palavras formadas com o sufixo -ista nas duas listas: com vocábulos em português e com os vocábulos em galego. As oito categorias da classificação semântica propostas foram:

1) Agentes, ou seja, é a categoria semântica de nomes agentivos em geral, que reúne também a agentividade direta e indireta proposta por BASílIO (2006:74). Por exemplo, em português: manobrista é quem manobra carros, e em galego: recepcionista é quem tem como ofício receber as pessoas;

2) Adeptos, ou seja, é a categoria semântica dos nomes que indicam adesão mental a idéias em geral; simpatia, afinidade, crença ou militância por ideais no âmbito artístico, científico, filosófico, político, social, religioso, por exemplo: em português: surrealista é o adepto dos ideais artísticos do surrealismo, e em galego: franquista é o adepto ou simpatizante dos ideais políticos do caudilho Francisco Franco;

3) Pertinentes a grupos, ou seja, é a categoria semântica de nomes que dão a noção de pertinência a grupos em geral, por exemplo, em português: paulista é pertencente a São Paulo, e em galego: deportivista é pertencente à torcida do time esportivo ou do Real Club Deportivo de la Coruña; 
4) Pacientes, ou seja, nomes que indicam o paciente de uma ação provocada por uma doença, vício ou sistema, por exemplo: em português: sonambulista é quem sofre as conseqüências do sonambulismo e em galego: autista é quem sofre de autismo;

5) Qualificativos característicos, ou seja, é a categoria semântica de nomes que identificam, caracterizam e qualificam em geral com valores físicos, morais, psíquicos e/ou de conduta, por exemplo, em português: acacianista é quem se parece à personagem Acaciano, e em galego pancista, entre outras acepções, significa quem tem uma grande $p a n z a^{1585}$;

6) Locativos, ou seja, é a categoria semântica de nomes que indicam locais em geral, por exemplo, em português brasileiro: capelista é o local onde se vendem capelas $^{1586}$, em português lusitano: florista é o local onde se vendem flores, em galego não foram encontrados exemplos nesta categoria semântica;

7) Instrumentos, ou seja, é a categoria de nomes que indicam instrumentos ou máquinas em geral, por exemplo, em português: reboquista é o veículo que reboca outros, em galego: multicopista é a máquina que imprime muitas cópias de um mesmo original.

8) Antropônimos, ou seja, é a categoria semântica que representa nomes próprios, por exemplo: Batista ou Baptista ${ }^{1587}$ e Evangelista no português; Bautista, Batista ${ }^{1588}$, Baptista $^{1589}$, Boutista ${ }^{1590}$, Avanxelista ${ }^{1591}$ e Evanxelista no galego. A título de ilustração, o nome do ilustre brasileiro Barão e Visconde de Mauá é Irineu Evangelista de Sousa. Convém notar que esta categoria foi encontrada única e exclusivamente na pesquisa de contexto, pois a acepção antroponímica não foi encontrada nos dicionários consultados.

O segundo passo foi o refinamento das categorias semânticas gerais encontradas na primeira etapa, formando subcategorias semânticas, por meio da elaboração de paráfrases, conforme proposto no capítulo 2 (páginas: 133 e 134), que procuram levar em conta a base da formação com o sufixo -ista. Desse modo, as categorias semânticas mais abrangentes e significativas tiveram vários níveis de subdivisões.

\footnotetext{
1585 Tradução: "barriga”.

${ }^{1586}$ Miudezas de armarinho, como por exemplo: botões e alfinetes.

1587 Variação ortográfica de Batista.

${ }^{1588}$ Variação ortográfica de Bautista.

${ }^{1589}$ Variação ortográfica de Bautista.

${ }^{1590}$ Variação ortográfica de Bautista.

${ }^{1591}$ Variação ortográfica de Evanxelista.
} 
Durante a pesquisa, percebeu-se que a maioria das formações com -ista pertencem à categoria semântica de agentes, que é a mais subdividida da classificação. Inicialmente, a categoria de agentes foi dividida em três grandes subcategorias: a) profissionais ou ocupacionais, isto é, de formadores de nomes que indicam profissionais ou agentes ocupacionais, por exemplo, em português: bridgista é quem joga bridge, e em galego: recepcionista é quem tem como ofício receber as pessoas; b) outros agentes, ou seja, que não são profissionais ou ocupacionais, mas são agentivos, por exemplo, em português: consumista é quem consome, não é uma profissão ou ocupação, mas é um agente, analogamente e em galego: fumista é quem fuma. Do mesmo modo foram feitas as subdivisões nas demais categorias e recursivamente na própria, conforme o encontrado nas duas listas de dados.

Convém notar que, juntamente com as subdivisões foram feitas as paráfrases para cada classe encontrada. Apesar de o ponto de partida para a classificação das palavras não ter sido a base da formação em -ista, mas sua designação semântica, a base foi importante na construção das paráfrases de cada categoria. Para não sobrecarregar a notação e comprometer a clareza da classificação semântica, usou-se uma notação de abrangência e universalidade para X. Em outras palavras, seja B a base da formação em -ista; e seja X, a variável usada nas paráfrases das classificações das palavras derivadas, $\mathrm{X}$ pode assumir os seguintes valores em relação a $\mathrm{B}: \mathrm{X}=\mathrm{B}, \mathrm{X}=\mathrm{B}-i s m o, \mathrm{X}=\mathrm{B}-$ dade, $\mathrm{X}=\mathrm{B}-i a, \mathrm{X}=\mathrm{B}-$ agem e $\mathrm{X}=\mathrm{B}-$ mente. Por exemplo: em fumista é "que X (verbo)", no qual X = B = fumar; em perfumista é "quem fabrica X (substantivo)", no qual X = B = perfume; em turista é "quem pratica X", no qual X $=\mathrm{B}-i s m o=$ turismo , em probabilista é "profissional especializado em X", no qual $\mathrm{X}=\mathrm{B}-$ dade $=$ probabilidade , em dermatologista é "médico especializado em X", no qual X = B-ia = dermatologia ; em canoísta é "que pratica $\mathrm{X}$ ", no qual $\mathrm{X}=\mathrm{B}$-agem = canoagem; em diarista é "pessoa remunerada X (advérbio com base temporal)", no qual $\mathrm{X}=\mathrm{B}-$ mente.

Dessa maneira obteve-se uma classificação semântica geral para as palavras formadas com o sufixo -ista, que abrange as acepções dos vocábulos encontrados na língua galega e os encontrados na língua portuguesa, exposta a seguir. 


\section{Classificação das palavras derivadas com o sufixo -ista.}

\section{AGENTE. Nomes agentivos em geral.}

\subsection{Profissionais ou ocupacionais.}

1.1.1. Que X (verbo). Por exemplo, em português: cronometrista (cronometrar) e em galego: veranista (veranear);

1.1.2. Remunerado por X (advérbio temporal). Por exemplo, em português: diarista (diariamente) e em galego: semanalista (semanalmente);

1.1.3. Que pratica X (nome substantivo). Por exemplo, em português: candomblezista (candomblé) e em galego: ocultista (ocultismo);

1.1.3.1. Que pratica/ joga X (modalidade lúdico-esportiva). Por exemplo, em português: capoeirista (capoeira) e em galego: futbolista (fútbol);

1.1.4. Que aplica X (nome substantivo). Por exemplo, em português: massagista (massagem) e em galego: golpista (golpe);

1.1.4.1. Que aplica X (técnica). Por exemplo, em português: água-fortista (águaforte) e em galego: aquarelista (aquarela);

1.1.5. Que processa (cria, usa ou transforma) X (nome substantivo).

1.1.5.1.Que faz/cria/produz X. Por exemplo, em português: mosaicista (mosaicos) e em galego: arreglista (arreglos musicales);

1.1.5.1.1. Que cria/ cultiva X (animais/vegetais). Por exemplo, em português: cacaulista (cacau) e em galego: caponista (capós);

1.1.5.1.2. Que fabrica X (produto manufaturado). Por exemplo, em português: calçadista (calçados) e em galego: perfumista (perfumes);

1.1.5.1.3. Profissional da criação mental e/ou artística de X. Por exemplo, em português: aderecista (adereços) e em galego: capista (capas de libros);

1.1.5.1.3.1.Escritor ou autor de X (gênero). Por exemplo, em português: contista (contos) e em galego: novelista (novelas); 
1.1.5.1.3.2. Autor ou compositor de $\mathrm{X}$ (música). Por exemplo, em português: sambista (samba) e em galego: sinfonista (sinfonías);

1.1.5.2. Que usa, transforma ou visa a X. Por exemplo, em português: bagagista (bagagens) e em galego: carteirista (carteiras);

1.1.5.2.1. Que comercializa X. Por exemplo, em português: cacaulista (cacau) e em galego: florista (flores);

1.1.5.2.2. Que coleciona X. Por exemplo, em português: medalhista (medalhas) e em galego: filatelista (filatelios);

1.1.5.2.3. Que usa ou opera X (instrumento / objeto). Por exemplo, em português: cinegrafista (cinégrafo) e em galego: telefonista (teléfono);

1.1.5.2.3.1.Que dirige X (veículo). Por exemplo, em português: ascensorista (ascensor) e em galego: tractorista (tractor);

1.1.5.2.3.2.Que toca $X$ (instrumento musical). Por exemplo, em português: flautista (flauta) e em galego: pianista (piano);

1.1.6. Que trabalha em $X$ (nome substantivo que indica local). Por exemplo, em português: berçarista (berçário) e em galego: oficinista (oficina);

1.1.7. Que possui X (nome substantivo cuja posse indica ocupação profissional). Por exemplo, em português: confeccionista (confecção) e em galego: accionista (acciones);

1.1.8. Profissional especializado em $X$ (nome substantivo que indica área de conhecimento). Por exemplo, em português: cientista (ciência) e em galego: esteticista (estética);

1.1.8.1. Músico especializado em X. Por exemplo, em português: bossa-novista (bossa-nova) e em galego: instrumentista (música instrumental);

1.1.8.2.Especializado em X (Ciência Biológica). Por exemplo, em português: geneticista (genética) e em galego: ecoloxista (ecoloxía);

1.1.8.2.1. Médico especializado em X. Por exemplo, em português: cardiologista (cardiologia) e em galego: ortopedista (ortopedia); 
Estudo comparativo de aspectos semânticos do sufixo -ista no português e no galego.

1.1.8.3.Especializado em X (Ciência Exata). Por exemplo, em português: grafista (Teoria dos Grafos) e em galego: alxebrista (álxebra);

1.1.8.4.Especializado em X (Ciências humanas). Por exemplo, em português: filologista (filologia) ou filólogo e em galego: folclorista (folclore);

1.1.8.4.1. Advogado especializado em X. Por exemplo, em português: civilista (direito civil) e em galego: tributarista (direito tributario);

1.1.8.4.2. Especialista em X (língua ou cultura). Por exemplo, em português: açorianista (açoriano) e em galego: galeguista (galego);

1.1.8.4.3. Especialista na sócio-política de X (local). Por exemplo, em português: asianista (Ásia) e em galego: vaticanista (Vaticano);

1.1.8.4.4. Especialista em $X$ (período histórico). Por exemplo, em português: medievalista (medieval) e em galego: novecentista (anos mil $e$ novecentos);

1.1.8.4.5. Especialista na obra de X (nome substantivo antroponímico). Por exemplo, em português: camonista (Camões), rosalista (Rosalía de Castro);

1.1.9. Outros profissionais. Por exemplo, em português: ritmista (ritmo) é quem marca o ritmo da música, e em galego: maratonista é o corredor de maratonas;

\subsection{Outros agentes}

1.2.1. Que X (verbo). Por exemplo, em português: caçoísta (caçoar) e em galego: fumista (fumar);

1.2.1.1. Que X (verbo) em exagero. Por exemplo, em português: blefista (blefar) e em galego: comprista (comprar);

1.2.2. Que faz, diz ou conta muito $X$ (nome substantivo). Por exemplo, em português: asneirista (asneira) e em galego: bromista (bromas);

1.2.3. Que discrimina baseado em X (nome substantivo). Por exemplo, em português: racista (raça) e em galego: sexista (sexo); 
Estudo comparativo de aspectos semânticos do sufixo -ista no português e no galego.

1.2.4. Que recebe $X$ (nome substantivo) periodicamente. Por exemplo, em português: pensionista (pensão) e em galego: bolsista (bolsa);

1.2.5. Que freqüenta $X$ (nome substantivo que indica local). Por exemplo, em português: agüista (águas termais) e em galego: bañista (baños públicos);

1.2.6. Que paga ou contribui X (advérbio temporal). Por exemplo, em português: mensalista (mensalmente), e em galego: anualista (anualmente).

2. ADEPTO. Nomes que dão a noção de adesão mental em geral, ou seja, adeptos, simpatizantes, seguidores, crentes, defensores, de determinada ideologia.

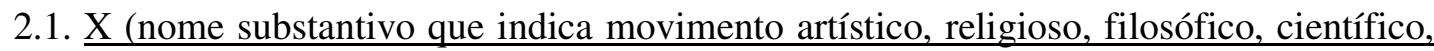
social, político). Por exemplo, em português: xintoísta (xintoísmo) e em galego: cubista (cubismo);

2.2. Apóia, simpatiza com, defende os interesses de $X$ (nome substantivo toponímico ou que indica um povo). Por exemplo, em português: bairrista (bairro) e em galego: españolista (España);

2.3. Apóia, defende, simpatiza com, segue, acredita em, propaga os ideais ou interesses de

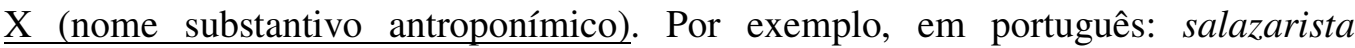
(Salazar) e em galego: fraguista (Manuel Fraga);

3. PERTINENTE. Nomes que dão a noção de membros pertencentes a grupos ou entidades em geral.

3.1. Gentílico. Natural ou habitante de X (nome substantivo toponímico). Por exemplo: em português nortista (Norte do Brasil) e em galego foi encontrada a forma paulista para referir-se ao natural ou habitante do Estado de São Paulo;

3.2. Religioso. Que pertence a X (nome substantivo que indica Ordem e/ou congregação religiosa). Por exemplo, em português: clarista (Santa Clara) e em galego: marista (congregación da Virxe María); 
Estudo comparativo de aspectos semânticos do sufixo -ista no português e no galego.

3.3. Político. Que pertence a X (nome substantivo que indica partido político). Por exemplo, em português: udenista (União Democrática Nacional (U.D.N.)) e em galego: falanxista (Falanxe);

3.4. Torcedor / jogador de time esportivo. Que pertence a X (nome substantivo que indica time esportivo). Por exemplo, em português: benfiquista (Sport Lisboa e Benfica) e em galego: deportivista (Deportivo de la Coruña);

3.5. Candidato a / aprovado em uma etapa seletiva. Que pertence ao grupo apto a $X$ (nome substantivo que indica a etapa em um processo seletivo ou de concorrência). Por exemplo, em português: semifinalista (semifinal) e em galego: medallista (medalla);

\subsection{Aluno.}

3.6.1. Que pertence a X (nome substantivo que indica entidade educacional). Por exemplo, em português: normalista (Escola Normal) e em galego: seminarista (seminario);

3.6.2. Que pertence a X (nome substantivo que indica período escolar). Por exemplo, em português: anista (ano letivo) e em galego: primeiranista (primeiro ano);

3.7. Membros em geral. Que pertence a $X$ (nome substantivo que indica Entidade, grupo, associação). Por exemplo, em português: acemista (A.C.M. - Associação Cristã de Moços); cineclubista (cineclube) e em galego: reservista (reserva militar);

3.8. Parte do Mundo. Que pertence a X (nome substantivo que indica divisão mundial). Por exemplo, em português: primeiro-mundista (Primeiro Mundo) e em galego: terceiromundista (Terceiro Mundo);

\section{PACIENTE. Nomes que indicam o paciente de uma ação, em geral.}

4.1.1. Que sofre ação de X (nome substantivo que indica doença, vício, ou sistema). Em português: sezonista (sezonismo ${ }^{1592}$ ) e em galego: autista (autismo);

\footnotetext{
1592 Malária.
} 
Estudo comparativo de aspectos semânticos do sufixo -ista no português e no galego.

\section{QUALIFICATIVO. Nomes que identificam, caracterizam e qualificam em geral com} valores físicos, morais, psíquicos e/ou de conduta.

5.1. Identidade. Que é X (nome substantivo ou adjetivo). Por exemplo, em português: agiotista (agiota) e em galego: voluntarista (voluntario);

5.1.1. Que é muito $X$ (nome substantivo ou adjetivo). Em português: caturrista (caturra) e em galego: emocionalista (emocional);

5.1.2. Que tem muito X (nome substantivo, em geral, que indica parte do corpo). Em português: pancista (pança) e em galego: pancista (panza).

5.2. Semelhança. Que se parece a X (nome substantivo ou adjetivo). Em português: acacianista (personagem Acaciano) e em galego: vampirista (vampiro);

5.3. Conduta. Que (é dado a, aprecia muito) gosta muito de X (nome substantivo ou adjetivo). Em português: detalhista (detalhes) e em galego: farrista (farras);

\section{LOCAL. Nomes que indicam locativos.}

6.1. Comércio. Onde se comercializa X (nome substantivo). Por exemplo, em português brasileiro: capelista (capela ${ }^{1593}$ ), em português europeu: florista (flores); não foram encontrados exemplos em galego;

\section{INSTRUMENTO. Nomes que indicam máquinas ou equipamentos.}

7.1. Que X (verbo). O único exemplo encontrado foi em português: reboquista (veículo que reboca outros veículos);

7.2. Que processa X (nome substantivo). Por exemplo, em português: balista (arremessa balas) e em galego: multicopista (imprime várias cópias);

\section{ANTROPONÍMICO. Nomes ou sobrenomes que designam pessoas.}

8.1.1. Em português: Batista e Evangelista; em galego: Bautista e Evanxelista.

${ }^{1593}$ Miudezas de armarinho. 


\section{Considerações sobre a classificação das palavras derivadas}

Inicialmente, deve-se ressaltar que a classificação semântica proposta no item anterior (páginas 251 a 256) refere-se tão somente às palavras formadas por meio de derivação com o sufixo -ista e não a uma classificação semântica do sufixo, lembrando que, de acordo com VIARO (2005), estas são diferentes. No entanto, a partir do estudo da classificação de palavras derivadas com o sufixo pretende-se chegar, então, a uma classificação semântica própria do sufixo -ista para o português e para o galego.

Assim, observando a classificação semântica das formações com o sufixo -ista, proposta, pode-se perceber que, diferentemente do esperado, foram encontradas as categorias semânticas que designam locais e instrumentos dentre as palavras formadas com o sufixo. Convém lembrar que, no final do capítulo 4 (página 241), na observação das ocorrências de formações com o sufixo -ista em corpora galego, português brasileiro e português lusitano, notou-se que um traço semântico comum era o caráter [+animado] e [+humano] das formações nominais, assim como, no capítulo 3 (página 173) ressalta-se a importância da observação de MiRANDA (1980: 62) quanto ao traço [+humano] das palavras formadas com o sufixo -ista. Entretanto, é no mínimo curioso notar que, nas listas usadas como corpora foram encontrados lugares e máquinas cujos nomes, designados por palavras derivadas com -ista, nada têm de traço humano.

No caso da categoria semântica que designa local (sexta categoria, descrita na página 256), foram encontrados apenas três vocábulos na língua portuguesa: alfarrabista, capelista e florista; e nenhum na língua galega. Neste caso, possivelmente o nome do negociador passou a designar o local do negócio, que se restringe ao comércio, somente no português. Em outras palavras, alfarrabista, capelista e florista que designam o comerciante de alfarrábios, capelas $^{1594}$ e flores, respectivamente, passaram também a designar o local onde se comercializam tais itens. A título de ilustração, em português, ir ao cinema, significa ir assistir a projeções de cinematógrafo, mas seu uso também promoveu uma segunda acepção da palavra cinema, que atualmente é a mais usada: "local onde se exibem projeções de cinematógrafo". Assim, a palavra cinema que é uma abreviação de cinematógrafo, além de designar a máquina agente da projeção do filme, passou a designar o local de sua projeção.

\footnotetext{
${ }^{1594}$ Miudezas de armarinho.
} 
Acredita-se, que de maneira semelhante ao que ocorreu com a palavra cinema em português, que, da função de agente instrumental, passou a designar o local onde ocorre a ação, tenha ocorrido com as três formações em -ista. Dado que, foram encontradas apenas três formações com essa característica semântica e que não se verificou tal característica na análise em corpora do capítulo anterior, faz crer que provavelmente suas ocorrências sejam pouco freqüentes; acredita-se, então, que a característica semântica que designa localidade não constitui, pelo menos atualmente, um traço semântico do sufixo -ista no português e ainda menos na língua galega, na qual não foram encontradas formações com a designação locativa.

Sabe-se que o sufixo -ista designa tanto substantivos quanto adjetivos no português e no galego. De acordo com os estudos de BASílio (2004: 61-62) e BASÍliO (2006: 79-92), a conversão de adjetivos em substantivos é muito comum, pois o adjetivo tem função de caracterizar, enquanto o substantivo tem a função de designar, e uma maneira eficiente de designar é por meio da caracterização, havendo mecanismos próprios de mútua conversão entre as duas classes. Acredita-se que no caso das formações de nomes agentivos instrumentais ou de máquinas (sétima categoria semântica, descrita na página 256) com o sufixo -ista, o adjetivo tenha passado a funcionar como substantivo, assim como em português telefone celular ficou conhecido como celular, e em galego escaleiras eléctricas ${ }^{1595}$ são atualmente são designadas como eléctricas; analogamente, acredita-se que os exemplos obtidos com -ista, nesta categoria tenham sofrido o mesmo processo. Por exemplo, em português: reboquista refere-se ao veículo reboquista, arcubalista refere-se à arma arcubalista, autocopista refere-se à impressora autocopista, balista refere-se à arma balista, minervista refere-se à impressora minervista, teleautocopista refere-se à impressora teleautocopista; e em galego: arcubalista refere-se à arma arcubalista e multicopista referese à impressora multicopista. Dado que, foram encontradas apenas sete formações com essa característica semântica, duas no galego e seis no português, no âmbito de armamentos militares (balista e arcubalista) e no âmbito de máquinárias de reproduções gráfica, ou seja, impressoras, também devido à especificidade destas formações, que não foram encontradas na análise em corpora do capítulo anterior, acredita-se que provavelmente suas ocorrências

1595 Tradução: “escadas rolantes”. 
sejam pouco freqüentes, ainda que antigas para a designação de instrumentos bélicos ${ }^{1596}$, e que tais vocábulos sejam formados pelo processo de conversão de adjetivos em substantivos e não pelo processo propriamente de derivação com o sufixo -ista. Neste caso, as observações levam a crer que a característica semântica que designa agente instrumental ou maquinário não constitui, pelo menos atualmente, um traço semântico do sufixo -ista no português e tampouco na língua galega.

Notou-se em corpora, que a classe semântica que designa nomes próprios de pessoas (oitava categoria semântica, descrita na página 256), apresenta apenas duas ocorrências, no português: Batista ${ }^{1597}$ e Evangelista e, analogamente, apenas duas ${ }^{1598}$ no galego: Bautista e Evanxelista. Tais ocorrências estão ligadas à influência exercida pela Igreja Católica, na Península Ibérica e em suas colônias, no campo da antroponímia, em geral, para diferenciar os católicos dos seguidores de outras religiões. Inicialmente, nos textos eclesiásticos as duas formas são encontradas também como fator de diferenciação entre João, o Batista, de João, o Evangelista, pois a formação em -ista, identifica univocamente cada João. Entretanto, a palavra batista significa "aquele que batiza", e, portanto, é um agentivo ocupacional; a palavra evangelista significa "aquele que evangeliza", analogamente também é um agentivo ocupacional. Entretanto, os agentivos ocupacionais ao serem usados como diferenciadores acabaram tornando-se adjetivos pelo processo de conversão e, posteriormente, antropônimos, por diferenciarem pessoas. Dessa maneira, diferentemente do sufixo - es em português, ou do sufixo - ez em galego, cuja característica semântica é a designação de antropônimos, conforme exemplo dado no capítulo 1 (página 86); o sufixo -ista não forma, então, nomes próprios de pessoas por derivação, podendo-se concluir que a característica antroponímica não corresponde a um aspecto semântico do sufixo -ista no português e tampouco na língua galega, ainda que possa aparecer em algumas de suas formações.

Na classificação semântica das palavras formadas com o sufixo -ista encontrou-se a categoria "adepto" (segunda categoria semântica descrita na página 254) que designa nomes

\footnotetext{
${ }^{1596}$ balista é de 1689 e arcubalista é do século XIX, segundo datação do dicionário HoUAISS (2001).

${ }^{1597}$ Considerou-se a palavra Baptista como uma variação ortográfica de Batista.

${ }^{1598}$ As demais palavras encontradas na função toponímica: Boutista, Batista e Baptista são variações ortográficas de Bautista; e Avanxelista é variação ortográfica de Evanxelista.
} 
que dão a noção de adesão mental em geral, ou seja, adeptos, simpatizantes, seguidores, crentes, defensores, de determinada ideologia. Essa categoria parafraseada por "adesão mental aos ideais de X”, abrange muitas ocorrências e tem se mostrado muito produtiva no século XX. Nas listas utilizadas como corpora da língua galega e corpora da língua portuguesa, notou-se que mais da metade de seus vocábulos foi classificada nesta categoria, muitos deles importados de outras línguas, principalmente do francês, inglês e alemão. Notou-se, ainda, que a maior parte das formações pertencentes a esta classe semântica, mas não todas, está associada paradigmaticamente ao sufixo -ismo, por exemplo: cubista - cubismo, surrealista surrealismo, budista - budismo, socialista - socialismo; mas bairrista - bairro, españolista Español. Conforme capítulo 1 (página 37), na Europa dos séculos XIV a XVI d.C., devido às traduções e estudos dos textos gregos da Antigüidade Clássica, em geral manuscritos levados pelos sábios ao fugirem dos limites do Império Bizantino com a ocupação turco-otomana, nasceu o movimento Humanista e Renascentista que recuperou no Ocidente a cultura helênica culminando na corrida pelo saber, nas Universidades e na base para a tecnologia dos últimos séculos. Dessa forma, no século XVIII e XIX o uso do sufixo -ismo, de origem grega, com sua já antiga designação de sistema de ideais e a associação ao sufixo -ista teve uma grande repercussão em vários âmbitos, principalmente no: artístico, político, filosófico, científico, e religioso. Assim, com as línguas veiculares francas do século XIX e XX, como o francês, o alemão e o inglês, esse tipo de construção penetrou em várias outras línguas, como o português, o castelhano e o galego. No caso da língua galega, dado que não foi possível estudar a datação dos vocábulos, fica difícil precisar se as formações estrangeiras chegaram a ela diretamente das línguas francas ou por meio do castelhano. No entanto, a partir de sua penetração, tal formação passou a ser facilmente produtiva também nas línguas receptoras, principalmente quando a base de formação com -ismo e -ista é um nome próprio, conforme atesta SANDMAnN (1989: 43) em seu corpus de pesquisa. A título de ilustração há, no português lusitano: Salazarista; no português brasileiro: Malufista e no galego: Fraguista. Conforme comprovação em corpora feita no capítulo 4 (páginas 231 a 242), pôde-se constatar que a categoria é bastante usada, sobretudo no século XX.

$\mathrm{Na}$ classificação feita das formações derivacionais com -ista, verificou-se também a existência da classe semântica cuja designação é de pertinência (terceira categoria, descrita 
Estudo comparativo de aspectos semânticos do sufixo -ista no português e no galego.

nas páginas 254 e 255), ou seja, pessoas pertencentes ou membros de determinados grupos característicos. Conforme comprovação em corpora feita no capítulo 4 (páginas: 232, 241 e 242), pôde-se constatar que a categoria é muito produtiva e seu uso é verificado, sobretudo na prosa jornalística. Tal categoria apresentou-se com várias subcategorias, baseadas nas características dos grupos aos quais se refere a palavra derivada com o sufixo. Desse modo, pertencente a esta categoria, a subclasse de gentílicos (categoria 3.1, na página 254), estudada com mais detalhes no capítulo 6, mostra que esse traço semântico, já antigo, do sufixo -ista desenvolveu-se e continua a ser produtivo, principalmente no português brasileiro. Não é um traço semântico encontrado no galego, pois as palavras que em corpora da língua galega foram encontradas (paulista e santista) são formações importadas do português brasileiro e, portanto, não são palavras formadas no próprio galego. Notou-se, ainda, que tal traço atualmente não se mostra produtivo no português lusitano, mas parece ser no português africano, e, portanto, é um traço característico da semântica do sufixo na língua portuguesa. É interessante notar que este traço do sufixo -ista, um formador de agentivos formar gentílicos, não é uma exclusividade do sufixo, pois em outras línguas há estruturas que são usadas com a dupla função, ou seja, podem formar gentílicos e também formar agentivos, por exemplo, na língua árabe há ${ }^{1599}$, e na língua hebraica há ${ }^{1600}$, conforme capítulo 3 (páginas 143 a 145).

A subclasse de pertinência religiosa (categoria 3.2, na página 254), também se mostra como uma categoria do sufixo -ista e não apenas de suas formações, embora pouco produtiva atualmente. Acredita-se que a característica se desenvolveu devido ao confinamento inicial das ocorrências do sufixo no âmbito religioso, principalmente na Idade Média, dada a veiculação do grego pela Igreja Católica, conforme capítulo 1 (página 34). Tal característica semântica de pertinência a entidades religiosas não é exclusividade das línguas galega e portuguesa, visto que também é encontrada, entre outras línguas ocidentais, no italiano, no francês e no castelhano.

A subclasse de pertinência escolar (categoria 3.6, na página 255), ou seja, que designa alunos de determinada entidade ou período educacional, também é uma categoria apresentada pelo sufixo -ista e não apenas por suas formações. Tal característica iniciou-se com o advento

1599 Transliteração: $\bar{\imath}$.

1600 Transliteração: $i$. 
das universidades e uma de suas primeiras formações é sorbonnistes ${ }^{1601}$ que designa os estudantes da Sorbonne ${ }^{1602}$. Acredita-se que, neste caso, a caracterização que estava confinada ao âmbito religioso acabou por migrar na língua francesa, ainda na Idade Média, para as universidades, dado que a educação nesse período estava a cargo da competência religiosa, pois, tanto as universidades quanto os mosteiros e seminários eram centros de estudos. A partir daí, generalizou-se a caracterização semântica no âmbito escolar, com a popularização dos vários níveis de ensino no século XIX e, como a língua francesa foi veicular a partir do século XVIII, seu léxico estendeu-se a outras línguas como o castelhano, português e galego, conforme o capítulo 1 página 86, disseminando, assim, a estrutura de formação $\mathrm{O}$ estudo das poucas datações encontradas faz crer que a subcategoria que designa candidato (categoria 3.5, na página 255), pessoa apta ou aprovada em determinado processo seletivo tenha decorrido da noção semântica expressa pela subcategoria de aluno, determinando, assim, um grupo de alunos selecionados e aptos ou aprovados em alguma etapa de seleção, generalizando-se, posteriormente, para pessoas não-discentes, como por exemplo: recordista e medalhista.

Acredita-se que, no final do século XIX e século XX, a característica semântica de pertinência a grupos também tenha se generalizado para designar membros de entidades, grupos e associações em geral (categoria 3.7, na página 255), a partir da idéia de pertinência religiosa associada à idéia de defesa de ideais, compondo outra subclasse da classe pertinência dentro das características semânticas designadoras do sufixo -ista. Dessa mesma maneira, também passou a designar políticos (categoria 3.3, na página 255) pertencentes a determinado partido, e esse tipo de designação semântica, que começou no português e galego do século XIX, conforme SANDMANN (1989: 44) verifica nos exemplos encontrados em seu corpus de pesquisa, conta hoje com uma grande produtividade veiculada, principalmente pela prosa jornalística, de acordo, também, com as constatações feitas em corpora no capítulo 4 (páginas: 232 e 241). Essa característica também é encontrada no castelhano conforme capítulo 3 (página 166), no catalão e no valenciano, e muitas das ocorrências são formadas a partir das próprias siglas dos partidos políticos, por exemplo, no galego: peneuvista (PNV) e no português: udenista (UDN). É interessante notar que, segundo GUILBERT (1975: 276) e já mencionado no capítulo 2 (página 94), o processo de transformação de uma sigla em uma nova palavra é essencialmente sociolingüístico, pois resulta da difusão dentro de uma

${ }^{1601}$ Segundo o dicionário HoUAISS, "sorbonista" em português.

${ }^{1602}$ Uma das universidades mais antigas da Europa, em Paris; segundo o dic. HouAIss, "Sorbona" em português. 
comunidade com adaptações fonéticas, entretanto também é lingüístico quando a sigla se transforma em uma base de derivação, como por exemplo, com o sufixo -ista.

Analogamente, a formação da categoria de pertinentes ou membros de torcidas de times de esportivos (categoria 3.4, na página 255), ou esportistas pertinentes a determinados times, já apontada por SANDMANN (1989: 44), mostra-se uma característica do sufixo -ista, atualmente muito produtiva na Itália e nas línguas de toda a Península Ibérica, conforme capítulo 3 (páginas: 159, 161 e 173). Assim encontram-se as formações no galego como, por exemplo, ferrolista (Racing Club de Ferrol) e as formações no português lusitano, por exemplo, benfiquista (Sport Lisboa e Benfica), mas também no português brasileiro, por exemplo, flamenguista (Clube de Regatas do Flamengo - RJ), porém, neste com menor produtividade. Conforme a comprovação em corpora no capítulo 4 (páginas: 232, 241 e 242).

Baseando-se nos dados encontrados nas duas listas usadas como corpora, considera-se que a subclasse que designa pertinência a partes do mundo (categoria 3.8, na página 255) e que se desenvolveu no século XX, também aponta para uma característica semântica própria do sufixo -ista que tem se mostrado produtiva no português, galego, castelhano e catalão, tendo sido estendida das noções anteriores de pertinência a grupos, entidades e associações.

Sabe-se, conforme CASEVITZ (1985: 69) e já comentado no capítulo 3 (página 142), que a terminação grega $-1 \sigma \tau \eta ́ \varsigma \varsigma$ era usada para formar nomes de agentes a partir de verbos terminados em $-\zeta \omega$, tal estrutura de formação de palavras disseminada pela koiné com o Império Alexandrino, conforme mapa 1.3 do capítulo 1 (página 33), posteriormente veiculada pelo latim do Império Romano (mapa 1.4 na página 34) e pela koiné do Império Bizantino (mapa 1.5 na página 35 e mapa 1.6 na página 36), retomada na Europa Ocidental durante o Renascimento, mas que, no entanto, só se tornou produtiva pelo início de sua veiculação através da língua francesa após os séculos XVIII e XIX, nas línguas receptoras de vocábulos com a estrutura. Assim, etimologicamente, o sufixo -ista, é um formador de agentivos deverbais, mas morfologicamente expandiu-se também como formador de agentivos denominais, aumentando, dessa maneira, sua designação semântica. Percebe-se, então, que o traço mais característico e importante do sufixo, desde suas origens, é a formação de nomes de agentes, assim como -eiro, -or e outros. 
Dessa maneira, analisando a classificação semântica das formações em relação à categoria de agentivos (primeira classe semântica descrita nas páginas 251 a 254), observa-se que há duas grandes subcategorias que designam: a) profissionais e agentes ocupacionais (categoria 1.1 descrita nas páginas 251 a 253), que corresponde, basicamente, à agentividade direta e indireta segundo a classificação semântica de BASÍlıO (2006: 76) descrita no capítulo 2 (página 176); b) outros agentes (categoria 1.2 descrita nas páginas 253 e 254). No primeiro caso, as categorias: 1.1.3. que pratica $\mathrm{X} ; 1.1 .4$. que aplica $\mathrm{X} ; 1.1 .5$ que processa $\mathrm{X}$; (página 251) correspondem à agentividade direta, ou seja, o agente tem relação direta com o nome designado pela base e a utiliza (a faz) designando assim sua função agentiva. A categoria 1.1.8. profissional especializado em X (páginas 252 e 253), corresponde à agentividade indireta, ou seja, a base designa entidades passíveis de estudo ou especializações e os agentes indiretos designam especialistas nas entidades. As demais subclasses de agentes profissionais ou ocupacionais: 1.1.1. que X (verbo) é a estrutura mais antiga de formação de agentivos com o sufixo -ista; 1.1.2. remunerado por X (advérbio temporal); 1.1.6. que trabalha em X (local); 1.1.7. que possui $X$; 1.1.9. outros; não são contempladas pela classificação semântica de BASílio (2006: 76). Pelos estudos de ocorrência em corpora feitos no capítulo 4 (páginas: 184, 195 e 196, 206 e 207, 215 e 216, 231 a 240) pôde-se constatar que, nas línguas portuguesa e galega, o maior uso das formações em -ista atualmente, como também no século XIX, de fato se dá na categoria que representa profissionais e agentes ocupacionais (categoria 1.1, páginas 151 a 253). De acordo com o capítulo 3, analogamente é uma categoria que tem grande ocorrência na língua francesa e na maioria de outras línguas, principalmente as que sofreram grande influência desta como veicular, em que palavras formadas com o sufixo aparecem, tais como: russo, polonês, alemão, inglês, italiano, catalão, valenciano, castelhano. Constata-se, então, que há palavras internacionais para agentes profissionais e ocupacionais cujas formações são feitas a partir do sufixo -ista, por exemplo: modista, florista, recepcionista, maquinista, ascensorista, eletricista, telegrafista, tratorista. Tais formações são, em geral, provenientes do francês e do século XIX para designar um profissional qualificado em determinada área (moda, eletricidade, recepção) ou profissional qualificado na operação de determinado instrumento, aparelho ou máquina (máquina que conduz o trem, ascensor, telégrafo). Acredita-se que a partir dessas designações agentivas diretas desenvolvidas na língua francesa como extensão da estrutura deverbal do sufixo, a estrutura derivativa expandiu-se semanticamente para designar agentes profissionais ou ocupacionais 
em geral, ainda que a base não mais representasse o objeto direto nem o verbo da ação, tanto no francês, quanto nas línguas receptoras dos vocábulos, e, assim, a estrutura semântica com o sufixo -ista passou a ser produtiva também nessas línguas.

É interessante notar que, além da divisão semântica dada neste capítulo (páginas 251 a 256), não somente no português e no galego, mas na maioria das línguas em que aparece, o sufixo presta-se, de maneira peculiar, à formação de nomes, principalmente no âmbito da música e dos esportes. No âmbito da música em geral, de acordo com os dados analisados, foi possível destacar cinco tipos de formações, no galego e no português:

a) músico que toca o instrumento $X$ (categoria 1.1.5.2.3.2, descrita na página 252), é uma categoria que apresenta várias formações com -ista, muitas das quais foram importadas, principalmente do italiano e do francês, e apesar de já ser antiga na sua produção semântica ainda hoje tem se mostrado produtiva. Por exemplo: violista ${ }^{1603}$ é uma formação que já havia no provençal por volta de 1180 , mas também no italiano, por volta do mesmo período; tubista $^{1604}$ (tuba) é uma palavra proveniente também do italiano por volta do ano 1320; de origem italiana também são as palavras violinista ${ }^{1605}$ (datado de 1565) e violoncelista ${ }^{1606}$ (datado de 1812). Entretanto, apesar da forte influência italiana sobre a nomenclatura musical, a palavra vihuelista ${ }^{1607}$ (datado de 1250) provém do castelhano; trompetista ${ }^{1608}$ (datado de 1280) provém do francês e virginalista ${ }^{1609}$ (datado de 1530) é proveniente do inglês. O que se sabe é que tais músicos atuavam nas cortes para entreter a nobreza, daí naturalmente que essas formações com -ista tenham se espalhado por toda a Europa, ao passo que localmente, os músicos populares tenham sido nomeados com os sufixos formadores de agentivos característicos de cada região nesse período. Por exemplo, no Brasil e em Portugal um instrumento popular no século XVI foi a viola, por isso o músico que a toca chama-se violeiro, formação com o sufixo - eiro. No entanto, se houvesse uma apresentação de música para a corte portuguesa com o instrumento clássico viola, haveria um violista, pois provavelmente seria um músico estrangeiro (ou não), mas dedicado a tocar o instrumento em

\footnotetext{
${ }^{1603}$ Músico que toca viola.

${ }^{1604}$ Músico que toca tuba.

${ }^{1605}$ Músico que toca violino.

${ }^{1606}$ Músico que toca violoncelo.

${ }^{1607}$ Músico que toca vihuela.

${ }^{1608}$ Músico que toca trompete.

${ }^{1609}$ Músico que toca virginal.
} 
várias cortes, e daí o nome internacionalmente conhecido. Convém notar que muitos dos instrumentos clássicos que se utilizam hoje em uma orquestra são do século XIX e a nomenclatura do músico que os toca, na maioria das vezes, é proveniente do francês ou do italiano, por exemplo: oboísta ${ }^{1610}$ (datado de 1834) é proveniente do francês, violoncelista ${ }^{1611}$ (datado de 1812) é proveniente do italiano. Ainda hoje, essa designação do sufixo é produtiva, por exemplo: tecladista e baterista; e ao passo que há as formas mais antigas no português e no galego com o sufixo -eiro para músicos dos instrumentos populares, para as quais atualmente também pode haver formas concorrentes com o sufixo -ista, por exemplo, em português: sanfonista é uma forma concorrente com sanfoneiro, e, analogamente em galego: gaitista e gaiteiro. Esse fato não é exclusivo do português e do galego, por exemplo, no leste europeu o violino é um instrumento popular, por isso em russo e em polonês existe a forma para o músico que toca violino com o sufixo agentivo do idioma, mas também existe a forma associada com o sufixo -ist (-istka), não tão freqüente, mas usada para o músico que atua numa grande orquestra.

b) músico autor de $X$ (categoria 1.1.5.1.3.2, descrita na página 152) é uma categoria que não apresenta muitas ocorrências em português ou galego, mas tem-se mostrado produtivo atualmente. Tal designação dada pelo sufixo -ista é de origem italiana, por exemplo: madrigalista ${ }^{1612}$ (datado de 1370) é de origem italiana. Mas, atualmente continua bem produtivo, por exemplo, em português: pagodista $^{1613}$ e em galego: muñeirista ${ }^{1614}$.

c) músico especializado em $X$ (categoria 1.1.8.1 descrita na página 152) é uma categoria não muito produtiva e é um desmembramento da categoria de designação de nomes de especialista, em geral proveniente do inglês, mas com produção própria no português. Por exemplo, instrumentalista é o especialista em música instrumental e é proveniente do inglês, entretanto bossa-novista é um especialista em música do tipo Bossa-Nova, e claramente é uma produção do português brasileiro.

d) músico pertinente a X é uma categoria especial na semântica das formações, pois ao passo que o músico é um agente, esta categoria desdobrou-se para a pertinência a um grupo

\footnotetext{
${ }^{1610}$ Músico que toca oboé.

${ }^{1611}$ Músico que toca violoncelo.

1612 Músico que compõe madrigais.

${ }^{1613}$ Músico que compõe pagodes.

${ }^{1614}$ Músico que compõe muñeiras (música folclórica galega).
} 
musical, classificada na página 255 como a categoria 3.7 que designa membros em geral. Por exemplo: corista (coro), duetista (dueto), quartetista (quarteto), camerista (câmera).

e) outros músicos designados pelo sufixo -ista, são formações agentivas cuja semântica a elas estendeu-se no contexto musical e está incluída na subclasse "outros profissionais" (categoria 1.1.9, descrita na página 253). Por exemplo: arranjista é o músico que faz arranjos musicais, contraltista é o músico que canta como contralto, ritmista é o músico que marca o ritmo da música, rufista é o músico que rufa o tambor.

No âmbito dos jogos e esportes, categoria 1.1.3.1. que pratica / joga X (modalidade lúdico esportiva), a nomenclatura dos jogos em geral é proveniente do inglês, no entanto a nomenclatura dos agentes é, em geral, proveniente do francês, tomando como base o nome do jogo em inglês que, em sua maioria, são pertencentes ao século XIX, por exemplo: beisebolista $^{1615}$ (século XIX), futebolista ${ }^{1616}$ (datado de 1958), parapentista $^{1617}$ (datado de 1980). Provavelmente essa estrutura de formação é uma especialização semântica da agentividade direta que também forma nomes de atletas, por exemplo: acontista (datado de 1871) é o atleta que arremessa acôncios ${ }^{1618}$, argolista (datado de 1913) é o atleta que utiliza argolas em seus exercícios. Desse modo, a categoria especializada, importada do francês, acabou por ter sua produção própria nas línguas receptoras. Da mesma maneira que no âmbito da música, também há formações cuja semântica a elas estendeu-se no contexto esportivo, por exemplo: meio-campista (século XX) é o jogador que atua na posição de meio de campo, maratonista (século XX) é o atleta que corre em maratonas. Contudo, nas listas usadas como corpora do galego e do português, a maioria das formações encontradas neste campo semântico são importadas, indicando que sua produtividade nas línguas estudadas é pequena.

A designação de profissionais especializados em determinada área de conhecimento (categoria 1.1.8, descrita na página 252 e 253) também se sobressai dentro das formações com o sufixo -ista, conforme o indicado pela classificação semântica proposta. A maior parte da nomenclatura de profissionais especializados formadas com o sufixo é proveniente do inglês ou do francês, e, em geral, pertencem ao século XIX e XX. Por exemplo: filologista (século $\mathrm{XX}$ ) entrou no português via inglês, ao passo que a forma concorrente filólogo (datado de

\footnotetext{
1615 Jogador de baisebol.

1616 Jogador de futebol.

${ }^{1617}$ Esportista que pratica parapente.

${ }^{1618}$ Flechas.
} 
1720) o foi por via do francês, entretanto a forma dentista (datado de 1836) é proveniente do francês. A designação semântica de especialista é muito produtiva nas áreas científicas e, em geral, mas não necessariamente, está associada paradigmaticamente com a especialidade designada pelo sufixo -ia. Por exemplo: dermatologista (datado de 1881) - dermatologia, ecologista (datado de 1981) - ecologia; no entanto, naturalista (datado de 1789) - ciências naturais e probabilista (datado de 1813) - probabilidade. Tal formação sobressai-se, principalmente na área médica (categoria 1.1.8.2.1, descrita na página 252), mas também na área de direito (categoria 1.1.8.4.1, na página 253) e outras áreas de ciências humanas como: língua e cultura (categoria 1.1.8.4.2, página 253) e sócio-política (categoria 1.1.8.4.3, na página 253), dada a quantidade de vocábulos encontradas nestas subclasses. A formação de nomes de profissionais especializados com o sufixo -ista é muito produtiva, entretanto a maior parte delas tem entrado na língua portuguesa e galega por meio das línguas francas veiculares como o inglês e o francês, assim, ainda que muitas palavras das duas listas usadas como corpora tenham sido classificadas nesta categoria, a produtividade própria no português e no galego mostra-se pequena.

Observando-se os dados classificados como agentes profissionais ou ocupacionais, notou-se que a maioria das formações com o sufixo -ista que designam profissionais, é geralmente composta por adjetivos que pelo processo de conversão tornaram-se substantivos, como por exemplo: médico dermatologista, advogado tributarista, profissional antenista, jogador meio-campista, profissional diarista, escritor contista, profissional recepcionista, músico instrumentista, atleta acontista.

Deve-se lembrar que etimologicamente o sufixo forma nomes agentivos, há, portanto, a categoria referente a outros agentes (categoria 1.2, descrita nas páginas 253 e 254) que não são profissionais ou ocupacionais, mas são simplesmente agentes, por exemplo: fumista, caçoísta, bromista. Tanto no galego quanto no português, em relação à categoria de agentes profissionais ou ocupacionais, esta apresenta um menor número de vocábulos classificados, como também não se mostrou expressiva nos estudos de ocorrência em corpora feitos no capítulo 4 (páginas: 184, 195 e 196, 206 e 207, 215 e 216, 231 a 240). A subclasse que designa quem discrimina baseado em X (categoria 1.2.3, página 253) apresentou apenas dois 
vocábulos na língua portuguesa: racista e sexista; e três vocábulos no galego: clasista $^{1619}$, racista $^{1620}$ e sexista ${ }^{1621}$; que são formações importadas do francês, constatando-se que tal subclasse não mostra produtividade nas duas línguas estudadas.

Assim, a categoria 1.2.1. que $X$ (verbo) (na página 253), analogamente à categoria 1.1.1 que $\mathrm{X}$ (verbo) (na página 251), correspondem a agentivos deverbais, ou seja, formam agentes a partir de verbos intransitivos, este com a acepção de profissionais e/ou ocupacionais e aquele com a acepção de agentes não-profissionais. Por exemplo, arrendista (arrendar) no português e tallista $^{1622}$ (tallar $^{1623}$ ) no galego. A lista de vocábulos classificados nestas categorias é grande, no entanto a maioria de suas formações são provenientes do francês e do castelhano, mostrando-se com pequena produtividade nas línguas galega e portuguesa.

No entanto, é curioso notar que sua subclasse, a categoria 1.2.1.1. que X (verbo) em exagero, apesar de apresentar poucos vocábulos, mostra uma produtividade significativa no português e no galego, por exemplo: comprista (comprar) e chufista ${ }^{1624}$ (chufar $^{1625}$ ), respectivamente. É interessante observar também que a categoria 1.2.2. que diz, faz ou conta muito $\mathrm{X}$, analogamente à categoria 1.2.1.1. que $\mathrm{X}$ (verbo) em exagero, designa um agente com o traço valorativo da demasia e do exagero, entretanto apresenta mais vocábulos que a subclasse anterior e, também, uma grande produtividade nas duas línguas estudadas, por exemplo: asneirista (asneira) no português e trapisondista ${ }^{1626}$ (trapisonda ${ }^{1627}$ ) no galego. Verificou-se, ainda, que a maioria dos vocábulos importados referentes a estas duas categorias é proveniente do castelhano e alguns da língua francesa. Devido ao traço valorativo, muitas vezes os vocábulos assinados nestas duas categorias são usados em contexto como adjetivos ou qualificativos, conforme foi constatado em corpora do capítulo 4, detalhado no Anexo I.

Convém notar que as categorias: 1.1.2. remunerado por $X$ (advérbio temporal), na página $251 ; 1.2 .4$. que recebe $X$ periodicamente; 1.2.5. que freqüenta $X$ (local); 1.2.6. que paga ou contribui $\mathrm{X}$ (advérbio temporal) na página 254; classificam agentes indicando a

\footnotetext{
${ }^{1619}$ Quem discrimina baseado na classe social.

1620 Tradução: "racista".

1621 Tradução: "sexista".

1622 Tradução: “escultor”.

1623 Tradução: "esculpir”.

1624 Tradução: "trocista".

${ }^{1625}$ Fazer troça.

${ }^{1626}$ Quem provoca muitas intrigas.

1627 Tradução: "intriga”.
} 
noção de grande frequiência ou constância, por exemplo, de acordo com o dicionário HoUAISS (2001): diarista é quem recebe sua remuneração diariamente; pensionista é quem recebe periodicamente uma pensão; alcovista é quem freqüenta alcovas; mensalista é quem paga ou contribui mensalmente. Acredita-se que, por um lado, a noção de agentes profissionais ou ocupacionais sugere a noção de freqüência, pois uma ocupação ou profissão é algo praticado com freqüência; por outro lado tal noção também é sugerida como decorrência da idéia semântica de grande intensidade. Embora poucos vocábulos tenham sido classificados nestas categorias, tal classificação mostra-se produtiva nas línguas galega e portuguesa.

Ainda, na classificação semântica, a categoria qualificativa (categoria 5, descrita na página 256) agrupa nomes que identificam, caracterizam e qualificam em geral com valores físicos, morais psíquicos e/ou de conduta. Como já foi visto, a diferenciação entre adjetivos e substantivos na qualificação é um processo complexo, entretanto nesta categoria classificaram-se os nomes que geralmente adjetivam, e quando são substantivos apresentam uma informação característica e identitária, conforme o disposto nas suas subclasses. É interessante notar que, nessa categoria, assim como em alguns casos da categoria de agentes, aparece um traço semântico valorativo que indica exagero ou obsessão e, no limite, passam a atribuir um valor pejorativo à derivação. É o caso das subclasses: 5.1.1. que é muito X e 5.3. conduta, que aprecia muito, gosta muito de X; dispostas na página 256 e que se mostraram com um grande número de vocábulos, muitos deles provenientes do castelhano e do francês, mas também com produções próprias. Por exemplo: emocionalista significa que é muito emocional, ou seja, a palavra emocional já qualifica, entretanto o sufixo -ista, neste caso, intensifica o qualificativo ao exagero. Analogamente, um detalhista não é apenas uma pessoa que é apegada aos detalhes, mas indica quem é muito apegado, apegado em demasia, em exagero e obstinado pelos detalhes, indicando, dessa forma, também um traço pejorativo.

Sabe-se que geralmente o sufixo -ista indica agentes, no entanto, nesse estudo, encontrou-se a categoria semântica que designa pacientes (quarta categoria, descrita na página 255) com quinze formações que ocorrem em corpora da língua portuguesa, associadas paradigmaticamente com o sufixo -ismo: absintista - absintismo; alcoolista - alcoolismo, 
addisionista - addisionismo, acromegalista - acromegalismo, autista - autismo, automatista - automatismo, colecionista - colecionismo, edipista - edipismo, enolista - enolismo, etilista - etilismo, infantilista - infantilismo, sezonista - sezonismo, soliloquista - soliloquismo, tabagista - tabagismo ou tabaquista - tabaquismo, virilista - virilismo. Analogamente foram encontradas seis formações com a designação de paciente em corpora galego: albinista albinismo, autista - autismo, mutista - mutismo seletivo, sonambulista - sonambulismo, negativista - negativismo, tabaquista - tabaquismo. Pode-se notar nos exemplos obtidos que há uma certa complexidade na distinção entre a noção de paciente, pertinente e/ou adepto e agente. Nestes casos, acredita-se que as formações em -ista decorram, não somente da relação paradigmática com o sufixo -ismo que forma o nome da doença, mas também do fato de que tais doenças ou sistemas provocam um comportamento peculiar no paciente, ou seja, o paciente também é um agente, impelido pela doença ou sistema designado pelo vocábulo em -ismo, ao qual está associado. Por exemplo, um autista é uma pessoa que pertence ao sistema do autismo, (ou ao grupo designado como autismo) e como tal, é impelido a agir de acordo com o comportamento estabelecido pelo sistema, classificado como doença, em outras palavras, um autista é quem padece das conseqüências ditadas pelo autismo. Notou-se, ainda, que a maioria dos vocábulos encontrados nesta categoria corresponde a adaptações de palavras importadas, principalmente do francês, cuja característica semântica apresentada é, geralmente, comportamental, ou seja, de comportamento único estabelecido no paciente (palavra formada com o sufixo -ista) por um sistema designado com o sufixo -ismo. Em corpora galego, todos os vocábulos encontrados correspondem a palavras importadas que apresentam a característica descrita. Um caso curioso é a palavra colecionista, que em alguns dicionários, tanto galegos como da língua portuguesa, como por exemplo, no HoUAISS (2001) e no dicionário da Real Academia Galega, fornecem como acepção da palavra o sinônimo de colecionador, já em contexto a derivação em -ista pode designar um aficionado, obstinado e/ou obcecado por fazer coleções. Com esta acepção última o vocábulo aparece em uma notícia no caderno metrópole do jornal $O$ Estado de São Paulo de 25 de julho de 2006 (Anexo III deste trabalho), referente a casos de pessoas que entulham suas casas com objetos diversos, explicando que os colecionistas padecem de um transtorno obsessivo compulsivo incontrolável, uma obsessão extrema por juntar e colecionar objetos. Desse modo, um colecionista é um adepto do sistema do colecionismo, cuja adesão mostra-se de tal afinco que caracteriza um comportamento doentio. Acredita-se que essa noção de exagero que no limite 
designa a condição patológica do enfermo, em alguns casos, seja derivada da noção de agente especialista, pois é alguém que conhece muito e profundamente o assunto e a ele se dedica sem restrições; em outros, possa estar associada à classe de adesão mental que, no limite, designa fanáticos por determinado ideal; o estudo das classificações semânticas leva a crer também que possa estar associada a noção de alta freqüência do comportamento designado pelo sistema em -ismo gerando o exagero doentio, pois uma alta freqüência significa que algo é feito muitas vezes, provocando a convergência, neste caso, da noção de frequiência e de intensidade, ao mesmo tempo; e, ainda, associada à característica de conduta com o traço semântico valorativo que indica a demasia, o exagero ou obsessão e, no extremo, indica um comportamento doentio designando, assim, pacientes de um transtorno comportamental, no qual desponta, também, um traço pejorativo. Dessa maneira, na língua portuguesa, o caso da palavra colecionista com a acepção encontrada em contexto, corresponde a uma formação própria, cuja característica semântica depreende-se da característica de pertinência, adesão mental, agente profissional especialista, qualificadas pelas noções de alta frequiência, intensidade, demasia e exagero na conduta, apontando para o traço pejorativo, além de estar ligada à associação paradigmática com o sufixo -ismo, diferentemente do que ocorre com as palavras importadas.

Convém notar que, a idéia semântica de obsessão e fanatismo gera, também, a idéia de incredibilidade, exatamente contrária à especialidade, e provoca outra associação semântica que indica o traço pejorativo. Por exemplo, o vocábulo cientificista, segundo o dicionário HouAISS (2001), significa aquele que aplica a noção de uma ciência livresca a qualquer campo do conhecimento, ou seja, aquele que faz uma ciência de má qualidade; analogamente a palavra filosofista, de acordo com o dicionário HoUAISS (2001), indica a pessoa que trabalha com filosofia sem fundamento ou com falsa filosofia, da mesma maneira a palavra agronomista no galego que indica uma forma depreciativa de agrônomo, e malhumorista significa um humorista que não desempenha bem a sua função. Estas derivações que indicam profissionais com o traço pejorativo formam um subconjunto das classificadas na categoria 1.1.9. outros profissionais da página 253 , no qual a forma depreciativa se sobressai. 
Observando a classificação feita, pode-se notar que entre "adesão mental" e "pertinência" há uma divisão artificial, pois, ao analisar semanticamente a primeira categoria evidencia-se que forma nomes de membros que pertencem a um grupo cuja característica é o ideal no âmbito: artístico, científico, filosófico, político, social, religioso. Porém, na classificação das palavras encontradas em corpora foi mantida essa divisão, pois, a classe "adesão mental" mostrou-se numericamente muito grande, com mais da metade dos vocábulos de cada lista usada como corpora, e expressiva em seu uso no século XX, conforme constatação feita no capítulo 4. Entretanto, como a maioria de seus vocábulos é de origem estrangeira, na classificação semântica do sufixo -ista no português e no galego dada a seguir, "adesão mental" constituirá uma subclasse de "pertinência".

Com relação às paráfrases, pode-se notar que há casos que não são por elas previstos, por exemplo: vocalista ${ }^{1628}$ significa um cantor e é classificado como agente profissional ou ocupacional, entretanto não há como fazer uma paráfrase usando-se vocal, vocalizar ou vocalismo; pois, o vocábulo entrou no português e no galego por meio da palavra vocaliste do francês. Da mesma maneira, há outras palavras que se encaixam nas paráfrases, mas que não são formações da língua portuguesa ou galega, por exemplo, a palavra ortopedista encaixa-se perfeitamente na paráfrase: médico especializado em ortopedia (categoria 1.1.8.2.1), entretanto, o vocábulo é originário do francês orthopédiste, cuja versão na língua portuguesa é datada de 1873, e cuja versão galega ainda não está datada. Por outro lado, também há palavras que se encaixam em mais de uma paráfrase, por exemplo, evangelista é: quem evangeliza (categoria 1.1.1); autor/escritor do evangelho (categoria 1.1.5.1.3.1); adepto do evangelismo (categoria 2.1). Ao observar as datações das palavras: evangelista (XIII), evangelizar (XIV), evangelho (XIII), evangelismo (1873); resta somente uma paráfrase, mas, ao verificar que evangelista é originário do grego euaggelistēs, veiculado pelo latim, concluise, então, que não é uma formação do português e do galego, mas uma palavra importada. Assim, convém ressaltar que as paráfrases foram usadas para auxiliar na classificação semântica das formações, mas não para um estudo da produtividade e/ou de semântica do sufixo na língua portuguesa e galega, pois para tal foi necessário um estudo histórico e etimológico, auxiliado, sempre que possível, das datações de cada vocábulo.

${ }^{1628}$ Segundo o dic. HouAISS (2001), "pessoa que canta” ou "o músico que canta". 
Estudo comparativo de aspectos semânticos do sufixo -ista no português e no galego.

\section{Classificação semântica para o sufixo -ista}

Feitas as considerações anteriores, segue-se a classificação semântica na língua portuguesa e galega para o sufixo -ista:

\section{AGENTE. Formador de nomes agentivos em geral.}

\subsection{Profissionais ou ocupacionais.}

1.1.1. Que X (verbo intransitivo). Em português: desenhista (desenhar) e em galego: tallista (tallar);

1.1.2. Que verbo transitivo direto $X$ (nome substantivo). Por exemplo, em português: sambista (samba) e em galego: pandeiretista (pandeireta);

1.1.3. Que trabalha em X (nome substantivo que indica local). Por exemplo, em português: sebista (sebo) e em galego: viveirista (viveiro);

1.1.4. Profissional especializado em X (área de conhecimento). Por exemplo, em português: camonista (obra de Camões) e em galego: galeguista (galego);

1.1.5. Outros. Por exemplo, em português: meio-campista é quem atua na posição de meio de campo, e em galego: porvirista é quem se dedica a decifrar o porvir;

\subsection{Outros agentes}

1.2.1. Que X (verbo intransitivo) ou que $X$ (verbo intransitivo) em exagero. Por exemplo, em português: caçoísta (caçoar) e em galego: chufista (chufar);

1.2.2. Que faz, diz ou conta (muito) X (nome substantivo). Por exemplo, em português: asneirista (asneira) e em galego: palabrista (palabra);

\subsubsection{Formador de nomes de agentes que fornecem a noção de freqüiência}

1.2.3.1. Que paga ou recebe $X$ (advérbio temporal). Por exemplo, em português: diarista (diariamente), e em galego: anualista (anualmente).

1.2.3.2. Que freqüenta $X$ (nome substantivo que indica local). Por exemplo, em português: agüista (águas termais) e em galego: bañista (baños públicos); 
2. PERTINENTE. Formador de nomes que dão a noção de membros pertencentes a grupos ou entidades em geral.

2.1. Adepto. Formador de nomes que dão a noção de adesão mental em geral, ou seja, adeptos, simpatizantes, seguidores, crentes, defensores, de determinada ideologia, que pode ser expressa pela associação paradigmática com o sufixo -ismo, por um nome toponímico ou que indica um povo, ou, ainda por um nome antroponímico. Por exemplo, em português: queremista (queremismo) e em galego: touriñista (Touriño);

2.2. Gentílico. Natural ou habitante de X (nome toponímico). Em português: nortista (Norte do Brasil) e não há produção própria no galego;

2.3. Religioso. Que pertence a X (nome de Ordem religiosa). Em português: tomarista (do Mosteiro de Tomar) e em galego: santiaguista (Orden de Santiago de Compostela);

2.4. Político. Que pertence a X (nome de partido político). Em português: udenista (UDN - União Democrática Nacional) e em galego: peseguista (PSG - Partido Socialista Galego);

2.5. Torcedor / jogador de time esportivo. Que pertence a X (nome de time esportivo). Em português: benfiquista (Sport Lisboa e Benfica) e em galego: deportivista (Deportivo de la Coruña);

2.6. Membros em geral. Que pertence a X (nome de entidade, grupo, associação). Em português: acemista (A.C.M. - Associação Cristã de Moços) e em galego: parrandista (parranda);

3. QUALIFICATIVO. Formador de nomes que identificam, caracterizam e qualificam em geral com valores físicos, morais, psíquicos e/ou de conduta.

3.1. Identidade. Que é X (nome substantivo ou adjetivo), que é muito $X$ ou que se parece a X. Por exemplo, em português: acacianista (personagem Acaciano) e em galego: tremebundista (tremebundo);

3.2. Conduta. Que (é dado a) gosta muito de X (nome substantivo ou adjetivo) ou é obstinado por X (verbo ou nome). Em português: colecionista (colecionar) e em galego: celticista (cultura e folclore celta); 
Estudo comparativo de aspectos semânticos do sufixo -ista no português e no galego.

Em resumo, baseando-se no estudo feito no capítulo, pode-se dizer que uma classificação semântica básica, no português e no galego do sufixo -ista é a de formador de:

1) agentes;

2) pertinentes;

3) qualificadores de identidade e conduta.

Como características semânticas principais das classes propostas, o sufixo -ista, na língua portuguesa e galega, pode indicar:
a) profissionais;
b) especialistas;
c) adeptos de doutrinas;
d) religiosos;
e) gentílicos (somente na língua portuguesa);
f) políticos;
g) torcedores de times esportivos;
h) membros de grupos em geral;

Além disso, o sufixo -ista, na língua portuguesa e galega, pode expressar as seguintes noções semânticas nas palavras que produz:
a) alta freqüência ou constância;
b) grande intensidade, ou seja, exagero, obsessão e fanatismo;
c) pejoratividade.

Convém lembrar, ainda, que a característica marcante do sufixo -ista é a evidência do traço [+animado] e [+humano]. 


\section{Considerações sobre a concorrência na formação de agentivos}

Segundo Vilela (1994: 76), no português, o sufixo -ista, por ser muito freqüente e abranger as mais variadas áreas da realidade extralingüística, sofre concorrência direta com os sufixos: -eiro, -or, -nte e composições com - $\log o$ e, por vezes, a mesma designação agentiva é dada com mais de um sufixo diferente promovendo a sinonímia, por exemplo: oftalmologista e oftalmólogo; biologista e biólogo; filologista e filólogo; farrista e farrante; comentarista e comentador; manobrista, manobreiro e manobrador; fumista, fumante e fumador. No entanto, o autor ressalta que, mantendo-se a base e alterando-se o sufixo, nem sempre se obtém a sinonímia e, muitas vezes, pode-se conseguir efeitos de diferença semântica, por exemplo: trabalhadora, trabalhadeira e trabalhista.

Já, de acordo com MiRANDA (1980: 84), -logo e -ista não formam sinônimos no português, afirmando que as produções com -logo apresentam um caráter mais formal que as produzidas com o sufixo -ista. Assim, de acordo com a autora, as palavras com -logo, por exemplo: antropólogo, biólogo, dermatólogo, filólogo, possuem um traço semântico muito mais formal que as palavras derivadas com o sufixo -ista: antropologista, biologista, dermatologista, filologista.

Em relação à concorrência sufixal, BASíLIO (2006: 74) afirma que a maioria dos processos de formação de nomina agentis a partir de substantivos, no português, ocorrem com os sufixos: -eiro e -ista. De maneira similar, VILELA (1994:75) sustenta que -eiro é o principal e mais antigo sufixo formador de nomes agentivos na língua portuguesa, sofrendo grande concorrência do sufixo -ista.

Conforme MiRANDA (1980: 84), a formação de agentivos denominais com traço [+humano] pela derivação com o sufixo -eiro apresenta uma característica semântica, segundo a autora, "nitidamente informal". Ao comparar as formações do sufixos -ista e -eiro, MiRANDA (1980: 86-87) afirma que: "as atividades de maior prestígio seriam designadas por agentivos em -ista; enquanto os ofícios de menor prestígio ou marginalizados seriam expressos por agentivos em -eiro." A autora, portanto, conclui que: "as regras X-ista e Xeiro, resultariam, pois, como definidoras de status" e ilustra com os seguintes exemplos com o sufixo -ista: cardiologista, novelista, ensaísta, projetista, paisagista, jornalista, cartazista; e os exemplos com -eiro: lixeiro, quitandeiro, borracheiro, verdureiro, jornaleiro, 
cartazeiro. Segundo a autora, sua hipótese de definição de status se tem mostrado um processo produtivo na língua, ainda que haja as formas engenheiro e balconista como contraexemplos.

Seguindo na comparação das formações com os sufixos -ista e -eiro, MIRANDA (1980: 88) observa que o uso do sufixo - eiro, em lugar de -ista, traz um sentido pejorativo para certas formações, por exemplo: noveleiro, flauteiro e batuqueiro. Em seguida, MIRANDA (1980: 88-89), apresenta uma segunda hipótese, na qual as formações com -ista teriam uma agentividade com um traço semântico mais intelectual e poderiam ter como paráfrase “especialista em X”. Já as formações com -eiro teriam, segundo a autora, uma agentividade com um traço menos intelectual e poderiam ter como paráfrase "quem faz algo em relação a X". Dessa maneira, MiRAndA (1980: 88-89) conclui que: "a divisão de formalidade e o sentido pejorativo seriam decorrência da divisão inicial de sentidos, combinados com o padrão social geral, que atribui maior valor às atividades intelectuais”.

Entretanto, segundo VILELA (1994:76), além da sinonímia entre as formações com os dois sufixos, por exemplo: trompeteiro e trompetista; ocorrem também convergências derivativas em que um dos derivados pode assumir valor desfavorável, por exemplo: cançoneteiro e cançonetista; ou podem lexicalizar entidades totalmente diferentes, por exemplo: jornaleiro e jornalista, grosseiro e grossista. Assim, conclui-se que não há como fazer generalizações semânticas diante de sufixos como o -ista e o -eiro, devido à vastidão semântica que abrangem.

Convém lembrar também que nenhum dos autores citados leva em consideração em seus estudos o ingresso de palavras por influência de línguas estrangeiras, como por exemplo: psicologista é influência do inglês psicologist, assim como a maioria dos nomes de especialistas; ciclista é influencia do francês ciclist, assim como a maioria dos nomes de agentes esportivos; gaitista é influência da semântica do sufixo -ista em italiano como formador de agentes que tocam determinado instrumento musical, mas produção própria na língua galega. Tampouco, nesses estudos, foram analisados os fatores diacrônicos, etimológicos, históricos ou simplesmente as datações das palavras derivadas com os sufixos concorrentes. 
Estudo comparativo de aspectos semânticos do sufixo -ista no português e no galego.

Utilizando como corpus o dicionário HouAISS (2001) da Língua Portuguesa, os pesquisadores ${ }^{1629}$ Dr. Zwinglio de Oliveira Guimarães Filho e Leandro Mariano obtiveram o gráfico seguinte, valendo-se das datações das palavras, quando existentes, formadas com o sufixo -ista e com o sufixo-eiro.

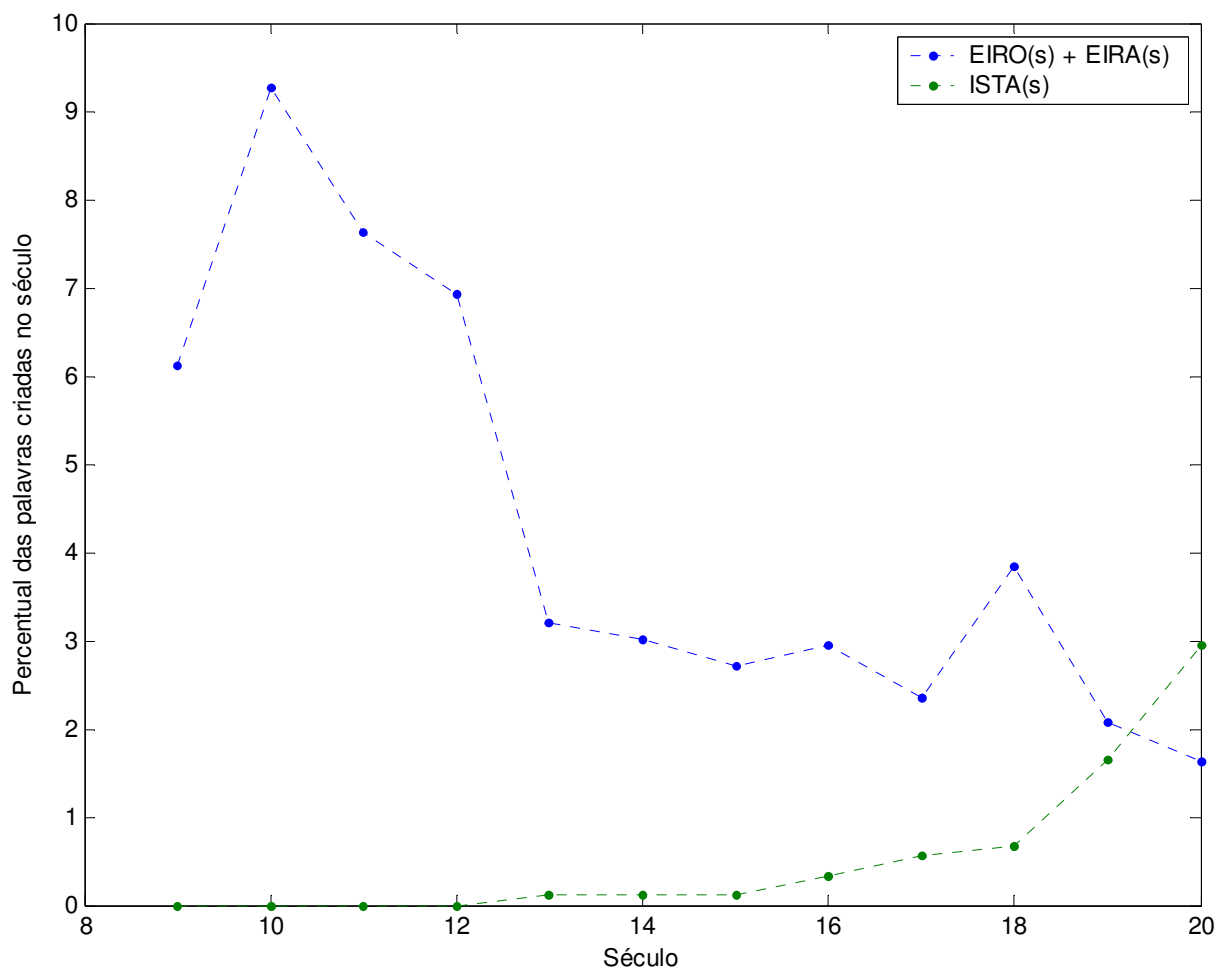

Gráfico 5.2. Produtividade dos sufixos -eiro e -ista, de acordo com o século.

Observando-se o gráfico, nota-se que, até o século XVIII, o sufixo -eiro era o mais produtivo no português, mas sua produtividade vinha em crescente declive. Como já se sabe, durante a idade média o sufixo -ista era quase improdutivo, mas sua produtividade vinha crescendo e no século XVIII, devido às influências dos intelectuais franceses, a sua produtividade passou a crescer mais rapidamente. Já em meados do século XIX, a produtividade do sufixo -ista, em crescente aclive, ultrapassou a produtividade decrescente do sufixo -eiro. E, no século XX, segundo o gráfico, o sufixo -ista mostra-se muito mais produtivo que o sufixo-eiro.

\footnotetext{
${ }^{1629}$ Do Instituto de Física da Universidade de São Paulo e membros do GMHP - Grupo de Morfologia Histórica do Português, cadastrado no CNPq sob coordenação do Prof. Dr. Mário Eduardo Viaro.
} 
Assim, acredita-se que determinados estudos não devam levar em conta apenas os fatos sincrônicos, mas aliá-los também à diacronia, conforme mostram os estudos de RIOTORTO (1998: 140). A título de ilustração, a palavra derivada com o sufixo -eiro(a): enfermeira(o) que significa "pessoa que cuida de enfermos" é do século XIII; e a formação com o sufixo -ista: berçarista que significa "pessoa que cuida de recém-nascidos em um berçário" é do século XX. Assim, contrariando as afirmações de MiRANDA (1980: 86-89), semanticamente não há traços de mais ou menos formalidade entre essas duas ocupações exemplificadas, como também não há traços de mais ou menos intelectualidade, ou de definição de status. Ambas, neste caso, são formações com os sufixos agentivos, entretanto o sufixo -eiro era mais produtivo no século XIII, e, portanto, natural que os agentivos dessa época datados tivessem sido com ele formados, independente de traços semânticos de formalidade ou intelectualidade. Já no século XX, o sufixo -ista é o mais produtivo e naturalmente formará mais agentivos no período, inclusive com características pejorativas, conforme foi visto. Dessa maneira, a comparação que pode ser feita entre os dois sufixos, tendo como apoio o gráfico que indica a produtividade dos sufixos de acordo com o século e sua análise, é tão somente que o sufixo -eiro tem uma grande produtividade como formador de agentivos desde o século XIII, sofrendo um natural desgaste devido ao seu grande uso, abrangência e polissemia. Entretanto, o sufixo -ista, passou a ter produtividade significativa a partir do século XIX, não tendo, até então, sofrido um desgaste tão intenso no uso em relação ao tempo quanto o sufixo -eiro, na língua portuguesa. Lembrando-se as análises e classificações anteriores feitas em corpora galego, conclui-se que, analogamente ao português, tal resultado também é valido na língua galega.

Desse modo, realça-se a importância do uso da diacronia juntamente com os estudos sincrônicos, observando-se o valor de estudos históricos e etimológicos, e verificando-se as datações, na busca de mapeamentos de aspectos semânticos dos sufixos nas formações derivacionais, bem como em outros estudos que envolvam a morfologia e a semântica das formações e/ou de seus componentes, bases e afixos. 
Estudo comparativo de aspectos semânticos do sufixo -ista no português e no galego.

CAPÍTULO 6 ESTUDO DOS VALORES GENTÍLICOS

Navegar é preciso.

(Fernando Pessoa) 


\section{As formações gentílicas a partir do sufixo -ista}

Os nomes gentílicos $^{1630}$ designam povos ou nações, podendo indicar também a procedência ou naturalidade de alguém. Em geral, o topônimo é a base da construção gentílica ou, muitas vezes, as suas formas latinas e latinizadas das respectivas localidades em questão, e por meio da derivação, com uma grande diversidade de sufixos, chega-se ao nome gentílico. Segundo BERGSTRÖM E REIS (2001: 96-102), quando os topônimos têm aparência de plural, em geral, o gentílico forma-se do singular hipotético, por exemplo: Cascais ${ }^{1631}$, cascalense ou cascalejo; Caldas ${ }^{1632}$, caldense; Betanzos ${ }^{1633}$, betanceiro. Os topônimos compostos formam os gentílicos geralmente do primeiro nome, por exemplo: Cercal do Alentejo ${ }^{1634}$, cercalense; Belém de Maria ${ }^{1635}$, belenense; Caldas de Reis ${ }^{1636}$, caldense. Mas há também gentílicos formados do último nome, por exemplo: Minas Gerais ${ }^{1637}$, geralista; Vila Nova de Famalicão ${ }^{1638}$, famalicense; San Pedro de Losón ${ }^{1639}$, losano. Existem, ainda, gentílicos formados de todo o composto, por exemplo: Belo Horizonte ${ }^{1640}$, belo-horizontino; Abre Campo $^{1641}$, abre-campista; Val do Carrio ${ }^{1642}$, valcarriano. Segundo a WIKIPEDIA (2006), na formação do nome gentílico composto com elementos designativos de duas ou mais nacionalidades diferentes, o primeiro adquire uma forma reduzida derivada da origem erudita da palavra, por exemplo: nipo-brasileiro, anglo-japonês, luso-africano. Quando não há forma para os gentílicos, determinam-se analiticamente, antecedendo o topônimo por os de ou $a s d e$,

\footnotetext{
${ }^{1630}$ É interessante notar que existe uma diferença entre os nomes pátrios e gentílicos ou étnicos. O nome pátrio é aquele que se refere a: continentes, países, regiões, estados, cidades, aldeias, vilas, povoados. O nome gentílico ou étnico é aquele que se refere apenas a raças e povos. Assim, por exemplo: israelense é pátrio, israelita é gentílico ou étnico, judeu é gentílico ou étnico, VASCONCELOS (1933: 139). Entretanto, neste estudo trabalhar-seá com o nome gentílico para designar tanto o pátrio quanto o étnico.

${ }^{1631}$ Cidade em Portugal.

1632 Cidade no Brasil.

${ }^{1633}$ Povoado na Galiza.

${ }^{1634}$ Cidade em Portugal.

${ }^{1635}$ Cidade no Brasil.

${ }^{1636}$ Povoado na Galiza.

${ }^{1637}$ Estado no Brasil.

${ }^{1638}$ Povoado em Portugal.

${ }^{1639}$ Localidade no concelho de Lalín, na Galiza.

${ }^{1640}$ Cidade no Brasil.

${ }^{1641}$ Cidade no Brasil.

${ }^{1642}$ Localidade no concelho de Lalín, na Galiza.
} 
por exemplo: os do Bosque da Saúde ${ }^{1643}$, os de Pereirón ${ }^{1644}$, os de (Santa Maria Scala) Coeli $^{1645}$.

Entretanto, não se pode estabelecer uma regra única e rígida, porque o uso e a tradição impõem os seus direitos, forçando até o emprego de vocábulos com pouca ou nenhuma analogia mórfica com a denominação toponímica. Por exemplo, segundo o Dicionário HouAISS (2001): o natural ou habitante do Estado do Rio de Janeiro é fluminense, do latim flumine, "rio"; o gentílico da cidade do Rio de Janeiro é carioca, do tupi kara"ïwa, "homem branco", e 'oka, "casa"; o do Estado do Rio Grande do Sul é gaúcho, do espanhol platino gaucho, "o habitante do campo"; o gentílico do estado do Rio Grande do Norte é potiguar do tupi poti'war, "o que come camarão".

Não surpreende que, perante a variedade de elementos para a formação de gentílicos, expressões múltiplas tivessem aparecido em relação a determinadas localidades. Por exemplo, segundo BERGSTRÖM E REIS (2001: 96-102): Braga, antigo nome Bracara Augusta, do latim bracarensis originou em português bracarense, a par de brácaro e de braguês; da forma hipotética *Conimbrica, de Conímbriga (nome céltico) fez-se conimbricense, do arcaico Colímbria saiu colimbriense, e de Coimbra provém coimbrão e coimbrense; da forma Olisipona, produziu-se o latim olisiponensis, de onde veio olisiponense, da forma arcaica Lisbona fez-se lisbonense, lisbonês, e até lisbonino, e da forma atual Lisboa formou-se lisboês e lisboeta; de Minas Gerais produziu-se mineiro, montanhês e geralista; de Santa Catarina produziu-se catarinense, santa-catarinense, barriga-verde, catarineta, catarinete, catarino, caterinete; de Paraná produziu-se paranaense, paranista e tingui; de Santiago de Compostela produziu-se: santiagués, santiaguense, santiagueiro, compostelano e compostelán; de Lugo produziu-se: lugués, lucense e luguense.

Entretanto, também é comum que o mesmo gentílico seja usado para designar os habitantes ou naturais de várias localidades, dado que há topônimos muito comuns. Por exemplo, valenciano, tanto no galego quanto no português, é o gentílico que designa o natural ou habitante: da cidade espanhola de Valência; da província espanhola de Valência; da cidade francesa de Valenciènnes; da cidade portuguesa de Valença do Minho; da cidade brasileira de

\footnotetext{
${ }^{1643}$ Bairro da cidade de São Paulo.

${ }^{1644}$ Aldeia na comarca do Deza, na Galiza.

1645 Localidade em Évora, Portugal.
} 
Estudo comparativo de aspectos semânticos do sufixo -ista no português e no galego.

Valença, no estado do Rio de Janeiro; da cidade brasileira de Valença, no estado da Bahia; da cidade brasileira de Valença do Piauí, no estado do Piauí.

Assim, em resumo, os nomes gentílicos são geralmente formados por derivação sufixal, na qual a base é dada pelo topônimo que dá nome ao lugar ou ao povo, acrescida de um sufixo. Há vários sufixos que podem ser usados na formação de gentílicos, por exemplo:

-íaco,-íaca. Austríaco, da Áustria; egipcíaco, do Egipto;

-ano, -ana. Alagoano, de Alagoas; alentejano, do Alentejo; Ferrolano (galego), de Ferrol;

-ão, -ãa (-án, -a: em galego). Gascão, da Gasconha; coimbrão, de Coimbra; ourensán (galego), de Ourense;

-ego, -ega. Galego da Galiza; manchego, da Mancha; cabrego (galego), de Cabrales ${ }^{1646}$;

-eiro, -eira. Berlengueiro, das Berlengas ${ }^{1647}$; mineiro, de Minas Gerais; betanceiro (galego), de Betanzos;

-ejo, -eja (-exo, -exa: em galego). Alcoutenejo, de Alcoutim ${ }^{1648}$; colarejo, de Colares $^{1649}$; castrexo (galego), de Castro de Cabras ${ }^{1650}$;

-enho, -enha (-eño, -eña: em galego). Barranquenho, de Barranco ${ }^{1651}$; estremenho, da Estremadura; ribeireño (galego), da Ribeira ${ }^{1652}$;

-eno, -ena. Chileno, do Chile; romeno, da Romênia; nazareno (galego), de Nazaré;

-ense. Alcobacense, de Alcobaça ${ }^{1653}$; chapecoense, Chapecó; estradense (galego), da Estrada $^{1654}$

-ês, -esa (-és, -esa: em galego). Albanês, da Albânia; chinês, da China; lugués (galego), de Lugo;

\footnotetext{
${ }^{1646}$ Povoado na Galiza.

${ }^{1647}$ Arquipélago português.

${ }^{1648}$ Localidade portuguesa.

${ }^{1649}$ Localidade portuguesa.

${ }^{1650}$ Localidade na Galiza.

${ }^{1651}$ Localidade portuguesa.

${ }^{1652}$ Localidade na Galiza.

${ }^{1653}$ Localidade portuguesa.

${ }^{1654}$ Povoado na Galiza.
} 
Estudo comparativo de aspectos semânticos do sufixo -ista no português e no galego.

-eta. Catarineta, de Santa Catarina; lisboeta, de Lisboa;

-eu, -éia. Europeu da Europa; galileu da Galiléia; macabeu (galego), da Macabéia;

-i. Bengali, de Bengala; malaui, da República do Malauí; tetuaní (galego), de Tetuán;

-ico, -ica. Minderico, de Minde ${ }^{1655}$; Ibérico, da Península Ibérica; hispánico (galego)

da Hispania;

-inho, -inha (-iño, -iña: em galego). Biscainho (ou biscaiño em galego), da Biscaia;

-ino, -ina. Nordestino, do Nordeste brasileiro; oliventino, de Olivença; arxentino (galego), da Arxentina ${ }^{1656}$;

-io, -ia. Algarvio, do Algarve; boêmio, da Boêmia; egípcio (galego), do Egito;

-ista. Alfamista, de Alfama; ambaquista, de Ambaca; macaísta, de Macau; paulista

(paulista em galego), de São Paulo; santista (santista em galego), de Santos;

-ita. Moabita, de Moab; vietnamita, do Vietnã; yemenita (galego), do Yemen.

-ota. Cairota, do Cairo; chipriota, do Chipre;

-oto, -ota. Minhoto (miñoto em galego), do Minho; penaguioto, de Santa Marta de Penaguião;

-ol, -ola. Espanhol (español em galego), da Espanha; mongol, da Mongólia;

Por outro lado, é interessante notar que nas classificações semânticas encontradas do sufixo -ista, em geral, não há menção das formações gentílicas. Mas, GoNZÁLEZ REFOXO E RÁBADE CASTIÑEIRA (1995: 50) o coloca como sufixo formador de gentílicos em galego fornecendo, como exemplo, a palavra: paulista, ainda que o topônimo-base seja a cidade de São Paulo no Brasil; no entanto, FerReIRo (2001: 156-157) explica que as formações gentílicas com -ista no galego aparecem como empréstimos do português brasileiro. De fato, em buscas na internet, não foi possível encontrar gentílico formados com o sufixo -ista cuja base fosse um topônimo galego. Conforme VAsConcelos (1933: 150): "este sufixo, que significa agente, serve, de modo bastante estranho, para formar alguns étnicos”, no português, e de acordo com MIRANDA (1980: 101), as formações gentílicas em -ista são improdutivas na

${ }^{1655}$ Freguesia portuguesa.

1656 Tradução: Argentina. 
Estudo comparativo de aspectos semânticos do sufixo -ista no português e no galego.

língua portuguesa. Já, Segundo o Dicionário HoUAISS (2001), “-ista funciona como sufixo gentílico de forma pouco freqüente, mas com fundamento no latim e mesmo no grego". Entretanto, na sétima acepção do sufixo -ista dada pelo dicionário AURÉLIO (1999) encontrase como formador de: "nomes gentílicos, por exemplo: paulista, sulista".

Na lista de 2.604 palavras terminadas em -ista extraída do Dicionário HoUAISS (2001), pode-se perceber que poucas há cuja função seja gentílica. Na verdade foram encontradas apenas vinte e cinco palavras, que representam $1 \%$ da lista, cuja acepção é gentílica e formadas a partir de nomes que designam topônimos: abre-campista, alfamista, américocampista, asa-nortista, asa-sulista, cabista, campista, continentista, esplonista, geralista, lajista, macaísta, malaquista, malauísta, nortista, paranista, paulista, roseirista, santista, são-bentista, são-felista, sertanista, sulista, tupi-paulista, união-paulista. Por outro lado, de 114 palavras terminadas em -ista extraídas do Dicionário da Real Academia Galega (2006), nenhuma delas é gentílica. Tampouco nenhuma das 1038 palavras sufixadas com -ista que aparecem no TILGA (2006) (Tesouro Informatizado da Lingua Galega) corresponde à função gentílica. Segundo o Dicionário da Real Academia Espanhola (2001), também no castelhano não se observam palavras formadas com o sufixo -ista em função gentílica. Entretanto, SANTIAGo LACUESTA e Bustos GiSBERT (2000: 4624) afirma que formações gentílicas com o sufixo -ista parecem ser pouco produtivas em castelhano, mas aponta llerista ${ }^{1657}$ como uma forma gentílica da localidade de Llera ${ }^{1658}$, ainda que a mais usada seja llerense. Segundo REALE (2004) e MigLIORINI (1968: 113-114), a função primeira e uma das mais antigas do sufixo -ista é designar um agente com uma competência particular em uma determinada doutrina, como por exemplo em economista e lingüista; entretanto, no francês essa conotação semântica foi estendida quando da criação das universidades, por exemplo sorbonnistes ${ }^{1659}$ designa os estudantes da Sorbonne ${ }^{1660}$ e louvanistes os estudantes da Universidade Católica de Louvain $^{1661}$, que, devido a uma peculiaridade semântica, passou a designar também os habitantes desta localidade. Dessa forma, a característica gentílica do sufixo -ista é

${ }^{1657}$ Com mais freqüência se refere aos seguidores da política (1966) do ex-presidente da Colômbia: Carlos Lleras Restrepo, que ao gentílico de Llera; nas pesquisas feitas na internet utilizando como ferramenta de busca o software encontrado em: http://www.google.com.

${ }^{1658}$ Localidade na Extremadura espanhola, aproximadamente a $100 \mathrm{Km}$ da fronteira com Portugal.

${ }^{1659}$ Segundo o Dicionário HOUAISS, "sorbonista” em português.

${ }^{1660}$ Uma das universidades mais antigas da Europa, em Paris, na França; Segundo o Dicionário HOUAISS, "Sorbona".

${ }^{1661}$ Localidade na Bélgica. 
considerada, de acordo com FERREIRO (2001: 156-157), um estrangeirismo proveniente da influência do português do Brasil no galego; é pouco produtiva no castelhano; é uma peculiaridade semântica no francês belga; e é desconhecida pelas gramáticas e dicionários consultados do italiano e outras línguas pesquisadas (alemão, armênio, árabe, basco, catalão, hebraico, inglês, polonês, russo e valenciano). Não obstante, contrariamente ao afirmado por MiRANDA (1980: 101), a formação gentílica com o sufixo -ista parece ser uma característica semântica produtiva e própria da língua portuguesa, principalmente encontrada e atestada no português brasileiro.

Esse pequeno grupo de palavras, extraídas do Dicionário HouAISS (2001), oferece algumas peculiaridades curiosas dentro do português. Das vinte e cinco palavras, uma delas, representando $4 \%$ da lista, refere-se aos habitantes ou naturais de uma localidade em Portugal: alfamista; uma palavra, também representando $4 \%$ da lista, refere-se aos habitantes ou naturais de uma localidade na África: malauísta; duas palavras, que representam $8 \%$ da lista, têm como base de seu gentílico localidades na Ásia: macaísta e malaquista; e a maior parte da lista, vinte palavras, que representam 80\%, referem-se aos habitantes ou naturais de localidades brasileiras. Ademais da lista obtida pelo Dicionário HouAISS (2001), VASCONCELOS (1933: 150) também aponta para mais três formações gentílicas a partir do sufixo -ista em localidades portuguesas: jarmelista, freixinista e carçonista. Ainda que, somente uma destas, freixinista, conste no dicionário da Porto Editora (2006) da Língua Portuguesa como forma gentílica, ao passo que o Dicionário da Língua Portuguesa Contemporânea da Academia das Ciências de Lisboa ${ }^{1662}$ registre freixiense, mas também acolha freixenista, freixonista e freixonita, como possíveis formas gentílicas para a mesma localidade. Por outro lado, a forma jarmelista consta no dicionário da Porto Editora (2006) como: "bovino ou designativo de bovino oriundo da região montanhosa do Jarmelo, no distrito português da Guarda, afim dos bovinos da raça mirandesa", ainda que em pesquisas em sítios da internet também apareça como função gentílica da localidade de Jarmelo. Já a forma carçonista não foi encontrada no dicionário da Porto Editora (2006) e tampouco no dicionário da Língua Portuguesa Online (2006), entretanto foram encontrados quatro sítios portugueses nos quais a aparição da forma se dá sob a função gentílica. Segundo BERGSTRÖM e REIS (2001: 102), a palavra ambaquista é o gentílico de Ambaca - região da província de

1662 Apud http://www.vilareal.com.pt/voznordeste/ 
Cuanza Norte, em Angola - ainda que a palavra não apareça no Dicionário HoUAISS (2001), tal termo consta no dicionário da Porto Editora (2006) como: "natural de Ambaca, região de Angola"; e também no dicionário da Língua Portuguesa Online (2006) sua acepção é dada como: "indivíduo pertencente ao grupo dos Lundas da região de Ambaca, em Angola". Dessa maneira, com a existência dessas quatro palavras gentílicas formadas com o sufixo -ista comprovadas por meio de gramáticos ou dicionários, acresceu-se, assim, a lista inicial de vinte e cinco para vinte e nove palavras.

Além dessa lista, em sítios na internet cuja língua oficial é o português, encontrou-se o gentílico brasileiro: ipiranguista ${ }^{1663}$ para os do bairro do Ipiranga em São Paulo; e encontraram-se oito formações gentílicas africanas: buenguista ${ }^{1664}$ para os da região de Buengas na província de Uige em Angola; cabindista $^{1665}$ para os da província angolana de Cabinda; dandista ${ }^{1666}$ para os de Dande na província angolana de Bengo; dondista ${ }^{1667}$ para os de Dondo em Moçambique; jambista ${ }^{1668}$ para os de Jamba na província angolana de Huíla; huambista ${ }^{1669}$ para os da província angolana de Huambo; lubanguista ${ }^{1670}$ para os de Lubango na província angolana de Huíla; pembista ${ }^{1671}$ para os de Pemba em Moçambique. Entretanto, tais formas não puderam ser comprovadas, pois não foram encontradas em dicionários e tampouco em gramáticas. Ainda assim, pode-se supor que a produtividade do sufixo -ista na formação de gentílicos na língua portuguesa têm aumentado, principalmente, nos novos países, como Angola e Moçambique, onde ainda são formadas novas cidades e que após a sua independência alteraram a nomenclatura toponímica, cuja origem era portuguesa, para nomes de origem africana; formando novos gentílicos, em particular, com o sufixo -ista, cuja origem é grega.

Observando-se os dados percentuais em relação à localização geográfica do topônimo da base de formação do gentílico, tem-se que: $6 \%$ da lista são topônimos asiáticos, 6\% correspondem a topônimos de Moçambique, 11\% são topônimos de Portugal, 19\% são

\footnotetext{
1663 http://www.bairrodoipiranga.com/, http://gazetadoipiranga.com.br/ e http://www.ipiranganews.inf.br/

$1664 \mathrm{http}: / /$ www.angonoticias.com/

1665 Idem.

1666 Ibidem.

${ }^{1667} \mathrm{http}: / /$ www.aeiou.pt/catalogo/internacional/africa/mocambique/

$1668 \mathrm{http}: / / \mathrm{www}$.angonoticias.com/

$1669 \mathrm{http}: / /$ www.uaisites.adm.br/iclas/biblioteca42.html

$1670 \mathrm{http}: / /$ www.sanzalangola.com/

${ }^{1671} \mathrm{http}: / / \mathrm{www}$. aeiou.pt/catalogo/internacional/africa/mocambique/
} 
Estudo comparativo de aspectos semânticos do sufixo -ista no português e no galego.

topônimos de Angola e 57\% são topônimos brasileiros. Assim, nota-se que a maioria dos topônimos-base de formação de gentílicos com o sufixo -ista são originariamente brasileiros. Conforme está disposto na tabela e gráfico a seguir.

$\begin{array}{cl}\begin{array}{c}\text { TOPÔNIMO } \\ \text { ÁSIA }\end{array} & \begin{array}{l}\text { GENTílICOS } \\ \text { Angalista, malaquista } \\ \text { ambaquista, buenguista, cabindista, dandista, jambista, huambista, } \\ \text { lubanguista } \\ \text { abre-campista, américo-campista, asa-nortista, asa-sulista, cabista, } \\ \text { campista, continentista, geralista, ipiranguista, lajista, nortista, paranista, } \\ \text { paulista, roseirista, santista, são-bentista, são-felista, sertanista, sulista, } \\ \text { tupi-paulista, união-paulista } \\ \text { BRASIL }\end{array} \\ \text { MOÇAMBIQUE } & \begin{array}{l}\text { dondista, pembista } \\ \text { POlfamista, carçonista, freixinista, jarmelista }\end{array}\end{array}$

Tabela 6.1. Localidade dos topônimos-base de gentílicos sufixados em -ista.

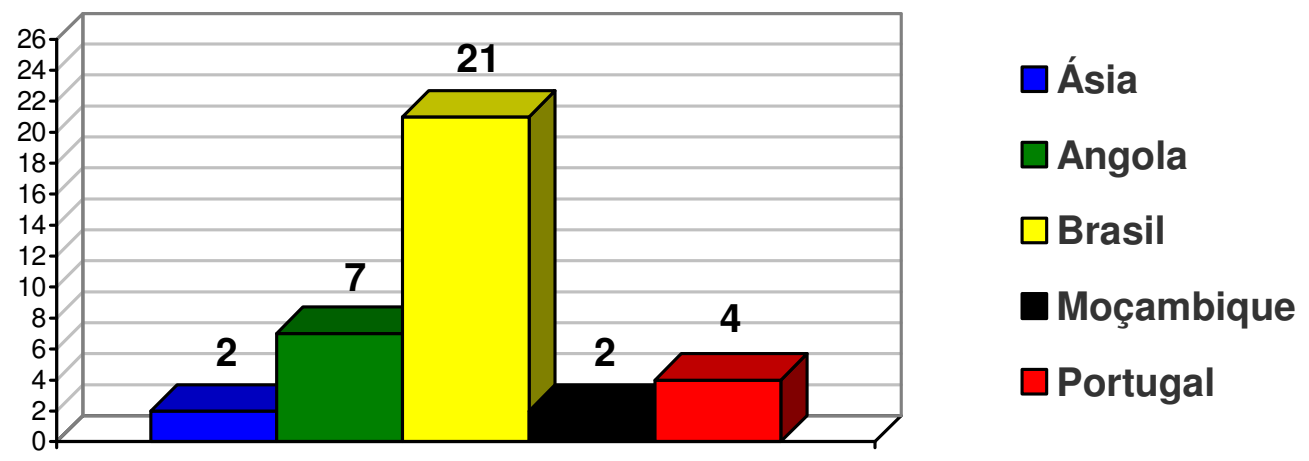

Gráfico 6.1. Localidade dos topônimos-base de gentílicos sufixados em -ista.

Do mesmo modo, utilizando apenas a lista com as vinte e nove palavras comprovadas em dicionários e/ou gramáticas da língua portuguesa, obtêm-se os seguintes dados percentuais em relação à localização geográfica da base de formação do gentílico, ou seja: 7\% da lista são topônimos africanos: Malauí e Ambaca; $7 \%$ da lista são topônimos asiáticos: Macau e Malaca; 14\% são topônimos portugueses: Alfama, Carção, Freixo de Espada Cinta e Jarmelo; e 70\% são topônimos brasileiros. Pode-se, então, construir a tabela seguinte de acordo com a localização geográfica dos topônimos-base da sufixação nominal gentílica, e gerar o gráfico 6.2, verificando que a maior parte dos gentílicos encontrados em dicionários e/ou gramáticas têm por base um topônimo brasileiro, alguns têm por base topônimos portugueses, uma minoria tem por base topônimos africanos (das palavras comprovadas em gramáticas ou em 
Estudo comparativo de aspectos semânticos do sufixo -ista no português e no galego.

dicionários) e asiáticos, mas nenhum topônimo galego aparece como base. Assim, acredita-se que a formação de gentílicos com o sufixo -ista é uma característica da língua portuguesa, que tem o Brasil como solo fértil para a sua produtividade.

\begin{tabular}{|c|c|}
\hline TOPÔNIMO & GENTÍLICOS \\
\hline ÁFRICA & malauísta, ambaquista \\
\hline ÁsIA & macaísta, malaquista \\
\hline BRASIL & $\begin{array}{l}\text { abre-campista, américo-campista, asa-nortista, asa-sulista, cabista, } \\
\text { campista, continentista, geralista, lajista, nortista, paranista, paulista, } \\
\text { roseirista, santista, são-bentista, são-felista, sertanista, sulista, tupi- } \\
\text { paulista, união-paulista }\end{array}$ \\
\hline PORTUGAL & alfamista, carçonista, freixinista, jarmelista \\
\hline
\end{tabular}

Tabela 6.2. Topônimos-base (confirmados) de gentílicos sufixados em -ista.

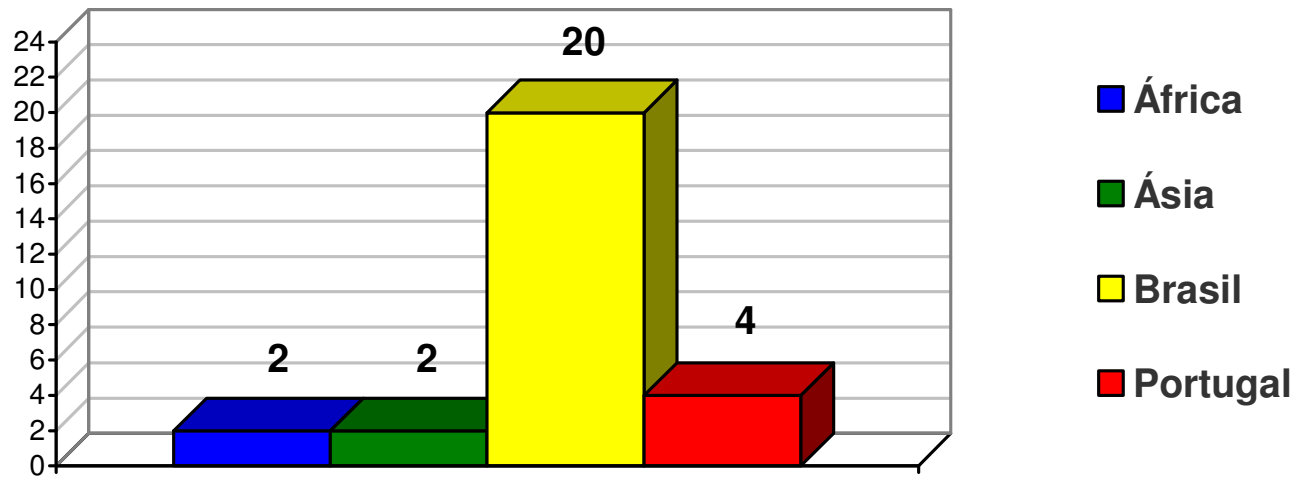

Gráfico 6.2. Topônimos-base (confirmados) de gentílicos sufixados em -ista.

De acordo com Bergström e ReIS (2001: 102), dicionário da Porto Editora (2006) e dicionário da Língua Portuguesa Online (2006) ambaquista designa o natural ou habitante da região de Ambaca em Angola. Segundo VASCONCELOS (1933: 150), carçonista é o natural ou habitante do povoado de Carção em Portugal, freixinista é o natural ou habitante do povoado de Freixo de Espada Cinta em Portugal, jarmelista é o natural ou habitante do povoado de Jarmelo em Portugal. Já, de acordo com o Dicionário HoUAISS (2001), malauísta é o natural ou habitante da República do Malauí na África, alfamista é o natural ou habitante do bairro de Alfama, em Lisboa em Portugal, macaísta é o natural ou habitante da cidade de Macau na Ásia, malaquista é o natural ou habitante da cidade de Malaca na Ásia, esplonista é o habitante da antiga cidade de Esplonos na Dalmácia, e as demais palavras (comprovadas) são gentílicos referentes a localidades brasileiras, de acordo com o dicionário HoUAISS (2001). 
Estudo comparativo de aspectos semânticos do sufixo -ista no português e no galego.

Assim, os gentílicos poder ser classificadas de acordo com o tipo do topônimo a que se referem: país, região, estado (província), cidade (vila) e bairro. Na lista de 29 palavras, apenas uma $(3,5 \%$ da lista) indica gentílico de país: malauísta; quatro $(13,5 \%)$ designam os de regiões: ambaquista, nortista, sertanista e sulista; também quatro $(13,5 \%)$ designam os de estados (província): continentista, geralista, paranista e paulista; dezessete palavras (59\%) designam os de cidades (vilas): abre-campista, américo-campista, cabista, campista, carçonista, esplonista, freixinista, jarmelista, lajista, macaísta, malaquista, roseirista, santista, são-bentista, são-felista, tupi-paulista, união-paulista; e três palavras (10\%) designam os de bairros: alfamista, asa-nortista e asa-sulista. Assim, observa-se que a maioria dos topônimos usados como base na formação dos gentílicos são cidades ou povoados, conforme a tabela e gráfico seguintes.

\begin{tabular}{|c|c|}
\hline TOPÔNIMO & GENTÍLICOS \\
\hline PAÍs & malauísta \\
\hline REGIÃO & ambaquista, nortista, sertanista, sulista \\
\hline ESTADO & continentista, geralista, paranista, paulista \\
\hline $\begin{array}{c}\text { CIDADE Ou } \\
\text { POVOADO }^{1672}\end{array}$ & $\begin{array}{l}\text { abre-campista, américo-campista, cabista, campista, carçonista, } \\
\text { esplonista, freixinista, jarmelista, lajista, macaísta, malaquista, } \\
\text { roseirista, santista, são-bentista, são-felista, tupi-paulista, união-paulista }\end{array}$ \\
\hline BAIRRO & alfamista, asa-nortista, asa-sulista \\
\hline
\end{tabular}

Tabela 6.3. Tipos dos topônimos-base dos gentílicos sufixados em -ista.

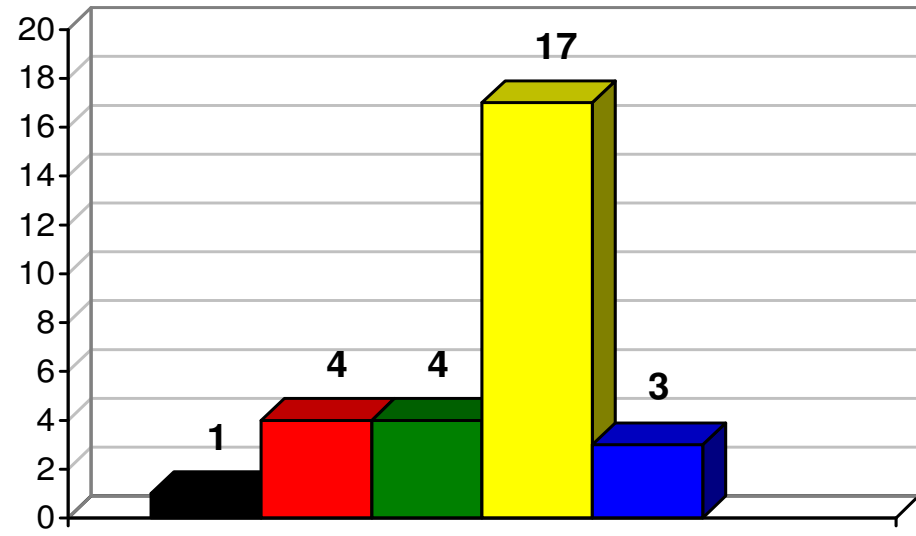

Daís

$\square$ Região

$\square$ Estado

$\square$ Cidade ou

Povoado

Bairro

Gráfico 6.3. Tipos dos topônimos-base dos gentílicos sufixados em -ista.

1672 Convém lembrar que as localidades consideradas como povoados ou vilas em Portugal e na Galiza, equivalem a cidades no Brasil, na África e na Ásia; devido a diferença de nomenclatura agrupou-se em uma única classe. 
A origem de Jarmelo é de tempos imemoriais, segundo o sitio oficial do concelho da Guarda $^{1673}$, têm vestígios pelo menos da idade do bronze, entretanto, somente em 1143, houve a primeira referência escrita, na qual D. Afonso Henrique deu o $1^{\circ}$ Foral ao povoado de São Pedro do Jarmelo. Não obstante, o local tornou-se mais conhecido pela história portuguesa no século XIV, quando três fidalgos de Jarmelo, invocando especiais razões de interesse para o rei, praticaram o bárbaro assassinato de D. Inês de Castro na Quinta das Lágrimas (como se chama hoje) em Coimbra, no dia 7 de Janeiro de 1355. Dado que não foi possível encontrar uma datação para a palavra jarmelista, o que se pode concluir apenas, é que o topônimo-base do gentílico já existia pelo menos no século XII, e dessa maneira, o termo jarmelista deve ter surgido na língua portuguesa depois do século XII.

Segundo o sítio oficial de Carção ${ }^{1674}$, a primeira referência escrita na qual o nome aparece data de 1187, quando os religiosos do convento de Castro de Avelãs deram ao Rei D. Sancho I a Herdade de Benquerença, local onde é hoje Bragança, recebendo, em troca, a povoação de Carção. Assim, sabe-se que o topônimo-base de carçonista já existia pelo menos no século XII. Dessa forma, o que se pode afirmar, dado que não foi possível encontrar uma datação para carçonista, é que o termo deva ter surgido no português após o século XII.

A respeito de freixinista, também não foi possível conseguir uma datação para a palavra portuguesa. Sabe-se apenas que no século XIII os naturais de Freixo de Espada à Cinta eram designados pelo gentílico freixeno. De acordo como os arquivos do CIPM (2006) do século XIII, encontraram-se, para designar freixo, topônimo relativo à vila de Freixo de Espada à Cinta, as seguintes palavras: fresno, freixeno, frexeno e freyseno. Foi encontrado, também, nos arquivos do CIPM (2006) do século XIII, que a 28 de Agosto de 1236, D. Sancho II entregava a vila de Álvia, como aldeia, aos de Freixo por meio das palavras seguintes: "Sancins. Dei gratia Port. Rex., Concilio de freixeno salutem..."1675

Já, a palavra macaísta é considerada obsoleta por Dicionário HOUAISS (2001) e sua datação é de 1557, ou seja, do século XVI. Atualmente no Brasil a forma usada para designar o habitante ou natural de Macau, na China, é macauense e em Portugal é macaense, datada de

\footnotetext{
1673 http://patrimonio-turismo.com/juntas/

$1674 \mathrm{http} / / /$ eurolista.clix.pt/sobrerodas/ptg/v-z/vimioso/

1675 Sancho, por graça de Deus rei de Portugal, saúda as autoridades freixinistas....
} 
Estudo comparativo de aspectos semânticos do sufixo -ista no português e no galego.

1899. Convém notar que a forma macaense, datada de 1911, no Brasil designa o originário da cidade de Macaé no estado do Rio de Janeiro, gerando bloqueio para a forma lusitana.

Segundo o Dicionário HoUAISS (2001), não há datação para a palavra malaquista, mas sim para a palavra malaquês, a qual se remete, como sendo de 1553 e, pelas consultas feitas aos dicionários de português lusitano e comprovação pela internet, parece ser a forma mais aceita para designar o habitante da cidade de Malaca na Malásia, em detrimento da forma sufixada com -ista. Convém ressaltar que Malaca, assim como Macau, foi uma importante colônia portuguesa durante 130 anos, conquistada em 1511 por D.Afonso de Albuquerque. Dessa forma, é natural supor que a datação da palavra malaquista seja do século XVI, mais especificamente, depois de 1511.

É interessante notar que do período das conquistas e descobrimentos marítimos portugueses também são as palavras paulista, datada de 1554 pelo Dicionário HoUAISS (2001), e santista, datada de 1543 também pelo Dicionário HouAISS (2001); designando os naturais ou habitantes do estado de São Paulo e da cidade de Santos, respectivamente. Segundo informação etimológica do Dicionário HouAISS (2001), a forma paulista surgiu do “topônimo São Paulo + -ista, em que -ista funciona como sufixo nominal gentílico (...); a forma paulistano (1554) foi desenvolvida para contraste inequívoco" do gentílico urbano e do estadual, na época de sua datação o contraste era entre o habitante da vila e o da capitania.

Quanto à forma ambaquista, não há datação em BERGSTRÖM E REIS (2001: 102), nem no dicionário da Porto Editora (2006) e tampouco no dicionário da Língua Portuguesa Online (2006). Mas, sabe-se que a região de Ambaca, em Angola, foi dominada pelos portugueses em 1611, pode-se supor, então, pela presença do termo nos dicionários portugueses, nas citações por gramáticos e nas referências encontradas na internet, que a forma seja proveniente, então, do século XVII. Um pouco posterior, mas também do século XVII é a forma campista, é datada de 1673, de acordo com o Dicionário HoUAISS (2001), para designar o natural ou habitante da cidade de Campos dos Goytacazes.

Conforme o Dicionário HoUAISS (2001), a datação de alfamista é 1742, ou seja, século XVIII. Alfama é um bairro de Lisboa, antigamente habitado por judeus, a palavra também significa refúgio ou asilo, pois é proveniente do árabe al-hamma (refúgio). Atualmente, a 
Estudo comparativo de aspectos semânticos do sufixo -ista no português e no galego.

palavra alfamista consta no dicionário da Porto Editora (2006) e do dicionário da Língua Portuguesa Online (2006) com a mesma acepção dada pelo Dicionário HoUAISS (2001).

Segundo o Dicionário HoUAISS (2001), a forma continentista, para a qual não há datação, designa o natural ou habitante do Estado do Rio Grande do Sul, pois o antigo nome do local era: Continente de São Pedro do Rio Grande do Sul, desde o início de seu povoamento no século XVIII até fins do século XIX. O seu gentílico em -ista foi muito utilizado e difundido no século XIX, prova disto é o livro $O$ Gaúcho de José de Alencar, publicado em 1870, no qual o termo é utilizado. Particularmente durante o período da revolução Farroupilha em 1835, a palavra continentista foi muito utilizada não somente com a acepção gentílica, como também para designar os adeptos dos ideiais da revolução. Atualmente, continentista é pouco usado em prol das formas: gaúcho, rio-grandense e riograndense-do-sul; já que o nome da região não contempla mais a palavra continente. Supõese, assim, que o gentílico continentista deva ter surgido durante o século XVIII ou XIX.

A forma gentílica lajista também não apresenta datação no Dicionário HoUAISS (2001); não obstante, sabe-se que a cidade de Laje, no estado da Bahia, foi fundada em 1864, portanto pode-se supor que o seu gentílico pertença ao século XIX ou XX. Analogamente, a forma gentílica paranista não apresenta datação no Dicionário HoUAISS (2001), sabe-se que a província do Paraná foi criada em 1853, por Dom Pedro II, portanto é natural supor que o gentílico pertença ao século XIX ou XX.

De acordo com o Dicionário HouAISS (2001), do século XIX (1881) é a forma gentílica esplonista, proveniente da forma em latim: splonistae, arum; com a mesma acepção de designar o habitante de Esplonos, ou Esplaunos, antiga cidade da Dalmácia.

Também não foi encontrada a datação, segundo o Dicionário HoUAISS (2001), para os gentílicos: asa-nortista e asa-sulista, no entanto como são provenientes dos topônimos que designam os bairros Asa-Norte e Asa-Sul, pertencentes à Brasília, é natural supor que sua datação seja do século XX, mais especificamente depois de 1960, ano de sua fundação.

Por meio de pesquisa e buscas na internet, bem como nos dicionários de português europeu, constatou-se que a forma malauísta é pouco usada em prol da forma malawiano e malauíta (malawita), ainda que o Dicionário HoUAISS (2001) apresente como formas concorrentes: malaui, malauiano, malauiense, malauíta, malaviano, malavita. A República 
do Malauí, ou Malawi, no sudeste da África, tornou-se independente do domínio britânico em julho de 1965, sendo então reconhecida pela ONU e sua língua oficial é o inglês. Provavelmente a forma mais usada, tanto no Brasil como em Portugal: malauiano sofreu influência, se não é empréstimo, do inglês, cujo termo gentílico é malawian. Segundo o Dicionário HoUAISS (2001), não há datação para malauísta, entretanto, é natural supor que seja depois da data do reconhecimento oficial do país, ou seja, depois de 1965, no século XX.

Nota-se também que as demais formas gentílicas em -ista encontradas são provenientes de topônimos brasileiros e pertencem ao século XIX e XX. Assim, pertencem ao século XVI, os gentílicos: macaísta (1557), da cidade de Macau na China (Ásia); malaquista (após 1511), da cidade de Malaca na Malásia (Ásia); paulista (1554), do estado de São Paulo no Brasil (América) e santista (1543), da cidade de Santos (Estado de São Paulo) no Brasil. Pertence ao século XVII os gentílicos: ambaquista (após 1611), da região de Ambaca em Angola (África) e campista (1673), da cidade de Campos dos Goytacazes (Estado do Rio de Janeiro) no Brasil. Pertence ao século XVIII o gentílico alfamista (1742), do bairro de Alfama na cidade de Lisboa em Portugal. Pertencem ao século XIX: abre-campista (1850), da cidade de Abre-Campo (Estado de Minas Gerais) no Brasil; esplonista (1881) da cidade de Esplonos na antiga Dalmácia; geralista (1899), do estado de Minas Gerais no Brasil; nortista (1899) da região norte do Brasil; são-felista (1857), da cidade de São Félix (Estado da Bahia) no Brasil; sertanista (1877), do sertão do Brasil e sulista (1899), da região sul do Brasil. Pertencem ao século XX: américo-campista (1926), da cidade de Américo de Campos (Estado de São Paulo) no Brasil; asa-nortista (depois de 1960), do bairro Asa-Norte da cidade de Brasília, capital do Brasil; asa-sulista (depois de 1960), do bairro Asa-Sul da cidade de Brasília, capital do Brasil; cabista (1924), da cidade de Arraial do Cabo (Estado do Rio de Janeiro) no Brasil; malauísta (depois de 1964), do país Malauí na África; roseirista (1944), da cidade de Roseira (Estado de São Paulo) no Brasil; são-bentista (1938), da cidade de São Bento de Abade (Estado de Minas Gerais) no Brasil; tupi-paulista (1953), da cidade de Tupi Paulista (Estado de São Paulo) no Brasil; união-paulista (1964), da cidade de União Paulista (Estado de São Paulo) no Brasil. Segundo o Dicionário HouAISS (2001), não estão datados os gentílicos brasileiros, mas pelo contexto histórico pode-se demarcar um período no qual se enquadram: continentista (século XVIII ou XIX), do Estado do Rio Grande do Sul (antigo Continente de São Pedro do Rio Grande do Sul) no Brasil; paranista (depois de 1853, ou seja, século XIX 
Estudo comparativo de aspectos semânticos do sufixo -ista no português e no galego.

ou XX), do Estado do Paraná no Brasil e lajista (depois de 1864, ou seja, século XIX ou XX), da cidade de Laje (Estado da Bahia) no Brasil. Também não se conseguiram as datações para os gentílicos portugueses: carçonista, do povoado de Carção em Vimioso; freixinista, do povoado de Freixo de Espada Cinta em Cinta e jarmelista, do povoado de Jarmelo na Guarda. Conforme a tabela e o gráfico, a seguir.

\begin{tabular}{cl} 
SÉCULO & \multicolumn{1}{c}{ GENTÍlICOS } \\
XVI & macaísta, malaquista, paulista e santista \\
XVII & ambaquista e campista \\
XVIII & alfamista \\
XIX & abre-campista, esplonista, geralista, nortista, são-felista, sertanista e sulista \\
XX & $\begin{array}{l}\text { américo-campista, asa-nortista, asa-sulista, cabista, malauísta, roseirista, são- } \\
\text { bentista, tupi-paulista e união-paulista }\end{array}$ \\
& $\begin{array}{c}\text { carçonista, continentista (XVIII ou XIX), freixinista, jarmelista, lajista (XIX } \\
\text { s.d. }\end{array}$ \\
& ou XX) e paranista (XIX ou XX)
\end{tabular}

Tabela 6.4. Datação dos gentílicos sufixados em -ista.

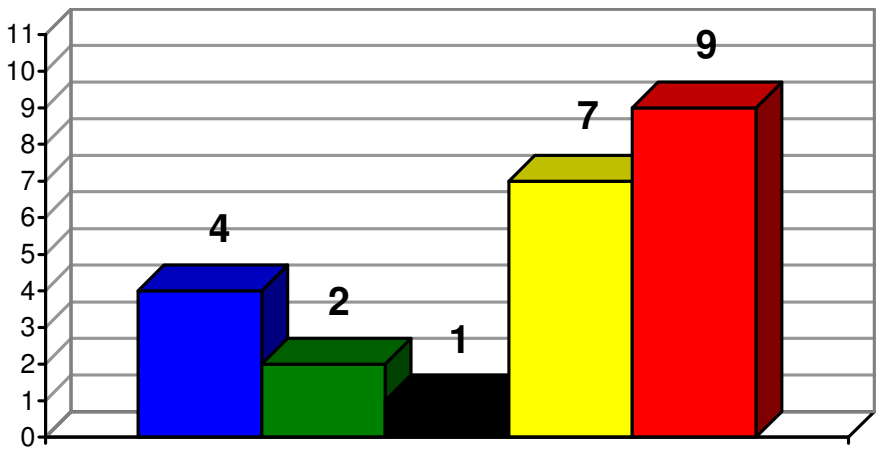

Séc. XVI

Séc. XVII

Séc. XVIII

Séc. XIX

Séc. XX

Gráfico 6.4. Datação dos gentílicos sufixados em -ista.

Analisando os dados do gráfico 6.4, nota-se que houve uma produtividade razoável do sufixo -ista na formação de gentílicos durante o século XVI, o século dos descobrimentos. Essa produtividade caiu nos dois séculos seguintes, século XVII e XVIII, mas voltou a crescer no XIX e tornou-se muito produtivo no português brasileiro durante o século $\mathrm{XX}$, principalmente como gentílico das novas cidades fundadas pelo território brasileiro.

Sabe-se que, na língua portuguesa, o sufixo -ista estava ligado à Igreja nos séculos XII, XIII e XIV. Sabe-se, também, que uma das categorias semânticas do -ista é designar religiosos pertencentes a um determinado seminário, mosteiro ou convento, por exemplo, do 
convento de Santa Clara $\rightarrow$ claristas. Dessa maneira, de pertencente ao "convento, seminário ou mosteiro de $X$ " forma-se $X$-ista. Pode-se supor que $X$-ista tenha começado a designar as pessoas que moravam próximas ao "convento, seminário ou mosteiro de $X$ ", mas que eram leigos. Dado que "convento, seminário ou mosteiro" é uma referência toponímica muito comum na língua portuguesa, pode-se supor que se generalizou para "natural ou habitante do topônimo $X^{\prime \prime}$, mesmo que o topônimo não mais tivesse o vínculo religioso, e essa acepção passou a ter uma boa produtividade na época dos descobrimentos e conquistas, pela necessidade de designar os habitantes de novas localidades descobertas, conquistadas e colonizadas. Ainda que a maior parte das cidades fundadas nesse período recebessem como topônimo o nome religioso associado ao dia de sua fundação e, por isso nestas cidades sempre era construída uma capela em devoção ao nome dado ao lugar, ao lado dos quais geralmente eram construídos também mosteiros ou conventos. A título de exemplo: paulista ${ }^{1676}$ já tem a função gentílica na principal acepção dada pelos dicionários; entretanto tomarista ${ }^{1677}$, ainda que seja uma forma jocosa e popular para se referir aos moradores e naturais da Cidade de Tomar $^{1678}$, não consta como tal nas acepções dos dicionários consultados, mas é natural supor que com o uso lhe seja reconhecida tal função e futuramente atribuída pelos especialistas.

No século XIX no Brasil, com a libertação dos escravos e com o processo crescente de imigração houve o povoamento de novas regiões com a fundação de vilas e cidades para a residência destes povos e seus descendentes, justificando, assim, a necessidade de se empregar novas formas gentílicas, tais como as sufixadas em -ista, que já haviam perdido o seu vínculo religioso. Da mesma maneira, no século XX no Brasil, com os projetos e medidas governamentais de povoamento do interior do território nacional, mudança da capital para o interior do país e outros investimentos, o sufixo -ista continuou a significar "natural ou habitante do topônimo $X$ " com uma boa produtividade para designar os habitantes das novas cidades e/ou bairros fundados a partir de então, já que pelo gráfico 6.3 pode-se notar que sua maior produtividade se dá com a base toponímica de cidade e/ou povoado.

Então, a respeito da função gentílica adquirida pelo sufixo -ista, pode-se propor uma primeira teoria baseada na extensão de sentido, ou seja, inicialmente o sufixo -ista designava, em português, o religioso pertencente ao "convento, seminário ou mosteiro de X" formando

\footnotetext{
${ }^{1676}$ Religioso da ordem jesuíta de São Paulo.

1677 Religioso do convento de Tomar.

${ }^{1678}$ Cidade portuguesa onde está o convento da ordem de Cristo: Convento de Tomar.
} 
$X$-ista e, analogamente ao que ocorre com Louvaniste ${ }^{1679}$, passou, por extensão de sentido a designar o habitante ou natural da região próxima ao "convento, seminário ou mosteiro de X". Em seguida, dado que "convento, seminário ou mosteiro de X" é uma referência toponímica bastante usada na língua portuguesa, supõe-se que houve generalização para "natural ou habitante do topônimo X”, mesmo que o topônimo X não mais tivesse o vínculo religioso, como por exemplo: Macau $\rightarrow$ macaísta; norte $\rightarrow$ nortista.

Por outro lado, uma segunda teoria que se pode propor é baseada na necessidade de novas formas gentílicas nas colônias, que não gerassem bloqueio com formas já usadas na metrópole, para designar os naturais ou habitantes das novas terras, durante os séculos dos descobrimentos marítimos: XVI e XVII; bem como a necessidade de novas formas gentílicas, no século XIX no Brasil, para designar os habitantes das novas cidades e vilas fundadas como decorrência dos processos de imigração (para o povoamento de regiões estratégicas, para o abastecimento de mão de obra nas lavouras) e de libertação dos escravos; e, posteriormente, no século XX, para designar os habitantes das novas localidades criadas com os projetos de integração nacional promovidos no Brasil para o povoamento do interior do país.

Aliada às duas teorias anteriores, pode-se propor uma terceira teoria baseada na crescente produtividade do sufixo -ista nos séculos XIX e XX na língua portuguesa, vista no capítulo 5, e em particular da sua função gentílica que já era verificada nos séculos anteriores. Aliada a essa teoria, baseando-se em VASCONCELOS (1933: 151):

por serem poucos os nomes em -ista a que está anexa a idéia de residência, o mais natural é que, assim como o sufixo - eiro usurpa (entre outras funções) as de agente e de étnico (...), assim o -ista, que já significava agente, se agregou a idéia étnica, ficando pois ele, a estes dois respeitos, sinônimo de -eiro.

Pode-se sustentar que o sufixo -ista, à semelhança do sufixo - eiro, que já representava a função agentiva e passou a representar também a função gentílica, tornando-se um concorrente deste na língua portuguesa, principalmente, como já foi visto, nos séculos XIX e XX, ainda que em séculos anteriores já tenha apontado para tal função. Convém lembrar, de acordo com o capítulo 3, que em outras línguas como o árabe, as formas gentílicas e agentivas podem ser designadas pelo mesmo sufixo.

1679 "Habitante ou natural da cidade de Louvain na Bélgica", por extensão de sentido de "estudante da Universidade Católica de Louvain”. 
Estudo comparativo de aspectos semânticos do sufixo -ista no português e no galego.

Quanto à produtividade, por não haver topônimos-base galegos na formação gentílica com o sufixo -ista, conclui-se que tal estrutura não é produtiva na língua galega, e, dado que, conforme gráficos 6.1 e 6.2, a maioria dos topônimos são de origem brasileira, reforça-se a afirmação de FERREIRO (2001: 156-157) justificando que a presença destas estruturas no galego sejam importadas do português brasileiro.

Conforme o gráfico 6.4, pode-se afirmar que nos séculos dos descobrimentos (XVI e XVII) a função gentílica do sufixo -ista mostrou-se produtiva no português, ainda que atualmente, não se mostre produtiva no português europeu, pois, ainda que não se tenha as datações das palavras carçonista, freixenista e jarmelista, é pouco provável que sejam criações do século XX, pois a datação destes topônimos está mais próxima ao período dos descobrimentos, quando também a sufixação com -ista era produtiva na função gentílica.

Após a segunda metade do século XIX e século XX, a função gentílica do sufixo -ista mostrou-se bem produtiva no português brasileiro, pois a maior parte dos gentílicos com topônimos brasileiros estão datados dos século XIX e XX. Levando em consideração os dados obtidos pela internet, se mostrou produtiva também no português africano, principalmente em Angola. Dessa maneira, pode-se concluir que a função gentílica do sufixo -ista, contrariando MiRANDA (1980: 101), ainda que não seja produtiva em outras línguas, o é sobretudo em português brasileiro com comprovações por dicionários e gramáticas, mas também o é, ainda que tímida, em português africano, de acordo com averigüação feita no corpus da internet.

É interessante notar que, tanto na Galiza quanto em Portugal ainda há localidades, principalmente pequenas aldeias, onde o gentílico somente é designado de forma analítica, existindo assim o potencial para a criação de novas palavras gentílicas, em particular com o sufixo -ista, ainda que atualmente seja muito rara a fundação de novas localidades topográficas nessas regiões. 
Estudo comparativo de aspectos semânticos do sufixo -ista no português e no galego.

\section{CONCLUSÃO}

Valeu a pena? Tudo vale a pena Se a alma não é pequena.

(Fernando Pessoa) 


\section{Considerações finais}

Nesta dissertação foram levantados vários aspectos das formações derivacionais com o sufixo -ista e estabelecido um método de trabalho para verificar os aspectos semânticos relevantes do sufixo no português e no galego.

Inicialmente, ao saber a origem grega do sufixo, fez-se um panorama histórico procurando identificar os limites atingidos pela língua grega e sua influência, mesmo quando veiculada por outras línguas francas. Procurou-se, também, identificar os fatos históricos e sociais importantes no desenvolvimento das línguas portuguesa e galega, que pudessem estabelecer conexão com o desenvolvimento de estruturas semânticas de produção de palavras com o sufixo estudado.

$\mathrm{Na}$ segunda etapa, foi feito um estudo da formação de palavras, concentrando-se no processo de sufixação e em três classificações semânticas de palavras sufixadas feitas por FreiXeiro MATO (1999: 228-234), SANDMANN (1989: 32-66) e Rio-TORTO (1998: 112-114), com a finalidade de extrair o essencial de uma classificação semântica e aplica-lo no caso específico das formações com o sufixo -ista no português e no galego, levando em conta alguns fatores relevantes descritos como os bloqueios, mas principalmente a dimensão histórica e também etimológica nos estudos. Pois, para um estudo semântico das características de formação oferecidas por um sufixo, além dos fatores sócio-lingüísticos, é necessário também conhecer os fatores lingüísticos que envolvem a semântica.

$\mathrm{Na}$ terceira etapa, sabendo-se que as influências recebidas do grego nas línguas portuguesa e galega também foram recebidas em outras línguas, foi feito um levantamento das ocorrências de palavras formadas com o sufixo de origem grega em várias línguas, tais como: japonês, hebraico, basco, russo, polonês, alemão, inglês, francês, italiano, catalão, valenciano, castelhano, galego e português; por meio de consultas a dicionários, complementado com a caracterização semântica de suas formações obtidas em artigos e gramáticas das línguas e, sempre que possível, também com a constatação por meio de falantes nativos. Assim notou-se que muitas palavras formadas com o sufixo -ista têm uma veiculação internacional, por exemplo: turista, terrorista, nudista, pianista, tenista, racista, pessimista, otimista, egoísta, marxista, comunista, imperialista; porém, em algumas línguas também apresenta formações próprias. Tal panorama forneceu dados suficientes para a 
elaboração de uma classificação semântica e genérica das formações em -ista, simples, porém capaz de abranger as várias categorias semânticas apontadas atualmente pelos dicionários, pelas gramáticas e pelos especialistas de cada língua, para as palavras derivadas a partir das formas que o sufixo grego assume internacionalmente em cada uma das línguas apontadas.

Em seguida, na quarta etapa do método, foi feita uma pesquisa em corpora das ocorrências de formações com o sufixo -ista, no galego, no português brasileiro e no português lusitano em vários textos; com o qual se pôde verificar que as ocorrências com sua formação começam a aparecer no século XVIII no português, mas somente há dados suficientes para fazer-se um estudo a partir do século XIX. Dessa forma, foram selecionadas em torno de setenta obras (trinta e cinco para o século XIX e trinta e cinco para o século XX) representativas dos gêneros prosaico, poético e teatral, bem como uma edição de jornal do século XX, para cada uma das três variedades idiomáticas. Desse corpora, foram extraídas todas as palavras sufixadas com -ista e classificadas de acordo com sua acepção encontrada em contexto, já que, segundo ULLMAN (1977:102-112): “todas as palavras, por muito precisas e inequívocas que possam ser, extrairão do contexto uma certa determinação que, pela própria natureza das coisas, só podem surgir em elocuções específicas". Assim, com os dados obtidos nas três variedades idiomáticas: galego, português brasileiro e lusitano, nos séculos XIX e XX, pôde-se concluir que o uso de formações com o sufixo -ista aumentou sensivelmente a partir do século XIX, continuando a aumentar no século XX nas três variedades idiomáticas, sendo a prosa o gênero mais propenso para sua utilização. Verificou-se, também que a língua galega aproximou-se da língua portuguesa no século XX, quanto ao uso do sufixo nos gêneros da escrita. Notou-se que, no século XIX, no português, tanto brasileiro quanto lusitano, os movimentos literários do Realismo e Naturalismo também propiciaram o uso das formações com o sufixo -ista no gênero prosaico. Foi observado ainda que no século XX houve uma grande freqüência no uso das formações com o sufixo especificamente na prosa jornalística. Notou-se também que, o campo semântico no qual o uso das formações com o sufixo em estudo mais abundaram nas três variedades idiomáticas foi o de designação de profissionais ou agentes ocupacionais, tanto no século XIX quanto no século XX. Observou-se que, no século XIX, o segundo campo semântico mais característico do uso das formações era a designação qualificativa, seguido do campo semântico da designação de adesão mental; no entanto, no século XX, houve uma inversão: o segundo campo semântico mais característico 
das formações passou a ser a designação de adesão mental, seguido do campo semântico da designação qualificativa. Verificou-se que na prosa jornalística o campo semântico de designação de pertinência a grupos apresentou um uso bastante expressivo nas três variedades idiomáticas estudadas. Assim pôde-se ter uma mostra, a título de ilustração, do uso das formações com -ista no galego, no português brasileiro e no lusitano no decorrer dos séculos XIX e XX, identificando-se a característica prosaica de uso das formações com o sufixo, bem como as categorias semânticas nas quais há mais ocorrências. Entretanto, as verificações e constatações obtidas nesta etapa do trabalho não se mostraram suficientes para uma classificação semântica específica do sufixo -ista.

$\mathrm{Na}$ quinta, e mais trabalhosa etapa do método, decidiu-se usar como corpora duas listas de vocábulos, uma para o galego e outra para o português, que representassem um inventário das palavras formadas com o sufixo nas línguas. Assim, foram coletadas todas as palavras pertencentes à língua galega terminadas com -ista encontradas no dicionário da Real Academia Galega (2006), no dicionário Pedagóxico da Real Academia Galega (2006), no dicionário da Língua Galega organizado por Freixó Cid (1999), no TILGA ${ }^{1680}$ e no CORGA $^{1681}$. Analogamente, foram coletadas todas as palavras pertencentes à língua portuguesa terminadas com -ista encontradas no dicionário Houaiss da Língua Portuguesa (2001), no dicionário da Porto Editora da Língua Portuguesa, na Infopédia ${ }^{1682}$ (2006) e na Conscienciopédia $^{1683}$ (2006). Primeiramente, foram analisados e selecionados todos os vocábulos das duas listas obtidas e removidas as palavras, tais como: conquista, crista, entrevista, ista $^{1684}$, lista, mista, revista, vista; que não são derivações com o sufixo -ista. Analogamente, foram removidas as variações ortográficas de uma mesma palavra, obtendo-se mil e oitenta e três (1083) vocábulos galegos e dois mil e trezentos e oitenta e cinco (2385) vocábulos brasileiros e portugueses. O passo inicial foi estudar as várias acepções de todos os vocábulos das duas listas de palavras usando como instrumento não apenas os dicionários supracitados, mas também outros da língua galega e portuguesa, bem como a internet para fornecer as acepções de todos os vocábulos em contexto. $\mathrm{O}$ passo seguinte foi fazer uma análise de todas as acepções das palavras derivadas, procurando, por meio de paráfrases

\footnotetext{
1680 http://www.ti.usc.es/tilg/

$1681 \mathrm{http}: / /$ corpus.cirp.es/corga/

$1682 \mathrm{http}: / / \mathrm{www}$. infopedia.pt/

$1683 \mathrm{http}: / /$ pt.conscienciopedia.ceaec.org.br/lista_de_ista/

1684 Tradução: "esta" (pronome demonstrativo feminino).
} 
genéricas, construir categorias semânticas comuns, e assim fazer uma classificação semântica das palavras formadas com o sufixo -ista no português e no galego. Seguiu-se, então, um estudo histórico e etimológico de cada vocábulo com o apoio do dicionário da Real Academia Española (2001) e dicionário Básico da Língua da editora Anaya (1999), Corominas (1954) e do dicionário Houaiss (2001), acompanhado da datação das palavras e de fatores extralingüísticos associados, marcando-se, principalmente, os vocábulos importados de línguas francas. Infelizmente, não foi possível encontrar as datações dos vocábulos galegos formados com o sufixo -ista. Com esse instrumental, teceram-se as considerações sobre a classificação das palavras formadas com o sufixo -ista e chegou-se a uma classificação semântica das características de produção do sufixo nas línguas portuguesa e galega. De posse da classificação semântica do sufixo, verificaram-se os estudos já propostos quanto à concorrência com outros sufixos na formação derivacional de agentivos constatando-se a importância de uma classificação semântica das características de produção dos sufixos aliada a estudos diacrônicos nos estudos comparativos de concorrência.

Na sexta etapa do método, foi feito, a título de ilustração, um estudo mais aprofundado de uma das subclasses semânticas do sufixo -ista: a formação de gentílicos, no qual se pôde diferenciar o comportamento do sufixo no Brasil, em Portugal e na Galiza, pinçando também alguns dados pontuais de formações no português africano. Assim, constatou-se que essa categoria semântica não é característica das formações na língua galega, e atualmente também não é produtiva na variedade lusitana da língua portuguesa, entretanto mostra-se produtiva na variedade brasileira e africana da língua portuguesa. Dessa forma, ficou realçada a importância de estudos mais aprofundados em cada uma das categorias semânticas do sufixo -ista encontradas na sua classificação no português e no galego.

De modo geral, percorrendo o traçado histórico, percebeu-se que o sufixo de origem grega tem sido veiculado para outras línguas, desde a Antigüidade Clássica, por meio das línguas francas. Inicialmente, com a koiné grega, o sufixo atingiu os limites do Império Alexandrino, posteriormente, já veiculado pelo latim, atingiu todo o Império Romano do Ocidente. Durante a Idade Média esteve confinado ao âmbito religioso. Desde o final da Idade Média até o século XIX, o sufixo foi veiculado pela língua italiana no âmbito artístico e pela língua francesa nos mais variados âmbitos. A partir de meados do século XIX, a importância 
do inglês cresceu como língua franca e, desde então, mostra-se como o veículo da propagação das palavras formadas com o sufixo.

Durante a Idade Média, confinado ao âmbito religioso, as formações derivadas com o sufixo -ista foram transmitidas pelo latim eclesiástico para as línguas romances por meio de palavras agentivas, tais como: batista, catequista, evangelista, exorcista. Ainda na Idade Média e no âmbito religioso, no qual a música erudita inicialmente também estava confinada, iniciou a designação do músico que toca determinado instrumento, por exemplo, organista. Com a migração da música para o âmbito das cortes, tal estrutura de formação espalhou-se por toda Europa e daí para outros locais, mostrando-se bastante produtiva em muitas línguas, sobretudo no italiano e no francês, com o desenvolvimento da música e a invenção de novos instrumentos. Assim palavras formadas com o sufixo -ista, designando músico que toca determinado instrumento, penetraram nas mais diversas línguas e em muitas delas a estrutura de formação tornou-se produtiva. Por exemplo, no japonês encontrou-se uma versão da palavra pianista, mas não há produção própria, já na maioria das línguas ocidentais modernas a estrutura mostra-se produtiva até os tempos atuais, por exemplo, com palavras tais como: tecladista e baterista. No âmbito da música, também, o sufixo passou a ser produtivo em muitas línguas ocidentais para designar o músico autor de uma determinada composição, por exemplo: sinfonista; e para designar o músico que executa determinada modalidade de música, por exemplo: instrumentalista; a partir daí generalizou-se na designação de músicos, por exemplo: vocalista.

Desse modo, a formação de agentes com o sufixo -ista popularizou-se, principalmente na língua francesa, de tal maneira que no século XVIII e XIX passou a ser muito produtiva com a designação semântica de profissional e agente ocupacional, e muitas destas formas foram veiculadas para outras línguas, por exemplo: modista, eletricista, maquinista. Nessa mesma categoria, no âmbito dos jogos e esportes, principalmente na língua francesa, o atleta ou jogador também é designado pela formação com o sufixo -ista, e também muitas destas formações foram levadas para outras línguas, por exemplo: futebolista, ciclista, tenista. A partir daí disseminou-se em outras línguas sua produção. Também a noção semântica de profissional especializado em determinada área teve grande produtividade no francês (dermatologista, ortopedista, naturalista) ao lado do inglês (filologista, biologista, fisicista), 
sendo estas duas línguas os principais veículos da forma que assume produção em outras línguas também.

Por outro lado, durante muito tempo a educação esteve confinada ao âmbito religioso: aos mosteiros e seminários, na Idade Média que levavam aos estudos das ordens religiosas e, posteriormente, passou a ser ministrada por religiosos em universidades e escolas seculares. Dessa maneira, o sufixo -ista, confinado ao âmbito religioso, passou inicialmente a designar o seguidor de determinada doutrina de uma ordem religiosa, por exemplo: paulista, seguidor da doutrina de São Paulo, conforme já antiga característica semântica do sufixo no grego para designar adeptos a doutrinas, mas que passou a designar o religioso pertencente a determinada ordem. Nesse contexto, surgiu a palavra seminarista para designar o seguidor da doutrina de um seminário, que se popularizou com a acepção de "aluno de um seminário", generalizandose como "aluno de uma entidade educacional", por exemplo, uma de suas primeiras formações é sorbonnistes ${ }^{1685}$ que designa os estudantes da Sorbonne ${ }^{1686}$. Acredita-se que, neste caso, a caracterização que estava confinada ao âmbito religioso acabou por migrar na língua francesa, ainda na Idade Média, para as universidades e generalizou-se a caracterização semântica no âmbito escolar, com a popularização dos vários níveis de ensino no século XIX e, como a língua francesa foi veicular a partir do século XVIII, seu léxico estendeu-se a outras línguas como o castelhano, o português e o galego. É interessante notar que, dessa maneira, iniciou-se o processo de generalização da estrutura de formação de nomes que designam membros de grupos em geral e fornecem a noção de pertinência. Por exemplo, no âmbito da música, que já designava o agente músico em geral, passou também a designar o músico que pertence a um grupo, por exemplo: corista e quartetista.

Em relação aos gentílicos, sabe-se que uma das suas primeiras formas ocorre no francês belga: louvanistes designa os estudantes da Universidade Católica de Louvain ${ }^{1687} \mathrm{e}$ passou a designar também os habitantes desta localidade. Dessa maneira, acredita-se que da designação de pertencente ao "convento, seminário, mosteiro ou universidade de $X$ ” forma-se $X$-ista. Pode-se supor que $X$-ista tenha começado a designar as pessoas que moravam próximas ao "convento, seminário, mosteiro ou universidade de $X$ ", mas que eram leigos. Dado que "convento, seminário ou mosteiro" é uma referência toponímica muito comum na

\footnotetext{
1685 Segundo o Houaiss, "sorbonista” em português.

${ }^{1686}$ Uma das universidades mais antigas da Europa, em Paris; Segundo o Houaiss, "Sorbona” em português.

${ }^{1687}$ Localidade na Bélgica.
} 
língua portuguesa, pode-se supor que se generalizou para "natural ou habitante do topônimo X’, mesmo que o topônimo não mais tivesse o vínculo religioso, e essa acepção passou a ter uma boa produtividade, principalmente na época dos descobrimentos marítimos portugueses, pela necessidade de designar os habitantes das novas localidades.

Na Europa dos séculos XIV a XVI, devido às traduções e estudos dos textos gregos da Antigüidade Clássica, em geral manuscritos levados pelos sábios que fugiram da ocupação turco-otomana, nasceu o movimento Humanista e Renascentista que recuperou no Ocidente a cultura helênica culminando na corrida pelo saber, nas Universidades e na base para a tecnologia dos últimos séculos. Dessa forma, no século XVIII e XIX o uso do sufixo -ismo, de origem grega, com sua já antiga designação de sistema de ideais e a associação ao sufixo ista teve uma grande repercussão em vários âmbitos, principalmente no: artístico, político, filosófico, científico, e religioso. Assim, veiculado pelas línguas francas dos séculos XVIII, XIX e XX, como o francês, o italiano, o alemão e o inglês, a designação de adesão mental dada pelas construções com o sufixo -ista, penetrou em várias outras línguas, como o português, o castelhano e o galego.

Já no século XX, a noção de adesão mental associa à noção de pertinência a grupos em geral desenvolveu a categoria semântica de membros de torcidas de times esportivos, muito produtiva nas Penínsulas Ibérica e Itálica, como também, desenvolveu a categoria de membros de partidos políticos, muito produtiva na maioria das línguas românicas.

Em relação à classe semântica qualidade característica, convém notar que já é antiga, principalmente na língua francesa. Sua noção semântica surgiu da noção de agente, cuja ação caracteriza sua conduta, por exemplo: egoísta, altruísta, otimista. Tal estrutura de formação semântica, importada do francês, tornou-se especialmente produtiva na língua castelhana, galega e portuguesa. Nestas, desenvolveu-se, juntamente com a noção de adesão mental, muitas vezes adquirindo a noção de exagero, obstinação e fanatismo, que por sua vez leva ou à noção de pejorativo, ou a uma característica doentia.

Então, quanto a forma relativa ao gênero, o sufixo -ista é bem peculiar, apresenta difenciação no russo, polonês, alemão, valenciano, italiano popular e castelhano popular; característica essa que já se apresentava no grego e no latim. Na língua inglesa, cuja estrutura já não dá margem a tal diferenciação, o sufixo não apresenta formas distintas para os gêneros. 
Entretanto, é pelo menos curioso que tal diferenciação não se dê nas línguas francesa, catalã, galega, portuguesa e castelhana normativa.

No castelhano popular encontra-se, em alguns casos: modisto $^{1688}$ e recepcionisto ${ }^{1689}$, para indicar uma profissão geralmente feminina e exercida por alguém do sexo masculino; novelisto $^{1690}$ e violinisto ${ }^{1691}$, para indicar certo grau de desprezo pelo modo como um agente masculino exerce sua atividade. No galego popular falado também já foram detectados alguns casos, talvez por influência do castelhano popular: modisto ${ }^{1692}$, telefonisto $^{1693} \mathrm{e}$ recepcionisto $^{1694}$, para indicar uma profissão geralmente feminina e exercida por alguém do sexo masculino, com valor pejorativo. No dicionário HoUAISS (2001) encontra-se uma única palavra com a forma -isto: modisto, com as seguintes acepções: "forma masculina de modista" e "cônjuge ou companheiro de modista".

É interessante notar que na língua galega e portuguesa dos séculos XII e XIII, o sufixo -or, um dos principais concorrentes do sufixo -ista na formação de agentes, também, na maioria dos casos, não possuía distinção para a forma feminina, porém com a sua alta produtividade e sua popularização acabou por formar essa distinção, em muitos dos casos, em -ora. Eventualmente, o sufixo -ista poderá também desenvolver-se nesse sentido nas línguas portuguesa e galega.

Assim, a influência da percepção da realidade atinge diretamente a fala popular, cujo reconhecimento é muito importante para a compreensão profunda de uma língua e suas estruturas. Se, por um lado, muitas vezes é nela que se conservam as formas arcaicas já perdidas na língua culta, por outro, geralmente, é a fala popular que mostra as tendências do desenvolvimento da língua.

\footnotetext{
1688 Tradução: "modista”, em forma masculina.

1689 Tradução: "recepcionista", em forma masculina.

1690 Tradução: autor/escritor de romances, forma masculina e pejorativa.

1691 Tradução: "violinista", na forma masculina e pejorativa.

1692 Tradução: "modista", em forma masculina.

1693 Tradução: "telefonista", em forma masculina.

1694 Tradução: "recepcionista", em forma masculina.
} 
Estudo comparativo de aspectos semânticos do sufixo -ista no português e no galego.

\section{REFERÊNCIAS BIBLIOGRÁFICAS}

Aos vencedores, as batatas.

(Machado de Assis) 


\section{Referências bibliográficas}

Adamo, Giovanni. Alcune osservazioni sulla terminologia dell'informatica. Seminario de Lessico Intellettuale Europeo. Nizza: Università Sophia-Antipolis, julho de 1996.

AgARD, F.B. A course in romance linguistics. Georgetown University Press, 1984.

AgUiAR, João. "O princípio da compaixão". In: Onde a terra acaba: colectânea de contos portugueses. Lisboa: Universidade de Lisboa, 2006.

AlenCAR, José de. Asas de um anjo. Rio de Janeiro: Biblioteca Nacional. www.bn.br, 2006. 2006. Guerra dos mascates. Rio de Janeiro: Biblioteca Nacional. www.bn.br, . O crédito. Rio de Janeiro: Biblioteca Nacional. www.bn.br, 2006.

2006. . O demônio familiar. Rio de Janeiro: Biblioteca Nacional. www.bn.br, . O gaúcho. Rio de Janeiro: Biblioteca Nacional. www.bn.br, 2006. . O guarani. Rio de Janeiro: Biblioteca Nacional. www.bn.br, 2006. . O que é o casamento. Rio de Janeiro: Biblioteca Nacional. www.bn.br, 2006. . Senhora. Rio de Janeiro: Biblioteca Nacional. www.bn.br, 2006. . Verso e reverso. Rio de Janeiro: Biblioteca Nacional. www.bn.br, 2006.

AleXANDRe, Marta. "Um comentário crítico". In: Jornal de letras, artes e idéias. Lisboa, 2000, p 15-18.

Aliandro, Hygino. Pocket dictionary of the Portuguese and English languages. São Paulo: McGraw-Hill do Brasil, 1972.

AlMEIDA, Diana. "Tinha chegado o circo". In: Onde a terra acaba: colectânea de contos portugueses. Lisboa: Universidade de Lisboa, 2006.

AlmeIDA, Onésimo Teotónio. "Em casa com o sinto de segurança apertado". In: Onde a terra acaba: colectânea de contos portugueses. Lisboa: Universidade de Lisboa, 2006.

Alvar, M. \& Pottier, B.. Morfología histórica del español. Madri: Gredos, 1983.

Álvarez CácCamo, Alfonso. A bandeira. (1997). A Coruña: eDixital, 2003.

do Castro, 1999. A meritória cortesia de Edón de Cigala. (1996). Sada: Ediciós

Álvarez, R.; Monteagudo, H \& Regueira, X.L. Gramática galega. Vigo: Galaxia, 6a Ed., 1995.

AlveS, Castro. Espumas flutuantes. Rio de Janeiro: Biblioteca Nacional. www.bn.br, 2006. . Navio negreiro. Rio de Janeiro: Biblioteca Nacional. www.bn.br, 2006.

AlVES, I. M. Neologismo - criação lexical. São Paulo: Ática, 1990. 
Estudo comparativo de aspectos semânticos do sufixo -ista no português e no galego.

AnChiETA, Padre José de. Obras completas. Rio de Janeiro: Biblioteca Nacional. www.bn.br, 2006.

ANDRADE, Alexandre. "Alguns quartos de hotel em Itália". In: Onde a terra acaba: colectânea de contos portugueses. Lisboa: Universidade de Lisboa, 2006.

AnJos, Augusto dos. Eu e outras poesias. Rio de Janeiro: Biblioteca Nacional. www.bn.br, 2006.

Antonil, André João. Cultura e opulência do Brasil. Rio de Janeiro: Biblioteca Nacional. www.bn.br, 2006.

Amaral, Amadeu. O dialeto caipira. São Paulo: O livro, 1920.

ANDRADE, Carlos Drummond de. In: Jornal de Poesia. Fortaleza: www.revista.agulha.nom.br/indice.html, 2006.

ANDRADE, Mário de. In: Jornal de Poesia. Fortaleza: www.revista.agulha.nom.br/indice.html, 2006.

ANDRADE, Reinaldo. Reencarnação. Pará de Minas: virtualbooks, 2003.

AÑón, Francisco. A leiteira. (1886). A Coruña: eDixital, 2002.

. Poesias varias. (1888). A Coruña: eDixital, 2002.

ARAÚJO, Murilo. Carrilhões. Rio de Janeiro: Biblioteca Nacional. www.bn.br, 2006.

Armada TeiXeIro, Ramón. ¡Non mais emigración! A Havana: Gran Teatro de Tacón, 1886.

_. Aturuxos. (1889). A Coruña: eDixital, 2002.

. Cousas e cousas. (1885). A Coruña: eDixital, 2002.

AronofF, Mark. Word Formation in Generative Grammar. Cambridge, Massachusets: MIT, 1976.

Assis, Machado de. A mão e a luva. Rio de Janeiro: Biblioteca Nacional. www.bn.br, 2006.

. Desencantos. Rio de Janeiro: Biblioteca Nacional. www.bn.br, 2006.

. Dom Casmurro. Rio de Janeiro: Biblioteca Nacional. www.bn.br, 2006.

. Esaú e Jacó. Rio de Janeiro: Biblioteca Nacional. www.bn.br, 2006.

. Iaiá Garcia. Rio de Janeiro: Biblioteca Nacional. www.bn.br, 2006.

2006.

. Memorial de Aires. Rio de Janeiro: Biblioteca Nacional. www.bn.br,

www.bn.br, 2006.

Memórias póstumas de Brás Cubas. Rio de Janeiro: Biblioteca Nacional.

Quase ministro. Rio de Janeiro: Biblioteca Nacional. www.bn.br, 2006.

. Relíquia de casa velha. Rio de Janeiro: Biblioteca Nacional. www.bn.br, 2006.

Assunção, Carlos (ed.). Lobato, António José dos Reis. A arte da grammatica da língua portugueza. $1^{\mathrm{a}}$ ed. 1770. Lisboa: Academia das Ciências de Lisboa, 2000. 
Azevedo, Álvares de. Lira dos vinte anos. Rio de Janeiro: Biblioteca Nacional. www.bn.br, 2006.

Azevedo, Artur de. Abel e Helena. Rio de Janeiro: Biblioteca Nacional. www.bn.br, 2006. www.bn.br, 2006.

A princesa dos cajueiros. Rio de Janeiro: Biblioteca Nacional. 2006.

Nova viagem à lua. Rio de Janeiro: Biblioteca Nacional. www.bn.br, www.bn.br, 2006 .

Nacionalwww.bn.br, 2006.

- O califa da rua do sabão. Rio de Janeiro: Biblioteca Nacional.

Badia I Margarit, Antoni Maria. Gramática catalana. Vol 2. Madri: Gredos, 1962.

Baltsan, Hauim. Webster's New World. Hebrew dictionary. New York: Prentice Hall, 1992.

BANDEIRA, Manuel. In: Jornal de Poesia. Fortaleza: www.revista.agulha.nom.br/indice.html, 2006.

Bandeira, Manuel; Coutinho, Afrânio; Pereira, Lúcia Miguel; Massaud, Moisés. Estudos sobre Machado de Assis. Pará de Minas: virtualbooks, 2003.

Barbosa, M. A. Léxico, produção e criatividade. Processos do neologismo. 2 ed. São Paulo: Global, 1990.

Barraclough, G. \& PARKer, G. Knaurs neuer: Historischer Weltatlas. Augsburg: Bechtermünz Verlag, 1999.

BARreto, Moniz. A literatura portuguesa do século XIX. Coimbra: Universidade de Coimbra, 1944.

BARRetTo, Paulo (João do Rio). A alma encantadora das ruas. Rio de Janeiro: Biblioteca Nacional. www.bn.br, 2006.

A profissão de Jacques Pedreira. Rio de Janeiro: Biblioteca Nacional. www.bn.br, 2006.

Barros, Carlos. Donas e xograis, señores e reis, na Galicia medieval. Santiago de Compostela: USC, s.d.

. El otro admitido: La tolerancia hacia los judios en la Edad Media gallega. Santiago de Compostela: USC, s.d.

. Galicia: Historia y Cultura. Santiago de Compostela: USC, s.d.

USC, s.d. . La frontera medieval entre Galicia y Portugal. Santiago de Compostela: Compostela: USC, s.d.

Novos documentos sobre a xudería e a sinagoga de Rivadavia. Santiago de

. Revuelta de los irmandiños: Los gorriones corren trás los halcones. Santiago de Compostela: USC, s.d. 
BARROS, Tomás. Vieiro de Señardade. Sada: Ediciós do Castro, 1978.

BARToš, Lubomír. La neología adjetival en el español. Praga: Studia Minora Facultatis Philosophicae Universitatis Brunensis, 1997.

Basílio, M. Estruturas Lexicais do Português. Petrópolis: Vozes, 1980.

. Flutuação categorial de base adjetiva no português falado. In: CASTILHo, A.T. Gramática do português falado. Vol. II: Níveis de análise lingüística. $4^{a}$ Edição. Campinas: Unicamp, 2002. P. 75 - 90.

2006.

. Formação de classes de palavras no português do Brasil. São Paulo: Contexto,

- O estudo da morfologia no português falado: condições de produtividade e condições de produção. In: CASTILHO, A.T. Gramática do português falado. Vol. III: as abordagens. Campinas: Unicamp, 1993. P. 364 - 372.

Teoria Lexical. São Paulo: Ática, 2004.

BasseTto, Bruno F. Elementos de filologia românica. São Paulo: Edusp, 2001.

BECHARA, E. Moderna gramática portuguesa. São Paulo: Nacional, 1969.

BEIRANTE, Rute. "Claramente". In: Onde a terra acaba: colectânea de contos portugueses. Lisboa: Universidade de Lisboa, 2006.

Berezin, Rifka. Dicionário Hebraico-Português.. São Paulo: Edusp, 2003.

Bergström, Magnus e ReIs, Neves. Prontuário Ortográfico e Guia da Língua Portuguesa. Lisboa: Editorial Notícias / Instituto Camões, 2001, pp. 96 a 102.

Bieito Fandiño, Antonio. A casamenteira. (1849). A Coruña: eDixital, 2002.

BILAC, Olavo. Almas inquietas. Rio de Janeiro: Biblioteca Nacional. www.bn.br, 2006. . A tarde. Rio de Janeiro: Biblioteca Nacional. www.bn.br, 2006.

2006. O caçador de esmeraldas. Rio de Janeiro: Biblioteca Nacional. www.bn.br, . Panóplias. Rio de Janeiro: Biblioteca Nacional. www.bn.br, 2006. . Profissão de fé. Rio de Janeiro: Biblioteca Nacional. www.bn.br, 2006. . Sarças de fogo. Rio de Janeiro: Biblioteca Nacional. www.bn.br, 2006.

BLANCO TORRES, Roberto. Xornalismo Irmandiño (1919-1923). Vigo: A nosa terra, 1999.

Bluteau, R. Vocabulário portuguez e latino. Coimbra: Collegio das Artes da Companhia de Jesus, 1712-1728.

BoAdo SánChez, Pedro. O tio Farruco. (1823). A Coruña: eDixital, 2003.

Bocage, António do. Sonetos e outros poemas. Rio de Janeiro: Biblioteca Nacional. www.bn.br, 2006.

BosQue, Ignacio \& DeMonte, Violeta. Gramática descriptiva de la lengua española. Real Academia Española. Colección Nebrija y Bello. Vol. 3 - Morfología. Madri: Espasa Calpe, 2000 . 
BossiER, Willen. "Os sufixos verbalizadores no léxico português moderno". In: Lingistica antverpiensia, series maior, $\mathrm{n}^{\mathrm{o}} 3$. Antuérpia: Instituto Superior de Tradutores e Intérpretes (H.I.V.T), 1998.

Branco, Camilo Castelo. Amor de perdição. Rio de Janeiro: Biblioteca Nacional. www.bn.br, 2006.

. Poemas. Rio de Janeiro: Biblioteca Nacional. www.bn.br, 2006.

. Teatro II. Lisboa: António Maria Pereira, 1929.

BREA, Mercedes. Galegisch: Externe Sprachgeschichte. In: Holtus, Günter et alli. Lexikon der Romanistischen Linguistik. Tübingen: Max-Niemeyer, 1983, v VI,2.

BRÉAL, Michel. Ensaio de semântica. Trad. Eduardo Guimarães. São Paulo: EDUC/Pontes, 1992

Brunswick, H. (Coord.). Diccionario da Antiga Linguagem Portuguesa. Lisboa: Lusitana s.d..

BuCK, Carl Darling. Comparative grammar of greek and latin. Chicago: The University Chicago Press, 1952.

Buarque de Holanda, Chico. Calabar: o elogio da traição. Rio de Janeiro: Civilização Brasileira, 1975.

BuENo, Francisco da Silveira. Dicionário escolar da língua portuguesa. São Paulo: MEC/FENAME, 1969.

Cabido, Xosé Cid. Foumán. Vigo: Xerais, 1987.

CAldeira, Fernando. A mantilha de renda. Lisboa: Imprensa do Diário da Manhã, 1880.

CÂMara JR., J. Mattoso. Contribuição à estilística portuguesa. Rio de Janeiro: Ao Livro Técnico, 1978. 1976. . História e estrutura da língua portuguesa. Rio de Janeiro: Padrão,

Cambridge Dictionary of American English. Cambridge University Press, 2000. CD.ROM, v. 1.1 .

Caminha, Adolfo. A normalista. Rio de Janeiro: Biblioteca Nacional. www.bn.br, 2006.

CAMões, Luis Vaz de. Canções e elegias. Rio de Janeiro: Biblioteca Nacional. www.bn.br, 2006. . Os lusíadas. Rio de Janeiro: Biblioteca Nacional. www.bn.br, 2006. . Sonetos. Rio de Janeiro: Biblioteca Nacional. www.bn.br, 2006.

CAMPOS, Humberto de. O Brasil anedótico. Rio de Janeiro: Biblioteca Nacional. www.bn.br, 2006.

Carballo, Francisco. Castelao no seu tempo. A Coruña: eDixital, 2004.

Carballo, Luís Amado. O galo. A Coruña: Nós, 1928.

Carballo Calero, Ricardo. Discurso político e discurso poético na literatura galega. A Coruña: eDixital, 2003. 
Estudo comparativo de aspectos semânticos do sufixo -ista no português e no galego.

Carballo Calero, Ricardo. Gramática Elemental del Gallego Común. Vigo: Galaxia, 1970.

Carvalho, Jorge Vaz de. "Efélides". In: Onde a terra acaba: colectânea de contos portugueses. Lisboa: Universidade de Lisboa, 2006.

CASEvitz, Michel. Le vocabulaire de la colonisation en grec ancien. Paris: Klincksieck, 1985.

CASTRO, Américo. La realidad histórica de España. México: Porrua, 1975.

Castro, Ivo (org.). Curso de História da Língua Portuguesa. Leituras Complementares. Lisboa: Universidade Aberta, 1991.

CASTRO, Rosalía de. Cantares gallegos. (1863). Vigo: Xerais, 2001. 1956. . Conto gallego. Santiago de Compostela: Cuaderno de Estúdios Gallegos, . Follas novas. (1880). Vigo: Xerais, 2000.

CESChIn, H. L. Osvaldo. Poesia e história nos cancioneiros medievais: O cancioneiro do infanção. São Paulo: Humanitas / FFLCH-USP, 2004.

Chagas, Pinheiro. A Morgadinha de Valflor. Lisboa: António Maria Pereira, 1924.

Christidis, A. F. Histoires de la langue grecque. In: La langue grecque et son histoire. Atenas: Centre de la Langue Grecque, 2003. 85-100.

Christol, Alain. Le grecque aux frontières de l'orient. In: La langue grecque et son histoire. Atenas: Centre de la Langue Grecque, 2003. 113-117.

CID, Freixó G. Xosé. Diccionario da Lingua Galega. 3. Ed. Vigo: Ir Indo, 1999.

CIPM - Corpus Informatizado do Português Medieval. http://cipm.fcsh.unl.pt/. 2006.

Coelho NetTo. A conquista. Rio de Janeiro: Biblioteca Nacional. www.bn.br, 2006. Turbilhão. Rio de Janeiro: Biblioteca Nacional. www.bn.br, 2006.

CoHn, Marc M. Nouveau Dictionnaire. Hebreu-Français. Paris:Larousse, 1989.

Collins, William. HaRland, Mike (Org.). Collins GEM Dictionary. English - Portuguese. Portuguese - English. Londres: Collins Clear, 1987.

CONSCIENCIOPÉDIA. Enciclopédia Digital da Conscienciologia. http://pt.conscienciopedia.ceaec.org.br/Lista_de_istas. 23 de dezembro de 2005.

Corbacho Quintela, Antón. Os periódicos dos imigrantes espanhóis. In Proceedings of the 2. Congresso Brasileiro de Hispanistas, 2002, São Paulo (SP) [online]. 2002 [cited 23 May 2006]. Available from World Wide Web: http://www.proceedings.scielo.br/

CORGA - CORPUS de REFERÊNCIA do GALEgo ACTUAL. http://corpus.cirp.es/corga/. 2006.

CoRnIDE, Xosé. Composicións galegas. (s. XVIII). A Coruña: eDixital, 2002.

Corominas, Joan. Diccionario crítico etimológico de la lengua castellana. Madri: Gredos, 1954. 
Estudo comparativo de aspectos semânticos do sufixo -ista no português e no galego.

CoRRÊA, Roberto Alvim. Dicionário escolar. Francês - Português. Português - Francês. Rio de Janeiro: MEC/FENAME, 1975.

CorTeSÃo, Jaime. Adão e Eva. Lisboa: Seara Nova, 1921.

COSERIU, E. Formen und Funktionen. Tübigen: Niemeyer, 1987.

. Principios de semántica estructural. Madri: Gredos, 1977.

Costa, Cláudio Manuel da. Poemas. Rio de Janeiro: Biblioteca Nacional. www.bn.br, 2006.

Costas González, Xosé Henrique. Aproximación linguística á fala de Vincios (Val Miñor). Santiago de Compostela: Universidade de Santiago de Compostela, 1986.

CovarRubias Orozco, Sebastián de. Tesoro de la lengua castellana o española. Edición de Felipe C.R. Maldonado; revisado por Manuel Camarero. $2^{\mathrm{a}}$ ed. Madri: Castalia, 1995.

Cruz e SousA. Broquéis. Rio de Janeiro: Biblioteca Nacional. www.bn.br, 2006. . Livro das mágoas. Rio de Janeiro: Biblioteca Nacional. www.bn.br, 2006. . O livro derradeiro. Rio de Janeiro: Biblioteca Nacional. www.bn.br, 2006. . Últimos sonetos. Rio de Janeiro: Biblioteca Nacional. www.bn.br, 2006.

CunHa, Celso. Política e cultura do idioma, Língua, nação e alienação. Rio de Janeiro: Nova Fronteira, 1981.

CunHA, Euclides. Ondas e outros poemas. Rio de Janeiro: Biblioteca Nacional. www.bn.br, 2006.

Curros EnríQuez, Manuel. A poesia gallega. A Coruña: Deputación Provincial da Coruña, 1998. . Aires d'a miña terra. (1880). A Coruña: eDixital, 2002. . Divino sainete. (1888). A Coruña: eDixital, 2002.

CURTo, Ramada. Teatro escolhido. Vol. I e II. Lisboa: Imprensa Nacional - Casa da Moeda, 2004.

DANTAS, Júlio. A ceia dos cardeais. Rio de Janeiro: Biblioteca Nacional. www.bn.br, 2006. . D. Beltrão de Figueroa. Lisboa: Portugal-Brasil, 1920.

Dato Muruais, Filomena. Follatos. Poesías Gallegas. (1891). A Coruña: eDixital, 2002.

Delgado Gurrianán, Florencio. Cantarenas. Sada: Ediciós do Castro, 1981.

DeL PICCHIA, Menotti. In: Jornal de Poesia. Fortaleza: www.revista.agulha.nom.br/indice.html, 2006.

Diccionario básico de la lengua. Anaya. Madri: Anaya, 1993.

Diccionario da lingua galega. Real Academia Galega. http://www.edu.xunta.es/diccionarios/index.html.

Dicionário da lingua galego-portuguesa. Dicionário e-Estraviz. Associaçom Galega da Lingua (AGAL). http://www.agal-gz.org/estraviz/.(2005).

Dicionário da língua portuguesa online. http://www.priberam.pt/dlpo/. 
Estudo comparativo de aspectos semânticos do sufixo -ista no português e no galego.

Dicionário da Porto Editora da língua portuguesa. http://www.portoeditora.pt .

Diccionario de la lengua española. Real Academia Española, 22 ${ }^{\mathrm{a}}$ Ed., 2001. CD.ROM, v. 1.0. http://www.rae.es.

Dictionary English-basque/ basque-english. www1.euskadi.net/morris/ (2006)

Dictionnaire Lilliput Langenscheidt. Français-espagnol. Berlim: Langenscheidt, 1961.

Diccionario pedagóxico da lingua galega. Real Academia Galega. http://www.edu.xunta.es/diccionarios/index.html.

Dicionário português-japonês da Webbusca. www.webbusca.com.br/tradutor/. 2006.

DIEGo, Vicente García de. Gramática Histórica Española. Editorial. Madrid: Editorial Gredos, 1951.

DiÉGUEz, Loís. As sete chagas. A Coruña: eDixital, 2002.

DiEste, Rafael. Antre a terra e o ceo. Proasa de mocedade (1925-1927). Sada: Ediciós do Castro, 1927.

. Dos arquivos do trasno. (1926). A Coruña: eDixital, 2002.

. Fiestra valdeira. (1927). A Coruña: eDixital, 2002.

DINIS, Júlio. As pupilas do senhor Reitor. Rio de Janeiro: Biblioteca Nacional. www.bn.br, 2006.

. (Joaquim Gomes Coelho). Teatro inédito. Vol. I e II. Porto: Civilização, 1979.

DoCAMPO, Xabier. A chave das noces. A Coruña: Via Láctea, 1988.

Dolores, Carmem. A luta. Rio de Janeiro: Biblioteca Nacional. www.bn.br, 2006.

ELIA, Sílvio. A língua portuguesa no mundo. São Paulo: Ática, 1989.

Elson, B. \& Pickett, V.. Introdução à Morfologia e à Sintaxe. Tradução de Aryon D. Rodrigues e outros. Petrópolis: Vozes, 1973.

Enciclopédia de línguas no Brasil. 2006. http:///www.labeurb.unicamp.br/elb/

ENTWISTLE, William James. Las lenguas de España. Madri: Istmo, 1973.

Euskaltzaindia (Real Academia de La Lengua Vasca). www.euskaltzaindia.net (2006).

FARIA, Ernesto. Vocabulário latino-português: significação e história das palavras agrupadas por famílias segundo os programas atuais. Rio de Janeiro: F. Briguiet, 1943.

Ferguson, C. "Diglossie”. In: Word, 1959, 15: 25-40.

FERNANDES, Millôr. Duas tábuas e uma paixão. Porto Alegre: L\&PM, 1982.

2006.

In: Jornal de Poesia. Fortaleza: www.revista.agulha.nom.br/indice.html,

Teatro completo. Vol. 1. Porto Alegre: L\&PM, 1994.

FERNÁNDEz ReI, Francisco. Ramón Cabanilla, Manuel Antonio e o mar da Arousa. Discurso lido polo Ilustrísimo Señor don Francisco Fernández Rei no acto da súa recepción da RAG. A Coruña: RAG, 1999. 
Estudo comparativo de aspectos semânticos do sufixo -ista no português e no galego.

FerreIRA, Aurélio Buarque de Holanda. Novo Aurélio século XXI: O Dicionário da Língua Portuguesa. Rio de Janeiro: Nova Fronteira, 1999.

FERREIRA, David Mourão. In: Jornal de Poesia. Fortaleza: www.revista.agulha.nom.br/indice.html, 2006.

FerReIro, Manuel. Gramática histórica galega. Noia: Laiovento, 2001.

FLECHIA, Giovanni. Tema nominale latino e italiano: Nomi in -ETA, -ITA, -ITE, -OTA, ISMO, -ISTA. Torino: Stefania Spina, 1996.

FonTe, Ramiro. O cazador de libros. Santiago de Compostela: Sotelo Blanco, 1997.

França Júnior. Como se fazia um deputado. Rio de Janeiro: Biblioteca Nacional. www.bn.br, 2006. 2006. O tipo do brasileiro. Rio de Janeiro: Biblioteca Nacional. www.bn.br,

Freitas, Horácio Rolim de. Princípios de Morfologia. Rio de Janeiro: Presença, 1981.

FreiXeiro MAto, Xosé. R. Gramática da língua galega. Vigo: A nosa terra, 1999, v III Semántica.

Freixó de Araúxo, Gabriel. A contenda dos labradores de Caldelas. (1671). A Coruña: eDixital, 2002.

Fruíme, Cura de. Composicións galegas. (s. XVIII). A Coruña: eDixital, 2002.

Fundação JaPão. Dicionário básico japonês português. São Paulo: Masao Ohno / Aliança Cultural Brasil-Japão, 1989.

Gallego 3. Instituto de la Lengua Gallega. Santiago de Compostela: Universidad de Santiago de Compostela, 1974.

Galicia Hoxe. Galicia Hoxe: único diario en galego. Santiago de Compostela: Compostela, 26 de junho de 2006.

GAMA, Basílio da. O Uraguai. Rio de Janeiro: Biblioteca Nacional. www.bn.br, 2006.

GarCIA, A. S. "Português do Brasil: questões de substrato, superstrato e adstrat". In: Soletras, 2003, Rio de Janeiro (RJ) [online]. 2003 [cited 23 May 2006]. Available from World Wide Web: <http://www.filologia.org.br/soletras/4/indice.htm>

GARCía BARDón, Salvador. Estudio estructural del español. Louvain: Université Catholique de Louvrain, 1967.

García BARros, Manoel. Ken keirades. Contiños da terra. A Coruña, 1931.

García-Bodaño, Salvador. Cidade virtual. A Coruña: eDixital, 2002.

GARRET, Almeida. D. Filipa de Vilhena. Porto: Lello \& Irmão, s.d. . Folhas caídas. Rio de Janeiro: Biblioteca Nacional. www.bn.br, 2006. . Frei Luís de Sousa. Porto: Porto, 1964.

2006 . . O arco de Sant'ana. Rio de Janeiro: Biblioteca Nacional. www.bn.br, 
2006.

. Viagens na minha terra. Rio de Janeiro: Biblioteca Nacional. www.bn.br,

GDLC - Gran diccionari de la llengua catalana. Barcelona: Enciclopèdia Catalana, 1998. http://www.grec.net/home/cel/dicc.htm.

GerLI, Michael (ed.). BerCeo, Gonzalo. Milagros de Nuestra Señora. Madrid: Cátedra, 2001.

Giner I FerRaNdo, Joseph. "El Valencià, una llengua romanica." In: El Valencià, una llengua del segle XXI. Valencia: Comité de l'Idioma Valencià (C.I.V.), s.d. http://www.centenardelaploma-manises.com/Llibres-Digitals_LLV/valenciasxxi.pdf

Glachant, T \& Robert, J. “Formation de l'adjectif éponyme”. In: Le français dans le monde. $\mathrm{N}^{\circ} 319$. Paris: Alliance Française, Janvier-février 2002.

GoMeS, A. F. Dias. O pagador de promessas. Rio de Janeiro: Ediouro, 1998.

GOMES, Luísa Costa. "A cama de pregos". In: Onde a terra acaba: colectânea de contos portugueses. Lisboa: Universidade de Lisboa, 2006.

GómEz, Joel. O feche indefinido. (1990). A Coruña: eDixital, 2003. Língua, 1992.

Un servicio policial (trancendencia nun acto). Ourense: Associaçom Galega da

Gonsar, Camilo. Cara a Times Square. Vigo: Galaxia, 1980.

Como calquera outro día. (1962). A Coruña: eDixital, 2002.

Desfeita. (1980). Vigo: Xerais, 1983.

GonzagA, Tomás Antônio. Cartas chilenas. Rio de Janeiro: Biblioteca Nacional. www.bn.br, 2006.

GonZÁlez Fernández, Isabel. Sufijos nominales en el gallego actual. Santiago de Compostela: Verba, 1976.

GonZÁlez M., E. E. “O Brasil como país de destino para os imigrantes espanhóis”. In: Fausto, B. (org.). Fazer a América. São Paulo: Editora da Universidade de São Paulo, 2000, p. 239-271.

GonZález-MiLlán, Xoán. Do nacionalismo literario a unha literatura nacional (1994). A Coruña: eDixital, 2004.

González Refoxo, María dos Anxos e Rábade Castiñeira, Xoán Carlos. E non chegou a ser palabra ... Afixos léxicos. Sufixación e prefixación lexical. A Coruña: Asociación Sócio-Pedagóxica Galega, 1995.

GonZÁlez, Rodríguez Eladio. Diccionario Enciclopedico Gallego-Castellano de la Real Academia Gallega. Vigo: Galaxia, 1961.

GORIS, Richard C. \& OKUBO, Yukimi. Collins Shubun English-Japanese Dictionary. S/l: Collins Publishers / Shubun Internacional Co., 1993.

GUARNIERI, Gianfrancesco. O melhor teatro de Gianfrancesco Guarnieri. São Paulo: Global, 1986. 
GUÉHO, Robert. "Suffixes: solderie, bagagiste, optionnel, confidentialité". In: Chroniques des nouveautés. Sarrebruck: 2003. http://www.unikassel.de/ clef/projets/RobertGueho/chroniques.

GUILBERT, Louis. La créativité lexicale. Paris: Larousse, 1975.

GuimarãeS, Alphonsus de. Poemas. Pará de Minas: virtualbooks, 2003.

HALLE, Morris. "prolegonema to a theory of word formation". In:Linguistic inquiry. Vol IV, Winter, 1973, p. 3-16.

Herculano, Alexandre. Arras por foro de Espanha. Rio de Janeiro: Biblioteca Nacional. www.bn.br, 2006.

www.bn.br, 2006.

Eurico, o presbítero. Rio de Janeiro: Biblioteca Nacional. . História de Portugal. Lisboa:Bertrand, s.d.

. O bispo negro. Rio de Janeiro: Biblioteca Nacional. www.bn.br, 2006.

Poesias. Rio de Janeiro: Biblioteca Nacional. www.bn.br, 2006.

Hofmann, O.; Debrunner, A. \& Scherer, A. Historia de la lengua griega.(título original: Geschichte der griechischen Sprache; traductor al castellano: Sánchez Pacheco). Madri: Gredos, 1986.

HoLtus, Günter et alli (org.) Lexikon der Romanistischen Linguistik. Tübingen, MaxNiemeyer, 1983.

HoRnBY, A.S. The advanced learner's dictionary of current English. 5a. ed. Londres: Oxford University, 1995.

Houaiss, Antonio. VILlar, Mauro (Org.). Dicionário eletrônico Houaiss da língua portuguesa. Versão1. Rio de Janeiro: Objetiva, 2001. CD.ROM, v. 1.0.

IGLESIA, Francisco María de la. A fonte do xuramento. A Coruña: Liceo Brigantino, 1882. Apólogos. A Havana: Gaita gallega, 1889.

INFOPÉdiA. Enciclopédia multimédia em Língua Portuguesa. Porto: Porto editora, 2006. http://www.infopedia.pt .

JunQUeIro, Guerra. A pátria. Porto: Lello \& Irmão, s.d. 2006. . In: Jornal de Poesia. Fortaleza: www.revista.agulha.nom.br/indice.html,

Juzarte, Teotônio José. Diário da navegação. Souza, J. S. e Makino, M (orgs.). São Paulo: Edusp, 2000.

Kedaitene, E.; Verkhucha, V. \& Mitrokhina, V. Dicionário Prático Português-Russo. Moscou: Russki Yazik, 1983.

KreutZ, Lúcio. "A educação de imigrantes no Brasil". In: LOPES, E. M.; FARIA Filho, L.M.; VeigA, C.G. (org.). 500 anos de educação no Brasil. Belo Horizonte: Autêntica, 2000, 347-370. 
Lamas CaRVAJAL, Valentín. Saudades gallegas. (1875). A Coruña: eDixital, 2002.

LAPA, M. Rodrigues. Estilística da língua portuguesa. Coimbra: Coimbra, 1979. - Vocabulário galego-português, tirado da edição crítica das cantigas d'escarnho e de mal dizer. Coimbra: Galaxia, 1965.

LAPESA, Rafael. Historia de la lengua española. Real Academia Española. Colección Nebrija y Bello. Madri: Espasa Calpe, 6 ${ }^{a}$ Ed., 2003.

LE Liguer. "Le suffixe -iste". In: Au bout de la langue. Paris: Le Liguer, 2005. http://users.skynet.be/Landroit/ABL/Lsuffiste.html

Le Petit Robert. Dictionnaire de la langue française. Bruxelas: Paul Robert, 1997. CD.ROM, v. 1.3. http://www.bvdep.com/robert.

LE ROBERT. Dictionnaire de la langue française. Paris: Le Robert, 1985.

LlORACH, Emilio Alarcos. Gramática de la lengua española. Madri: Gredos, 9a Ed., 2001.

LobAto, Lúcia M. P. (org.) A semântica na lingüística moderna: o léxico. Rio de Janeiro: Francisco Alves, 1977.

LóPEZ-EIRE, Antonio. Una ejemplar historia de la lengua: la historia de la lengua griega. In: La langue grecque et son histoire. Atenas: Centre de la Langue Grecque, 2003. 101-106.

López Ferreiro, Antonio. A tecedeira de Bonaval. (1895). A Coruña: eDixital, 2003. . O castelo de Pambre. (1895). A Coruña: eDixital, 2002. . O niño de pombas. A Coruña: eDixital, 2002.

LONGMAN GROUP. Longman dictionary of contemporary English. Londres: Longman, 1987.

LORENZO, Ramón. "Breve historia da lingua galega". In: Atas do $1^{\circ}$ Congresso Internacional de ABRALIN. Salvador: ABRALIN, 1994.

Lourenzo González, Manuel. Auto do Entroido. A Coruña: Asociación Sócio-Pedagóxica Galega, 1995.

LuGRís Freire, Manuel. A festa de tacón. A Havana: Gaita gallega, 1885. . Gramática do Idioma Galego. A Coruña: Moret, 1931. . Non mais emigración. A Havana: Gaita gallega, 1885.

MACEDo, Joaquim Manuel. Luxo e vaidade. Rio de Janeiro: Biblioteca Nacional. www.bn.br, 2006.

- O primo da Califórnia. Rio de Janeiro: Biblioteca Nacional. Acervo eletrônico: www.bn.br, 2006.

Magalhães, Valentim. Flor de Sangue. Rio de Janeiro: Biblioteca Nacional. www.bn.br, 2006.

MAIA, Clarinda de Azevedo. História do galego português. Coimbra: Fundação Calouste Gulbenkian, 1986.

Maleval, Maria do Amparo Tavares (Org.). Estudos galegos (2). Niterói: UFFUniversidade Federal Fluminense, 1998. 
Universidade Federal Fluminense, 2002.

Estudos galegos (3). Niterói: UFF-

Mariñas del VAlLe, Jenaro. $O$ asento. (1986). A Coruña: eDixital, 2004.

Martignon, Marino. Riflessione sulla língua: Il codice lingüístico. 2004. http://www.insegnareitaliano.it/documenti/Laboratorio/italiano/Martignon/riflessione_sulla _lingua/Il_codice_linguistico_2004.PDF.

MARTINS, Nilce Sant'anna. Introdução à estilística. São Paulo: T. A. Queiroz, 2000.

MATos, Fred. Anomalias. Rio de Janeiro: Biblioteca Nacional. www.bn.br, 2006.

MATOS, Gregório. Poesias. Rio de Janeiro: Biblioteca Nacional. www.bn.br, 2006.

Matos, Joaquim. Os primeiros passos do Romantismo - o toucador de Garret. Porto: Universidade do Porto, 1999.

MatTe Bon, Francisco. Gramática comunicativa del español. Madrid: Edelsa, 2003.

Mattos E Silva, Rosa Virgínia. A língua portuguesa em perspectiva histórica: Do português europeu para o português brasileiro: algumas questões. Salvador: ABRALIN, 1999.

Contexto, 1993.

. O Português Arcaico. Morfologia e Sintaxe. São Paulo:

O Português brasileiro. Página do Instituto Camões. 2002. [cited 23 May 2006]. Available from World Wide Web: <www.institutocamões.pt/cvc/hlpbrasil/index.html>

MAURER JR., T. H.. Gramática do latim vulgar. Rio de Janeiro: Livraria Acadêmica, 1959. . Unidade da România Ocidental. São Paulo: USP, 1951.

Mayoral, Marina \& Roig, Blanca (ed.). CASTro, Rosalía DE. Follas novas. Vigo: Edicións Gerais de Galicia, 1990-2000.

MeILlet, A.. Aperçu d'une histoire de la langue grecque. Paris: Hachette, 1930.

Melo Neto, João Cabral de. In: Jornal de Poesia. Fortaleza: www.revista.agulha.nom.br/indice.html, 2006.

MenÉndez Pidal, Ramón. El idioma español en sus primeros tiempos. 7a. ed. Madri: Espasa-Calpe, 1968. . Orígenes del español. 3a. ed. Madri: Espasa-Calpe, 1950. . Presente y futuro de la lengua española Vol. I. Madri: EspasaCalpe, 1964.

MENDES, Murilo. In: Jornal de Poesia. Fortaleza: www.revista.agulha.nom.br/indice.html, 2006.

Méndez FerRín, Xosé Luís. Arnoia, Arnoia. Vigo: Xerais, 1985.

Menjot, Denis. Les Espagnes Médiévales 409-1447. Paris: Hachete, 1996.

Mettmann, Walter (ed.). Afonso X. Cantigas de Santa Maria. Coimbra: Coimbra, 19591972. 
Estudo comparativo de aspectos semânticos do sufixo -ista no português e no galego.

MEYER-LüBKE, Wilhelm. Romanisches Etymologisches Wörterbuch. 6 unveränderte Auflage. Heidelberg: C. Winter, 1992, c. 1935.

Mifflin, Houghton. A Practical and Authoritative Guide to Contemporary English. Coleção: Book of English Usage. The American Heritage, 1996.

Migliorini, Bruno. "Italianista”. In: Profili di parole. Florença: Le Monnier, 1968, pp. 112114.

Miranda, Neusa Salim. Agentivos denominais e deverbais: um estudo da produtividade lexical em português. Rio de Janeiro: UFRJ, 1980.

Mendes Ferrín, Xosé Luís. Resposta ao discurso lido polo Ilustrísimo Señor don Manuel María Fernández Teixeiro no acto da súa recepción da RAG. A Coruña: eDixital, 2003.

Moliner, María. "El sufijo -ista”. In: El almanaque del léxico. Barcelona: maio, 2002.

Monteagudo, Henrique. Historia social da lingua galega. Vigo: Galáxia, 1999.

MonTeIro, José Lemos. Morfologia Portuguesa. Campinas: Pontes, 1991.

MonTEIro, Luís de Sttau. A guerra santa. Lisboa: Ática, 1974.

MonTENEGRO, Amador. Fábulas i epigramas. (1892). A Coruña: eDixital, 2002. . Mouxenas. (1896). A Coruña: eDixital, 2002.

MorAeS, Antônio Ermírio. Brasil S.A. Rio de Janeiro: Objetiva, 1996.

Neves, Álvaro Seiça. In: Jornal de Poesia. Fortaleza: www.revista.agulha.nom.br/indice.html, 2006.

Noblat, Ricardo (Org.). O complô que elegeu Tancredo. Rio de Janeiro: JB, 1985.

O CoRreio da MANHÃ. Lisboa: imprensa do Correio da Manhã, 24 de julho de 2006.

O estado de São Paulo. São Paulo: Júlio Mesquita, 08 de junho de 2006.

O’NeIL, Alexandre. In: Jornal de Poesia. Fortaleza: www.revista.agulha.nom.br/indice.html, 2006.

Otero Pedrayo, Ramón. O fidalgo e a noite. A Coruña: Cadernos da Escola Dramática Galega, 1979.

OXFORD. The concise Oxford. English-Arabic dictionary. Oxford: Oxford University Press, 1982.

PAz, Ramón Mariño. Historia da lingua galega. Santiago de Compostela: Sotelo Blanco, 1998.

PenA, Martins. Quem casa, quer casa. Rio de Janeiro: Biblioteca Nacional. www.bn.br, 2006.

Pereira, Aureliano. Cousas d'a aldea. (1891) A Coruña: eDixital, 2002.

Pernas Cora, Gustavo. ¡Ai, que sería de nós sem os obreiros! (1996) A Coruña: eDixital, 2002.

Pessanha, Camilo. In: Jornal de Poesia. Fortaleza: www.revista.agulha.nom.br/indice.html, 2006.

Pessoa, Fernando. Fernando Pessoa, por ele mesmo. Pará de Minas: virtualbooks, 2003. 
. Mensagem. Pará de Minas: virtualbooks, 2003.

. Obras poéticas. Pará de Minas: virtualbooks, 2003.

. O guardador de rebanhos. Pará de Minas: virtualbooks, 2003.

. O marinheiro. Pará de Minas: virtualbooks, 2003.

www.revista.agulha.nom.br/indice.html, 2006.

PIEL, J.M. Estudos de Lingüística Histórica Galego-Portuguesa. Lisboa: Imprensa NacionalCasa da Moeda, 1989.

. Miscelânea de etimologia Portuguesa e Galega. Coimbra: Universidade de Coimbra, 1953.

Pintos, Xoán Manuel. A’ Galicia. (1861) A Coruña: eDixital, 2002.

PISANI, Vittore. Breve historia de la lengua griega. Montevideo: Facultad de Humanidades y Ciencias - Universidad de la República, 1954.

Prado \& Silva, A. (org.) Novo dicionário Melhoramentos ilustrado. São Paulo: Melhoramentos, 1964.

Pondal, Eduardo. Queixume dos pinos. (1886) A Coruña: eDixital, 2002.

Prieto, Maria Helena de Teves Costa Ureña. Do grego e latim ao português. Lisboa: Fundação Calouste Gulbenkian, 1995.

QORPO SANTO. Mateus e Mateusa. Rio de Janeiro: Biblioteca Nacional. www.bn.br, 2006.

. Um assovio. Rio de Janeiro: Biblioteca Nacional. www.bn.br, 2006.

QUEIRóz, Eça. Alves \& cia. Rio de Janeiro: Biblioteca Nacional. www.bn.br, 2006.

. A cidade e as serras. Rio de Janeiro: Biblioteca Nacional. www.bn.br, 2006.

2006.

. A ilustre casa de Ramires. Rio de Janeiro: Biblioteca Nacional. www.bn.br,

. A relíquia. Rio de Janeiro: Biblioteca Nacional. www.bn.br, 2006.

www.bn.br, 2006.

. Cartas d'amor - o efêmero feminino. Rio de Janeiro: Biblioteca Nacional.

. Contos. Porto: Lello \& Irmão, s.d.

2006.

. O crime do padre Amaro. Rio de Janeiro: Biblioteca Nacional. www.bn.br,

. O primo Basílio. Rio de Janeiro: Biblioteca Nacional. www.bn.br, 2006.

. São Cristovão. Rio de Janeiro: Biblioteca Nacional. www.bn.br, 2006.

QUental, Antero. Antologia. Rio de Janeiro: Nova Fronteira, 1991.

. Sonetos completos. Rio de Janeiro: Biblioteca Nacional. www.bn.br, 2006.

Quino. Tiras de Mafalda. Buenos Aires: Kevin Quennet, 2005. http://www.mafalda.net.

Quintanilla, Xaime. Donosiña, drama em três autos. (1920). A Coruña: eDixital, 2002. 
Estudo comparativo de aspectos semânticos do sufixo -ista no português e no galego.

RAPOSO, Eduardo Paiva. Algumas observações sobre a noção de "língua portuguesa". In: Boletim de Filologia $n^{0}$ 29, 1984, p. 592.

Real ACADEmia ESPañola. Diccionario de La Lengua Española. Madri: Real Academia Española, 1984.CD-ROM

REALE, Luigi M. "Italianista: chi era costui? Un preludio a Internet. Parola di Bruno Migliorini”. In: Italianistica Online: portale di studi italianistici ideato e prodotto da Luigi M. Reale. Florença: Italianistica e Italianistica in Rete, Janeiro de 2004. http://www.italianisticaonline.it/2004/def-migliorini/

RIO-ToRTo, Graça Maria. Morfologia derivacional: teoria e aplicação ao português. Porto: Porto Ed., 1998. (Org.). Verbos e nomes em português. Coimbra: Almedina, 2004.

RochA Lima, C. H. Gramática normativa da língua portuguesa. Rio de Janeiro: José Olympio, 1972.

RoDRIGUES, Nelson. Teatro completo.Vol. 1,2,3 e 4. Rio de Janeiro: Nova Fronteira, 2004.

RODRIGUES, Urbano Tavares. “A torre de luz”. In: Onde a terra acaba: colectânea de contos portugueses. Lisboa: Universidade de Lisboa, 2006. . As torres milenárias. Amadora: Bertrand, 1975.

Algarve, 1960. Teixeira Gomes e a reação antinaturalista. Lisboa: Casa do

Rodríguez LóPez, Xesús. A cruz de salgueiro. (1899). A Coruña: eDixital, 2002. _. Costumbres gallegas. A malla. (1884). A Coruña: eDixital, 2002. eDixital, 2002. . Cousas d'as mulleres e outras poesías. (1890). A Coruña: . O chufón. (1899). A Coruña: eDixital, 2002. . Pasaxeiras. (1898). A Coruña: eDixital, 2002.

RUAIX, Josep. El català /3: lèxic i estilística. Moià: Ruaix, 1987.

RuCQuOI, Adeline. História Medieval da Península Ibérica. Lisboa: Estampa, 1995.

Rull I Muruzabal, Xavier. "Descripció del sufix $\{$-ist $/ \mathrm{m}\}$ " In: Jornal of catalan studies. Barcelona: UOC - Universita Oberta Catalá, 2000.

SÁ-Carneiro, Mário de. A confissão de Lúcio. Pará de Minas: virtualbooks, 2003. 1995. . Juvenília dramática. Lisboa: Imprensa Nacional - Casa da Moeda,

SAID Ali, M. Gramática histórica da língua portuguesa. Rio de Janeiro: Melhoramentos, 1930.

SAlinas, Galo. A torre de Peito Burdelo. (1890). A Coruña: eDixital, 2002. . Entre dous mundos. A Coruña: eDixital, 2002. . ¡Filla ...!. (1892). A Coruña: eDixital, 2002. 
2002.

. ¡Lenda de horrores! A mitra de ferro ardente. (1894). A Coruña: eDixital,

Sandmann, Antônio J. Competência lexical. Produtividade, restrições e bloqueio. Curitiba: UFPR, 1991.

Curitiba: Scientia et Labor / Ícone, 1989.

SANTA MARIA, Manuel de. Descrição da Ilha de Itaparica. Rio de Janeiro: Biblioteca Nacional. www.bn.br, 2006.

Santiago Lacuesta, R. \& Bustos Gisbert, E.: "La derivación nominal". In: BosQue, I. \& Demonte, V. (eds.): Gramática descriptiva de la lengua española. Madri: Real Academia Española / Espasa-Calpe. 2000, vol. 3, p. 4572-4573.

Saraiva, José H. História concisa de Portugal. $20^{\circ}$ ed. Sintra: Europa-América, 1999.

Saramago, José. In nomine Dei. São Paulo: Companhia das Letras, 1993. Que farei com este livro?. São Paulo: Companhia das Letras, 1998.

Saramago, José et Alii. Estudos sobre José Saramago. Pará de Minas: virtualbooks, 2003.

SARmiento, Padre. Coloquio de 24 gallegos rústicos. (s. XVIII). A Coruña: eDixital, 2002.

SEIXAS, João Guisan. A tábua ocre de Núbia (ou o significado da vida). Viana do Castelo: Teatro do Noroeste, 1998.

Seminarios Estudios de DeZa. Descubrindo Deza. Nº 4. Lalín: S.E.D., 2002.

Silva, Amós Coelho da. Presença do Latim Clássico. In: VIII Congresso Nacional de Lingüística e Filologia, 2004. Rio de Janeiro (RJ): http://www.filologia.org.br/cnlf/8/index.html, 2003

Silva, António José da (o Judeu). Guerra do alecrim e da manjerona. Rio de Janeiro: Biblioteca Nacional. www.bn.br, 2006.

Silva, Fernando Correia da. In: Jornal de Poesia. Fortaleza: www.revista.agulha.nom.br/indice.html, 2006.

Silva Neto, Serafim da. História da língua portuguesa. $1^{\text {a }}$ ed. Rio de Janeiro: PresençaMEC, 1957.

MEC, 1956.

. Textos medievais portugueses e seus problemas. Rio de Janeiro:

Starets, S. \& Voinova, N. Dicionário Prático Português-Russo. Moscou: Russki Yazik, 1986.

1986.

Dicionário Prático Russo-Português. Moscou: Russki Yazik,

StanisŁawsKi, Jan. The great Polish-English Dictionary. Varsóvia: Wiedra Powsechna, 1969.

SuassunA, Ariano. Auto da compadecida. Rio de Janeiro: Agir, 1979.

Tagliavini, Carlo. Origine delle lengue neolatine. $2^{\text {a }}$ ed. Bolonha: Riccardo Patron, 1952. 
Estudo comparativo de aspectos semânticos do sufixo -ista no português e no galego.

Taunay, Visconde de. Inocência. Rio de Janeiro: Biblioteca Nacional. www.bn.br, 2006.

TeKavčIC, Pavao. Gramática storica dell'italiano. Volume III: lessico. Bolonha: Società editrice il Mulino, 1972.

TeysSIER, Paul. História da Língua Portuguesa. São Paulo: Martins Fontes, 1997.

TILGA - TeSouro Informatizado DA LinguA GaLEGA. http://www.ti.usc.es/tilg/. 2006.

TMilg - Tesouro Medieval Informatizado da Lingua Galega. http://corpus.cirp.es/tmilg/. 2006.

Torneiro, Manuel Álvarez. Poemas (1982). A Coruña: eDixital, 2002.

Ullman, Stephen. Semântica: uma introdução à ciência do significado. Trad. J. A. Osório Mateus. Lisboa: Calouste Gulbenkian, 1977.

VALGODE, José. In: Tribuna de Valgode. http://valgode.de/, 2006.

VAlladARES, Marcial. Cantigueiro popular. (1867). A Coruña: eDixital, 2002.

. Diccionario Gallego-Castellano. Santiago de Compostela: Seminario Conciliar Central, 1884. (edição faxímilar: http://www.bvg.es/).

Majina, ou a filla espúrea. Conto gallego-castellano de miña abó. (1880). A Coruña: eDixital, 2002.

VArela, Fagundes. Poemas. Pará de Minas: virtualbooks, 2003.

VAREla-BuXán, Daniel. A xustiza dun muiñeiro. Se sei ... non volvo a casa. (1938). Pontevedra: Artes gráficas Portela, 1977.

. O ferreiro de Satán. Taberna sin dono. (1941). Lugo: Celta, 1975.

VAsConcelos, Carolina Michaelis de. Lições de filologia portuguesa. Lições práticas de português arcaico. Lisboa: Revista de Portugal, 1946.

Vasconcelos, José Leite de. Nomes étnicos em português. In: Revista da Universidade de Coimbra, vol XI. Coimbra: 1933, p. 139 - 157.

Universidade, 1928.

Opúsculos. Filologia vol I e II. Coimbra: Imprensa da

VÁzQuez Pintor, Xosé. A sombra da memoria. (1999). A Coruña: eDixital, 2002.

VERDE, Cesário. Poesias Completas. Rio de Janeiro: Biblioteca Nacional. www.bn.br, 2006.

ViARo, Mário E. Para um estudo da semântica sincrônica dos sufixos derivacionais em português do século XIII. Grupo de Estudos Lingüísticos do Estado de São Paulo. Taubaté: Unitau, 2003. CD-ROM (com. 95).

Globo, 2004a.

. Por trás das palavras. Manual de etimologia do português. São Paulo:

. Problemas de morfologia e semântica histórica do sufixo -eiro. Grupo de Estudos Lingüísticos do Estado de São Paulo. São Carlos: UFSCar, 2005.

. Os sufixos portugueses em uma visão diacrônica. Anais do Cellip. Londrina: UEL, 2004b. CD-ROM. 
Estudo comparativo de aspectos semânticos do sufixo -ista no português e no galego.

VIEIRA, Padre. Sermões. Rio de Janeiro: Biblioteca Nacional. www.bn.br, 2006.

Vilela, Mário. Estudos de lexicología do português. Coimbra: Almedina, 1994.

Vilar PonTe, Antón. Nouturnio de medo e morte, bárbara nécdota realista em dous tempos (sin literatura) que puído andar nos romances dos cegos. (1927). Santiago de Compostela: Nós, 1935.

Villanueva, Georgina (Dir.). Diccionário Básico de la Lengua. Madri: Anaya, 1993.

VITERBO, Joaquim de Santa Rosa. Elucidário das palavras, termos e frases que em Portugal antigamente se usaram e que hoje regularmente se ignoram. $2^{\mathrm{a}}$ ed. Porto: Civilização, s.d

WAHRIG, G. Wörterbuch der deustchen Sprache. München: Deustcher Taschenbuch, 1999.

WAKISAKA, Katsunori (org.). Michaelis: diccionario prático português-japonês. São Paulo: Melhoramentos, 2000.

WARTbURG, W. von. La fragmentación lingüística de la Romania. Madri: Gredos, 1979.

WierzbickA, Anna. Semantics: primes and universals. Oxford/ New York: Oxford University Press, 1996.

WiKPÉDIA DiCIONÁRIOS. Língua Alemã. http://de.wiktionary.org/wiki/. 2006. . Língua Espanhola. http://es.wiktionary.org/wiki/. 2006. . Língua Francesa. http://fr.wiktionary.org/wiki/. 2006. . Língua Galega. http://gl.wiktionary.org/wiki/. 2006. . Língua Inglesa. http://en.wiktionary.org/wiki/. 2006. . Língua Italiana. http://it.wiktionary.org/wiki/. 2006. . Língua Portuguesa. http://pt.wiktionary.org/wiki/. 2006.

WilliaMs, Edwin Bucher. Do latim ao português: fonologia e morfologia históricas da língua portuguesa. Traduzido por Antônio Houaiss. Rio de Janeiro: Ministério da Educação e Cultura, Instituto Nacional do livro, 1961.

Wright, Roger. Latín tardío y romance temprano en España y la Francia Carolingia. Madri: Gredos, 1989.

Wörterbuch. Spanisch - Deutsch / Deutsch - Spanisch. Colônia: Buch und Zeit, 1999.

ZALIZNiaK, A. Pequena gramática russa. Moscou: Russki Yazik, 1986.

Zlochevsky, Huzeff. Dicionário básico Português-Hebraico/Hebraico-Português. São Paulo: Tnuat Aliá, 1988.

ZINGARELLI, Nicola. Il nouvo Zingarelli: vocabolario della lingua italiana. $11^{a}$ Ed. Milão: Zanichelli, 1990.

ZINK, Rui. "Amanhã chegam as águas". In: Onde a terra acaba: colectânea de contos portugueses. Lisboa: Universidade de Lisboa, 2006. 